Universidade de Brasília

Instituto de Ciências Sociais

Departamento de Antropologia

Programa de Pós-Graduação em Antropologia Social

Tese de Doutorado

\title{
A AMBÍGUA CONDIÇÃO NEGRA EM CUBA \\ Relações Raciais e Mobilizações Coletivas Antirracistas
}

Bárbara Oliveira Souza

Brasília, 09 de dezembro de 2015 
Universidade de Brasília

Instituto de Ciências Sociais

Departamento de Antropologia

Programa de Pós-Graduação em Antropologia Social

Tese de Doutorado

\title{
A AMBÍGUA CONDIÇÃO NEGRA EM CUBA \\ Relações Raciais e Mobilizações Coletivas Antirracistas
}

\author{
Bárbara Oliveira Souza
}

Tese apresentada ao Programa de Pós-Graduação em Antropologia Social da Universidade de Brasília como requisito parcial para obtenção do título de Doutor.

Orientador: Professor Dr. José Jorge de Carvalho 


\section{Banca Examinadora:}

Prof. Dr. José Jorge de Carvalho (Presidente) - Departamento de Antropologia, UnB Prof. Dr. Kabenguele Munanga - Departamento de Antropologia, USP

Prof. Dr. Stephen Grant Baines - Departamento de Antropologia, UnB

Prof ${ }^{a}$. Dr ${ }^{a}$. Gleides Simone Formiga, Secretaria de Educação/DF

Prof. Dr. Arivaldo Lima Alves - Departamento de Ciências Sociais, UNEB

Prof ${ }^{a}$. Dr ${ }^{a}$. Marcela Stockler Coelho de Souza, Departamento de Antropologia, UnB (Suplente) 
Ao movimento afrocubano

Para meus filhos 
Me siento orgullosa de pertenecer a una raza que por sí sola, y a costa de sacrifícios, procura elevar-se a la altura de las demás y lucha, trabaja y estudia para vencer. Bastante tiempo hemos tenido el dogal y la mordaza, tanto tempo hemos callado, así pues el espíritu del siglo reclama que nuestra voz se levante

(Úrsula Coímbra, I888)

Tengo, vamos a ver, que siendo un negro nadie me puede detener a la puerta de un dancing o de un bar. O bien en la carpeta de un hotel gritarme que no hay pieza, una mínima pieza y no una pieza colosal, una pequeña pieza donde yo pueda descansar

(poema Tengo, de Nicolás Guillén, I964)

No digas que no hay racismo Donde hay un racista Siempre y cuando Donde quiera que me encuentre El prejuicio de una forma u otra está presente Negro delincuente concepto legendario Visto como el adversario en cualquier horario 


\section{Agradecimentos}

A oportunidade de realizar a pesquisa em Cuba foi única. Sou grata por ter tido a experiência de vivenciar no país, nesses quase dois anos, uma miríade de culturas, linguagens, debates, paisagens, músicas e experiências. Essa Ilha caribenha é cheia de particularidades e histórias que inundaram meus sentidos desde os primeiros dias de chegada. Conhecer mais do universo cubano a partir, também, das várias relações que estabeleci com ativistas antirracistas possibilitou debates e uma percepção mais ampla do nosso legado na Diáspora Africana nas Américas.

Minha preparação para a mudança a Cuba envolveu a participação de várias/os professoras/es, amigas/os e familiares, sem os quais não teria sido possível chegar a Ilha com toda a família, sem tantos atropelos. Agradeço a todas essas pessoas, mesmo que em alguns casos não estejam citadas aqui.

Sou grata às/aos professoras/es que participaram na minha banca de qualificação ou que estabeleci algum diálogo posteriormente: Maria Auxiliadora (Dorita) do NesCuba/UnB, Stephen Baines (DAN/UnB) e Edileuza Penha de Souza (NEAB/UnB). Edileuza, além de participar na banca, foi um elo incrível com ativistas antirracistas cubanos, que conheci logo no início da pesquisa. Agradeço a atenção de Dionísio Poey (NesCuba/UnB) pelo diálogo estabelecido. Deixo meus agradecimentos enfáticos pela leitura da tese, participação na minha defesa e análises feitas aos professores: Kabenguele Munanga (USP), Stephen Baines (DAN/UnB), Gleides Simone Formiga (SE/DF) e Ari Lima (UNEB) e Marcela Stockler (DAN/UnB). Agradeço, também, a orientação do professor José Jorge de Carvalho (DAN/UnB) e suas as reflexões inspiradoras sobre a questão racial. Pelo suporte cotidiano, sou agradecida à Rosa Cordeiro, Jorge Máximo e Cristiane Romão, funcionários da secretaria do Departamento de Antropologia da $\mathrm{UnB}$.

Agradeço ao Conselho Nacional de Pesquisa Científica e Tecnológica - CNPq pelo apoio dado à pesquisa e pela bolsa concedida em parte de meu curso de doutorado, o que auxiliou enormemente meu processo de pesquisa.

À amiga Caridad Massón, pesquisadora do Instituto Cubano de Investigação Cultural Juan Marinello, agradeço a acolhida desde a primeira conversa no CEPPAC/UnB, Brasília, em outubro de 2013. Caridad foi fundamental, posteriormente em Havana, no meu processo de vinculação como pesquisadora associada ao Instituto Cubano, o que possibilitou a realização da 
pesquisa de campo, de seminários, atividades de cartografia social, publicações e tantas outras parcerias feitas. Agradeço também aos companheiros Rodrigo Espina e Guillermo Lopez pelas parcerias realizadas.

Sou grata ao Antonio Martínez, professor da Cátedra de Antropologia, da Faculdade de Biologia da Universidade de Havana, por me receber como parte da turma no diplomado "Cuba: Genes, Culturas, y Racialidades", realizado entre o $2^{\circ}$ / sem de 2014 e I\% sem de 20I5. Participar desse diplomado foi uma excelente oportunidade para imergir no universo do ativismo antirracista e nas pesquisas sobre o tema em Cuba.

Resultados parciais dessa tese foram discutidos em seminários e tertúlias que participei em Havana. Faço destaque ao seminário internacional "Identidades y Movilizaciones Colectivas: Miradas desde Contextos Americanos" que organizei em Havana, Cuba, em parceria com Daniel Brasil (UnB/UBC), Caridad Massón (ICIC), Rodrigo Espina (ICIC) e Guillermo López (ICIC). Agradeço a participação de professoras/es de várias universidades do Brasil, de Cuba e Canadá, de pesquisadores, ativistas e líderes comunitários pelo rico debate que gerou aportes preciosos à pesquisa. Sou grata à vinda para o seminário de Bruce Miller (UBC), Stephen Baines (UnB), Isis Lustosa (LEPDT/UFG), Daniel Viegas, Rosa Acevedo, Izabela Salles e Alfredo Wagner de Almeida (Projeto Nova Cartografia Social) e Matilde Ribeiro (UNILAB), que interagiram de forma intensa conosco. Aos professores Alfredo Wagner de Almeida (UFAM), Rosa Acevedo (UFPA), Matilde Ribeiro (UNILAB) e Stephen Baines (UnB) agradeço, também, pelas conversas e sugestões de leituras para a pesquisa.

A partir do diálogo no Seminário, foi possível realizar duas oficinas de cartografia social em Cuba, parceria do Projeto Nova Cartografia Social com o Instituto Juan Marinello, em localidades nas quais estão situados alguns dos coletivos que interagi na pesquisa: comunidade de La Ceiba (uma das áreas articuladas pela Red Barrial Afrodescendiente) e o bairro La Marina (projeto Identidad y Barrio). Essas foram experiências muito ricas de aprendizado, e de aporte para o estudo, que contaram com a participação de Rosa Acevedo (UFPA), Reginaldo Silva (UEA), Alfredo Wagner de Almeida (UEA/UFAM), Daniel Brasil (UnB/UBC), Guillermo López (ICIC), Caridad Massón (ICIC), Rodrigo Espina (ICIC), Maritza López Mc Bean (Red Barrial Afrodescendiente) e Raúl Dominguez, Kimbo (Projeto Identidad y Barrio), além de lideranças comunitárias.

Minha estada em Cuba e o desenvolvimento da pesquisa não teriam sido os mesmos sem a presença da amiga, a ativista Irene Esther Ruiz, mi mamá cubana. Sou grata às conversas, trocas e 
experiências compartilhadas. Seu compromisso com a pauta racial e sua imensa disposição em contribuir com articulações sobre o tema foram vitais para minha estada em Cuba. À Maritza López Mcbean, la presidenta, companheira de jornada, que aportou muito à pesquisa, ao Rolando Zulueta, o querido chichi, e à Moraima López, deixo meu muito obrigada.

Agradeço muitíssimo ao grupo de ativistas e pesquisadores/as entrevistados/as para o trabalho, que me receberam, em grande parte das vezes, em suas casas e são meus principais interlocutores na tese: Yulexis Almeida, Roberto Zurbano Torres, Tomás Fernandez Robaina, Norberto Mesa, Tato Quiñones, Daysi Rubiera, Norma Guillard, Bienvenido Rojas, Esteban Morales Domínguez, Georgina Herrera, Gisela Arandia, Zuleica Romay, Kimbo (Raúl Dominguez), Mirna Rosa Padrón, Diarenis Calderón, Beatriz Zulueta, Eric Corvalán, Mavis Alvarez, Beatriz Zulueta, Clara Urrutia, Niurka Nuñes, Noemi de Cárdenas, Heriberto Feraudy, Regla Gonzales Miró. À Deyni Terry, sou muito grata pelo apoio e debate sobre a luta pela garantia de direitos. Ao Alejandro de La Fuente agradeço pelo diálogo sobre relações raciais em Cuba.

Deixo meus agradecimentos aos coletivos, projetos e organizações com os quais estabeleci maior proximidade: Afrocubanas, a Articulação Regional Afrodescendente nas Américas, capítulo cubano (ARAAC), a Red Barrial Afrodescendiente, a Cofradía de la Negritud (CONEG), o Projeto Alianza Unidad Racial (AUN), o Projeto La Marina Identidad Barrial, a Red de Mujeres Afrodescendientes de la América Latina y Caribe, capítulo cubano, a Comissão Aponte, vinculada à União dos Escritores e Artistas de Cuba, e o projeto mirArte diaDia.

Sou grata aos que se disponibilizaram a dialogar sobre temas específicos do trabalho em entrevistas em grupo: Olga Lidia Tió Valencia, Maria Martinez Romero, Yoana Gonzalez Valdes, Gilberto Quintana Arredondo, Danay Ramos, Mercedes Cañete, Carlos Ernesto Cañedo Tapanes, Lizmare Machado Lao e Liban Moya Hernández.

$\mathrm{Na}$ importante tarefa de transcrição das entrevistas, Marina Ruiz, Damayante Abreu e Yaimara Sanchez Martinez foram fundamentais. Sou agradecida à dedicação delas a esse trabalho. À Luana Lazzeri Arantes agradeço as trocas, a revisão minuciosa e o diálogo inspirador e divertido sobre a tese. Agradeço, também, à Paula Balduíno pelo apoio durante a pesquisa e pelos afagos, mesmo que digitais.

A família traz o legado do amor cotidiano. Meus agradecimentos à: minha mãe, Josélia Abreu, que se apaixonou por Cuba e que durante a pesquisa foi uma colaboradora incansável; meu pai, Waldimiro de Souza, que nos ensinou o valor de nossa herança afrobrasileira; Izabel Oliviera, 
irmã caçula, que deixou o carinho e a leveza em tempos áridos; aos meus irmãos, Paulo, José e Artur Higino, pelo companheirismo e afeto; Daniel Brasil, meu bumbo, parceiro de vida e de mundos, que deixa tudo mais colorido; Meus filhos, pequenas sementes de amor, João Caetano, Dandara e Luiza, que são gigantes inspiradores. 


\title{
Resumo
}

$\mathrm{Na}$ presente tese, intitulada "A Ambígua Condição Negra em Cuba: Relações Raciais e Mobilizações Coletivas Antirracistas", analiso o ativismo afrocubano em diferentes contextos, a partir do diálogo com as narrativas das/os agentes sociais que são protagonistas no processo de ressignificar discursos em relação ao legado negro e ao racismo no país. Reflito sobre as dinâmicas atuais que permeiam as relações raciais, o mito cubano da igualdade, a ideologia da mestiçagem, a construção da nação e as percepções sociais sobre identidade. Ao passo que teço análises sobre o único país da região proclamado como socialista há quase seis décadas, busco um olhar ampliado sobre as estratégias de luta dos afrodescendentes no contexto da Diáspora Africana nas Américas, ao salientar suas interações com outros países latinoamericanos, com ênfase para o Brasil. A abordagem teórica permeia estudos das ciências sociais sobre relações raciais e a leitura crítica dos conceitos de sociedade civil e movimento social, à luz das especificidades cubanas.

Palavras Chaves: Movimento Afrocubano - Relações Raciais - Racismo - Movimentos Sociais

\begin{abstract}
This present thesis entitled "The Ambiguous Black Condition in Cuba: Racial Relations and Collective Anti-Racist Mobilizations" analyses Afro-Cuban activism in different contexts from the narratives of social agents who are protagonist in the process of re-signifying discourses related to the black heritage and to racism in the country. In the thesis, I address the ways in which racism materializes within Cuban institutions and society. While focusing on the single American country in which socialism is the proclaimed form of government for almost six decades, I search for a broader overview of the strategies for the struggle undertaken by afrodescendents in the context of the African Diaspora in the Americas, in highlighting its interactions with other Latin-American countries, notably Brazil. The theoretical approach permeates studies in social science about racial relations, and the critical reading of concepts about civil society and social movements, in the light of the Cuban particularities.
\end{abstract}

Key words: Afro-Cuban Movement - Racial Relations - Racism - Social Movements 


\section{SUMÁRIO}

INTRODUÇÃO.

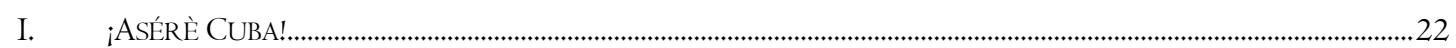

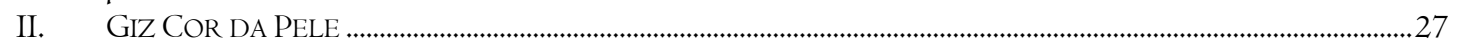

III. "ISSO FICA ENTRE NÓS" ...................................................................................................................................34

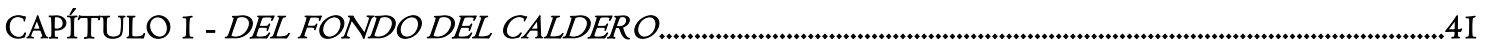

I.I. ENTRAMOS NEGROS E SAÍMOS AFROdESCENDENTES .....................................................................................46

1.2. COR, RAÇA, NEGRITUDE E AFRODESCENDÊNCIA ....................................................................................67

I.3. Mito Da IGUALDADE, MESTIÇAGEM E NAÇÃo .........................................................................................9I

1.4. ¡NO HABLE DE ESO! ................................................................................................................ 117

I.5. MOVIMENTO AFROCUBANO NOS ESTERTORES DA GUERRA FRIA .................................................... I I 128

I.6. O COPO E O RACISMO........................................................................................................................................ I I

CAPÍTULO 2 - SUBVERSÃO HISTÓRICA E MOBILIZAÇÕES NEGRAS EM CUBA.................................... I59

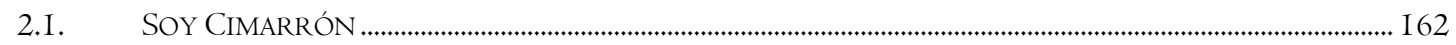

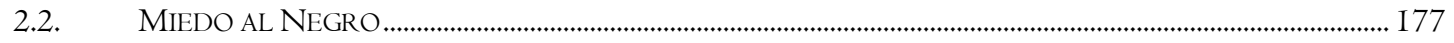

2.3. SOCIEDADES NEGRAS, MAMBISES E MINERVAS ..................................................................................... 183

2.4. POPULAÇÃO NEGRA E A REPÚBLICA CUBANA......................................................................................... 190

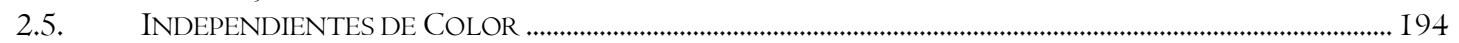

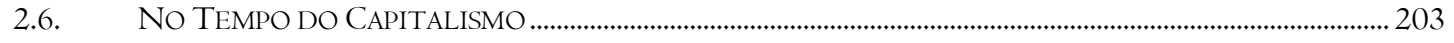

CAPÍTULO 3 - ;VIVA LA REVOLUCIÓN, ABAJO EL RACISMO!...............................................................218

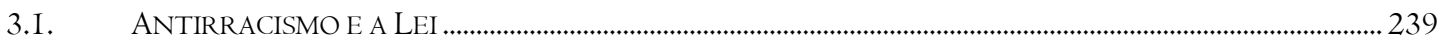

3.2. EQUidADE E REPRESENTAÇÃo SIMBÓLICA: AÇÕES AFIRMATIVAS EM CUBA ........................................2.252

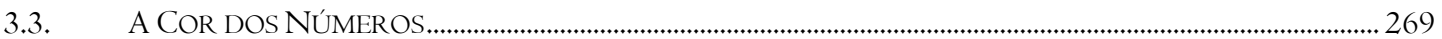

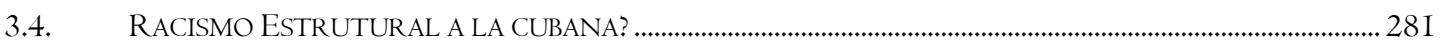

CAPÍTULO 4 - FLUXOS E REFLUXOS DO MOVIMENTO AFROCUBANO ………………………………......28

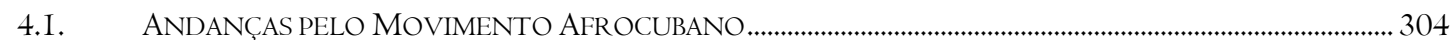

4.2. COFRADÍA DE LA NEGRITUD ……………………….............................................................. 316

4.3. ARTICULAÇÃo REGIONAL AFRODESCENDENTE......................................................................................... 32 I

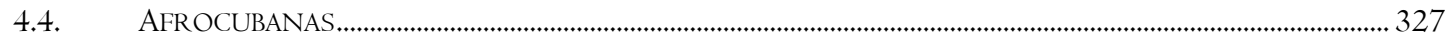

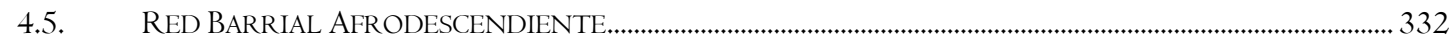

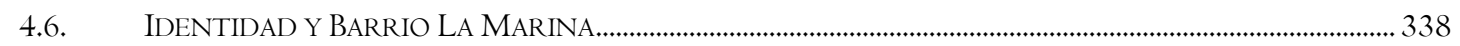

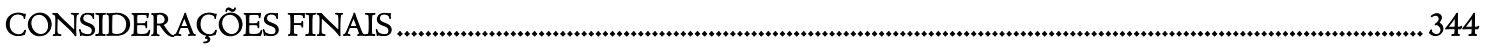

INFORMAÇÕES SOBRE ATIVISTAS E ENTREVISTADAS/OS PARA A PESQUISA...................................352

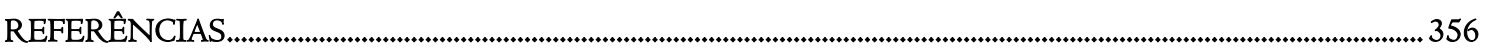

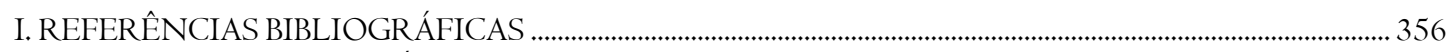

II. FILMES E DOCUMENTÁRIOS ......................................................................................................................... 368

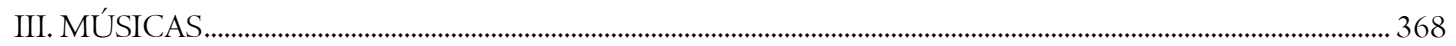

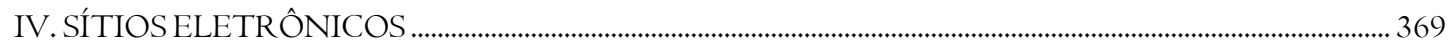

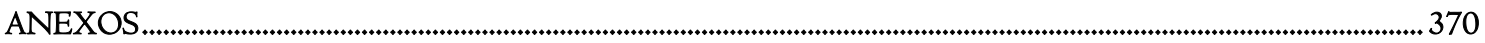

a) Membros do Bureau Político do Comitê Central do Partido Comunista de Cuba....................... 370

B) Quadro da Presidência da Assembléia Nacional do Poder Popular - Legislaturas de 1976 A

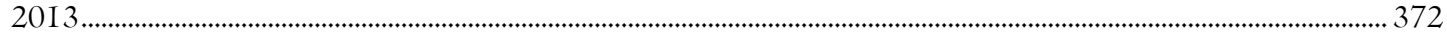

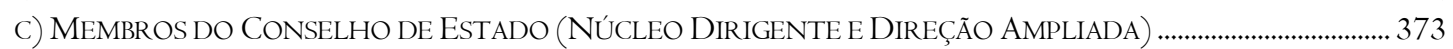

D) CaRta de Autorização de Pesquisa Para o Doutorado EM Cuba ................................................................. 377 


\section{LISTA DE FIGURAS}

FigURA I - MAPA DE CUBA, POR PROVÍNCIA E POPUlaÇão, 20I3. ACESSO EM: OI/IO/20I5........................................23

Figura 2: ANÚNCIO ALUSIVO AO BLOQUEIO dOS EUA CONTRA CUBA NA AVENIDA BOYEROS, HaVANA, CUBA .

Figura 3: "LA BODA DE PANCHA Jutía Y CANUTO RASPADURA". LITOGRAFIA DE VíCTOR PATRÍCIO DE LANDALUZE, FINAL DO SÉC. XVIII..

Figura 4: LANÇAMENTO DA DÉCADA DOS Povos AFrodESCENDENTES, EM 20/08/20I4, NA CASA DE ALBA, HAVANA, CUBA...

Figura 5: RETRATA KIMBO (LIDERANÇA DO BAIRRO LA MARINA, MATANZAS) E QUADRO DE CAMILO CINFUEGOS (LÍDER DA REVOLUÇÃO SOCIALISTA CUBANA) ......................................................................................78

FIGURA 6: IYABO (INICIADO NA SANTERIA QUE NO PRIMEIRO ANO SÓ VESTE BRANCO), NO MALECÓN, HAVANA, CUBA.

FIGURA 7: MATÉRIA SOBRE MESA REDONDA, PROGRAMA TELEVISIVO DE DEBATE, NO JORNAL GRANMA .......... I I 2 FIGURA 8: MATÉRIA DO JORNAL JUVENTUD REBELDE, CUBA, DE I8 DE JULHO DE 20I4 ......................................... I I 2 FIGURA 9: ORTIZ (I975). SÍNTESE DOS CENSOS DE I532 A I907 ........................................................................ I75 FIGURA I0: RUÍNAS DA CASA DE QUINTÍN BANDEIRA, LOCALIZADA EM CENTRO HAVANA,..................................... I86 FIGURA I I: VISITA A CASA DE QUINTIÍN BANDERA, COM GRUPO PARTICIPANTE DO DEBATE SOBRE SUA HISTÓRIA, EM 22/05/20I4..... 186

FIGURA I2: FOTO DE MEMBROS DO PARTIDO INDEPENDIENTES DE COLOR .................................................................. I96 FIGURA I3: MANCHETE REFERENTE AO MASSACRE DO PARTIDO IMPEDIENTES DE COLOR, COM MENÇÃO AOS SEUS LÍDERES, ESTENOZ E IVO NET …………………………………………………………………………….... I 199

FIGURA I4: FOTO DE ENFORCAMENTO DE MEMBROS DO PARTIDO INDEPENDIENTES DE COLOR, EM I9I2 ...... I99

Figura I5: PROPAGANDA ELEITORAL DO PARTIDO SOCIALISTA DE CUBA, COM EXALTAÇÃO À CAMPANHA PELA IGUALDADE RACIAL. PUBLICADO EM NOTICIAS DE HOY, EM I2/09/1952 .............................................................. 204

FIGURA I6: GRÁFICO SOBRE CONDIÇÕES DE MORADIAS, CENSO 20I2 …………………………………………………. 2I0

FIGURA I7: BAIRRO CENTRO HABANA, COM ALTO ÍNDICE DE MORADIAS PRECÁRIAS E GRANDE PRESENÇA AFRODESCENDENTE ENTRE OS SEUS MORADORES.

FIGURA I8: BATISTA E SEUS SEGUIDORES, REPRESENTADOS PELA OPOSIÇÃO COMO PRIMATAS E COM REPRESENTAÇÕES ESTEREOTIPADAS DO FENÓTIPO NEGRO. PANFLETO DE I DE DEZEMBRO DE I 954 .... 2 I 4

FIGURA I9: FOTO DAS COMEMORAÇÕES DO DIA DO TRABALHADOR, I ${ }^{\circ}$ DE MAIO DE 20I4, HAVANA, CUBA ....... 2 I 8 Figura 20: QUEIMA DO BONECO DE SAN JUAN, NO DIA 24 DE JULHO DE 20I5, NO BAIRRO LA MARINA, MATANZAS, CUBA.

FOTO 2I: CORTEJO COM O BONECO PELO BAIRRO LA MARINA, MATANZAS, CUBA, COM PARADAS NOS CABILDOS E CASAS DE SANTERIA, PALO MONTE ABACUÁS. PASSAGEM DO DIA 23 PARA 24 DE JUNHO DE 20I4............248

Figura 22: QUADRO COM PERCENTUAL DA POPULAÇÃO DE 25 ANOS OU MAIS, SEGUNDO RAÇA/COR, QUE TERMINOU OS ESTUDOS PRÉ-UNIVERSITÁRIOS (SECUNDÁRIOS) OU SUPERIORES EM BRASIL, CUBA E EUA DÉC. I980. 253

FIGURA 23: QUADRO DO NÚMERO DE MATRÍCULAS NO ENSINO SUPERIOR, CUBA, 2000 A 2008. FONTE: ALMEIDA, 20I4.

FIGURA 24: QUADRO SOBRE PARTICIPAÇÃO DE ESTUDANTES, POR COR, NAS MATRÍCULAS DE ENSINO SUPERIOR DE CUBA. 261

FIGURA 25: QUADRO SOBRE PERCENTUAL DA PARTICIPAÇÃO DE MULHERES NAS MATRÍCULAS DE ENSINO SUPERIOR EM CUBA

FIGURA 26: QUADRO DOS CENSOS DE POPULAÇÃO EM CUBA, POR COR, DE I774 A 2002 ........................................ 27I

FIGURA 27: LEVANTAMENTO FEITO POR LOVEMAN (20I4: 24I) SOBRE AS PESQUISAS CENSITÁRIAS E O QUESITO

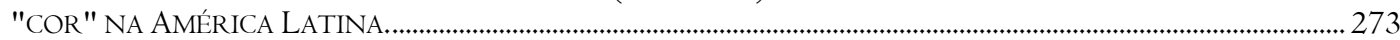

FIGURA 28: QUADRO SOBRE PROPORÇÃO DE POPULAÇÃO CUBANA POR COR, DE I 981 A 20I2 ................................2. 273

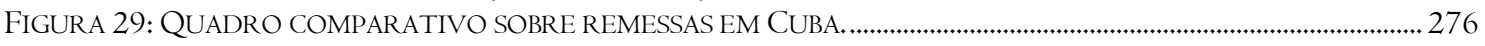

FIGURA 30: GRÁFICO SOBRE PARTICIPAÇÃO DAS REMESSAS, POR OCUPAÇÃO E COR DA POPULAÇÃO CUBANA (20II) 276

FigURA 3I: DEBATE PROMOVIDO PELA ARAAC, CAPÍTULO CUBANO, EM ALUSÃO AO DIA DA ÁFrICA, NO DIA 29 DE MAIO DE 2014

FIGURA 32: OFICINA COMUNITÁRIA REALIZADA PELA RED BARRIAL AFRODESCENDIENTENO BAIRRO POGOLOTI,

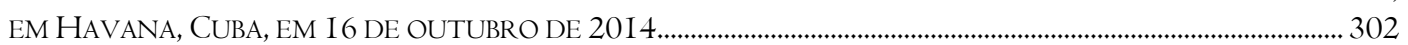

FIGURA 33: QUADRO SINTÉTICO DAS MOBILIZAÇÕES ANTIRRACISTAS EM CUBA REALIZADAS A PARTIR DOS ANOS 1990.

FIGURA 34: FOTO DA COORDENAÇÃO EXECUTIVA DA ARAAC, 2014.

FIGURA 35: DEBATE PROMOVIDO PELA ARAAC-CUBA EM OUTUBRO DE 20I4, COM JAMES EARLY E COORDENAÇão DE GiSEla ARANDia, NA CASA DE Alba, HaVAna, CubA. 
FIGURA 36: CONVITE PARA A ATIVIDADE PROMOVIDA PELO COLETIVO AFROCUBANAS, REFERENTE AO DEBATE SOBRE A REPRODUÇÃO DOS ESTEREÓTIPOS RACISTAS NA FAMÍLIA, REALIZADO NO DIA 20/02/2015, EM HAVANA, CUBA.

FIGURA 37: ATIVIDADE REALIZADA EM 20I4, PARCERIA DA AFROCUBANAS E DA RED BARRIAL AFRODESCENDIENTE.

Figura 38: La Ceiba de Balcón ARimaO, "La Gala Cultural", I5/I I /2013

FiguRA 39: IROKO, OU CEIBA, DA COMUNIDADE DE LA CEIBA, SITUADA EM BALCÓN ARIMAO, LA LiSA, HAVANA, 2015. 334

FIGURA 40: OFICINA REALIZADA PELA RED BARRIAL AFRODESCENDIENTE, NO BAIRRO POGOLOTI, EM HAVANA, DE I5 A I9/09/20I4, SOBRE DISCRIMINAÇÕES E DIREITOS.

FIGURA 4I: OFICINA DE AVALIAÇÃO, REALIZADA JUNTO A REPRESENTANTES DE DIVERSOS COLETIVOS ANTIRRACISTAS, EM I5/08/20I4, HAVANA, CUBA.

Figura 42: MARGarita, DO PROJETO MuÑECA NEGRA, COM A BONECA "FrANCISCA" DO QUILOMBO DE CONCEIÇÃO DAS CRIOULAS (BRASIL), 2015.

Figura 43: BONECA FranCiSCA, DA CASA DE MARGarita, DO Projeto MuÑECA NEGRA, La Lisa, HaVANA, 2015.

FIGURA 44: REUNIÃO DO GRUPO GESTOR DO PROJETO IDENTIDAD Y BARRIO LA MARINA, REALIZADA EM I7/I0/20I4, NA CASA DE Milagro, Bairro La Marina, MatanZas, Cuba. 340

Figura 45: ESPETÁCULO DE RUMBA, TOCADO POR RUMBA TIMBA, NO BAIRRO LA MARINA, EM AGOSTO DE 2014.

FIGURA 46: ENTRADA DO BAIRRO LA MARINA E A PRESENÇA DE DUAS IYABOS. 


\section{LISTA DE SIGLAS}

ARAAC - Articulación Regional Afrodescendiente de Las Américas y del Caribe, Capítulo Cubano

AUR - Alianza Unidad Racial

CDR - Comités de Defensa de la Revolución

CEERT - Centro de Estudos das Relações de Trabalho e Desigualdade

CELAC - Comunidade dos Estados Latinoamericanos e Caribenhos

CERD - Comitê para a Eliminação da Discriminação Racial da ONU

CFN - Conjunto Folklórico Nacional

CIR - Comité Ciudadano de Integración Racial

CNPq - Conselho Nacional de Pesquisa Científica e Tecnológica

CONAQ - Coordenação Nacional de Articulação das Comunidades Negras Rurais Quilombolas

CONEG - Cofradía de la Negritud

CTC - Central dos Trabalhadores de Cuba

DAN/UnB - Departamento de Antropologia da Universidade de Brasília

EUA - Estados Unidos da América

FMC - Federación de Mujeres de Cuba

IBGE - Instituto Brasileiro de Geografia e Estatística

ICAN - Instituto Cubano de Antropología

ICIC - Instituto Cubano de Investigación Cultural Juan Marinello

ICRT - Instituto Cubano de Radio e Televisão

IPEA - Instituto de Pesquisa Econômica Aplicada

LLCE - Laboratório Latino-Americano de Avaliação da Qualidade do Ensino

M-26 - Movimento 26 de julho

MINREX - Ministério das Relações Exteriores de Cuba

MIR - Movimiento de Integración Racial Juan Gualberto Gómez

MNU - Movimento Negro Unificado 
NYT - New York Times

OIT - Organização Internacional do Trabalho

ONE - Oficina Nacional Estatística de Cuba

ONG - Organização Não Governamental

ONU - Organização das Nações Unidas

PCC - Partido Comunista de Cuba

PIC - Partido Independientes de Color

PNAD - Pesquisa Nacional por Amostragem de Domicílios

PSP - Partido Socialista Popular de Cuba

SEPPIR - Secretaria de Políticas de Promoção da Igualdade Racial

UH - Universidad de La Habana

UJC -Unión de la Juventud Comunista

UMAP - Unidades Militares de Ajuda à Produção

UNITA - Unión para la Independencia Total de Angola

UnB - Universidade de Brasília

UNEAC - Unión de los Escritores y Artistas de Cuba

UNESCO - Organização das Nações Unidas para a Educação, a Ciência e a Cultura

UPEC - Unión de Periodistas y Escritores de Cuba

URSS - União das Repúblicas Socialistas Soviéticas

UTC - Unión de los Trabajadores de Cuba

WWF - World Wild Life Found 


\section{Introdução}

Essa pesquisa versa sobre os processos vinculados às mobilizações coletivas voltadas para as relações raciais e a luta antirracista no contexto cubano contemporâneo. Compreendo essas mobilizações como representativas das ações empreendidas pelo conjunto de organizações e agentes sociais que reconhecem a necessidade de atuar e produzir conteúdos como ferramentas contra a opressão racial, bem como para o exercício de identidades coletivas. Busco analisar as estratégias que os sujeitos empreendem em seus espaços cotidianos para amplificar suas demandas e percepções sociais, bem como para incidir na transformação de sua realidade.

Coletivos e agentes sociais vinculados à pauta antirracista em Cuba têm fomentado, sobretudo a partir de meados da década de 1980 e com mais fôlego na segunda metade dos anos 1990 e 2000, uma maior capilaridade da discussão em espaços públicos, uma ampliação do debate nos meios de comunicação e nas pesquisas. Observa-se um crescimento nas demandas por políticas públicas estruturadas para o tema, como as de ordem legal, econômica e educacional.

Essas mobilizações coletivas se manifestam de variadas formas organizativas, com base em diferentes estratégias. O que as vinculam é a especificidade e o foco na questão racial, em sua abordagem privilegiada para as relações raciais e para as mobilizações contra o racismo. Importante destacar que não se traduzem como expressões políticas homogêneas e integradas com base em diretrizes comuns. É a partir de sua heterogeneidade que pautam suas ações em diferentes esferas, das comunidades locais às redes internacionais.

A pesquisa é focada nas organizações vinculadas à pauta racial e às mobilizações políticas coletivas dos agentes sociais que se autodenominam "afrodescendentes" ou "negros" em Cuba ${ }^{1}$. Tem como objetivo analisar as dinâmicas e processos organizativos das mobilizações coletivas antirracistas no país e suas particularidades vivenciadas em um regime socialista que promoveu uma ampla mobilização das camadas mais populares e a construção de um modelo social, econômico e cultural distinto em relação aos demais países da América Latina, e que hoje vive um agitado processo de mudanças econômicas e sociais.

Como brasileira, pesquisadora dos movimentos sociais de base identitária, tendo como pano de fundo meu país e a diversidade do ativismo negro nessa nação continental, me interessou, desde

\footnotetext{
I Os termos "negro" e "afrodescendente" são construídos a partir de diferentes contextos, conforme abordado no capítulo I. O emprego desses termos é feito no cotidiano estudado e são categorias nativas utilizadas para caracterizar a identidade coletiva pelos agentes sociais, coletivos e grupos focados na luta antirracista.
} 
minha chegada a Cuba, buscar compreender esses processos organizativos insulares e sua bagagem histórica que agrega na contemporaneidade elementos fundamentais. Instigava-me poder refletir sobre quais seriam as especificidades desse processo no único país da Diáspora Africana nas Américas que vivenciou, nos últimos cinqüenta anos, um processo diametralmente contrário do ponto de vista social, econômico e político, que foi a Revolução de caráter socialista.

O estudo centra-se em algumas organizações, projetos e coletivos antirracistas, dentre os quais se destacam: (I) a Afrocubanas, organização de mulheres negras que se mobiliza a partir de um projeto de estudo e pesquisa sobre a questão da mulher negra e dá voz a suas denúncias e reivindicações; (2) a Articulação Regional Afrodescendente nas Américas, capítulo cubano (ARAAC); (3) a Red Barrial Afrodescendiente, que atua nos bairros La Liza e Pogolotti, em Havana; (4) a Cofradía de la Negritud (CONEG), uma das organizações pioneiras em Cuba; (5) o Projeto Alianza Unidad Racial (AUR), focado no debate legal e de direitos; (6) o Projeto La Marina Identidad Barrial, de caráter comunitário situado no bairro La Marina, em Matanzas; (7) a Red de Mujeres Afrodescendientes de la América Latina y Caribe, capítulo cubano; (8) a Comissão Aponte, vinculada à União dos Escritores e Artistas de Cuba; (9) e o projeto mirArte diaDia, que envolve artistas e ativistas.

Majoritariamente, as organizações incorporadas nesse estudo atuam em Havana ou Matanzas. Um olhar mais amplo sobre o país não foi possível nesse trabalho, por questões vinculadas ao tempo, ao financiamento para deslocamento e às possibilidades de realizar uma imersão em campo satisfatória. Todavia, algumas das lideranças entrevistadas relatam processos de mobilizações antirracistas em outras regiões do país, como Camaguey e Santiago de Cuba, o que pode ser objeto de uma pesquisa futura, mais abrangente.

Os termos "articulação" e "mobilizações coletivas" referem-se às ações, conexões e redes estabelecidas que são construídas a partir da particularidade de cada caso. São processos dinâmicos, que permeiam a contínua construção de laços ou o seu desatamento, numa lógica fluida das relações sociais internas e externas estabelecidas nos espaços dos coletivos e junto aos agentes sociais.

Uma parte das organizações sociais pesquisadas é exclusivamente composta por mulheres, como as Afrocubanas ou a Rede Latinoamericana e Caribenha de Mulheres Afrodescendentes, Capítulo Cubano. As dinâmicas das relações de gênero nessas instâncias são importante elemento de organização desses grupos. O papel de homens e mulheres nas organizações mistas e os objetivos 
e as motivações comuns compartilhadas em organizações exclusivamente de mulheres são questões que o presente trabalho também busca refletir.

O debate acerca do aspecto identitário perpassa toda a discussão da pesquisa. São pontos centrais: a construção das categorias "negra(o)", "mulata(o)", "afrocubana(o)", "branca(o)", "mestiça(o)"; e como se estabelece a percepção da identidade racial e seus reflexos nos processos mobilizatórios de organizações antirracistas; como são construídas as fronteiras entre o "nós" e o "outro" e quais são as dinâmicas de fluidez dessas barreiras.

Outra dimensão fundamental para a pesquisa refere-se às diferentes estratégias narrativas e discursivas dos agentes sociais e dos coletivos quando pautam a luta antirracista. É com base nas narrativas e discursos que os sujeitos constroem percepções sobre suas ações, estratégias e sobre sua própria identidade. Parte dessas estratégias narrativas envolve um recontar de suas histórias, de seus mitos e de seus ícones. O reposicionamento e o recontar da "história oficial" compõe um dos recursos relevantes, inclusive com destaque ao que se amplifica e ao que se omite. Esse dinamismo narrativo explicita desejos, receios e perspectivas de legitimar dinâmicas de resistência e luta.

O lócus do discurso é instigante para refletir sobre as relações de poder e sobre as dinâmicas que são estabelecidas entre "resistência" e "dominação". Ao se questionar a rigidez da dominação como poder estabelecido e a resistência como a oposição organizada ao poder institucionalizado, busco refletir sobre as ambigüidades e fissuras presentes nessa relação.

Apresento, a seguir, algumas questões centrais para o desenvolvimento da investigação sobre a mobilização política coletiva em torno da pauta antirracista em Cuba: Existe racismo no país? Se sim, como se manifesta e qual é a percepção de sua existência pela sociedade cubana? Qual é o papel do Estado no que se refere à questão racial e ao combate ao racismo? Qual é o contexto atual da luta contra o racismo no país? Como são constituídas as percepções sociais sobre as categorias identitárias baseadas em fenótipo? Há um movimento negro em Cuba? Como se organizam as mobilizações sociais para esse tema em Cuba? Quais são os principais acordos e desacordos sobre o tema? Quais são os impactos dessa pauta a partir das articulações em nível internacional, especialmente no contexto da Década dos Povos Afrodescendentes, declarada pela Organização das Nações Unidas (ONU)? Por fim, a questão central que move esse trabalho: Como se conformam as mobilizações coletivas antirracistas em Cuba, seus enredos, relações, representações, construções e desconstruções? 
O trabalho está organizado em quatro capítulos, contendo Introdução; capítulo I: "Del Fondo del Caldero"; o capítulo 2:"Subversão histórica e Mobilizações Negras"; capítulo 3: "; Viva la Revolución! Abajo el Racismo!"; capítulo 4: "Fluxos e Refluxos do Movimento Afrocubano", considerações finais e referências bibliográficas.

No capítulo I, delineio os principais períodos das mobilizações antirracistas e afrodescendentes na América Latina e seus reflexos nos processos cubanos, como as lutas abolicionistas e independentistas (especialmente na passagem do século XIX para o XX); as dinâmicas organizativas afrodescendentes nas repúblicas do continente (com ênfase para a formação de partidos focados na temática); os processos vivenciados nos anos I970, I980, com a ampliação da institucionalização de movimentos negros e a mudança de bases legais constitucionais em vários países, como, por exemplo, no Brasil. As influências desses processos mais abrangentes, em Cuba, são particulares, especialmente a partir dos reflexos que a própria Revolução traz. $\mathrm{O}$ último grande período que delimito em relação às mobilizações negras está vinculado à Conferência Mundial de Combate ao Racismo, à Discriminação Racial, à Xenofobia e Intolerâncias Corretalas, realizada em Durbin, África do Sul, em 200I, com ênfase para a seção "Entramos negros e saímos afrodescendentes".

Faço, também, uma ampla reflexão sobre conceitos e categorias identitárias vinculadas à perspectiva étnicorracial, seu legado colonial, ressemantização pelos movimentos e as amplitudes e variedades de empregos possíveis, sempre a partir do diálogo com os próprios ativistas. Os impactos que as ideologias de nação, do branqueamento e da mestiçagem geram para as relações raciais e seus reflexos para a construção do que denomino "mito da igualdade", a partir especialmente do diálogo com Hasenbalg (2005), estão presentes na seção "Mito da Igualdade, Mestiçagem e Nação".

O debate sobre as estratégias do discurso e as relações de poder está mais profundamente presente na seção "No Hable de Eso!", a partir da reflexão sobre interditos, controles e poderes que emanam do discurso, especialmente os vinculados às relações raciais. Ao abordar as mobilizações sociais e as dinâmicas da sociedade civil, me aprofundei, na seção "Mobilizações Afrocubanas nos Estertores da Guerra Fria", no diálogo com diversas teorias das ciências sociais. Dentre os campos teóricos, reflito sobre algumas pesquisas da denominada "teoria dos movimentos sociais" e suas possíveis reverberações ou incongruências em Cuba. Por fim, a última parte do capítulo I, "O copo e o racismo", traz análises sobre teorias vinculadas ao racismo, relações raciais em diálogo com narrativas de ativistas entrevistados e com dados de campo. 
O capítulo 2, "Subversão Histórica e Mobilizações Negras", volta-se para a estratégia de reposicionar a história, de dar visibilidade aos ícones e eventos epitomizantes ${ }^{2}$ a partir da narrativa do ativismo afrocubano. Diversos marcos históricos das mobilizações antirracistas em Cuba são abordados, com base no diálogo entre as abordagens dos ativistas na atualidade e a forma como incorporam esses signos às suas mobilizações. A compreensão de como os feitos históricos, muitos deles silenciados pela historiografia oficial, são trazidos à tona e incorporados às estratégias coletivas desses movimentos, é um ponto fundamental para a compreensão dessas mobilizações em Cuba.

As reflexões sobre as narrativas e o reposicionar histórico vão desde as experiências quilombolas e palenqueras, passando pelas mobilizações abolicionistas, pelas lutas independentistas e os movimentos negros na república. A mobilização das Minervas, mulheres negras que se manifestavam em jornal suas perspectivas, o partido Independientes de Color, as sociedades negras, a mobilização nos sindicatos e no então Partido Socialista, bem como outras formas organizativas floreiam o capítulo.

No "; Viva la Revolución! Abajo el Racismo!" são abordadas dinâmicas das relações raciais na contemporaneidade, em diálogo com diversos elementos estruturais que atravessam a Revolução, como as reformas de base, as amplas políticas inclusivas, especialmente no campo educativo, profissional e de acesso à saúde. Por outro lado, estão as situações ambivalentes que invisibilizam historicamente a negritude nos meios de comunicação, na educação, no mercado de trabalho, e se refletem também no modo como muitos dos espaços de mobilização negra foram controlados e cerceados historicamente. Abordo como essa dimensão está presente nos espaços de poder, onde aprofundo um olhar sobre a ocupação histórica dos postos políticos da mais alta hierarquia cubana, como o Conselho de Estado, a Assembléia Nacional do Poder Popular e o Bureau do Partido Comunista de Cuba, e estabeleço reflexões sobre as ações afirmativas em Cuba, com uma visão de contraponto com o Brasil.

Na terceira seção desse capítulo, "A Cor dos Números", teço considerações sobre como se materializam nas pesquisas censitárias e quantitativas as representações por cor na sociedade cubana. A melhor qualificação desses dados e sua ampla divulgação e análise é uma das fortes demandas dos coletivos antirracistas com os quais dialoguei na pesquisa. Por fim, encerro o

\footnotetext{
${ }^{2}$ Conceito que diz respeito à forma como a complexidade dos processos históricos se reduz a uma série de eventos que marcam a construção da nação, de um determinado povo ou coletividade. É um termo cunhado por Raymond Fogelson (apud Furniss I998: I8). Maiores detalhes sobre o conceito no capítulo 2.
} 
capítulo com uma análise sobre aspectos relacionados ao conceito de racismo estrutural, à luz dos pontos analisados no decorrer da tese, em especial nas seções anteriores do próprio capítulo 3.

No capítulo 4, "Fluxos e Refluxos do Movimento Afrocubano", o debate é voltado para as dinâmicas, relações e perspectivas das mobilizações coletivas antirracistas no país. Em diálogo com os capítulos precedentes, mas traçando um olhar sobre esse processo no pós-Revolução, pondero sobre as vozes dissonantes acerca da questão racial que se fizeram presentes em vários momentos.

Essas vozes ganham fôlego com as intensas mudanças econômicas e sociais vividas na sociedade cubana após a queda do bloco socialista. É nesse período, com ênfase nos anos 1990 e 2000, que ressurgem alguns coletivos voltados para a pauta racial. As razões para o que denomino "ressurgir" estão vinculadas à própria fragilidade do Estado após a ampla crise econômica. $\mathrm{O}$ agravamento da desigualdade teve significativos impactos sobre a população negra, os recorrentes casos de demissões de negros, especialmente nos espaços laborais dolarizados (provenientes da "economia emergente") como os turísticos, paladares, restaurantes e cooperativas rurais, os insucessos nos processos impetrados na justiça e a falta de perspectivas de mudanças ou respostas a esse quadro, foram fatores que motivaram o surgimento dos primeiros coletivos afrocubanos, depois de décadas de Revolução.

Somam-se a isso, as crescentes relações de Cuba com o cenário internacional, especialmente a partir do contexto da Conferência Mundial de Durban e seus desdobramentos, tanto por parte do Estado, como da sociedade civil. E por fim, a convergência de ideias, debates, reflexões, trocas, expressões artísticas e intelectuais, pesquisas e redes que ganham maior expressividade nesse período. Nesse cenário, foram fortalecidos novos paradigmas de discurso sobre a questão racial, que rompiam com o silencio oficial de décadas e as visões vinculadas ao "mito da igualdade".

Interessante observar que, nos últimos anos, é crescente a produção que discute as relações raciais e traz à tona o legado histórico da população negra em Cuba. São muitos os autores e autoras cubanas, em grande parte negros, que brindam à sociedade estudos sobre diversos períodos, inclusive sobre a contemporaneidade ${ }^{3}$. Todavia, isso ainda não está fortemente presente em diversas áreas do conhecimento. São poucas as pesquisas vinculadas às ciências sociais, por exemplo, especialmente as que envolvem pesquisa de campo. Esse quadro se agrava com a

\footnotetext{
${ }^{3}$ Alguns exemplos que podemos destacar são: MORALES (2012), ZURBANO (2015), ROBAINA (2004, 2012), ROMAY (2012), PRIETO (2006, 2015), RUBIERA et al. (2012), DE LA FUENTE (20I4).
} 
pequena disponibilidade de dados socioeconômicos oriundos de levantamentos como o Censo, desagregados pelo quesito cor, à sociedade em geral.

Nesse sentido, essa pesquisa objetiva ser mais uma contribuição para os estudos sobre a questão racial, de forma a ampliar o debate sobre o tema no país, a partir de suas particularidades políticas, econômicas, históricas e sociais. Está presente, além das especificidades e estratégias mobilizatórias de parte das organizações vinculadas às mobilizações antirracistas em Cuba, o horizonte analítico dessas dinâmicas no Brasil. Portanto, espera-se que o trabalho também possa contribuir para o intercâmbio dessa temática entre os países. Para dar continuidade à introdução, na sequência farei um panorama cubano, com informações amplas, dados sobre a pesquisa de campo e estratégias metodológicas, com o objetivo de melhor situar a investigação.

\section{I. ¡Asérè Cuba!}

Compreender Cuba é, por si só, uma tarefa complexa. Sua economia, redes de solidariedade, dinâmicas sociais e instituições partem de parâmetros, muitas vezes, estruturalmente diferente de outros países latinoamericanos. A complexidade do exercício de compreensão da particularidade cubana no debate do racismo é uma faceta também fundamental.

De acordo com a Oficina Nacional Estatística de Cuba, seu território, localizado na região do Caribe, ocupa 109.884,0I Km2, divididos em um arquipélago composto de Ilhas e cayos (ilhas de porte menor). A população total do país é de cerca de II milhões e duzentas mil pessoas, das quais 2, I milhões de pessoas vivem em Havana e quase 153,5 mil na cidade de Matanzas5 , as duas localidades investigadas na pesquisa ${ }^{6}$.

A população cubana apresenta a proporção de $64,1 \%$ de brancos, $9,3 \%$ de negros e $27,6 \%$ de mestiços, de acordo com o Censo de 2012. Esses são dados muito questionados pelos coletivos e ativistas antirracistas. As ponderações são feitas em relação à metodologia, forma de aplicação dos questionários, até a desagregação dessas informações em dados socioeconômicos no país?

\footnotetext{
${ }^{4}$ Asérè - De origem Carabalí, o termo é bastante presente como linguagem ritual entre os Abacuá, que significa "yo te saludo". Também é falado de forma corriqueira nos diálogos interpessoais do país.

${ }^{5}$ Esse é o quantitativo populacional da cidade de Matanzas. A província de Matanzas, que reúne diversas outras cidades, além dessa, possui 694.476 pessoas, conforme o mapa acima.

6 Fonte: Oficina Nacional Estatística de Cuba (ONE). Dados de 2013. Acesso em: 06/I0/2015. http://www.one.cu/aec2013/esp/OI_tabla_cuadro.htm

${ }^{7}$ Esse debate será aprofundado na seção "A cor dos números", no capítulo 3.
} 


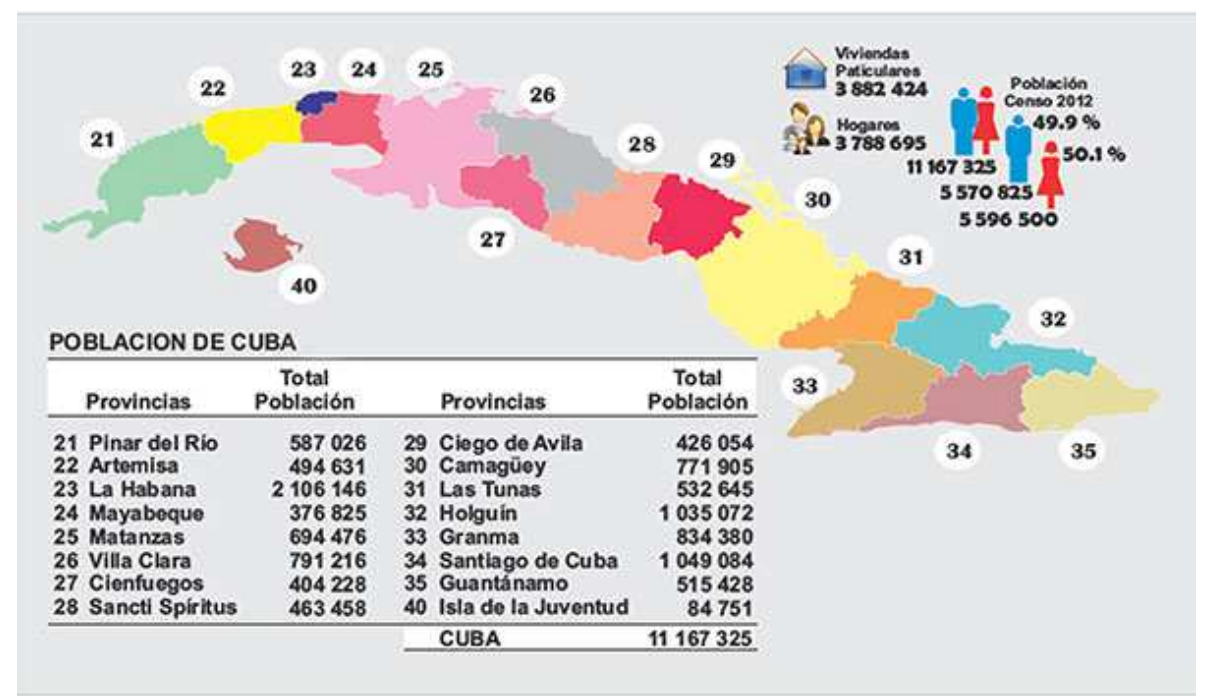

Figura I - Mapa de Cuba, por província e população, 2013. Acesso em: 0I/I0/2015.

Fonte: http://www.juventudrebelde.cu/file/img/fotografia/2013/I I/33057-fotografia-g.jpg

Cuba foi colônia espanhola por séculos, desde a invasão, em I492, e do quase aniquilamento dos povos originários da Ilha. Foi o penúltimo país a abolir a escravidão, realizada em I886, apenas dois anos antes do Brasil. Vivenciou um longo processo de guerras pela independência, que culminou numa intervenção estadunidense, em I899. É declarada República, em 1902, e seus governos tiveram, até 1959, estreita vinculação com os Estados Unidos. Na nova república cubana, período não menos excludente, ocorreu um dos eventos mais marcantes da história da mobilização em prol dos direitos de negras e negros em Cuba. Em I9I2, há um escandaloso massacre dos integrantes do Partido Independientes de Color'.

As lutas e mobilizações antirracistas se mantiveram em outros períodos republicanos, mesmo depois de tamanho massacre, como nas organizações conhecidas como "Sociedades Negras". Em outros casos, ganhou uma roupagem diferente na atuação por meio dos sindicatos, partidos e centrais de trabalhadores. Dentre as pautas, havia a demanda pela necessidade de avançar concretamente em uma legislação que tipificasse e regulamentasse a discriminação racial e de efetivar o acesso da população negra ao mercado de trabalho, a espaços educacionais, econômicos e de poder.

A partir da Revolução de 1959, houve diversas reformas no país, logo em seus primeiros anos, como a nacionalização de empresas, a reforma agrária, a campanha nacional de alfabetização. Foram criadas as chamadas organizações de base da Revolução, como Sindicatos, a Federação de

\footnotetext{
${ }^{8}$ Os registros do massacre divergem no número de mortos, que variam entre dois mil a cerca de cinco mil pessoas negras brutalmente assassinadas pelo exército comandado pelo então presidente José Miguel Gomes. Mais informações no capítulo 2 .
} 
Mulheres, os Comitês de Defesa da Revolução, dentre outros, e, por consequência, desestimuladas outras formas organizativas que não estivessem vinculadas a essa estrutura. Em I962, a Revolução declara seu caráter socialista e sua aproximação com a União Soviética.

Logo em seus primeiros anos, se tornou ilegal qualquer restrição a negros ou brancos em clubes recreativos, centros de trabalho, bairros, instituições. Até a Revolução, a realidade cubana apresentava contextos bastante segregados. Regiões inteiras do país eram proibidas para pessoas negras, como parques e praias. Em poucos meses, uma mudança crescente da cor dos funcionários dos bancos, das universidades, dos clubes e casas de show começou a ocorrer.

Após a série de medidas tomadas nos primeiros anos da Revolução, surge a narrativa socialmente construída, de que o racismo foi erradicado no país, em amplas as esferas da sociedade. Desse período em diante, falar sobre racismo se tornou uma postura antirrevolucionária. Esse processo se enrijece na década de 1970, com o crescimento da influência da União Soviética no país, especialmente nos anos conhecidos como "quinquenio gris".

O silenciamento do debate sobre esse assunto na sociedade de forma geral dificultou enormemente o amadurecimento sobre a temática, o que permite que na atualidade se conviva com piadas racistas em teatros públicos em 20I4. Portanto, mais que uma simples herança do passado, a problemática racial toca a atual sociedade cubana de diferentes formas em várias esferas da vida social.

Com a crise do bloco socialista, no final dos anos 1980, Cuba vivencia uma severa crise econômica, chamada de "período especial"10, cujos impactos são sentidos na sociedade cubana até os dias atuais. Mesmo após quase três décadas de crise, parte das políticas sociais da Revolução apresenta resultados consideráveis presentemente. Para uma brasileira, é impactante chegar a um país latinoamericano e perceber que praticamente não há população em situação de rua. Nos quase dois anos que residi em Cuba, não vi nenhuma criança ou adolescente nessa condição.

\footnotetext{
9 Quinquenio Gris (ou cinza), seria a corrente ideológica cultural fortemente presente nos anos 1970. A partir da denominação criada pelo escritor cubano Ambrosio Fornet, esse seria o período no qual, em nome da pureza ideológica e do compromisso com a Revolução, muitos intelectuais, artistas e tradições foram marginalizados ou silenciados pelo esquecimento. Nesse período, pessoas assumidamente homossexuais e praticantes de manifestações de matriz africana, tais como a Santeria, sofreram repressão e controle.

Io O modelo econômico anterior ao chamado "período especial" era baseado na economia planificada, com característica centralizada e significativa participação estatal sobre os meios de produção. A partir dos anos I990, inicia-se em Cuba a abertura para outras formas de produção, como as empresas mistas, cooperativas, o cuentapropismo (trabalho por conta própria) e outras dinâmicas econômicas que fogem ao padrão planificado do modelo socialista anterior.
} 
Os dados sociais são impactantes para um pequeno país latinoamericano, cuja economia sofre um bloqueio dos Estados Unidos há mais de cinco décadas ${ }^{\text {II }}$. O analfabetismo foi declarado superado já nos primeiros anos da Revolução. Suas taxas mais atualizadas nesse campo estão entre as mais baixas do mundo. Dentre os mais de onze milhões de habitantes, a taxa é de 0,2\%, a menor do mundo, ao lado de Letônia e Lituânia. Anteriormente ao triunfo da Revolução, em I958, 23,6\% da população cubana era considerada analfabeta e esse número chegava a 4I,7\% entre a população rural ${ }^{12}$.

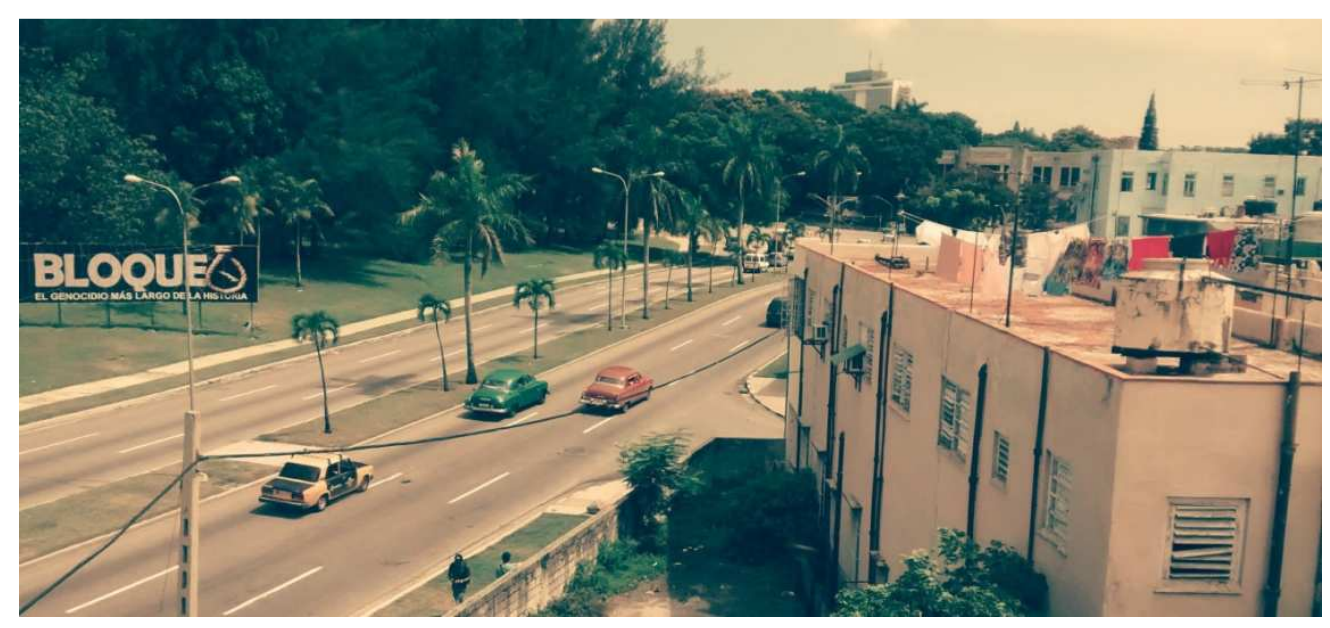

Figura 2: Anúncio alusivo ao bloqueio dos EUA contra Cuba na Avenida Boyeros, Havana, Cuba, 2015. Foto: Bárbara Oliveira.

A Unesco, em 2009, apresentou estudo ${ }^{13}$ que concluiu que os estudantes cubanos, em alguns campos, quase duplicam os resultados dos alunos de outros países da América Latina. Cuba teve $70 \%$ dos seus estudantes com notas acima de 350 pontos de um total de 500, enquanto a média na Argentina, Uruguai e Chile foi de 300 pontos. México e Brasil tiveram uma média instável, na casa dos 250 pontos.

Para além da educação, no campo da saúde há fortes investimentos estatais e o nível de qualidade do serviço é muito superior ao da região. No país, se convive com taxas de homicídios baixas. $\mathrm{O}$ Índice de desenvolvimento Humano - IDH de Cuba é considerado alto, de 0,78. O país ocupa a $58^{a}$ posição, de acordo com o ranking de 20I5. O Brasil, por exemplo, está situado na $85^{\mathrm{a}}$ posição, com uma taxa de 0,73 .

\footnotetext{
II O fim do Bloqueio ainda não se efetivou e, portanto, seus efeitos práticos não são sentidos apesar do processo de reaproximação entre EUA e Cuba, iniciado em dezembro de 2014.

${ }^{12}$ Fonte: ONE, Cuba.

${ }^{13} \mathrm{O}$ estudo da Unesco é periódico e denomina-se Prova LLCE - Laboratório Latino-Americano de Avaliação da Qualidade do Ensino. Esse informe específico foi o Segundo Estudo Regional Comparativo e Explicativo na América Latina e no Caribe, publicado em 2009.
} 
Atualmente, Cuba vive numa atmosfera cinquentista. Os carros fabricados nos anos 1940 e I950, popularmente denominados "almendrons" ${ }^{14}$, circulam pela cidade e representam uma grande parte da frota de veículos. Não há engarrafamentos e os automóveis não abarrotam as cidades, como em outros grandes centros pelo mundo. Os pedestres tomam as ruas frequentemente, ocupadas por meninos jogando bola, ávidos jogadores de dominó, grupos conversando, músicos, pescadores, namorados. As ruas se enchem de cubanos que transitam a qualquer hora do dia e da noite. Os cinemas e teatros de rua também estão presentes em grande número, com entradas a preços cubanos de difícil mensuração em real ${ }^{15}$, exatamente por serem muito baratos.

Há poucos edifícios altos. As cidades são horizontalizadas. E os estilos arquitetônicos se mesclam em meio à urbi. São casarões majestosos do século XVIII e XIX, que demonstram todo o poderio econômico da então potência açucareira, muitos em mal estado, mesclados com edificações feitas nos anos 1940 e 1950, que convergem diversos estilos dentre os quais o Art Decó e o Construtivismo. Há também vários prédios estilo soviético que lembram a arquitetura de edifícios de Brasília, a capital brasileira.

Isso está imerso em um contexto de grande precariedade econômica. De fato, é sintomático como parte das políticas é mantida com relativa qualidade com tão escassos recursos. Todavia, essa carência está presente em outros campos de forma mais significativa. O déficit de moradias é bastante alto e uma parcela da população vive em habitações precárias, algumas inclusive com risco severo de desabamento. Os prédios públicos, em geral, estão em mau estado de conservação. Essa dificuldade estrutural está presente também em universidades e centros de pesquisa, onde costumam faltar alguns materiais básicos como papel, computadores e impressoras. Essas dificuldades econômicas se refletem, também, nas famílias. São fatores que indicam, portanto, que qualquer análise sobre essa realidade cubana precisa ser feita de modo cauteloso, dada a complexidade e a especificidade do país.

Nesses cinqüenta e seis anos de Revolução, buscou-se com muita ênfase a construção da igualdade entre os cubanos e cubanas, com foco na dimensão material e na superação da luta de classes. Construiu-se fortemente a ideia de "unidade nacional", de "somos todos cubanos", ou como José Martí16 destacou: "más que negro, más que blanco, nosotros somos cubanos". E essa busca pela igualdade teve um significativo impacto sobre a diversidade e a alteridade, e sobre a própria discussão sobre as desigualdades raciais.

\footnotetext{
${ }^{14}$ Em uma referência a "grande amêndoa".

${ }^{15}$ O Real é a moeda corrente no Brasil, desde I994.

${ }^{16} \mathrm{Um}$ dos líderes do processo de luta pela independência de Cuba.
} 
A "cor cubana", todavia, não dá conta das diferenças etnicorraciais. A "cor negra" não esteve, como ainda não está, presente de modo equivalente nos meios de comunicação, nos livros didáticos, nos espaços de poder político e econômico. Ainda nos dias de hoje, há uma exaltação da mestiçagem, sendo o "mestiço" o representante da união das raças em Cuba, da unidade ${ }^{17}$. Porém, nos espaços sociais de poder a representação do que em Cuba se considera "mestiço" é pequena. Além disso, o mito da mestiçagem constitui uma estratégia de homogeneização que busca suavizar a percepção sobre os relevos do racismo.

O peso do conceito de mestiçagem (e sua influência no embaralhamento da percepção sobre as diferenças e as desigualdades raciais) se fundiu com o forte discurso de igualdade. Idealizada, a igualdade tem parte de sua inspiração no processo de independência, e ganha força com a Revolução socialista. Nessa trilha, a partir do viés da superação das desigualdades de classes, fundamentou-se a narrativa de construção da nação cubana para "todos os cubanos". Com forte influência do marxismo soviético, as identidades do proletariado se sobrepuseram às demais (ZURBANO, 20I2).

A batalha pela superação das desigualdades materiais, por si só, não foi suficiente para solucionar o impasse do racismo no país. E outros fatores são também presentes na estruturação dessas desigualdades, como o sexismo, a homofobia e o preconceito com a origem camponesa e rural. E sob muitos corpos incide uma sobreposição de estigmas, como o vivenciado pelas mulheres negras. Nesse sentido, a abordagem do presente estudo busca visibilizar diferentes perspectivas da vivência de agentes sociais relacionadas à questão racial.

\section{Giz Cor da Pele}

Antes de prosseguir com a tese, acredito ser fundamental apresentar um pouco de minha trajetória. A minha inserção no debate em Cuba reacendeu questões há muito discutidas em minha família. Quando iniciei minha participação em aulas e debates sobre relações raciais em Havana, escutei de muitos colegas cubanos questionamentos sobre meu pertencimento racial: "você não é negra, é mestiça" ou "aqui em Cuba existem os negros, mulatos, mestiços e brancos. Você estaria na categoria mestiço ou mulata. Negro é outra coisa"18.

\footnotetext{
${ }^{17}$ Aprofundarei essa perspectiva no capítulo I.

I8 Tradução minha.
} 
Essas ponderações feitas atiçaram minha memória. Aos seis anos, na série de alfabetização, a turma realizou uma atividade de comemoração do dia dos pais. Cada criança deveria desenhar o seu pai e descrever suas características. Nesse período, eu era a única negra na minha classe, realidade presente nas escolas particulares de Brasília até os dias de hoje. Lembro bem que todas as demais crianças usaram o giz denominado pelo grupo como "cor da pele", que possui um tom entre o bege e o rosa, para ilustrar os seus pais. Usar esse giz para o meu seria impossível. Busquei o marrom e concluí o desenho. Logo abaixo vinha a descrição: "Moreno, alto, cabelos enrolados". Meu pai agradeceu o desenho e pontuou com firmeza: "Está lindo. Só tem um detalhe: eu não sou moreno, sou negro. E você também é negra".

Desde pequena, convivi com o debate sobre o racismo. Vivenciei uma situação familiar bastante difícil que obrigou todo nosso núcleo a lidar diretamente com a questão. Minha mãe, filha de um casal português, foi duramente criticada por casar-se com um negro. Dentre os adjetivos dirigidos pela minha avó materna ao meu pai e aos filhos, estava "macaco e macaquinhos". $\mathrm{Na}$ adolescência, por diversas vezes, fui questionada se minha profissão era doméstica ou fui incorporada no estereótipo sexualizado da "mulata"19 no Brasil.

Durante a escola pública secundária, no Setor Leste, em Brasília, e também na Universidade de Brasília, onde estudei Ciências Sociais e, mais especificamente, antropologia, realizei atividades, debates, manifestos e ações vinculadas à questão racial e à luta contra o racismo. Participei, ainda na graduação, de grupos de pesquisa sobre o tema, que ampliaram minha percepção sobre o assunto.

Aos vinte e quatro anos, em 2004, me incorporo como parte do quadro da nascente Secretaria de Políticas de Promoção da Igualdade Racial, que no âmbito do Governo Federal, coordena a política de combate ao racismo em nível federal. A experiência na SEPPIR foi importante para possibilitar o contato com uma grande pluralidade de organizações do vasto movimento negro brasileiro. Participei de inúmeras atividades, seminários, conferências com organizações de mulheres, jovens, quilombolas, de tradição de matriz africana, ciganos, empreendedores negros.

Estive presente nas três Conferências Nacionais de Promoção da Igualdade Racial, realizadas no Brasil, respectivamente em 2005, 2009 e 2013. Os milhares de participantes de todos os estados do país debatendo uma multiplicidade de pautas são uma prova viva do quão multifocal é a

19 "Mulata" é um termo de origem pejorativa, utilizado para descrever a fusão branca e negra, em alusão ao cruzamento entre o cavalo e o burro, que geram a "mula". 
questão racial e o quão amplo é o espectro de políticas públicas necessário para a superação do racismo.

A partir do trabalho na SEPPIR, conheci parte das lideranças quilombolas no Brasil. No mestrado, aprofundei minha interação com esse universo. A dissertação final de curso foi voltada para o movimento quilombola no país ${ }^{20}$. No doutorado, a probabilidade se materializa de ir a Cuba, o que se apresentou como um desafio interessante de estudo. Analisar as possibilidades e especificidades das dinâmicas do racismo num contexto tão próximo e distante do que eu provinha se apresentava como uma oportunidade ímpar.

Ao imergir no universo das lutas antirracistas em Cuba, muitas vezes foi necessário me distanciar de perspectivas fortemente presentes no contexto brasileiro, para poder compreender a particularidade cubana. Essa Ilha, localizada a apenas $150 \mathrm{~km}$ de Miami, vivencia uma significativa crise econômica e uma série de fortes mudanças estruturais na sociedade. Nesse contexto, pós-queda do Bloco Socialista Soviético e com a crise do Período Especial, se reacende também a pauta de denúncias e reivindicações antirracistas, debate há muito adormecido no trato com o Estado e com a sociedade para essa temática. Esse processo traz implicações visíveis, mais recentemente, à forma como essa questão passa a ser vista e tratada em Cuba. A pesquisa, ora apresentada, buscou também analisar as dinâmicas de mobilizações políticas coletivas, ideais de vida coletiva e individual e os projetos de futuro dos ativistas e militantes negros e negras em Cuba.

Um dos aspectos interessantes de ter a oportunidade de vivenciar o campo em Cuba para me aprofundar no estudo sobre as relações raciais e sobre as mobilizações antirracistas no país, é contribuir para uma percepção mais ampla do racismo e suas distintas formas de expressão na Diáspora Africana nas Américas. Apesar das inúmeras especificidades, Cuba compartilha muitos elementos vivenciados em outros países das Américas, como o Brasil.

Nesse sentido, sinalizo para a importância do diálogo entre distintos processos americanos sobre o tema, já que o flagelo da escravidão tomou contornos mais contundentes no continente e os reflexos do legado colonial e suas reconfigurações atuais marcam fortemente as relações raciais nesses países. Penso que o intercambio entre essas narrativas particulares possibilita um maior entendimento do processo como um todo e seus efeitos contemporâneos, no que Brasil e Cuba, últimos a abolir a escravidão, são protagonistas.

\footnotetext{
${ }^{20}$ A dissertação, defendida em setembro de 2008, denomina-se "Aquilombar-se: Panorama histórico, identitário e Político do Movimento Quilombola Brasileiro".
} 
A minha entrada na Ilha ocorreu por uma multiplicidade de fatores. Aprofundar o estudo sobre as mobilizações políticas coletivas afrocubanas e acerca das relações raciais em Cuba demandava, necessariamente, uma imersão profunda no campo. De forma a viabilizar essa mudança, foi possível articular a minha vinda para Cuba com toda minha família, uma vez que meu marido pode transferir seu trabalho e seus interesses de pesquisa para Havana, e eu já havia concluído os créditos de disciplinas no doutorado e poderia me dedicar integralmente ao trabalho de campo e à elaboração da tese. $\mathrm{O}$ fato de eu ser bolsista do $\mathrm{CNPq}$ no transcurso da pesquisa foi outro fator fundamental, pois viabilizou parte do custeio, das passagens dentro de Cuba, a compra de grande parte da bibliografia e a possibilidade de que eu participasse em congressos e seminários sobre o tema no país.

Ao ter essa proposta de estudo, fui interpelada por muitos no Brasil sobre a existência de racismo em Cuba. Obviamente, essa seria uma das grandes questões que norteariam meu estudo na Ilha. Algumas análises apontavam para a existência de um racismo "a la cubana" e para um rigoroso controle estatal do debate sobre essa temática. Esses seriam, então, outros aspectos a serem trabalhados na pesquisa. $\mathrm{O}$ aprofundamento dessas e de tantas outras questões só foi possível após o início do trabalho de campo.

Ainda no Brasil, na preparação para o exame da qualificação para o doutorado, pude perceber a dificuldade de acessar materiais cubanos sobre o tema. Há pouca coisa disponível na internet e praticamente nada em livrarias ou bibliotecas brasileiras. A invisibilidade sobre relações raciais em Cuba é bastante significativa no Brasil, apesar dos vários laços históricos que nos aproximam nesse tema. Uma ida a Cuba era vital não apenas para fazer o trabalho de campo, mas também para acessar a bibliografia e os dados sobre o assunto.

Assim, nos últimos dias de dezembro de 2013, numa manhã de sol, pousava em Havana o avião que transportava eu e minha família. Era o inicio da jornada dos 18 meses de pesquisa de campo do doutorado. Em poucos dias no país, pude presenciar algumas cenas que indicavam a complexidade do que se avizinhava.

$\mathrm{Na}$ parte antiga da cidade de Havana, conhecida como Habana Vieja, há diversas mulheres que oferecem o serviço de tranças "afro" aos transeuntes que cruzam as ruas. Ao dialogar poucas palavras com uma delas, me foi relatada a diferença de um cabelo "bom" e um cabelo "ruim": a qualidade. O primeiro, liso, seria de melhor "qualidade". O segundo, "crespo", teria uma qualidade inferior, o que justificaria a denominação para o cabelo "bom" e "ruim". Interpelada sobre a possibilidade dessa afirmação ser racista, minha interlocutora teve uma reação explosiva e 
afirmou: "se no Brasil isso é racismo, é um problema de lá. Aqui em Cuba isso não é racismo, pois racismo aqui não existe ${ }^{\prime \prime 2 I}$.

Outro episódio marcante se deu na apresentação que assisti, durante o Festival Internacional de Circo, em Havana, em agosto de 20I4. Na abertura do espetáculo, um número buscava representar a tríade racial conformadora do país: um "galego", uma "mulata" e um "negro". A mulher negra estava representada como uma "mulata sexualizada", que se dividia na relação entre o "galego" e o "negro", fato que, por si só, já indicava os preceitos estigmatizados presentes na cena. Mas, o mais complexo ainda estava por vir, o ator que representava o negro era, para minha surpresa, branco, e tinha o rosto e pescoço pintados de preto, uma boca bastante estereotipada, além de luvas e peruca para complementar o visual de seu personagem.

Visualizar na apresentação de comédia a naturalização da estereotipia do fenótipo negro num corpo branco me trouxe algumas perplexidades. Haveria ausência de profissionais negros para tal representação, num país cuja presença afrodescendente é tão significativa? A representação estereotipada negra ali feita, já abolida em boa parte do mundo, é um lugar comum da comédia nacional cubana?

Em Cuba, há uma histórica tradição do teatro Bufo, muito popular no século XIX, baseado nos arquétipos do "el negrito", "la mulata" e o "el gallego". Como reflete Inés Maria Martiatu Terry (2000), do ponto de vista da representação simbólica, o fenômeno Bufo tinha como pano de fundo diferentes aspectos, sendo a nacionalidade é um deles. Importantes ideólogos dessa época, como Francisco de Arango y Parreño e José Antonio Saco, além de defender a construção da Nação Cubana, independente da Espanha, sonharam com o branqueamento da Ilha, enfatizando "el miedo al negro" e a não aceitação dos africanos e seus descendentes como cubanos. José Saco excluía os africanos e seus descendentes do projeto em construção da Nação cubana: "Branquear, branquear e depois nos fazer respeitar" ou "Cuba seria branca e poderia começar a ser cubana". Eram elementos que compunham o contexto de nascimento do teatro Bufo.

O intrigante é a manutenção dos arquétipos básicos do teatro Bufo em pleno século XXI, sem aparentes questionamentos. O que propulsiona esse tipo de representação em Cuba na contemporaneidade? Nicolás Guillén, reconhecido poeta cubano, negro, nascido em 1902, pontuou décadas depois de José Saco e outros pensadores do final do século XIX, que "Cuba já sabe que é mulata. Mas, não quer ser, quer se passar por branca".

\footnotetext{
2I Tradução livre minha. Fala original em espanhol.
} 


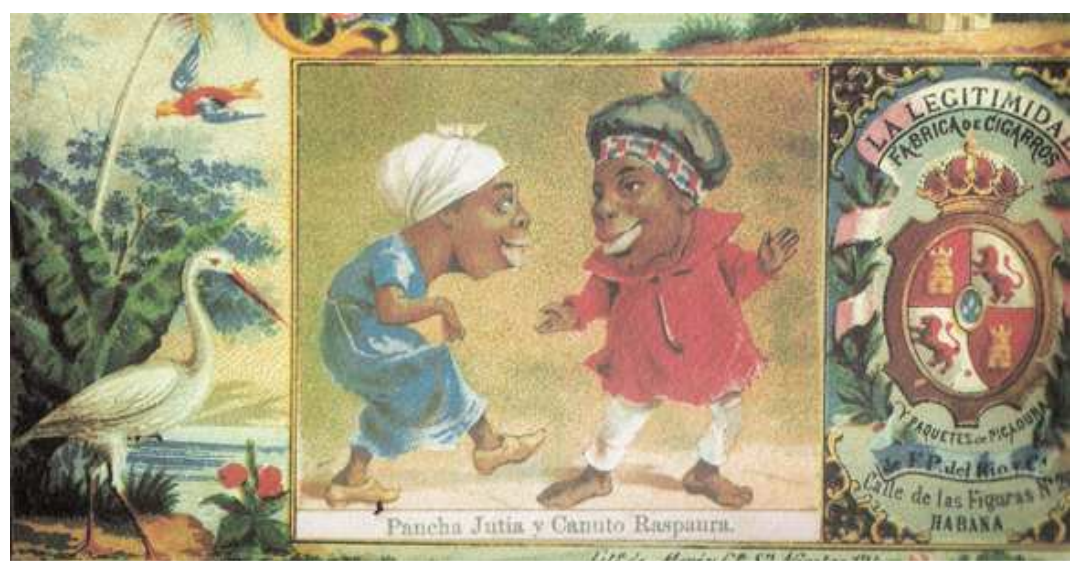

Figura 3: "La Boda de Pancha Jutía Y Canuto Raspadura". Litografia de Víctor Patrício de Landaluze, final do Séc. XVIII. Ilustração representativa do Teatro Bufo, com estereotipia dos traços fenotípicos negros ${ }^{22}$.

Para poder imergir nesse universo, para além das experiências cotidianas, o registro oficial dessa pesquisa junto ao governo cubano era fundamental. As preocupações antes de vir a Cuba eram muitas no que se referia à autorização para pesquisa. Os planos para o doutorado poderiam tornar-se muito restritos caso não fosse possível obter a autorização oficial. As primeiras tratativas para essa licença foram dialogadas com o Instituto Cubano de Investigação Cultural Juan Marinello, vinculado ao Ministério da Cultura. Após cerca de oito meses de processos de análise, o Instituto aprovou a vinculação da presente pesquisa ao seu corpo de investigações. Com as cartas de autorização do Instituto Juan Marinello assinadas, foi possível transitar por bibliotecas, arquivos públicos, realizar as entrevistas e participar da disciplina de pós-graduação na Universidade de Havana sobre relações raciais.

Cursar o diplomado de pós-graduação², "Cuba: Genes, Culturas, y Racialidades", na Universidade de Havana, coordenado pelo professor Dr. Antonio J. Martínez Fuentes, foi uma oportunidade ímpar no processo de entrada em campo. Nesse curso, foi possível conhecer uma série de atores fundamentais no debate e no estudo das relações raciais em Cuba. Além do conhecimento propiciado pela leitura e discussão de textos, a partir das aulas pude marcar entrevistas e conhecer projetos desenvolvidos em Cuba.

A necessidade do exercício do estranhamento, na pesquisa, me impulsionou, na medida do possível, a buscar desnaturalizar conceitos sobre como a organização desses grupos é estabelecida, a própria ideia de movimento social e as relações com o Estado nacional. Definitivamente, a realidade cubana se mostrou como um universo à parte.

\footnotetext{
${ }^{22}$ Editada pela Oficina do Historiador da Cidade de Havana, Ed. Canaricard, I995.

Disponível em: http://hemisphericinstitute.org/hemi/es/e-misferica-52/martiatuterry (acesso em 04/03/2015).

${ }^{23}$ Categoria de curso de pós-graduação.
} 
Primeiramente, me causou estranheza o fato de uma parte das organizações antirracistas possuir alguma articulação ou vinculação institucional com os órgãos estatais e nenhuma delas ter um caráter oficializado. Não são legalizadas como associações, organizações não governamentais. $\mathrm{O}$ acesso a esse processo de legalização do associativismo ainda é restrito no país. Apesar da não legalidade, essas organizações têm uma atuação cotidiana e parte de suas ações ocorrem, inclusive, em espaços estatais, como muitos dos debates e conferências realizados. Têm, portanto, uma existência não legal, mas de fato.

Em segundo lugar, são grupos que têm objetivos e demandas apresentadas de maneira diferente do que tradicionalmente podemos observar no Brasil. O debate cubano sobre ações afirmativas em universidades, por exemplo, se apresenta de modo incipiente (ROBAINA, 2004). O principal foco é a sensibilização para a existência do racismo e a inserção da temática no cotidiano das comunidades. Outras demandas envolvem a regulamentação do crime de racismo, a relação com a polícia e a visibilidade de ícones históricos afrocubanos.

Mais uma dimensão que merece destaque é a experiência de viver em Havana como estrangeira, um forte marcador identitário. Os brasileiros, por serem latinoamericanos, são vistos como mais próximos. Há um verdadeiro frenesi com as novelas brasileiras e com o carnaval, especialmente o que chega às televisões cubanas, provenientes do Sambódromo do Rio de Janeiro. Na percepção de muitos cubanos, a proximidade dessas nações deve-se à forte influência cultural de povos africanos, como os Yorubanos e os provenientes do tronco lingüístico Bantu tanto em Cuba como no Brasil. Como exemplo, citam que, fenotipicamente, há semelhança entre as pessoas que caminham em ruas de Havana ou de Salvador. A musicalidade é outro elemento agregador das identidades cubanas e brasileiras na visão local.

Todavia, mesmo com esses fatores presentes, o fato de ser estrangeira marcou minha estada em Cuba, sobretudo no início das relações. Na Ilha, há um termo usado para identificar os estadunidenses, mas que também é aplicado para muitos estrangeiros, especialmente europeus e canadenses: Yuma. E o que é ser yuma em Cuba? O que se escuta, com regularidade, é que yumaé uma derivação lingüística de "yunai", termo bastante usado na Costa Rica, que é derivado de United (United States). Há também quem vincule sua origem com o filme de I957 "3:10 to Yuma" ou em espanhol "el tren de las tres a Yuma". O termo é usado, em outras ocasiões, para referir-se aos Estados Unidos propriamente: dito "me voy para la yuma", ou vou para os Estados Unidos. 
Dado os efeitos do bloqueio econômico vivenciado no país há mais de cinco décadas e as carências materiais existentes - como o acesso a equipamentos, produtos tecnológicos, medicamentos não existentes no país e outros produtos, parte das vezes as relações estabelecidas com os yumas envolvem também o objetivo, ainda que implícito, de obter bens de consumo, recursos, ou mesmo viagens ao exterior. Afinal, a realidade é de uma significativa escassez de recursos e uma disputa acirrada pelos mesmos.

Essa disputa entre os ativistas é mais ampla, de ordem protagônica e de capital simbólico. Dado o contexto de escassez material de Cuba e os limitados contatos com o exterior (seja pela restrição de internet, bibliografia, viagens, dentre outros), o acesso a esses universos se torna emblemático e os conflitos derivados disso parte das vezes se fazem presentes nas relações estabelecidas entre lideranças. São disputas, em algumas ocasiões, presentes em outros contextos, como o brasileiro e o colombiano, entre ativistas de movimentos sociais.

Em Cuba, ocorrem tentativas de invalidar ou neutralizar as demandas e argumentações desses coletivos, a partir da exaltação desses conflitos oriundos da disputa por recursos materiais ou simbólicos. Todavia, a complexidade da pauta racial e da luta antirracista é muito mais ampla e relevante. Portanto, tentativas de deslegitimar a visão crítica a partir de tais argumentos, traz implicitamente uma resistência ao debate sobre o racismo e sobre a problemática racial.

\section{III. "Isso fica entre nós"}

Nessa seção, compartilho um pouco das experiências e conflitos vivenciados durante o trabalho de campo e abordo escolhas metodológicas do estudo. A frase ouvida por mim inúmeras vezes: "isso fica entre nós”, exemplifica, em parte, a tensão que vivi nas relações construídas durante a pesquisa.

O que fica restrito à dimensão pessoal? O que se refere à esfera pública e pode ser explicitado na tese? Como se enredam essas relações? Como foi a chegada num país estrangeiro? Nova cidade, nova dinâmica, novas pessoas, outra língua, outros diálogos e perspectivas. Enfim, são questões que tornam esse momento da pesquisa e as interações dela geradas um complexo difícil de descrever. Minha intenção é tentar, ao menos, refletir sobre alguns dos elementos desse processo. 
O estudo foi desenvolvido seguindo os padrões de uma etnografia por meio da observação participante. As técnicas utilizadas baseiam-se, primordialmente, na observação intensa e participante dos espaços de discussão e das ações empreendidas pelos agentes sociais e organizações coletivas vinculadas às mobilizações contra o racismo no contexto cubano. Acompanhei, de forma sistemática, diversas atividades promovidas por esses coletivos, nos quase dois anos da pesquisa.

A pesquisa envolveu, ainda, entrevistas livres realizadas com lideranças e ativistas, bem como pesquisadores e estudiosos do tema, além do levantamento de dados secundários sobre o assunto, disponibilizados no arquivo público, bibliotecas e outras bibliografias relacionadas. As entrevistas enfocaram, ademais de temas voltados às organizações antirracistas, narrativas de vida das lideranças e relatos memoriais de fatos vivenciados que impactaram a percepção do entrevistado ou entrevistada em relação às relações raciais na Ilha.

Creio ser importante refletir sobre a própria prática da observação participante, posto que não se traduz como uma relação dada, que transcorra sem ocorrências ou causalidades. Estabelece-se uma dinâmica complexa, na qual o universo estudado e seus sujeitos te observam como alguém que tem um papel para além da participação e interação social. No trabalho de campo, essa relação foi diversa para mim, envolvendo um misto de euforia, ansiedade e temor pelo contato com o novo, e os desafios que esse contato impunha.

Especialmente nos primeiros encontros, foi perceptível nas interações uma grande receptividade com o universo brasileiro e com a luta contra o racismo em meu país, com destaque para as organizações do movimento negro, os avanços legais e para as políticas públicas voltadas para igualdade racial. Por outro lado, muitas vezes, meus interlocutores e interlocutoras eram explicitamente cautelosos com as palavras, o que ressaltava o cuidado na interação com alguém que estudava o tema e agentes sociais vinculados.

Interessante também perceber que essas relações foram sendo moldadas ao longo do tempo, e em alguns casos se traduziram em vínculos mais próximos e afetivos, que permearam outras esferas para além da pesquisa. De toda forma, a cautela novamente surgia em determinadas situações nas quais uma informação ou cena vivenciada era ocasionalmente classificada como inapta para a pesquisa: "isso que estou te falando não pode entrar na tese. Fica entre nós".

Gerald Sider (1993: 23), em seu estudo sobre o povo Lumbee, faz uma abordagem interessante que complexifica esse processo da observação participante. $O$ autor relativiza a ação de participar 
e simultaneamente examinar à distância as relações sociais e materiais onde estamos imersos. Em geral, essas relações geram muita tensão nas pessoas que estão sendo estudadas e também nos antropólogos e antropólogas. Sider destaca que não se pode desconsiderar a interconexão entre o conhecimento e a precaução, presentes nessa relação. As pessoas que estão sendo estudadas são, com todo o direito, cautelosas.

Geertz (1989), sobre as interpretações levadas a cabo em uma pesquisa, fala da produção de conhecimento por meio da riqueza, da textura e do detalhe, ao invés da parcimônia, do refinamento e da elegância - no sentido usado pelos cientistas naturais. Assim, a busca nesse estudo foi reunir a maior quantidade de dados, visando uma contextualização das dinâmicas locais, e um diálogo qualificado do processo de elaboração da etnografia e das relações estabelecidas nessa construção.

Dialogo também com o que reflete Ortner (1995) sobre a etnografia como uma tentativa de compreender outra forma de vida, sendo a "pessoa" o instrumento de conhecimento. Essa tentativa de conhecimento é intimamente ligada ao trabalho de campo, à vivência etnográfica, que permeia, simultaneamente, aspectos intelectuais e morais, a partir de processos construtivos e interpretativos, em uma dinâmica corporal dada em espaço e tempo.

Porém, acho fundamental complexificar a relação muito presente nos estudos etnográficos entre a pesquisadora e o informante, cujo olhar muitas vezes reproduz esse último como "objeto" da pesquisa. José Jorge de Carvalho (2002) faz reflexões relevantes no que se refere à voz e ao silenciamento nos estudos etnográficos.

Em interlocução com esse autor, parto da premissa que o universo de coletivos e ativistas por mim estudados é composto por sujeitos, que se posicionam e que, inclusive, por vezes, divergem de meus pontos de vista. O que busco realizar é um diálogo com esses pares, com esses sujeitos, sobre as questões que norteiam esse estudo. No processo de investigação e posteriormente a ela, esse diálogo foi estabelecido e deverá ser mantido, sendo essa pesquisa uma das perspectivas possíveis ao debate sobre as mobilizações antirracistas e a questão racial em Cuba.

Entrevistas livres, gravadas e não gravadas, conformaram parte importante da metodologia. Além das entrevistas, busquei, na medida do possível, o registro fotográfico e áudio-visual. Como instrumental utilizei um gravador, máquina fotográfica, tripé e caderno de campo. Para o desenvolvimento desta pesquisa, trabalhei também com fontes documentais, gravação de seminários e encontros sobre o tema racial, textos escritos por ativistas e pesquisadoras/es do 
tema, além de matérias jornalísticas, programas televisivos, filmes e documentos governamentais e de organizações antirracistas.

O momento das entrevistas e a interação ali existente entre a antropóloga e a pessoa entrevistada é extremamente sensível e se reflete, também, nos resultados advindos desse diálogo. As reflexões de Le Ven et al. são interessantes:

\begin{abstract}
Durante o processo (às vezes longo, às vezes curto, mas sempre intenso de realização das entrevistas [...], o ponto que mais nos intrigou - e sobre o qual mais conversamos, foi o momento da entrevista. Não o momento de análise dos dados ou o processo técnico da transcrição, nem mesmo questões sobre utilização e importância desta metodologia, mas o instante da entrevista. Este instante, foi o que sentimos, é mais que mera parte de uma técnica (ou mesmo da utilização de uma metodologia) e comporta dimensões possivelmente inesperadas numa investigação acadêmica (LE VEN et al., 1997: 2I4).
\end{abstract}

O instante da entrevista apresenta dimensões subjetivas dos sujeitos entrevistados que perpassa, dentre outros aspectos, sobre a memória. $\mathrm{O}$ ato de rememorar implica o passado e o presente. No caso em questão, das entrevistas com lideranças do Movimento Antirracista Cubano, rememorar remete ao passado vivido e ao passado idealizado, transmitido oralmente pelas gerações. Ainda sobre a memória, cabe destacar a seletividade da mesma, ou como Le Ven et al. (I997) mencionam, a memória do esquecimento.

[...] a memória permite a relação do corpo presente com o passado e, ao mesmo tempo, interfere no processo 'atual' das representações. Pela memória, o passado não só vem à tona das águas presentes, misturando-se com as percepções imediatas, como também empurra, 'desloca' estas últimas, ocupando o espaço todo da consciência. A memória aparece como força subjetiva, ao mesmo tempo profunda e ativa, latente e penetrante, oculta e invasora (BOSI, 1987: 9).

A memória, fortemente presente no momento da entrevista, é um elemento importante para reflexão da prática etnográfica. Além da memória, outra dimensão relevante diz respeito aos lugares e papéis desempenhados pela "pesquisadora” e pela "pesquisada”. São muitos os autores pós-coloniais que complexificam essa relação, como Spivak (1999) e Hall (2006, 1997). Desestrutura-se o lugar do "pesquisador(a)" isento, imparcial e do "pesquisado(a)" irreflexivo(a), além de serem postas em evidência as relações de poder estabelecidas entre as partes envolvidas. Nessa perspectiva, o deslocamento de eixo traz rebatimentos também para a lógica colonial e póscolonial que permeia o contexto no qual o conhecimento é forjado.

[...] o projeto fundamental dos teóricos pós-coloniais latino-americanos de antes era a tarefa da descolonização. Essa tarefa foi deixada de lado, por um bom tempo, com o crescimento da nossa absorção do olhar universalizante da Antropologia europeia e, mais recentemente, norte-americana. [...] O ponto central que está por trás do olhar pós-colonial é lutar, como diz Mignolo, por um deslocamento do locus de enunciação, do Primeiro para o Terceiro Mundo. O interesse é de relocação. Não se trata apenas de devolver o olhar - o que é um pouco a alternativa colocada pela crítica da reflexividade nas etnografias mas de tentar mudar a origem do olhar, exercitando assim o que ele chama de uma hermenêutica pluritópica (CARVALHO, 200I: II9). 
Ao avançar na discussão, Carvalho pondera que a condição de subalternidade é a condição do silêncio. Nesse debate, recupera Spivak em uma discussão sobre a Índia, que pode nos interessar. Ao abordar o debate sobre a queima das viúvas (ritual conhecido como sati), feito tanto por tradicionalistas indianos quanto com os colonialistas ingleses, Spivak invoca um horizonte de significantes que a distingue das visões anteriores geradas sob uma ótica ocidentalizada.

A autora argumenta que o significante sati vem dos Vedas e do Dharmasastra, textos sagrados de mais de três mil anos de antigüidade. Ao reinterpretar esse significante, Spivak constrói um suporte hermenêutico que desafia a pretensão da modernidade europeia de resolver teoricamente as questões colocadas pelos pensadores de hoje, independente de onde se situem. Essa profundidade temporal desloca o caráter periférico da sua condição de indiana. Há, portanto, uma realocação do lugar privilegiado de fala, da ótica privilegiada. É a voz do lugar subalterno tendo espaço de se posicionar.

Percebo a importância desse debate no contexto da pesquisa sobre as relações raciais em Cuba, e as organizações ali presentes que constroem suas estratégias a partir de suas particularidades locais. O olhar, portanto, de uma brasileira, negra, que acompanha as mobilizações políticas de organizações negras no Brasil, sob uma realidade distinta, mas inserida no contexto latinoamericano, possiblita uma ótica diferente sobre o assunto.

Ao empreender uma escrita etnográfica, busco evitar a representação dos "outros" como sujeitos abstratos e a-históricos. Na construção de sua trama identitária, sociedades e grupos étnicorraciais constroem complexas imagens de si e dos outros que os cercam, bem como das relações de poder e de conhecimento que os envolve.

As reflexões sobre os diálogos estabelecidos com o "outro" e a materialização desses na escrita etnográfica, me remete a James Clifford:

Com a expansão da comunicação e da influência intercultural, as pessoas interpretam os outros, a si mesmas, numa desnorteante diversidade de idiomas. [...] Esse mundo ambíguo, multivocal, torna cada vez mais difícil conceber a diversidade humana como culturas independentes, delimitadas e circunscritas. A diferença é um efeito de sincretismo inventivo (CLIFFORD, I998: 58).

A ciência, em nenhuma de suas leituras, pode efetivar e ratificar a "verdade" de tais imagens. Desse modo, em sintonia com reflexões de Doria (200I), me deparo com os impasses colocados pela impossibilidade do uso acrítico das teorias e dos modos de operação de escrita que produzem, preservam, cultivam "verdades" não perecíveis. A escrita etnográfica, 
fundamentalmente, se articula num enredo de palavras que concretiza as relações estabelecidas com o "outro".

Muito mais do que o método (que permeia a seleção de informantes, a transcrição de textos, de genealogias, dentre outros), a escrita etnográfica envolve nossa construção das construções de outras pessoas. Traz uma dimensão relacional fundante. O fazer etnográfico é a tentativa de empreender uma leitura a partir de outras leituras, percepções e inserções sociais.

A pesquisa realizada em Cuba teve como foco principal Havana e Matanzas, cidade situada a cerca de $90 \mathrm{~km}$ da capital. O tempo de trabalho de campo totalizou um ano e seis meses, de janeiro de 2014 a julho de 20I5. Até a finalização da escrita, em novembro de 20I5, estivemos eu e minha família morando em Havana.

Participei de dezenas de reuniões de coletivos antirracistas, cursos, oficinas, seminários, mobilizações, encontros e debates sobre o tema. Acompanhei, também, a repercussão da questão nos meios de comunicação, TVs, jornais impressos e rádio. Pude cursar a segunda fase do primeiro curso sobre a questão racial na pós-graduação de $\mathrm{Cuba}^{24}$. Em Cuba, também foi possível acessar ampla bibliografia e filmografia produzida, sobretudo, nos últimos anos. A maioria desses exemplares é financiada pelo Estado cubano e sua venda ou distribuição é feita em livrarias estatais. Outras fontes de pesquisa foram os blogs e sítios na internet sobre o tema, tais como negracubanateniaqueser.com ou afrocubaweb.com.

Foram realizadas trinta e cinco entrevistas com lideranças, ativistas e estudiosos e estudiosas do tema. Ao todo mais de sessenta horas de entrevistas gravadas, além das demais oriundas de debates, seminários e atividades desses coletivos ou relacionados ao tema que somam oitenta horas adicionais. Parte considerável desse acervo tem registros de áudio, vídeo e fotografias das atividades que acompanhei.

Ademais dos encontros promovidos pelas organizações antirracistas de Cuba que participei, cabe mencionar a realização do Seminário "Identidades e Mobilizações Coletivas: Perspectivas desde diferentes contextos americanos", que reuniu pesquisadores, professores e ativistas do Brasil, Canadá e Cuba. Sob coordenação minha, de Daniel Brasil, Caridad Massón e Rodrigo Espina, o Seminário foi realizado entre os dias I4 a I6/04/2015, em Havana. Constituiu-se como um momento rico de debate para essa pesquisa, pois vários debates enfocaram as mobilizações negras e a luta contra o racismo no país e nas Américas.

\footnotetext{
${ }^{24}$ Coordenado pelo professor Dr. Antonio J. Martínez Fuentes, da Faculdade de Biologia, Cátedra de Antropologia.
} 
Para concluir essa parte introdutória, destaco o quanto a experiência de morar em Cuba no período da pesquisa foi significativa para mim, tanto como pesquisadora quanto como pessoa. Foi uma vivência singular envolta em grandes acontecimentos, como a reaproximação, depois de décadas de rompimento, das relações de Cuba e EUA, junto a fatores relacionados às minhas próprias vivências, que possibilitaram a expansão de minha consciência de ser parte de uma dinâmica Afrodiaspórica mais ampla. As trocas que tive nesse período, especialmente com as e os ativistas com os quais dialoguei, ultrapassam as fronteiras desse estudo. São legados que carregarei comigo para a vida. 


\section{Capítulo I - Del Fondo del Caldero}

El viaje más largo empieza por el primero paso ${ }^{25}$

Tato Quiñones

O que significa "el fondo del caldero" e por que essa expressão abre o capítulo, estabelecendo aqui uma relação direta com as mobilizações coletivas antirracistas? A expressão "el fondo del caldero" refere-se aos que estão embaixo, na rabeira da sociedade, excluídos, remete à subalternidade. É uma expressão que aparece muito nas narrativas e reflexões sobre racismo em Cuba, exatamente por perpassar uma das motivações das mobilizações: embaralhar as disposições sociais dadas, nas quais as desigualdades raciais são naturalizadas e invisibilizadas. São, majoritariamente, os negros e negras que ocupam o fundo da caldeira.

A sociedade cubana, assim como a brasileira e tantas outras formadas pela lógica colonial, é fundada na violência. Estruturada na eliminação do outro, no genocídio, primeiro dos povos indígenas, depois dos africanos e seus descendentes. E a eliminação se dá por dois caminhos: a primeira é física. A segunda se concretiza pela negação da identidade, pela invisibilidade, pelo esquecimento, ou, a partir do que Clastres (1996) denomina etnocídio. Na trilha desse estudo, é possível observar que em distintos períodos da história cubana, negras e negros se organizaram, se rebelaram e denunciaram a situação de violência e de exclusão que vivenciavam. E continuamente foram silenciados, seja pela força física ${ }^{26}$, seja pela invisibilidade e pelo silenciamento. Em ambos os casos, a negação do outro é o enredo da canção.

Há, todavia, o movimento contra-hegemônico, a voz que insiste em se opor, em apresentar outra perspectiva, em contestar o status quo. Tomando o rumo argumentativo de Hall (2006), são efetivas as "guerras de posições culturais" travadas por aqueles que entoam um discurso não hegemônico e marginal. E nesse lugar se encontra o discurso antirracista e as ações dessas mobilizações coletivas em Cuba.

Trabalho com a perspectiva de que os movimentos sociais negros antirracistas em Cuba incorporam em suas narrativas a luta pela abolição da escravidão, as mobilizações por direitos e igualdade na República e as iniciativas e ações empregadas no período Revolucionário,

\footnotetext{
${ }^{25}$ Tradução minha: A viagem mais extensa começa pelo primeiro passo.

${ }^{26}$ Como no caso do ataque aos membros do Partido Independiente de Color (1912) e da Conspiración de la Escalera (1812), conforme detalharei a seguir.
} 
especialmente a partir dos anos 1990 e 2000. São significativos os avanços obtidos no que se refere à visibilidade e à própria mobilização para o tema, nos últimos anos. Há uma ou duas décadas atrás, debates públicos e notícias sobre a questão racial na imprensa eram impensáveis, como destaca Tato Quiñones ${ }^{27}$ :

Yo puedo decirte que sí y lo he vivido a lo largo de toda mi vida, una reunión como la que hubo hoy en La Casa del Alba (sobre racialidad en Cuba, realizada en abril de 20I4) era impensable. Impensable hace 20 años atrás. Lo que se ha publicado sobre este tema en los últimos años en Cuba supera con creces todo lo que no se publicó en los años 1960 hasta los 1990. Lo que ha pasado en los propios medios de comunicación y los cursos sobre África y las Mesas Redondas sobre el racismo, el reconocimiento de que el racismo existe y sobrevive en Cuba. Si hay racismo hay discriminación porque el racismo no es una entelequia, es una subjetividad como es el prejuicio racial, se sabe que eso existe y como se expresa en la realidad y la expresión de la realidad es la discriminación y la discriminación siempre es un acto de poder. (Entrevista com Tato Quiñones, realizada em 29/05/2015).

Apesar das conquistas alcançadas nos últimos tempos e do crescimento dos grupos que atuam com a temática, o espaço que as organizações e coletividades compartilham ainda é da invisibilidade e, muitas vezes, da desconfiança. Quando avançam um pouco em seu trabalho, não raro surgem acusações de dissidência e contra-revolução.

E quem são essas e esses que insistem em pontuar, em contestar, em mover-se sobre o tema? São ativistas que manifestam suas posições em debates, conversatórios, boletins, blogs, coletivos, artigos, trabalhos comunitários, mesmo que de forma muitas vezes tímida, desarticulada. E podemos chamá-los de movimento social? Podemos dizer que seriam um movimento antirracista? Um movimento negro ou afrodescendente que é parte da sociedade civil cubana?

Falar sobre movimentos sociais, e mais especificamente, movimentos afros em Cuba, é sempre complexo. A realidade cubana é única nas Américas. Seu modelo político não dialoga com nenhum outro no continente, o que torna a aplicação do olhar teórico tradicional sobre as mobilizações sociais em Cuba um pouco desviada.

Nesse capítulo, busco dialogar com teóricos de movimentos sociais e de movimentos negros com a especificidade cubana, sempre tendo como eixo a narrativa de ativistas e militantes cubanos. Algumas rotas obrigatórias cruzam esse caminho: contextualizar o debate sobre relações raciais e racismo na América Latina; enfrentar o desafio do discurso da mestiçagem para as mobilizações negras; compreender o nacionalismo e a construção da identidade cubana; debater sobre as identidades essencializadas que permeiam esse tema; refletir sobre agência e relações de poder e

\footnotetext{
${ }^{27}$ Escritor, jornalista e Babalawo. Foi membro da Cofradía de la Negritud e é autor do boletim digital Desde La Ceiba, importante veículo de comunicação do ativismo antirracismo. Meu contato com Tato iniciou em debates e seminários que assistíamos sobre o tema racial em Havana, em 20I4. Depois se aprofundou em entrevista marcada em sua casa, além dos diversos contatos e interações relizados em atividades que realizamos juntos no bairro La Marina, em Matanzas.
} 
resistência; e, por fim, analisar os movimentos sociais e a atuação da sociedade civil à luz das mobilizações antirracistas.

O caminhar se inicia numa perspectiva mais ampla, numa análise do contexto latinoamericano, para aterrissar mais a frente no caso cubano. George Marcus (I986) aponta a importância de uma contextualização das etnografias, muito vinculadas ao local, com contextos e processos mais globais. Creio que essa seja uma perspectiva fundamental para o presente estudo. As mobilizações antirracistas em Cuba estão embebidas de um contexto mais amplo, regional e internacional, com o qual dialoga e constrói vínculos e distanciamento, mas que não pode ser ignorado e invisibilizado.

Lao-Montes (2009) destaca quatro períodos importantes do que ele denomina "política negra na América Latina". O primeiro são os "movimentos assistêmicos" do período colonial, cujo apogeu ocorreu no século XIX. O segundo, que vai de I9I4 a 1945, permeia o que ele denomina a "consolidação dos movimentos negros em todo o Atlântico", onde surge o panafricanismo e a Associação Universal para o Melhoramento Negro -UNIA, que vivencia seu apogeu nessa época. Também menciona as organizações negras de caráter nacional, como a Frente Negra, no Brasil. O terceiro envolve um período da década de 1940 a I970. Os anos I945 a I955 ficaram marcados por um ciclo sistêmico de lutas pela descolonização na África, Ásia e Caribe. Entre 1955 e 1975, cabe destaque os movimentos afroamericanos dos Estados Unidos, e o movimento pelos direitos civis, que geraram reflexos para a Diáspora. O quarto momento abarca o final dos anos 1980 e início dos 1990 até a atualidade. Marca os processos constituintes latinoamericanos até a Conferência da ONU de Durban, em 2001.

Ao analisar o contexto mais amplo das mobilizações negras na América Latina, e em diálogo com Lao-Montes, identifico quatro marcos temporais que, em diferentes países e contextos, apresentam similitudes que nos instigam a pensar amplamente os fluxos e refluxos da Diáspora Africana na América Latina. Esses marcos tiveram grande influência nos diversos países da região, com ênfase naqueles com significativa população negra tais como Cuba, Brasil e Colômbia.

O primeiro, entre os séculos XVIII e XIX, é o período de lutas pela abolição da escravidão, em muitos casos mescladas com as lutas pela independência. Um dos eventos de maior relevância desse período é a Revolução Haitiana, que desestruturou diversos paradigmas simbólicos, econômicos e políticos da época. A partir da luta pela abolição da escravidão, galgou-se o processo de independência. Surge, então, a primeira República nas Américas. Tudo isso capitaneado por negros e negras, que em sua maioria iniciou as primeiras batalhas na condição de 
escravizados. O Haiti passa a ser a grande referência libertadora e a inspirar processos revolucionários e rebeldes. Também influenciou o crescente "medo ao negro", que em Cuba foi levado às últimas conseqüências em várias situações durante o século XIX, como a Rebelião de Aponte e a Conspiração de la Escalera, e anos mais tarde, no século XX, com o Partido Independientes de Color.

O segundo momento de singular importância ambienta-se nas primeiras décadas do século XX, quando as nascentes repúblicas da América Latina começam a dar seus primeiros passos. É nesse período que negros e negras, já mobilizados em agremiações recreativas, como os clubes negros no Brasil, as sociedades negras em Cuba, ou organizações culturais, buscam em alguns contextos específicos, estruturar espaços de representação política para ascender ao poder pelas vias legalmente estabelecidas na época: Os partidos políticos. É a primeira vez que surgem organizações que tinham como objetivo alcançar o poder e promover mudanças a partir de estruturas partidárias, com foco específico no combate ao racismo e na população negra.

Os grandes exemplos desse período são o próprio Partido Independientes de Color, em Cuba, fundado em 1908 e dramaticamente extinto em 1912; A Frente Negra Brasileira, fundada em I93I; e o Partido Autoctono Negro, fundado no Uruguai também nesse período.

O terceiro momento refere-se a uma especificidade latino-americana, mas não cubana, de vivenciar o processo de redemocratização no final dos 1970 e nos anos 1980. É nesse período que importantes processos organizativos, de caráter mais ampliado, se estruturam na região. Um dos casos mais emblemáticos talvez seja do Movimento Negro Unificado no Brasil, criado em 1978, com capilaridade nacional.

Esses processos de mobilização tiveram relevante impacto nas elaborações das novas Cartas Magnas desses países, que passaram a incorporar significativos marcos legais para a população negra, ainda que insuficientes para o tamanho da demanda existente. Destaco, como exemplo, o Artigo 68, do Ato das Disposições Constitucionais Transitórias da Constituição Federal de 1988, que assegura o direito à terra para comunidades quilombolas no Brasil, e a Lei 70, de 1993 que assegura o direito aos territórios palenqueros na Colômbia. Em ambos os casos, essas legislações foram incorporadas tanto no Brasil como na Colômbia por uma forte articulação dos movimentos negros desses países. No Brasil esse processo marcou o período de redemocratização do país e os debates da Constituição Federal de 1988. Na Colômbia, a Lei 70 foi proposta por organizações afrocolombianas e é um marco importante. 
Cuba, nos anos 1960 e 1970, teve significativa atuação na conquista da independência de países africanos, como Angola e Congo, e apoiou a luta contra o apartheid. Essa ligação de Cuba com os processos independentistas africanos se inicia na segunda metade da década de I960, com a missão chefiada por Che Guevara ao Congo ${ }^{28}$. Internamente no país, a pujante influência soviética reinava, onde a ideia de igualdade ganhou fôlego e comportamentos e estéticas fora do padrão eram questionados, coagidos ou classificados como contra-revolucionários.

Nesse período, cabe destacar as influências do movimento pelos direitos civis dos EUA em Cuba. Vários ativistas de organizações como os Panteras Negras tiveram relações com Cuba e apoiaram, mesmo que temporariamente, a Revolução. Alguns residiram na Ilha e tiveram livros e textos publicados. Norberto Mesa ${ }^{29}$ relata as influências desse movimento:

Entonces en ese mundo de la lectura me empecé a leer cosas que tenían que ver con el problema negro norteamericano (en los años 1960). Los activistas negros en ese periodo tienen mucha influencia acá, los panteras negras. Leí cosas de los panteras conocí un grupo de ellos e inclusive conocí de algunas de las cosas que ellos hacían. Algunos de ellos tuvieron que desviar aviones allá en Estados Unidos y venir para Cuba, se refugiaron aquí en Cuba. Leí la historia de mi vida, la autobiografía de Malcolm X y estaba al tanto de eso. Pero no tenía una mirada hacia el tema racial aquí en Cuba. No tenia, eso lo mío era lo de afuera, lo que estaba pasando en Estados Unidos, no me había detenido a mirar que estaba pasando en Cuba, entonces llega un momento en que empiezo a preocuparme por las cosas políticas que estaban pasando en Cuba. (Entrevista realizada com Norberto Mesa, em 09/07/2015).

Muitos dos ativistas relatam essa influência que tiveram do movimento dos direitos civis, mas que a reflexão para parte dos atuais ativistas, sobre as relações raciais em Cuba, viria tempos depois, como relatado por Norberto. Na década de 1980, apesar de não vivenciar um momento político semelhante ao da América Latina, há certa retomada em Cuba, depois de décadas da Revolução, do debate sobre a presença de mulheres e negros em espaços de poder. É criada, então, a proposta de reserva de vagas para esses dois segmentos em diversos cargos e espaços públicos. A ação foi duramente criticada por seus resultados limitados, mas simbolizou uma mudança paradigmática e os primeiros passos para debater as desigualdades a partir de um viés mais amplo que o econômico. Esse debate se intensifica a medida que a crise no bloco socialista se amplifica e a situação econômica de Cuba se agrava, no final da década de I980 e nos anos 1990.

\footnotetext{
${ }^{28}$ Essas relações de Cuba influenciaram, inclusive, o cinema brasileiro. Glauber Rocha filmou o "Leão de 7 cabeças" no Congo, onde aborda a luta contra o fim da relação colonial e da lógica escravocrata. Um dos personagens é inspirado no Che, desde trejeitos, figurino e a postura "revolucionária".

${ }^{29}$ Norberto Mesa é um dos ativistas que dialoguei na pesquisa. É fundador da Cofradía de la Negritud, criada em 1998 (um dos primeiros coletivos da pauta antirracista em Cuba). É formado em engenharia pecuarista, com experiências também no campo turístico. Estivemos juntos em diversas atividades vinculadas à questão racial em Havana, no período de minha pesquisa de campo, entre 2014 e 20I5. Na entrevista, foi possível compreender mais profundamente sua vivência e história vinculada à luta contra o racismo, e os impactos desse processo em sua vida profissional e familiar.
} 
O quarto momento emblemático para essas mobilizações negras e antirracistas na América Latina desenvolve-se no final dos anos 1990 e 2000, onde se ampliam as trocas e espaços de convivência de organizações e movimentos negros no contexto da Diáspora Africana. A Conferência Mundial contra o Racismo, a Discriminação Racial, a Xenofobia e Formas Correlatas de Discriminação, organizada pelas Nações Unidas, em Durban, na África do Sul, de 3 I de agosto a 08 de setembro de 200I, é, obviamente, um marco por colocar em evidência no cenário internacional a agenda antirracista e possibilitar o fortalecimento das articulações em escala mais ampla. A Conferência de Durban é a confluência de uma série de Conferências Mundiais da ONU contra o Racismo e a Discriminação ${ }^{30}$.

Dedicar-me-ei, a seguir, a refletir sobre esse processo pós-Conferência de Durban, seus impactos para América Latina, para, por fim, chegar a uma análise mais detalhada dessa questão em Cuba. As reflexões, a partir da contemporaneidade, dos três períodos anteriores a Durban serão melhor detalhados em capítulos posteriores.

\section{I.I. Entramos Negros e Saímos Afrodescendentes}

A Conferência mundial de Durban e seus processos mobilizatórios de preparação são referências e geraram impactos na região como um todo. Os próprios documentos finais e o Plano de Ação constituem-se como referências e estimulam a ampliação das mobilizações nos âmbitos nacionais e internacional.

$\mathrm{Na}$ Conferência de Durban, para além do reconhecimento do racismo e das discriminações sofridas, há a demanda por retratação e por justa reparação dos povos afetados, com destaque para os afrodescendentes e indígenas da América Latina. Há também a explícita vinculação da exclusão e pobreza com o racismo:

Enfatizamos que a pobreza, o subdesenvolvimento, a marginalização, a exclusão social e as disparidades econômicas estão intimamente associadas ao racismo, discriminação racial, xenofobia e intolerância correlata, e contribuem para a persistência de práticas e atitudes racistas as quais geram mais pobreza (Plano de Ação de Durban, 200I, Artigo I8).

Mesmo com o abandono da Conferência pelos Estados Unidos e Israel, e a abstenção de Canadá e Austrália, estiveram presentes mais de I70 países e houve a participação de milhares de

\footnotetext{
${ }^{30}$ A primeira delas foi realizada pela ONU em I978, e a segunda em I983, em Genebra, Suiça.
} 
coletivos, movimentos e organizações da sociedade civil. A participação e o protagonismo latinoamericano foi central, com reflexos diretos nos resultados da Conferência:

Consideramos essencial que todos os países da região das Américas e de todas as demais zonas da diáspora africana reconheçam a existência de sua população de origem africana e as contribuições culturais, econômicas, políticas e científicas dadas por essa população, e que admitam a persistência do racismo, a discriminação racial, a xenofobia e as formas conexas de intolerância que a afetam de maneira específica, e reconheçam que, em muitos países, a desigualdade histórica no que diz respeito, entre outras coisas, ao acesso à educação, à atenção à saúde, à habitação tem sido uma causa profunda das disparidades sócioeconômicas que a afetam (Declaração de Durban, Artigo 33, 200I).

O processo de Durban foi mais abrangente do que a Conferência em si. Diversas pré-conferências nacionais e regionais com a presença de organizações do movimento negro foram realizadas, como a Conferência Regional das Américas, em Santiago, Chile, entre os dias 4 a 7 de dezembro de 2000. Em 2006, em Brasília, Brasil, ocorre a Conferência Regional das Américas sobre Avanços e Desafios do Plano de Ações Contra o Racismo, Discriminação Racial, Xenofobia e Intolerância Correlata, promovida pelos Governos do Brasil e Chile, com ênfase também para participação da sociedade civil. Em 2009, é a vez da Conferência de Revisão da $3^{\text {a }}$ Conferência das Nações Unidas contra o Racismo, realizada em Genebra, na Suíça, que estabelece novas metas para o Plano de Ação de Durban de 200I.

A participação da delegação cubana, em 200I, foi importante, especialmente por ter sido chefiada por sua maior representação política, o então presidente, Fidel Castro. Em declarações dadas no processo da Conferência de Durban, Fidel, quando questionado sobre a experiência cubana de combate ao racismo, argumentou que havia feito enormes esforços para erradicá-lo. Mas, mencionou que se tratava de um problema cultural que se soma à herança de uma presença yanke imposta na Ilha por muito tempo. Destacou, ainda, que não basta ditar leis radicais. Há que se fazer um esforço maior, mais constante e mais eficiente. "Em Cuba temos experiência, todos os dias aprendemos algo novo, para chegar ao patamar de uma sociedade inteiramente justa" (Fidel CASTRO, in: HOZ, 2012: 44).

No livro de Pedro de la Hoz (2012), constam alguns trechos dos discursos de Fidel Castro, feitos durante a Conferência de Durban. Destacarei, a seguir, um deles:

\footnotetext{
Ninguém tem o direito de sabotar essa Conferência que busca aliviar, de alguma forma, os terríveis sofrimentos e a enorme injustiça que esses feitos significaram e ainda significam para a imensa maioria da humanidade. Nem muito menos alguém tem o direito de colocar condições, exigir que não se fale nem sequer de responsabilidade histórica e indenização justa, o sobre a forma como vamos decidir qualificar o horrível genocídio que em esses mesmos instantes se comente contra o povo palestino por parte de líderes de extrema direita que, aliados à superpotência hegemônica, atuam hoje em nome de outro povo que ao longo de quase dois mil anos foi vítima das maiores perseguições, discriminações e injustiças cometidas na história. Quando Cuba fala de compensação e apóia essa ideia como inevitável dever moral com as vítimas
} 
de racismo, contando com um importante precedente nas indenizações que estão sendo recebidas pelos descendentes do próprio povo hebreu, que em pleno coração da Europa sofreu um odioso e brutal holocausto racista, não pretende a impossível busca dos familiares diretos ou os países concretos de procedência das vítimas por feitos ocorridos durante séculos. O real e incontestável é que dezenas de milhões de africanos foram capturados, vendidos como mercadoria e enviados ao outro lado do Atlântico para trabalhar como escravos, e que 70 milhões de aborígenes índios morreram no hemisfério ocidental como consequência da conquista e colonização européias. [...] A brutal exploração não foi concluída quando muitos países se tornaram independentes, nem sequer depois da abolição formal da escravidão. [...] Os países desenvolvidos e suas sociedades de consumo, responsáveis na atualidade pela destruição acelerada e quase irremediável do meio ambiente, tem sido os grandes beneficiários da conquista e da colonização, da escravidão, da exploração impiedosa e o extermínio de centenas de milhões de filhos dos povos que hoje constituem o terceiro mundo, da ordem econômica imposta à humanidade após duas monstruosas e destrutivas guerras pela divisão do mundo e seus mercados, dos privilégios concedidos aos Estados Unidos e seus aliados em Bretton Woods, do FMI e as instituições financeiras internacionais criadas exclusivamente por eles e para eles (discurso de Fidel Castro na Conferência de Durban, 200I. In: HOZ, 20I2: 47-5I) $)^{31}$.

Nesse discurso, Fidel aborda temas fundamentais, como a necessidade de reparação com relação às históricas violações, como o longo processo escravista, e faz uma crítica bastante contundente à postura fugidia de Estados Unidos e Israel frente à grande relevância dos temas propostos e acordados na Conferência pelos países. Todavia, pouco aborda a situação dos afrodescendentes no seu país e propostas para resolução dessas iniqüidades e reparações. Trata o racismo em Cuba como "resquícios culturais", que se amparam em um passado republicano ou colonial, sem realizar uma crítica dos processos gerados também no período revolucionário.

Alguns desafios para os afrodescendentes no continente, como a superação do analfabetismo, em Cuba são conquistas. Cabe destaque também a qualidade das políticas públicas de saúde e educação prestadas pelo Estado e a segurança pública, onde há taxas muito reduzidas de assassinado, em relação aos demais países da América Latina ${ }^{32}$.

Todavia, há uma sobrerrepresentação de negros em prisões, conforme denunciam muitos dos ativistas entrevistados. É comum haver maior número de abordagem da polícia cubana a pessoas negras para identificação e checagem do carnê de identidade. Um dos primeiros documentários que trata as relações raciais na contemporaneidade cubana, intitulado "Raza", ou "Raça" em português, aborda pessoas nas ruas de Havana, entre 2007 e 2008. Um dos jovens negros entrevistados, ao ser questionado se há racismo em Cuba, responde: Por supuesto loco! Mira la policía. Además de la policía, los hoteles, los bares en CUC $C^{33}$. Loco, y como nosotros vamos a seguir con eso? (Trecho do documentário "Raza”, direção Eric Corvalan/ 2008).

\footnotetext{
${ }^{31}$ Tradução minha.

${ }^{32}$ Brasil, nesse quesito de segurança púlica, figura como um dos países latinoamericanos com situação mais grave, sobretudo para os jovens negros. Para mais informações, ver: Mapa da Violência, 2012.

${ }^{33}$ Em moeda dolarizada, denominada Peso Cubano Conversible.
} 
Além da questão que permeia a relação com a polícia, são muitas demandas e reivindicações apresentadas por ativistas e coletivos antirracistas na Ilha que ainda não se efetivaram no cotidiano do país. Algumas das denuncias referem-se ao franco processo de piora na sociedade cubana fruto das desigualdades geradas pela economia emergente, empiricamente muito embranquecida ${ }^{34}$.

Até a atualidade, em Cuba não há um espaço institucionalizado no âmbito do Estado para coordenar, formular e implementar políticas de igualdade racial, num modelo semelhante ao implementado em outros países da América Latina. Algumas iniciativas ainda incipientes estão sendo levadas a cabo, como a inclusão de temas importantes da história dos afrocubanos no processo formativo de professores e professoras. Mas não haver um espaço estatal que coordene e monitore esse processo, fragiliza a efetiva implementação dessas políticas. Também não existe uma instância especifica no Estado para acolher e sistematizar as demandas e propostas dos coletivos do movimento afrocubano.

A falta de uma regulamentação da legislação que criminaliza práticas de racismo é outro agravante para o avanço na temática. Apesar da Constituição caracterizar a discriminação racial como ilegal, e de esse crime estar previsto no Código Penal, não há uma diretriz que ampare sua aplicabilidade, o que dificulta o acesso à justiça e aos direitos para as vítimas. Nos casos dos processos judiciais por crimes de racismo, as decisões não consideram a existência de práticas discriminatórias, mesmo em situações onde explicitamente isso ocorreu. Tampouco pude acompanhar campanhas estatais sobre discriminação racial, entendendo a discriminação racial como a prática do racismo e a efetivação do preconceito. A discriminação, nesse sentido, é a adoção de práticas que efetivam o racismo e o preconceito, estes últimos situados no campo da doutrina e dos julgamentos (GOMES, 2005).

$\mathrm{Na}$ América Latina de forma ampliada, no período pós-Durban, houve um crescente processo de institucionalização das políticas de igualdade racial, com destaque para Brasil, Equador, Venezuela, Colômbia, e um crescimento do diálogo ou do embate dos movimentos negros com os Estados nacionais.

\footnotetext{
34 Os dados oficiais do Censo não permitem uma análise aprofundada dessa questão. As informações são disponibilizadas de forma limitada e já tabelada. Não consegui obter os microdados para uma análise mais criteriosa, apesar das solicitações feitas ao ONE - Observatório Nacional Estatístico de Cuba. Todavia, algumas pesquisas de menor vulto, como Gozales e Al. (20II) indicam um predomínio crescente de brancos no setor dolarizado da economia, ou na chamada "economia emergente". Nos vários contatos que tive com o setor hoteleiro dolarizado em Cuba, no período da pesquisa, em cidades como Varadero, Havana, Viñales, Trinidad, Santa Clara, empiricamente tive contato com funcionários majoritariamente brancos em todas as funções, especialmente na recepção e direção. Quando havia negros, estavam atuando como garçons ou na limpeza. Mesmo nesses casos, foram poucas ocorrências.
} 
No Brasil, em 2003, cria-se um ministério, a Secretaria de Políticas de Promoção da Igualdade Racial (SEPPIR), vinculado à Presidência da República, com a missão de coordenar e formular as políticas de igualdade racial em âmbito federal, fomentar seu debate com estados e municípios, ampliar espaços de diálogo com a sociedade civil e a articulação do tema em espaços multilaterias, como as Nações Unidas.

O cenário atual não está favorável à melhor estruturação dessa pauta. Uma das ações do Governo brasileiro, em resposta à recente crise política e econômica, foi uma reforma ministerial, anunciada no dia 02/10/2015, que, entre outras medidas, fundiu três ministérios em um só: SEPPIR, Secretaria de Política para as Mulheres e Secretaria de Direitos Humanos foram extintas e foi criado o Ministério das Mulheres, Igualdade Racial e Direitos Humanos. Tal ato poderá agravar a fragilidade das políticas e produzir um efeito cascata de redução em série dessa política nos estados e municípios, que poderão de forma análoga fechar suas instâncias voltadas para a promoção da igualdade racial. São análises pendentes para o médio e longo prazos.

Mesmo com esses últimos acontecimentos, cabe ressaltar que após o processo de Durban houve inegavelmente uma ampliação do debate do movimento negro brasileiro internamente no país e internacionalmente. A pressão produziu efeitos visíveis no posicionamento do então presidente Fernando Henrique Cardoso (1995-2002). Contradizendo toda sua postura anterior, assumiu publicamente pela primeira vez que o Brasil é um país racista e reconheceu as mazelas desse processo para a nação.

No estudo de Flavia Rios sobre o movimento negro brasileiro e suas articulações com a sociedade política e o Estado, a importância da Conferência de Durban aparece com ênfase:

\footnotetext{
A conferência de Durban foi tão importante para os rumos das políticas públicas antirracistas brasileiras que alguns ativistas chegam a estabelecer esse evento como o divisor de águas no contexto de enfretamento das desigualdades e discriminação raciais, bem como na reorientação das estratégias do ativismo nacional e transnacional. Além dos militantes, há numerosas indicações de analistas afirmando que esse evento planetário foi imprescindível para as negociações e acordos adicionados à agenda do Estado brasileiro na primeira década do século XXI [...]; principalmente porque foi no processo preparatório para a conferência que se estabeleceu um consenso (entre agentes não-governamentais e governamentais) acerca da necessidade de medidas específicas a serem adotadas pelo Estado para combater o racismo. (RIOS, 20I5: 206)
}

Outras ações importantes para a superação do racismo foram realizadas após 200I, no Brasil. Dessas, cabe destacar o amplo e contraditório debate sobre as cotas nas universidades, que culminou com a aprovação de sua constitucionalidade, em 2012, pelo Supremo Tribunal Federal; a Lei $n^{\circ}$ I0.639/2003 que inclui no currículo oficial da Rede de Ensino fundamental e médio a obrigatoriedade da temática História e Cultura Afro-Brasileira; o reconhecimento oficial de mais 
de duas mil e quinhentas comunidades quilombolas por meio da Certidão da Fundação Cultural Palmares (com um avanço muito tímido e limitado da regularização fundiária e da emissão de títulos de terras aos quilombos); a aprovação da Lei n ${ }^{\circ} \mathrm{I} 2.288$ de 20 de julho de 20I0, que institui o Estatuto da Igualdade Racial e o Sistema Nacional de Promoção da Igualdade Racial; a aprovação das cotas nos concursos públicos federais em 2014.

Esses avanços estão imersos em outras dinâmicas ainda complexas para a superação do racismo no Brasil. Apesar de haver uma ampla jurisprudência, com uma série de casos julgados com condenação por práticas racistas, ainda é um desafio lograr essa vitória. Muitas vezes, as denúncias morrem no seu nascedouro, no momento em que é apresentada a demanda à polícia, por despreparo de muitos desses agentes públicos em lidar com o tema ou num esforço de minimizálo.

Em um rápido diálogo entre o caso brasileiro e o caso cubano, os avanços concretos na agenda de igualdade racial, apesar das inúmeras limitações políticas e orçamentárias são palpáveis no Brasil, conforme apresentei sucintamente acima. Todavia, há uma ampla exclusão e vulnerabilidade da população negra no país que faz com que do percentual de pessoas miseráveis no país, $70 \%$ delas sejam negras e que continuem sendo os corpos negros os mais vulneráveis a homicídios e prisões ${ }^{35}$. De acordo com a campanha "Jovem Negro Vivo", da Anistia Internacional iniciada em 20I4, o número de homicídios no Brasil cresceu I48,5\% em 32 anos. São mais de 30 mil assassinatos de jovens por ano, dos quais $93 \%$ são de homens e $77 \%$ de negros.

Muitos dos desafios hoje presentes para a população negra brasileira, e que compõem a demanda de várias das organizações antirracistas do país, tais como o fim do genocídio da juventude negra $^{36}$, educação e saúde de qualidade, acesso amplo a universidade, maior representatividade nos espaços de poder, como o parlamento, são demandas que se encontram em outro patamar em Cuba, exatamente pelas ações inclusivas e reformas que foram efetivadas pela Revolução socialista.

\footnotetext{
${ }^{35}$ Há uma apatia social para o tema, como denuncia diversas campanhas como a "Jovem Negro Vivo", da Anistia Internacional. Na relação com a polícia, a situação é crítica. Em alguns casos, houve orientação explícita do comando da Polícia Militar para revista de todos jovens "negros e pardos", como o ocorrido em Campinas, em 2013 - matéria disponível em: http://noticias.uol.com.br/cotidiano/ultimas-noticias/2013/0I/23/ordem-da-pm-determinarevista-em-pessoas-da-cor-parda-e-negra-em-bairro-nobre-de-campinas-sp.htm. Acesso em 17/09/2015. Esse reforço discriminatório incita a violência e a estigmatização desse segmento etário e racial, que éa principal vítima de homicídios no Brasil.

${ }^{36}$ Pautada por diversas mobilizações, como a Reaja ou seja morta, Reaja ou seja morto.
} 
Como aprofundarei melhor a análise no capítulo III, Cuba possui resultados palpáveis no que se refere à inclusão da população mais pobre, onde se inclui uma grande parcela negra, em políticas sociais e acesso a serviços e mercado de trabalho. Há um amplo quadro de profissionais qualificadas/os negras/os, uma parcela considerável de integrantes das Assembléias do Poder Popular desse segmento racial, apesar de não haver uma mudança na alta hierarquia de $\operatorname{poder}^{37}$. As taxas de homicídio são baixas e isso impacta nos números positivos nesse quesito. As políticas de educação e saúde, universais, beneficiam também essa parcela.

Por outro lado, em Cuba, as ações concretas para a superação do racismo ainda são insuficientes, especialmente no que diz respeito à visibilização da temática. É necessário, por exemplo, incorporá-la nos currículos escolares e universitários, ampliar o acesso à educação (especialmente nas universidades), diversificar a representação racial na mídia, regulamentar legislação específica que garanta punição aos atos de racismo no país, fomentar ações para incluir a população negra na economia emergente como turismo ou gastronomia, formar a polícia na perspectiva racial, qualificar o Censo para viabilizar a estratificação dos dados a partir do quesito cor e desenvolver uma política habitacional que reverta as desigualdades raciais muito marcadas nesse campo. Enfim, muito pouco foi efetivamente concretizado como política de promoção da igualdade racial pelo governo cubano nesse período pós-Durban.

O Comitê para a Eliminação da Discriminação Racial da ONU (CERD), ao examinar os informes periódicos de $\mathrm{Cuba}$ (do $14^{\circ}$ ao $18^{\circ}$ ), apresentados entre os dias 16 e $\mathrm{I} 7$ de fevereiro de 20II, fez uma série de recomendações em 03 de março de 20II. Dentre essas, destaca-se a necessidade de que o Estado cubano efetive a Declaração e o Plano de Ação de Durban, uma vez que o país não incluiu em seu informe dados sobre o assunto. Também faz referência a uma posição apresentada pelo Estado cubano nesses informes, que considera que os preconceitos raciais na sociedade cubana "no tienen una significativa entidad y se expresan particularmente en las esferas más íntimas de la vida, con mayor frecuencia en la relación de pareja", e recomenda campanhas educativas e ações midiáticas para romper com essa situação, além de ressaltar a necessidade de legislação específica que tipifique o crime de racismo.

Alguns dos ativistas criticam o fato de não haver um compromisso real do Estado cubano e do Partido Comunista com essa pauta, o que ficou explícito no relatório supracitado. Posto que não há ações sistemáticas e continuadas com vistas a combater o racismo, alguns dos ativistas criticam que no relatório feito por Cuba à ONU foi mencionada a criação de comissão para tratar os

\footnotetext{
${ }^{37}$ Conforme dados e análises realizadas no capítulo 3 da presente tese.
} 
temas de igualdade racial junto ao Comitê Central do Partido Comunista, mas que a mesma foi desativada tão logo cessou o processo do relatório:

En el año 20II, Cuba presentó un informe ante al Comité para la Eliminación de la Discriminación Racial de las Naciones Unidas. En ese informe se habla, inclusive, que (el Estado cubano) hizo una comisión en el Comité Central del Partido para darle la idea de hay una preocupación. Pero, después que pasó eso, a los 3 meses, ya no existía la Comisión, la desatibaron. (Entrevista com Norberto Mesa, realizada em 09/07/2015).

O momento atual, com a institucionalização da Década dos Povos Afrodescendentes, se materializa como uma nova oportunidade de avançar nas ações para o tema, de forma articulada com outros países da América Latina. Ao abordar a Década e a especificidade de Cuba nesse processo, Zuleica Romay ${ }^{38}$, destaca as contradições hoje vivenciadas:

Desde el punto de vista estatal yo no percibo todavía un programa ni una respuesta organizada a la convocatoria del decenio (de los afrodescendientes), no la veo. Aún no está. Yo le veo un papel importante, un lugar muy importante a esa respuesta a la llamada sociedad civil. Yo creo que la voz cantante, fijate no hablo de las medidas de más trascendencia, pero si de la mayor capacidad de iniciativa la tiene que tener la sociedad civil. Porque también hay una realidad: Cuba es un país donde hay muchas cosas importantes que están en juego, o sea la mirada del país hoy no se va a detener en el decenio de afrodescendientes ni en el programa del decenio si las personas sensibles en Cuba no llaman suficientemente la atención sobre eso, no generan iniciativas para involucrar al Gobierno, no presentan proyectos para que el Gobierno lo respalde y no organizan un discurso, no demandante, pero si de llamar la atención sobre los problemas. Porque, como que en Cuba hay tantas políticas universalistas que están aplicadas que desde el punto de vista estatal esta inventada con cualquiera a ver, es verdad que las escuelas la tercera parte están en mal estado y que la mitad que los hospitales constructivamente son un desastre, pero el tema como Educación, Salud, Seguridad y protección social ya Cuba puede decir que cumplió las metas del decenio. La mayoría de los países no tienen lo que tiene Cuba, entonces te das cuenta que el Estado en Cuba no se tiene que esforzar. Cómo logramos que haya algo más, porque hay una fuerza ahí, porque en realidad lo que en muchos lugares la gente se propondría como meta, Cuba lo logró. Tiene que haber una sociedad civil y un movimiento de activista que agite, agite, impulse, compulse, genere iniciativas. [...] Entonces para un Estado las cosas siempre se ven desde arriba, eso no tiene problema aquí; entonces mañana las Naciones Unidas mandan un cuestionario y Cuba lo responde y es de los más destacados. Pero, si hicimos una Revolución, hay que plantearse el asunto de otra manera, [...] que hay que hacer es, y qué faltó y ahí es donde hay que concentrarse. Porque si nos preguntamos qué hay que hacer, la respuesta siempre va a ser general y siempre va a ser buena. ¿Qué falta? No que después de (la Conferencia de) Durban nadie dio respuesta [...] No es que no la haya en la realidad. No la hay en el pensamiento, no está en la política y eso si es serio, tenemos un reto ahora con el decenio y te empiezan a medir a partir del compromiso. (Entrevista com Zuleica Romay, realizada em I8/08/20I4).

${ }^{38}$ É cientista social e escritora. Ativista antirracista, é integrante da ARAAC, e atualmente também é presidenta do Instituto Cubano do Livro, órgão vinculado ao Ministério da Cultura, uma das poucas pessoas negras que ocupam cargos desse nível no país. Por sua militância no tema racial, é uma das que dialogo na pesquisa. Realizei entrevista com Zuleica na sede de seu trabalho, além de ter acompanhado algumas atividades por ela organizadas ou nas quais era debatedora. 


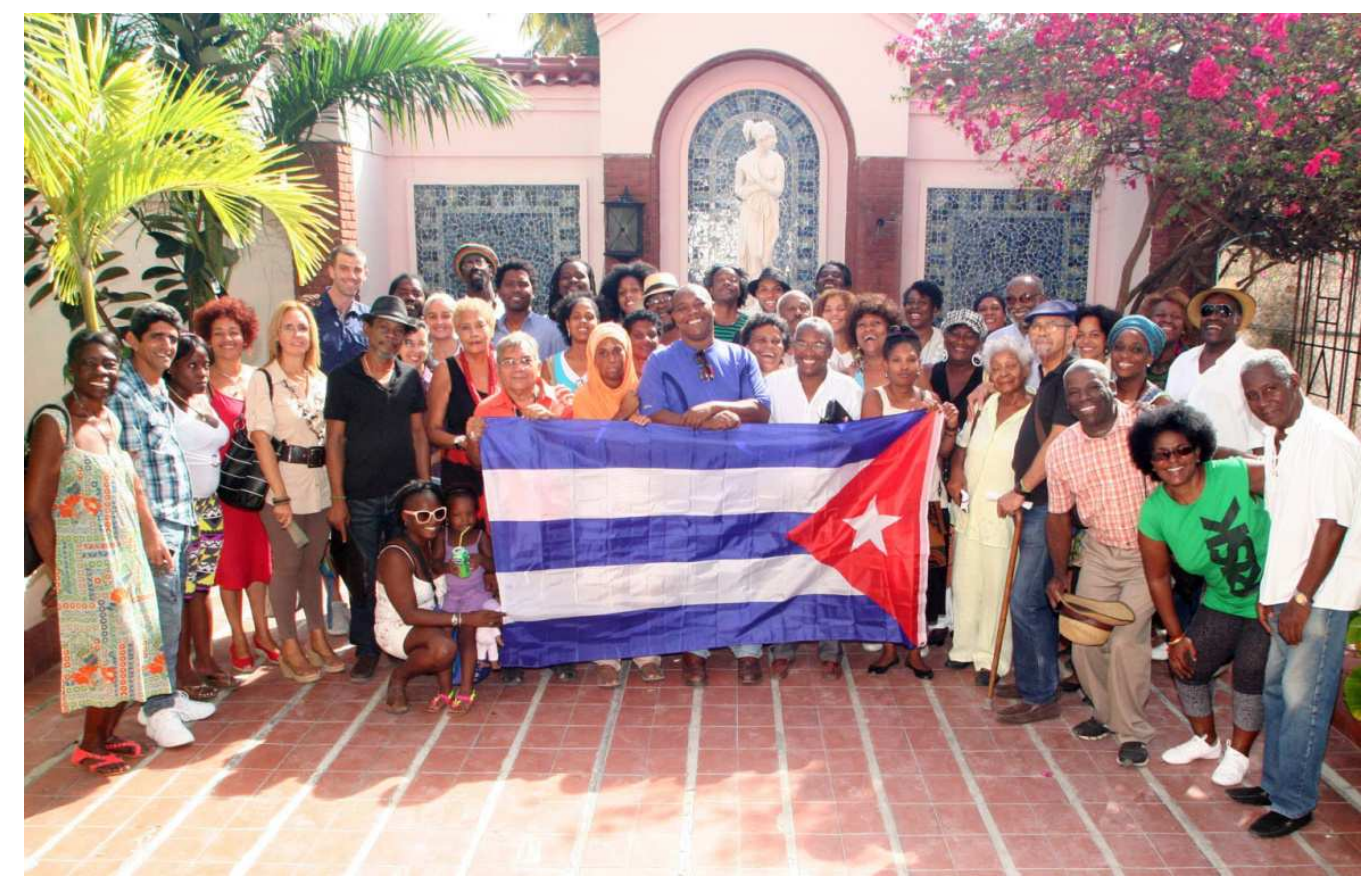

Figura 4: Lançamento da Década dos Povos Afrodescendentes, em 20/08/20I4, na Casa de Alba, Havana, Cuba. Foto disponível em: afrocubaweb.com. Acesso em 08/03/2015.

$\mathrm{Na}$ abordagem de Zuleica Romay, portanto, se por um lado, Cuba se encontra em uma situação bastante diferente em relação aos demais países da América Latina no que se refere a indicadores sociais, sobretudo os voltados para saúde, educação, expectativa de vida, por outro, visualiza-se uma crescente desigualdade racial. Para além da invisibilidade, não há uma atuação política voltada para esse fim que supere pequenas e incipientes iniciativas. Apesar do crescimento da produção bibliográfica, acadêmica e a ampliação de coletivos e organizações antirracistas, não há uma incorporação continuada e significativa desse tema por parte da esfera política e estatal que possibilite a efetivação de ações concretas.

Nesse cenário, as influências para a pauta racial são originadas internamente, especialmente por esse movimento antirracista, mas refletem desdobramentos externos que influenciam o país, como a própria década dos povos afrodescendentes. Rolando Zulueta ${ }^{39}$ reflete essa expectativa interna acerca das deliberações internacionais sobre o tema:

El racismo no es solamente cubano, es un problema internacional. Pero, bueno estamos hablando en el caso particular de Cuba y nos toca a nosotros los cubanos resolver esa situación. Creo que tenemos todo, por lo menos en mi persona, tengo toda la fuerza y creo que tengo capacidad y en esa lucha me estoy entregando para contribuir con mi poquito granito de arena en esa edificación que debe ser realmente tratar. Si al menos no podemos erradicarlos en los IO años que nos quedan, tratar de paliar esta situación

\footnotetext{
${ }^{39}$ Historiador e professor do Instituto Superior Politécnico José Antonio Echeverría - CUJAE, é integrante da Red Barrial Afrodescendiente. No período da pesquisa, tivemos intensos contatos em atividades em seu bairro, La Lisa, como também na comunidade de La Marina. A entrevista foi gravada em uma das várias vezes em que estive em sua casa, no período de 2014 e 2015.
} 
negativa, porque desgraciadamente es una situación negativa que nos queda y creo que debemos aprovechar todo esto que se está viendo desde el punto de vista internacional, como es ese decenio de los afrodescendientes, para poder a través de tareas, proyectos, de hacerle a las personas más visible la situación, formar en ellos capacidades y darles la autoestima y todas las herramientas necesarias para que ellos comprendan que esto es un fenómeno de hombres y mujeres y en esta medida todo esto debe ser un gran proceso por el cual tiene que transitar nuestro proceso de educación desde los niveles más bajos. (Entrevista com Rolando Zulueta, realizada em 02/02/2015).

$\mathrm{Na}$ abordagem de Zulueta, a dinâmica de influências externas, como a década dos povos afrodescendentes, é uma oportunidade de se ampliar o apoio às iniciativas comunitárias realizadas, com o objetivo de fomentar o debate sobre o tema. Interessante, também, analisar a ênfase dada por Zuleica Romay à necessidade de construção de um discurso de pressão da sociedade civil sobre o Estado. Esse discurso vem num crescente, mas ainda localizado e disperso no seio dos próprios coletivos antirracistas afrocubanos. A denúncia do racismo e a construção de propostas de políticas voltadas para a questão racial são fundamentais, também, no fortalecimento dessa pauta na sociedade civil.

Há dificuldades de ordem estrutural, financeira e legal que são importantes. A não legalização de nenhum desses grupos dificulta o estabelecimento de parcerias nacionais e internacionais. Não necessariamente o formato de organização não governamental ou de associação resolveria essa demanda. Apesar de ser uma das reivindicações de parte dos coletivos, não se adequa necessariamente a forma de mobilização de todos esses grupos.

Tomando diversos exemplos brasileiros, como o Movimento Negro Unificado, o Movimento Sem Terra ou a própria Coordenação Nacional de Quilombos (CONAQ), não há personalidade jurídica de suas organizações. Todavia, há possibilidades de articular projetos e ações por meio da rede de associações com as quais esses movimentos têm relação. Esse processo, em Cuba, é mais difícil, exatamente pela quase não existência de organizações coletivas da sociedade civil legalizadas. Ainda no diálogo com Brasil, o estímulo exacerbado de oficialização dos coletivos da sociedade civil, especialmente na última década, com ações orçamentárias destinadas também a isso, gerou em muitos casos um caos administrativo e a falência de muitas dessas organizações ${ }^{40}$.

Outros pontos que trazem reflexos negativos vivenciados por muitos coletivos em Havana são: a quase absoluta ausência de vínculos dessa mobilização com as organizações de massa da Revolução impedem uma expansão do debate por essas vias; A falta de internet e de ferramentas

\footnotetext{
${ }^{40}$ Como exemplo, menciono o ocorrido com parte das associações quilombolas no Brasil. A partir do estímulo promovido pelo Governo Federal, por meio da ação de fortalecimento institucional das representações das comunidades quilombolas, no âmbito do Programa Brasil Quilombola (criado em 2004), foram oficializadas muitas associações. Todavia, por desconhecimento dos trâmites legais e burocráticos, muitas dessas associações estão inadimplentes e em crise administrativa e financeira. Esse é um dos casos que complexifica a necessidade de legalização das organizações da sociedade civil.
} 
de comunicação restringe o círculo de atuação de muitos ativistas e grupos, apesar de não impedir a divulgação e o compartilhamento de boletins e informes; As limitações para realizar manifestações e atos públicos sobre a questão racial, que não sejam interpretadas como dissidentes, também é outro complicador.

A mobilização antirracista trabalha a construção de um discurso que visibiliza um cenário contrário ao senso comum e ao discurso do Estado e da sociedade cubana sobre o tema. Os ativistas defendem que o racismo é um dos graves problemas de Cuba e que suas engrenagens estão presentes na atualidade, também a partir de dinâmicas racistas contemporâneas, não apenas como resquícios do passado colonial ou republicano. Esse é um discurso incômodo, que tem sua reverberação controlada e reduzida na mídia, nos cinemas, teatros, nas escolas e nas abordagens políticas. A experiência vivenciada por Eric Corvalán $n^{41}$, diretor do documentário Raza é um dos exemplos.

Cuando hice las entrevistas en la calle (para el documental) me pidieron el carnet, me quitaron la cámara, me llevaron a la estación de policía. Volví a salir, volví a filmar. Me botaron de la Televisión cuando salió el documental. A mí me botaron del ICRT ${ }^{42}$ después de 15 años trabajando. Es incréible! [...] Eso es una parte de la censura. Por ejemplo, a mi me pusieron raza en el Multicine infanta, me hicieron una entrevista por el televisor y la compañera que me hizo la entrevista, la sancionaron. La cambiaron de puesto de trabajo, estuvo dos meses en otro programa. Solo por la entrevista, porque además cuando sale la entrevista siempre tu grabas tres programas y tu pones uno para que tengas, uno de espera por si pasa algo. No pusieron el programa (en la televisión) y a ella la sancionaron. A mí me dijeron por problemas de presupuesto usted no puede trabajar más aquí. Yo dije: como que problema de presupuesto si yo me gradué? (Me contestarán) No, por problema de presupuesto usted no trabaja más aquí. Y yo me fui, eso fue en el 2009. O sea que he pasado siete años y es que ahora, después de siete años, yo estoy viendo la luz. Todavía, no sé porque, fijate me dieron la confirmación del libro para la feria ayer me dieron la confirmación que van a poner raza (el documental) en los cine de la capital. (Entrevista realizada com Eric Corvalán, em 18/06/2015).

Para além de haver uma produção restrita sobre o tema, uma parte considerável dessa produção teve circulação limitada e seus criadores, escritores, sofreram algum tipo de sanção, como no caso acima descrito por Eric Corvalán. Interessante, também, ressaltar os sinais de abertura para o tema, com a possibilidade de que obras que foram restritas, como Raza agora possam ser visibilizadas por iniciativa de órgãos estatais, como destacou Erica ao final desse trecho.

Essa visão, porém, de que há escassa produção sobre o tema, apesar dos avanços, e circulação restrita, é contrastada por alguns acadêmicos que destacam a vasta produção cubana sobre a

\footnotetext{
${ }^{41}$ Cineasta e documentarista dirigiu um dos importantes documentários sobre o tema racial na atualizada que se chama "Raza", de 2008. No percurso da pesquisa, assisti primeiramente o documentário Raza, que aborda de uma forma interessante o tema racial no país. Posteriormente, nos conhecemos em atividades vinculadas à questão racial, inclusive em um debate em Havana que participei sobre violência contra a juventude negra no Brasil. Depois, realizei entrevista na qual conheci mais sobre sua trajetória e os impactos da realização desse filme em sua trajetória pessoal e profissional.

${ }^{42}$ Instituto Cubano de Radio e Televisão.
} 
questão racial e a cultura afrocubana como uma de suas importantes ações para a superação do racismo. Pedro de la Hoz (2012: 173-I74) ressalta como alguns dos principais marcos disso a criação do Conjunto Folclórico Nacional, da Casa de África, Casa do Caribe, Instituto Juan Marinello, o Programa da Rota do Escravo (vinculado à Unesco) e o Instituto Fernando Ortiz.

Essa visão não é compartilhada, contudo, pelos ativistas entrevistados, nem mesmo por pesquisadores do tema, alguns vinculados ao próprio Instituto Juan Marinello acima citado. Há uma percepção de que as respostas para o tema, por parte do Estado, têm sido insuficientes.

No período de minha pesquisa, um dos fatos mais relevantes para a pauta racial é a interlocução entre a Comissão Aponte e a vice-presidência de Cuba. Em encontros mensais realizados desde março de 20I4, são apresentadas prioridades ao vice-presidente para o tema racial e definidas algumas linhas de ação, conforme descreveu o representante da Comissão, Heriberto Feraudy ${ }^{43}$, no programa Mesa Redonda no canal Cuba Visión, em alusão ao dia internacional de combate à discriminação racial, 2I de março de 2015:

Problemas sí existen. [...] y por lo que han planteado aquí los compañeros, nosotros le solicitamos por la Comisión Aponte al Vicepresidente primero Díaz Canel una reunión. Hoy justamente hace un año que él nos convocó para escuchar cuál era nuestra preocupación. Nosotros en aquella oportunidad le planteamos a Díaz Canel la falta de sistematicidad que hay en el tratamiento a la discriminación racial en Cuba, la falta de coherencia que hay con relación al tratamiento de la discriminación racial en Cuba, la necesidad de establecer una estrategia para atender esta problemática, independientemente de todo lo que ha hecho la Revolución, pero como el fenómeno existe y que los enemigos si se estaban preparando para eso, que se daban pasos, a veces se da un paso adelante y se dan 5 atrás (Fala do presidente da Comissão Aponte, Heriberto Feraudy, no debate televisivo Mesa Redonda, alusivo ao dia internacional de combate à discriminação racial, 2I de março de 20I5).

Os encontros mensais, apesar de serem reconhecidos como um dos avanços, são criticados pelos demais coletivos e ativistas que não se vêem representados pela Comissão Aponte por terem, algumas vezes, visões opostas dos problemas raciais em Cuba, conforme será explanado no decorrer do trabalho ${ }^{44}$. Questionam também o fato de haver uma verticalização do debate com consequente invisibilidade das demais iniciativas existentes.

A visão comparada é interessante para diferenciar os desafios existentes no período pós Durban para o Brasil e para Cuba. Esse é um debate complexo, que envolve variados fatores e trazem reflexos sobre a sociedade civil, os movimentos sociais e para as estruturas estatais.

\footnotetext{
${ }^{43}$ Heriberto Feraudy foi um dos militantes que também dialoguei na pesquisa. No período da pesquisa, foram poucas as oportunidades de encontro, pois muitas das atividades e reuniões da Comissão Aponte foram fechadas para o público. Todavia, tive a possibilidade de realizar uma entrevista com Feraudy, que compõe os dados de campo, realizada na sede da UNEAC (União dos Escritores e Artistas de Cuba).

${ }^{44}$ Algumas dessas divergências serão detalhadas na seção "Antirracismo e a Lei", na abordagem de uma seleção de paladar, exclusiva para mulheres brancas.
} 
Nesse período pós-Durban, é possível perceber um avanço na institucionalização da política de igualdade racial na região, com algumas exceções. Por outro lado, quais foram os efeitos concretos vivenciados pela maioria da população negra nesses países? É possível afirmar que nesses países passa a se conformar uma elite negra? A sociedade deixou de apresentar os efeitos do racismo estrutural? E como Cuba vivenciou esses momentos? Como sua especificidade histórica impactou na estruturação de suas mobilizações, na estruturação do Estado para lidar com essa questão?

Agustín Lao-Montes (2009) faz um contraponto ao processo de Durban e sua influência junto às mobilizações negras nas Américas. Destaca que houve conquistas parciais dos movimentos negros ou afrolatinos, o que em sua opinião facilitou a criação de condições para o surgimento de elites negras neoliberais e conservadoras, para sua incorporação na estrutura estatal ou para o que ele denomina como ONGização de seus lideres e organizações. Ele enfatiza, contudo, a necessidade de superar dicotomias enrijecidas entre Estado e sociedade civil, muito presentes na simples caracterização de cooptação a todas as formas de participação na formulação de políticas públicas ou nas relações com organismos e ONG internacionais.

Ainda nas reflexões de Lao-Montes, alguns líderes e organizações se burocratizam e se convertem em empregados ou clientes dos Estados ou de entidades internacionais (como o Banco Mundial ou a Agencia Estadunidense para a Ajuda Internacional - USAID). Para ele, existem ainda outros que obtém algum financiamento, mas tem cuidado de conservar uma autonomia organizacional e política dos Estados ou de financiadores. Destaca também aquelas organizações que buscam completa autonomia e distanciamento de órgãos estatais e fundos internacionais. Para LaoMontes é fundamental analisar e avaliar os efeitos gerados pelas alianças e financiamentos com instituições estatais e internacionais (onde se incluem alguns dos representantes mais poderosos do capital transnacional e dos Estados Unidos).

Gohn (20II) pontua que o movimento negro ou afrodescendente também teve conquistas em suas pautas de luta no Brasil, como por exemplo, com a aprovação da política de cotas nas universidades. A autora faz referência aos resultados contraditórios desse processo. Por um lado, as demandas sociais são colocadas como direitos, mesmo que limitados. De outro, há perdas, de acordo com Gohn, principalmente de autonomia dos movimentos e do estabelecimento de estruturas de controle social de cima para baixo, nas políticas governamentais para os movimentos sociais. Há estratégias de controle social, mas guiadas pelas políticas públicas. Como exemplo, destaca as conferências nacionais temáticas, como as de Políticas de Promoção da Igualdade Racial. 
Gohn (20II) pondera ainda que na primeira década deste milênio, as ONGs e entidades do terceiro setor se fortaleceram. Interessante observar que essas antes serviam de suporte aos movimentos sociais populares. Na visão de Gohn, os movimentos enfraqueceram-se e tiveram de alterar suas práticas, incorporando-se ao trabalho das ONGs numa perspectiva mais propositiva e menos reivindicativa ou crítica. Nesse período, as manifestações de rua diminuíram ${ }^{45}$. $\mathrm{O}$ chamado terceiro setor passou a atuar com grupos sociais específicos, vulnerabilizados, com ação focada em projetos.

Antes de abordar especificamente esse processo em Cuba, volto a analisar rapidamente os pontos levantados por Lao-Montes e Gonh com relação à América Latina e, mais especificamente, ao Brasil e Colômbia. Observando as dinâmicas dos movimentos negros brasileiros, de fato é possível observar um fortalecimento das ONG e a caracterização de sua atuação por meio de projetos vinculados ao próprio Estado ou a financiamentos internacionais, conforme Gohn (20I I) destaca. Nesse conjunto, visualizo no caso brasileiro, algumas situações em que o processo de mobilização política mais crítica foi, aos poucos, se configurando como uma atuação mais propositiva exatamente nesse processo de ampliação do protagonismo das ONG em detrimento dos movimentos negros. Por outro lado, como Lao-Montes pondera em relação à Colômbia, não são todos os movimentos que estabelecem esse tipo de parceria e que formataram sua atuação à conformação de ONG. O Movimento Negro Unificado, no Brasil, é um exemplo, e a Coordenação Nacional de Comunidades Negras Rurais Quilombolas, outro. Ambos não aderiram ao modelo de ONG.

Portanto, apesar de não dizer respeito à totalidade, muitas das organizações negras configuraram sua ação mais concreta e cotidiana na execução de projetos em parcerias estatais ou financiamentos nacionais ou internacionais. Em alguns desses casos, é possível observar um grau de cooptação, mas em outros tantos casos houve a ampliação do espectro de atuação em ações concretas antirracistas, que na situação de fragilidade financeira e estrutural anterior não seria possível ${ }^{46}$.

Não se pode ignorar, por outro lado, a importância do estabelecimento de parcerias com organismos e instituições internacionais para fortalecer a pauta antirracista e as próprias

\footnotetext{
${ }^{45} \mathrm{O}$ artigo de Gohn é de 201 I e não abarca o processo das grandes manifestações de 2014 no Brasil, que nasceram como uma contestação do valor das passagens de ônibus e evoluiu para um grande processo mobilizatório com uma mutiplicidade de demandas paralelas, muitas delas contraditórias, como a legalização do aborto e sua criminalização. ${ }^{46}$ Algumas organizações vinculadas ao movimento negro, a partir da possibilidade de financiamento para alguns projetos e ações, empreenderam ações de maior abrangência. A premiação que o Centro de Estudos das Relações de Trabalho e Desigualdade (CEERT) passou a organizar para escolas que implementam a Lei 10.639/2003 é um dos exemplos.
} 
estratégias do movimento negro brasileiro. Na Conferência preparatória para Durban, realizada no Chile em dezembro de 2000, foi exatamente a articulação com a Fundação Ford que possibilitou a participação em peso de ativistas do movimento negro brasileiro e a inserção de muitas dessas pautas no documento que norteou a Conferência Mundial de Durban, na seqüência, o que se caracterizou como uma resposta ao Governo brasileiro da época, como destaca Rios (2015):

\begin{abstract}
No caminho para Durban, nem sempre as relações entre agentes governamentais e civis foram amistosas. Os ativistas brasileiros foram derrotados em Genebra, quando o governo de FHC desistiu de sediar a conferência das Américas no Brasil, optando por Santiago do Chile. $\mathrm{Na}$ época, autoridades governamentais temiam reações públicas de manifestantes brasileiros, posto que tinham viajado o mundo imagens da repressão contra negros e indígenas no contexto das comemorações dos 500 anos de "descoberta" do Brasil282. Em resposta, o movimento social conseguiu apresentar, graças aos incentivos financeiros da Fundação Ford, a segunda maior delegação de ativistas na conferência do Chile, cujo documento foi fundamental para os rumos de Durban. (RIOS, 20I5: 2I5).
\end{abstract}

Sobre o que Lao-Montes denomina cooptação do Estado, com a incorporação de lideranças dos movimentos negros como empregados estatais, acredito que em alguma medida ocorreu dinâmica semelhante no Brasil. Todavia, esse processo é muito mais complexo do que a simples cooptação pode descrever. No caso brasileiro, há uma histórica relação entre parte dos movimentos negros brasileiros com os partidos de esquerda (HANCHARD, 200I). No processo de redemocratização do país, mesmo os partidos mais conservadores, estabeleceram interlocução com a pauta e com ativistas negros (RIOS, 2015). O Partido dos Trabalhadores e o Partido Democrático Trabalhista têm uma importância fundamental na articulação com várias dessas organizações negras.

A articulação com a sociedade política e o próprio Estado refletiu em diversos momentos desde o período de redemocratização, como na criação de órgãos locais na década de $1980^{47}$, da Fundação Cultural Palmares, em 1988 - órgão federal, além do crescimento de iniciativas para a pauta racial no governo Fernando Henrique Cardoso (1995-2002), e os impactos da Conferência Mundial de Durban (200I) sobre as políticas desse governo (RIOS, 20I5).

A partir da vitória do presidente Lula, integrante do Partido dos Trabalhadores, nas eleições de 2002, a pressão e diálogo desses coletivos com histórico de atuação junto a esse partido sobre o novo governo foi considerável. A criação de uma instância de coordenação das políticas de igualdade racial, em nível federal, é derivada, em grande medida, da resposta necessária às demandas do movimento negro (RIBEIRO, 20I4). Nesse processo, tem-se a compreensão de

\footnotetext{
${ }^{47}$ Alguns desses órgãos foram criados no início dos anos 1980, como o Conselho de Participação e Desenvolvimento da Comunidade Negra de São Paulo, em 1984 (RIBEIRO, 20I4; SANTOS, 2006).
} 
que é estratégico que atores vinculados às lutas negras estejam em espaços estatais e políticos para otimizar as possibilidades de efetivação das pautas históricas do movimento negro na execução das políticas públicas, como as ações afirmativas nas universidades, a regularização fundiária de quilombos, a mudança curricular na educação para uma perspectiva inclusiva da cultura e história afrobrasileira e africana, dentre outros aspectos. A proposta da Secretaria nasce de um diálogo direto com alguns dos coletivos do movimento negro:

Entre a posse do presidente Lula, em I ${ }^{\circ}$ de janeiro de 2003, e a criação da SEPPIR (em 2I de março de 2003), foi formado um Grupo de Trabalho com a tarefa de elaborar a proposta dessa Secretaria. Por parte do Movimento Negro, estiveram representadas nesse grupo, composto por cinco organizações nacionais, a Coordenação Nacional de Entidades Negras, o Movimento Negro Unificado, a União de Negros pela Igualdade, o Partido dos Trabalhadores/Secretaria Nacional de Combate ao Racismo; e o Partido Comunista do Brasil. (RIBEIRO, 2014: 233-234).

Se há uma crítica de que as estruturas do Estado são embranquecidas, também acredito ser estratégico haver um processo de ocupar esses espaços a partir de uma diversidade de experiências vividas, inclusive as experiências relacionadas com as relações raciais e movimentos sociais. $\mathrm{O}$ desafio é conciliar, para ativistas e lideranças, essa entrada e o não distanciamento de suas bases e princípios de atuação. A representatividade negra nos espaços de poder, de ativistas antirracistas, é importante por potencializar pautas de interesse desse segmento. Ampliar a representação nesses espaços demanda uma reformulação não apenas simbólica, mas estrutural. Esse processo esteve presente em algumas das estruturas estatais das últimas décadas, de acordo com Rios (2015: 223), onde foi gestada e emergiu uma "elite política negra, composta por indivíduos que direta ou indiretamente atuaram no movimento social, nos partidos políticos e no Estado".

Cabe ainda destacar que o lócus político que esses órgãos de igualdade racial, sejam os existentes no Brasil, Equador, Bolívia, Venezuela, dentre outros países da região, ocupam dentro do status quo político de seus Estados nacionais, é bastante fragilizado. Não há dúvida que a criação desses espaços é uma conquista dos movimentos negros. Também não há dúvida de que avanços substantivos ocorreram nessa última década, com muita influência da atuação desses órgãos em seus respectivos países. Todavia, no quadro geral, suas estruturas administrativas são muito frágeis, possuem pouco orçamento e quadro de funcionários reduzido.

Com relação ao Brasil, além da dimensão orçamentária, há limitações para efetivar a transversalidade da pauta nas políticas públicas (RIBEIRO, 20I4). Falta orçamento, equipe e foco político, o que acaba por colocar muitas vezes as políticas de igualdade racial como a última das prioridades. Além disso, se a promoção da equidade étnicorracial se ancorar apenas nas políticas setoriais, sem uma alteração estrutural, não representará uma significativa quebra do 
status quo. Um forte exemplo dessa fragilidade é a própria fusão ocorrida em 2015 do ministério de políticas de igualdade racial, junto ao de políticas para mulheres e direitos humanos.

Outro ponto que merece destaque no diálogo com Lao-Montes é a possível criação de uma elite negra majoritária e a manutenção da situação de exclusão e desigualdade da grande maioria da população negra. No processo de institucionalização do movimento negro brasileiro, se consolidou também uma elite afrodescendente, que foi fundamental para muitas das respostas dadas pelo Estado brasileiro ao tema racial (RIOS, 2015). Nas últimas décadas, tomando o Brasil como referência, os dados apontam para o fortalecimento de políticas de igualdade racial e ações afirmativas, como o crescimento da presença negra nas universidades ${ }^{48}$. Todavia, grandes problemas estruturais, como as alarmantes taxas de homicídio entre os jovens negros e a grande concentração de negros entre o conjunto dos segmentos mais empobrecidos e miseráveis não tiveram sinalização de reversão estrutural. Até apresentam um agravamento do quadro, como no caso das taxas de homicídio ${ }^{49}$.

São as contradições vivenciadas numa realidade de extrema desigualdade social e racial que demandam maior atenção e resposta por parte do Estado e da sociedade brasileira. Não é a existência ou não dessa elite negra que fragiliza essa redução das iniqüidades, necessariamente. Sua ausência do cenário político, inclusive, provavelmente tornaria a situação de exclusão da população negra menos evidente e as respostas do Estado mais fragilizadas.

Em Cuba, esse processo teve um caráter diferenciado, exatamente pela sua especificidade. No período pós-Durban, o debate sobre a questão racial na Ilha cresceu consideravelmente. Houve um aumento de debates em espaços públicos, palestras e conversatórios promovidos em grande medida por coletivos antirracistas. De La Fuente ressalta essa mudança paradigmática, fruto de um processo de mobilização, ativismo e insistência de muitos:

Finalmente, a través del trabajo y el esfuerzo de muchos, el racismo se convirtió en tema de investigación y debate. No se trata de un logro menor, puesto que el silencio sobre las llamadas «diferencias raciales» tiene hondas raíces en el imaginario nacional y constituye uno de los presupuestos centrales de la cubanidad. Es un silencio patriótico, cuyo certificado de nacimiento hay que buscarlo en las luchas anticoloniales del siglo xix -la mítica manigua redentora de los cubanos- y en los escritos de aquellos que, como José Martí, se empeñaban en inventar y construir una nación independiente y viable, participativa y armónica, en la que era mejor esquivar o soslayar divisiones y conflictos como los raciales. (DE LA FUENTE, 2012: 93).

\footnotetext{
${ }^{48}$ Ações Afirmativas e Inclusão: Um balanço. Cadernos do GEA . - n.I (jan./jun. 20I2). - Rio de Janeiro: FLACSO, GEA; UERJ, LPP, 2012.

${ }^{49}$ http://www.mapadaviolencia.org.br/pdf20I3/mapa2013_homicidios_juventude.pdf
} 
Cabe destacar que um dos primeiros momentos em que o tema racial entra na pauta da Assembleia do Poder Popular com destaque explícito foi em 20 de novembro de 20II, por meio de um comunicado da Comissão Aponte denominado "Informe sobre la Problemática Racial en Cuba", onde participaram Abel Prieto, Miguel Barnet, Zuleica Romay, Mariela Castro, Ricardo Alarcón e Heriberto Feraudy Espino, dentre outros.

Nesse período, também há um crescimento da participação de ativistas, lideranças e intelectuais antirracistas e negros em articulações internacionais, ampliando as conexões e redes estabelecidas entre esses coletivos em âmbito local para o internacional, como as conexões de Cuba com a Rede de Mulheres Afrolatinoamericanas e Afrocaribenhas ${ }^{50}$.

Parte das organizações e coletivos hoje existentes, como a Articulación Regional Afrodescenditente para las Americas y el Caribe - Capitulo Cubano - ARAAC e a Rede Barrial Afrodescendiente, surgiram nessa mesma época. A incorporação do próprio termo "afrodescendente", presente em discursos e nos próprios nomes de muitos coletivos, é um reflexo dessas conexões internacionais (DE LA FUENTE, 20I2), muitas delas estabelecidas no período pós-Durban.

As questões levantadas por Lao-Montes acerca dos reflexos pós-Durban nos movimentos afrodescendentes não são totalmente aplicáveis em Cuba. Por exemplo, no que se refere à ONGização e ao estreitamento de parcerias com governos ou instituições internacionais. Há grandes limitações para legalizar organizações da sociedade civil, seja qual for a área de atuação. Essa, portanto, já seria uma barreira inicial ao próprio processo de ONGização do qual LaoMontes menciona.

No caso dos coletivos que atuam com a questão racial, nenhum deles é legalizado formalmente, seja no modelo de associações ou ONG. Há um projeto em análise na Assembleia Nacional do Poder Popular que deve culminar em mudanças nas regras para o associativismo, mas ainda não está aprovado. Das poucas organizações da sociedade civil legalizadas atuantes no país, nenhuma delas tem a luta antirracista como uma bandeira. O Centro Memorial Martin Luther King, ligado à igreja Batista, por exemplo, é uma dessas poucas oficializadas, mas não atua diretamente com o tema, para além de projetos pontuais.

\footnotetext{
${ }^{50}$ Quando me refiro ao local, situo esse olhar a Havana e Matanzas, onde realizei a pesquisa de campo, e junto a um delimitado grupo de organizações. Porém, há informações de outras atividades semelhantes em curso em outras regiões do país, como Cárdenas e Santiago de Cuba, além de existirem outros coletivos dentro da própria cidade de Havana.
} 
A não existência de organizações antirracistas legalizadas faz com que seja dificultado o processo ocorrido em outros países da América Latina: o crescimento do financiamento nacional ou internacional das ONG ligadas à pauta negra ou afrodescendente. Porém, é possível perceber formas pontuais de apoio ou financiamento, sempre intermediadas por Centros ou Institutos como o Martin Luther King, todavia em escala muito reduzida e controlada.

Outra dimensão presente é o crescimento das representações cubanas em esferas internacionais de debate e participação social. Internamente, em Cuba, a disputa por esses espaços de representação no exterior gera, muitas vezes, conflitos e desgastes nos coletivos e na relação inter grupos. Há, inclusive, um conceito de la calle $e^{s I}$ aplicado aos atores que participam dessas viagens: rineterismo cultural. O rineterismo é uma expressão coloquial cubana para denominar a prostituição e os trabalhadores informais que vendem aos turistas mercadorias clandestinamente como charutos e rum pela izquierda, que é outra expressão que representa o comércio ilegal. Nesse caso, é usado para caracterizar a situação de uma participação de alguns ativistas cubanos em espaços internacionais. A existência do termo e o seu uso nessas circunstâncias é um dos resultados desse desgaste e do latente conflito gerado internamente nesses coletivos e nas relações estabelecidas entre eles.

Como em Cuba não há uma instância estatal para lidar com o tema, também não é possível falar, a partir dos mesmos moldes, em uma cooptação para a estrutura estatal de ativistas afrocubanos. Alguns dos ativistas que entrevistei ocupam cargos de direção importantes, como é a situação de Zuleica Romay que é presidenta do Instituto Cubano do Livro, mas seu trabalho no Estado não é relacionado à luta antiracista, e ela é uma das raras representantes negras nesse nível dirigente.

Com relação aos coletivos, alguns têm sua atuação vinculada a um suporte estatal, como a Comissão Aponte. Em alguma medida, são estabelecidas parcerias com a vice-presidência ou com outras estruturas do governo. Todavia, os apoios dados não refletem em uma estruturação maior desse coletivo. A Comissão Aponte não possui sede própria, telefone, orçamento para implementar ações. As iniciativas que realiza são custeadas pela própria União dos Escritores e Artistas de Cuba (UNEAC), da qual está vinculada, ou por outros órgãos de governo, mas sem uma autonomia da própria organização para a gestão das ações ou recursos.

\footnotetext{
${ }^{51}$ Da rua, termo coloquial.
} 
Retomando o foco sobre o processo de mobilização social pós Durban, passa a haver uma ênfase na produção e circulação de conhecimento em dimensão ampla e a interlocução com espaços multilaterais, como os órgãos das Nações Unidas e bloco de países, como a CELAC ${ }^{52}$.

Nesse período, são criadas ou fortalecidas redes internacionais ou regionais dos movimentos afrodescendentes ou negros na América Latina. Organizações como o Mundo Afro, no Uruguai, a Red Afrovenezuelana, o Geledés no Brasil, a Rede Latinoamericana de Juventude Afrodescendente de caráter regional, a Organização Negra Centroamericana de Honduras, a Articulação Regional Afrodescendente para as Américas e o Caribe - ARAAC, a Aliança Estratégia de Afrodescendentes da América Latina e Caribe, a Rede de Mulheres Afrolatinas e Afrocaribenhas e outras organizações e ativistas latinoamericanos estreitaram seus vínculos na conformação de redes regionais.

A ARAAC, capítulo cubano, promoveu em outubro de 2014 um debate sobre a Década dos Povos Afrodescendentes. Na exposição feita por uma de suas integrantes, Gisela Arandia ${ }^{53}$, o coletivo pondera a necessidade de avançar em ações práticas para o tema e marca a diferença do que denomina "sociedade civil" e o "Estado", mas com ressalva às relações necessárias com o Estado para que haja efetivas respostas às demandas colocadas:

[...]Assumir a década dos povos afrodescendentes como uma tarefa a mais. Não apenas como uma data, e sim como um momento permanente. Serão dez anos onde devemos contribuir, em um momento particularmente difícil do mundo e também particularmente difícil da realidade cubana. Se trata de uma possibilidade de oferecer nosso apoio, de oferecer nosso modesto conhecimento, a todas as instituições cubanas, desde ARAAC e desde outras instituições cubanas que também lutam por essa obrigada equidade social. As vezes conciliar o discurso teórico não é facil. Mas sim é mais fácil a ação. Por Cuba tem uma oportunidade. E qual é essa oportunidade? É que ao longo dessas cinco décadas, Cuba criou espaços institucionais que permite enfrentar o trabalho contra a discriminação. Como podemos articular-nos, como podemos trabalhar, como podemos concentrar-nos em isso que é a essência. Em que lugar da sociedade cubana estão precisamente essas desigualdades sociais? Estão exatamente em bairros marginais, em bairros pobres. Espaços onde no princípio da Revolução houve uma luta por vencer esses espaços de marginalização, mas não foi possível, pois desmontar o racismo não é só uma ação política. Desmontar o racismo é um processo complicado, um processo de pensamento, um processo de ações. Esse tema não há sido um tema nobre. Porque há um mito e é o mito onde falar da discriminação racial pode quebrar a unidade nacional.

[...] Algumas pessoas me perguntavam: Porque o lançamento da Década dos Povos Afrodescendentes será feito nesse contexto das instituições? Por razões simples. Porque não é possível construir a equidade sociais de costas para as instituições. Podemos fazer projetos interessantes, podemos avançar

52 O Encontro da CELAC, realizado em 20I4, teve como um dos temas abordados a superação das desigualdades raciais na região. Apesar da questão racial não ter sido um dos temas de maior visibilidade, sua presença nessa instância, com a participação nos debates de ativistas, marca a estratégia de ampliação dos espaços de diálogo.

${ }^{53}$ Faz parte da coordenação de ARAAC e da Rede de Mulheres Latinoamericanas e Caribenhas - Capítulo Cubano. Ativista e pesquisadora sobre a questão racial, tem publicações sobre o tema. Coordenou o projeto Color Cubano, criado em 2001 e extinto em 2009, um dos pioneiros no país. Mantive contato com Gisela durante várias atividades e encontros sobre a questão racial em Havana, no período de 2014 a 2015. Em parte dos casos, as atividades eram organizadas pelos coletivos que Gisela fazia parte. Além dos vários contatos nesses espaços, realizei entrevista em sua casa, onde pudemos aprofundar o diálogo sobre o tema racial e a luta antirracista. 
em muitas coisas, podemos avançar na literatura, e não resta dúvida que a literatura nesse tema avançou muito nos últimos anos [...] e nós, como sociedade civil, temos uma responsabilidade extraordinária. Ainda que pareça que não avançamos, sim estamos avançando. (Gisela Arandia, exposição feita no lançamento da Década dos Povos Afrodescendentes, em I3 Outubro de 20I4, Casa de Alba, Havana, Cuba).

A fala de Gisela remete a outro aspecto relevante. Há uma necessidade elementar de que essas demandas, denúncias e reivindicações sejam ouvidas e se transformem em políticas públicas. Sem uma ação do Estado mais efetiva, é difícil que iniciativas dos coletivos por si só alcancem mudanças em ampla escala. Por isso, ela justifica a necessidade de envolver representantes governamentais nas atividades de seu coletivo.

As mídias sociais e as redes de comunicação são ferramentas importantes do ponto de vista mobilizatório muito utilizados na América Latina pelos movimentos afrodescendentes. Em Cuba, cabe destacar a extrema limitação de acesso à internet. As causas, não amplamente publicadas oficialmente, parecem apontar para dois fatores fundamentais: as dificuldades tecnológicas, muitas delas ocasionadas pelo Bloqueio imposto pelos EUA ${ }^{54}$; e a outra, também importante, diz respeito ao controle no acesso à informação por parte do governo cubano. Com a restrição do acesso à internet, imagina-se ter menos influência das iniciativas dissidentes e contrarevolucionárias no país ${ }^{55}$.

A maioria dos/as ativistas entrevistados em Cuba possui apenas email, majoritariamente institucional, vinculado a órgãos como o Ministério da Cultura. A conexão dos emails é feita nas linhas telefônicas, sem gerar acesso à internet. Outra parte dessas lideranças acessa os emails em contas como o gmail em ciber cafés ou cartões pagos para internet, com valor da hora bastante alto, em dólar, o que restringe muito o seu uso. Há rumores, também, de que a antiga Oficina de Interesses, oficializada desde 20 de julho de 2015, como embaixada dos Estados Unidos, ceda seus computadores para uso de organizações politicamente próximas, inclusive algumas com atuação racial.

Mas, mesmo nesse caso cubano, onde há forte restrição tecnológica e política ao uso da internet, a rede de comunicação e informação se configura como uma parte importante das mobilizações antirracistas. Textos, cartas, articulações, informações são intercambiados entre ativistas por email, e em alguns casos, em formato impresso, e até por ligações telefônicas. O boletim "Desde la Ceiba", produzido por Tato Quiñones, por exemplo, é divulgado periodicamente nas listas de

\footnotetext{
${ }^{54}$ De acordo com o Bloqueio, nenhuma peça, software ou tecnologia pode ser utilizada em Cuba se tiver mais de I0\% de patente estadunidense.

${ }^{55}$ Existem, na atualidade, zonas em algumas localidades de cidades cubanas que disponibilizam internet wi-fi, a um custo ainda alto para cubanos: Cerca de 2 Cuc (equivalente ao dólar) a hora.
} 
emails de ativistas. Outro fator importante são os blogs e sites, como o negracubanateniaqueser.com, de autoria de Sandra Alvarez ${ }^{56}$, ou o site afrocubaweb.com.

O período pós-Durban, portanto, trouxe reflexos e influências tanto para as mobilizações afrodescendentes da sociedade civil na região, como também para as estruturas estatais e a elaboração de políticas públicas. Os desafios ainda são enormes no sentido de reverter desigualdades raciais historicamente construídas, mas é possível elencar alguns desses avanços, e busquei ressaltar parte deles.

\section{I.2. Cor, Raça, Negritude e Afrodescendência}

Refletir sobre o uso de categorias sociais e desconstruir seus paradigmas são processos fundamentais na análise dos fenômenos sociais. Nesse sentido, proponho pensar sobre as diversas categorias vinculadas às relações raciais empregadas no meio social cubano, como signos compartilhados na experiência dos grupos e coletivos estudados que se incorporam como símbolos contingentes, aleatórios, constituídos em diferentes circunstâncias políticas e sociais.

Atualmente, o debate sobre as relações raciais em Cuba está em um flanco processo de expansão. Ainda que não esteja presente no cotidiano de uma grande parcela da sociedade, as reflexões sobre o tema aparecem nos debates de televisão, nas rádios, jornais impressos, publicações, boletins digitais. Nessa rica discussão, surgem conceitos e estratégias construídas por ativistas, intelectuais e coletivos, relacionadas com questões conceituais.

Nesse espectro de ideias, signos como "raça", "cor", "negra(o)", "mestiça(o)", "mulata(o)", "branca(a)" e "afrodescendentes", se por um lado refletem essencialismos identitários e categorias genéricas, por outro lado também apontam estratégias dos agentes sociais e coletivos na luta por direitos.

Parte da intelectualidade, no contexto cubano, argumenta que a categoria "cor" seria a saída para o dilema colonial que a categoria "raça" traz ${ }^{57}$. Todavia, "cor" está imersa em contradições não

\footnotetext{
${ }^{56}$ Psicóloga, é coordenadora e autora do blog Negra Cubana Tenía Que Ser. Divulga matérias, textos, manifestos, artigos vinculados à mobilização antirracista, à identidade afrocubana, relações de gênero e diversidade sexual. Durante a pesquisa em Cuba, tive contato pessoal apenas uma vez com Sandra, pois atualmente ela vive na Alemanha. Contudo, mantivemos comunicação pela internet no período, e acompanhei publicações suas no blog, site e facebook.

${ }^{57}$ Esse debate surge em seminários e artigos acadêmicos. Um dos que falam sobre o tema é Guanche (2015).
} 
menos significativas. Cor também se refere aos mesmos conteúdos que geram os estereótipos ${ }^{58}$ presentes na categoria "raça". O uso do termo "cor" aparece embebido de estereótipos racistas, pois sua classificação e seu uso social permeiam uma dimensão além do estrito "cor da pele", por si só já problemático. O termo pressupõe outros traços fenotípicos, como tipo de cabelo, traços do rosto, tamanho dos lábios, nariz. Além da manutenção dos estereótipos da raça no uso da categoria "cor", há uma contínua menção à ideia de raça, como no uso dos termos "racismo", "racialidade", "discriminação racial".

Igualmente presente no contexto colonial, o conceito "cor" ou "color", em espanhol, balizou a categorização das pesquisas censitárias feitas em Cuba, e também no Brasil, durante todo o período colonial. O interessante dessa análise é que havia duas categorias: "os brancos" e os "de cor". Portanto, a cor estava nesse contexto marcadamente vinculada aos negros.

Cabe destacar que a categoria "cor" é uma generalização e uma compressão significativa de uma ampla gama de identidades. Se tomarmos como exemplo os povos indígenas, se pode observar que são classificados como cor "vermelha", ou mesmo por meio da classificação genérica "índio", que engloba os Macuxi, os Wapixana, dentre vários outros povos. Se tomarmos os brancos, idem. Quem seria o branco? Os descendentes de Eslavos, Irlandeses, Bascos, Judíos? Os classificados pela cor negra, preta, parda, quem seriam? Os descendentes de Yorubanos, Carabalíes, Massai? A categoria "cor" constrói uma classificação genérica de uma ampla variedade de identidades.

Por outro lado, se a categoria é então relacionada com o fenótipo de certos grupos da sociedade, e não vinculada à origem ou ascendência, por que exatamente a cor amarela representa os "orientais", por exemplo? Esses são fenotipicamente amarelos? Steve Biko, em um dos muitos processos judiciais que sofreu no contexto do Apartheid, na África do Sul, teve o seguinte diálogo com o juiz:

- Juiz: "Por que seu povo se diz negro? Vejo-te mais marrom que negro".

- Steve Biko, "Por que vocês se dizem brancos? Vejo-te mais rosa que branco".

Termos como "negro", "mestiço", "branco", "mulato", "amarelo" ou "de cor" são bastante comuns nas narrativas populares, políticas e acadêmicas, nos contextos brasileiros e cubanos. São termos que estão mais além da simples descrição, já que fundamentaram um código colonial para

\footnotetext{
${ }^{58}$ Para SOUZA (2008) e Alli, o conceito de estereótipo deriva da generalização e atribuição de valor, em grande parte das vezes negativo, a algumas características de um grupo, reduzindo-o a estas característicass e distorcendo seus sentidos amplos. Essa generalização, no caso dos estereótipos, pode impor ao individuo ou ao grupo o lócus de inferioridade, incapacidade 'nata' ou mesmo periculosidade ou marginalidade.
} 
a conformação de relações de dominação e subordinação entre o colonizador e o colonizado. Esses termos, todavia, tem sido ressemantizados através de uma variedade de processos políticos, culturais e econômicos.

Como destaca Quijano (2000) a ideia de raça e cor tem sido o instrumento mais eficaz de dominação social concebido nos últimos cinco séculos. Em sua caracterização moderna, foi construída na formação das Américas e do sistema capitalista, entre os séculos XV e XVI, e nos séculos seguintes, imposto a toda a população do planeta, como parte da dominação colonial europeia.

Quijano (2000) argumenta, ainda, que com base nesse critério básico de classificação da população, as identidades sociais foram compartimentadas, de um lado, como "índio", "negro", "asiático" (ou amarelos), "branco" e "mestiço". De outro lado como: "América", "África", "Europa", "Ásia", e "Oceania". Sobre essa classificação, segundo o autor, se fundamenta o eurocentrismo do modelo capitalista e a conseqüente distribuição mundial de trabalho, além de ser estruturante para a configuração de poder.

Acredito que a conformação dessas identidades não é congelada, mas seus constructos sociais geram relações que constroem lugares estigmatizados. A identidade negra, nos países com herança colonial, é vinculada a uma percepção social historicamente estigmatizada. Goffman (2005) define estigma como forma de classificação social pela qual uma pessoa identifica a outra, segundo certos atributos seletivamente estabelecidos pelo sujeito classificante, como positivos ou negativos e desabonadores. Os estigmas ocasionam a negativa do reconhecimento da identidade negra, a vergonha de si próprio, sentimentos de insegurança, isolamento e sofrimento.

As categorias, tais como elencadas por Quijano, ocupam um lugar simbólico importante nas relações sociais em Cuba e Brasil, e categorizam grupos heterogêneos. Todavia, é uma tarefa complexa categorizar os "negros cubanos", por exemplo. O esforço colonial de pasteurizar essas identidades não dá conta dos múltiplos processos de afirmação de identidades e mobilizações que deslocam, rompem ou contestam o conjunto de significados vinculados ao termo "negro", por exemplo, ou à "raça".

Freqüentemente, a luta ideológica consiste na tentativa de obter um novo conjunto de significados para um termo ou categoria já existente, de desarticulá-lo de seu lugar na estrutura significativa. Por exemplo, é justamente por conotar aquilo que é mais desprezado, despossuído, ignorante, incivilizado, inculto, maquinador e incompetente que o termo "negro" pode ser contestado, transformado e investido de um valor ideológico positivo (HALL, 2006: I93). 
Em diálogo com o conceito de "luta ideológica" de Hall (2006), proponho uma reflexão sobre o conceito de "raça". Para além da abordagem fundada a partir de perspectivas biológicas que balizaram uma hierarquia dos grupos humanos, existe uma recente apropriação política do termo, sobretudo por movimentos sociais, e sua acepção como constructo social, fruto das relações sociais.

O conceito de "raça", conforme concebido no contexto colonial, com base nos estudos de Gobineau (I853) e outros, balizava uma diferença biologicamente fundada entre os diferentes fenótipos humanos e traçava uma hierarquização entre os grupos a partir dessas concepções. Tanto em Cuba, como no Brasil, isso fundamentou teorias sobre a mestiçagem e o branqueamento, inclusive com políticas de estímulo à migração europeia na primeira metade do século XX.

Nesse contexto, também surgem as teorias racistas da ideologia nazista, fundadas em aspectos biológicos e orientadas para a superioridade ariana. Cabe destacar, ainda, a segregação racial nos Estados Unidos, vigente até poucas décadas atrás, e o Apartheid, na África do Sul, que perdurou legalmente até o princípio dos anos 1990. A ideologia racista, que defende uma superioridade racial, organiza o Estado e a Sociedade para a manutenção desse status quo hierarquizado e excludente de forma explícita.

$\mathrm{Na}$ América Latina, apesar de não ter havido uma explicitação da hierarquia racial ou mesmo da segregação em leis e políticas pelo Estado ao longo do século $\mathrm{XX}$, os afrodescendentes e indígenas compartilham de forma majoritária os espaços de maior marginalidade no acesso a direitos e espaços de e poder (HASENBALG, 2005; GONZALEZ et al., 201 I; WADE, I997). Essas análises e estudos concluem que, apesar de não haver um vínculo biológico em sua significação, "raça" é uma dimensão socialmente construída que traz impactos para a vivência social de forma diferenciada entre os grupos racializados.

O debate sobre o conceito de "raça" é amplo nas ciências sociais. É apontado como um constructo social e político, situacional e relacional. Sua conformação depende, necessariamente, de uma análise do contexto social do qual diz respeito. Não se refere a uma dimensão intrinsecamente presente nos indivíduos, naturalmente dada.

Em um trabalho sobre o contexto colombiano, Wade (1997) faz algumas ponderações sobre o conceito de "raça" que são interessantes para esse trabalho. Ele reafirma que essa categoria não tem nenhum fundamento em aspectos biológicos. E aborda o caso de alguns acadêmicos (E.G. 
MILES apud WADE, I997) que sequer a utilizam como categoria analítica, fazendo uma priorização por etnia ou classe. Segue apresentando sua posição de que "raça" é uma construção social e que o fato de desconhecer que essa é uma categoria analítica gera uma visão reducionista, dos impactos que esse conceito autonomamente gera no meio social. Para aprofundar o debate, diferencia as categorias "raça" e "etnia":

Estos dos términos no pueden ser separados radicalmente porque ambos se refieren a identidades establecidas en la interacción entre el identificarse a sí mismo y el identificar al otro, a nivel individual y colectivo; ambas se refieren en cierto sentido a los orígenes de una persona y de una colectividad, y a cómo estos orígenes influyen en el ser social. Pero el significado de las identificaciones étnicas y raciales es bastante diferente. Las identificaciones raciales utilizan las diferencias físicas como señales, no sólo cualquier diferencia física, sino aquellas que se convirtieran en objeto de manipulaciones ideológicas en la historia de la expansión colonial occidental. Por lo tanto, la alusión a tales diferencias físicas inevitablemente invoca significados que han sido construidos durante siglos de explotación: substituí el término "etnicidad" (o "nación", o "pueblo") por "raza" corre riesgo de enmascarar estos significados. [...] Las identificaciones étnicas (por su vez) no sólo usan cualquier signo de diferencia cultural, sino tienden a favorecer a aquellos que se piensa que se derivan de una geografía de la cultura. La noción de "lugares" es básica para la etnicidad. (WADE, 1997: 17).

Apesar de estarem intrinsecamente vinculadas às identidades forjadas socialmente, "raça" e "etnia", como argumenta Wade, são categorias diversas, que se referem a dimensões e representações sociais também distintas. No caso desse estudo, apesar do caráter étnico estar presente nos vínculos identitários de vários coletivos estudados, por questões vinculadas à tradição e ao território, o foco está voltado para as identidades raciais, no sentido apresentado por Wade.

As construções sociais do conceito "raça" e o peso das características físicas que são objeto da ideologia racista compõem o que José Jorge de Carvalho chama de racismo fenotípico, que no caso cubano tem grande aplicabilidade. Construído a partir do referencial branco, o racismo fenotípico, com a revolução industrial, se dissemina em uma escala monumental:

Antes do século XVIII não havia meios tecnológicos para difundir o imaginário produzido com a finalidade de impor a superioridade branca no mundo inteiro. Assim como Walter Benjamin construiu uma história das transformações da obra de arte na era de sua reprodutibilidade técnica, devemos agora incluir um recorte racial ou fenotípico em seu modelo interpretativo e refletir sobre a difusão e mesmo a naturalização das imagens do mundo clássico (da chamada beleza greco-romana) e do mundo europeu moderno. (CARVALHO, 2007: 05).

De acordo com Adesky (2009), é por meio da categoria raça como um constructo social que torna-se possível a compreensão de um campo ideológico que fundamenta estereótipos e preconceitos advindos de uma sociedade racista. O conceito de raça, para Lawrance et al. (2004), baseia-se numa classificação ilusória do ser humano criada (modernamente) por europeus 
(brancos), que atribui valor humano e status social usando 'branco' como o modelo da humanidade, com a finalidade de estabelecer e manter privilégio e poder ${ }^{59}$.

Com base nessa acepção, a categoria "raça" reflete as diferentes dinâmicas e relações sociais forjadas a partir das diferenças fenotípicas e culturais existentes. Há uma ressemantização do termo, por meio do reposicionamento desse conceito originário na modernidade como vinculado à hierarquia biologicamente fundada das raças, para uma apropriação social e política de seu uso.

Remeto, novamente, esse debate a Stuart Hall (2006), que faz uma análise das categorias "raça" e "etnia" aplicadas às comunidades pós-migratórias não brancas na Grã-Bretanha, onde o termo "raça" é aplicado geralmente aos afro-caribenhos e "etnia" aos asiáticos. De acordo com o autor, essa abordagem dá um tom grosseiro à descrição dessas comunidades. A multiplicidade de identidades que são compactadas e comprimidas em um pacote homogêneo de "raça", "branco", "negro" ou mesmo "afrodescendente" destoa da diversidade desses grupos.

Ainda em diálogo com esse autor, é possível refletir sobre a ideia biologizante da utilização da categoria "raça". Como conceito biológico, raça não existe, conforme destaca Hall (2006: 69):

\footnotetext{
As diferenças atribuíveis à "raça" numa mesma população são tão grandes quanto aquelas encontradas entre populações (ditas) racialmente definidas. "Raça" é uma construção política e social. É a categoria discursiva em torno da qual se organiza um sistema de poder socioeconômico, de exploração e exclusão - ou seja, o racismo.
}

Sua narrativa discursiva muitas vezes é permeada por um discurso que agrega a dimensão biologizante da ideia de raça. Hall (2006) dá ênfase ao que chama a "concepção mais ampla do racismo", que abarca em sua estrutura discursiva o racismo biológico e a discriminação cultural. Eles seriam concretizados de acordo com as circunstâncias. Ditos populares cubanos, como "eso es cosa de negros", "portese como un blanco" ou "negro de alma blanca" são alguns dos exemplos dessa narrativa articulada entre o biológico e o social que é materializada nas relações sociais.

Os processos de construção das identidades étnicorraciaias, longe de serem monolíticos, se constituem pela agencialidade dos múltiplos sujeitos envolvidos nessas relações. No caso dos ativistas e dos coletivos, há uma ressemantização dessas categorias, como uma linguagem política. No Brasil, são os movimentos sociais negros que ressemantizam o termo "raça", num processo

\footnotetext{
59 Ronald Chisom and Michael Washington, Undoing Racism: A Philosophy of International Social Change. People's Institute Press. People's Institut for Survival and Beyond. I444 North Johnson Street. New Orleans, Louisiana, 70I 16.1997. Second Edition. p. 30-3I.
} 
afirmativo, em contraponto a uma realidade social que os invisibilizava, que os excluía. Dinâmica de reposicionar esse conceito como relevante nas relações sociais é apresentado por Guimarães:

\footnotetext{
Renascida na luta política, a noção (de raça) é recuperada pela sociologia contemporânea como conceito nominalista - isto é, para expressar algo que não existindo, de fato, no mundo físico, tem realidade social efetiva (GUIMARÃES, 1999 apud GIMARÃES, 2011: 266).
}

Há, também, um deslocamento do signo "negro" para um lócus afirmativo. As narrativas do movimento negro, aos poucos, especialmente a partir de seu processo mais intenso de institucionalização nos anos 1970, passam a imprimir o "orgulho" de assumir a negritude. Questionam termos classificatórios de identidade como "moreno", "pardo", "mulato", "café com leite" e tantos outros. As estratégias políticas dessa afirmação negra são mais amplas, contudo. Como destaca Guimarães (1999: 5I): "A assunção da identidade negra, significou, para os negros, atribuir à ideia de raça presente na população brasileira que se auto-define como branca a responsabilidade pelas discriminações e pelas desigualdades que eles efetivamente sofrem".

A ressemantização que o Movimento Quilombola fez do termo genérico "quilombo" no Brasil é outro exemplo. A partir de um contexto pejorativo onde se concebeu a categoria "Quilombo" como sinônimo de foragidos, negros pobres, fugitivos, há uma apropriação e ressemantização do termo pelos coletivos dessas comunidades. Esse termo se converte em um dos eixos da conformação da identidade quilombola hoje. Rompe com o estigma colonial e se traduz como um conceito de identidade coletiva que fundamenta a luta por direitos dessas comunidades.

Sem ignorar as mobilizações relacionadas com esse tema realizadas ao longo do século XX em Cuba, cabe destacar que processo similar de afirmação da identidade se produz, no pósRevolução, sobretudo a partir do final da década I990, com a formação dos primeiros coletivos antirracistas na Ilha e a articulação maior dos ativistas. Esses utilizam, fundamentalmente, como narrativa discursiva o conceito de "negro" e "afrodescendente", ou fazem referência direta à dimensão racial. Inclusive, são categorias marcadamente presentes nos nomes de muitos dos coletivos existentes, como La Cofradía de la Negritud, Afrocubanas, Rede Barrial Afrodescendiente, Alianza Unidad Racial, ARAAC.

O reposicionamento de signos, categorias e expressões faz parte das estratégias políticas de muitos ativistas e coletivos antirracistas da Ilha. Gisela Arandia, por exemplo, pontua a necessidade de deslocar a percepção sobre o vínculo com a África, a afrodescendência e o que ela pontua como "africania": 
Hace poco estaba en un evento sobre religión y alguien dijo desde la mesa y desde el público: 'no no somos africanos', y yo pedí la palabra: '¿si no somos africanos que somos? Porque los europeos, los blancos, nunca dicen nosotros no somos europeos, o polacos, o ingleses, o franceses. Entonces nosotros no somos africanos, pero somos la Diáspora Africana lo cual significa que la esencia identitaria es africana con la característica en América Latina, particularmente en Cuba, que esa identidad africana esta también en los no negros, está también en los no afrodescendientes, los blancos también forman parte de esa identidad africana, eso está presente. Por tanto yo creo que no hace tanta falta seguir repitiendo en el discurso cultural que en las obras de arte esta la africania, que en la cultura esta la africania, en el teatro, todo eso es verdad lo sabemos pero el problema nuestro actual no es ese si tenemos esa africania, primer problema no lo asumimos lo cual eso sí y hay que trabajar en eso y segundo pesa la secuela la consecuencia de esa africanidad, que es la palabra que me gusta usar, está en una desventaja social absolutamente visible, entonces ese es el conflicto, esa africanidad presente en los barrios en las comunidades está en desventaja social está en desventaja cultural, no tiene lo que yo digo, no solo no tiene dinero sino que tampoco tiene capital simbólico, no saben cómo poder organizar su vida, vender lo que sea, vender tortilla, para vender tortilla necesita una estrategia comprar pan, aceite, entonces eso es lo fundamental que tenemos que trabajar desde esta perspectiva serena de acercamiento con otros pueblos comunes, cuando oigo eso que no quiero saber de nada más que de Cuba siento como un poco de pena y a su vez de miedo hacia dónde vamos (Gisela Arandia, entrevista realizada em 12/09/2014).

Gisela, acima, para além de deslocar o próprio sentido do pertencimento à africanidade, também foca essa identidade como uma estratégia de luta. A partir do reconhecimento dessa "africanidade", ela ressalta a denúncia do legado colonial e pos-colonial sobre os afrodescendentes, que se concentram entre os que vivem em uma situação de pobreza, de violência e violação dos direitos.

Em referência ao Programa de Atividades para a Implementação da Década Internacional dos Povos Afrodescendentes, da ONU, destaca, a discriminação racial pode ser agravada pela sobreposição de outras formas de discriminação, baseadas em fatores etários, de gênero, língua, religião, política, de origem, pobreza, deficiência.

Por isso, há uma importância ímpar na estratégia dos coletivos dos movimentos sociais de buscar reverter o discurso de invisibilidade dessa identidade afrodescendente e, por outro lado, também miniminizar os efeitos da discriminação racial como promotora das situações de exclusão e pobreza.

O discurso colonial e imperialista acentua o papel de dominação, exclusão e racismo. Para Foucault (2006), o discurso é constituído de práticas comunicativas e representativas que se estruturam como forma de poder. O discurso não seria simplesmente a tradução das lutas e dos sistemas de dominação, mas aquilo pelo qual disputam as mobilizações políticas coletivas, o poder que queremos nos apoderar. Interessante observar esse processo junto a coletivos cubanos, que reposicionam a categoria "negro" e "afrodescendente" como uma estratégia central de suas lutas políticas, a partir de um reposicionar do discurso colonial. Processo similar de ressemantização foi vivenciado no Brasil, pelos movimentos negro e quilombola, como supracitado. 
As dinâmicas que conduzem à classificação de conjuntos heterogêneos de pessoas ou grupos sociais baseados em identidades genéricas como "negro" ou "afrodescendientes" são variadas e necessitam ser analisadas em cada contexto específico. Nas relações discursivas entre a academia, Estado, movimentos sociais, há uma disputa sobre a aplicação, significação e usos dessas categorias.

No contexto cubano atual, muitas das controvérsias existentes mesclam as estratégias das mobilizações antirracistas, os discursos identitários, com conjunturas políticas vivenciadas nos estertores da Guerra Fria. Os reflexos disso surgem em narrativas de parte dos acadêmicos e de representantes do Estado. $O$ trecho, a seguir, ilustra uma visão dessas percepções:

\footnotetext{
La llamada «conciencia racial» es a la larga tan mortífera y autoexcluyente para el debate y su solución plena [...] también en el contexto nacional Nicolás Guillén (1902-1989) esgrimió el color cubano como una cualidad alcanzada por la nación, como una marca de la cultura muy por encima de la natura. Pues no somos afro, ni euro, ni aborigen, ni chinos, ni todo el manojo de grupos humanos inmigrantes, somos todo lo anterior y mucho más: cubanos, cual síntesis novedosa de siglos de historia. Quienes hemos tenido la ocasión de escuchar o leer una y otra vez los argumentos del supuesto «antirracismo» racista, sabemos demasiado bien hacia dónde va el camino si se inclina la balanza de un solo lado del problema. A exacerbar la situación y no a tratarlo a partir de lo real, sino de lo imaginado, de lo construido cuidadosamente por la subversión. Es un modo de seguir el juego del norte a un discurso acompañado por la doble moral: la asignación de cuotas, cual acción afirmativa, y el impune asesinato de jóvenes identificados como "negros" o "afroamericanos" (GUANCHE, 2015 $\left.5^{60}\right)$.
}

Guanche questiona a identidade afrodescendente e os conceitos vinculados a uma estratificação racial ou de cor. Há nesses discursos um reforço explícito da ideia da cor invisível, da "cor cubana", da "unidade nacional", no sentido em que a identidade sobressalente é a identidade cubana, em detrimento das demais e como se as diferentes identidades estivessem em disputa. $\mathrm{O}$ discurso político da chamada "luta antirracista", como destacado por Guanche, é concorrente à construção do "todos nós somos cubanos", o que, a partir dessa leitura, geraria rupturas na imagem totalizante nacional.

Ademais, as iniciativas de denúncia do racismo e de afirmação da identidade racial são situadas como ações subversivas e de mimese do modelo do hemisfério norte. Essa argumentação reflete muitas das tensões que presenciei em campo no percurso da pesquisa, nas relações entre parte da academia e da burocracia estatal com os ativistas e coletivos antirracistas.

A argumentação implícita ou explícita que vincula essas mobilizações com processos "dissidentes", orientados ao "norte", não dialoga com a linha política defendida por una grande

\footnotetext{
${ }^{60}$ Artigo disponível em: http://negracubanateniaqueser.com/2015/03/25/el-racismo-contra-la-pared/
} 
parte dos coletivos antirracistas em Cuba ${ }^{61}$. Ainda assim, é uma ferramenta utilizada, em diferentes situações como demonstrado no texto acima, para deslegitimar a ação e a própria existência do ativismo afrodescendente e antirracista. A ideia de subversão ou dissidência tem um peso importante em Cuba e essa vinculação está cheia de simbolismo, que em grande medida reflete o intento de controlar o discurso.

Essa visão é contraposta por ativistas que questionam o modelo monolítico de que "cubanos somos todos" e de que "não se devem tocar nos problemas de iniqüidade racial". Para muitos desses, é exatamente essa desigualdade que incide com veemência na divisão do país e não tratá-la agrava a situação, conforme destaca Quiñones:

\begin{abstract}
A partir de los 1960, 1962, 1961, el tema de la cuestión racial en Cuba comienza a convertirse en un tema tabú, del cual no puede hablarse sin riesgo a ser tu conceptuado como una persona ideológicamente incorrecta. Razón para esto: La división entre blancos y negros puede servir de cuña para que el imperialismo logre dividir al pueblo cubano. iAlgo completamente absurdo! Lo que divide al pueblo cubano justamente es, que el no reconocer la diferencia de saber que no somos iguales, que tenemos que ser una unidad basada justamente en esa diferencia. Quienes nos dimos cuenta de eso, estuvimos diciéndolo desde siempre, no ahora. La vida nos ha dado la razón. Llegamos a esta altura de existencia [...] que el problema se convierte en lo que se ha convertido después de los años 90 en una serie de autoridad moral y hasta política diría yo, sobre el asunto. Muchos compañeros y compañeras que fuimos batalladores de estas ideas por los años 1960, 70 los 80, ya han muerto. Otros se cansaron, otros se fueron, pero bueno aquí quedo yo y otros y otras que quedamos y gozamos de un cierto respeto de parte de todo el mundo tanto de jóvenes, activistas como de las autoridades porque somos históricos. (Entrevista com Tato Quiñones, realizada em 29/05/20I4).
\end{abstract}

No Brasil, comparativamente, há aqueles que situam os discursos antirracistas e pró-políticas de igualdade racial e de ações afirmativas também como divisionistas, como fragmentários da idealização de um conjunto nacional anteriormente harmônico. Alguns cientistas sociais brasileiros, como Ivonne Maggie e Peter Fry ${ }^{62}$, afirmam que "as cotas para negros nos vestibulares das universidades públicas vão racializar a sociedade brasileira”, ou ainda "vai haver uma divisão racial do Brasil”, ou que "discriminar, mesmo que positivamente, é uma forma de racismo contra a tradição brasileira”, entre outras posições semelhantes.

Essas argumentações surgem com força na primeira década dos anos 2000, período em que se discutia no país a criação de ações afirmativas nas universidades. Os dados estatísticos da época apontavam imensa desigualdade no acesso entre os grupos negro e branco. A presença de jovens negros na universidade representava 20,8\% da presença branca em 2002 (IPEA, 20I0). Em 2004, o partido com tendências à direita, Democratas (DEM), ingressou no Supremo Tribunal

\footnotetext{
${ }^{61}$ Essa, por exemplo, não é a posição de nenhum dos ativistas entrevistados. Todos alegam defender a "Revolução", tendo essa concepção diferentes perspectivas. Há a argumentação, também, de que a luta contra o racismo de forma explícita é uma peça chave para fortalecer esse projeto que é a "Revolução".

${ }^{62}$ MAGGIE, Y. e FRY, P. A reserva de vagas para negros nas universidade brasileiras. Rio de Janeiro, Enfoques (Revista Eletrônica), vol. I, nº I, 2002.
} 
Federal, em 2004, com ação contra a legalidade e constitucionalidade das cotas ou ações afirmativas no país com base no critério raça/cor. Em 2010, o julgamento aprovou sua constitucionalidade por unanimidade.

Nas pautas dos coletivos antirracistas desses países, Cuba e Brasil, a partir de suas especificidades, há uma forte politização vinculada à mobilização contra as desigualdades existentes na sociedade entre os grupos raciais. As disputas entre as diferentes narrativas sobre a questão racial e sobre as categorias "negro" e "afrodescendente" estão no centro desses discursos. Na perspectiva dos movimentos sociais antirracistas, em sua diversidade discursiva, se pode verificar um relativo consenso que é o intento de visibilização desse segmento afrodescendente, negada pela ideologia da mestiçagem, da cor invisível, ou mesmo pela ideia de unidade nacional, e a realocação desse signo como uma identidade positiva de luta.

Nos processos que permeiam as construções identitárias e os vínculos no âmbito das mobilizações antirracistas é interessante perceber as dinâmicas de solidariedade que são estabelecidas nesses coletivos. A ideia binária branco/não branco existente em muitas das narrativas permite que sejam compartilhadas experiências de estigmatização, exclusão e discriminação, como, por exemplo, nos meios de comunicação, no acesso e permanência no mercado de trabalho, nas instituições de educação, justiça e segurança pública, e nas condições de moradia. A abordagem de Kimbo ${ }^{63}$ é bem interessante nesse sentido:

Mira, yo me siento contento ahora, por qué me siento contento porque actualmente la presidenta del Gobierno provincial, no es problema de racismo yo hablo claro, es una negra, una negra que viene con los mismos pasos que Lazo, una negra que atiende al pueblo, una negra que ha tratado de resolver los problemas de esta provincia porque es una negra que tiene vergüenza, una negra que piensa. ¿Pero que pasa con esto? Yo soy realista, los alrededores les molesta porque es negra y está mandando, le molesta que ella este mandando a esos blancos, a esa negra no la puso cualquiera, a esa negra la puso Raúl Castro, pero lo de alrededor le molesta y esas son las cosas que a mí me molestan, que nosotros los negros hasta cuando, hasta cuándo y hasta donde y no lo digo ahora en esta grabación lo digo donde quiera porque me siento negro cien por ciento y con mis negros me muero que yo sé que a mi ellos no me van hacer daño. (Kimbo, La Marina. entrevista feita em I3.09.14).

\footnotetext{
${ }^{63}$ Raul Dominguez, Kimbo, é uma liderança comunitária importante do bairro La Marina, Matanzas, Cuba. É educador popular e tem fortes ligações com tradições afrocubanas, como a Santeria e a cultura Abacuá. No percurso da pesquisa, conheci Kimbo a partir da conexão de educação popular de Maritza Lopez, em um primeiro encontro feito em sua casa, em abril de 20I4. Irene Esther esteve comigo nessa primeira ida. Após esse momento, nossos contatos passaram a ser frequentes, em atividades e reuniões feitas em La Marina. Uma das propostas construídas pela comunidade, a partir do contato com as pesquisas de doutorado de Daniel Brasil e minha, foi a criação do Projeto Identidad e Barrio La Marina. O projeto realiza diversas atividades no bairro e se mantém até o presente. Kimbo é um dos organizadores de eventos importantes, como a queima do muñeco San Juan, que representa Ogun, e o festival de comunida tradicional.
} 


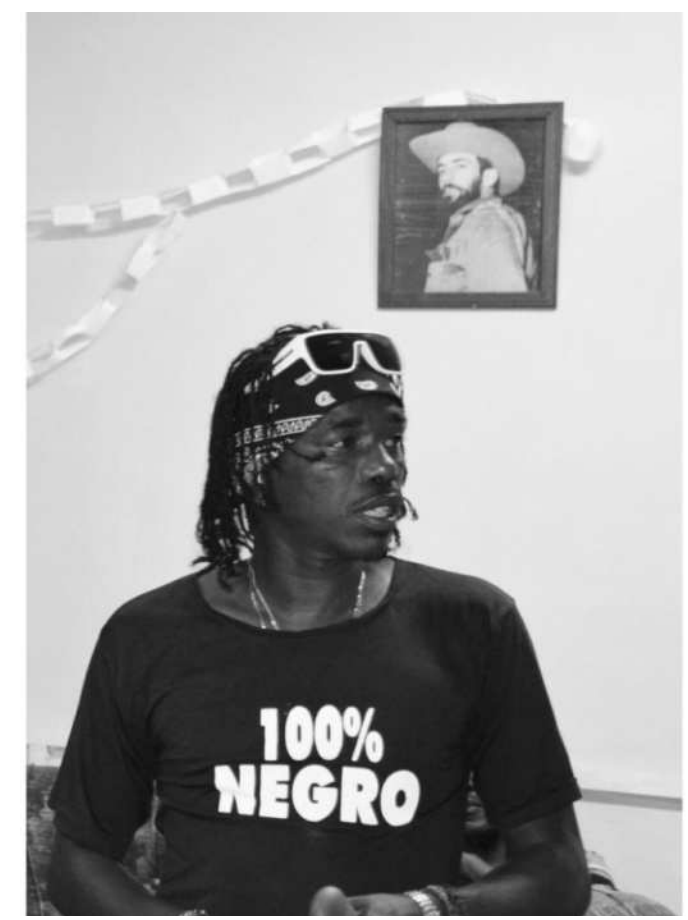

Figura 5: Retrata Kimbo (liderança do bairro La Marina, Matanzas) e quadro de Camilo Cinfuegos (líder da Revolução socialista cubana), em outubro de 20I4, em Matanzas, Cuba. Foto: Bárbara Oliveira.

Essa visão dicotômica branco/não branco ou branco/negro, todavia, não é congelada. Um dos exemplos é a dinâmica associativa que envolve, muitas vezes, negros e brancos, sem nesse caso haver necessariamente uma oposição completa tanto de interesses como de estratégias. Os vínculos de reciprocidade e solidariedade podem extrapolar os agentes sociais vinculados a uma categoria racial única, já que muitas vezes suas articulações incorporam sujeitos que se autoidentificam como "negros", como "afrodescendentes" e inclusive como "brancos". Esse é o caso, por exemplo, da Rede Barrial Afrodescendiente que converge uma variedade de afiliações raciais entre seus membros, mesmo havendo uma predominância que se autodenominam como "negras/os".

Em outros momentos, há uma perspectiva ampliada da identidade "afrodescendente", quando se incorpora nessa percepção coletiva, sujeitos que se autodeclaram "brancos", e compartilham práticas tradicionais como a Santeria ou o ativismo em coletivos antirracistas. Nessas relações, são compartilhadas estratégias comuns, o que cria condições para que uma nova política de solidariedade seja possível. Essas são dinâmicas que complexificam essas construções identitárias, como afirma Tato Quiñones:

Cualquier persona que camine por La Habana hoy, se da cuenta de la cantidad de hombres y mujeres blancos, jóvenes en la mayoría que han sido iniciados en la santería cubana que es digamos la versión cubana del candonble. Tu caminas por las calles, hoy mismo antes de llegar vi cuatro iyabó que se le llama, han asumido esa cultura, ¿esos son afrodescendientes o no? Yo pregunto: ¿qué será afrodescendiente? ¿Tener el color de la piel oscura o asumir su cultura? ¿Qué nos hace afrodescendiente? ¿Descendimos de 
África por el color de la piel? ¿Descendimos de África porque asumimos una cultura? Una pregunta, pero yo no tengo respuesta. (Entrevista com Tato Quiñones, realizada em 29/05/20I4)

É interessante observar que os espaços vinculados às tradições do Palo Monte, Santeria e Abacuá em Cuba são espaços interraciais e possuem um número substancial de presença de indivíduos que se autodeclaram "brancos", apesar de uma vinculação fortemente dada com a origem africana. Além disso, nos próprios coletivos e atividades promovidas por grupos antirracistas, não necessariamente vinculados aos aspectos da tradição e fortemente vinculados à identidade "negra" ou "afrodescendente", é possível identificar a participação também de pessoas "brancas", que compartilham naquele espaço estratégias comuns. Não se caracterizam como espaços segregados.

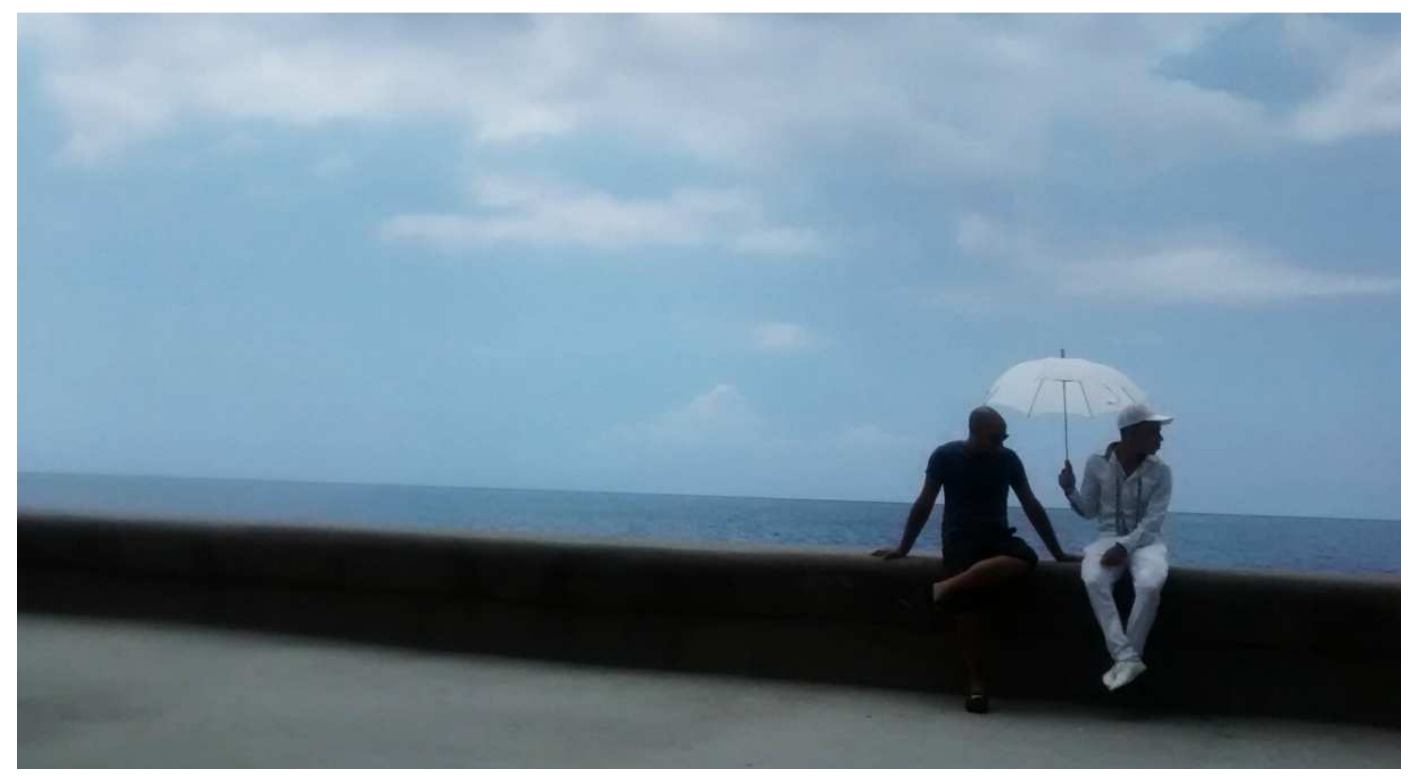

Figura 6: Iyabo (iniciado na Santeria que no primeiro ano só veste branco), no Malecón, Havana, Cuba, 2014. Foto: Bárbara Oliveira.

No caso dos vínculos desses grupos com bairros ou espaços territoriais marcados, esse processo se torna ainda mais sintomático. A complexidade vivida nesses locais agrega, à luta antirracista, dinâmicas que fortalecem a identidade por meio das denominadas "culturas tradicionais". O bairro La Marina, em Matanzas, vivencia esse processo, onde nesse caso a marcação do espaço "negro" é muito presente, havendo também a afirmação desse espaço como não homogêneo e interracial:

La comparsa se había perdido primeramente por dos cosas: (por ser acá un) barrio marginal y un barrio de negros. Era por eso, donde hoy por hoy yo he dado una galleta sin mano al Gobierno, al Partido, que no siempre uno puede decir que nadie es malo, aquí malos somos todos, bueno no existe nadie. [...] Entonces ahí la comparsa sale en el 200I, y fue un golpe muy duro para el Gobierno, que nunca pensaba que del barrio de La Marina, marginal, de negros, pudiera existir una comparsa que prácticamente tenia gays, abacua, masones, santeros, santeras, paleros, muchachos con "problemas". Esa comparsa la hice con los "problemas" del barrio. Los muchachos que tenían problemas, muchachos que no trabajaban. Los documentales que yo tengo del (Centro) Martin Luther King se han visto el cambio y la mejoría que ha 
existido en el barrio, debido a los talleres, debido a que sí se puede, debido a que nadie me puede pasar por arriba. Si usted se respeta, se da a respetar. (Entrevista com Kimbo, realizada em I3/09/2014)

$\mathrm{Na}$ continuidade, Kimbo destaca o caráter interracial de seu bairro, de sua família, ainda assim fazendo a marcação da vinculação com a identidade negra e com a crítica ao racismo:

Sí había problema de racismo, sí existe racismo. En ese tiempo existía mucho racismo. Pero ahora me atrevo a decirte, aquí está la mezcla de blanco con negro ahora, está un poco más amplia, pero todavía existe, de que existe, existe, dentro y fuera (do Bairro). Aquí tenemos mucho, mucho racismo porque yo no acabo de entender cosas que podemos ser capaces todos. Yo aprendí de esto que en la unión está la fuerza. Da lo mismo el blanco que el negro, que el jabao, que el chino, porque yo soy el más negro de mi familia y en mi familia todo el mundo es blanco, porque yo vengo de la familia de los Valdés. En mi familia todo el mundo es blanco, hay chino, hay mulato y hay de todo eso y entonces por ahí es donde empezamos. (Entrevista com Kimbo, realizada em I3/09/2014).

É fundamental, para a compreensão desses coletivos e grupos, a análise das identidades raciais, étnicas, além de tradicionais ou religiosas. Os elementos da "afrodescendência" ou "negritude" são decisivos para a identidade desses ativistas, lideranças e agentes sociais, mas são construídos a partir de diferentes estratégias nos variados coletivos. No caso do projeto "Identidad y Barrio La Marina", trabalha-se a luta antirracista a partir de uma afirmação das manifestações culturais do bairro "negro", "marginal", termos utilizados por Kimbo para descrever as construções sociais feitas acerca de seu bairro, como a "comparsa" no período dos carnavais.

No bojo da retomada de atividades vinculadas à santeria, aos abacuá e às tradições do bairro La Marina, se realizam debates onde a dimensão racial é tratada, no contexto das atividades culturais e vinculadas à tradição. Visualizo como um processo semelhante ao que Hanchard (200I) fez referência no Brasil: o fenômeno culturalista que predominava no movimento negro do Rio de Janeiro e de São Paulo nos anos I980, muito ligado ao movimento Black Soul, aos blocos de carnaval e outros espaços culturais.

Há outras organizações, em Cuba, que norteiam suas estratégias de um modo distinto, voltadas para o diálogo com os poderes públicos e midiáticos, como é o caso da Cofradía de la Negritud, que desde sua criação manifesta-se por meio de cartas e informes ao governo, ao partido e a veículos de comunicação como o Granma e o Juventud Rebelde. Inclui em suas estratégias também o diálogo comunitário, como as rodas de conversa em "La Ceiba", cujo foco sobre essa dimensão identitária racial é predominante.

Esses dois exemplos acima reforçam as estratégias empregadas por diferentes coletivos centradas em perspectivas sobre a "identidade", mas com recursos e linguagens bastante distintos. As lutas políticas baseadas em identidade são o cerne de produções bibliográficas, como, por exemplo, a 
obra de Franz Fanon. Bhabha (1998), ao refletir sobre a obra de Fanon, Pele Negra Máscaras Brancas, destaca a força da argumentação de Fanon para as lutas políticas baseadas em identidade.

À medida que uma serie de grupos cultural e racialmente marginalizados assume prontamente a mascara do negro, ou a posição da minoria, não para negar sua diversidade, mas para, com audácia, anunciar o importante artifício da identidade cultural e de sua diferença, a obra de Fanon torna-se imprescindível. À medida que grupos políticos de origens diversas se recusam a homogeneizar sua opressão, mas fazem dela causa comum, uma imagem publica da identidade da alteridade, a obra de Fanon torna-se imprescindível. (BHABHA, 1998: 102).

A leitura que Bhabha faz das mobilizações identitárias com base em Fanon são instigantes para a pesquisa sobre grupos antirracistas em Cuba e suas narrativas de identidades construídas, com base em categorias genéricas que possibilitam a construção de uma causa comum, do estabelecimento de redes de solidariedade, da luta contra as desigualdades e contra as situações de violência vivenciadas. É um processo político de extravasar e ressemantizar as categorias coloniais.

Homi Bhabha (I998: 68) faz um diálogo interessante com Walter Benjamin para abordar a tradição do oprimido, da linguagem de uma consciência revolucionária onde: "o estado de emergência em que vivemos não é a exceção, mas a regra. Temos que nos ater a um conceito de história que corresponda a essa visão". E o estado de emergência está entranhado na luta contra a opressão colonial.

O estado de emergência transborda no discurso e nas narrativas dos ativistas entrevistados. Aparece exatamente no processo de reversão do conceito colonial "negro", como pejorativo, feio, inferior, para defendê-lo como uma identidade política. A seguir, trago um trecho da entrevista feita com Maritza López Mc Bean ${ }^{64}$, da Rede Barrial Afrodescendiente, sobre esse reposicionar da categoria "negro":

Esa es otra de las anécdotas: le gritaron negra, como una intención de cosa mala, fea, y en el momento que se lo gritaron sintió como estaban trataron de lastimarla. Pero (en aquel momento) no tuvo herramientas para poder responder eso que ella sintió como humillación. Y, por ejemplo, ahora ella es una persona negra, negra, negra de piel y una de las cosas que siempre dice con mucho orgullo es: Soy negra ¿y qué? ¿cuál es tu problema con que sea negra? O sea, que como que está creciendo, como que está asumiéndose y que no le duele porque lo que traemos de atrás es tan grande, ¿cómo te va a doler ser negra? (Entrevista com Maritza Lopes, Rede Barrial Afrodescendiente, realizada em I5/08/2014)

\footnotetext{
64 Maritza é uma liderança comunitária bastante atuante nos bairros nos quais o coletivo Red Barrial Afrodescendiente atua, especialmente em La Lisa e Pogoloti, situados em Havana. É educadora popular e coordena a Casa Comunitária Paulo Freire, situada na comunidade La Ceiba, em La Lisa. O primeiro contato com Maritza foi em sua casa, oportunidade que tive para conhecer sua família e outras integrantes da Red Barrial. Foram muitas as interações que tivemos ao longo do tempo da pesquisa, com periodicidade, tanto em projetos que envolviam a sua comunidade, como a Cartografia Social de La Ceiba, como em atividades realizadas em La Marina, Matanzas, ou em entrevistas para a pesquisa. Algumas das oficinas e seminários sobre a questão racial que acompanhei em Havana também foram organizadas pela Red Barrial Afrodescendiente, inclusive a avaliação ampla da pauta racial feita com diversos coletivos da cidade, no segundo semestre de 2015.
} 
As vivências extremas nos diferentes âmbitos fomentam o estabelecimento de uma rede de solidariedade entre os que experimentam situações comuns de racismo e discriminação. Nessa conjuntura, o abrigo de categorias genéricas como "negro" e "afrodescendente" possibilita a luta comum, concebida a partir de estratégias forjadas politicamente. Seria um essencialismo identitário, com fins estratégicos (SPIVAK, I987).

A partir da necessidade de construir identidades políticas, grupos em situação subalternizada muitas vezes acessam laços de experiência social comum para mobilizar afins. Esse processo pode gerar a afirmação de uma diferença aparentemente essencial. Spivak defende que tal "essencialismo estratégico" pode ser muitas vezes necessário se for situado no lócus dos sujeitos dominados.

Apesar da crítica ao conceito de "essencialismo estratégico", formulado por Spivak, Butler também não desconhece a necessidade de apelar a tais categorias em algumas situações: "habría un imperativo político para usar estos errores necesarios o categorías equivocadas" (BUTLER, I989: 9I; 1993: 322). Dado que em geral "los esfuerzos de cabildeo (o de presión) son virtualmente imposibles sin recurrir a las políticas de identidad" (BUTLER, I990: 32). Butler crê, como Spivak, apesar de que a multiplicidade e heterogeneidade das referencias excedem a univocidade do signo, que são termos que são utilizados com fins estratégicos (BUTLER, I990).

Stuart Hall (2006) reflete sobre esse processo como uma luta ideológica. Essa dinâmica passa por uma contestação, por um deslocamento semântico, reposicionando suas significações do campo positivo para o negativo. É esse fluxo que gera um novo conjunto de significados para um termo, o que esse autor caracteriza como luta ideológica.

Como dito a princípio, para além de serem termos eminentemente essencialistas, eles são repletos de sentido para a ação política. Um diálogo sobre os conceitos de essencialismo estratégico (SPIVAK, I989), essencialismo operacional (BUTLER, I990, 1989, 1993) e luta ideológica (HALL, 2006) é frutífero para o debate sobre as identidades "negras" ou "afrodescendentes" e sua apropriação no processo de luta por direitos. Interessante também perceber que a partir das mobilizações baseadas nessas identidades, que não estão semanticamente congeladas, há um compartilhar de estratégias comuns que dão sentido à ação política coletiva. 
No caso das mobilizações negras na América Latina, a dimensão da identidade coletiva como elemento agregador e mobilizador esteve presente em diversos momentos históricos. E a partir dessas identidades essencializadas, são constituídas diferentes formas de agência e de ação em suas realidades sociais específicas. A identidade coletiva pressupõe dinâmicas internas e externas ao grupo que possibilitam a construção dos parâmetros identitários comuns:

A identidade coletiva é uma definição interativa e compartilhada produzida por numerosos indivíduos e relativa às orientações da ação e ao campo de oportunidades e constrangimentos no qual a ação acontece (MELUCCI, I988: 342).

Cabe destacar que Hall (2006: 26), ao abordar a complexidade das identidades afrocaribenhas, aponta que "na situação da diáspora, as identidades se tornam múltiplas". Thomas (apud BAINES, 2000) frisa que identidades e tradições não são apenas diferentes uma das outras, mas são constituídas em oposição a outras. Baines (2000: 155) destaca que "em situações coloniais assimétricas e altamente politizadas, ocorrem processos não somente de selecionar aspectos do passado ou costumes do presente que sejam privilegiados na construção de uma identidade étnica, mas também de rejeitar radicalmente o que é local e tradicional”.

No processo violento de colonização e pós-colonização, no qual a identidade africana e dos afrodescendentes foi fortemente estigmatizada nos países da América Latina e, por conseguinte, também em Cuba, o subterfúgio pode ter sido a busca por uma identidade fugidia que apresente, de forma menos estigmatizada, o peso do racismo.

Por outro lado, parece haver, nas organizações antirracistas, uma maior apropriação e valorização desse campo identitário afirmativo, que destaca o vínculo com a negritude e a Diáspora africana. A identidade que marca a constituição do "ser negro" ou ser "afrodescendente", pode se configurar como fruto de uma perspectiva de diferença profunda, estrutural:

\footnotetext{
A luta dos movimentos sociais inspirados no projeto de "políticas da identidade" não alcançarão a radicalidade do pluralismo que pretende afirmar, a menos que os grupos insurgentes partam de uma consciência clara da profundidade de sua "diferença", ou seja, da proposta de mundo alternativa que guia sua insurgência. Diferença é aqui entendida e definida não com referência a conteúdos substantivos em termos de "costumes" supostamente tradicionais, cristalizados, imóveis e impassíveis em relação ao desenvolvimento histórico, senão como diferença de meta e perspectiva por parte de uma comunidade, de um povo (SEGATO, 2007: I8).
}

Compartilham uma solidariedade comum, marcada pela experiência da negritude como identidade política. Fissuras internas surgem nesse contexto, complexificando as dinâmicas de solidariedade e de compartilhamento comum. Para além de não se tratar de identidades fixas e congeladas, há também os contrapontos ao processo de incorporar essas categorias de identidade racial no contexto de mobilizações em Cuba. Tratarei, a seguir, especificamente das muitas 
controvérsias que permeiam o termo "afrodescendente". Esse debate transborda as fronteiras terminológicas.

O termo afrodescendente se fortalece como marcador identitário no processo da Conferência de Durban: "Em Santiago, entramos sendo Negros e saímos Afrodescendientes", como destacou Romero Rodríguez, da organização Mundo Afro, em Santiago, Uruguai, na Conferência Regional das Américas, em 2000.

$\mathrm{Na}$ atualidade, "afrodescendente" se apresenta como um constructo comum da Diáspora Africana nas Américas, como uma identidade de caráter político. E os usos e apropriações do termo afrodescendente são muito variados, como destaca Lao-Montes (2009). De acordo com o autor, foi um termo gestado e negociado pelas redes transnacionais do movimento negro na América Latina, e adotado posteriormente pela ONU, por ONGs, e por diversas organizações internacionais (desde a Fundação Ford até o Banco Mundial). Como categoria política, o significante afrodescendente também representa a vontade de desenvolver laços entre membros da diáspora africana global nas Américas e em outras partes do mundo (LAO-MONTES, 2009).

O processo de ressemantização e incorporação de um termo balizado politicamente em instâncias internacionais de mediação e articulação política, tal como o que se deu com o "afrodescendente", é interessante para situar alguns dos coletivos cubanos estudados. A partir das perspectivas de Spivak e Buttler sobre o caráter estratégico do uso de categorias essencializantes, em que essa identidade é central para a luta política, e abarcando o que Hall (2006) denomina "luta ideológica", o termo "afrodescendente" em Cuba tem se fortalecido nos coletivos antirracistas. É um processo de reposicionamento dessa categoria, historicamente vinculada a uma visão folclorizada ou estigmatizada. Processo semelhante foi vivenciado com o termo "negro":

\footnotetext{
Por exemplo, é justamente por conotar aquilo que é mais desprezado, despossuído, ignorante, incivilizado, inculto, maquinador e incompetente que o termo "negro" pode ser contestado, transformado e investido de um valor ideológico positivo. O conceito de "negro" não é propriedade exclusiva de qualquer grupo social específico ou discurso isolado. (HALL, 2006: 194).
}

Há um amplo debate nos coletivos entre intelectuais que estudam o tema e ativistas sobre esse conjunto de categorias. Apesar de serem termos que possibilitam um compartilhar identitário, esse processo não ocorre sem fissuras ou arestas. $\mathrm{O}$ uso do termo "afrodescendente" é visto como uma estratégia agregadora por muitos desses, como a ARAAC, a Rede Barrial Afrodescendiente, a Afrocubanas, dentre outros. Gisela Arandia, da ARAAC, que também compôs na época de Durban a delegação cubana que participou da Conferência Mundial da ONU, relata o processo de debate desse termo e seu sentido dado por uma estratégia politicamente construída: 
A Santiago chegamos sendo negros e saímos Afrodescendentes. Isso disse o uruguaio Romero Rodrigues referindo à forma como esse contexto de Durban, essa Conferência Mundial, permitiu essa agenda, saindo de classificações étnicas, de classificações antropológicas, para entrar em uma agenda política que busca criar a igualdade social. Isso é o que significa "entramos negros, saímos afrodescendentes (Gisela Arandia, exposição feita no lançamento da Década dos Povos Afrodescendentes, em 13 Outubro de 2014, Casa de Alba, Havana, Cuba) ${ }^{65}$.

O conceito "afrodescendente" e as diversas estratégias construídas coletivamente são articulados numa escala mais ampla, o que representa uma territorialidade estendida e difusa. Em muitos casos a atuação está localizada nos bairros, nas comunidades, sem excluir, todavia a articulação das redes numa dimensão mais ampla.

Mira en el caso de nosotros, los de la Rede Barrial Afrodescendiente, asumimos el nombre (Afrodescendiente). No creas que no nos hemos encontrado personas muy comprometidas que me han dicho que por qué ese nombre, o sencillamente que se lo quitemos. Pero ese no fue el criterio de una sola persona sino de unas cuantas personas. Una de las opiniones que nos hizo asumir el tema fue la explicación que dieron lideres como Agustín Lago Montes o Dagoberto de Venezuela o los colombianos Oepsi Cambell que desde la izquierda han asumido el termino afrodescendiente con una nueva mirada. Pues como dice Freyre, se está como repintando, decantando, relanzando al mundo y ellos asumen la afrodescendencia o el termino como afrodescendiente desde la perspectiva que una persona puede medir seis pies, tener el pelo por aquí, los ojos azules y tener un antecedente de origen africano y cuando tu le dices afrodescendiente le estas incluyendo para el lado de acá. Y a nosotros por la coloración de la piel, más negra, también nos incluyen en la misma medida. Para mí me parece más digna que la palabra mestiza y no vamos hablar de mulata porque viene de mula. (Entrevista com Maritza Lopez Mc Bean, da Rede Barrial Afrodescendiente, realizada em I5/08/20I4).

Os fluxos e refluxos entre as mobilizações antirracistas em Cuba e no mundo são muito presentes, como ocorreu no processo recente de apropriação do termo "afrodescendente". Roberto Zurbano $^{66}$ aborda esse período de crescimento da articulação dessas mobilizações numa escala que extrapola o local e o nacional:

O importante é o que ocorreu antes em Cuba: os lutadores antirracistas se sentiram parte de um movimento regional muito antes que parte de um movimento nacional. Nós formamos parte de um movimento regional (Roberto Zurbano em 20 de agosto de 20I4, Casa de Alba, Havana, Cuba) ${ }^{67}$.

Em Cuba, paira sobre o termo "afrodescendente" certa desconfiança, que tem uma raiz no que vínhamos tratando anteriormente: a percepção ambígua da luta antirracista, que por um lado é "sujeita à interferência dos Estados Unidos" com explícitos fins políticos dos estertores da Guerra Fria, e por outro, sofre um controle ideológico, seja diretamente pelo Estado ou pela sociedade política, ou seja, pela academia. Há outro elemento importante nesse debate: a

\footnotetext{
65 Tradução minha.

${ }^{66}$ É um ativista antirracista com grande participação no debate e em atividades realizadas em Cuba. Escritor, publica artigos sobre o tema com frequência, além de ter conhecimento amplo sobre arte e cultura. É integrante da coordenação da ARAAC. Trabalha na Casa de Las Americas. Tivemos encontros contínuos em atividades e seminários sobre a questão racial que participei em Havana. Algumas foram organizadas por Zurbano, como um debate sobre a violência contra a juventude negra, no qual pude refletir sobre essa questão no Brasil. A entrevista mais aprofundada para a tese foi realizada em sua casa, situada no bairro Centro Habana que tem forte tradição de rumba. ${ }^{67}$ Tradução minha. Fala original em espanhol.
} 
construção do nacionalismo cubano e da ideologia da unidade nacional, que por muitas vezes é utilizada para ressaltar a "periculosidade" da narrativa dos coletivos afrocubanos.

As narrativas de ativistas e estudiosos do tema racial materializam vários dos elementos conflitivos que permeiam a construção do termo "afrodescendente" e sua incorporação como elemento identitário mobilizador. A seguir, apresento algumas falas de ativistas e acadêmicos sobre o termo "afrodescendente" que sinalizam para as fissuras existentes:

No estoy de acuerdo con la denominación de afrodescendencia para categorizar a la población por el color de la piel, porque creo firmemente que afrodescendiente somos todos los cubanos; si hablamos de la existencia de una cultura mestiza, de que en la cultura cubana tuvo participación de creyentes hispánicos, de creyentes africanos, y creyentes de otra procedencia que en su mezcla dieron origen a una cosa totalmente nueva que es lo cubano. Pues, afrodescendientes somos todos, porque si utilizamos el termino para vincularlo con un determinado color de piel o un determinado origen ancestral, ¿como que yo caigo entonces en una descendencia distinta a la de mis hijos? Ahí tampoco puedo separar el problema personal del problema científico y creo que en eso está en juego la unidad de la nación cubana. Si empezamos a dividirnos por orígenes ancestrales, los cubanos desaparecerían porque todos seriamos hispanodescendiente, afrodescendiente o chinodescendiente y así sucesivamente y donde quedaría esa esencia de lo cubano (Niurka Nuñez ${ }^{68}$, Entrevista em 2I/05/20I4)

A narrativa de Niurka, pesquisadora do Instituto Juan Marinello sobre temas raciais, aborda um elemento muito presente que embaralha o sentido do termo "afrodecendente" como uma identidade política diaspórica de interconexão, conforme discutido no processo de Durban anteriormente, com o debate feito em Cuba sobre as mesclas que conformam a "identidade nacional", o "cubano". Essa última visão dialoga fortemente com o que pondera Fernando Ortiz (1963) sobre a transculturação que origina os cubanos. A partir de diversos povos de origem européia - como Galegos e Açorianos; de origem Africana - como os Carabalí e os Yorubanos; e de Povos Indígenas - como os Taínos, se constituiu o "cubano", a "cubanidade" como resultado dessa mistura que gerou uma nova conformação. Uma grande "mestiçagem cultural e de raças" que gerou um novo produto que representa o "ser cubano", de acordo com Ortiz em diversas de suas obras, em especial no "Contrapunteo cubano del tabaco y el azucar".

Em situações de debates públicos, como no seminário Orígenes, realizado em Matanzas, em outubro de 20I4, é possível perceber o antagonismo de percepções sobre o uso do termo "afrodescendente". Durante sua exposição, Jesus Guanche, membro da UNEAC, da Comissão

\footnotetext{
${ }^{68}$ É pesquisadora do Instituto ao qual eu fiquei vinculada oficialmente em Cuba, o Juan Marinello. É formada em antropologia, em curso feito na então URSS, no final dos anos 1980. Os contatos com Niurka foram mais esporádicos ao longo da pesquisa, ocorridos especialmente em alguns eventos feitos no próprio Instituto. A entrevista para a tese também foi realizada no Instituto.
} 
Aponte (que visa tratar e propor ações antirracistas) e coordenador da Rota do Escravo ${ }^{69}$, faz a seguinte análise:

Desde el punto de vista de la ciencia más general, todos los seres humanos somos afrodescendientes con lo que el término envuelve a toda la humanidad y no se encuentra circunscrita a una parte de ella. Nuestra acepción es inclusiva, antirracista y antidiscriminatoria y es la acepción que menos se emplea por las personas que obviamente reclaman derechos. Ahí se emplea con una combinación muy particular que sustituye al término negro o negra en Estados Unidos, que son los que promovieron con su carácter de influencia global, sin término, donde se le da una connotación despectiva al término anterior y luego el término adquiere una connotación positiva e dignadora y diferenciadora de una agrupación humana. También se ha sido interpretado como un tipo de racismo en dirección contraria, como un rechazo al acervo cultural presentado en ese pá́s [...] Y ellos son los que se abrogan el derecho de dar unas clases de democracia y el antirracismo, sobretodo en el territorio cubano, que le siguen la rima que constantemente se están haciendo eso sin ningún tipo de asesoramiento, sin problemas. Sabemos perfectamente quiénes son estos intelectuales cubanos, a quien se dedican, a partir de las motivaciones de quien. La anterior acepción [...] consciente o inconsciente niega, neutraliza, silencia o sustituye las denominaciones nacionales y el reconocimiento de la formación de estados nacionales históricamente nuevos, brasileño por afrobrasileño, uruguayo por afrouruguayo, por ejemplo, cubano por afrocubano, dominicano por afrodominicano, es decir un discurso diferenciador y separatista en un contexto regional que atenta la integración. (Exposição feita no evento Origenes, em Matanzas, de I0 a I3 de outrobro de 20I4).

Jesus Guanche coloca de forma explícita algumas das diferentes percepções sobre o emprego do termo "afrodescendente" em Cuba, seus usos e estratégias políticas derivadas. Mais uma vez, com referência ao contexto da Guerra Fria, coloca o termo como um produto socialmente conformado no contexto dos Estados Unidos e que passa a ser aplicado na América Latina. Situa, ainda, os ativistas (ou os que reclamam direitos) como racistas ao contrário, ao promoverem uma segmentação de um grupo humano sobre outro. Há um indicativo muito explícito que a alusão à afrodescendência fere o sentimento de nação e de povo nacional. Por fim, afirma que a perspectiva verdadeiramente antirracista é a que concebe toda a humanidade como geneticamente afrodescendente.

Essa perspectiva de uma afrodescendência genérica baseia-se nos estudos que indicam que os primeiros gêneros da espécie humana são provenientes do continente africano. Portanto, teríamos todos uma origem comum, geneticamente falando, como o próprio Guanche afirma em outro trecho de sua exposição: "desde el punto de vista genético toda la poblacion del orbe es afrodescendiente con múltiples mutaciones y adaptaciones"

Há o embarralhamento de diferentes concepções nessa argumentação de Guanche. As construções sociais e possíveis iniqüidades estabelecidas a partir das diferenças fenotípicas de seus indivíduos são de ordem social. Cientificamente, não há diferenças biologicamente dadas para conformar

\footnotetext{
${ }^{69}$ Projeto vinculado à UNESCO em vários países da Diáspora Africana nas Américas que objetiva visibilizar a escravidão e seus impactos.

${ }^{70}$ Exposição de Jesus Guanche, como representante da Comissão Aponte, no Seminário Orígenes realizado em Matanzas, Cuba, I3 de outubro de 2014.
} 
diferentes raças humanas ${ }^{71}$, conforme reconhecido pelo próprio Guanche em sua argumentação. Portanto, o debate que vem sendo feito por ativistas dentro e fora de Cuba refere-se às construções sociais das raças e seus impactos sobre os indivíduos de forma diferenciada, que pode ocasionar dinâmicas de privilégio ou exclusão a depender de como esses signos são manejados nas relações sociais. Ao referir-se a uma afrodescendência de ordem genética, Guanche não está dialogando com o fenômeno social do qual os ativistas e coletivos antirracistas se referem atualmente no contexto cubano.

A segunda argumentação de Guanche que restringe a construção do termo "afrodescendente" ao contexto estadunidense, e afirma que é a partir da sua influência global que o mesmo teria sido implementado em diferentes contextos também é falha por não considerar as múltiplas dinâmicas que permeiam a ressemantização identitária de cunho político-social. Autores, inclusive cubanos, anteriores ao movimento pelos direitos civis no Estados Unidos, como Fernando Ortiz, já empregavam a terminologia "afrocubano" ou "afro".

No processo mais recente, do qual muitos ativistas cubanos fazem referência, o termo "afrodescendente" foi cunhado após debate com representantes da sociedade civil das Américas, em Santiago, em 2000, cuja presença latinoamericana foi majoritária. A partir da compreensão da importância de construir uma conceituação categórica que envolvesse a todos os provenientes da Diáspora Africana, concebeu-se o termo "afrodescendente", agora com um sentido político de articulação numa escala mais ampla.

Reduzir esse processo amplo a uma simples imposição do modelo estadunidense é reduzir a agencialidade dos múltiplos sujeitos que atuaram nesse processo. Ainda em diálogo com Guanche, invalidar do ponto de vista das ciências sociais um conceito estabelecido pelos movimentos sociais com objetivos políticos é não considerar a multiplicidade de estratégias de resistência e de estabelecimento de vínculos sociais que podem ser conformados pelos sujeitos sociais.

Por fim, a indicação feita por Guanche de que construções identitárias de sujeitos sociais a partir de suas diferenças e de estratégias de lutas por direitos seja uma substituição das denominações e das formações nacionais, mais uma vez reforça o intento de construir uma homogeneidade sintética. A sociedade cubana é composta por uma miríade de diversidade social. Um "cidadão cubano" pode ter uma sobreposição de identidades que convivem com a identidade "cubana", tais quais "afrodescendente" ou "negro", "branco", "mestiço", "santero", "marinero", "oriental",

${ }^{71}$ Biologicamente, não existem raças humanas. Raça, nesse caso biológico, é sinônimo de subespécie - trata-se de diferença genética entre espécies. No caso da espécie homo sapiens não são reconhecidas subespécies, ou seja, raças. 
"guarriro", "abacuá", "mulher", "homem", dentre outros. Algumas dessas identidades podem ser conformadas coletivamente como um fio condutor para a mobilização coletiva. Não necessariamente isso leva a uma "separação" e a uma "fragmentação", como exposto por Guanche. Insinuar, no final, de que esse processo ocasionaria uma possível fragmentação da América Latina, que caminha para uma "integração regional" é desconsiderar a ordem desigual e colonial vivenciada pelos sujeitos subalternizados nesses países, que concentram em grande medida os "afrodescendentes" e os "indígenas" nos lugares de exclusão.

A narrativa de Guanche reflete a posição apresentada e explicitada por muitos intelectuais cubanos durante o período do estudo. Reflete, ainda, uma das posições presentes na Comissão Aponte, grupo que na atualidade tem estabelecido a maior interlocução com o Estado cubano e assessorado o governo cubano para esse tema. Situar o discurso antirracista e os próprios ativistas em um lócus de desconfiança, no qual "sabemos quem são", "a que se dedicam", "a partir das motivações de quem"7", gera um processo de deslegitimação e coerção social que complexifica os conflitos existentes em Cuba para tratar o tema.

O discurso contrahegemônico dos ativistas e coletivos, por outro lado, apresenta outro panorama dessa questão. Interessante perceber a própria diversidade de alguns coletivos. Esteban Morales ${ }^{73}$, escreveu um ensaio datado de 08 de julho de 2015, no blog negra cubana tenía que ser, e dentre os pontos abordados destaco:

\footnotetext{
Afrodescendiente, es más bien un término político, que tiende a reconocer a los que se sienten como tal y no solo a los que lo son. Que tiene como objetivo recuperar como similares, a todos aquellos, que originalmente trasplantados desde África, o sus descendientes, andan hoy por el mundo, como una diáspora, a veces recién emigrada, entre los que se encuentran los que más sufren la explotación y la discriminación. [...] No nos cansamos de repetir, que la raza no existe. Se trata de un constructo social. Pero el color sí. Y los procedentes de África, en general, llevan sobre si ese estigma. Por lo que a donde quiera que emigran, lo hacen, casi siempre, para quedar ubicados dentro de los sectores sociales en mayor desventaja. Van a los peores barrios, a los empleos peor remunerados y sufren las mayores desatenciones en todos los aspectos de su vida social. Aun en países como Cuba, que hizo una revolución y que tanto ha avanzado en la atención de su población, todavía el color se hace sentir como una variable de diferenciación social y discriminación. [...] Por tanto, rescatar el término afrodescendiente, es tener una herramienta, para poner en el lugar que les corresponde, a sectores poblacionales que sufren aun los lastres de la esclavitud y la trata. Y que son los que más padecen también la reproducción de estos lastres, por las incapacidades sociales aun no resueltas. (DOMINGUEZ, 2015: s/p).
}

\footnotetext{
${ }^{72}$ Frases pronunciadas por Guanche (2014).

${ }^{73}$ Esteban Morales é professor de Economia da Universidade de Havana e autor de diversos artigos e livros sobre a questão racial, como o Desafios de la Problematica Racial en Cuba, de 2012. É ativista antirracista, vinculado especialmente à ARAAC e à Comissão Aponte. Foi um dos entrevistados para essa pesquisa. Ainda no período da qualificação, no Brasil, pude ler alguns trabalhos de Esteban sobre a questão racial. Em Havana, acompanhei eventos nos quais ele era palestrante ou participante. E, além dos contatos ocorridos em diversas atividades, a entrevista mais aprofundada foi marcada no Instituto Fernando Ortiz, que é uma referência nas ciências sociais em Cuba.
} 
Esteban Morales ressalta a importância do termo "afrodescendente" como uma ferramenta para a luta contra as desigualdades raciais. Estabelece-se, a partir de sua percepção, como um marcador das diferenças sociais construídas com base na cor. A perspectiva apresentada por Morales dialoga com o olhar da maioria absoluta dos ativistas, tal como pode ser verificado no depoimento de Maritza, da Rede Barrial Afrodescendiente:

Yo pienso que la polémica (con el uso del término "afrodescendiente) parte fundamentalmente del mundo intelectual. Nosotros, los que decidimos seguir afrontando o afirmando el término desde nuestra práctica cotidiana, sentimos mucho respeto por los intelectuales que $[. .$.$] han hecho un aporte$ muy grande a la cultura nacional, a Cuba y también al mundo. [...] Pero estamos en el siglo XXI e igual que nosotros respetamos a todos y a todas, yo pienso que también hay que pedirle a esa parte de la intelectualidad, que tiene todo el derecho de esgrimir ese criterio y a mantener esa misma batalla, que con el mismo respeto que nosotros los tratamos nos traten ellos a nosotros. Hemos escuchado en los últimos tiempos de intelectuales de mucho prestigio que afrodescendiente, que afrocubano, afro es un soberbio disparate. Bueno, soberbio disparate para ellos, porque cada cual le hace la lectura al acto como quiere verla. Para nosotros tiene otro enfoque. Lo único que nosotros le pedimos a ellos es respeto y compromiso, compromiso a saltarnos una barrera de una guerra que no es inteligente ni importante hoy. Lo importante es vincularnos unos y otros con los saberes de unos y otros, no es más importante el saber del de abajo que del de arriba, ni del de arriba que del de abajo, lo importante es saber; [...] Nosotros los respetamos a todos y a todas y los vamos a respetar más si visitan más nuestras comunidades, de además de lo que han publicado que eso se ve mucho menos. Hay mucho menos compromiso de bajar a conversar y a dialogar siempre desde el mismo nivel de horizontalidad con el de abajo, es muy fácil juzgar desde arriba de evaluar desde arriba y eso los convierte en dictadores y los aleja de ser los intelectuales respetables que son. Ese es mi critério. (Entrevista com Maritza Lopez, realizada em I5/08/2014).

O conflito está explicitado na fala de Maritza. $\mathrm{O}$ debate sobre os termos adequados ou não ao debate racial tomam parte do que é publicado, televisionado ou dialogado em seminários e conferências. Por parte de alguns acadêmicos, fica evidente o intento de controlar ou restringir estratégias narrativas construídas pelos próprios ativistas. Daysi Rubiera ${ }^{74}$, outra ativista do coletivo Afrocubanas, destaca o uso do termo afrocubano em seu cotidiano de ação e pondera sobre os questionamentos existentes ao seu uso:

Yo pienso que el termino afrocubanas, por eso el grupo es afrocubana o afrocubano, el grupo nuestro
se llama así, yo pienso que este término marca la diversidad y la diferencia en relación con la unidad
cubana que tiene como centro la cultura contemporánea en nuestro país, porque la unidad cubana en
la cultura tiene una importancia radical y dentro de esa unidad el término marca la diversidad y la
diferencia pero que además, para mi concepto, este es un término que tiene mucho que ver con los
debates que se llevan a cabo en torno a las investigaciones que se hacen relacionada con la herencia
africana y con los debates que se arman en relación con la secuela que ha dejado desde el punto de vista
social, desde el punto de vista cultural y sicosocial de la esclavitud; sin este término esos debates no
tienen sentido, para mi criterio, y sin ese término no hay diferencia en la unidad cubana en relación con
la cultura porque muchas veces decimos este es un problema de la cultura este es un problema muy
cultural pero la población entiende de cultura la música la danza y el teatro que a veces hasta se queda
afuera la literatura y entonces en esa unidad que hay afrocubana para mí a marca la diferencia y la
diversidad por tanto yo pienso que eso es muy importante como también entiendo que
afrodescendiente es un término muy político de carácter muy político que se acuño en una reunión por

${ }^{74}$ Daysi é uma importante referência na luta antirracista em Cuba, especialmente pela ênfase que dá em seu trabalho acadêmico e ativista para as mulheres negras. No período da pesquisa, estivemos juntas em diversas atividades organizadas por coletivos vinculados ao tema, especialmente nas coordenadas por Afrocubanas, do qual Daysi faz parte. A realização da entrevista foi feita na casa de uma amiga comum, Irene Esther. É historiadora de formação. 
uno de los líderes latinoamericano, no recuerdo como se llama, entonces entiendo que afrodescendiente es un término de carácter netamente político para esta lucha que se lleva a cabo no solamente en Latinoamérica sino en el mundo entero (Daysi Rubiera, Entrevista em 0I/08/20I4).

Além de um debate de termos ou categorias, essas reflexões, muito presentes em Cuba na contemporaneidade, apontam para o momento chave que vive o país para a questão, numa dinâmica que permeia a transição de um modelo mais centralizador na relação entre o Estado e a sociedade civil, para algo mais fluido e politonal, vivenciado a partir dos anos I990, e para uma crise dos valores da "identidade nacional" como o reflexo do ser cubano completo, totalizante.

Esses processos que se engendram nos discursos do movimento social antirracista cubano, direcionados em sentido contrário à visão estabelecida, abalam as bases da narrativa homogênea de nação. Para dar seqüência a esse debate, é fundamental tratar de forma mais aprofundada essa ideia de Nação Cubana, da identidade "cubana" e dos modelos totalizantes que conformam as narrativas dessa identidade nacional. Abordar a porosidade desse sólido totalizante, questionado de forma mais continuada pelos movimentos sociais cubanos que ganham força a partir dos anos 199075, é um dos pontos centrais para a compreensão do debate racial atual.

\section{I.3. Mito da Igualdade, Mestiçagem e Nação}

Falar da questão racial em Cuba sem mencionar o peso dos elementos que dão o tom à construção da Nação cubana deixaria qualquer análise incompleta. Dentro dessa dinâmica, a ideia de mestiçagem é importante na constituição da identidade cubana, reforçada em estudos, políticas e narrativas ao longo do século XX. A partir de 1920, estudos sobre o tema passaram a destacar os elementos, como as raízes africanas, que conformavam a identidade nacional, a cubanidade, a partir de ingredientes presentes na música, linguagem, dança, comida (DE LA FUENTE, 20I4).

Fernando Ortiz foi um dos pesquisadores da época que trabalhou sobre aspectos vinculados ao que denomina "mestiçagem cultural e de raças", que teve como produto a construção da "cubanidade". De acordo com Ortiz:

No hubo factores humanos más trascendentes para la cubanidad que esas continuas, radicales y contrastantes transmigraciones geográficas, económicas y sociales de los pobladores, que esa perenne transitoriedad de los propósitos y que esa vida siempre en desarraigo de la tierra habitada, siempre en desajuste con la sociedad sustentadora (ORTIZ, I963: 95).

\footnotetext{
${ }^{75}$ Abordarei mais profundamente a especificidade dessas mobilizações antirracistas em Cuba pós-período especial em seção específica nesse capítulo I sobre movimentos sociais e no capítulo 4.
} 
O debate sobre mestiçagem esteve muito vinculado à ideologia da branquitude, presente na América Latina. A mestiçagem é uma ideologia historicamente evidente, a partir de suas particularidades, nas sociedades cubana, peruana, nicaragüense, brasileira, colombiana, enfim, permeia profundamente as relações raciais na região ${ }^{76}$. Como se constitui a ideologia da mestiçagem? Quais são as implicações do mito da mestiçagem para as relações raciais? Quais são os vínculos da ideologia da mestiçagem com a ideia de Nação?

Peter Wade (2003) pondera que falar sobre identidade negra na América Latina está correlacionado com a conformação dos Estados nacionais, processo onde essa identidade se define. $\mathrm{O}$ autor ressalta que os muitos trabalhos escritos sobre o tema reforçam o papel que a construção da mestiçagem teve para a definição da nação, sendo a mistura entendida como elemento formador de uma população nacional ${ }^{77}$. $\mathrm{O}$ branqueamento, nesse sentido, seria a espera de um futuro nacional mais branco e menos negro e indígena. De acordo com Wade (2003), nesse discurso, negro e indígena se identificam como algo arraigado no passado, algo inferior, algo que necessita ser superado.

É por meio da ideologia da mestiçagem que se concebe o "mestiço". São as especificidades locais que caracterizam essa delimitação do conceito de mestiço. Todavia, as raízes coloniais e os usos dessas teorias e preceitos nas jovens repúblicas latinoamericanas dão um tom compartilhado à questão. De acordo com a definição dada pela Real Academia Espanhola, mestiçagem é o cruzamento de diferentes raças, o conjunto de indivíduos que resultam desse cruzamento e a mescla de culturas distintas, o que produz uma nova ${ }^{78}$. É interessante analisar os elementos presentes nessa definição, pois permeiam a noção de fusão da diferença, seja ela cultural ou racial, para o estabelecimento de uma nova conformação totalizante dessa diversidade. A ideia de unidade que suprime as diferenças está presente no significado dado à mestiçagem em sua etimologia. Esse significado reflete o processo de construção mais recente do termo no contexto colonial e pós-colonial da América Latina.

No caso cubano, a ideologia da mestiçagem permeia não apenas o debate racial, mas também o conceito de identidade e cultura cubana. A própria ideia de Fernando Ortiz de "transculturação" para a formação da "cubanidade", da identidade cubana, envolve uma fusão de elementos originários que geram um novo, mestiço. Portuondo faz uma reflexão da obra de Ortiz

\footnotetext{
${ }^{76}$ Para mais informações sobre o debate acerda da mestiçagem na América Latina: vide: QUIRÓS, RONALD et al. (2007); WADE (2013), DOMINGUES (2005), STOLCKE (2007), COSTA (200I).

${ }^{77}$ Tais como: STUTZMAN (I98I); FRIEDEMANN (1984), apud WADE (2003).

${ }^{78}$ Disponível em lema.rae.es/drae/srv/search?key=mestizaje
} 
exatamente sobre o conceito de "transculturação", que dialoga com a ideia de mestiçagem para a conformação de uma cultura nacional integrada:

La conformación de estratos originales en la estructura étnica de la población cubana (formaciones etnoculturales originales) integra formas de síntesis de sus ingredientes, donde el "hecho" se trasciende. La unidad, antropológica y originaria (constitutiva), trasciende en el etnos toda linealidad temporal y transfigura la significación de factores humanos de origen diverso, adjudicándoles, en su conexión e integridad, nuevas dimensiones de sentido. Pero si bien la unidad en el mestizaje, devenida factor antropológico constitutivo en el etnos, encarna lo típico y la posible existencia de tipos humanos originales, la cubanidad no es reducible al etnos o a su relativa provisionalidad; esto es, al modo históricamente transitorio y con ingredientes frecuentemente fugaces, en que la unidad se fragua en los mestizajes. Como cualidad peculiar de la cultura de Cuba, la cubanidad se forma para Ortiz a expensas de los desgarramientos del etnos y de la aspiración a una forma o unidad superior, que lo trasciende en su cualidad provisoria y se revela en los orígenes y en su condición de futuridad (PORTUONDO, I999: $3)$.

O significado da mestiçagem, contemporaneamente construído, tal como visto na definição dada pela Real Academia Espanhola e no próprio conceito de "cubanidade" em Ortiz, remete à sua construção ideológica que faz alusão à mescla de raças e culturas e à conformação de novas referências a partir de fontes originárias.

Isso se funde com os pilares da ideologia racial e do racismo científico, que tiveram grande influência sobre a América Latina no século XIX e meados do século XX. Nesse período, havia um flanco debate sobre a diferenciação biológica das raças e os males que o cruzamento entre elas causaria à conformação de um povo, de uma nação. A influência desses preceitos racistas, contudo, apresentaram um caráter diferenciado na região, onde a possibilidade de branqueamento e mestiçagem, ao invés de degenerar a raça, seria a solução para a superação do "atraso".

Os preceitos científicos raciais, de diferenciação biológica, já eram alardeados em períodos anteriores na Europa. No século XVIII, Kant discorre sobre as raças, respectivamente em 1775 e 1785, em pronunciamentos pouco conhecidos. Kant não acreditava que a mistura das raças pudesse ocasionar um novo ser humano original. Para ele, longe de melhorar a espécie humana, a mestiçagem a degradava: "os produtos bastardos - escreve Kant, num fragmento inédito de 1790 - degradam a boa raça sem melhorar proporcionalmente a raça ruim" (KANT, I790, apud MUNANGA, 1999: 26-27).

Kant, assim como outros pensadores da época, comungava das ideias e princípios sobre a mestiçagem como elemento degradante das raças humanas. Entre os séculos XIX e XX, diversos estudiosos, como Gobineau, dão seqüência às ideias também baseadas na deterioração racial. Gobineau defendeu que a "degeneração" das culturas tinha íntima relação com a mestiçagem. (BETHENCOURT, 2013). 
A principal obra de Gobineau, intitulada "Ensaio sobre a desigualdade das raças humanas", foi produzida no período de I853-I855. A obra reforçava a perspectiva das raças inatas e imutáveis. Sem muita ressonância na França da época, foi posteriormente traduzido e publicado nos Estados Unidos em 1856, e em 1898, na Alemanha. Mas foi efetivamente a propaganda nazista que fortaleceu o legado de Gobineau (BETHENCOURT, 2013).

A teoria da deterioração das raças pela mestiçagem foi um dos pilares das teorias defendidas por A. Hitler, em Mein Kampf (1922). Ele a concebia como a degradação das raças humanas, o aniquilamento das qualidades do povo conquistador, bebendo nos estudos de Gobineau. Uma das ações mais drásticas derivadas dessa teoria foi a esterilização, a partir de I933, dos "mestiços" nascidos na Alemanha.

Num revés dessa premissa, mas fundada na perspectiva assimilacionista e de aculturação, a França, nos anos 1930, adota a política da "mestiçagem cultural", em oposição às noções de pureza racial e cultural, e da hierarquia das raças, presentes na ideologia nazista. "Trata-se de um projeto de aculturação, ou melhor, de assimilação, configurando-se como ideologia colonial da França republicana e cumprindo funções política e pedagógica" (MUNANGA, I999: 45).

Outro aspecto desse debate sobre a mestiçagem, contudo, contaminou a América Latina nesse período histórico, sobretudo no início do século XX. Com grande influência das teorias eugenistas, houve uma sobrevalorização do estímulo ao processo de branqueamento das populações de muitos países da região, no qual se registraram uma série de iniciativas estatais de incentivo à migração europeia. Todavia, o almejado branqueamento culminou na construção idealizada da sociedade mestiça, composta pela mescla das "grandes raças", de acordo com a abordagem raciologista, que seria principalmente composta pelos negros, brancos e indígenas. Como destaca Munanga (1999), essas são categorias cognitivas, fundadas na lógica colonial, que a partir de uma suposta justificativa biológica, apresenta-se como um constructo ideológico:

A mestiçagem não pode ser concebida apenas como um fenômeno estritamente biológico, isto é, um fluxo de genes entre populações originalmente diferentes. Seu conteúdo é de fato afetado pelas ideias que se fazem dos indivíduos que compõem essas populações e pelos comportamentos supostamente adotados por eles em função dessas ideias. A noção de mestiçagem, cujo uso é ao mesmo tempo científico e popular, está saturada de ideologia. (MUNANGA, I999: I8).

A influência da ideologia da mestiçagem e do branqueamento, como o processo de fusão entre grupos raciais originais que geram um novo e os estímulos à migração europeia para branquear a nação, tiveram grande peso sobre a América Latina. 
Em Cuba os reflexos desses preceitos são sentidos na atualidade. De acordo com o ativista Norberto Mesa,

El mestizaje es un cuento. ¿Es un paso necesario para llegar a qué? Pero el mestizaje no es la meta. La meta es el blanqueamiento. El mestizaje es para estar en vías del propósito que esta trazado desde los fundadores de la Nación cubana: Los negros, hay que eliminarlos, los negros no hacen parte de la nación cubana. (Entrevista realizada com o ativista Norberto Mesa, da Cofradía de la Negritud, em 09/07/20I5.)

Expressões cubanas como "adelantando la raza" e a diferenciação social entre "mulatos" e "negros" são alguns dos exemplos da materialização da ideologia do branqueamento e da mestiçagem em Cuba contemporânea. Bienvenido Rojas ${ }^{79}$ também aborda sua percepção do fenômeno:

\begin{abstract}
Aquí una negra se casa con un blanco. La mujer queda embarazada. Entonces, cuando va a dar a luz todo el mundo está pendiente de saber cómo va a ser el pelo de la criatura, eso es una provocación si va a tener el pelo lacio o lo va a tener rizado. ¡Eso es racismo! O sea, qué importa el pelo, lo que importa es la persona que sea una persona de bien, que sea una persona educada, inteligente en fin saludable. Esa es la mayor preocupación. (Entrevista com Bienvenido Rojas, em 04/05/20I4).
\end{abstract}

Essas construções sociais sobre "adelantar la raza" ou a excessiva preocupação com os possíveis traços físicos que o filho de um casal interracial possa ter, demonstram o peso que ambas ideologias têm na sociedade cubana atual. É importante ressaltar que a abordagem que faço nesse trabalho diz respeito ao constructo social, à dimensão ideologizada da mestiçagem, à narrativa social construída da mescla de raças e da mescla de culturas. Não traz nenhuma referência às interações genéticas e biológicas.

As relações raciais em Cuba estão permeadas desses valores que trazem conseqüências práticas para a sociedade de forma geral. É comum encontrar não-brancos de pele mais clara que ao serem classificados como "negros" rapidamente façam a correção e se apresentem como "mulatos" ou "mestiços". Esse processo marca, portanto, uma fragmentação de uma possível solidariedade entre os não-brancos como vítimas de discriminação e uma determinação da identidade racial a partir dos padrões hegemônicos brancos. Ao se apresentar em um patamar diferenciado do signo de maior estigmatização, o "mulato" ou "mestiço" busca maior possibilidade de ascensão social. Seria algo semelhante ao que Hasenbalg, para o caso brasileiro, denomina "expectativa individual de mobilidade ascendente".

\footnotetext{
${ }^{79}$ Ativista de coletivos afrodescendentes é integrante da ARAAC. Tem diversas iniciativas voltadas ao debate sobre o tema racial, especialmente no campo das comunicações, como programas de rádio, jornais e livros. É jornalista e um dos programas que coordena se chama Songo Roco Songo, voltado para a cultura afro. Meus contatos com Bienvenido ocorreram em diversos momentos durante a pesquisa, especialmente em atividades e debates raciais, além do curso de diplomado que realizamos na Universidade de Havana. Dentre os encontros, destaco a entrevista mais profunda que realizei com Bienvenido no jardim da UNEAC, em abril de 2014.
} 
Por outro lado, as relações raciais em Cuba não se apresentam de forma rigorosa. A identidade racial pode ser fluída e flexível, a depender do contexto. Conforme relato abaixo de Noemi de Cárdenas ${ }^{80}$, os indivíduos podem manipular os signos em busca de um espaço socialmente mais valorizado, que nesse caso cubano é referenciado pela identidade branca:

Los mestizos no se asumen como mestizos. El padre de mi hija es mestizo, pero en su carné de identidad le pusieran piel blanco, y él tampoco protestó. La gente trata de blanquearse. Él no es racista, pero no se molesta si lo ponen blanco en el carné de identidad. En su interior, como esta en el interior de los cubanos, está el deseo latente del blanqueamiento. (Noemi de Cárdenas, entrevista feita em I4/07/2015).

Em outras situações, a marcação dos signos vinculados à subalternidade surge independentemente da tentativa dos indivíduos de desvincular-se delas, exatamente pelo fato da percepção racial refletir uma construção social mais ampla. A manipulação particular do espectro de cores cubano, ou como denomina Carlos Hasenbalg, do contínuo de cores, é limitada pelos próprios signos que estigmatizam os não-brancos de forma geral. Apesar de trazer impactos diferenciados a depender da intensidade da presença desses traços, os signos racistas atingem os não-brancos de forma abrangente. O relato da recepção do casamento de Niurka Nuñes, pesquisadora cubana do tema racial reflete bem esse ponto:

Yo me gradué en la Unión Soviética en el año 1989 y regrese de la Unión Soviética con un marido mulato. En mi casa eso fue un problema, sobre todo para mi abuela. Había muchas discusiones en torno al tema, no discusiones desagradables porque a fin de cuentas en mi casa siempre hubo respeto a las decisiones que tomara cada uno. Sabía que no había agresiones, pero sí preocupaciones muy evidentes con Eugenio, sobre todo cuando salí embarazada. Muchos cuestionamiento en onda: sabrá peinar a la niña, si sale el pelo malo, cosas de ese tipo. Además, con él mismo hubo discusiones acerca del tema de la raza en Cuba porque él se consideraba a sí mismo como blanco, a partir del contexto en el que había nacido y crecido y era el contexto de un solar del barrio Cayo Hueso, uno de los barrios más tradicionales de La Habana, un barrio predominantemente negro y mestizo. Al él ser un mulato claro de piel pues en aquel entorno llamémosle de negros creció con conciencia blanco y él recibe el impacto de ser considerado como mulato, aunque por supuesto a lo largo de su trayectoria vital también había habido mecánicas del tipo de saberse considerado como mas como mulato, pero el impacto más grande lo sufre cuando entro en mi familia donde simplemente era mulato. (Entrevista com Niurka Nuñes, realizada em 2I/05/20I4).

Numa sociedade na qual não há um rígido sistema de classificação racial, fenômenos como o ocorrido com os maridos de Noemi e Niurka, supracitados, de convivência de uma autoidentificação que transita entre os marcadores de negritude e branquitude são possíveis e compõem o complexo sistema das relações raciais cubanas. Mas é sintomático perceber que os lugares são dispostos a partir de uma hierarquia racial explícita. Essa hierarquia leva, por um lado, à negação de vínculo com os signos coloniais subalternizados da negritude, e, por outro, a um

${ }^{80}$ É ativista feminista, bastante atuante especialmente com a pauta de combate à violência contra a mulher. É professora do Instituto Superior e Artes. Tivemos encontros periódicos em aulas realizadas de línguas. Não possui uma vinculação com nenhum dos coletivos estudados, mas mantém relações especialmente com algumas integrantes dos coletivos de mulheres negras. Alguns dos encontros que participei com ativistas, também tiveram a participação de Noemi. A entrevista foi realizada em minha casa, em julho de 2015. 
assombro quando esses signos retornam aos indivíduos como marcadores sociais de desvalorização e estigmatização.

Essa tentativa de desvincular-se do signo negro é gerada por uma série de construções imagéticas, ideológicas e sociais que situam os negros e negras em um lócus social marginal, perigoso, primitivo $^{81}$, feio, incapaz. A manipulação, por tanto, de muitos dos indivíduos, seria buscar desvincular-se desses signos estigmatizantes. É sobre o reposicionar desses signos estigmatizados que atuam muitos dos ativistas que acompanhei no trabalho de campo em Cuba. Deyni Terry ${ }^{82}$, ativista antirracista e advogada, guarda com carinho um poema que recebeu na infância, exatamente por situá-la como mulher negra no lugar do desejado, do amor. A seguir, transcrevo um trecho do poema:

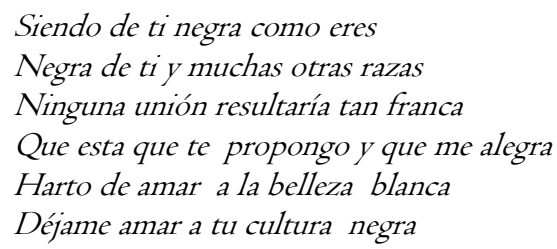

Ao mencionar o poema, Deyni relata também o quanto essas imagens contrahegemônicas da valorização da negritude foram importantes para sua construção e valorização como mulher negra. Destaca, ainda, que os espaços de visibilidade da beleza eram embranquecidos, como as rainhas do carnaval, que na sua juventude nos anos 1970 e I980, eram em quase sua totalidade brancas. E foi esse estímulo de valorizar-se que impulsionou Deyni a estudar mais sobre a questão racial, além de se engajar na atuação antirracista no país:

En los años 1970 al 1980, se hacia la selección de la estrella el carnaval y los luceros. Esa estrella era la que iba en la carroza por todo el pueblo y en todos los municipios y esa estrella llevaba seis luceros. Y mi observación silenciosa es que siempre por lo regular eran mujeres blanca o mulatas blanconazas de tez muy clara, pero no recuerdo en mi historia de vida qué estrella y lucero del carnaval fueron mujeres de tez negra. Porque desde mi niñez, yo era muy joven pero no recuerdo que fueran mujeres de tez negra. Todos estos antecedentes me llevaran a mí al estudio de los tema de la racialidad. Vengo a estudiar para la Universidad de La Habana en el año 1984, matriculo en la carrera de Derecho Ciencias Jurídicas, me recibo como abogada. [...] Ya te había dicho que me interesaba siempre tributar desde mi racialidad ser una mejor persona. Me gradúo de abogada y comienzo a chocar directamente con los temas legales en Cuba con los asuntos de hombres y mujeres negros. Comienzo a conocer demandas por exceso policial, comienzo atender como abogada, comienzo en Centro Habana ${ }^{83}$ a chocar de lleno con el conflicto socio

\footnotetext{
${ }^{81}$ Como ocorre com as tradições de origem africana como a Santeria, a tradição Abacuá, o Palo Monte que com freqüência são vistas como práticas "animistas", conforme descreverei em exemplos ao longo do trabalho.

${ }^{82}$ Deyni Terry, ativista da Alianza Unidad Racial e da ARAAC, tem grande experiência com o campo jurídico e legal em Cuba. Foi juíza e atualmente atua como advogada em Buffet voltado aos direitos habitacionais, em Havana. Sua atuação como ativista é focada no direito à igualdade e na importância do acesso à justiça para pessoas discriminadas. Participamos juntas, no percurso da pesquisa, de diversas atividades voltadas para o tema no país, organizadas por coletivos antirracistas. Estive presente, também, em oficinas realizadas por AUR que possibilitavam o compartilhar de experiências de vítimas de discriminação e as ações que são desenvolvidas de apoio pelo seu coletivo. A principal entrevista para a tese foi realizada em sua casa.

${ }^{83}$ Bairro de Havana muito adensado, com grande percentual de moradias precárias e uma grande presença negra.
} 
racial, los excesos policiales las ocupaciones ilegales, sin cumplir todos los fundamentos que la policía debía cumplir, el seguimiento investigativo de manera digamos indiscriminada contra determinadas personas. (Entrevista com Deyni Terry, ativista antirracista e advogada, realizada em I5/05/20I4).

A narrativa de Deyni faz alusão a um aspecto fortemente marcado nas sociedades colonizadas, que é o reforço cotidiano ao padrão estético "branco". José Jorge de Carvalho (1999, 2000), destaca que "os seres humanos que classificamos como caucasianos", ou seja, os fenotipicamente de pele clara, olhos claros, cabelos lisos e narizes finos concebidos como "brancos" ocidentais, "europeus em geral e muito particularmente os anglo-saxões", impuseram a todo o mundo um padrão de valor e beleza para toda a espécie humana, primeiramente a "ferro e fogo", e atualmente por meio da "indústria cultural e do controle político e financeiro".

Carvalho argumenta ainda que essa imposição cresceu com o colonialismo, especialmente a partir do século XVI, "quando os europeus colonizaram a América e consolidaram o tráfico de escravos da África para o dito Novo Mundo". Esse processo que incluía uma combinação de "escravidão, colonialismo e capitalismo marcou a imagem do homem branco ocidental como superior aos nãobrancos (que começaram a ver-se como não-brancos) dos demais continentes" ${ }^{84}$.

Outro aspecto trazido pela fala de Deyni refere-se à dimensão de agencialidade que está imersa na percepção dos ativistas negros, que experimentam o racismo e as vivências de discriminação e a partir deles buscam realizar uma ação contrahegemônica, que questione os valores introjetados na sociedade. Deyni busca esse espaço em sua atuação como advogada, numa tentativa de inserir um olhar sobre as desigualdades raciais em um meio onde o racismo não é tratado como um tema de relevância.

Também é sintomático visualizar na abordagem de Deyni, uma vez mais, essa diferenciação dos lugares sociais de mulatos, negros e brancos, a partir do viés do embranquecimento. As mulheres escolhidas como as rainhas do carnaval são majoritariamente brancas, ou em menor número, mulatas de pele muito clara, "branconazas", nos termos de Deyni. Nessa abordagem, a hierarquia racial está mais uma vez marcada, a partir do referencial branco: as brancas majoritariamente ocupam esse espaço da beleza e destaque, e em espaços minoritários, são incluídas mulatas de pele muito clara, mas nunca uma mulher negra, reproduzindo a lógica do contínuo de cores a partir da perspectiva de Hasenbalg (2005).

\footnotetext{
${ }^{84}$ Disponível em http://www.revistacinetica.com.br/cep/jose jorge.pdf (Acesso 10/2013).
} 
A manipulação dos signos vinculados aos fenótipos raciais em Cuba são fortemente presentes nas relações sociais. Ao refletir sobre esses processos no espaço cubano que eu me inseri, proponho dialogar com o debate feito por Carlos Haselbalg sobre as desigualdades raciais no Brasil. Para esse autor, as estratégias coloniais brasileiras demandaram a construção de um "grupo intermediário de mestiços" na hierarquia social. Isso se deve a falta de trabalhadores brancos qualificados para ocupar posições intermediárias na sociedade colonial brasileira, dada a menor presença branca por um grande período, a grande concentração de homens e poucas mulheres brancas e a maneira como foi "difundida a miscigenação racial" no Brasil, o que gerou um sistema particular de "classificação multirracial" (HASENBALG, 2005: 244).

Essa "miscigenação racial" deu origem ao que Hasenbalg (2005) denomina contínuo de cor, como produto das "categorias raciais originais". Na lógica do contínuo de cores, pequenas diferenças no tom da pele ou nos traços são concebidas como "marcadores sociais significativos", flexibilizando o sistema racial. $\mathrm{O}$ autor concebe que existem oportunidades diferenciadas de mobilidade social com base nas diferentes "matizes de cores". Pode haver a incorporação de alguns membros "não-brancos" da sociedade, mais claros, que ascendem à classe média ou, mais raramente à alta. Mesmo com o fim da escravidão, a cooptação gerada pelo "contínuo de cor" se manteve, o que gera fraturas na construção de um projeto político onde as aspirações políticas e econômicas de um grupo subjugado estejam organizadas. Esse é substituído por projetos individuais de mobilidade social ascendente. Esse processo, para Hasembalg, "inibiria o senso de solidariedade necessário ao sucesso das organizações a favor dos direitos dos negros".

Em diálogo com os estudos sobre Cuba, Aline Helg (2004) apresenta o sistema classificatório racial cubano como dual dividido entre negros e brancos, a partir do fato de que houve um quase extermínio dos povos indígenas, o que ocasionou sua pouca representação nas grandes divisões raciais cubanas. A autora destaca que a origem desse sistema dual em Cuba tem raiz no século XIX, na ascensão da produção açucareira e do tráfico negreiro. Nesse período, se constrói o termo "de color", que englobava tanto negros com pele mais escura como mais clara, os também denominados "mulatos". O termo "negro" também era usado para os dois casos.

Ressalta, ainda, Helg (2004: 25) que esse modelo dual se manteve na Revolução, período no qual foram publicados livros que seguiam apresentando o termo negro de forma abrangente, tanto para referir-se a negros livres e escravos, como para negros e mulatos, em contraponto aos brancos. Por fim, faz a diferenciação da classificação cubana do sistema racial estadunidense de "uma gota de 
sangue negro" ${ }^{85}$. A linha que divide os brancos dos negros e mulatos, para essa autora, seria o ancestral de origem africano visível fenotipicamente. Por fim, fala de uma hierarquia ascendente, que parte do mais africano até o mais europeu.

Acho importante refletir sobre o que Helg (2004) denomina sistema dual de classificação racial em Cuba. Sem dúvida, a linha que separa os brancos dos negros é constituída a partir dos traços fenotípicos, como também argumentado pela autora. Mas, essa relação se dá de forma mais complexa na atualidade, impondo uma dinâmica hierarquizada entre negros e mulatos, a partir do referencial do embranquecimento, conforme argumentei e exemplifiquei acima.

É fato que muitas das pesquisas censitárias do período colonial reproduziram essa dinâmica de equiparar negros livres e escravos, mulatos e negros, em diversas ocasiões. Também, essa reunião categórica dos negros em contraponto aos brancos esteve presente em algumas publicações no período revolucionário, conforme argumentado pela autora. Porém, não é possível reduzir a análise das percepções sociais do sistema classificatório racial a uma visão simplesmente dual. $\mathrm{O}$ próprio censo realizado já na Revolução, nos anos I98I, 2002 e 2012, incorporou dentre suas categorias os termos branco, negro e mestiço. E, nas dinâmicas sociais e narrativas sobre as relações raciais, essa diferenciação aparece marcada.

A partir dos dados obtidos na pesquisa e das análises que deles faço, acredito que a dinâmica do contínuo de cores se aplica de um modo mais assertivo à complexidade do sistema de classificação racial cubano. No período da pesquisa de campo, acompanhei alguns relatos de ativistas que argumentavam que em ocasiões em que estavam denunciando alguma situação de discriminação racial, pessoas por eles concebidas como mulatas ou até negras se manifestavam no sentido de negar qualquer vínculo com a negritude em frases como: "apesar de não ser negra, me solidarizo com a demanda". Ou, ainda, outros casos onde mesmo havendo um reconhecimento de sua negritude, o indivíduo se apresentava como uma pessoa que jamais havia sofrido racismo, debilitando a denúncia feita.

No programa televisivo alusivo ao Dia Mundial Contra a Discriminação Racial, 2I de março de 2015, denominado "Mesa Redonda"86, a jornalista Arleen Rodriguez, mediadora do debate, relatou as dificuldades que encontrou para estabelecer vínculos com o movimento feminista, pelo

\footnotetext{
${ }^{85}$ Oracy Nogueira (2006), em estudo comparativo sobre relações raciais no Brasil e nos Estados Unidos, destaca que no Brasil o preconceito racial se exprime por estigmatização fenotípita, o "preconceito de marca", enquanto nos EUA o racismo se caracteriza pelo "preconceito de origem", vinculado à ascendência, independente da aparência. O sistema da gota de sangue remete à hereditariedade.

${ }^{86} \mathrm{O}$ programa pode ser assistido na íntegra no link: http://www.cubainformacion.tv/index.php/sociedad/61884\%C2\%BFRacismo-en-Cuba?-Tema-de-la-Mesa-Redonda (acesso em I7/09/2015).
} 
fato de, em sua perspectiva, não ter sido impactada por nenhuma barreira pelo fato de ser mulher. Sua assertiva compôs a pergunta dirigida a José Estrada, negro, militante da União da Juventude Socialista, se já havia sofrido racismo. Sua resposta seguiu a linha argumentativa da inexistência desse fenômeno em sua vida particular:

Arleen Rodriguez (periodista): José Luis Estrada yo le decía: tú, cómo te digo y como un hombre no blanco, vamos a usar términos y después me van a corregir los académicos, has tenido dificultades en tú vida, o tú eres de esas generaciones como yo que jamás sentí que como mujer me discriminaban en ningún sentido y digo: me cuesta trabajo hacer una batalla feminista porque nunca he encontrado obstáculos en mi desarrollo.

José Luis Estrada (Unión de la Juventud Socialista): En el caso personal no, yo a decir verdad nunca he sentido esa discriminación.

Após essas afirmações que esvaziam o próprio objetivo de expor televisivamente o debate sobre racismo, em um dos poucos atos relacionados ao Dia Internacional de Combate à Discriminação Racial em 20I5, José Luis menciona uma pesquisa levada a cabo em alguns bairros sobre a questão racial e afirma ter conhecimento de que existe o racismo, mas se desvincula como sujeito negro desse universo. É como se sua condição de liderança de uma organização importante dos movimentos de base da Revolução o desvinculasse de todo o processo de estigmatização de negros na televisão, no ambiente escolar, na relação com a polícia, nos espaços dolarizados, na sociedade cubana como um todo.

Essa naturalização das práticas racistas da sociedade cubana dialoga com o que De La Fuente (20I4: 35) denomina "democracia racial cubana" ${ }^{87}$. Na atualidade, esse mito parte do pressuposto de que a Revolução solucionou os problemas raciais da sociedade. Se há o reconhecimento de que existem elementos racistas na atualidade, eles são tratados como resquícios de um passado colonial e republicano, que na subjetividade dos indivíduos se materializa. Esse mito, mais do que expresso em diálogos cotidianos, baliza posições oficiais do Estado cubano sobre o tema. Em 2011, em informes internacionais apresentados ${ }^{88}$, o governo cubano argumenta que os preconceitos raciais na sociedade cubana não são expressivos e são restritos especialmente às relações privadas, com ênfase para as relações conjugais.

Destaco, ainda, outra fala sobre o tema do vice-ministro de cultura de Cuba, Fernando Rojas, que no documentário Raza reconhece que existe racismo no país, ainda que ele prefira chamá-lo de

\footnotetext{
${ }^{87}$ Aqui o autor se refere à argumentação feita por políticos cubanos do início do século XX, que alegavam que os próprios negros é que não aproveitaram as oportunidades dadas pela República.

${ }^{88}$ Informes periódicos do governo de Cuba (do $\mathrm{I}^{\circ}$ ao $\mathrm{I}^{\circ}$ ), apresentados ao CERD entre os dias 16 e 17 de fevereiro de $201 \mathrm{I}$.
} 
"discriminação racial", mas numa escala mais branda do que o existente em outros países do mundo:

Yo creo que si existe racismo, no por supuesto en una escala minimamente comparablea de qualquer otro lugar del mundo, ni por supuesto a la historia pre-revolucionaria. Yo prefiero decir, incluso, aun que la expresión más comum sea racismo, prefiero decir que existe discriminación racial. Pero me gusta destacar eso que acabo de decir, los grados son muy inferiores a los de otras realidades y muy, muy inferiores a la realidad anterior a 1959. (Fernando Rojas, vice-ministro de Cultura de Cuba, documentário Raza, 2008).

Portanto, em um contexto onde não existe racismo, ou o que existe são apenas resquícios de discriminação racial provenientes de tempos idos republicanos e coloniais manifestos em ambientes íntimos, se constrói o que denomino "mito da igualdade racial cubana". É fortemente amparado nos legados que mencionei anteriormente, dos quais se pressupõe a existência de uma igualdade entre os diversos segmentos raciais, exatamente pela ausência, ou quase, de desigualdades raciais e do próprio racismo estrutural.

O mito complexifica-se com a afirmação que o legado revolucionário faz com que as práticas discriminatórias em Cuba existam numa escala muito mais branda em relação aos outros países do mundo, conforme destacou Rojas no trecho supracitado.

Outro ponto relevante na construção desse mito é a percepção de que o racismo é uma prática inerente às relações sociais, que tanto brancos podem ser racistas com negros, como negros podem ser racistas com brancos, inviabilizando e negando o caráter sistêmico do racismo, que no caso cubano não prescindiu de estar amparado numa dinâmica hierarquizada a partir do referencial hegemônico branco:

Hay muchas maneras de discriminar. Hay blancos que discriminan a los negros, como hay negros que discriminan a los blancos. Yo he vivido todas esas experiencias. Por eso as veces yo discuto con algunos compañeros que presentan la cosa como se fuera siempre del mismo modo. Mira, hay de todo, por que hay el negro que también discrimina el blanco. (Entrevista com Mavis Alvarez ${ }^{89}$, realizada em 28/05/20I4).

Por fim, são os negros que ocupam o reverso do racismo. Além de poderem estar situados como agentes racistas, podem ser vistos como os causadores de sua situação de exclusão. As desigualdades raciais existentes são vistas por muitos como frutos de uma posição vitimizada dos

\footnotetext{
${ }^{89}$ Mavis é uma ativista ligada à pauta de mulheres e de agricultura familiar. Publicou livros sobre esses temas, alguns vinculados a sua experiência ampla, desde a Revolução, com a pauta fundiária e agrícola, inclusive em instituições oficiais do Estado cubano. Em sua casa, situada em Vedado, foram realizados alguns encontros que participei com ativistas antirracistas. Encontrei com Mavis, também, em debates organizados por coletivos antirracistas. Mavis não integra nenhum dos coletivos vinculados à pauta racial, mas participa de algumas das suas atividades. A entrevista para a tese foi feita em sua casa, oportunidade que tive também de conhecer as várias interações que Mavis teve com os movimentos pela terra no Brasil, como o Movimento Sem Terra.
} 
próprios negros que não aproveitaram devidamente as oportunidades oferecidas pela Revolução, como destaca uma das entrevistas:

No pueden estar hablando siempre desde la posición del oprimido, reclamando por que el gobierno tiene que hacer, tiene que dar. Hay que reclamar también hacia adentro. Porque los negros si quieren que cambien algo también tienen que cambiar su actitud. Ahora no pueden reclamar derechos a la educación, no pueden reclamar derecho a determinados derechos ciudadanos. Que les van a reclamar? Atención medica? Oportunidades de empleo? Entonces hay que reclamarse también hacia dentro. Autoreclamarse. (Entrevista com Mavis Alvarez, realizada em 28/05/20I4).

A construção desses mitos que constituem a ideia de uma igualdade racial a la cubana além de engessarem as respostas do Estado ao problema, acabam por situar as demandas e denúncias de ativistas como extremadas, sem fundamentação e, em muitos casos, vistas como contrarevolucionárias. É uma forte ideologia que invisibiliza e impõe obstáculos a essas mobilizações e movimentações que tentam imprimir um contradiscurso sobre a questão racial.

Retomando o diálogo com Hasembalg, cabe refletir sobre as estratégias ideológicas do branqueamento e da democracia racial no Brasil, somadas ao impacto do contínuo de cor e da fragmentação da identidade racial dos não-brancos, parte do projeto de branqueamento das elites com vistas a superar o "subdesenvolvimento brasileiro" (HASENBALG, 2005: 247). Diferentemente do postulado pelas teorias vinculadas ao racismo biológico, como de Gobineau, a ideologia do branqueamento brasileiro se refletia no estímulo à migração europeia para, a partir da colonização no país, proporcionar um contínuo branqueamento desse espectro de cores.

Longe da ideia de "raças puras" de Gobineau, o branqueamento brasileiro pregava o clareamento fenotípico. Nesse sentido, voltando à Hasenbalg (2005: 248), o mulato ou o mestiço representariam "um passo à frente em direção à redenção da raça". Outro aspecto trabalhado pelo autor é de que "o dinheiro branqueia". Ou seja, os negros que alcançam um determinado nível econômico e são capazes de reproduzir valores e comportamentos da elite branca se distanciam de seus grupos originários (HASENBALG, 2005: 249).

Por fim, o mito da democracia racial brasileira seria para Hasembalg "o símbolo integrador mais poderoso criado para desmobilizar negros e legitimar as desigualdades raciais vigentes desde o fim da escravidão" (2005: 250). A sustentação desse mito, no período pós-colonial brasileiro, se reforça pela não discriminação lega $1^{90}$, pela presença de uma pequena minoria não-branca na elite e conflito racial dissimulado. Então, mais de cem anos após a abolição os negros continuam

\footnotetext{
${ }^{0}$ Diferentemente de países onde explicitamente a segregação esteve presente nos códigos legais, como Estados Unidos e África do Sul, no Brasil, como em Cuba, a legislação não explicitava bases legais racistas e segregacionaistas, apesar de isso compôr a realidade social.
} 
reproduzindo padrões de desigualdade elevados na sociedade. Mas, por muito tempo, se defendeu, inclusive oficialmente, que não havia preconceito e discriminação racial no Brasil. Haveria, portanto, oportunidades iguais aos brancos e negros no país ${ }^{91}$.

O rápido contraponto com o olhar sobre as relações raciais brasileiras é importante para percebermos o contexto no qual as relações raciais na Diáspora Africana nas Américas está imerso. As dinâmicas coloniais presentes no cotidiano, apesar das particularidades, são baseadas em estratégias semelhantes nos contextos brasileiros e cubanos. A ideologia do branqueamento, do mito da democracia racial e do contínuo de cores, guardadas as particularidades de cada situação, dialogam em grande medida.

As especificidades cubanas têm reflexos especialmente nos anos de Revolução e nas construções sociais provenientes desse processo único. As argumentações desse mito a la cubana envolvem o legado de políticas sociais inclusivas da Revolução, que atingiu preferencialmente os mais pobres, onde os negros estavam muito representados. Os impactos dessas políticas sociais abrangentes são imensos nas famílias negras dos ativistas entrevistados, conforme descreverei melhor no capítulo 3.

Em Cuba, ao contrário do Brasil, se observa uma grande presença de profissionais qualificados negros, como médicos, engenheiros, professores universitários, que romperam em suas famílias com ciclos geracionais onde não havia registro de acesso anterior ao nível superior. Como esse exemplo, há diversos outros que foram e continuam sendo impactantes na realidade social cubana e que, por suposto, beneficiam a população negra92.

Mas o debate não pode se restringir às políticas e ações sociais construídas pela Revolução. Em trechos específicos da tese, trarei dados e dialogarei com as narrativas dos ativistas que denunciam uma persistente invisibilidade de pessoas negras nos meios de comunicação, nos filmes e novelas, nos livros de história e literatura nas escolas, nos espaços mais altos na hierarquia política do país, nos setores turísticos e voltados à economia dolarizada. Há uma sobreposição de negros nos cárceres, conforme a denúncia sistemática de ativistas e estudiosos do tema ${ }^{93}$. A abordagem da

\footnotetext{
9I $\mathrm{Na}$ atualidade, essa imagem de "democracia racial" vem sendo fragilizada. As abordagens na imprensa sobre denúncias de racismo são mais frequentes, inclusive em canais esportivos. As mudanças legais e institucionais nos últimos anos são outras referências da ampliação do debate sobre o racismo no Brasil.

${ }^{92}$ Tais como: inclusivo sistema de saúde, sistema educacional gratuito e público, acesso a cinema, teatro e outros eventos culturais por preços muito acessíveis ou gratuitos, possibilidade de aquisição de livros com custo muito baixo nas livrarias estatais, dentre outros aspectos.

${ }^{93}$ Sobre esse aspecto, não fui autorizada a acessar dados oficiais desagregados por raça cor, apesar das tentativas realizadas.
} 
polícia também privilegia o controle das pessoas negras, conforme veremos mais adiante. A base legal existente, e a forma como o judiciário cubano lida com as denúncias de racismo, expõe as vítimas a um não acesso aos direitos. Enfim, há uma série de problemas estruturais relacionados ao racismo que demandam um reconhecimento concreto do Estado e da sociedade. Demandam também ações e respostas contundentes aos fatos.

Em situação análoga à brasileira, em Cuba, desde I90I, a Constituição cubana prevê a igualdade entre os cidadãos, incluindo brancos e negros. Não há legislações que explicitem o racismo. Cuba, após especialmente 1962, passou por um longo processo no qual o racismo era negado socialmente, e o próprio Estado não o reconhecia como um problema. A ideologia da igualdade, por outro lado, contribuiu para a construção de um senso comum de que em Cuba as oportunidades eram iguais a todos, sem distinção.

Todos esses aspectos contribuíram para que concepções, como as apresentadas anteriormente, de que são os próprios negros os que não aproveitaram as oportunidades, deslocando sua posição de vitima a algoz; ou de que tanto os negros como os brancos são racistas, negando o caráter sistêmico e estrutural do racismo que foi construído a partir do referencial hegemônico branco, se fortalecessem na sociedade cubana. O próprio reconhecimento e o tratamento adequado ao tema é fragilizado exatamente pela percepção de que o racismo não é problema, ou quando existe algum nível de reconhecimento do racismo, o mesmo é considerado débil e menor.

Essas argumentações que fundamentam o "mito cubano da igualdade racial" são fatores que dificultam o avanço na concretização de ações de Estado para o tema e embaralham os processos de mobilização social antirracista no país. Portanto, apesar das particularidades presentes em Cuba, muitos dos mecanismos existentes na Diáspora Africana nas Américas estão também marcados na materialização das relações raciais na Ilha.

Falar sobre o mito da igualdade, sobre a ideologia da mestiçagem e do branqueamento remete ao próprio processo constitutivo da nação cubana. A ideia de unidade nacional, de um povo unificado, é muito presente no imaginário social. Esse constructo, reforçado na Revolução Socialista, têm raízes na Guerra de Independência, no exército dos Mambises, e no ideário de construção da então nascente Nação cubana. Após as lutas pela independência da Espanha, e depois de quatro anos de intervenção estadunidense, a República é oficialmente conformada em 1902. 
As lutas pela independência tiveram o envolvimento ativo de muitos negros, inclusive no alto escalão, como é o caso de Antônio Maceo e Quintín Bandeira, que foram generais do exército. Havia um amplo e forte sentimento de construção de uma nação baseada na igualdade e inclusão: "uma nação para todos" como afirmou Jose Martí. Essa perspectiva norteou, e norteia, muito do discurso revolucionário sobre a nação, conforme destaca Zuleica:

La Revolución tuvo un discurso del principio, un discurso unitario que no reconocía las diferencias pero que tampoco las aceptaba y entonces no las aceptaba como algo natural no te pasaba nada porque te reivindicaste como eres, pero tampoco nadie te aplaudía ni te decía que eso estaba bien. Es lo que pasaba entonces ese discurso unitario, esa compulsión a la unidad, que no es nueva. ¿Porque ahora dicen en el 1959, y qué escribía Félix Varela en el periódico El Habanero, desde allá, y qué decía Martí? Para los cubanos desde el siglo XIX la unidad es una obsesión, es como ese sueño, que tu nunca lo logras y la Revolución lo que vino fue a legitimar eso y a darle a eso solidez entonces en aras de esa unidad. Todos somos iguales y entre nosotros no sé qué cosa, y ese discurso predominó durante 30 años prácticamente. Es ya en la segunda mitad de los 1980 que todo empieza a coincidir. Coincide en que la propia sociedad cubana se va diversificando, coincide que todas esas influencias culturales te demuestran que hay algo más, coincide que en el resto del mundo la gente está reivindicando sus particularidades, y entonces todo eso desemboca en ese sentimiento de identidad nacional. (Entrevista com Zuleica Romay, ativista e escritora, realizada em I8/08/20I4).

As ideologias do nacionalismo cubano, formuladas e reformuladas nos vários processos históricos vivenciados em Cuba, também possuem incidências sobre a participação e mobilização da parcela negra. No processo independentista, com grande protagonismo desse segmento, a ideia de Nação os incorporava como parte intrínseca. Todavia, com o nascimento da República, esse processo não se efetiva e com base no discurso da universalidade e da democracia racial, há o rechaço a qualquer iniciativa política baseada no princípio racial, apesar do forte racismo existente contra os afrocubanos.

Nos espaços políticos, a partir desse constructo que só mantinha o status quo existente, em que os negros tinham uma participação meramente simbólica, houve uma mobilização em sentido contrário. Milhares de pessoas, majoritariamente negras, se organizaram no Partido Independientes de Color. A possibilidade concreta de alteração dos paradigmas vigentes culminou em um dos maiores massacres da história recente da América Latina, em 19I2. Como narrativa discursiva, estava novamente presente o mito do universalismo e da "democracia racial". Um dos fatos que buscou justificar o massacre foi o fato de que o Partido Independientes de Color ameaçava a construção da Nação Cubana e da unidade, ao criar uma guerra das raças ${ }^{94}$.

Depois, entre os anos 1930, 1940 até 1950, as movimentações negras contra o racismo utilizaram outras estratégias para não conflitarem diretamente com os ideários da suposta "democracia racial cubana". Naquele contexto, tais ideários foram usados como uma ferramenta

${ }^{94} \mathrm{Na}$ seção Independientes de Color detalho o massacre do Partido Independientes de Color e os impactos desse processo nas mobilizações afrodescendentes em Cuba. 
de controle que ampliou as limitações organizativas dos negros, ao tornar ilegais ou mesmo "racistas ao contrário" agrupações com fins políticos de defensa dos direitos de um segmento racial discriminado ou luta contra a discriminação racial. Por isso, nesse período, os sindicatos, organizações de trabalhadores e partidos foram muito acessados por ativistas como meio de mobilizar-se para a pauta racial.

A Revolução de 1959 traça um novo delineamento da ideia de Nação e da própria construção da igualdade, onde "cubanos somos todos", e qualquer reforço à diferença poderia danificar esse projeto. Esteban Morales, ao frisar o motivo pelo qual o debate racial não tinha espaço para ser aprofundado nos primeiros anos da Revolução, constrói sua argumentação em torno da noção de "unidade":

Teníamos que enfrentar la supervivencia a la propia revolución. Esa supervivencia que la teníamos que enfrentar todos, las bombas y los mercenarios iban a venir lo mismo para negros que para blancos. Y entonces sencillamente eso fue una conciencia que se creó de unidad. Esa conciencia de unidad duro muchos años y de muchos años que avanzamos. (Entrevista com Esteban Morales, realizada em I4/05/20I4).

O processo da Revolução, como destacado por Esteban, reforça a ideia de unidade, de um só povo. Essa ideologia da igualdade e da unidade também é alimentada pela forma como a Revolução abraça o socialismo, e o próprio marxismo. Depois do triunfo revolucionário, Cuba rompe com os históricos vínculos com os EUA e assume, em abril de I960, sua adesão ao socialismo. Como coloca Zurbano, a partir desse momento:

[...] sus pensadores (de la Revolución) más destacados (políticos, ideólogos, académicos y otros) abrazaron al marxismo como su principal fuente teórica, en una controversial aplicación de lo que algún estudioso ha llamado marxismo cubano; para el cual el papel de la clase social engloba y supera al de raza, cuestión por la cual las problemáticas raciales cubanas, aunque agudamente identificadas por el propio Fidel Castro en dos intervenciones públicas durante el año 1959, no serán asumidas posteriormente como tareas prioritarias para el nuevo gobierno. Huelga decir, entonces, que las grandes medidas universalistas de la Revolución resultaron suficientes para la mayoría de la población negra y mestiza, antes marginada por la pobreza, el analfabetismo, la insalubridad y el racismo secular que, con tales medidas, se reducen a su mínima expresión e insertan a dicha población en la transformación radical gestada después de 1959. El rechazo a cualquier tipo de discriminación se incorpora como parte del ejercicio revolucionario cotidiano. (ZURBANO, 2012: I5-I6)

Como ressaltado por Zurbano, o ideal de classe social passa a se sobrepor em relação às identidades raciais, étnicas, além de outras que pudessem ser compreendidas como fragmentadoras da unidade nacional, dessa unidade dos trabalhadores e camponeses. As identidades raciais e étnicas foram secundarizadas em prol da identidade unificadora do proletariado. Alguns casos demonstram isso, como, por exemplo, o fato de muitas das sociedades negras, existentes antes da Revolução, terem sido fechadas e substituídas por clubes "obreros". 
Portanto, os laços de solidariedade estimulados eram exatamente os vinculados ao trabalho, à classe social, à identidade proletária, e não mais os vínculos de identidade racial ou étnica.

Ainda sobre o peso do que Zurbano denomina "marxismo ortodoxo no estilo soviético", houve uma forte influência sobre instituições culturais, militares, econômicas e educacionais, desde o final dos anos 1960 até meados dos 1990. No campo educacional, Zurbano destaca que o currículo focava um "marxismo caricaturado". Os impactos sobre as identidades étnicorraciais e sobre o próprio debate sobre o racismo foram severos:

Para el marxismo dogmático que se impuso en Cuba a finales de la década del sesenta y hasta la del noventa del pasado siglo, la categoría raza fue desestimada y estigmatizada la demanda antirracista; ambas fueron acusadas de dividir la clase obrera y minar la unidad nacional frente al imperialismo. Clase y lucha de clases fueron conceptos clave de ese marxismo dogmático que vivió a espaldas de los conflictos étnicos en la antigua URSS y en Cuba, consecuentemente, también evadió las problemáticas raciales que tenían lugar más allá del centro de trabajo (ZURBANO, 2012:2I).

A construção da cubanía, da noção de pertença à nação cubana, na atualidade mescla elementos vinculados ao ideal de nação, baseada nos princípios martianos do processo independentista, com os novos campos de significações que foram introduzidos com a Revolução, especialmente a partir dos valores marxistas de construir uma nação proletária.

Todavia, após a queda do Bloco Socialista, e a ruptura de muitas das bases da própria Revolução, vários dos ideais que foram incorporados a essa cubania com a Revolução, como a igualdade, a solidariedade, o rompimento da relação entre patrão e empregado e da lógica de exploração pelo capital, vêm erudindo. Há um processo de quebra de muitos desses valores, o que imprime outros tons à cubanidade. No entanto, a exaltação da unidade nacional e da cubanidade são argumentos utilizados para invalidar denúncias de racismo e práticas discriminatórias. Portanto, acaba sendo, muitas vezes, um recurso para debilitar demandas sociais.

Muitos dos valores criados ou fortalecidos com a Revolução, como os ideais de solidariedade e de igualdade citados anteriormente, foram conformados em longos processos. Contudo, de acordo com Yulexis Almeida ${ }^{95}$, alguns eventos epitomizantes marcam essas dinâmicas:

La propia campaña de alfabetización que de manera masiva hace que se incorporen muchos jóvenes como docentes, esto es importante porque permite que muchos jóvenes estén incorporados a una tarea tan importante como esta e involucra a la juventud en un proceso donde hay un sentimiento, una conciencia de unidad a favor de la sociedad donde hay una serie de valores ahí y que uno está de alguna manera promoviendo que son importantes (Entrevista com Yulexis Almeida, em I6/06/20I4)

\footnotetext{
95 Yulexis é uma das ativistas antirracistas entrevistadas na pesquisa. É integrante da coordenação do Coletivo Afrocubanas. Professora de Sociologia da Universidade de Havana, ela me convidou para participar de um dos cursos que elaborou sobre Quilombos e Palenques nas Américas. Tivemos, ao longo da pesquisa, diversos encontros, especialmente nas atividades organizadas por Afrocubanas. A entrevista mais aprofundada para a tese foi realizada em sua casa, situada no bairro Nuevo Vedado, em Havana, em junho de 2014.
} 
A campanha de alfabetização e outras ações emblemáticas da Revolução, como a reforma agrária, as grandes mudanças econômicas e sociais e o fim dos espaços segregados públicos e privados, reúnem o conjunto de eventos epitomizantes que marcam a construção da unidade nacional. Essa totalidade, contudo, imprime e visibiliza valores, formas e cores, e invisibiliza outros que no projeto idealizado de nação e de povo cubano não preenche adequadamente as expectativas. Numa alusão simplista, seria como um baú de onde são escolhidos, de forma aleatória, alguns símbolos que conformarão o enredo dessa nação totalizante.

Bhabha (1998), ao abordar, a partir de referências literárias, a narrativa da construção do conceito de Nação, a situa como uma tensão entre o pedagógico e o performático. A dimensão pedagógica concebe o povo como objeto dos discursos nacionais. Por sua vez, a dimensão performática reforça a origem comum e os laços essenciais que delineiam a unidade.

Os fragmentos e retalhos culturais usados pelo nacionalismo são freqüentemente invenções históricas arbitrárias. Qualquer velho fragmento teria servido da mesma forma. Mas não se pode concluir que o princípio do nacionalismo... seja ele próprio de modo algum contingente e acidental. (Gillnet, E. Nations and a Nationalism. Oxford, Basil Blackwell, 1983, apud BHABHA, I998).

Além da dinâmica de trazer à luz alguns elementos e invisibilizar outros na construção dessa narrativa da Nação para Todos, cabe destacar o peso que o mito da igualdade imprimiu no país e o quanto, em alguma medida, o mesmo não se adequou às iniqüidades prévias entre os diferentes segmentos societários, dos quais os negros e negras estavam em situação de grande vulnerabilidade. Yulexis destaca sua percepção da construção da unidade e das complexidades existentes no processo:

Esta etapa se conoce como la etapa de la desestratificacion social. Sin embargo, en este proceso asumíamos que como trabajar en función de la igualdad, además es que también es una etapa que hay un vuelco importante hacia la construcción de la unidad, a fomentar a consolidar la unidad nacional frente al eterno enemigo, los Estados Unidos y esto hace que todo el tiempo estemos en función de acceso igualitario a todo, medidas igualitarias en todos los sentidos, pero los desiguales no pueden tratarse como iguales y ahí es donde ha estado nuestra principal limitación y es el principal desafío que tenemos es la actualidad. (Entrevista com Yulexis Almeida, em I6/06/2014)

O tratamento igualitário aos que estavam desigualmente situados na sociedade pré-revolucionária, como argumenta Yulexis, é um dos desafios ainda presentes na atualidade cubana, e que se torna cada dia mais complexo com o avanço das desigualdades ocasionadas pelas remessas e pelo acesso desigual de negras(os) e brancas(os) à economia dolarizada. Portanto, nessa perspectiva, a construção da igualdade, que se não se baliza pelo princípio da equidade, pode acabar ocasionando a continuidade de iniqüidades prévias, que são retroalimentadas na atualidade.

A formação da nação para todos, igualitária, imprimiu outro elemento muito sintomático que foi o tabu para tratar assuntos relacionados às diferenças e desigualdades. Por décadas, após os primeiros 
anos da Revolução, reinou um silencio sepulcral sobre o tema, e qualquer alusão, por exemplo, à discriminação racial era compreendido como uma tentativa de ameaçar também o projeto unitário de nação.

Hoje em dia, há um deslocamento da narrativa sobre a unidade, em relação ao defendido por décadas na Revolução. A unidade cubana é vista, por ativistas e estudiosos do tema, como uma conquista da Revolução que corre o risco de ser quebrada, fraturada, caso não se observe atentamente e não se comece a dar respostas às desigualdades raciais existentes. Niurka Nuñez, a seguir, destaca o risco dessa iniqüidade racial afetar a unidade do país, bem como o perigo de se incorporar algumas identidades políticas como "afrodescendente":

Entonces creo que en Cuba hoy aunque mucha gente lo mira en el contexto comparativo con otras sociedades multirraciales y consideran que Cuba que el problema no es grave, yo pienso que es grave, si es un problema que si no se atiende de manera adecuada puede dar al traste con la unidad nacional, porque además lastra la dignidad humana a cualquier nivel y puedo seguir haciendo un listado de los porques. Yo creo que el problema sí merece atención particular que además no ha recibido hasta el día de hoy, porque ha habido intereses sobre el tema pero no ha habido políticas destinadas específicamente al tratamiento de esta problemática como las ha habido por ejemplo con la mujer, que se ha tenido una atención particular y que se ven los resultados a pesar de que seguimos siendo una sociedad machista. Y todo lo que tú quieras hay resultados y hay política específicamente diseñada en función de lograr avanzar en el tema de la igualdad de la mujer. Esto es lo mismo! Y no puede ser un problema de los negros, tiene que ser un problema de la sociedad en su conjunto porque en eso está en juego la unidad de Cuba (Entrevista com Niurka Nuñez, realizada em 21/05/20I4).

Feraudy também destaca a importância da unidade para o avanço na luta antirracista:" queremos que hayan más organizaciones, grupos de negros y blancos en favor de esta unidad, la lucha es dura dura y continua" (Entrevista com Heriberto Feraudy Espino, realizada em I7/06/20I4).

A abordagem feita pelos ativistas e pesquisadores reforça o ideário da nação, de unidade, de um só povo, e no caso explicitado com a fala de Niurka, busca validar a própria abordagem das desigualdades raciais na ameaça existente ao projeto de unidade cubana. Mas, a forma como é pensada essa unidade é, outras vezes, criticada por não incorporar diferenças e tratamentos adequados aos desiguais, como refletido por Yulexis. Essa construção da ideia de Nação passa por dinâmicas narrativas ambivalentes, que ora são críticas ao racismo e ora o reforçam, seja por meio de seu silenciamento ou do discurso da suposta igualdade racial. A concepção de unidade, por outro lado, também traz esse componente ambivalente. Por vezes, abordar as diferenças e denunciar as desigualdades causa divisão da unidade, e, por outro lado, trabalhar esses aspectos raciais seria importante para manter a unidade alcançada.

Dentro dessa ideia de unidade que conformaria o povo cubano, há uma diversidade de pertencimentos étnicorraciais distintos. Essas diferenças estão expressas, por exemplo, entre os que se identificam como descendentes de árabes, chineses, africanos e europeus, sobretudo 
espanhóis, e inclusive entre os que se identificam como indígenas. No campo das iniqüidades, cabe destacar que a própria ideologia do branqueamento e o mito da igualdade racial são elementos importantes na produção de desigualdade de acesso a bens, serviços, a espaços de poder, entre os diferentes segmentos raciais na sociedade. Não há visibilidade sobre esses matizes na narrativa da unidade historicamente construída. Como alega Helg (2004), a Constituição cubana de 1976 e sua pequena reforma feita nos anos 1990 afirma a unidade, porém nega as diferenças.

A convivência da desigualdade racial com o projeto unitário, como destacado por Yulexis, está presente até a contemporaneidade, apesar do grande esforço de inclusão e de redução das desigualdades realizado desde 1959. Todavia, cabe frisar o empenho feito nos últimos anos, sobretudo a partir dos anos 1990, de intelectuais, ativistas, artistas, agentes sociais, coletivos de arte, comunidades de tradições de matriz africana, de construir uma narrativa contrahegemônica sobre a Nação e sobre a unidade cubana, incorporando aspectos até então invisibilizados, como o debate racial. Essa mobilização foi diversa, com a participação de artistas, músicos e representantes das tradições afroreligiosas, como pontua De La Fuente (2012: 95):

La formación de un movimiento social y cultural afrocubano está ligada indisolublemente a los esfuerzos realizados por un grupo de activistas e intelectuales que, en los años 90, comenzaron a cuestionar el silencio oficial que hasta ese momento había proscrito cualquier discusión sobre la discriminación racial como un intento de dividir la sociedad socialista cubana. En el inicio, esos activistas e intelectuales denunciaron la existencia de conductas e imaginarios racistas de forma más o menos aislada, desde sus propios campos de acción y desde sus disciplinas y espacios respectivos. Pero hacia fines de los 90, y con mayor claridad en la década siguiente, esos actores sociales y culturales comenzaron a confluir en redes y espacios compartidos, donde era posible intercambiar ideas, contactos, experiencias y proyectos.

De que forma a construção da ideia de igualdade, de um só povo, dialoga com a ideologia da mestiçagem em Cuba? O mito de que seria possível branquear o país por meio da mestiçagem, que esteve fortemente presente no final do século XIX e início do século XX, também está presente até os dias atuais com ênfase no imaginário social e nas relações raciais estabelecidas, como vimos anteriormente. A narrativa de muitos ativistas aborda essa problemática como um dos aspectos relevantes para análise do contexto atual. Zuleica Romay destaca, a seguir, o quão presente está no cotidiano das relações a ideia do branqueamento e da mestiçagem, constituídos a partir de uma lógica hierárquica racial:

Ed William habla mucho de esto en este libro de Casa de las Américas que compilo Sacha Saulibe El negro en el Caribe, Ed William en varios pasajes habla de esto, en el Caribe cualquier negro que asciende reafirma su estatus social uniéndose a una persona más clara incluso en el Caribe pasa que generalmente el más claro tiene menos nivel o tiene menos nivel cultural o tiene menos nivel económico porque se hace como una negociación, tu das y yo doy y el más claro lo que aporta es eso que es el más claro y el más oscuro aporta todo lo demás, casi el sesenta por ciento o quizás un poco más quizás las dos terceras partes de las parejas que yo conozco son así, hombres y mujeres oscuros que tienen un nivel cultural, económico, científico casados con personas más claras que tienen un nivel inferior, dos de cada tres, empieza a poner en una lista las parejas que tú tienes deamigos y te vas a dar cuenta (Entrevista com Zuleica Romay, em I8/08/20I4) 
Apesar da visão crítica a esses fenômenos, sobretudo por ativistas e intelectuais do tema, a lógica de branqueamento e mestiçagem surge nas relações raciais cubanas com grande ênfase. A ideologia da mestiçagem como ideal de integração racial, como retrato homogeneizante da nação também integra esse mosaico de percepções sobre o tema.

Essa representação homogeneizante da nação cubana oculta ou minimiza as diferenças e as desigualdades existentes e fragiliza as mobilizações coletivas baseadas em identidade. Busca gerar uma pasteurização étnicorracial bastante evidente. Vemos, abaixo, um exemplo da forma como a ideologia da mestiçagem se expressa na sociedade cubana, para além dos espaços domésticos e familiares em Cuba:

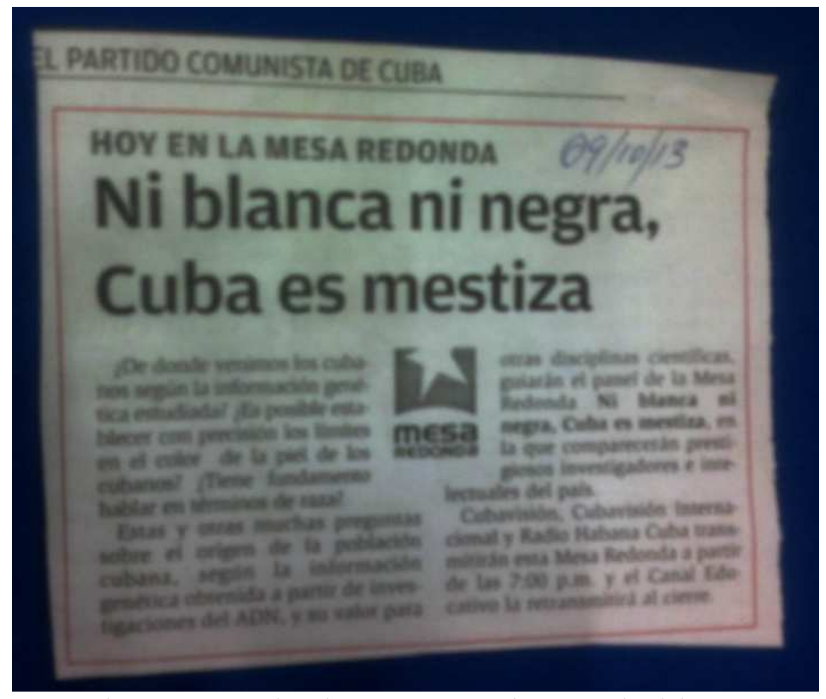

Figura 7: Matéria sobre Mesa Redonda, programa televisivo de debate, no jornal Granma, um dos principais de Cuba, veículo do Partido Comunista de Cuba, em 09/10/2013.
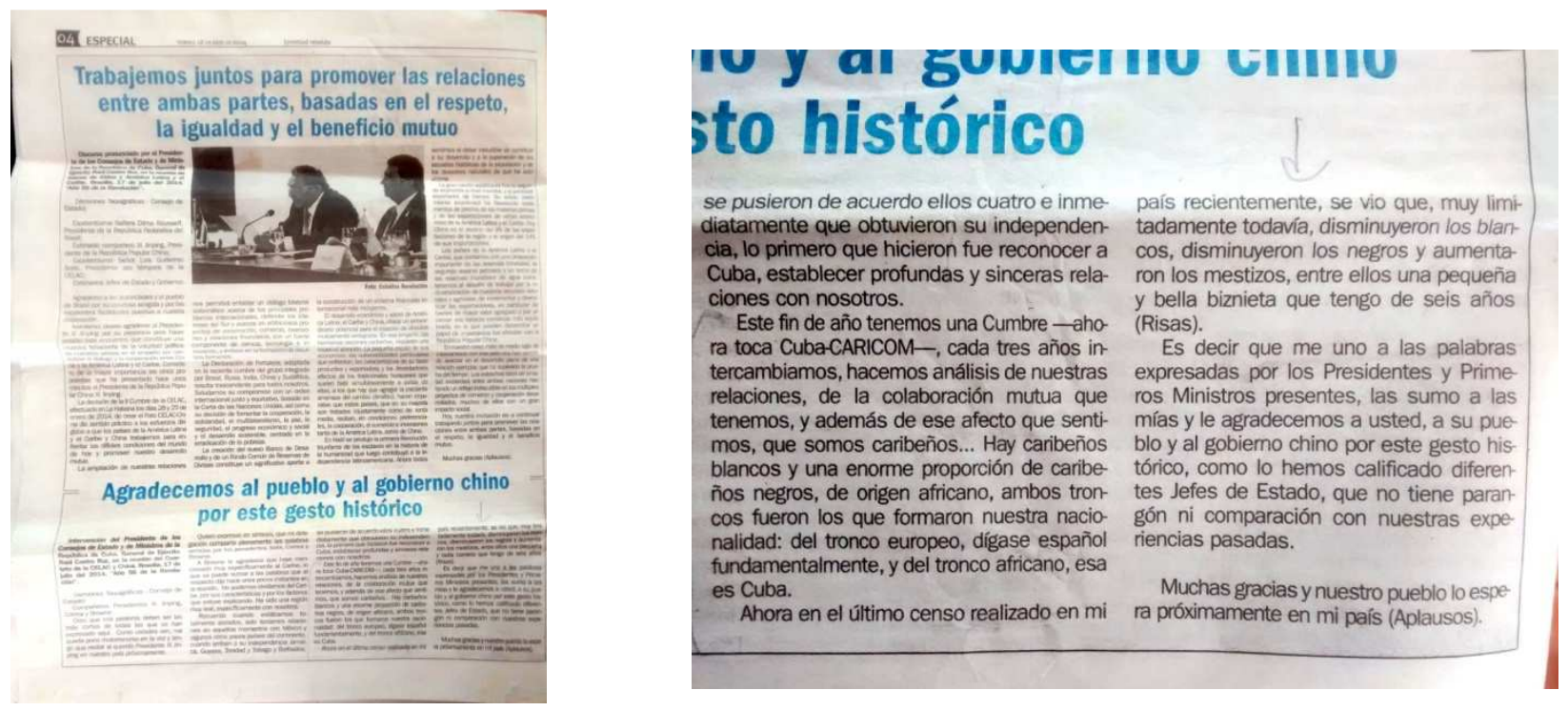

Figura 8: Matéria do Jornal Juventud Rebelde, Cuba, de I8 de julho de 2014. 
No primeiro exemplo, há uma explícita menção à mestiçagem como o lócus agregador e homogeneizador da sociedade cubana, a partir da negação da identidade negra e branca. $\mathrm{Na}$ segunda matéria, há uma menção à abordagem pelo Presidente Raul Castro sobre a composição de cor da população cubana, a partir das pesquisas censitárias, onde se ressalta a categoria "mestiço", em crescimento percentual em comparação às demais categorias, "negro" e "branco".

A construção dessas categorias de cor, que moldam identidades, sempre relacionais, traz implícitas concepções distintas acerca de cada uma delas. A categoria "branco" remete ao imaginário do colonizador, à herança espanhola. Nesse caso, esse grupo é imageticamente conformado como descendente de espanhol, apesar das outras ascendências envolvidas. Acredita-se, e essa é uma das denúncias de ativistas e militantes, que a proporção de "brancos" seja sobretaxada, por complexidades na forma como as pesquisas censitárias são feitas.

A categoria "negro" seria vinculada aos descendentes de africanos. Traz implícita a possibilidade de ser sujeito de ação discriminatória. Também não está envolta nos privilégios da branquitude, conforme discutido anteriormente. A categoria "mestiço", por sua vez, seria permeada pela limiaridade. Seriam mestiços aqueles não incorporados nem na categoria "brancos" nem "negros". E a percepção dessa categoria extrapola a identificação dos indivíduos e passa a referirse a uma caracterização mais geral de um povo e de uma cultura. Como a matéria do Granma, de 09/10/2013, destaca, "Cuba não é nem negra, nem branca. Cuba é mestiça".

Todavia, apesar dessa exaltação da mestiçagem como o produto da cubanidade, houve historicamente a construção de uma nação branca, onde inclusive a não menção diretamente à cor, reforça essa imagem hegemônica branca, conforme destaca Esteban:

\footnotetext{
Cuando definía al cubano lo definía como un hombre blanco. En general Cuba históricamente ha estado definida así en muchos lugares y en lugares que yo he ido la gente me ha preguntado que si en Cuba había negros. Realmente hay que decir que nosotros en general, la sociedad cubana fue históricamente vendida como una sociedad blanca. La sociedad cubana no es blanca, es más, la sociedad cubana es extraordinariamente mestizada, extraordinariamente heterogenia desde el punto de vista de la filiación racial, del color, de los rasgos etc. (Entrevista com Esteban Morales, em I4/05/20I4)
}

Nesse contexto, se diluem as diferenças e, por sua vez, as desigualdades, e pouca solidez resta para refletir sobre as iniqüidades entre a representação branca ou negra nos meios de comunicação, nos espaços de poder, na educação, nas ações da segurança pública, dentre outros. É um processo, portanto, de estimular a despolitização do debate. Seja pela não aceitação do conceito de negro, seja pela não aceitação do conceito de afrodescendente, seja pelo não reconhecimento da existência do racismo. Quando somos todos cubanos, minimiza-se o espaço para as 
subjetividades, para as identidades raciais, e também para a reflexão sobre desigualdades e o racismo.

Em Cuba, o mito da mestiçagem tem grande presença até os dias atuais. Os reflexos do avanço do debate e da atuação dos coletivos antirracistas, intelectuais, de artistas, dentre outros vem corroendo essa percepção internamente. Mas, ainda está presente no cotidiano das relações. Inclusive entre ativistas e intelectuais do tema, se pode perceber a presença dessa ideologia. Há um uso constante dos termos mestiço, mulato, para classificar fenotipicamente as pessoas, e com relação ao primeiro termo, mestiço, para abordar também a identidade cubana, a cubanidade. Em muitos estudos, há uma alusão direta ao conceito de transculturação como o processo que culminou na mestiçagem racial e cultural cubana.

Há, obviamente, uma diferenciação entre o que se concebe como cor da pele, para fins de coleta de dados estatísticos, e a construção da noção de raça com uma conotação política que é feita pelos movimentos negros e antirracistas, ativistas, intelectuais. Em Cuba, as classificações de cor existentes no Censo são: Branco, Negro e Mestiço. Asiático esteve presente em Censos anteriores, mas foi excluído a partir de 2002. Porém, o ideário da mestiçagem extrapola as categorias de cor presentes nas pesquisas censitárias. Passa a permear uma noção de hibridismo mais ampla, que caracteriza a própria sociedade cubana e sua cultura.

Alguns acadêmicos, como Guanche, em sua exposição no Seminário Origenes, realizado em Matanzas, vinculam a mestiçagem cubana ao aspecto genético, extrapolando as abordagens de cunho social, fenotípica ou cultural:

\footnotetext{
[...]Ante tantas secuelas de términos y condiciones de ideas por empezar a interpretar la realidad de la época colonial hasta nuestros días podemos decir a estas alturas con el debido apoyo de los estudios sobre el ADN que sin duda todos somos mestizos del color y afrodescendiente, todo depende del clima con que se valore y los alcances del texto donde centramos el discurso y de la complejidad, compromiso, responsabilidad de cada(no) (Exposição de Guanche - Encontro Origenes, Matanzas, I3/10/2014).
}

Essas abordagens dão um tom de que a partir de diferentes matrizes, a mestiçagem é concebida idealisticamente como o espaço da agregação de distintas ordens, sociais, culturais, raciais e até genéticas. Compõe uma parte importante do enredo que alicerça os mitos de construção do povo cubano, da nação cubana, das características físicas, sociais e culturais que geram essa percepção do ser cubano.

O conceito de transculturação, em Ortiz, forte em Cuba, inclusive nas ciências sociais, parte da dimensão dos fluxos e refluxos entre diferentes povos e culturas em contato, ocasionado, por exemplo, pelo contato colonial. Para esse autor, a transculturação seria a interação constante, uma 
transmutação entre dois ou mais componentes culturais, cujo produto final é a criação de um todo cultural, como um terceiro produto (ORTIZ, I963). Para Ortiz, "a verdadeira história de Cuba é a de uma intricada história de transculturação" (ORTIZ, I963: 99). A interação de diferentes elementos culturais geraria outro produto, ums nova textura, com influência dos elementos anteriores, porém independente de suas origens.

Indo ao extremo dessa percepção, a categoria "mestiço" passaria a ser a identidade que englobaria inclusive, do ponto de vista idealizado, os elementos que a originaram, como expresso na matéria anteriormente vinculada do jornal Granma, onde há alusão explicitamente ao mestiço como a característica da sociedade cubana, não mais vinculada à dicotomia "branco" e "negro". Todos seriam "mestiços".

Nas sociedades onde as relações raciais são marcadas por espaços de exclusão definidos e explícitos, o sistema de dominação e exclusão se torna bastante evidente. A ideologia da mestiçagem, por outro lado, oculta essas relações raciais desequilibradas e hierarquizadas, por meio do embaralhamento dos signos e das percepções sobre o fenômeno. Contribui ativamente para o ocultamento das identidades e das diferenças, e gera espaços de exclusão de diversos segmentos societários, cujo estigma da invisibilidade se fortalece.

As diferentes percepções construídas sobre o mito da mestiçagem estiveram muito vinculadas à construção do ideal de nação. Apesar de haver um ambiente de convivência de diferentes percepções sobre a nação e sobre as diferentes categorias étnicorraciais, acredito que a ideologia reforçada no período pós-Revolução foi a ideologia da cor invisível. Essa concepção parte do ideal de igualdade, de unidade e de universalidade. Após a Revolução, a igualdade passou a ser um referencial fundamental dos discursos. Não que esse discurso tenha nascido com a Revolução, mas foi reforçado por ela. Por isso, o mito da igualdade racial é vinculado à ideologia da mestiçagem, mas não é totalmente explicado por ela.

Medidas como o fim da segregação racial em clubes e ambientes de trabalho, efetuadas logo nos primeiros anos da Revolução, se tornaram símbolos dessa percepção. Foram ações fundamentais, naquele momento histórico, para reforçar a ideia de que se estava construindo a igualdade entre todos. E, nesse processo, a narrativa que galgou espaço baseou-se na ideia de que cubano somos todos, só existe a cor cubana.

O que eu classifico no presente trabalho como o mito da igualdade racial cubano refere-se a essa construção socialmente dada de que a unidade cubana, a nação cubana é de todos e de que existe 
esse espaço identitário que agrega todos e todas: a cor cubana. Também com base nessa ideologia se constrói a percepção de que abordar as especificidades, as identidades particulares, as diferenças geraria fraturas e rupturas na unidade cubana.

O mito da igualdade e a ideologia da mestiçagem e do branqueamento não são fenômenos exclusivos de Cuba, tendo sido vivenciados em diversos outros países da América Latina. No século XX, a nação e a cultura brasileira, por exemplo, passam a ser concebidas como a síntese dos elementos culturais, étnicos e raciais, no ideal da mestiçagem. Nesse debate, Gilberto Freyre destaca-se, principalmente com sua obra "Casa Grande e Senzala”, de I933, com a construção da argumentação da 'democracia racial'. Esses elementos foram constituintes da percepção ideológica da nação brasileira hegemônica (PECHINCHA, 2006).

Em sintonia com o argumentado por Pechincha (2006), acredito que o discurso de nação brasileira é hegemônico. Essa hegemonia se consolida pelo alcance de seu discurso, pela abrangência e pela repetição de seus ideários. O que se coloca, e o movimento negro é central nesse processo, é que discursos e vozes dissonantes ecoam e apresentam-se como contraponto à ideologia integradora de nação brasileira.

No Brasil, a aplicação mais concreta do mito da mestiçagem foi o processo encampado por Getúlio Vargas, a partir de 1937. Costa (20II) destaca que essa brasileiridade, monocultural e mestiça, influenciada fortemente por Freyre, encontra sua relação política mais efetiva na Campanha de nacionalização levada a efeito por Vargas, com o objetivo declarado de integrar culturalmente os imigrantes e seus descendentes como um esforço de abrasileiramento dos recém-chegados, especialmente europeus, a partir dessa concepção de brasilidade.

Os princípios vigentes até meados dos anos 1970 da ideologia da mestiçagem no Brasil, como ressalta Costa (2010) são a intervenção estatal a partir da ideia essencialista de brasilidade, onde algumas expressões culturais são visibilizadas e outras silenciadas; a "Brasilidade", uma identidade mestiça não étnica, que englobaria e assimilaria as demais; a ideia de raça é desqualificada como instrumento político, mesmo que na prática oriente as hierarquizações estabelecidas pelos agentes sociais. Esses são, na visão do autor, os elementos que alicerçam o mito da democracia racial, componente indispensável da ideologia da mestiçagem.

De acordo com Costa (201I), no Brasil o período dos anos I930 até os anos 1970 é marcado pela ideologia da mestiçagem. É, somente, a partir do final dos anos 1970, que essa ideologia começa a perder, progressivamente, sua força integradora e passa a ser questionada. Essa mudança 
paradigmática é ocasionada e protagonizada, sobretudo, pelos movimentos negros, que a partir desse período, passam a contestar essa ideologia. É um processo de reversão lento, mas hoje já fortemente presente em diversos âmbitos da sociedade brasileira.

Tanto no caso brasileiro, como no caso cubano, o contradiscurso dessa perspectiva homogeneizante da nação, da cultura e da identidade nacional é protagonizado pelos ativistas e movimentos sociais. Esses passam a questionar esses espaços solidificados e a oxigenar os paradigmas nacionais com outros olhares, vivências e narrativas.

Nessa perspectiva, o horizonte de uma nação possível emerge como um espaço concebido a partir das heterogeneidades, que permita a visibilidade e garanta o direito às diferenças. Essa nação possível se constitui a partir de uma aliança entre os povos, culturas e diferenças, administrada por um Estado pluricultural, por meio da admissão, por parte do Estado, de que seu desenvolvimento futuro se concebe com base nas comunidades e que a sua constituição efetiva se processa melhor com o progresso das culturas (SEGATO, 2007: 2I).

A nação se configura como um ente homogeneizador, aglutinador. Todavia, apesar do esforço totalizador, não é possível sufocar as identidades que a compõem. A concepção de nação produz essa multiplicidade de discursos e identidades. A perspectiva totalizante que traz a ideia da mestiçagem ou da "cor cubana" e do "somos todos cubanos" está inserida em um contexto discursivo, no qual questionar essas posições socialmente estabelecidas é um esforço contrahegemônico considerável. Por isso, refletir sobre as estratégias discursivas é fundamental. É o que buscarei trabalhar nessa próxima seção.

\section{I.4. ¡No Hable de Eso!}

Inicio essa seção descrevendo uma situação do cotidiano de um dos coletivos antirracistas que eu acompanhei. Esse exemplo simples, das percepções coletivas sobre o tema, traz diversos elementos para dialogar sobre as tramas sociais que envolvem o discurso e como elas são controladas, vigiadas e podem, por outra dimensão, promover alterações dos códigos e signos estabelecidos.

No primeiro encontro que tive com a Red Barrial Afrodescendiente, em abril de 2014, Maritza Lopez, Hildelisa Leal e Damayanti Matos distribuíram pequenas tiras de papel para os presentes. Algumas delas diziam: "No hable de eso"; "Ese tema es candela"; "La Revolución acabó con 
eso", "¿Ay, quien te dijo que hay racismo en Cuba?", "No cojas lucha con eso"; "Ese tema nos divide", "No hables de eso ahora", "por favor, que con todo el problema que hay, ja qué viene de hablar de eso ahora?", "Eso no es prioridad en este minuto".

Todas essas frases são muito presentes no cotidiano, nas vivências, nos corpos e nos hábitos cubanos. Nas atividades nos bairros sobre a questão racial essas frases surgem com freqüência e indicam as interdições e os tabus presentes no cotidiano. $\mathrm{Na}$ avaliação de Maritza Lopez:

La mayor parte de nuestra población, incluso la que está cercana a la Red barrial, no tiene percepción de la magnitud del problema. Por eso es que en algunas de las presentaciones que nosotros llevamos, primero llevamos como unos cintillos de qué es lo que más dice la gente. Por ejemplo una de las cosas que mucha gente dice es: "La Revolución acabo con eso" o "¿Ay, quien te dijo que hay racismo en Cuba?". iEs que duele! Hay quien dice: "Ese tema es candela" y mira mis ojos. Porque hay quien habla más con gestos que con lo que expresa. Son aparentemente dicharachos, pero dicharachos que hacen pensar. Esas son las cosas que más la gente dice. (Maritza Lopez, entrevista realizada em I5/08/20I5).

Os discursos que permeiam a construção das ideias sociais sobre a questão racial envolvem cuidado e controle. São temas que podem causar rusgas nas relações interpessoais, problemas políticos de ordem institucional, desprezo ou rechaço. As frases colhidas pela Rede exemplificam parte das barreiras que necessitam ser transpostas para se abordar o tema. Para além de explicitar posições localizadas e individualizadas, essas reações ao tema indicam elementos pactuados em um nível societário mais amplo. A dimensão do interdito permeia, inclusive, os valores vinculados à boa educação, e aos bons costumes. Não é uma ação bem vista tratar das relações raciais ou mesmo abordá-las numa perspectiva identitária:

Yo pienso que las relaciones interraciales en Cuba tienen como particularidad que ha habido toda una, toda una organización social, ha habido un discurso social, más que una organización un discurso social que ha tratado de convencer a la gente de que distinguirse racialmente es de mal gusto, eso viene desde la colonia. Se ha entendido que un gesto de buena educación es no eludir al color de las personas, eso es verdad relativamente porque el paternalismo también es muy ofensivo; y cómo es Irene ${ }^{96}$, Irene que ya es una persona mayor, no una negrita ella clara, oye ella no tiene edad para que le digan negrita, ese diminutivo paternalista es como para no. Entonces en Cuba ese racismo de buenas maneras, ese racismo de buenas costumbres se legitimó durante mucho tiempo y contribuyo a que hubiera socialmente una especie de consenso para encubrir el problema racial. (Entrevista com Zuleica Romay, realizada em 0I/08/20I5).

É sintomático perceber como se reforçam, pelas estratégias discursivas, preceitos construídos socialmente, tais como os interditos vinculados à abordagem da dimensão racial. Os discursos, contudo, são práticas descontínuas, que se cruzam, se ignoram ou se excluem (FOUCAULT, 2006: 52-53). Nessa multiplicidade de abordagens sobre o tema racial, estão dispostas as diferenças entre uma possibilidade de verdade e aquela verdade construída e aceita por uma dada

\footnotetext{
${ }_{96}^{9}$ Faz referência à Irene Esther Ruiz, uma das ativistas também entrevistadas na tese.
} 
sociedade. Seria a verdade interessada a determinado grupo social, aquela que não contradiz o status quo, a verdade oficial (FOUCAULT, 2006: 35).

As tirinhas de papel, que reproduzem algumas das abordagens socialmente construídas sobre o tema, trazem diversos elementos que dialogam com as reflexões foucaultianas sobre o discurso. A "verdade" que interessa é aquela que silencia esse debate, que o invisibiliza, que o situa no lócus das coisas solucionadas, que não há por que tocar, abordar. Por isso, várias das tirinhas remetem ao interdito. Inclusive, nos contatos interpessoais, se busca dissimular essa dimensão, como sinaliza Zuleica ao falar sobre o inconveniente socialmente construído de se falar na cor das pessoas.

As dinâmicas sociais que contribuem para a manutenção dessas verdades, desses valores, se amparam em rituais específicos de propagação e validação dos discursos. São dinâmicas que também coagem os movimentos que desconstroem essa verdade. As formas de controle são múltiplas, e, novamente, as tirinhas trazem algumas delas. A seguir, a partir das reflexões de Foucault (2006), as classifico em três categorias de acordo com o tipo de controle e exclusão

- Contestação da veracidade do discurso: "La Revolución acabó con eso", "¿Ay, quien te dijo que hay racismo en Cuba?";

- Sinalização de que discursos que possam, de alguma forma, corroer o status quo são perigosos: "No hable de eso"; "Ese tema es candela"; "Ese tema nos divide", "No hables de eso ahora", "por favor, que con todo el problema que hay, ‘a qué viene de hablar de eso ahora?";

- Indicação de desprezo e não importância ao discurso: "Eso no es prioridad en este minuto", "No cojas lucha con eso".

As categorias foucaltianas de controle e exclusão são: (i) a interdição, operacionalizada pelo tabu e pelo direito privilegiado; (ii) a rejeição, a invalidação do discurso, num dualismo entre a loucura e a razão; e (iii) a busca pela verdade, que confronta divergentes visões e valida a verdade oficial. O controle do discurso seria, então, uma parte inerente das sociedades:

\footnotetext{
Suponho que em toda a sociedade a produção do discurso é ao mesmo tempo controlada, selecionada, organizada e redistribuída por certo número de procedimentos que têm por função conjurar seus poderes e perigos, dominar seu acontecimento aleatório, esquivar sua pesada e temível maternidade (FOUCAULT, 2006: 8-9).
}

Esse processo fluido e aleatório permeia também as estratégias de inversão dos signos, de seus significantes e significados, como explicitado no exemplo abaixo: 
Tengo una abuelita que tiene más de sesenta y tantos años que cuando empezó a venir a los primeros encuentros me decía: no pero yo no soy negra, eso que ustedes están hablando tiene que ver mucho con las personas negras, pero yo no, yo soy mestiza, y en la medida en que ha ido participando por ejemplo, ahora empieza reconocer, dentro de sus ancestros, la importancia que tuvo su abuelo chino, su abuela negra, su otra abuela blanca porque los matrimonios interraciales conforman su base ancestral pero ella fue educada para no reconocer ninguna de esas bases a no ser la clara, le dolía la parte negra y la parte china y ya ella hoy por ejemplo hasta cuenta cosas de sus abuelos que dice que en otro momento no se le hubiera ocurrido. (Maritza Lopez, entrevista realizada em I5/08/2015).

Nesse caso, há uma inversão de valores agregados aos significados de "negro" e "chinês", que passam a ser positivamente valorados e ocorre um deslocamento de sua posição de ocultamento inicial para a visibilidade, para compor o discurso público.

Esses discursos refletem as relações sociais e os valores que ratificam o status quo, ou as estratégias para questioná-lo. São permeados pelas relações de poder e dominação inerentes a esse meio social. Por outro lado, essas relações de poder e dominação não são uma reprodução social total, elas apresentam fissuras, ambigüidades e contradições inerentes a toda situação de poder desigual, que possibilitam questionamentos das relações de poder e dominação, a partir da agencialidade dos sujeitos (ORTNER, I995).

Ortner (1995) reflete sobre a tradição binária presente em muitos estudos sobre resistência versus dominação, em que o aspecto ambíguo dessas construções não são questionados. A dominação se constitui como uma forma de poder fixa e institucionalizada e a resistência é a oposição organizada ao poder institucionalizado. O rebuscamento desses estudos, de acordo com Ortner, vem com Foucault (1999), em "A história da sexualidade", que chama atenção para as formas de poder menos institucionalizadas, e com Scott (2004), que destaca as formas de resistência menos organizadas.

Esse debate sobre resistência e dominação, a partir de uma visão que desconstrói a rigidez desses conceitos, é significativo para essa pesquisa. Os coletivos antirracistas em Cuba se posicionam em contraponto ao discurso público ${ }^{97}$ sobre a questão racial. A dinâmica de resistência é derivada de um processo de conscientização dos agentes sociais sobre as relações raciais vivenciadas, sobre a necessidade de se embaralhar essas disposições e fomentar redes de solidariedade entre os coletivos.

São mobilizações que se opõem ao racismo, que produz desigualdades palpáveis na relação com instituições públicas, como a polícia, nos setores da economia emergente, como os espaços turísticos que são bastante embranquecidos. Muitas vezes, essa relação de contraposição acaba se

\footnotetext{
${ }^{97}$ Utilizo aqui o conceito de discurso público de Scott (2004)
} 
materializando no Estado, que seria o responsável por mediar ou executar a maioria das demandas dos coletivos antirracistas. Essas demandas permeiam, por exemplo, o estabelecimento de leis que regulamentem a criminalização de atos discriminatórios, a formação de professores sobre o tema, a incorporação de forma mais representativa dessa temática e de trabalhadores negros nos meios de comunicação. Zurbano faz uma análise sobre a política oficial relacionada ao racismo e às relações raciais em Cuba, nas décadas de regime socialista:

[...] el modo en que la política oficial del socialismo cubano se ha comportado frente al racismo insular, primero elaborando su propia ceguera ideológica ante la supervivencia y renovación del racismo, después provocando un largo silencio sobre el tema y, finalmente, no asumiendo, explícita o implícitamente, alguna política racial o estrategias, directas o indirectas, con qué enfrentar la presencia del racismo en la isla. (ZURBANO, 2015: 17)

Essa colocação toca em pontos que marcam o contraponto feito pelas organizações sociais frente ao Estado. Todavia, uma oposição direta e simplista entre subordinados e dominantes não pode ser feita nesse caso, pois há diversos fatores complexificam essa trama.

As pessoas que militam na pauta antirracista em Cuba têm vinculações de reciprocidade com a Revolução - um ente quase mitológico, tal como explicitado no depoimento abaixo:

Para mí la Revolución cubana cobro sentido el 22 de marzo de 1959 que fue la primera vez que Fidel Castro se refirió al tema de la discriminación racial y el racismo que lo hizo de una manera muy fuerte. Entonces fue que para mí la Revolución cubana cobra un sentido. [...]Ahí fue que yo tome conciencia de esto, de lo que significaría, lo que podía significar la Revolución para los de abajo en general y para los negros los descendientes de africanos como es mi caso, aunque también lo soy de español en particular. Y eso significó un compromiso que se tradujo después en una militancia. Yo no soy militante del Partido, nunca lo he sido, pero si tengo un compromiso militante con la Revolución cubana. (Entrevista com Tato Quiñones, realizada em 29/05/2014).

Por outro lado, há um forte processo de reconhecimento dos avanços proporcionados pela Revolução no que concerne às políticas sociais, educacionais, de saúde, dentre outros. Mas, há também a percepção de que esse vínculo de reciprocidade é falho em outros tantos pontos, sobretudo em relação às desigualdades raciais e ao racismo no caso das narrativas presentes nesse estudo. Parte dessas fissuras se reflete nos silêncios, ainda muito presentes sobre o assunto, cuja percepção vincula esses tabus existentes com as estratégias da própria Revolução, que não propiciaram essa abertura:

[... Entonces lo que educa, lo que forja, lo que fragua la conciencia es eso que en Cuba nunca existió (el racismo). O sea, lo racial siempre fue parte de otra cosa. Ahora a veces nosotros nos preguntamos, ipor que aquí en Cuba la gente no tiene conciencia racial? No, aquí la gente tiene conciencia del color, porque todos los días algo o alguien te recuerda cuál es tu color. Pero que hay mucha gente que no revierte esa experiencia en voluntad de enfrentarse. Bueno, zy cómo es posible, si la propia Revolución debió darle a la gente el empuje para eso? Es que la Revolución durante muchos años le dijo a la gente que eso no era importante, usted primero es cubano, entonces agarramos al pobre Martí, que siempre lo tenemos de como de un Hombre que es más que blanco, más que negro. Es muy difícil ahora tener una población con una conciencia racial fraguada, firme, con voluntad de lucha. Hoy el cambio de la situación requiere 
de forjar esa conciencia. Entonces en Cuba eso es un poco lo que ha pasado, las cosas que se han logrado se han logrado de forma tan fácil que la gente no está entrenada para este tipo de lucha, para este tipo de reivindicación que es civil, la gente no tiene entrenamiento y como además tampoco hay un ordenamiento legal que deje las cosas claras, se queda difícil. (Entrevista com Zuleica Romay, realizada em 0I/08/20I4).

Zurbano também reforça esse aspecto do vínculo com a Revolução, mas com quebras em alguns aspectos, como esse relacionado à dimensão racial. Nesse caso, contudo, há uma percepção de relação estabelecida para essa troca entre Estado e Sociedade Civil, mesmo que adornada com certo pessimismo:

Hay organizaciones como la que yo milito por ejemplo que son parte de la sociedad civil afirmativa de la Revolución, pero critica de la Revolución con respecto al tema racial que pretendemos hacerles propuestas al Gobierno cubano para que se ocupe de este tema, para que resuelva algunos elementos que queremos hacerle propuestas de trabajo, de acciones de posibles leyes, acciones legales que debían enriquecerse. El Gobierno no está convencido de eso y tampoco, como no discute nada de eso, tiene expertos de esa historia que le digan esto se puede hacer de esta manera o de esta otra. (Entrevista com Roberto Zurbano, realizada em I5/I0/20I4).

Os vínculos de reciprocidade e de não reciprocidade com a Revolução são importantes para compreender as dinâmicas existentes. Mas, são também fundamentais os processos de reciprocidade intra e entre organizações:

En el camino de la Rede Barrial Afrodescendiente todavía quedan cosas por hacer en el año (20I4), entre ellos un encuentro con Afrocubanas, que tenemos mucha cooperación, que queda pendiente. Nosotros siempre a final de año damos cuentas a ARAAC que hacia dónde vamos, que estamos haciendo, como nos movemos, escuchamos criterios de personas que como miembros de ARAAC tienen un compromiso muy fuerte con el tema, siempre escuchamos todo lo que nos dicen, tomamos nuestras propias decisiones, pero escuchamos con mucho respeto las experiencias que tienen. (Entrevista com Maritza Lopez, realizada em I5/08/20I4)

Cabe destacar também os desencontros estabelecidos nas redes de solidariedade e de reciprocidade das organizações e agentes sociais, o que ressalta o dinamismo dessas relações:

Cuando se crea el grupo de ARAAC, que yo soy una de las personas que invitan a la fundación, a la creación de esta actividad el grupo de Afrocubanas se siente un poco que tributarias de este supuesto gran proyecto y pensando en que este era el proyecto mayor y que los proyectos pequeños debíamos que tributar a este gran proyecto, cada quien desde su lugar, desde su posición, desde lo que hacía y como lo hacía; nosotros hicimos un proyecto de trabajo y lo presentamos a ARAAC. Dio la coincidencia que cuando se crea ARAAC, a mí me nombran coordinadora del eje de género. Yo estaba presentando mi proyecto como coordinadora del grupo de Afrocubanas y que lógicamente se adecuo a las características de diferentes ejes de ARAAC, de todo el eje de género. Propusimos un proyecto de trabajo de diferentes seminarios durante seis meses. Lo cumplimos al máximo, con la calidad requerida, porque buscamos todos los expertos de los temas que habíamos propuesto para que se diera. pero en mi caso personal tuve una decepción muy grande, y es que se buscaban los expertos de los diferentes temas para que dieran los seminarios, los talleres, pedidos de favor, no tengo dinero para pagarte, no tengo transporte para moverte, no tengo nada que darte, pero si te pido por favor, que me ayudes. Fue muy triste que después que uno hacía todos esos esfuerzos y movía a todos sus contactos, entonces de ARAAC iban una o dos personas a los talleres y muchas de las otras personas que iban eran haladas por nosotras, entonces yo decidí cumplir con el plan que había propuesto y cuando termine el plan pedí que me sustituyeran en la coordinación de género. Entonces comenzamos a reactivar el grupo de Afrocubanas. (Entrevista com Daysi Rubiera, realizada em 0I/08/20I4). 
Portanto, os vínculos são estabelecidos e desconstruídos num processo dinâmico, não linear, característico das relações sociais. Apesar da convergência em vários momentos e em outros tantos da não convergência, esses coletivos e agentes sociais comungam de uma perspectiva ampla comum: há racismo em Cuba e é fundamental falar sobre esse assunto numa escala mais ampla e formular políticas públicas para responder a essas questões. A forma, o método, as estratégias são debatidas e propostas de diferentes maneiras. Não há uma unidade organizativa, há sim uma diversidade narrativa que conforma essa rede de mobilizações antirracistas no contexto cubano.

Cabe também destacar que os lugares ocupados por esses agentes sociais e coletivos não conformam os mesmos espaços na hierarquia socialmente construída entre eles. Há assimetrias de poder nessas relações internas nos coletivos e entre as organizações e atores sociais. São assimetrias geradas muitas vezes por fatores externos a esse universo, como agentes do Estado ou interlocutores internacionais.

É o que ocorre, por exemplo, com a Comissão Aponte, vista pelos demais coletivos como interlocutora privilegiada do Estado e da sociedade política, por ter atuado na construção de propostas de políticas públicas para a pauta racial encaminhadas ao vice-presidente do país, entre o segundo semestre de 2014 e primeiro de 2015.

Nosotros (Comisión Aponte), en aquella situación planteamos a Días Cannel, la falta de sistematicidad que hay en el tratamiento con relación a la discriminación racial en Cuba, la falta de coherencia que hay en el tratamiento a la discriminación racial en Cuba. La necesidad de establecer una estrategia para atender esa problemática, independiente de todo lo que ha hecho la Revolución. Que de modo sistemático no existe y que si, los enemigos están se preparando para eso. Que a veces se dan pasos adelante y cinco atrás. [...] Entonces él (Días Canel, vice presidente de Cuba) nos dijo: Preparen un plan. Hagan una propuesta. [...]Estuvimos cinco meses trabajando en esa propuesta y entregamos a Días Canel. Entre las cosas que se planteaba era criar una estructura o un observatorio que sirviera de vehículo y instrumento para dar segmento a la problemática en el país. Existía la discriminación de género y se crearan la Federación de Mujeres Cubanas. Existía la discriminación por asuntos religiosos y se creó una oficinal el Comité Central del Partido, para el tema de la discriminación homosexual también se creó un organismo. Y que pasaba con la discriminación por el color de la piel, que es el más antiguo y uno de los más injustos. [...] Para nuestra sorpresa, Días Canel dijo: No, por el momento no. Por el momento, yo personalmente voy a atender el problema. Vamos a reunirnos todos los meses, vamos a analizar todos los meses un tema de carácter económico, social, jurídico, científico e operativo. Y comezamos a reunirnos una vez al mes con el vice presidente. (Heriberto Feraudy Espino, no debate televisivo Mesa Redonda, realizado em 20 de março de 2015$)$.

A Comissão e alguns de seus membros delimitaram quais seriam as formas de diálogo com outros agentes sociais e coletivos e em que nível esse diálogo se realizaria. Nesse caso, em específico, houve certo desconforto por parte de muitos outros coletivos e sujeitos atuantes na temática pelas dificuldades para se efetivar essa construção de modo ampliado e conjunto. Ouvi muitos desses reclamos em ocasiões públicas e debates. 
Em outro trecho do debate na Mesa Redonda, Feraudy destaca que o papel de mediação entre a sociedade civil e o Estado já está estabelecido, exatamente pela interlocução direta que essa Comissão estabelece com o vice-presidente de Cuba:

\begin{abstract}
Ahora vienen los temas de las demandas que tiene la población. En una otra reunión, le planteamos a Días Canel las diferentes luchas por el problema de discriminación racial, y como desde la UNEAC no tenemos estructura para atender esas demandas, pues la Comisión Aponte no tiene una oficina, no tiene un coreo, no tiene secretaria. No se puede dejar ni una demanda por atender. Y hasta ahora tenemos prueba de luchas que se han hecho y que se han sido atendidas debidamente. Yo creo que la necesidades de establecer un puente entre representantes de la sociedad civil y el Estado está. Que no se va limitar solamente a eses programas e reuniones. Hay un plan de reuniones con otras instituciones [...] Debo apuntar que en esas acciones, no es sólo la Comisión Aponte que está trabajando. Hay otros estamentos, otras asociaciones que están desarrollando sus acciones. Pero, nosotros queríamos un poco alejarnos un poco de lo que yo llamo la cultura del "lepe lepe", la retorica, el debate, la catarse. Habria que identificar acciones de como resolver el problema. ¡Ojo! Esa problemática tiene que atualizarse con los nuevos desafíos. ¿Vamonos a dejar esa batalla al enemigo, al subversión? ¿Quienen són los que están promoviendo la subversión actualmente, de que color són? (Heriberto Feraudy Espino, no debate televisivo Mesa Redonda, realizado em 20 de março de 2015).
\end{abstract}

É, portanto, uma interação entre a sociedade civil e o Estado, nesse caso, mediada pelas dinâmicas e programas já estabelecidos pela Comissão Aponte. As demais organizações antirracistas de Cuba, aqui estudadas, questionam esse processo e buscam estabelecer outras formas de diálogo com o Estado, como a interlocução com o Ministério da Cultura feita pela ARAAC ou as cartas e manifestações enviadas pela Cofradía de la Negritud à direção da Assembleia do Poder Popular. São interações que demonstram as dinâmicas relacionais entre parte dessas organizações e representantes estatais e da sociedade política.

Em outras situações, a maior interação de alguns agentes sociais com interlocutores internacionais também gerou sensações ambíguas que em momentos são traduzidas como quebras de reciprocidade entre os pares. Essas queixas têm grande concentração nas críticas realizadas em diferentes circunstâncias vinculadas ao fato de não se compartilhar de forma adequada esse espaço de representação em seminários, congressos e encontros realizados no exterior. Sobre essa dimensão, também surgem, por vezes, pílulas do contexto da Guerra Fria, quando esses viajantes recorrentes são questionados se não estariam sendo financiados em alguma medida pelo "inimigo".

$\mathrm{Na}$ trama das relações sociais, são muitos os delimitadores dessas relações, que ora afrouxam e ora apertam os laços. Os exemplos supracitados têm o papel de sinalizar a complexidade das dinâmicas que são estabelecidas interna e externamente nos coletivos antirracistas. Também cabe reforçar que essas dinâmicas demonstram a multiplicidade de estratégias existentes para a pauta racial e a capilaridade crescente de iniciativas sociais. 
Esses coletivos e atores apresentam como um dos eixos de ação um discurso contra hegemônico que visa reposicionar os espaços sociais existentes para se tratar sobre as relações raciais, sobre as categorias empregadas e os valores dos signos que são historicamente estabelecidos. Esse processo, com toda sua complexidade, remete à posição de resistência que muitas dessas agrupações ou indivíduos ocupam nesse espaço social. Essas dinâmicas de resistências não são intrínsecas aos grupos. São posições relacionais, temporais, e são estabelecidas em oposição a algo. No caso dos coletivos, a oposição refere-se a um sistema de opressão, a uma linguagem de significados e valorações sociais, à hierarquização das relações com base em aspectos vinculados à dimensão racial:

El antirracismo tiene un significado político fuerte. Mas en una sociedad como la nuestra, no sé si es socialista, capitalista democrática, lo que sea, el antirracismo en una sociedad donde los negros han sido preparados, los negros han formado parte de la Revolución, los negros han formado parte de la trasformación, tienen que formar parte de los resultados, tienen que formar parte del cambio, tienen que formar parte del futuro también, de esos proyectos de la nación, que hay muchos [...]. Yo pregunto siempre: ¿los negros como van ahí? Hay uno que me dijo: eso después se resuelve. Si es después no cuentes conmigo para eso, no. Si tú dices que lo más importante es la ciudadanía, ¿que cosa es la ciudadanía? Yo sé, negro ciudadano o ciudadano negro pleno, sabiendo que hay cosas que yo tengo, resueltas para seguir luchando como negro que nadie me impide en mi condición de negro seguir luchando, que nadie me diga que es un defecto, que nadie me diga que es un complejo. Déjame llegar con esa condición hasta donde llega, hasta donde llegue esta condición. No me va a servir para todo, hay momentos que me va servir mi condición humana, mi inteligencia y mis posibilidades. Pero tú tienes que partir de algo y de eso no nos dejaron partir. Por eso estamos tan jodidos por la mayoría de nosotros, por eso hay que articular la política de ellos que hay gente con mucha capacidad. Esa organización de abogados negros contra la discriminación racial yo creo que le toca un papel muy importante en esta jugada, muy importante. Yo no sé nada de leyes, pero ellos sí y ellos saben lo que tienen que poner en la Constitución para que no sigan jodiéndonos a nosotros. (Entrevista com Roberto Zurbano, realizada em I5/I0/2014).

A resistência também é um dos elementos fundamentais para a constituição de grupos contra hegemônicos que estão relacionalmente situados em espaços marginalizados:

A única alternativa para reconhecer que os subalternos têm uma cultura autentica a priori subalternizada é ver as respostas subalternas ad hoc e incoerentes, motivadas não pelos seus próprios sentidos de ordem, mas sim de algum conjunto de ideias que foi chamado a existir na situação da dominação dela mesma (ORTNER, I995: I80)98.

A consciência e a intencionalidade da ação dos ativistas e das mobilizações antirracistas é uma característica central desses processos. No caso do coletivo Afrocubanas, a consciência sobre a questão racial ganha uma nova dimensão a partir da abordagem da invisibilidade das mulheres negras nos estudos e nas narrativas existentes sobre o assunto.

Afrocubanas inicia aproximadamente en el 2010 donde un grupo de mujeres intelectuales deciden hacer algo más que el trabajo de manera aislada hacíamos, en realidad esto empieza, es una idea de Lalita y de Daisy, Lalita que trabaja desde la dramaturgia el teatro y Daisy que es historiadora con una larga trayectoria ambas del abordaje del tema, pues se les ocurre crear este grupo de mujeres que de alguna

\footnotetext{
98 Tradução minha.
} 
manera intentan visibilizar la problemática que atraviesa fundamentalmente la mujer negra en el país porque otra característica de la lucha antirracista en nuestro país es que hay mucha resistencia a trabajarla desde el género o sea se trabaja la discriminación racial, se trabaja de la historia hay muchos proyectos pero cuando usted dice género ya ahí se derrumbó el asunto, entonces las mujeres comprendimos la necesidad de crear un grupo que intentara articular ambas cosas y de esta manera ir sensibilizando y trabajar el tema desde estas dos aristas. (Entrevista com Yulexis Almeida, realizada em 16/06/2014).

A consciência do espaço de resistência dialoga com o que Scott (2004) denomina "processos menores de resistência”, de Every day forms of resistance. Para o autor, esses processos também são transformativos, independente de serem conscientes ou não. No caso da pesquisa desenvolvida em Cuba, a contestação e reflexão coletiva ou individual do status quo e das relações raciais passam, necessariamente, por um processo de tomada de consciência que permeia a atuação militante.

Em muitos casos, a não consciência dessas relações raciais estabelecidas podem, ao contrário de se caracterizar como resistência, ocasionar uma efetiva colaboração com o sistema vigente. É o que analisa Christine Pelzer White (2008). Segundo ela, algumas formas identificadas por Scott (2004) como resistência estão colaborando para a própria perpetuação do sistema. Traz como exemplo as cantigas que algumas mulheres vietnamitas entoavam e que faziam alusão a algo de conotação sexual. Esse ato foi interpretado em alguma medida como resistência. Mas, isso não produziu nenhuma alteração significativa, apenas a perpetuação e manutenção do sistema.

No caso do universo dessa pesquisa, os ativistas entrevistados relataram seus processos de tomada de consciência de quem são e de como se situam em seu meio social. Há uma compreensão que o lugar socialmente estabelecido para os "negros" ou "negras" é estigmatizado. As pessoas entrevistadas abordaram histórias que permearam diferentes momentos da vida, desde experiências na escola primária, a vivências em ambientes laborais já como adultos. Maritza traz um relato de seu processo de tomada de consciência, cuja a dramatização se dá por situações cotidianas nas quais ela se reduzia à "negra" e os espaços socialmente disponibilizados para esse segmento eram muito marcados:

Nosotras (yo y mi hermana) nos criamos en la doctrina de que todos éramos iguales. Yo nací en pleno periodo de la Revolución, yo nací en 1964. No sé si mi hermana, que es mayor que yo, haya tenido encuentro con el tema racial desde niña, porque yo cuando niña no sentí que eso me marcaba y no tenía ninguna importancia. Cuando crecí, mi memoria lo que tengo es mis estudios secundarios que lo hice en una beca, era una opción que teníamos muchos muchachos de la misma edad. Ahí siempre a mí me dijeron "la negra", y eso por un lado me distinguía y por otro lado como me devaluaba. Pero, en aquel momento yo no tenía conciencia de que significaba ser la negra, después comencé a trabajar, después de trabajar quise estudiar, seguir estudiando y estudie. Y eso me siguió acompañando independientemente de los resultados que tuviera. Ya en el periodo de primera juventud, a partir de los 19 años en adelante, independientemente de los resultados que tuviera, era siempre "la negra", y eso empezó a marcarme hasta el punto que ya terminando otros estudios que hice que están relacionados con la electrónica, no tiene nada que ver con lo yo hago ahora, empecé a trabajar en un lugar y es algo que vi. Había mucha sintonía en mucha gente que entraron unos de los que nos graduamos; uno dirigía la juventud, o sea eran líderes 
de la UJC, la Unión de Jóvenes Comunistas, otros se vincularon más a las labores administrativas. Pero vi que era muy común que muchos de los que nos vinculamos a las labores sindicales éramos negros y negras y eso fue lo que a mí me toco, ser la secretaria general del sindicato porque me destacaba en muchas cosas, pero no aplicaba para ser la principal de la UJC, ni para la principal en lo administrativo y eso también le fue dando una lectura a mi vida. (Entrevista com Maritza López, realizada em I5/08/20I4).

Experiências no nível particular de ativistas conformam a trama da construção do que é denominado por eles como "consciência racial". Contudo, a dinâmica importante nessa tomada de consciência é que sua relevância social está presente não tanto na história do seu processo de formação, mas nos projetos de atuação no meio social. É na realização, na efetivação, na concretização desses projetos que esses coletivos e atores formam e transformam o seu universo sociocultural (ORTNER, I995: I87).

La Rede Barrial Afrodescendiente a ver, dice Pablo Freyre de que una tiene que ser coherente entre el pensamiento, la acción y la palabra y yo pienso que La red barrial afro descendiente es el resultado de esa coherencia $[. .$.$] cuando yo mire así a mi alrededor, como hace un rato te hablaba de mi conciencia racial,$ empecé a visualizar tanta gente que me había ayudado a crecer que estaban ahí presentes, que habían escrito libros o artículos, o habían sido excomulgados porque plantearon el tema en un lugar que a alguien no le gusto, tenía poder y lo desplazo, y eso me dio mucho orgullo pero a la vez mucho compromiso. Porque todavía yo no estoy muy clara de por qué llegue a ese lugar. Me imagino que tiene que haber sido por mi trayectoria de vida, hablando de la coherencia. Pero escuchar los testimonios que allí se dieron, qué se pensaba, los diferentes ejes que tenía ARAAC, la forma democrática en las que se propuso que todos los que nos involucramos, participáramos, el hecho de que hubiera un eje específicamente que fuera de trabajo comunitario, a mí me hizo comprometerme mucho más y como otra de las cosas que dice Freyre es "usa el mínimo espacio de tu poder", tratáramos de tener todos los que hemos sido convocados una incidencia. Pues mi incidencia fue convocar a mi zona para esa lucha. (Entrevista com Maritza López, realizada em I5/08/20I4).

A abordagem de Maritza sobre a sensibilização que vivenciou a partir do debate fomentado por outros ativistas e intelectuais sobre a questão racial em Cuba traz um extrato de um dos pontos centrais que permeia, no meu ponto de vista, a agência desses sujeitos, a partir de seus corpos e de suas experiências. Esses sujeitos aprendem e apreendem novos referenciais discursivos, outras tramas de significados e recorrem a esse sistema para manter acesa a motivação que impulsiona ações que, muitas vezes, contradizem o status quo e o discurso "verdadeiro", no sentido foucaultiano (2006).

Nesse contexto de relações assimétricas, em que a abordagem sobre as relações raciais é tratada em grande parte das vezes a partir do viés do interdito, da negação ou da irrelevância, a resistência desses agentes sociais e coletivos se materializa nesses atos de contraposição, de desafio. São atos e concepções baseados em ações conscientes desses sujeitos contra aspectos subjetivos, como a lógica do colonialismo interno (ZURBANO, 20I5) e contra vivências de discriminação racial que tocam suas experiências cotidianas nas relações sociais que reproduzem esses valores coloniais construídos e reconstruídos. 


\section{I.5. Movimento Afrocubano nos Estertores da Guerra Fria}

Os movimentos sociais afrodescendentes ou negros ${ }^{99}$ na América Latina são atores centrais na atualidade e historicamente se conformaram como forças antissistêmicas e contra-hegemômicas

chaves. É preciso, então, delimitar o que denomino "movimentos sociais", "sociedade civil" e posteriormente o que entendo por "movimento antirracista ou afrodescendente".

Nessa seção, buscarei fazer uma reflexão sobre os conceitos de sociedade civil, movimentos sociais e a especificidade desse movimento antirracista. Para isso, farei um debate sobre os conceitos de racismo, bem como busco caracterizar os agentes sociais que militam nos coletivos afrocubanos.

As reflexões acerca dos movimentos sociais são diversas, não havendo, portanto, uma única concepção. As mobilizações sociais que emergiram na Europa, a partir do final da década de 1960, provocaram o aparecimento de novas abordagens que influenciaram de modo significativo os estudos sobre os movimentos sociais.

Na década de 1970, como pontua Alonso (2009), surgem três correntes principais da teoria dos movimentos sociais: Teoria de Mobilização de Recursos (MCCARTHY e ZALD, I977), a Teoria do Processo Político (MCADAM, I982; TILLY, 1978) e a Teoria dos Novos Movimentos Sociais (TOURAINE, I983, 1973; HABERMAS, I987, MELUCCI, I988).

Nesse período, se fortalece uma multiplicidade temática nas mobilizações sociais. Essas mobilizações passam a permear questões relativas às relações de gênero, étnicorracial, etária, socioambientais, dentre outras. São o que muitos teóricos denominam "Novos Movimentos Sociais", que estruturam sua ação a partir das demandas relativas ao direito à diferença, tais como os movimentos feministas, de pessoas com deficiência, ambientalistas. A referência ao "novo", nessa abordagem dos novos movimentos sociais, é colocada por Gohn como "uma nova forma de fazer política e a politização de novos temas." (GOHN, 2007: I24).

Um dos autores de referência para essa teoria, Alain Touraine (1983, 1973) destaca que os movimentos sociais seriam consequência da pluralidade de linguagens e conflitos das sociedades pós-industriais ou pós-materialistas. Para esse autor, os movimentos sociais seriam definidos por três princípios básicos. O primeiro deles diz respeito à identidade, coletivamente construída por

\footnotetext{
${ }^{99}$ Emprego os dois termos para assegurar a diversidade de seu uso pelos agentes sociais e para sinalizar os diferentes contextos de sua construção conceitual.
} 
um grupo social. Ele parte do pressuposto que essa percepção de identidade coletiva precisa ser consciente para se caracterizar como movimento social. Todavia, a construção dessa identidade se dá exatamente no conflito. Outro ponto importante é o princípio de oposição. Um movimento só se organiza a partir da oposição a algo. E, na ação, a delimitação desse adversário se torna mais explicita.

Das autoras brasileiras que trabalham com o tema, Maria da Glória Gohn é uma das que estabelece amplo debate com as novas teorias dos movimentos sociais. De acordo com Gohn (20I I), os movimentos sociais são as ações sociais coletivas de caráter sociopolítico e cultural que viabilizam formas distintas da população se organizar e expressar suas demandas. Os movimentos sociais utilizam diferentes estratégias que vão desde a simples denúncia até a pressão direta (mobilizações, marchas, concentrações, passeatas, distúrbios à ordem constituída, atos de desobediência civil, negociações). A atuação por meio de redes sociais, locais, regionais, nacionais e internacionais ou transnacionais é uma das estratégias de organização na atualidade, viabilizada, frequentemente, pelo uso de ferramentas como a internet.

Ainda para Gohn (2007), os movimentos sociais simbolizam um conjunto de ações coletivas que objetivam a reivindicação de melhores condições de vida, a partir de um viés contestatório, e buscam estabelecer a construção de uma nova sociabilidade humana.

Com relação às mobilizações negras é bastante complexo compreendê-las como processos que emergem no contexto dos anos 1960. Se analisarmos as narrativas sobre as mobilizações negras abolicionistas no século XIX e pelos direitos e inclusão desse segmento na primeira metade do século XX, os elementos trazidos por Touraine, como, por exemplo, a ênfase na identidade coletiva, já estavam presentes.

Nesse caso, não há necessariamente uma mudança de orientação desses movimentos para focos subjetivos vinculados à identidade apenas a partir da década de 1960. A luta antirracista e por direitos da população negra baseada na construção de uma identidade coletiva compartilhada, numa situação de subalternidade socialmente fundada, ocorre desde o período da colônia em Cuba, com os cabildos, e posteriormente, na República, com a formação do Partido Independientes de Color e das sociedades negras, por exemplo. Cabe destacar que essa não é uma particularidade da história cubana, tendo sido vivenciada em outros contextos americanos provenientes da lógica colonial. 
Outra dimensão é que os movimentos negros na Diáspora Africana nas Américas não se enquadram totalmente no que os teóricos dos "Novos Movimentos Sociais" denominam "pósmaterialismo". Hanchard (200I) reflete sobre o movimento social afro-brasileiro e diz que esse não pode ser de forma holística denominado como "pós-material", como muitos desses estudiosos descrevem os novos movimentos sociais, no sentido de diferenciar essas mobilizações do eixo: partidos, uniões e sindicatos. No caso do movimento negro brasileiro, que dialoga muito com o vivenciado em Cuba, "as formas de preconceito, discriminação e desigualdade a que reagiram movimentos como o MNU e o Agbara Dudu certamente têm uma dimensão material" (HANCHARD, 200I: 186). Destaca, ainda, o autor que a sobreposição de múltiplas formas de opressão e identificação social, tais como classe social, gênero, raça, orientação sexual, complexifica a questão identitária e da superação do debate materialista.

Mais um aspecto a ser refletido é o não aprofundamento do olhar teórico dos "Novos Movimentos Sociais" para os movimentos negros. A própria produção brasileira sobre o tema não se dedica a esse olhar, e em muitos casos desconsidera essa especificidade. Todavia, isso não é exclusivo da produção brasileira. Hanchard (200I) ressalta perspectiva semelhante, com diversos teóricos centrais dessa teoria, e traz uma citação mais explícita de Habermas, que talvez seja uma das justificativas para essa ausência:

\footnotetext{
Depois do movimento norte-americano pelos direitos civis - que desde então, desembocou numa autoafirmação particularista de subculturas negras, somento o movimento feminista situa-se na tradição dos movimentos de libertação burgueses-socialistas. A luta contra a opressão patriarcal e em prol do cumprimento de uma promessa que há muito se transformou em lei confere ao feminismo o ímpeto de um movimento ofensivo. Os movimentos de resistência e retirada almejam opor-se aos campos de ação formalmente organizados, em prol de campos comunicativamente estruturados e não da conquista de novos territórios. (HABERMAS, I987: 393, apud, HANCHARD, 200I: I86).
}

Para além da forma reducionista com que Habermas refere-se ao Movimento Afroamericano dos Estados Unidos, que traz implicações para o olhar sobre outras mobilizações antirracistas na Diáspora Africana, ele delimita diferenciações estanques entre o movimento feminista e afro, como se fluxos e relações não existissem na prática e na vivência desses coletivos. Como ressalta Hanchard (200I), a dinâmica de interação entre os movimentos é um elemento importante, como, no caso do movimento negro brasileiro, com as relações estabelecidas com a esquerda, com os movimentos feministas (brancos e negros) e com os exilados políticos. O contato entre esses múltiplos movimentos sociais gerou dinâmicas de transmissão, conflito, intercâmbio e ampliação das estratégias e ideias políticas.

Em relação a Cuba, esses fluxos e refluxos de interconexões se dão também entre os coletivos baseados em diferentes pautas, como feminista, racial, de bairro, de diversidade sexual, de 
tradições de matriz africana. Uma das primeiras organizações que se poderia chamar de "sociedade civil" foi Magín, um coletivo feminista que reuniu diversas ativistas em prol da pauta de relações de gênero no final dos anos 1990. Algumas importantes ativistas antirracistas afrocubanas na atualidade provém desse coletivo feminista, como Irene Esther Ruiz, Norma Guillard e Daysi Rubiera. Portanto, as fronteiras rigorosamente definidas entre o que se denomina movimento feminista e movimento negro não refletem a multiplicidade das interações sociais.

Alguns dos elementos apontados pela teoria dos "Novos Movimentos Sociais" são interessantes para dialogar sobre a especificidade dessas mobilizações em Cuba, mesmo apresentando fissuras em sua aplicabilidade. Um deles é o mosaico de construção da identidade coletiva desses grupos. Como pondera Hall (2006: 346), compreender os processos identitários envolve dinâmicas vinculadas ao "significante flutuante", o que faz com que a identidade negra não seja uma categoria em essência.

É a partir do olhar para a "diversidade e não para a homogeneidade da experiência negra, que devemos dirigir integralmente a nossa atenção criativa agora" (HALL, 2006: 346). Essas diferenças têm identificações subjetivas próprias e permeiam também outras identidades, como as de gênero, de orientação sexual, de classe.

Nos coletivos aqui estudados essas diferenças vinculadas às múltiplas identificações subjetivas estão presentes, e enriquecem esse emaranhado social. Daysi Rubiera, ao falar do processo de articulação do coletivo Afrocubanas, que nasceu de um livro sobre as mulheres negras, destaca a problemática de perceber a identidade negra como homogênea, o que acaba por reforçar outras invisibilidades:

\footnotetext{
Me puse a pensar después que hacía falta hacer algo que tuviera que ver con las mujeres. Se hablaba mucho de discriminación racial pero cuando se hablaba de discriminación racial nada más se contemplaba al varón, lo englobaban siempre dentro de todo el proceso de los varones. Comenzó el debate muy incipiente en aquel momento pero comenzó el debate por la cuestión racial en Cuba, pero igual que en América Latina el debate era masculino, las mujeres siempre estábamos ocultas no aparecíamos aunque estuviéramos presentes y se me ocurrió hacer el libro de Afrocubanas (Entrevista com Daysi Rubiera, realizada em 0I/08/20I4).
}

Essa perspectiva do olhar das mulheres e da sobreposição de identidades, inclusive na mobilização social, é também presente na história do Movimento Negro Brasileiro, como relata (SILVA, 2003: 17):

No Brasil, como resposta a um quadro de opressão específica vivenciado pelas mulheres negras, constituiuse, a partir de meados da década de 1980, o Movimento de Mulheres Negras. Organizadas até aquele momento em instituições de homens e mulheres, nas quais, o mais das vezes, desempenhavam apenas tarefas 
de suporte, distantes dos processos de decisão política, as mulheres negras resolveram organizar-se em comissões para discutir e produzir alternativas para suas questões.

Além do debate sobre a sobreposição e fluidez das identidades, e os intercâmbios entre coletivos, há outro aspecto a ser abordado nesse diálogo com teóricos dos movimentos sociais: o entendimento que a existência dos coletivos sociais é fundada a partir da contestação constante do Estado. De acordo com Petras et al. (2005), a reivindicação insistente e a posição contestatória em relação ao Estado representam a espinha dorsal dessas organizações. Apesar de serem organizações cuja estrutura e dinâmica estão apoiadas na atividade política, os movimentos sociais não se institucionalizam necessariamente como outras formas de organização política, como ONGs, sindicatos e partidos políticos (FELTRAN, 2005).

Os fundamentos dos movimentos sociais se baseiam em pressionar o Estado para que este produza, forneça e garanta políticas que ajudem a suprir as carências que originalmente levaram à mobilização social daqueles que compõem o movimento. No entanto, no contexto cubano, o princípio de "oposição", como coloca Petras et al. (2005) precisa ser necessariamente relativizado, pois as dinâmicas que permeiam esses coletivos são mais complexas na materialização dessas relações

Percebo que o Movimento Afrocubano se constitui como agente de pressão social, que mobiliza o Estado para efetivar respostas às suas demandas. Em Cuba, esse movimento de pressão é frágil, pelas inúmeras particularidades que existem no país e pela grande presença do Estado nos meandros das mobilizações realizadas por esses coletivos. Esses são processos de organização muito recentes, com pouca maturidade ou capilaridade social, como destaca Zuleica Romay:

Yo creo que tenemos ahora la oportunidad de generar más iniciativas (para la superación del racismo). En Cuba, hay algo que no hemos logrado por esa misma tendencia al pensamiento vertical que es que los compañeros entendamos, sobre todo de ARAAC, que seremos más influyentes mientras seamos más y estemos más organizados. No es lo mismo hablar a nombre de cien que de mil. Y en eso sí hay que hacer grandes esfuerzos porque gente dispersa con ganas de hacer cosas hay muchas, pero gente organizada y estimulada para trabajar no. Yo creo que falta organizar una respuesta gubernamental también. Pero la fuerza de la organización es importante para eso. (Entrevista com Zuleica Romay, realizada em 0I/08/20I4).

O que Zuleica trata como "tendência ao pensamento vertical" também reflete a especificidade da relação estabelecida entre o Estado cubano e os coletivos sociais. Em muitos casos, há o entendimento de que sem uma centralização do tema, sem uma liderança que impulsione esse movimento, não se avançará suficientemente.

Os ativistas, para exemplificar, recorrem ao fato de que a Federação de Mulheres Cubanas - FMC foi liderada por muitos anos pela ex-guerrilheira de Sierra Maestra Vilma Espín, esposa de Raul 
Castro, e que agora o movimento LGBT em Cuba tem uma forte atuação de Mariela Castro, filha de Raul Castro. Atribuem, em suas análises, a maior visibilidade desses dois movimentos ao papel desempenhado por essas duas lideranças, que impulsionaram a pauta de gênero e de diversidade sexual no país.

As narrativas dos ativistas também apresentam o contraponto de que no caso racial não houve um apadrinhamento por uma figura importante ou a constituição de uma forte liderança ${ }^{100}$. Por essas questões colocadas, há a percepção de que a falta de uma organização verticalizada faz com que o movimento antirracista em Cuba seja mais frágil, pois destoa do histórico de alinhamento centralizado dos movimentos sociais nesse país. Também destoa pelo fato de não haver um vinculo robusto com o Estado, como o que ocorre com a Federação de Mulheres Cubanas que se organizou no seio do processo revolucionário e tem uma relação estreita com o Estado e com o Partido Comunista de Cuba, inclusive para financiamento e diretrizes.

Essa busca pela unidade, pelo centralismo do movimento afrocubano, remete ao debate sobre as tensões entre a segmentação e unidade que Goldman (200I) faz em seu estudo sobre o movimento negro de Ilhéus. As fragmentações, as redes sociais, em geral esquecidas pela macropolítica, são fundamentais para compreender processos e movimentações entre esses coletivos e ativistas. Goldman ressalta como que a busca idealizada de um dos seus interlocutores pela unidade do movimento afrocultural de Ilhéus-Bahia acabou por represar a multiplicidade e a complexidade das relações na dinâmica organizativa local.

Interessante perceber no caso cubano, por um lado, como há um conflito colocado entre ativistas e coletivos sobre a luta por uma unidade imaginada e a crítica continuada à fragmentação, e, por outro, uma miríade de dinâmicas próprias de cada um desses grupos ou ativistas que torna esse movimento diverso, complexo e polifonal.

Nessa dinâmica de múltiplas formas organizativas, há coletivos e ativistas que pautam suas ações a partir da ênfase em atividades e propostas que buscam ampliar o processo de conscientização e reflexão sobre a questão racial em Cuba e do racismo em comunidades determinadas ou no próprio meio acadêmico. O Estado é um interlocutor importante para alguns, tanto para manifestações de denúncias, como para o diálogo sobre propostas de mudanças, como as de ordem legal e as educacionais. E o conflito é inerente nessa relação, como relatado por Kimbo:

\footnotetext{
${ }^{100}$ Abordarei mais profundamente esse tema no capítulo IV.
} 
Llega un buen día y llega el juez, llegaron los compañeros que necesitaban hablar con nosotros porque existía un problema. Habíamos hecho la Casa Comunitaria, pero en aquel momento yo no tenía el doce grado, pero yo tengo más expediente cultural que me atrevo a decir donde quiera que yo llegue, y se lo digo a cualquiera analgumen como le digo a esas personas aquí en Matanzas, que no tienen sentido de pertenencia que no tienen deseo de tirar a esta provincia con lo cultural que es hacia delante. Hicimos la Casa Comunitaria y después pusieron a una persona que nunca ha hecho nada por este barrio a dirigirnos a nosotros. Yo soy el coordinador y dije: yo me voy, y yéndome yo, se fue todo el mundo, que eso fue lo que paso en el proyecto. Se quedó renga y todo el mundo venía a hablar conmigo, no negrito eso no es así. Porque a mí me hizo cambiar esto; ya yo tengo mi doce grado, mi compromiso era sacar el doce grado y yo lo hice. [...] Hoy por hoy, yo se los dije a ellos, si no me atienden a mí, yo no los atiendo a ellos. El Proyecto Comunitario para Cuba entera que me conoce todos los talleristas que hacen este mismo trabajo que hago yo, como también en la parte de Latinoamérica que me conocen, muchos líderes también han compartido conmigo, el proyecto la Marina está bajo, y la responsabilidad se la echo tanto al Gobierno como al Partido como a los dirigentes de esta provincia, porque si nosotros hasta ayer nos reuníamos en casa y todos éramos felices y todo fue muy bien desde que tratamos de unirnos así, para mí que ellos pensaron que nosotros estábamos haciendo contrarrevolución que nos tenían que meter a alguien dentro de nosotros. (Entrevista com Kimbo, realizada em 20/05/2014).

$\mathrm{Na}$ abordagem feita por Kimbo, há um conflito latente na forma como se desenvolvem as relações entre representantes do Estado e a própria comunidade. Há uma tentativa de fortalecer a gestão comunitária e um rechaço aos processos de interferência direta de representantes de governo. $\mathrm{Na}$ impossibilidade de se ter uma gestão comunitária direta, há a estratégia de mobilizar-se de forma desvinculada de espaços comunitários oficiais, como a casa de cultura do bairro. Há, nesse caso, a busca por distanciar-se, opor-se ao Estado e assumir uma postura mais crítica.

Para complexificar, o Estado também figura como um ente referencial para outros coletivos. Parte dos grupos tem algum tipo de vinculo com o Estado, seja mais estreito, como o caso da Federação de Mulheres Cubanas ou das organizações de base da Revolução, ou mais difuso, como no que se refere à Comissão Aponte.

Além disso, várias dessas organizações almejam se institucionalizar e ter o reconhecimento por parte do Estado de suas ações. Por outro lado, oficializar esses coletivos, como associações, por exemplo, não é um processo fácil. Nenhum dos coletivos antirracistas estudados é legalmente reconhecido como associação, como mencionado anteriormente. Isso, obviamente, não inviabiliza que sejam coletivos e grupos atuantes em seu meio social.

No que se refere ao conceito de sociedade civil, sua aplicação em Cuba usualmente traz implicações difíceis, pois os parâmetros são distintos e a construção desses limites é uma tarefa complexa. Arato e Cohen (2000: 09) sustentam o conceito delimitando os espaços do Estado, mercado e sociedade civil, em contextos democráticos. Mais uma vez ressaltando posições semelhantes ao de Melucci e Habermas, Arato e Cohen (200I) destacam que o "o papel político da sociedade civil $[\ldots]$ não está relacionado diretamente com o controle ou a conquista do poder, senão com a geração de influência mediante a atividade das associações democráticas e a discussão 
não restrita à esfera pública cultural”. E nesse cenário, há tratativas de influenciar as decisões políticas nas relações estabelecidas com o Estado, caso isso não ocorra, as expectativas construídas são frustradas.

Hall (2006) para debater os limites do que se denomina "sociedade civil" e "Estado" reflete sobre as categorias de hegemonia em Gramsci (I97I), que, por sua vez, tem dificuldades de estabelecer fronteiras muito explícitas entre essas instâncias, derivadas das "imensas complexidades da sociedade nas formações sociais modernas - as trincheiras e fortificações da sociedade civil". Hall (2006) cita também Althusser, que nesse debate, se recusa a distinguir entre Estado e sociedade civil, ponderando que essa distinção pertence apenas à "ideologia burguesa", que situa o Estado no papel de controle amplo das instâncias sociais.

O estabelecimento dessas diferenciações e fronteiras é um exercício, de fato, complicado. No caso cubano, essa complexidade é reforçada, por viver o país um socialismo particular e processos avançados de mudanças sociais e econômicas, a partir dos anos 1990, que têm impulsionado uma fragmentação de estruturas enrijecidas, tal como o lugar dos movimentos de base na sociedade, e apresentado novas formas de associativismo.

A sociedade civil não segue a mesma relação com o Estado em países com outro modelo político. A divisão tríplice proposta por Arato e Cohen (200I) não é um modelo eficiente para pensar as dinâmicas sociais num país cujo modelo político é de partido único, o Partido Comunista de Cuba, e que o desenho institucional segue uma lógica diferenciada no que se refere ao modo de representação política.

Todavia, a complexidade social demonstra que há espaços diferenciados da sociedade civil e do Estado. Diferentemente do que Althusser argumenta, as relações sociais estabelecidas nos locais onde fiz minha pesquisa ressaltam essa diferenciação. Concordo que não sejam fronteiras fixas e congeladas, mas há um processo de associativismo que não pode ser confundido com o Estado, como vimos na abordagem feita por Kimbo.

Para fazer essa análise, proponho um diálogo com categorias nativas. A sociedade civil tradicionalmente existente em Cuba, como fruto da Revolução, seria composta pelas organizações de base, com estreita vinculação com o Estado, conforme veremos a seguir. E, especialmente a 
partir dos anos 1990, surgem novas formas de ativismo social, o que dá outros contornos ao que se denomina sociedade civil em Cuba ${ }^{101}$.

Nesses casos, não se pode traçar limites rigorosos e fixos entre essas categorias. A oposição e desvinculação com o Estado também não é necessariamente dada. Em reflexão semelhante à feita por diversos autores latinoamericanos com relação à argumentação de Cohen sobre a rigidez de seu conceito e falta de fluidez entre as três esferas, Estado, mercado e sociedade ${ }^{102}$, mas marcando a especificidade de Cuba, creio ser difícil demarcar uma separação rigorosa entre elas, pela grande presença ou influência do Estado no mercado e nas dinâmicas da sociedade civil. Além disso, os atores que integram a sociedade civil podem também ser parte da sociedade política, e, simultaneamente, ainda, atuar no Estado. Esse seria mais um dos exemplos que demonstram certa fluidez entre esses limites.

É fundamental, contudo, fazer uma diferenciação, mesmo com alguns percalços, em relação ao que estou chamando de sociedade política e sociedade civil cubana. Para Arato e Cohen (200I) a sociedade política é integrada por organizações políticas, como partidos políticos e parlamentares. Por sua vez, a sociedade civil seria a institucionalização do social, composta, por exemplo, por associações, movimentos sociais e coletivos.

No que caracterizo como sociedade política ${ }^{103}$ estão presentes atores políticos, como os membros do Partido Comunista de Cuba. Cabe destacar que o status de ser integrante do Partido é valorizado na sociedade cubana ${ }^{104}$, sendo esse um lócus restrito. Para entrar no partido, é necessário, como requisito, a avaliação da história de vida política e de participação em atividades revolucionárias. O processo do aspirante é verificado antes da inclusão. A sociedade política, por meio do Partido Comunista de Cuba, tem como função orientar politicamente as ações empreendidas em diversas instâncias de Cuba, inclusive em parte das organizações sociais consideradas como sociedade civil.

\footnotetext{
I0I Tomo como referência o período Revolucionário. Nos primeiros anos da Revolução, algumas das organizações da sociedade civil afrodescendentes anteriormente existentes se mantiveram por algum tempo. Mas, foram paulatinamente encerrando suas atividades, em dinâmica inversa ao avanço da implementação das reformas de base da própria Revolução.

${ }_{102}$ Para mais informações, ver: DAGNINO, OLVERA, PANFICHI, 2006.

${ }^{103}$ Ao tentar refletir sobre a caracterização da "sociedade política" e "sociedade civil" em Cuba, destaco, mais uma vez, a fluidez desses limites e que a construção dessas categorias de diferenciação nos auxilia para analiticamente compreender melhor essa realidade social, sem tratá-la, contudo, como barreiras intransponíveis.

${ }^{104}$ Um dos exemplos da valorização do status de militante do Partido é que em qualquer processo judicial ou investigativo, dentre as informações pessoais necessárias nos documentos declaratórios, como nome, data de nascimento e endereço, está a informação do pertencimento ou não ao PCC e/ou outras organizações que denomino como "sociedade civil oficial", tais quais CDR e UJC.
} 
No que se refere à sociedade civil, faço três grandes diferenciações para a compreensão da lógica cubana: (I) Sociedade civil oficial, (2) Sociedade civil reconhecida, e (3) Sociedade civil dissidente. As organizações que denomino como "sociedade civil oficial" são caracterizadas como organizações de base da Revolução, fundadas, em sua maioria, logo nos primeiros anos pós 1959 e que são importantes espaços formadores e de defesa do princípio revolucionário. Possuem um caráter misto. Em sua estrutura, a representação nacional é assalariada, com escritório e recursos custeados pela estrutura governamental. Porém sua atuação na base, no nível local, é feita de forma voluntária, sem vínculo salarial.

Sua relação é marcada pela atuação estreita tanto com a sociedade política, especificamente o Partido Comunista, como com o Estado. Nesse grupo, estão (i) os Comitês de Defesa da Revolução situados em todos os bairros de Cuba, cujo lema é: que sejam vigilantes, atentos e combativos; (ii) A Federação de Mulheres de Cuba, FMC, que também possui estrutura descentralizada e foi criada logo no início da Revolução; (iii) os sindicatos, como a União dos Trabalhadores de Cuba; e (iv) as representações estudantis, como a Federação de Estudantes Secundários. O grau de autonomia é mínimo para pautas que estejam fora do espectro priorizado pela sociedade política e pelo Estado. De acordo com os dados levantados pela pesquisa, nenhuma dessas organizações possui uma atuação sistemática com a questão racial e o combate ao racismo. Portanto, elas não são objeto central de análise na presente pesquisa.

Em segundo lugar, visualizo as coletividades sociais antirracistas que são compostas por ativistas que se denominam defensores da Revolução, mas são críticos à situação de exclusão e desigualdade racial que vivenciam os negros e negras em Cuba. A esse conjunto denomino de "Sociedade Civil Antirracista Reconhecida". O "reconhecido", nesse caso, não significa oficializado ou legalizado. Inclusive, nenhuma delas se encontra oficializada como uma associação ou organização não governamental, por exemplo. Todavia, são coletivos que possuem, em parte, um certo nível de reconhecimento do Estado e buscam, em sua maioria, uma legitimação nessa relação por meio da legalização e valorização de sua atuação.

Essas organizações convivem, ocasionalmente, com situações ambíguas. Por um lado, recebem algum suporte estatal, como apoio para publicação, préstimo de salas públicas para seminários e debates e alguma interação com canais de televisão e rádios estatais. Nesses casos, sua atuação é valorizada e compreendida como fundamental para contribuir com os novos desafios da Revolução, potencializados com a queda do bloco socialista. 
Por outro lado, sobre sua atuação paira muitas vezes a dúvida de estarem desgastando a "unidade nacional" ou a própria Revolução ao darem visibilidade ao debate racial e às mazelas do racismo, ou são questionados pelas estratégias utilizadas. Muitos ativistas desse conjunto de coletividades passaram por algum tipo de coerção ou constrangimento por parte das instituições estatais em algum momento de sua atuação política nessa pauta ${ }^{105}$.

Em geral, esse conjunto de organizações possui uma frágil estrutura para realizar suas atividades, pois não tem sede e não são legalizadas. Para além do pouco apoio que recebem do Estado, não possuem recursos para ampliar sua atuação por outras regiões do país, por exemplo. O trabalho desempenhado é voluntário. Alguns exemplos dessas entidades são a Rede Barrial Afrodescendiente; a Cofradía de la Negritud; a Afrocubanas; o projeto Alianza Unidad Racial, o Projeto Identidad y Barrio La Marina; a Red de Mujeres Afrodescendientes Latinoamericanas y caribeñas - capítulo cubano; a ARAAC - Articulación Regional Afrodescendiente de las Americas y el Caribe, dentre outros. São organizações com atuações e escopos muito diversos entre si, criadas majoritariamente a partir dos anos 2000, tendo os pioneiros sido criados ainda na década de 1990. Sobre esse conjunto dediquei a maior parte da presente pesquisa.

Há um coletivo, desse conjunto de organizações com atuação antirracista, que tem também um caráter híbrido. Possui algum nível de vinculação oficial em sua atuação e uma ligação com a sociedade política e o Estado, todavia seus membros atuam de forma voluntária e sem uma estrutura mais robusta de apoio estatal, em contraponto ao conjunto de organizações caracterizadas como "sociedade civil oficial". Estaria nessa situação híbrida a Comissão Aponte, criada em 2009, que possui vinculação institucional com a União Nacional dos Escritores e Artistas de Cuba - UNEAC, e agendas periódicas com o governo, inclusive com representantes da vice-presidencia.

Em terceiro, estão os coletivos antirracistas que apresentam uma crítica além da dimensão racial, ao envolver também uma oposição sistêmica ao regime socialista. Eles defendem, por exemplo, o que chamam de democratização da imprensa e o fim do modelo de partido único. A esse conjunto, denomino "Sociedade Civil Antirracista Dissidente"106. Dissidente é um termo nativo, usualmente empregado em Cuba, que caracteriza os grupos ou indivíduos que se opõem ao regime e que ocasionalmente estreitam relações com os Estados Unidos. Um dos coletivos que

\footnotetext{
${ }^{105}$ Nas seções específicas desse trabalho sobre os movimentos sociais antirracistas, detalho melhor alguns desses casos a partir da narrativa dos ativistas. O detalhamento desses casos está no capítulo 4.

${ }^{106}$ Os estudos sobre o universo dos coletivos da sociedade civil dissidente ocorreram principalmente pelo estudo de documentos e publicações feitos por esses grupos. Tive dificuldade de acessar atividades desses coletivos durante a pesquisa.
} 
incorporo nesse conjunto, o CIR - Comité Ciudadano para la Integración Racial, se apresenta abertamente como parte da "fraterna sociedade civil dissidente de Cuba"107.

Diversas denúncias de aproximação desses grupos com o governo dos Estados Unidos são feitas, inclusive no que se refere ao financiamento de parte delas ${ }^{108}$. Sob sua atuação, não há reconhecimento estatal e nenhum suporte pelo governo de Cuba. Alguns dos exemplos desse grupo de organizações atuantes em Cuba com a pauta antirracista são o CIR - Comite Ciudadano de Integración Racialiog e o Movimiento de Integración Racial Juan Gualberto Gómez.

Apesar das pautas que se referem especificamente à luta antirracista serem muitas vezes convergentes com as organizações que eu categorizei como "Sociedade Civil Antirracista Reconhecida", a marcação da diferença de concepção política entre esses grupos é bastante significativa, o que limita uma atuação articulada entre elas. Zurbano, que integra a ARAAC, apresenta sua percepção da forma como estão situadas as organizações antirracistas em Cuba:

[...] Incluso muchos hacen de esa critica al Gobierno una crítica sistémica y se convierte en lo que se llama organizaciones disidentes y otras que forman parte de esas organizaciones disidentes que forman parte de esa sociedad civil opositora que hay en Cuba. (Entrevista com Roberto Zurbano, realizada em I5/I0/2014).

Os fragmentos de Guerra Fria ainda são presentes em Cuba nos dias atuais. São resquícios de uma relação que por décadas dividiu o mundo em dois blocos e que influenciou correntes ideológicas em grande escala. Após a queda do Bloco Socialista, no final da década de 1980, houve uma intensificação de hostilidades entre Estados Unidos e Cuba, culminando em uma série de atentados, cujas provas encontradas demonstram que foram executados por alguns grupos dissidentes em Miami ${ }^{10}$. Ao pensar na especificidade vivenciada por Cuba nesse processo, é impossível não incorporar essa dimensão na análise que ora faço da sociedade civil cubana. Esses elementos estão nas narrativas, nas ações e na forma como se organizam órgãos estatais e o conjunto da sociedade política e da sociedade civil.

Essa sociedade civil padece de uma extrema fragilidade para ampliar seu espectro de reverberação do debate racial. Das organizações que aqui concebo como "oficiais", como a FMC e o CDR, não há uma incorporação dessa questão como um elemento central de sua atuação. Nem sequer

\footnotetext{
${ }^{107}$ Fonte: www.cir-integracion-racial-cuba.org

${ }^{108}$ Para mais informações, acessar: http://alongthemalecon.blogspot.com/2013/05/breakdown-of-20-million.html ou http://www.afrocubaweb.com/racismdiscourseII.htm. Vide também MORALES, Esteban. El tema racial y la subversión anticuba. Disponivel em: http://www.lajiribilla.co.cu/2007/n33I_09/33I_I8.html

${ }^{109}$ http://www.cir-integracion-racial-cuba.org/

${ }^{110}$ Para maiores detalhes: Morais, Fernando. Os últimos soldados da Guerra Fria. São Paulo, Cia das Letras, 20 I I.
} 
como elemento secundário. De acordo com as narrativas, não há prioridade política para o tema, posto que o Partido também não o prioriza.

A fragilidade de incorporação dessa questão por essas organizações é abordada em muitas falas de lideranças e ativistas. Destacarei, a seguir, exposição de Esteban Morales, feita no Ato Inaugural da Década dos Povos Afrodescendentes ${ }^{111}$, em Havana, Cuba, sobre a necessidade de incorporação dessa temática pelo que eu denomino "Sociedade Civil Oficial", organizações de base, de massas, da Revolução:

Em minha opinião, o mais importante que pode ocorrer em Cuba nessa Década dos Povos Afrodescendentes é que esse tema possa se institucionalizar no sentido de ser considerada como parte da ação da sociedade civil. Porque o que está passando com os companheiros nos bairros é que a problemática racial não está na agenda de nenhuma de nossas organizações políticas e de base. E, portanto, os maiores freios existentes para que esses projetos comunitários avancem é que estejam presentes nas organizações dos municípios, que não tem presentes em suas agendas esse problema. Esse problema deve estar na agenda de trabalho do partido (Partido Comunista de Cuba) nos municípios, do movimento sindical, dos Comitês de Defesa da Revolução, da FMC (Federación de Mujeres Cubanas). Assim, quando um trabalho comunitário tratar o tema, não será uma organização comunitária específica, mas todas ao mesmo tempo. Atuando de maneira conjunta, horizontal e verticalmente. Essa mudança deve vir desde os bairros, desde a base, tem que funcionar desde onde estão as pessoas. Porque já se passaram mais de cinquenta anos e nossas organizações políticas e de massa têm que modernizar-se, e ter mais dentro delas aqueles problemas novos que tem essa sociedade mais de 50 anos depois, que não tínhamos nos anos 1960, que não o tínhamos nos anos 1970. As vezes o choque fundamental que temos para que o trabalho comunitário avance, o temos nas organizações de base. Não o fazem por que são más pessoas, por que são contrarevolucionários? Não o fazem porque não estão programadas para isso. Então deve-se estar programado para isso. Porque os problemas novos dessa sociedade devem estar na agenda das organizações políticas e de base. Se não, isso não vai funcionar. E por isso, para mim, o mais importante que nós podemos conseguir nesses próximos dez anos (a Década dos Povos Afrodescendentes) é que esses problemas novos passem a formar parte da institucionalidade. Porque a sociedade se vai dinamizado, a medida que o tempo vai passando e novos problemas vão surgindo. (Esteban Morales, exposição feita na inauguração da Década dos Povos Afrodescendentes em Cuba, Havana, em 20 de agosto de 20I4) ${ }^{112}$.

A fala de Esteban reforça a visão estatal do que é considerado como sociedade civil, ou seja, as organizações de base e de massa da Revolução, que eu categorizo como "sociedade civil oficial". Essa não é uma visão isolada de Esteban, está presente na abordagem de muitos atores sociais.

É sintomático que esse grupo, que denomino "sociedade civil oficial", concentra o que se compreende como sociedade civil em Cuba de forma majoritária. Essa percepção é muito presente na visão social sobre o tema. No período no qual estive em Cuba, esse tema foi tratado várias vezes no jornal "Granma", veículo de comunicação do Partido Comunista Cubano. Dentre as várias matérias publicadas entre 2014 e $2015^{113}$, destaco um dos artigos que objetivamente

\footnotetext{
III Década dos Povos Afrodescendentes estabelecida pelas Nações Unidas de 2015 a 2024.

112 Tradução minha, destaque meu.

I13 Alguns dos artigos publicados nesse período: "La sociedad civil cubana no tiene nada que hablar con mercenarios", de 07 de abril de 20I5, "Reitera sociedad civil cubana denuncias contra el bloqueo", de I6 de outubro
} 
delineou o que se concebe oficialmente como sociedade civil, publicado no de 02 de abril de 2015 intitulado: "La sociedad civil cubana", assinado por Lissette Pérez Hernandez, professora de direito da Universidade de Havana.

Para Hernández (2015), a sociedade civil é aquela que "ha dejado de ser primitiva y se organiza como sociedad política, con un Estado que la ordena y la regula". Há, portanto, uma ideia estreita que apenas as organizações que estão no âmbito da regulação estatal, oficializadas, e em estreito vínculo com o Estado se constituem como sociedade civil. O primitivo, por outro lado, imprime uma ideia de progressão evolutiva das organizações sociais, que acaba por estigmatizar formas diversas de associativismo e dinâmica social.

Posteriormente, a autora define os indivíduos que atuam como cidadãos na sociedade civil: "en el caso como electores $[\ldots]$ y en otro caso como trabajadores" ${ }^{114}$. Em Cuba, a sociedade civil seria expressa por sua dimensão associativa, cujo destaque da autora inclui: trabalhadores, camponeses, estudantes, mulheres e definidos setores da sociedade que se agrupam. Esse processo pode dar-se pelas organizações profissionais ou pelas organizações de massas, surgidas no processo histórico que "representan determinados intereses y una vía de incorporar a sus miembros a la edificación y defensa de la sociedad socialista".

A autora ainda ressalta algumas dessas organizações que no seu entender compreendem a "sociedade civil cubana", tais como a Federação de Mulheres Cubanas, a Central de Trabalhadores de Cuba, os Comitês de Defesa da Revolução e as Federações de Estudantes de ensino médio e universitário. Todos esses, como destacado anteriormente, tem sua organização e atuação muito relacionada com a sociedade política, inclusive no que concerne à sua pauta de atuação.

Como já explicitado, há uma percepção ampla entre os ativistas entrevistados que a temática racial não é de fato incorporada pelas organizações que eu denomino "Sociedade Civil Oficial", o que reduz a capilaridade de debate na sociedade cubana. A possibilidade de incorporação viria de uma nova "programação", como coloca Esteban, de uma orientação centralizada para esse fim. Há também uma expectativa de massificação, que abarque a questão de modo horizontal, a partir de uma orientação vertical. Com todas as complexidades do corpo social, haver a expectativa de que

de 20I4, "Sociedad civil cubana aborda retos de governabilidad y participación ciudadana", de I7 de março de 2015, "Sociedad civil cubana piensa a las Américas", de I7 de março de 2015.

${ }^{114}$ Destaque meu. 
esse processo se dê de forma massificada, a partir de uma "programação" revelaria uma visão um pouco padronizada da sociedade civil?

A seguir, aprofundarei o olhar sobre essas complexidades da relação entre a sociedade civil, a sociedade política e o Estado, em diálogo com alguns exemplos. As expectativas existentes na relação com o Estado ou com a sociedade política, a meu ver, estão presentes nas narrativas de muitas dessas organizações e acabam embaralhando, na percepção desses, os limites entre uma esfera e outra. É o que argumenta Zuleica Romay, da ARAAC, na entrevista feita para essa pesquisa:

En ARAAC me exigen un tipo de participación que no es la que yo quiero tener. Primero porque no me corresponde tener. Yo tengo un cargo estatal. Fuera del mundo siempre se interpreta que el Estado cubano lo manipula todo. Por tanto cuando tu es una persona que tiene un cargo estatal importante, yo tengo el rango de viceministro, es un cargo importante, cuando una persona con un cargo estatal importante esta a su vez protagonizando en una organización, la primera acusación que se produce es que la organización está siendo manipulada, eso es así. Entonces yo lo he explicado muchas veces, los compañeros de ARAAC no entienden porque muchos no tienen la experiencia de cómo se manipula eso, yo sí. Yo he tratado de estar lejos para evitar la acusación que al final va a perjudicar a ARAAC (Zuleica Romay, entrevista realizada no dia I8/08/20I4).

Os limites entre o Estado e a sociedade civil, nesse caso, são confusos e as críticas feitas à delimitação de Arauto e Cohen (200I) das três dimensões: mercado, Estado e sociedade civil, são aqui bastante coerentes. As confusões de percepção entre a importância da participação de Zuleica Romay, por um lado, e as possíveis interpretações de cooptação que isso poderia gerar, por outro, tornam as dinâmicas muito mais complexas do que as divisões teóricas tentam delimitar.

Há, nesse exemplo, uma tentativa enfática da ARAAC de ampliar o reconhecimento de sua atuação pelo Estado e haver a institucionalização de sua atuação, seja pela legalização, seja pelo apoio político e material de seus pleitos, seja pela tentativa de protagonismo de representantes da alta hierarquia estatal em seu grupo. Outra dimensão importante é a influência (ou tentativa de) que existe em muitos desses casos da Sociedade Política e do Estado na definição das prioridades e diretrizes dessas organizações.

No ato de inauguração da Década dos Povos Afrodescendentes, realizado no dia 20 de agosto de 20I4, organizado pela ARAAC, dentre os participantes, estava o vice-ministro da cultura Fernando Rojas. Em suas considerações finais, destaca:

Há algo, por suposto, substantivo: que tenhamos participado dessa convocatória, que participemos dessa iniciativa, iniciativa essa respaldada por nosso Estado, por nossa Revolução e que tenhamos isso aprovado. Creio que o que sai dessa Convocatória é que deve ser uma responsabilidade de instituições de governo e de organizações (da sociedade civil). [...] Em nosso país, esse esforço de condução tem 
sido liderado pelo Partido. Foi o Partido que nos alertou a ter esses mecanismos de consertação, de encontro (para debater o tema racial), e eu creio que deve seguir sendo assim. Mesmo que efetivamente, como Esteban dizia, em determinados níveis de organização e participação de nossa sociedade civil, eu sim acredito que exista uma sociedade civil em Cuba, ainda não exista a necessidade de abordar esses fenômenos e atender essas tarefas. E acredito que, entre outras razões, que deve seguir sendo dessa maneira, que conduza o partido, que conduza as Instituiçôes, porque ainda que seja perfeitamente pertinente que nós tenhamos cada vez mais atores novos, como ARAAC, há tentativas de minar por dentro o sistema institucional cubano. Eu não sou dos que acredita que promover reivindicações como a luta antirracista causa dano às instituições cubanas. Eu creio que não, que as fortalecem. Todavia, também não se pode descartar que gente que não nos queira pretenda utilizar não apenas essa, mas outras reivindicações para corroer nossas instituições. E qualquer exercício de transformação vinculado à escrita, à criação, à concertação, em minha modesta opinião, deve estar acompanhada dessa previsão. Eu creio que seja perfeitamente possível harmonizar, de dar a esse tema o peso que merece conciliando com o sistema institucional que é a Revolução. Creio que não fazer as duas coisas de uma só vez, seria ruim para a Revolução e para a causa específica que estamos defendendo e discutindo hoje. E como sabem, quase todos vocês, contem conosco, com nosso ministério, contem com nosso esforço que o Partido nos recomendou e que estamos fazendo para seguir junto em essa luta (Exposição de Fernando Rojas Vice-Ministro de Cultura de Cuba, na inauguração da Década dos Povos Afrodescendentes, em Havana, Cuba, em 20 de agosto de 20I4) ${ }^{115}$.

A posição apresentada por Fernando Rojas reflete muito da relação estabelecida entre Estado e as diferentes dimensões da Sociedade Civil cubana. É como uma relação sinérgica de retroalimentação entre essas duas dimensões. Todavia, no cotidiano desses coletivos e organizações e nas suas relações estabelecidas com o Estado, as minúcias são muito mais complexas.

A classificação da sociedade civil cubana, por Lissette Pérez Hernandéz, no artigo do "Granma" supracitado, traz essa relação estreita com a sociedade política, denominada na fala de Fernando Rojas como uma atuação social que deve ser conduzida pelo Partido e pelas instituições da Revolução. Nessa visão, uma não observância a esse ponto pode ocasionar dano ao projeto revolucionário. No que se refere especificamente à questão racial, a abordagem feita por Rojas ainda dá destaque a outro ponto central: os limites definidos para essa ação. O Partido orientou a debater a questão racial em conferências, seminários e que é um tema que, até o momento, ele não visualiza necessidade de ser tratado pelas organizações de base da Revolução, ou seja, na lógica dele, pela sociedade civil (organizações de massa da Revolução).

Essa ausência do debate racial traz impactos seqüenciais a toda a estrutura política e decisória do país, conformada para incorporar representantes oriundos dessa "sociedade civil oficial" nas Assembleias provinciais (estaduais) e na Nacional do Poder Popular. Uma grande parcela dos candidatos que se incorporam em cargos eletivos como delegados (para o nível estatal) e como deputados (para o nível nacional) provêm dessas organizações denominadas como "sociedade civil", as organizações de base da Revolução.

${ }^{115}$ Destaque meu e tradução minha. 
Caridad Massón ${ }^{116}$, ao abordar o sistema eleitoral cubano, fala do peso das indicações feitas pelas organizações de base para os cargos eletivos. Chegam a representar metade de todo o contingente do poder legislativo:

El sistema electoral de Cuba es bastante arbitrario. Tu vas a la base empieza muy democrático, tu puedes desde la base llegar a ser un delegado de base y llegar a ser diputado desde la base. En la base, la gente elije lo que quiere, sabe lo que quiere que quiere, pero ya de ahí para arriba empieza la selección. [...] Se divide el país en circunscripciones electorales, entonces en cada circunscripción de acuerdo a la cantidad de habitantes se puede elegir dos o tres personas que son los candidatos. [...] Es muy democrático, cualquiera puede salir de ahí. Pero de ahí para arriba es cuando empieza la cuestión ya ¿Quiénes son los de la provincia los que selecciona esa asamblea municipal? (Esos) salen de ese conjunto pero ya preseleccionados anteriormente. Lo digo con conocimiento porque yo fui delegada del poder popular y luego esa misma asamblea debe proponer los diputados a la asamblea nacional. Pero, aquí hay una cuestión, la asamblea nacional se divide como en el $50 \%$ son personas que salen de la base y el otro $50 \%$ lo nominan las organizaciones (de massa), o sea, la Federación de Mujeres Cubanas, los CDR. (Entrevista com Caridad Massón, realizada em 03/06/2015).

Essa "sociedade civil oficial", onde se conformam potenciais candidatos a delegados e deputados, não abarca as demais formas organizativas que classifiquei anteriormente como "sociedade civil reconhecida" e "sociedade civil dissidente". Conforme explicitado por Rojas em sua avaliação, esse não seria o momento em sua avaliação de incorporar na atuação dessas organizações o tema racial, o que é um dos fatores que invisibilizam o debate racial no âmbito das assembleias estaduais e nacional do Poder Popular. Esse silêncio foi rompido raras vezes, como no caso da intervenção de Heriberto Feraudy Espino, da Comissão Aponte, na VIII Sesión de la Asamblea Nacional del Poder Popular, em Havana, em 23 de dezembro de 201 I.

Os demais grupos antirracistas não possuem legitimação oficial de seu espaço. Há um limbo para a atuação deles, sejam os defensores ou contrários à Revolução. Em algumas das entrevistas, parte dos ativistas questionou termos como mobilização social (restrito no contexto da Revolução às atividades mobilizatórias das organizações de base, que eu denomino "sociedade civil oficial"), ativista (termo muitas vezes vinculado ao papel exercido de mobilização dos sindicatos nos centros de trabalho), militante (termo que designa os militantes do partido comunista) e a própria utilização do termo sociedade civil, pelo seu uso atrelado às organizações de base da Revolução, conforme discutido anteriormente.

O elemento da periculosidade, da manipulação pelo "inimigo", da ingenuidade dos ativistas, é outro elemento fortemente presente no imaginário e nas construções feitas sobre essa atuação

\footnotetext{
${ }^{116}$ Historiadora e pesquisadora do Instituto de Investigación Cultural Juan Marinello. A relação com Caridad foi iniciada em contatos, ainda no Brasil, na Universidade de Brasília, no segundo semestre de 20I3. Os preparos para vir a Cuba, e nossa vinculação oficial com o Instituto e a autorização para a pesquisa, tiveram grande contribuição de Caridad. No percurso da pesquisa de campo, além da entrevista que realizei sobre a pesquisa, organizamos diversas atividades, como seminário sobre o tema e projetos de cartografia social.
} 
social antirracista. Aparece destacado em diferentes abordagens feitas, especialmente por alguns membros da academia ou das estruturas estatais, sobre as mobilizações antirracistas no país.

Em situações mais extremas, as críticas de parte da academia se amplificam e ressoam questionamentos da própria mobilização antirracista e do uso de termos identitários tais como negros, afrodescendente e categorias como "cor" ou "raça". Chega-se a sugerir paralelismo entre essas lutas e o nazismo ${ }^{117}$, como no exemplo abaixo:

Para colocar el racismo contra la pared y extirparlo de un modelo socialista de desarrollo, en tanto incompatible con la condición humana y con la justicia social, no es posible constreñir el tema a un color, ni al perverso criterio de «raza». A estas alturas del estado del conocimiento sobre el tema, racializar el problema del racismo y la discriminación racial es un proceder tan racista como el mito fascista de lo «ario». Es tratar de apagar el fuego con combustible, es tratar de fragmentar la nación en un contexto internacional de alianzas e integración (GUANCHE, 2015 ${ }^{118}: \mathrm{s} / \mathrm{p}$ ).

Cabe traçar uma diferenciação do uso do termo "raça" por Estados totalitários e suas ideologias, do modo como se utiliza o termo "raça" em investigações sociais nas últimas décadas, e como ocorre nos movimentos sociais negros ou afrodescendentes. Como reflete uma vasta bibliografia, "raça" nesse contexto é uma construção social e política (HASEMBALG, 2005; GONZALES et al., 20II; HANCHARD, 200I; CARVALHO, 2005). O conceito "raça" é situacional e relacional. Sua conformação depende necessariamente de uma análise do contexto social ao qual se refere. Há uma ressemantização do termo para uma apropriação social e política de seu uso.

Fazer alusão ao processo de luta contra o racismo negro ou afrodescendente como equivalente ao nazismo ou a outros regimes totalitários, é ignorar o contexto e a lógica da construção de cada um desses processos históricos. A ideia do risco do "não alinhamento", ou da "não programação", tomando o termo utilizado por Esteban, demonstra um dos elementos presentes nessa relação entre as esferas da "sociedade civil", da "sociedade política" e do "Estado", que traz resultados para o cotidiano dos coletivos estudados nessa pesquisa, seja no nível individual, como coerções ou perda de cargos diretivos, ou coletivo, a partir de restrições impostas que dificultam sua operacionalização e a organização de suas atividades.

Mas, essa relação, especialmente no âmbito do que eu denomino "sociedade civil reconhecida" se dá de forma ambivalente, com relações conflitivas e coercitivas por um lado, e apoio pontual para atividades, por outro.

${ }^{117}$ Ver Guanche, 2015.

${ }^{118}$ Artigo disponível em: http://negracubanateniaqueser.com/2015/03/25/el-racismo-contra-la-pared/ 
Essas tensões não são as únicas dinâmicas existentes entre essas diferentes esferas, mas constituem-se como um elemento marcante. O receio de um fortalecimento da influência dos Estados Unidos no país "justifica" e permeia essas muitas dessas preocupações. Mais um dos reflexos dos estertores da Guerra Fria, em pleno século XXI.

Nas estratégias e na construção social dessas mobilizações antirracistas são elaboradas as categorias que definem quem são esses sujeitos. Os agentes sociais entrevistados para essa pesquisa se autodenominam de variadas formas e são percebidos também a partir de uma trama relacional complexa. As categorias concebidas em Cuba para tais agentes passam por processos muito específicos em relação ao vivenciado em outros meios sociais. São influenciados na atualidade pelo contexto da Revolução e de suas estratégias narrativas, pelos resíduos da Guerra Fria, mesmo em tempos de aproximação com o "inimigo", como é denominado por muitos por aqui os Estados Unidos, e pelos processos vivenciados a partir da crise dos anos 1990 de intensas mudanças no contexto social. Por outro lado, são também forjadas de forma local, a partir de uma trama de signos oriundos de processos diversos específicos.

Esse é um debate central para essa pesquisa. A construção de categorias, tais como "militante", "ativista", "liderança", "dirigente", socialmente dadas, permeia a atuação desses sujeitos e suas estratégias de reprodução e contestação da estrutura social. E narra o dinamismo que as mobilizações sociais têm encampado nos últimos tempos no contexto cubano. Nesse trecho da tese, privilegiei as percepções de cubanos de diferentes origens, idades e identidades raciais, sem vinculação com mobilizações antirracistas, para apresentar visões mais próximas do senso comum em relação a essas categorias.

Diferentemente do que ocorre em outros universos, como o brasileiro, o termo "militante" é empregado em Cuba de modo bastante específico. Remete-se aos militantes do Partido Comunista de Cuba ou aos militantes da Unión de la Juventud Comunista - UJC. Não se refere a outras instâncias de atuação social, nem mesmo àquelas organizações de base, vinculadas à estrutura da revolução, tais como a Federación de Mujeres Cubanas - FMC e os Comites de Defensa de la Revolución - CDR. Alguns dos atores sociais entrevistados para essa pesquisa declararam ser militantes do Partido ou que integraram a UJC, e fazem de forma marcada essa diferenciação, cabendo o termo militante a essas esferas. De acordo com Lizmare Machado Lao: 
"Militante en Cuba es el militante de la juventud y del partido, son las personas militantes que hay aquí en Cuba"III.

Nesse enredo construído pelo processo da Revolução, o termo "ativista", por sua vez, foi historicamente cunhado para os integrantes dos sindicatos e das demais organizações de base, da "sociedade civil oficial". Socialmente, esses "ativistas" têm o papel de mobilizar seus centros de trabalho para determinadas pautas, articular as diversas áreas para atividades que envolviam a mobilização de trabalhadores e de comunitários.

Aquí se le llama activista a personas que pertenecen a diferentes tipos de organizaciones puede ser tanto de masa como organizaciones de trabajadores, organizaciones de masas se le llama en Cuba a los CDR y la FMC y otro tipo de organizaciones es por los diferentes tipos de sindicatos, sindicato de la industria alimenticia, el sindicato del comercio y demás. Estas organizaciones tienen un activista. Este activista se desempeña en varias cosas puede ser, activista de emulación, de deportes que es el que organiza las actividades del deporte y demás dentro de una sección sindical o dentro del sindicato. En Cuba no existe un activista por si propio que pueda hacer una actividad dada, no existe, siempre está ligado a una organización de masas o alguna organización política. Se dice masa porque agrupa grandes masas no como el caso del partido y la juventud son personas seleccionadas por sus funciones, por su forma, por sus características que pertenezcan a esa organización se habla con ellos si quieren bien sino también. (Entrevista realizada com Liban Moya Hernandez, morador de Havana, realizada em 09/09/2015).

Liderança e líder são empregados em diferentes contextos e podem relacionar-se a agentes sociais com destacada atuação em ambientes oficiais ou com relações estreitas com o Estado, ou ainda para designar aqueles que atuam em diferentes frentes, como espaços comunitários, artísticos, acadêmicos, mesmo sem vinculação oficial.

Também se emprega o termo "dirigente" para referir-se a sujeitos com atuação junto a um determinado grupo social, também independente de haver alguma vinculação institucional ou não. O uso das categorias "líder" e "dirigente" muitas vezes se misturam do ponto de vista semântico, havendo uma predominância maior do primeiro nos usos cotidianos.

A forma como esses termos são empregados não é rígida, mas sua percepção social ampla indica um alto grau de convergência em seu significado. Esse processo começa a se embaralhar com mais força a partir dos anos 1990, especialmente com relação ao que se constrói como significado da categoria "ativista".

As mobilizações sociais, até então muito restritas às estruturas da Revolução e às organizações de base, como a FMC e os CDRs, começam a ganhar nova roupagem. É nesse período dos anos 1990, que surgem coletivos que tratam a pauta racial de forma mais autônoma em relação ao Estado. Sem oficialidade - nem como organizações não governamentais, nem como associações;

${ }^{\text {I19 }}$ Entrevista realizada em 09/09/2015. 
esses coletivos têm se amplificado nos anos 2000, e permeiam quase uma dezena de organizações, apenas no universo estudado para essa pesquisa.

No âmbito dessas mobilizações caracterizadas como sociedade civil mais desvinculada do Estado, muitos dos agentes sociais que as integram são denominados como "ativistas". Nesse caso, há um deslocamento semântico desse termo, que hoje abarca um universo de significados mais amplo. É o exemplo que podemos verificar, por exemplo, no caso de Gisela Arandia:

Si yo tuviera que definirme de una forma, yo diría que me siento fundamentalmente una activista social. Es ahí donde creo que me siento más cómoda. Entonces también por supuesto he tenido que expensar a mi esfuerzo, y del mundo académico, no solamente la licenciatura estoy en la fase de la discusión de mi doctorado en la pre defensa. Tal vez si no hubiera vivido en Cuba, eso no me hubiera interesado tanto, pero aquí el activismo social es casi como una mala palabra, es como un desprecio. Los activistas sociales aquí no se consideran como ocurre en Estados Unidos y Europa o en otros lugares de América Latina: Una activista social es una persona importante. Aquí los activistas sociales son como personas fracasadas (suena el timbre) como personas que no han tenido capacidad para buscarse una vida. Por ejemplo, en el contexto de la UNEAC lo que representa todo el aspecto del trabajo comunitario, se considera que la gente que está ahí o que hace un tipo de trabajo de otras son las personas que no tienen una obra, porque no saben escribir porque son frustrados, fracasados. Y lo más importante, tal vez por eso escribí un libro, en parte porque la gente me presionaba y porque sentía la necesidad de hacerlo (Entrevista com Gisela Arandia, realizada em 12/09/2014).

A abordagem de Gisela Arandia é sintomática, pois aponta o processo de coerção social vivenciado por aqueles que são vistos e atuam como "ativistas sociais" nesse sentido empregado, e as ferramentas utilizadas para agregar elementos que contrabalanceiem esse processo. Ela expõe algumas das concepções negativas vinculadas ao termo, como sendo pessoas fracassadas e frustradas. Um destaque importante é a ênfase dada para sua imersão no mundo acadêmico e no fato de ter escrito um livro, como elementos que confundem os sinais de desprestígio dessa categoria e incorporam maior legitimidade ao ativismo. Essa sinalização reforça a academia e o mundo letrado como o espaço legitimado, o espaço erudito socialmente valorizado em contraponto ao universo do ativismo.

Esse rápido debate é necessário, especialmente, para localizar os termos "militante", "ativista", "líder", "liderança", "dirigente" que usarei na presente pesquisa a partir do diálogo com o contexto no qual os mesmos são forjados. Para os agentes sociais dos coletivos antirracistas estudados, utilizarei, sobretudo, o termo ativista, por dialogar melhor com esse contexto das mobilizações sociais pós anos 1990, especialmente a partir das categorias nativas empregadas. 


\section{I.6. O Copo e o Racismo}

Nessa última seção do capítulo I, meu objetivo é fazer um diálogo sobre o que caracteriza a motivação desses movimentos que é a luta antirracista. Para falar de antiracismo, é importante falar de racismo propriamente e de como ele está presente na vivência concreta dos sujeitos, nas relações sociais. Sua expressividade ocorre em situações corriqueiras e cotidianas, como o compartilhar de copos, de espaços sociais, de construção de papeis sociais.

Para tratar de mobilizações antirracistas, que se contrapõem a um "colonialismo interno", a partir do conceito dado por Zurbano (2015), cabe refletir sobre o racismo enquanto ideologia de poder que incide nos corpos sociais e se inscreve em suas relações. Para abordar a expressão do racismo na sociedade cubana contemporânea, Zurbano trabalha o conceito de neo-racismo, conforme exponho a seguir:

Llamo neo-racismo a un fenómeno que integra gestos, frases, chistes, críticas y comentarios devaluadores de la condición racial (negra) de personas, grupos, proyectos, obras o instituciones. No se trata de simples gestos $\mathrm{u}$ opiniones personales marcadas por el prejuicio racial, sino de conductas que ejercen tal prejuicio sin miramientos y se producen hoy en espacios públicos institucionales o no -incluyendo los medios de difusión y la publicidad- que resultan lesivas y humillantes para aquellos a quienes se dirige, aunque algunos les aceptan acrítica o irremediablemente. Se suman a esto ciertas prohibiciones burocráticas, limitaciones administrativas y exigencias policiales que, injustificadamente, colocan a las personas negras en desagradables situaciones por su evidente o velado matiz racista; dichas situaciones aunque no siempre resulten denunciadas, publicadas o criticadas por aquel que las sufre, forman parte de un creciente y cotidiano anecdotario que suele atravesar todas las generaciones, profesiones y sexos de estas personas, generalmente de tez muy oscura, haciendo un énfasis mayor entre los jóvenes, pero también entre mujeres y ancianos. (ZURBANO, 2012: 4-5).

Zurbano levanta questões fundamentais vivenciadas na complexidade das relações raciais na sociedade cubana de hoje: os espaços marginais, a invisibilidade e o silenciamento desse debate, as estratégias de coerção ao tema (institucionalizadas ou não) e a desigualdade crescente, sobretudo desde os anos 1990. E faz um destaque pouco presente nas narrativas sobre o racismo em Cuba: ele não surge como fenômeno apenas no período especial, é anterior a ele.

Em muitas das abordagens feitas sobre o tema durante a pesquisa, o racismo é concebido como um elemento restrito ao íntimo e silencioso seio das famílias e aos aspectos subjetivos individuais. Assim reforça a ideia que o racismo enquanto fenômeno estrutural (aqui incluindo a dimensão institucional) não era uma variável social presente nas décadas de 1960, 1970, ou que seus resquícios seriam dissipados com o avançar das políticas igualitárias da Revolução e a extinção das classes sociais. Após mais de cinqüenta anos de Revolução, com o dinamismo social e especialmente com a crise dos anos 1990, as relações raciais e o próprio racismo passam a ser 
variáveis a serem consideradas. A fala de Fernando Rojas, vice-ministro de Cultura de Cuba reconhece que o racismo é um fator que merece atenção e cuidado:

[...] Durante muito tempo a realidade nos levava a crer que não era necessário adotar de forma direta ações contra o racismo e a discriminação. E havia a ideia de que a mesma transformação social acabaria com todas as formas de discriminação, de um modo mais ou menos automático. Eu creio que a mudança nas circunstâncias na vida material e espiritual tem nos ensinado que isso não é automático, e que as reivindicações que em algum momento nos pareciam parciais, são também reivindicações políticas. E me parece que essa compreensão vem crescendo e que dela devemos extrair a resposta às perguntas que se fizeram aqui, e a outras que já se fizeram antes e a outras que ainda virão. (Exposição de Fernando Rojas Vice-Ministro de Cultura de Cuba, na inauguração da Década dos Povos Afrodescendentes, em Havana, Cuba, em 20 de agosto de 20I4) $)^{120}$.

Como ideologia, o racismo opera na ordem do subjetivo, não se propaga apenas em situações de desigualdade econômica. O próprio silenciamento para a questão, fomentado a partir de 1962 , ocultou diversos processos discriminatórios que se davam no cotidiano da sociedade cubana, e que nessa pesquisa afloram a partir das falas dos ativistas entrevistados, como relatado por Zurbano:

Mi abuela tenía un amigo que se llamo Compadrito, que era un gran santero que vivía allá en Vegas, que ella iba el 3 de diciembre a cocinar, a matar animales y a cocinar porque era un gran santero para celebrar Santa Bárbara, Chango el 4 de diciembre. A Compadrito le quitaron todos los santos y se lo montaron en un camión y se lo llevaron a la policía. Eso es hizo en Cuba, y a la semana se lo devolvieron todo. Pero ese tipo de humillaciones se hizo porque un santero era algo de un rezago del pasado y para el mundo los soviéticos eso era un animismo una cosa terrible y aquí esas marcas y esas modas y esos dogmatismos y esos extremismos se vieron y este hombre sufrió mucho por ese fenómeno y tuvo como dos años que no pudo celebrar fiesta de santo. (Entrevista com Zurbano, realizada em I5/I0/20I4).

O racismo esteve presente não apenas na perseguição de práticas tradicionais de origem africana, como também em situações nas quais excluiu negros e negras dos espaços de liderança, como no vivenciado por Mavis no processo de formação das cooperativas agrícolas, nos anos 1970:

Yo tuve una experiencia en el campo de La Habana. Y acá pasó algo muy curioso. Preparando las condiciones para formar las cooperativas, lo primero que hacíamos era buscar a los líderes del lugar, que era nuestro punto de apoyo y buscar a quién se proponía a estar ahí. Había un hombre que era campesino, más revolucionario, más trabajador, era miliciano. Ese es el hombre de aquí para la tarea de promover la cooperativa. Déjame decir que cuando presentamos esa propuesta, mire piensen en fulano. (Dijeran:) "Un negro dirigindo la cooperativa? No! Hasta ahí no llegó yo". Y ese hombre, que nosotros lo llevamos y lo propusimos, pero no votaran por él. Propusieran otro y el que salió fue otro, un blanco. Esa fue una experiencia que tuve aquí, en la provincia Habana, en el campo. Estoy hablando de 1976, 1977. Fíjate que después de tantos años de la Revolución, todavía había gente que decía: "Como a ustedes se le ocurre ponerse un negro a dirigir una cooperativa de blancos?" (Entrevista realizada com Mavis Alvarez, em 28/05/2014).

O recurso de remeter a existência do racismo apenas pós-período especial, nos anos 1990, reduz e distorce as vivências que trazem uma multiplicidade de experiências com o tema ao largo dos anos da Revolução. Contudo, as reflexões sobre a questão racial nos impõe a necessidade de se analisar com cautela esses processos.

${ }^{120}$ Tradução minha. 
As ações empreendidas pelo viés inclusivo da Revolução não podem ser desconsideradas, especialmente no tocante ao acesso a políticas públicas. A última pesquisa censitária feita antes da Revolução (1953) em comparação com a realizada em I98I $^{121}$, que publicou alguns dados desagregados por cor, demonstra um significativo avanço de equiparação entre negros e brancos. Nesse período, como destaca De La Fuente (2014), a expectativa de vida era bastante alta em comparação com demais países da América Latina, além de ser mais equânime entre brancos e negros. O mesmo se refletia no acesso à educação, inclusive no nível universitário (DE LA FUENTE, 2014: 397).

Mas, a alta hierarquia política mantinha um padrão embranquecido, assim como os meios de comunicação e a abordagem histórica e cultural na educação. Havia a vinculação de tradições de origem africana, tais como a Santeria, Palo Monte e Abacuá, com primitivismo, animismo e periculosidade. As denúncias de racismo e discriminação foram por décadas ocultadas, e até a atualidade há dificuldades legais e institucionais para encaminhá-las. São vários elementos que trabalhavam o reforço de uma sobrevalorização branca e uma negação ou visão estigmatizada da identidade negra.

Zurbano, a seguir, reflete que há um crescente nas manifestações racistas, a partir dos anos 1980, do que ele denomina neo-racismo. Muitos dos pontos levantados por ele como exemplos da existência do racismo se mostraram presentes em períodos anteriores à década de 1980, conforme já argumentei anteriormente, o que questiona a visão de que o racismo como fenômeno surge a partir do período especial:

Dichas manifestaciones neo-racistas vienen expresándose, desde mediados de los años ochenta, con cierta impunidad a través de chistes, comentarios, declaraciones e imágenes publicitarias; pero también de modo muy sutil en la presencia excesiva de personas negras en barrios marginales, en cárceles, en trabajos manuales y mal remunerados y otro "oficios" de dudosa reputación social, contrastando con la escandalosa ausencias de personas negras en importantes sectores de la sociedad, que van desde los medios masivos, pasando por los esplendorosos espacios turísticos y del mercado en divisas hasta las altas esferas del Estado. No se trata de un fenómeno que irrumpe con la crisis económica y la caída del campo socialista; creo que el neo-racismo adquiere en los años noventa una velocidad, visibilidad y mutaciones muy significativas, pero germinó en etapas anteriores al llamado Periodo Especial. (ZURBANO, 20I2: $4-5)$.

A falta de debate sobre o tema e de um aprofundamento dos estudos das ciências sociais acerca das relações raciais é outro importante reflexo. Sintomático perceber que em Cuba, a antropologia biológica possui visibilidade, muitas vezes superior à social. Vinculada à faculdade de biologia da Universidade de Havana, há uma cátedra de antropologia biológica. Em contraponto, não há nenhuma instância que forme antropólogos sociais em Cuba. As poucas e localizadas experiências

I21 O censo de 1970 captou essa informação, mas não houve divulgação de nunhum desses dados. 
de formação de antropólogos de viés mais cultural e social não tiveram prosseguimento ao longo dos anos.

Os estudos produzidos sobre o tema, em uma grande medida, refletem um debate geneticista sobre raça. Na Convenção Internacional de Antropologia, realizada em março de 2015, os estudos de maior destaque enfocavam essa dimensão. A conferência magistral, feita por Beatriz Marcheco Teruel, do Centro Nacional de Genética, tinha como título: "Color de la piel, mestisaje étnico e identidad genética". O estudo apresentou os resultados sobre a composição genética da população cubana.

Na matéria publicada no Granma, no dia 10 de março de 2015, sobre a conferência de Beatriz, destaca:

El más reciente estudio realizado por un equipo de profesionales en el campo de la genetica, para caracterizar la estructura de la población cubana, reveló las peculiaridades del mestisaje en nuestro archipiélago y el origen de nuestros ancestros, y sobre todo, corroboró la certeza martiana de que no hay razas, y aquella del acervo popular: En Cuba, quien no tiene de Congo, tiene de Carabali".

$\mathrm{Na}$ conferência magistral, a pesquisadora ressaltou, ainda, que na mostra de I.0I9 homens e mulheres de todas as províncias de Cuba, $72 \%$ dos marcadores genéticos são provenientes de ancestrais europeus, 20\% de africanos e $8 \%$ de nativos americanos. As conclusões desse estudo nos levam a algumas breves reflexões. Haveria alguma dúvida sobre a miscigenação genética da espécie humana? A principal conclusão do estudo é afirmar a mestiçagem das raças. Em alguma medida, essa mestiçagem sugere alguma matriz pura? Se os seres humanos todos são provenientes do continente africano, de acordo com os registros fósseis e estudos sobre a origem da espécie humana (FOLEY, 2003; PENA et al. 2005-2006), quais são os objetivos de dados como: "72\% dos genes dos cubanos são provenientes do continente europeu" ou "20\% são provenientes do continente africano"?

Por fim, o mais sintomático do estímulo a pesquisas que visam comprovar as particularidades da mestiçagem genética cubana é não haver semelhante atenção a pesquisas sociais que versem sobre a questão racial, apesar da grande relevância que esse tema tem na atualidade. Com relação aos estudos genéticos sobre raça, há uma severa crítica à sua percepção como uma construção biológica:

No passado, a crença de que "raças" humanas possuiam diferenças biológicas substanciais e bem demarcadas contribuiu para justificar discriminação, exploração e atrocidades. Recentemente, porém, os avanços da genética molecular e o sequenciamento do genoma humano permitiram um exame detalhado da correlação entre a variação genômica humana, a ancestralidade biogeográfica e a aparência física das pessoas, e mostraram que os rótulos previamente usados para distinguir "raças" não têm significado 
biológico. Pode parecer fácil distinguir fenotipicamente um europeu de um africano ou asiático, mas tal facilidaed desaparece completamente quando procuramos evidências dessas diferenças "raciais" no genoma das pessoas. Apesar disso, o conceito de "raças" persiste, qua construção social e cultural. (AZEREDO, I99I apud PENA et al. 2005-2006).

Se por um lado, as diferenciações genéticas entre os grupos humanos não fornecem evidências científicas da diferença de raças do ponto de vista biológico, raça enquanto uma construção social é sim relevante na análise de como se moldam relações no âmbito societário, como pondera Azeredo acima. E as percepções sobre raça a partir dessa dimensão social e suas implicações são pouco abordadas em estudos e pesquisas sociais em Cuba, mesmo já representando um crescente em relação aos anos I960, I970 e I980.

Cento e vinte e nove anos após a abolição da escravidão, cento e quatorze anos após a proclamação da República de Cuba, cinqüenta e seis anos após a Revolução socialista, os negros em Cuba estão sobrerrepresentados nas camadas mais vulneráveis, nos bairros com maior percentual de moradias precárias com risco de desmoronamento, nos cárceres, e sua presença vem decrescendo nos últimos anos nos níveis mais elevados de ensino ${ }^{\mathrm{I22}}$.

Para além de resquícios ou resíduos da escravidão, do regime republicano, as dinâmicas de desigualdade racial incidem na sociedade atual e são reconfiguradas no presente. Para Nascimento (1980: 35), na América Latina, se pratica a discriminação racial de maneira mascarada, sutil, aberta ou encoberta. Essa discriminação utiliza as diferentes tonalidades de cor epidérmica do negro como mecanismo para conseguir que o homem negro desapareça através da ideologia do branqueamento.

Wieviorka (2007) aponta que o racismo surge na linguagem corrente das sociedades ditas ocidentais no período compreendido entre as duas guerras mundiais e passa a ser conhecido mundialmente no pós-guerra. Sua inscrição como palavra é recente no dicionário Larousse, feita em 1932. As práticas e ideais que fundamentam esse conceito são muito anteriores, ganhando um caráter específico com o colonialismo europeu sobre a África e América.

Todavia, o fenômeno do racismo é muito anterior, e esteve presente em diversas sociedades humanas, como destaca Moore (2007: 38): "O racismo é um fenômeno eminentemente histórico, ligado a conflitos reais ocorridos na história dos povos". Moore faz um estudo de diversos textos sagrados que datam de períodos muito anteriores a idade moderna, mas já indicam a presença do racismo nas relações estabelecidas entre os povos.

${ }^{122}$ Dados específicos sobre esse tema podem ser vistos na seção "A Cor dos Números", nessa tese. 
Dentre as referências trazidas pelo autor, está Rig-Vega, texto sagrado indiano que aborda a "raça negra" em um duplo significado de conflito e de maléfico, perspectiva recorrente em outras literaturas religiosas dos povos euro-asiáticos e semitas, como destaca Moore:

De entrada, nota-se que a autodenominação das tribos leucodérmicas invasoras, procedentes do sul do Irã e da Ásia Central, é arti, ou ária (traduzido por: "gente de pele nobre"), e que seus oponentes, os negros dracidianos, são designados globalmente como dasyu ( denominação coletiva para "negros") ou anasha ("gente de nariz chato"). Assim, o Rig-Vega relata que Idra, suposto líder dos invasores arianos, logo transformado em semi-Deus, ordenou a seus súditos guerreiros para "destruir o dasyu" e "eliminar a pele negra da face da Terra". O Rig-Veda, que descreve os grandes combates entre esses brancos e os autóctones negros em termos de uma luta entre a "luz" e as "trevas", diz, textualmente, que Indra "matou os bárbaros de nariz chato (anasha)" e "assoprou com força sobrenatural, fazendo desaparecer da terra e dos céus a pele negra que Indra tanto odeia" (Soma Pavamana 9.73.5). Após a vitoriosa conquista das terras dos anashas, relata o Rig-Veda, Indra ordenou a seus seguidores para "desencouraçar as peles negras dos anashas". (MOORE, 2007: 5I).

O conceito de raça e a forma como esse conceito baliza a ideologia racista colonial não exclui a perspectiva de que o racismo como prática foi o alicerce ideológico de muitas das relações estabelecidas entre povos ao longo da história da humanidade, como exemplifica Moore. No presente trabalho, até pelos efeitos vivenciados no contexto de estudo terem relação com perspectivas coloniais sobre o fenômeno do racismo, o enfoque dado será desse período em diante.

Arendt (2006) reforça o processo de construção da ideologia racista no século XVIII e sua emersão nos países ocidentais durante o século XIX. Nessa caminhada, no século XX, o racismo foi um dos pilares da ideologia da política imperialista. Essa virada traz mudanças estruturais, uma vez que "a ideologia difere da simples opinião na medida em que se pretende detentora da chave da história, e em que julga poder apresentar a solução dos "enigmas do universo" e dominar o conhecimento íntimo das leis universais "ocultas", que supostamente regem a natureza e o homem” (ARENDT, 2006: I89). Para a autora, poucas ideologias sobressaíram-se de forma tão enfática. Dessas, destaca duas: a ideologia que interpreta a história como luta de classes e a que interpreta a história como uma luta natural entre raças.

Como ideologia, o racismo baliza-se não apenas em aspectos doutrinários teóricos, mas fundamentalmente políticos. Arendt (2006) coloca que "toda ideologia que se preza é criada, mantida e aperfeiçoada como arma política e não como doutrina teórica”. E os impactos dessa ideologia são brutais para pensarmos as sociedades modernas:

O racismo pode destruir não só o mundo ocidental, mas toda a civilização humana. Quando os russos se tornaram eslavos, quando os franceses assumiram o papel de comandantes da mão-de-obra negra, quando os ingleses viraram "homens brancos" do mesmo modo como, durante certo período, todos os alemães viraram arianos, então essas mudanças significaram o fim do homem ocidental. Pois, não importa o que digam os cientistas, a raça é, do ponto de vista político, não o começo da humanidade, mas o seu fim, não a 
origem dos povos, mas seu declínio, não o nascimento natural do homem, mas a sua morte antinatural (ARENDT, 2006: 187).

O imperialismo tem como sua principal arma ideológica, de acordo com Arendt (2006), o racismo. A noção de racismo é estreitamente vinculada à noção de raça e se manifesta de distintas formas. Wieviorka (2007) destaca alguns conceitos que diferenciam suas formas de manifestação: (I) Racismo Científico, que alega a existência de raças cujas características biológicas e físicas teriam direta correlação com as características psicológicas e intelectuais; (2) Relações Raciais e o conceito de Raça como constructo social e político, onde o racismo se estrutura a partir das relações; (3) Racismo Institucional, que trata do racismo estrutural que opera para a manutenção do status quo desigual, independente de explicitação de preconceitos ou discriminações, como está presente na diferenciação de isolamento de grupos raciais em bairros, escolas e empregos, por exemplo; (4) Racismo Cultural, que passa do discurso sobre a inferioridade biológica para a inferioridade cultural. Nesse caso, a diferença cultural legitimaria o discurso racista.

Para Lawrance (2004), o racismo estrutural é fundado na normalização e legitimação de uma variedade de dinâmicas - históricas, culturais, institucionais e interpessoais - que rotineiramente estabelecem vantagens aos brancos, produzindo resultados adversos, que podem ser cumulativos, para os sujeitos estigmatizados por sua identidade étnicorracial.

Esse processo constitui um sistema hierarquicamente desigual, caracterizado principalmente pela supremacia branca, que gera preferências, privilégios e concentração de poder para as pessoas brancas, em detrimento de grupos racialmente oprimidos, como os negros, e outros grupos étnicos como povos indígenas, ciganos. A escola é um espaço onde essa ideologia racial se materializa com grande ênfase:

En la escuela hay muchos elementos conservadores en la enseñanza. No se habla de la raza porque todos los cubanos somos iguales. Martí lo dijo, cubano es más que negro, más que blanco, más que mulato. Pero hay negros, blancos y mulatos y entonces en esa diferencia los padres, los niños negros, los niños blancos que no tenían las mismas oportunidades y que no pensaban igual y que hay refranes y modos de sociabilidad y que hay maneras de jugar maneras de socializar, maneras de no socializar en determinados momentos o socializar para una cosa y para otra cosa no, o socializar solo cuando estás obligado en espacios públicos como la escuela, las movilizaciones etcétera. Pero puertas adentro de tu casa, la historia es otra y se educa de otra manera, y se comenta de otra manera y se emiten criterios racistas de todos modos. Eso yo lo aprendí porque era así por ejemplo había cumpleaños de muchachos en la cuadra que se hacían de niños y la abuela dice a este no vamos y a aquel si vamos, estos no nos invitaron y estos sí y uno no va a donde no lo inviten, usted tiene que ser digno y respetarse mucho si no lo invitan usted no va a ese lugar porque si va y alguien le recuerda que no ha sido invitado usted es humillado y al que te humille tú tienes que responder, aunque sea violentamente pero tienes que responder. Creo que (la educación para tratar esos temas) no está en la manera de educar en Cuba, no ha estado nunca en la manera de educar en Cuba. (Entrevista com Roberto Zurbano, realizada em I5/I0/20I4).

Zurbano dá destaque à dimensão da ideologia da "cor cubana", da "identidade cubana" que sufoca e invisibiliza as demais identidades e como esses aspectos são daninhos ao amadurecimento 
dessa questão na sociedade e nas relações sociais. Roberto Diago, em depoimento apresentado no documentário Raza (2008) fala da forma como os traços físicos negros eram tratados no ambiente escolar, e como isso incidia numa construção corpórea desvalorizada:

Fuimos tan maltratados que en ocasiones hemos sentido complejo de nuestros labios, lo que se dice "bemba". Yo recuerdo cuando yo era niño, en la foto del dia de las madres, venia un fotógrafo a tirar las fotos y la maestra me decía: esconde, esconde la "bemba". Y yo lo hacía. ¿Pero "bemba" que "bemba"? ¿Yo tengo labios gruesos, y qué? "Bemba", "Pasa". ¡Imagínate! Esos son traumas que van existiendo y llega un momento determinado que la persona empieza a sentir odio por uno mismo".

Ambas as abordagens são interessantes para tocar o chão das experiências vividas, para possibilitar o contato de como a ideologia do racismo se concretiza nas relações sociais e nos corpos sociais. Esse último relato de Diago dialoga com o que Gomes (2005) caracteriza como racismo: comportamento resultante da aversão, por vezes, ódio, em relação a pessoas que possuem um pertencimento racial observável por meio de sinais, como cor da pele e tipo de cabelo. Percebido por muitos como uma brincadeira, o uso de termos pejorativos como bemba e pasa para classificar os traços negros, de forma pejorativa, como vivenciado por Diago e tantos outros, expressa uma aversão e uma repulsa em relação às características fenotípicas negras, bem como reafirma o espaço hegemônico branco da beleza.

Por outro lado, é exatamente na vivência concreta do racismo que surgem dois processos importantes presentes nas percepções dos ativistas: um seria a "consciência racial", desdobrada a partir da compreensão desses fenômenos e de como está presente a ideologia racista nesse campo. É o processo de quebra de naturalização das praticas racistas no cotidiano social. A outra dimensão é a motivação para a ação, para a mobilização, que também decorre de experiências geradas a partir de vivências de discriminação racial e racismo desses sujeitos.

Esses conceitos, mais uma vez, cobram sentido em situações vivenciadas e nas construções simbólicas que são feitas a partir dos preceitos racistas. O relato de Regla Mirón ${ }^{123}$, liderança comunitária de seu bairro, La Marina, Matanzas, de suas primeiras reuniões com o grupo de educação popular de sua região, é sintomático dessa materialização do racismo nos sujeitos sociais:

Lo que yo no estudié, empecé a estudiarlo en la educación popular. Ahí me fui metiendo dentro de esas cosas de los talleres. El primer día para mí fue funesto. La primera reunión con ese grupo gestor, una parte había unos cuantos negritos, o vamos a decirle, yo y el Kimbo nada más éramos negritos, y todos

\footnotetext{
${ }^{123}$ Regla é uma das lideraças comunitárias do bairro La Marina, em Matanzas, Cuba. É educadora popular e atualmente diretora do Centro Comunitário de Cultura do bairro. Tive encontros com Regla durante a pesquisa, em seu bairro, apenas no início do campo, no primeiro semestre de 20I4. As causas desse distanciamento de Regla das pesquisas em curso e do projeto criado por alguns dos moradores do bairro, o Identidad y Barrio La Marina, foram geradas por conflitos entre as lideranças comunitárias, por distintas posições nas propostas para a comunidade.
} 
los demás eran blanquitos. Cuando yo llegue el primer día, había un solo vasito y era plástico, había un termo de café, no había más nada. Yo no hable, yo no decía nada porque imagínate tu, los blanquitos estos, ¿para que yo vine? [...] Yo vi que empezaron a tomar del mismo vaso los blanquitos y Kimbo que era el negrito. Yo, muy molesta, ¿pero, esto que cosa es? Los blanquitos y los negritos tomando en el mismo vaso, ¿y eso que cosa es? Yo no voy a tomar y no tomé. Al segundo encuentro, la segunda reunión, ya cuando llegamos, nos daban un beso, se daban besos, yo no acostumbraba de darme besos con mi mama y mi papa. Porque mi papa era un señor mayor, negro, estibador, abacua, que yo no podía sentarme en las piernas de él, porque él decía que no, porque él era hombre y yo una niña y toda esa serie de cosas y eso se me fue metiendo dentro. Yo me recuerdo que mi papa me daba besos nada más el día de mi cumpleaños, de ahí en fuera no me daba más besos, me lo daba todo en la vida pero no me daba besos y a veces un beso significa mucho. Y entonces bueno, yo vi que todo el mundo se daba un beso cuando llegaba. ;"Mira Regla volvió a venir"! ¡Ah! Los besos de blanquitos. Eso fue para mí una enseñanza. No había más vasos y había calor y tenía ganas de tomar agua y me gustaba el café y fumarme un cigarro, entonces me dije: si el Kimbo, negrito, toma vaso, toma café y agua en un solo vaso de los blanquitos, entonces yo misma dije, es porque él tiene el carné de salud actualizado. Yo también voy a tomar y empecé a tomar mi café con los blanquitos en un solo vaso. Ya después en la otra reunión, yo lleve vaso, conseguí vasos y lleve y empezamos a beber todos, pero ese choque de un vaso para mi significó mucho (Entrevista com Regla Gonzales Miró, realizada em 24/06/20I4).

Durante a pesquisa e a vivencia em Cuba, por diversos momentos, escutei frases como "los negros son más racistas que los blancos". O relato de Regla, para mim, é bastante simbólico de como a ideologia racista, vivenciada pelos atos discriminatórios e pelos estereótipos no cotidiano das relações sociais, se internaliza nos corpos e nos hábitos. E eles passam a ditar formas de comportamentos, conscientes ou não, baseados na superioridade branca.

Não que os negros sejam mais racistas que os brancos, como alguns alardeiam nessa popular frase cubana. Os negros estão inseridos num contexto social que forma e informa seus valores, moral, ideologia e subjetividades. A ideologia racista, contudo, não pode ser atribuída aos negros. No contexto pós colonial vivenciado pelos países latinoamericanos, dos quais Cuba se inclui, a ideologia racista jamais foi uma estratégia de poder e supremacia negra. O que torna essa avaliação do senso comum deslocada ao imputar aos próprios negros a prática mais violenta do racismo.

Um dos exemplos do que acabo de mencionar está em um dos pontos abordados no relato de Regla. O seu interdito para dividir o copo com os demais "blanquitos" não era relacionado com a percepção de que esses últimos eram inferiores, sujos, indignos desse compartilhamento. Esse lugar do indigno estava repousado, exatamente, na percepção de Regla sobre ela mesma e sobre o grupo racial que ela concebia que fazia parte, grupo do qual incluía também Kimbo. Um dos pontos que representam essa percepção, nessa frase, está no choque de Regla ao visualizar Kimbo, também, negro, tomando água e café no mesmo copo dos "blanquitos" e que ele deveria estar fazendo isso, pois seu "carné de salud devia estar atualizado".

Numa sociedade onde os valores vinculados à branquitude são estimulados nos meios de comunicação, no sistema educacional, nas relações familiares e sociais mais amplas, nas estruturas 
de poder político e econômico, existe, por outro lado, a construção reversa de imagens negativas e preconceituosas em relação ao negro. Mesmo os próprios sujeitos sociais que se identificam e são vistos como negros não estão imunes ao preconceito contra o negro. Os efeitos do preconceito podem gerar a interiorização por pessoas do próprio grupo discriminado, o que gera impactos na auto-estima.

O cerne das relações raciais em países como Cuba e Brasil, onde as situações de racismo não são necessariamente explícitas, não estão em códigos legais, nem em políticas segregadas, está na ideologia racista que permanece viva na dimensão subjetiva que, concretamente, delineia as relações sociais e os espaços econômicos e de poder. Por isso, o processo de ressemantizar esses símbolos, esses estereótipos, essas subjetividades é tão complexo. Mas, ao menos em parte, esse é um dos grandes desafios que se propõem as mobilizações antirracistas em Cuba. 


\section{Capítulo 2 - Subversão histórica e Mobilizações Negras em Cuba}

Abordar a contemporaneidade da questão racial e das mobilizações antirracistas em Cuba passa, necessariamente, por um olhar sobre períodos passados nas estruturas presentes. A construção e reconstrução das narrativas sobre as lutas antirracistas na história de Cuba compõem um significativo elemento das estratégias discursivas de muitos desses ativistas, grupos e coletivos.

O reposicionamento das peças da história, dos "heróis" e "heroínas", a visibilidade de lutas e batalhas ocultas conforma uma das importantes estratégias de fortalecimento identitário, do estabelecimento de redes de solidariedade, além de representarem suportes históricos para demandas e ações do movimento afrocubano.

Esse processo de repaginar os marcos históricos permeia a complexa rede de memórias que expressa como os sujeitos concebem seus referenciais ao longo do tempo, o que reforçam e trazem à tona e o que ocultam. Sider (1993: 06), ao analisar a relação ente os povos Lumbee e o Tuscarora, da Carolina do Norte (EUA), reflete sobre as diferentes abordagens acerca de suas origens históricas e como elas se mesclam com as múltiplas estratégias para lidar com as relações de dominação.

Contrapõe o que os antropólogos influenciados pela tradição de Malinowski chamariam de história como "mapa" ou "history as a charter". Argumenta que pode até haver esse processo, mas reduzir a utilização da história por esses grupos para um determinado fim acaba como por invisibilizar as tensões, as relações de poder hierarquizadas, os medos e angústias envolvidas.

Nesse estudo de Sider (1993), os atores sociais concebem histórias tanto míticas como presumivelmente reais para justificar ou legitimar interesses e demandas coletivas. Por um lado, converte-se a história como um fenômeno intelectual, um assunto de ideias e palavras, suavizando a expressão material direta da história. O autor destaca que as múltiplas maneiras de como as histórias das pessoas se moldam em seus corpos e vidas fazem com que as conexões entre a história e os interesses do grupo apareçam sem fissuras e costuras. É o processo no qual um povo confronta de forma antagônica não apenas a versão de sua história feita por outros, mas suas próprias.

O panorama, portanto, expressa, simultaneamente, ambas posições: as histórias importadas dos sistemas dominantes em transformação e as histórias reclamadas da vida cotidiana. A construção 
de uma releitura do passado e de uma visão de futuro envolve a mobilização das pessoas para aceitarem uma nova história, que se move contra as correntes de poder da história presente. Permeia as histórias múltiplas que os grupos vivem interna e externamente, as histórias de seus sonhos e esperanças e aquelas vinculadas às relações de poder, provenientes da consciência que eles possuem sobre o que lhes ocorreu e o que ainda poderá ocorrer (SIDER, I993).

As reflexões de Sider são inspiradoras, mas é preciso explicitar diferenças das realidades pesquisadas por ele e por mim. Cabe destacar, primeiramente, que o universo social que estudei não se constitui como um grupo étnico específico. Os ativistas e organizações afrocubanas conformam uma rede de atores que atuam a partir de uma identidade racial e se organizam na pauta antirracista.

O relevante dessa discussão da construção de novos referenciais históricos, ou do reposicionamento dos existentes, é que essa é uma estratégia marcante na conjuntura cubana. É um processo protagonizado não apenas por ativistas, como também por intelectuais e acadêmicos que têm, sobretudo nas últimas décadas, produzido novas perspectivas sobre a história de negros e negras em Cuba. São perspectivas bastante silenciadas e invisibilizadas até os dias atuais.

A experiência dos movimentos, segundo Gohn (20II), não provém de forças congeladas do passado, embora essa memória tenha importância crucial que, quando resgatada, dá sentido às lutas do presente. A forma como se sucede a incorporação e ressignificação desses referenciais históricos, a partir da ação militante desses agentes sociais e coletivos, demonstra como os olhares para essa trilha histórica são diversos e podem abarcar diferentes perspectivas e visões.

No caso dos Estados Unidos e a construção de seu enredo de Nação, Stolkin (apud FURNISS, 1998) argumenta que o tema relacionado à "regeneração por meio da violência", o imperativo moral da agressão como meio para alcançar o "processo" e a "civilização" tem sido fundamentais para moldar as construções passadas e presentes da identidade estadunidense, assim como sua política externa e interna.

Furniss (1998: I8) reflete sobre outra dimensão que diz respeito à forma como a complexidade dos processos históricos se reduz a uma série denominada por Raymond Fogelson como "eventos epitomizantes", que seriam incidentes dramáticos que servem como símbolos condensados, convenientes e facilmente assimilados. Esses "eventos epitomizantes" se relacionam tipicamente com as ações heróicas dos indivíduos cujos valores, princípios morais, motivações para a ação 
definem os ideais públicos. No caso de seu estudo sob o universo estadunidense, alguns dos exemplos seriam "a liberdade", "a coragem", "o progresso por meio do trabalho árduo".

Dialogar com Stolkin sobre o caso cubano é relevante, pois os processos históricos narram e justificam as ações presentes e moldam a "identidade cubana" como "resistente", "revolucionária", "anti-imperialista". Esses processos se amparam nos "eventos epitomizantes", aqueles que são facilmente acessíveis na memória coletiva e constroem o enredo de nação. Alguns dos eventos epitomizantes que balizam os princípios morais da Revolução são encontrados em outdoors, paredes de escolas e ruas, nos livros de história e programas televisivos. A campanha de alfabetização, a reforma agrária, as ações para a superação da segregação racial em bancos, parques e praias e o próprio triunfo revolucionário são alguns dos eventos "epitomizantes" que marcam a nação cubana.

Esses eventos epitomizantes construídos como narrativas totalizantes da história e da construção do ideal de Nação são criticados por ativistas e coletivos. A crítica refere-se à invisibilidade dos signos e narrativas dos afrocubanos na história de Cuba e nos meios educacionais, como destaca Esteban Morales:

\begin{abstract}
El tema del racismo y la discriminación no hemos avanzado lo suficientemente, yo diría que es uno de los temas, o posiblemente uno de los temas más atrasados dentro de la sociedad cubana del que menos conciencia tenemos del que menos respuesta institucional tenemos porque hasta hoy en nuestras escuelas primarias no se menciona el color y hasta hoy mismo el tema racial en nuestras universidades no se estudia, se estudia, en centros especiales muy localizados como Centro de Antropología, Centro Marinello, Centro FLACSO, Y en algunas universidades hay estudiantes que plantean algo, pero yo he tenido que discutir con un profesor en una Facultad, porque su estudiante le ha dicho que va hacer su trabajo de curso o su tema de diploma en el tema racial y él le ha dicho por qué tu escoge ese tema si ese no es un tema importante no es interesante (Entrevista com Esteban Morales, realizada em I4/05/20I4).
\end{abstract}

O debate sobre a troca da "mãe da pátria" reflete a disputa por um reposicionar desses eventos epitomizantes. Norberto Mesa, ativista da Cofradía de la Negritud, questiona o fato de, após a Revolução, a mãe da pátria ter sido modificada por lei. A mãe de Antonio Maceo, líder afrocubano da independência foi substituída pela mãe de José Marti, líder branco, também do processo de independência:

El día 12 es el bicentenario de Mariana Grajales ${ }^{124}$. Entonces en el día de las madres, en el periódico Granma, sale en un escrito tremendo sobre Leonor Pérez. Leonor Pérez es la madre de José Martí. Nosotros (Cofradía de la Negritud) le mandamos una carta a Granma donde decimos: Bueno está bien sus meritos por ser la madre de José Martí, pero esta Mariana Grajales. Si se va hablar del día de las madres dedicarle una página, porque que en la percepción del cubano común Mariana Grajales es la madre de la patria. Entonces le digo en la carta que ya Mariana Grajales había tenido el titulo de madre de la patria porque un gobierno anterior (à Revolução) que le había dado ese título, en el gobierno de

${ }^{124}$ Mãe do líder independentista afrocubano Antonio Maceo. 
Batista, en la década del 1940. La Revolución, cuando llego, lo quitaron eso (de Mariana Grajales ser la madre de la patria) pero que para el cubano, en la cabeza de los cubanos, Mariana Grajales es la madre de la patria. (Entrevista com Norberto Mesa, da Cofradía de la Negritud, realizada em 09/07/2015).

No âmbito das organizações e mobilizações antirracistas, há um mosaico de "eventos epitomizantes" constituintes da Nação, como a "Revolução" e a "Guerra contra o Apartheid na África", a "luta contra o inimigo do norte", bem como aqueles relacionados às lutas negras, que foram invisibilizados nesse contexto amplo e resgatados por esses coletivos. O recontar e a visibilização do processo do Partido dos Independientes de Color, das Sociedades Negras, dos cabildos, de ativistas do princípio do século, e inclusive dos ativistas que já nos primeiros anos da Revolução refletiram publicamente sobre o racismo, como René Beautancour, compõem um discurso que desloca parte desses "eventos epitomizantes" para a construção de outras referências históricas que marcaram a população negra. Zurbano ressalta, a seguir, a importância de visibilizar essas histórias esquecidas como estratégia de luta:

Es menester reivindicar una historia y un pensamiento propios de alta elaboración, que no es usual encontrar en las bibliografías sobre el tema, pero que existe, y es un formidable instrumento de lucha. Si contamos con ese legado de nuestros mejores pensadores, teorías y conceptualizaciones históricas y contemporáneas, debemos hacer un esfuerzo para sistematizarlas y discutirlas, insertadas en los debates científicos y políticos actuales, activando así las condiciones propositivas de este conocimiento. Finalmente, junto a la necesidad de indagar en la historia propia, es necesario defender el activismo social y político que algunos académicos y científicos sociales ejercen, estimulando que acerquen teorías y conceptos al terreno de los debates y propuestas del movimiento antirracista. (ZURBANO, 2012: 06).

O resgate dos referenciais históricos, dos quais muitos poderão se converter em novos "eventos epitomizantes", permite iluminar a memória coletiva, questionar espaços já estabelecidos no status quo e refletir sobre como se posicionam os sujeitos que integram esses coletivos antirracistas como agentes de mudanças das estruturas desiguais. A seguir, farei um caminho sobre marcos dessa narrativa histórica, entrecruzando autores cubanos e estrangeiros, além de histórias de vida e memórias de ativistas e militantes entrevistados.

\section{I. Soy Cimarrón}

A reinterpretação dos três grandes períodos da história cubana - colonial, republicano e revolucionário, nas narrativas dos ativistas antirracistas é uma estratégia de luta. Bienvenido aborda a importância de reconstruir as referências para a atuação como militante ativista. Ressalta, ainda, que esse processo discursivo deve alimentar-se em fontes além das experiências pessoais e familiares: 
Hago un llamado de que también hace falta el tema este que además de vivirlo y de sentirlo, hace falta también estudiarlo. Porque hay personas que han dedicado su vida entera a hacer investigaciones sobre el tema. Estos libros de Esteban Morales y hay muchísimos de otros escritores en el país, que han develado toda la problemática racial en Cuba desde los tiempos coloniales. Entonces eso hay que beberlo en su fuente, no basta con que tu sientas o no sientas, no basta con los ejemplos personales de si mi mama o mi papa, mi hermano o mi hermana, no no no (Entrevista com Bienvenido Rojas, realizada em 04/05/2014).

Essa percepção visibiliza o impactante legado da história cubana para a temática. O sistema colonial e o monumental tráfico negreiro inauguram uma relação de mercantilização e desumanização em escala e proporção jamais vista na história. Nesse período, variadas estratégias e formas de luta foram encampadas por negras e negros, tanto de forma coletiva como individualmente.

Esse histórico, além de ser importante para a análise do presente, é também uma constante nas narrativas de ativistas e militantes antirracistas. Nesse capítulo, me proponho a aprofundar a reflexão sobre as formas mobilizatórias de luta contra a escravidão e pela reafirmação dos direitos da população negra em Cuba. Analiso, também, os reflexos que esses fatos históricos têm na vida e na percepção de ativistas negras e negros, no sentido de se constituírem como "eventos epitomizantes" que marcam as mobilizações contemporâneas.

$\mathrm{O}$ processo de colonização cubano teve início na virada do século $\mathrm{XV}$ para o XVI. O desenvolvimento econômico da Colônia tinha como fundamentação a utilização de força de trabalho escravizada, tanto indígena como africana. As origens da escravidão negra remontam aos tempos da conquista da Ilha. Durante cerca de quatro séculos essa instituição incidiu na vida econômica, política, social e cultural do país.

Como resultado das batalhas em condições desiguais entre os povos originários e os colonizadores, como produto das jornadas extenuantes de trabalho e do contágio com enfermidades extremamente danosas, houve um quase genocídio dos povos indígenas.

Tomás Fernandez Robaina (2012) resgata uma das justificativas ideológicas utilizadas pela historiografia burguesa para a substituição da mão-de-obra indígena pela africana: a "lenda do Padre de Las Casas". Segundo o autor, o Padre argumentava a necessidade de transladar africanos a Cuba como forma de evitar a extinção dos povos originários, que não estavam habituados ao regime de trabalho extenuante. Já nesse período é reforçado o estereótipo de que os africanos são mais resistentes e fortes para longas jornadas de trabalho escravo. Sobre esse período, Quiñones (I994) destaca: 
El genocidio de los aborígenes cubanos trajo por consecuencia que, apenas comenzado el siglo XVI, se introdujeran en Cuba los primeros africanos para trabajar como esclavos en las plantaciones, las minas y el servicio doméstico, dándose con ello inicio al monstruoso tráfico negrero que en poco menos de cuatro siglos arrebató millones de seres al continente africano. Sólo entre I790 y I865, se introdujeron en Cuba alrededor de seiscientos mil africanos esclavizados (QUIÑONES, I994: I3).

Os registros apontam que a primeira autorização para a introdução de escravos trazidos de África para a região do Caribe foi assinada pelo rei Carlos I de España em I5I7 (NÚÑEZ JIMENEZ, 1998). Fernando Ortiz (1975), entre outros, afirma que a partir de I5I8 já havia escravizados africanos em Cuba: "Para substituir o trabalho aborígene introduziram, desde os primeiros tempos, a escravidão negra [...]. As rebeliões de índios e negros foram contínuas, de modo que não faltou em Cuba ocasião de rédea frouxa para os impulsos belicosos" (ORTIZ, I975: 22$23)^{125}$.

No primeiro período da colonização até a ocupação inglesa de La Habana em I763, as estimativas apontam para a introdução de cerca de sessenta mil escravizados. O período posterior a essa data até a abolição da escravidão apresentou um crescimento significativo do tráfico negreiro na Ilha. Em pouco mais de cem anos, as estimativas chegam a quase um milhão de africanos aportados em Cuba (NUÑEZ JIMENEZ, I998).

Fernando Ortiz também destaca o crescimento populacional negro em Cuba nas últimas décadas do regime de escravidão:

Quase contemporaneamente com a raça branca, chegou em Cuba a raça negra, mas sua importância não foi considerável até que $[. .$.$] foi sentida, de modo extraordinário, a grande necessidade de braços para as$ plantações, de tal maneira que em meados do século XIX, houve em Cuba mais negros que brancos (ORTIZ, 1975: 23) 126 $^{2}$

O sistema escravista nas Américas contabilizou cerca de I5 milhões de africanos (INIKORI, 1992), homens e mulheres, arrancados de suas terras. Esse empreendimento marcou profundamente o continente africano e americano. Em todo o Caribe, o número estimado está em torno de seis milhões de africanos transladados durante a escravidão (LÓPEZ VALDÉS, 2003). $\mathrm{Na}$ região da América hispânica, Cuba e Puerto Rico foram últimas colônias espanholas na América a se tornarem independentes, e nelas a escravidão tinha um peso econômico decisivo. Todavia, a abolição da escravidão em Porto Rico, por exemplo, ocorreu I3 anos antes de Cuba, em 1873. Cuba foi, oficialmente, o penúltimo país a abolir a escravidão em todo o mundo, em I886, sucedido apenas pelo Brasil, que a realizou em I888.

${ }^{125}$ Tradução minha.

${ }^{126}$ Idem. 
As primeiras gerações de escravizados que foram trazidas a Cuba eram provenientes de distintos povos do continente africano. Em um levantamento dos anúncios comerciais de escravizados e escravizadas em La Habana, no período de 1790 a I825, Nuñez Jimenez relaciona um total de trinta etnias mencionadas nos jornais da época. São elas:

Arará, Bengala, Brique, Buase, Briche, Bibí, Carabalí, Carabalí Biche, Carabalí Brícamo, Carabalí Suama, Congo, Congo Luanda, Congo Luango, Congo Real, Chocho, Gagar, Gangá, Gragá, Ibo, Isuama, Lucumí, Macuá, Machá, Mandinga, Mandinga Fula, Mozambique, Mina, Mina Popó, Minatantí e Mondongo (1998: I5).

Desses grupos citados nos anúncios comerciais da época, Nuñez Jimenez (I998) destaca os povos que em maior grau aportaram contribuições à construção da sociedade cubana, inclusive pelo peso demográfico de sua presença. São eles os Mandingas, que estavam situados principalmente na região onde hoje se encontra Gana e Nigéria; os Congos, provenientes especialmente de Congo e do Zaire na conformação atual; os Lucumís ou Yorubás, que englobam os Achantis, Dahomeanos, Fantis, Ararás, dentre outros povos, provenientes de regiões hoje pertencentes especialmente à Benin e Nigéria; Os Carabalís incorporam diversas etnias que foram arrancadas da região de Calabar, próximo à margem da foz do rio Niger, na região onde na atualidade se encontra a Nigéria; Os Moçambiques, provenientes na região onde atualmente se encontra Moçambique; Os Minas, trazidos da antiga Costa dos Escravos, onde hoje se encontra a república do Togo, a oeste de Benin.

Essa memória do legado africano e de como esse legado fez parte das famílias, dos hábitos e tradições, está muito presente nas falas de ativistas. Aparece, por vezes, entremeado pelas situações de discriminação vivenciadas, cujo preconceito ${ }^{127}$ contra tradições com a Santeria e o Palo Monte se manifesta até os dias atuais:

Las personas se discriminan entre sí porque dicen que es una religión diabólica (La Santería, Palo Monte, Abacuá). Las personas no ven que los africanos venían en un barco africano cantando canciones yoruba. Yo recuerdo que cuando mi abuelo falleció, yo llegue a mi casa y le conté a mi mama que mi abuelo estaba cantando una canción en lengua yoruba. Mi abuelo era Congo, mi mama se puso las manos en la cabeza y dijo ay hoy mi papa se va a morir. Y, efectivamente, mi abuelo en la madrugada falleció. Son conocimientos histórico ancestrales que las familias deben respetar y conocer, que no tienen nada que ver con temas diabólicos. El africano veía una piedra y tenía símbolos, porque la piedra es el otan, el otan es inteligencia. Porque las piedras resisten embistes de huracanes, y los africanos cuanto no tuvieron que resistir para poder vivir en los contextos donde fueron llevados de manera arbitraria. Porque una de las más antiguas violaciones de derechos humanos que se conocen, no la más antigua porque había anterior

\footnotetext{
${ }^{127}$ A palavra preconceito deriva do latim prae, antes, e conceptu, conceito (CASHMORE, 2000). O preconceito racial funda-se no julgamento prévio negativo dos membros de um grupo racial de pertença, de uma etnia ou de uma religião ou de pessoas que ocupam outro papel social significativo. Esse julgamento prévio apresenta como características principais sua inflexibilidade, uma vez que tende a ser mantido independente de fatores que o conteste. O preconceito perpassa, ainda, a relação social entre os diferentes grupos raciais (GOMES, 2005). O racismo, como doutrina da supremacia racial, se apresenta como fonte principal do preconceito racial (BENTES, I993).
} 
esclavos, hubo vikingos, mucha esclavitud en algunos contextos, pero no con esta amplitud, con la cantidad de africanos que fueron traídos a Cuba, esclavizados con tanta violencia. ¿Por qué mi abuela se tenía que llamar Josefina cuando ella era yoruba? ¿Por que mi abuelo se llamaba José cuando es un nombre católico? ¿Donde están los nombres africanos? ¿Como yo puedo ir ahora que en Cuba se modificó la ley migratoria y puedo ir a Ghana, puedo ir a Uganda a buscar mis ancestros si yo no conozco mi identidad, si el cubano no tiene identidad jurídica desde el nombre? (Entrevista com Deyni Terri, realizada em I5/05/20I4).

Os vínculos ancestrais dos povos africanos tocam as famílias na atualidade, como destaca Deyni. Muitos dos ativistas têm nas memórias de suas famílias lembranças, histórias e contos que indicam a origem de seus ancestrais africanos, como no caso supracitado. É interessante, mais uma vez, perceber esse contraste com a realidade de muitas famílias brasileiras, sobretudo para mim que tenho a memória de minha família negra completamente apagada em relação à origem dos nossos ancestrais africanos.

Voltando às abordagens e narrativas sobre o período colonial, além da diferenciação a partir do local de origem, as denominações na então Cuba colonial diferenciavam os negros crioulos dos negros de nação. Os primeiros eram os nascidos na colônia, os "ladinos", os provenientes da Espanha ou fluentes na língua dos seus amos, como destaca Nuñez Jimenez (1998). Já os segundos eram oriundos diretamente da África (ROBAINA, 2012). As culturas e tradições desses povos estão fortemente presentes em Cuba na atualidade, seja na língua, nos costumes, nas tradições sagradas como o Palo Monte, de origem Banto ${ }^{128}$, a Santeria, de origem Yorubá e o Abacuá, de origem Carabalí.

Uma das estratégias do sistema colonial espanhol para controle das mobilizações negras era organizar a população em "confrarias" ou "cabildos" negros, a partir de uma determinação étnica. Os escravizados urbanos muitas vezes gozavam de maior capacidade para se organizarem, apesar de estarem sob controle mais rigoroso que os que viviam no meio rural (DESCHAMPS CHAPEAUX, 1983).

Os cabildos de nação foram conformados em toda a Ilha. Para além de se constituírem como espaços de controle do poder colonial, os cabildos foram fundamentais para as dinâmicas sociais e para a expressão da identidade étnica dos diversos povos africanos trazidos a Cuba.

Muitos desses espaços se mantêm até a atualidade como centros de referência de suas comunidades locais. No bairro La Marina, em Matanzas, por exemplo, existe até os dias atuais

${ }^{128}$ O termo "Banto" ou "Bantu" foi introduzido em I862 pelo linguista alemão Guillermo Enrique Bleek, que o utilizou para unificar, desde uma perspectiva das línguas, a diversidade cultural de milhares de povos da Africa equatorial e meridional (ROBAINA, 2004). 
um Cabildo Lucumi, Yorubá, que foi criado em I8I4, como declara a cuidadora desse espaço tradicional, Clara Urrutia Noriega ${ }^{129}$ :

Ese cabildo Santa Tereza, Lucumí, empezó en el año I8I4 con Blas Cárdenas que era el abuelo de mi abuela. Él nació en Pueblo Nuevo, el vino con los esclavos. El entro con los primeros babalaos que entraron en Cuba. Entro Blas Cárdenas y estaba en Pueblo Nuevo en la casa de Blas que allí se quedo después el difunto Venerardo Alfonso, en esa casa en Pueblo Nuevo. Ya después mi abuela y él se mudaron para acá (La Marina) para la cuadrita de mi difunto abuelo Juan Villamil. Después, mi abuela busco lo suyo y a partir de que mi abuela monta Oyá, I2 de octubre del 1946 oI9 45 ahí siempre me troco. Lo tengo guardado en una libreta pero como hice un santo no sé donde tengo guardada las cosas, es que mi abuela vuelve a retomar el cabildo Santa Teresa que ya mas nunca nosotros lo hemos dejado caer. (Entrevista com Clara Urrutia Noriega, ou Ochun Taguarde - nome tradicional, Cabildo Santa Tereza, La Marina, Matanzas, Cuba, realizada em I8/I0/20I4).

O cabildo trazia uma linguagem cimarrona, pois nesses espaços havia um refúgio para a africanidade. Além de se constituírem como forte influência cultural para a sociedade cubana, desde aspectos lingüísticos até a dimensão do sagrado, expressas na atualidade principalmente pelos Abacuás, pela Santeria e pelo Palo Monte ${ }^{130}$. Para a oficialidade colonial, os cabildos deveriam ter um santo católico como patrono. A identificação dos santos católicos com os orixás e divindades africanas foi uma das estratégias utilizadas para fugir do controle e da repressão colonial. Esse é um elemento presente até os dias atuais em muitos cabildos, como o Lucumi, de La Marina, Matanzas:

Esta virgen es de allí (del Cabildo), es de nosotros. Es de mi abuela es de mi madrina, y es la tradición de nosotros que no se puede perder. El I4 de octubre se le hace la procesión todos los años, este año yo la hice a las seis de la tarde, pero mi familia, después que mi abuela murió, decidieron sacarla como mi abuela la sacaba antes. Porque antes mi abuela la sacaba con la banda y todas esas cosas. Entonces a partir de las once de la noche salimos con ella para hacer la procesión y la subimos a las doce con el tambor aña atrás. (La virgen) representa Oyá, es santa Teresita de Jesús. (Entrevista com Clara, realizada em I8/10/2014).

Nos cabildos de nação eram criadas redes de solidariedades que estavam presentes desde a atenção com seus membros que passavam por necessidades até a compra da liberdade de escravizados pertencentes ao coletivo (LAVIÑA, I989). Promoviam uma multiplicidade de atividades de educação, artesanato, moradia, empréstimos, enterros, festas (CHILDS, 20II).

Essas organizações, fundadas por aspectos étnicos, agregavam pessoas negras, livres e escravas, que compartilhavam uma herança lingüística, cultural e geográfica com raízes africanas. "Os descendentes africanos elegiam o ingresso em essas associações para definirem sua identidade conjuntamente com outros que compartilhavam uma mesma etnia" (CHILDS, 20II, pg.34).

${ }^{129}$ Clara é a cuidadoa do Cabildo Santa Tereza, em La Marina, Matanzas, Cuba. É um cabildo vinculado às tradições Yorubá. Atualmente, a casa se encontra com problemas estruturais. Tive alguns contatos com Clara no período da pesquisa, em parte das idas à La Marina. Realizamos entrevistas em sua casa, que fica localizada ao lado do tradicional Cabildo.

${ }^{130}$ Cabe também destacar a presença do Vodu e de outros cultos de origem africana na Ilha. Aqui menciono os três de maior abrangência. 
Esse é um aspecto importante, como salienta o autor, de que a identificação com a categoria genérica "negro" não foi um processo imediato. A identificação, sobretudo nos cabildos de nação, remetia a um pertencimento étnico. Apesar de "branco" e "negro" serem categorias que marcavam diferenças fundamentais na sociedade colonial, havia matizes que complexificavam o processo de construção identitária.

Outra forma de organização dos negros e negras no período colonial, como forma também de ampliar o controle espanhol, eram as confrarias. Para africanas/os e afrodescendentes, as confrarias significavam, nos terríveis tempos da escravidão, apesar da sua finalidade de controle, um veículo de socialização e de expressão cultural, como os cabildos de nação, todavia com a sanção da igreja católica. A confraria, para fundar-se, deveria ter um santo católico como patrono. As festas celebradas para os santos nas confrarias traziam, ocultamente os orixás. São Cristóvão era Aggayú; São Pedro, Ogun; Santa Bárbara, Shangó.

No livro escrito por autoras do coletivo Afrocubanas, para visibilizar a presença das mulheres negras na história de Cuba, há um destaque para o fato de que a presença de mulheres africanas na primeira metade do século XVI ainda era reduzida. Apenas em Baracoa, os monges "Belemitas" admitiram mulheres em seu engenho e celebraram casamentos entre os escravizados. Esse quadro se reverte no século XIX, após a restrição do tráfico negreiro, quando se amplia o interesse em incrementar a reprodução, numa lógica mercadológica. (FUERTES, 20I0).

Marques e Parron (201I) e Berbel et al. (2010) apontaram a integração histórica de Brasil e Cuba nos quadros da economia mundial capitalista do século XIX. Após I820, esses países foram os únicos do dito Novo Mundo que mantiveram o tráfico transatlântico de africanos escravizados. Essas duas economias escravistas apresentaram grande dinamismo, sendo convertidas nas maiores produtoras mundiais de café e de açúcar. As trajetórias políticas foram igualmente singulares: em um universo amplo de novas repúblicas, de norte a sul do continente americano, o império do Brasil e a colônia espanhola de Cuba representaram casos ímpares.

Fernando Novais ressalta que a acumulação gerada pelo tráfico negreiro acabava, em grande medida, nas mãos dos comerciantes metropolitanos especializados na circulação dos cativos africanos. De acordo com este autor, "é começando com o comércio de escravos que é possível entender a escravidão colonial, e não o contrário” (NOVAIS apud FUNARI, I996: 27). A estrutura colonial escravocrata tinha, pois, como um de seus alicerces os mercadores de escravos e seus interesses. Para sustentar esse sistema, havia grande construção ideológica, amparada em estudos científicos e em bases legais, que reforçavam a coisificação desses seres humanos. 
A lógica de violência e coerção aos negros era outro elemento estrutural do regime escravista, como assinala Freitas (1978: 33), citado por Treccani (2006):

Os castigos e tormentos infligidos aos escravos não constituíam atos isolados de puro sadismo dos amos e seus feitores, constituíam uma necessidade imposta irrecusavelmente pela própria ordem escravista, que, de outro modo, entraria em colapso. Pois, sem a compulsão do terror, o indivíduo simplesmente não trabalharia, nem se submeteria ao cativeiro.

As mulheres negras, além de estarem submetidas a extremo rigor de trabalho, eram vitimas de castigos cruéis, como chicotadas e mordaças, inclusive no período gestacional. Esse quadro era complexificado com o assédio, contínuos estupros e violência sexual (FUERTES, 20I0).

As práticas cotidianas, a base legal e a bagagem ideológica que desumanizava os africanos, homens e mulheres, e seus descendentes, nas colônias do dito "Novo Mundo", demonstram que esses foram submetidos a violências e sacrifícios inomináveis. Calcular a dimensão dos níveis insuportáveis de barbarismo associados à escravidão na América amplia a percepção do quão importante foram as mobilizações, estratégias de redes de solidariedade, os palenques, quilombos, a cimarronagem e as demais formas de organização dos africanos e de seus descendentes, para sobreviver, tanto individual como coletivamente.

As relações estabelecidas entre escravizados e senhores dependiam de uma série de fatores e não se pode homogeneizar essas relações (GENOVESE, I97I). Há referências que apontam também diferenças no trato entre os séculos XVI e entre os séculos XVIII e XIX (LAVIÑA, I987). Apesar de se ter em conta essas diferenças existentes, por exemplo, entre a situação dos escravizados urbanos e rurais, o período histórico e outros fatores que impactaram nas relações estabelecidas, o elemento comum que permeia todo o período de escravidão é a violência, como linguagem de afirmação de poder.

A todo esse aparato repressivo e comercial, houve forte reação e levantes tanto em Cuba, como em outras colônias da América, tais como Brasil, Colômbia e Equador. A esses movimentos de luta pela liberdade, pela abolição da escravidão, denominei como o primeiro grande momento das mobilizações negras em Cuba. $\mathrm{O}$ apogeu desse período de mobilizações ocorre exatamente nos séculos XVIII e XIX, com picos durante a Rebelião de Aponte e a Conspiração de la Escalera. A luta pela liberdade, presente desde o princípio da escravidão em Cuba, ocorreu também por meio da formação de palenques - chamados no Brasil de quilombos.

De acordo com José Jorge de Carvalho (1996), nas diversas regiões das Américas, nas quais o regime escravista se estruturou, registrou-se movimentos de rebelião contra essa ordem. O 
primeiro deles é datado de I522, na ilha de Hispaniola: "Isso significa dizer que a história do cativeiro negro nas Américas se confunde com a história da rebelião contra o regime escravagista” (CARVALHO, I996: I4).

A escravidão era um sistema de opressão. A explosão de violência nas plantações respondia a causas estruturais e as formas de oposição ao sistema foram múltiplas e variadas em função das circunstâncias de cada lugar e de cada momento (DESCHAMPS CHAPEAUX, 1986). Em Cuba, conforme destaca Estella Rey, há registros de rebeliões negras e indígenas a partir de I524, com íntima relação com a situação de exploração existente na Colônia. As mobilizações de oposição ao regime foram de grande monta, como ressalta Estella Rey:

La magnitud alcanzada por este problema motivó incluso que el Consejo de Indias se ocupase de él y dictaminase que todos los indios que en dicha guerra y durante su rebelión fuesen presos $[. .$.$] los hayan y$ tengan por esclavos las personas que los tomaren e se sirva de ellos como esclavos propios [...] También existen evidencias de sublevaciones de esclavos negros. En I533, se produjo un alzamiento en las minas de cobre. Los esclavos murieron peleando y sus cabezas, empaladas, fueron exhibidas como escarmiento a la entrada del poblado (REY, 20I3) ${ }^{131}$.

As diversas mobilizações contrárias à situação de degradação e violência vivenciada no sistema escravista em Cuba tiveram no apalencamento e na cimarronagem uma expressão importante. A cimarronagem apresentava expressões em Cuba de caráter rural e urbano. Sobre esse último, Tomás Fernandez Robaina (20I2: II) aponta que "em não poucas ocasiões, os escravos domésticos escapavam das casas $[. .$.$] mas não sempre com direção ao monte ou aos palenques. Se$ escondiam em bairros marginais, o que segundo Pedro Deschamps Chapeaux, se denominava cimarronagem urbana"132.

$\mathrm{Na}$ contemporaneidade, além de estar presente como evento "epitomizante" das lutas negras, o símbolo do palenque, do quilombo, do cimarrón permeia as narrativas sobre os comportamentos de ativistas. Alguns deles se autointitulam "cimarrón", exatamente por ocuparem esse espaço contra-hegemônico com relação à luta antirracista. Tomás Robaina é um dos que incorpora em suas narrativas sua identidade cimarrona ${ }^{133}$.

O processo de cimarronagem e de apalencamento foi um perigo real e efetivo para o poder colonial. Para se estabelecerem, os cimarrones contavam com uma rede de apoio dentro das plantações e ofereciam ajuda a outros escravizados e escravizadas que queriam fugir. Dadas as

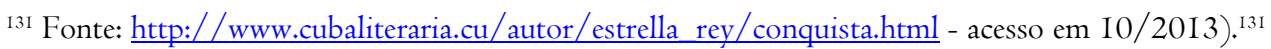

${ }^{132}$ Tradução minha.

${ }^{133}$ Em diversos eventos e seminários que acompanhei, Tomás Robaina destaca que é um cimarrón, fazendo alusão ao seu discurso contrahegemônico com relação à questão racial e a luta antirracista.
} 
circunstâncias, os fazendeiros buscavam estabelecer mecanismos de repressão para controle dos rebeldes. Todavia, apesar das condições desfavoráveis para os escravizados, foram realizadas contínuas sublevações, que em alguns casos, deram origem a palenques mais estruturados (PRICE, 1996).

Em Cuba colonial, havia referência oficial aos cimarrones apenas com o viés de transgressão que deveria ser duramente combatida, pois representava uma ameaça ao sistema econômico e político vigente:

Durante el período colonial, la referencia al cimarronaje se hacía sólo em documentos oficiales, para informar o consultar sobre la contención de esta "mácula fatal" consecuente com la esclavitud, sobre todo cuando en las primeras décadas del siglo XIX, la plantación devino un método económico difundido para crear productos tropicales encaminados al mercado extranjero, lo que incremento el numero de esclavos, y fueron más urgentes las necesidades libertarias entre estos... y de un antídoto entre sus dueños (ZÚÑIGA, 20II: I3).

Em meados do século XVIII, os palenques causaram bastante transtorno e mobilização das forças escravocratas. Alguns palenques, como Mario y Del Portilho, situados na costa sul de Manzanillo ${ }^{134}$, estabeleciam forte e contínuo comércio com a colônia inglesa vizinha, Jamaica, dada a dimensão de sua organização. Esses palenques ocupavam parte das vastas terras montanhosas ${ }^{135}$ e, na época, com pouca densidade populacional ${ }^{136}$.

$\mathrm{Na}$ contemporaneidade, as apropriações do signo da "cimarronagem", e a vinculação com essa identidade "palenquera", todavia, partem de distintas perspectivas. Diferentemente da afirmação da "cimarronagem" como a identidade contrahegemônica dos ativistas antirracistas cubanos, como visto na afirmação de Tomás Robaina ${ }^{137}$ acima, alguns dos sujeitos engajados se contrapõem à experiência idealizada do quilombo, como espaço apartado, autônomo, exatamente para ressaltar as estratégias que são necessárias na atualidade.

Gisela Arandia, ao analisar o processo de organização de um painel sobre a questão racial, levado a cabo em 20I4, destaca a necessidade de se estabelecer diálogos e negociações com as instâncias

\footnotetext{
${ }^{\text {I34 }}$ Localizada na parte oriental de Cuba, próxima a Santiago de Cuba.

${ }^{135}$ Cuba é formada, majoritariamente, por planícies onduladas, com colinas e montanhas situadas em grande parte no sul da ilha. O clima é considerado tropical. Há uma estação relativamente seca de novembro a abril e uma estação mais chuvosa de maio a outubro.

${ }_{136}$ Zuñiga, 201 I.

137 Um dos ativistas entrevistados para a pesquisa, Tomás Robaina tem forte atuação com o tema racial. É pesquisador vinculado à Biblioteca Nacional de Cuba, com produção bibliográfica sobre a cultura afrocubana e a questão racial em diversos livros. É integrante do coletivo ARAAC e da Cofradía de La Negritud. Ao longo da pesquisa, mantivemos contatos contínuos no Diplomado que cursei na Universidade de Havana, além de muitas atividades focadas no tema que participei. Estive algumas vezes em sua casa, e em uma delas gravei uma entrevista mais aprofundada para a tese. Sua casa, situada no bairro Cerro, está localizada em frente à primeira fábrica construída na Revolução, pelo então Ministro Che Guevara.
} 
estatais, o que na sua visão diferenciaria esse processo de mobilização antirracista do lócus que foi ocupado na história pelo "quilombo", pelo "palenque":

Es un panel para hablar de racismo, es un panel para hacer alianzas con las instituciones. Entonces puede parecer cínico de mi parte, tal vez lo sea, pero alguien tiene que hablar con ellos. ¿Quien va hablar con ellos? Yo no quiero un proyecto de barracón, a mi no me interesa el barracón ni me interesa el quilombo, ni el palenque. Esa es una historia maravillosa que yo admiro que me emociono, que lloro con ella, pero yo lo que quiero ahora es mi derecho de ciudadanía, mi condición de ciudadana de este país, de la nación. ¿Cuál es mi espacio en la nación? El hecho que durante 50 años (de Revolução), el racismo no haya ocupado el espacio público, ni siquiera espacios privados, ni una asociación de negros, de un grupo de negros, ni una logia de negros, ni una cofradía, ni un nada, hace que sea muy difícil organizar el discurso porque no tenemos referencias. (Entrevista com Gisela Arandia, realizada em I2/09/2014).

A idealização do quilombo, do palenque e do cimarrón auxilia na reflexão sobre as estratégias discursivas na atualidade. Cuba, contemporaneamente, não apresenta registros conhecidos de palenques ou outros grupos correspondentes que se organizem e tenham como demanda esse reconhecimento identitário e territorial. Esses se traduzem como referências simbólicas das lutas negras a partir de estratégias específicas, mesmo que seja para buscar contrapor-se a elas, como no caso acima mencionado.

As estratégias de luta por direitos de afrodescendentes, no período colonial, incorporavam, além dos quilombos, a tentativa de acesso à justiça. Essas dinâmicas de resistência negra que envolviam revoltas e reclamações judiciais tinham grande força nas regiões de exploração mineral, em Havana e entorno. Dada a grande concentração de negros, escravizados e libertos, a mobilização era muito intensa. Zuñiga (20II) registra que em 1620, "los esclavos se hallaban a punto de insubordinarse y los criolos eran los más indisciplinados" ${ }^{38}$. Os escravizados "cobreros", como eram denominados aqueles que trabalhavam nas minas, eram muito numerosos em meados do século XVII, e, de acordo com a autora, estabeleciam estreita relação de parceria.

A população de escravos que trabalhavam com cobre era cada vez mais complexa, muitos se concebiam como mulatos $[. .$.$] e a maioria era de crioulos mestiços. A comunidade, muito unida por sua ascendência,$ adquiriu consciência de seus direitos a terra por seu parentesco e cultura concebidos com os naturais da região, os indígenas. A comunidade de escravos preservou sua identidade. (ZUÑIGA, 20I I: 17) ${ }^{139}$.

Nesse período, há a demanda dos chamados "escravizados do rei” de serem reconhecidos no império ultramarinho, com os deveres militares de defender o território e reconhecer o poder real, assim como ter os mesmos direitos dos demais súditos. Todavia, a prática permitia, em alguns

\footnotetext{
${ }^{138}$ Zuñiga cita Academia de la Historia de Cuba: Papeles de Maceo. Editora de Ciencias Sociales, La Habana, I998.

${ }^{139}$ Tradução livre da autora. Trecho original: "La población de esclavos cobreros era cada vez más compleja, mucho se reputaban mulatos $[. .$.$] y la maioria eran criollos mestizos. La comunidade, muy unida por su ascendência, adquirió$ consciência de su derecho a la tierra por su parentesco e cultura ligado con los naturales (indígenas). La comunidade de esclavos preservo su identidade” (Zuñiga, 20II: I7).
} 
períodos, maior ou menor acesso a terras para plantio e liberdade, mas não houve reconhecimento formal desses direitos.

A legislação hispânica aplicada à Colônia reconhecia alguns direitos para os escravizados. Assim, foram inúmeros os processos judiciais que apresentavam demandas dos negros em situação escravizada para evitar a desagregação familiar, a troca de senhores, para denunciar maus tratos ou o direito à liberdade. Todavia, obter resultados positivos junto à justiça era extremamente difícil, pois havia fraude e tendência de proteger os interesses da elite. $O$ cotidiano, desse modo, se mantinha muito violento, sem a efetividade dos poucos direitos reconhecidos (FUERTES, 2010).

As iniciativas de buscar a justiça para reivindicar direitos violados, para denunciar situações de racismo vividas ou para promover mudanças em realidades sociais desiguais, foram estratégias presentes nos diferentes períodos históricos de Cuba, como veremos nas seções a seguir. Todavia, a construção ideológica dos direitos iguais para todos, com o nascimento da República, e reforçada na Revolução, invisibilizou muitas dessas demandas. São vários os casos, inclusive na atualidade, de processos de denúncia contra atos de discriminação racial que não são exitosos na justiça, exatamente pelo não reconhecimento da existência do racismo.

No período colonial, diferentemente da República e da Revolução, havia uma explicitação dessa hierarquização racial nos códigos legais. E com base nesse código, se inviabilizava muitas das demandas apresentadas na justiça. Como reflexo dessa conjuntura, se manteve a ação continuada de formação de cimarrones e palenques. E, de acordo com Zuñiga (20II), a rebeldia dos cimarrones e do seu apalencamento foi uma reação espontânea à crueldade e exploração violenta do sistema colonial.

A subsistência dos palenques se constituiu como seu calcanhar de Aquiles, porque, se por um lado, eram autônomos em sua organização, seu sistema econômico dependia, em alguma medida, das fazendas, ou ao menos, do mundo dos senhores escravistas. Para realizar trocas, furtos ou venda, contavam com a colaboração de pessoas livres ou escravizados com liberdade de movimentar-se (LAVIÑA, 1987).

Nas colônias insulares espanholas, porém, a consolidação de palenques com uma permanência mais estruturada e longeva foi um fator menos presente. Há registros de cimarrones que de forma pouco estruturada viveram anos, até décadas, nos montes (BARNET, 20I2). Mas não aparecem palenques estruturados, como nos casos do Brasil, Colômbia, Venezuela, Suriname, Jamaica, 
dentre outros. Uma das possibilidades pode ter sido suas condições geográficas, as estratégias de controle colonial, ou outras formas de luta e resistência contra a escravidão (LAVIÑA, I987).

No princípio do século XIX, há um recrudescimento da repressão aos cimarrones e palenques, mesmo período em que há uma queda ou término do tráfico negreiro na grande maioria dos países da América Latina e um aprofundamento em Cuba e Brasil. Nesse período, qualquer ação que revia ou assegurasse algum direito para pessoas negras, fossem libertas ou escravizadas, era, em geral, vetada pela administração na ilha. Isso ocorreu, por exemplo, quando a Ordem Real, em I8I2, autorizou a entrada na carreira eclesiástica de descendentes de africanos. Essa menção não compôs o marco normativo cubano. "Impossível era sua aplicação na Ilha, porque era contrário ao equilíbrio da sociedade, na qual o africano e seus descendentes eram considerados como camadas sociais inferiores, fossem escravos ou livres". ${ }^{140}$ (ZUÑIGA, 20I I: 28).

Em meados do século XIX, entre os anos I820 e I830, Cuba se transformou em um paraíso para os exploradores e plantadores de cana de açúcar. Matanzas foi um ponto referencial desse período, tanto pelo fato de ter um dos portos mais importantes do país, como por ser um paraíso das grandes plantações:

Por el puerto de Matanzas se entraron cientos de miles de negros esclavos, que constituyo uno de los puertos fundamentales para la trata. Todo el mundo sabe que Cuba por lo menos hasta el siglo XIX sin azúcar no había país, la riqueza de este país se fomentó sobre el trabajo esclavo y fundamentalmente sobre la plantación y afortunadamente o desgraciadamente la plantación azucarera va a florecer entre los territorios cubanos, en el territorio matancero. Matanzas va a llenarse de una gran cantidad de ingenios de azúcar, por toda la evolución que tuvo desde el cachimbo, el trapiche, el ingenio hasta el central, y el puerto es muy importante, no solamente por la entrada de esa fuerza como mano de obra, sino también por la salida de esa misma azúcar que se hizo bajo el sudor y la muerte de cientos de negros, bueno también no solamente azúcar, otros productos finales porque no solamente era azúcar, eran mieles, alcoholes y otros derivados de la industria azucarera. Pero evidentemente el puerto es un lugar que genera un sistema de relaciones entre los hombres que trabajan en el puerto y un sistema de relaciones que se generan no solamente con los que trabajan en el puerto, sino también con las personas que llegan al puerto. (Entrevista com Rolando Zulueta, realizada em I5/I0/20I4).

A importação de escravizados foi intensificada nesse período, apesar de ilegal (Madden, I964). Os dados disponíveis sobre a composição da população demonstram a significativa presença negra no período:

O Censo de 1828 coloca em evidência a riqueza alcançada pela Ilha de Cuba e também a desigual composição racial: Mais de $50 \%$ da população era composta de negros, entre livres e escravos. Da importância crescente de mulatos e negros livres, proprietários e artesãos, constitui-se também o indicador, como destacado pelo historiador Pedro Deschamps Chapaux, de igual presença numerosa no campo do que o sacerdote católico norteamericano Abiel Abbot chama Monteneiros, camponeses brancos médios ou

${ }^{140}$ Tradução livre da autora. Original: "Impossible era su aplicacion em la Isla, porque iba contra el equilíbrio de la sociedaden la cual el africano y sus decendientes se consideraban estamentos inferiores, fueron esclavos o libres”. 
humildes, e se assombra com a quantidade de negros e mulatos livres ${ }^{\text {I4I }}$ (ZUNIGA, 20II, apud DESCHAMPS CHAPEAUX, Pedro. El negro em la economía habanera del siglo XIX. União de Escritores de Cuba. La Habana, I97I).

O quadro síntese dos censos de I532 a 1907 apresenta o quantitativo populacional com desagregação nas categorias "branco", "de cor livre" e "de cor escravo". No quadro se pode observar o amplo crescimento de população escravizada em meados do século XIX, o que coincide com o incremento do tráfico negreiro e das plantações na Ilha. Segue abaixo o quadro síntese:

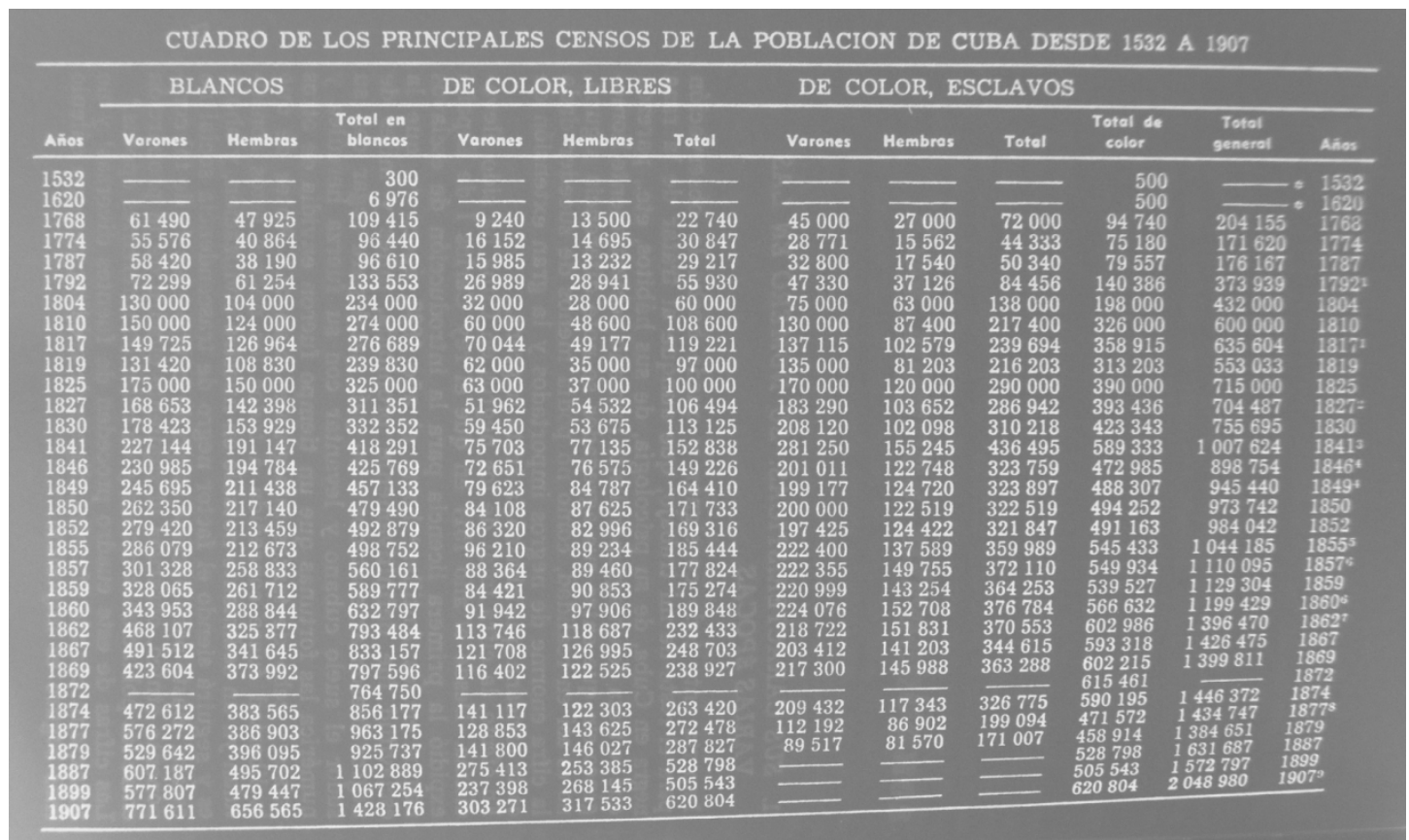

Figura 9: ORTIZ (1975). Síntese dos Censos de I532 a I907. Tradução: Varones: Homens; Hembras: Mulheres

Os territórios eram uma dimensão fundamental para as organizações cimarrones. Todavia, a ocupação historicamente feita nas regiões montanhosas que tinha pouca densidade demográfica foi substancialmente ameaçada em meados do século XIX, pela internalização das atividades produtivas na Ilha. Esse processo tem estreita vinculação com o crescimento do tráfico negreiro nesse período. Como o quadro de Ortiz acima demonstra, a população de origem africana escravizada cresceu de 72 mil em I768 para 436 mil em I84I.

[...] O processo colonizador avançou até o interior do território oriental de Cuba com as plantações de cana, de açúcar e de café, e nos anos 1840, o habitat possível dos palenqueros se reduziu substancialmente. Eles sofreram os efeitos das apropriações de terras em favor dos donos das grandes plantações e foram

\footnotetext{
${ }^{141}$ Tradução livre da autora. Original: "El censo de I828, puso en evidencia la riqueza alcanzada por la isla de Cuba y tambien la desigual composicion racial: Más de 50\% de la poblacion de negros, entre libres y esclavos. De la importância cresciente de mulatos y negros libres - proprietários y artesanos - da pruebas el destacado historiador habaneiro Pedro Deschamps Chapaux, al igual que de la numerosa presencia en los campos de lo que el sacerdote católico norteamericano Abiel Abbot llama Monteneiros, campesinos blancos médios ou humildes, y se asombra del numero de mulatos y negros libres." (Zuñiga, 20II, apud Deschamps Chapeaux, Pedro. El negro em la economia habanera del siglo XIX. União de Escritores de Cuba. La Habana, I97I).
} 
expulsos das beiras dos rios ou afetados pela poluição das fábricas, sem respaldo legal para reclamar seus direitos, mesmo havendo dedicado o trabalho sobre esse território por gerações (ZUÑIGA, 20II: 35$)^{142}$.

Nos anos que se seguiram, as mobilizações negras em Cuba foram amplificadas, especialmente com a expulsão das terras dos palenques e com o não reconhecimento dos seus direitos. E a ampliação do tráfico negreiro potencializava essa situação de tensão.

Esse período histórico é presente na tradição oral da Santeria, na atualidade. A ampliação do tráfico negreiro é abordada no mito de Ifá, intitulado "La maldición del Rey de Oyó", como destaca Tato Quiñones, com outro enfoque:

Yo recordaba un acto de Ifa que nos cuenta no la desintegración del imperio. Los yorubas no eran un imperio, era, digamos, ciudades estados que tenían muy buenas relaciones. Eran ciudades con sus correspondientes jefes religiosos, militares, relaciones comerciales y culturales muy estrechas. La ruptura de esas relaciones fue lo que provoco la guerra civil entre los yorubas, que empezaron a esclavizarse y a venderse como esclavos justamente por provisiones, armas, pólvora, cosas necesarias para la guerra civil. Esto coincide con la revolución haitiana. Cuba asume el rol de azucarera del mundo. La primera en producción azucarera necesita mano de obra esclava, y mucha. Comienzan a importar esclavos, los yorubas se están vendiendo, por eso es la tremenda cantidad de descendiente de yoruba, los llamados Lucumí (en las regiones productoras de azúcar), mientras los otros caen en el occidente del país, que ahí es donde está la zona más rica. Donde se producía azúcar era en la zona occidental. Hay muchos yorubas en oriente, en Camagüey y otros africanos pero de otros orígenes, de otras nacionalidades. Esa historia está en Ifa, la maldición del rey de Oyó y la flecha que lanzo que partir de ahora comenzaran a venderse como esclavos unos a otros. Eso es historia, es folclor, esta visión oral fue la historia que nunca se asumió. (Entrevista com Tato Quiñones, realizada em 29/05/2014).

A perspectiva dos efeitos devastadores do tráfico e da Diáspora para o povo Yorubano pela cosmovisão do Ifá, relatada por Tato Quiñones, é bastante rica para dar o tom de quão múltiplas podem ser as formas e linguagens de construção desses processos históricos que marcam o olhar contemporâneo. Também marca o peso que o tráfico transatlântico teve para esse povo e para sua cultura.

A partir do século XIX, e com forte influência da Revolução Haitiana, as mobilizações negras em prol da abolição da escravidão se intensificam. Para além desses fatores na atualidade terem forte significância para as contra-narrativas às histórias oficiais, cabe destacar que a mobilização pela abolição constituiu-se como um dos marcos históricos do movimento afrocubano.

${ }^{142}$ Tradução livre da autora. Original: El processo colonizador avanzó hacia el interior del território oriental de Cuba con las plantaciones de caña de azucar y de café; y em los años I840 el habitat posible de los palenques se redujo em sustância. Para entonces, vegueros y estancieros sufrían los efectos de las apropiaciones de tierras por los dueños de las plantaciones, y fueran expulsados de las riberas de los ríos o afectados por la polución provocada por las fabricas, sin respaldo legal para reclamar sus derechos, no obstante haberse dedicado por generaciones al trabajo sobre ellas" (Zañuga, 20II: 35). 


\subsection{Miedo al Negro}

O 'medo ao negro', apesar de ser uma concepção criada no período da Revolução do Haiti, especialmente durante a primeira metade do século XIX, está presente nas relações raciais e na forma como se percebem as mobilizações afrocubanas na atualidade. É o que denunciam ativistas e coletivos antirracistas em Cuba. Esse seria um legado cultural daninho que, a partir de diferentes estratégias, se materializa na criminalização, na repressão, na coerção e na intimidação de mobilizações políticas negras que visem se contrapor à lógica de poder embranquecida.

No período no qual o 'medo ao negro' se conforma, durante o processo revolucionário haitiano, Cuba vivenciava uma intensa ampliação do tráfico negreiro. Nesse cenário, a conquista do Haiti, pelos negros anteriormente escravizados, representava uma grande ameaça ao poderio colonial e uma inspiração às mobilizações negras. "A existência de um Estado livre conformado de antigos escravos no vizinho Haiti, tornou-se uma ameaça para a cooperação entre os perturbadores e uma evidência de que se podia alcançar a autodeterminação" (ZUÑIGA, 20I I: 35) I43. $^{14}$

Em I804, o povo de uma pequena ilha caribenha, Saint-Domingue, declarou sua independência da França e o fim do sistema colonial. A nova República do Haiti foi a primeira nação politicamente independente da América Latina, sendo um importante referencial para os movimentos revolucionários que se iniciaram a partir de I8I0. Comandada por Toussaint Louverture e Jean-Jacques Dessalines, a revolução do Haiti teve início como uma revolução de escravizados pela liberdade, transformando-se posteriormente na luta pela independência (GRAU, 2009). No processo de consolidação do fim da escravidão, Toussaint, ex-escravizado, questiona o então poder colonial francês:

É possível acreditar que os homens que conheceram a liberdade ficarão de braços cruzados vendo como a desbaratam? [...] Se tivéssemos mil vidas, sacrificaríamos todas elas antes de ver nos submetidos de novo à escravidão. [...] Temos sabido como enfrentar o perigo para alcançar a liberdade; saberemos enfrentar a morte para defendê-la (JAMES, 200I: I87-I89, Apud, GRAU, 2009: 68).

A Revolução haitiana constitui-se como um acontecimento de grande força para a história da luta negra. De acordo com José Franco (2010), a épica das massas de escravizados rebeldes, durante treze anos de guerra, desafiou a brutalidade de uma ordem opressiva, defendida pelos exércitos das três potências mais poderosas da época, França, Inglaterra e Espanha. Esse processo

\footnotetext{
${ }^{143}$ Tradução livre da autora. Original: La existência de um Estado de antigos esclavos en el vecino Haití, quedó como amenaza para la cooperación a los perturbadores y como evidencia de que podia alcanzarse la autodeterminacion" (Zuñiga, 20II: 35).
} 
revolucionário colocou em xeque também uma ordem escravista e colonialista amplamente vigente no ocidente. A Revolução do Haiti se contrapôs a um ordenamento que regia, no plano das ideias, o ponderável e o imponderável no espaço da imaginação política de um sistema internacional sustentado pelo racismo, colonialismo e pela escravidão.

Nesse período, como reflexo da Revolução Negra Haitiana, há nas demais colônias um enrijecimento do controle sobre a escravidão. Em Cuba, se fortalece a movimentação próescravismo. Isso gerou, por outro lado, um acirramento também das estratégias de mobilizações políticas coletivas de negros e negras. O Haiti, nesse cenário, figurava como o exemplo da ameaça ou do modelo a ser seguido, dependendo do ponto de vista.

É nesse momento histórico que é cunhada uma das expressões mais usadas na contemporaneidade para abordar o receio social de tratar a questão racial: "El miedo al negro". Foi uma expressão oriunda do período da Revolução do Haiti que denominava o temor que havia entre a elite branca cubana de se reproduzir os mesmos processos revolucionários haitianos. Para além da Revolução vizinha que gerava os mais profundos temores, nessa trama estavam enredadas também as teorias racistas da época, que marcavam diferenças hierárquicas, inclusive biológicas, entre os brancos e negros.

O intrigante é como essa percepção do "medo ao negro" integra os discursos e a percepção de ativistas antirracistas no presente, exatamente para expressar as situações de interdito ou coerção vividas no trato do tema racial. Abaixo, algumas abordagens sobre o tema:

Pero qué más de internacionalistas que aquellos hombres y mujeres que fueron alcanzados de su tierra desde África y que conformaron fundamentalmente el núcleo básico de la población cubana del siglo XVIII y del XIX cubano. Porque incluso llego un momento según plantean algunos censos que había casi una mayoría de los negros sobre la población blanca en Cuba, y de ahí "El Miedo al Negro", y de ahí las políticas de blanqueamiento de la Cuba de entonces, de la primera mitad del siglo XIX y de la segunda mitad del siglo XVIII. (Entrevista com Rolando Zulueta, realizada em 02/02/20I5).

El miedo al negro prevalece, sin embargo cuando entras a internet y busques nuestro sitio vas a ver que hay un escrito en inglés y otro en español un artículo mío que dice "Hay que parar el miedo al negro", porque la teoría lombrosiana sigue. La policía a veces detiene a una persona en el Prado (avenida) solo porque es negro. He visto a un agente del orden interior tocar por el brazo al otro para indicarle que se acercaba un negro. Y vas a observar en nuestro muro cuántas fotos tenemos de policías deteniendo a hombres y mujeres negras y no es una casualidad. El miedo al negro sigue, está en Cuba lamentablemente. (Entrevista com Deyni Terry, realizada em I5/05/20I4).

Posteriormente entonces se habló del "Miedo al Negro", por qué todo lo que emprendemos los negros y negras causa temor. ¿Qué cosa ha hecho el poder para satanizar? Tiene que lo que se hace a manos de una persona negra es malo, es negativo, es lo peor. Hay imágenes de como desde los pintores más famosos, mucho antes de la formación de la nacionalidad cubana, y después, en la actualidad, han representado el negro y la negra en el arte. Mucho refleja el "Miedo al Negro". (Maritza López, entrevista realizada em I5/05/20I4). 
As narrativas dos três ativistas que destaco acima, Rolando Zulueta, Deyni Terry e Maritza López, abordam a dimensão história do conceito "medo ao negro". As duas últimas falas situam a existência nos dias atuais do "medo ao negro". O controle e a percepção dos negros como perigosos, negativos, subversivos inunda essas visões, que são alimentadas pelas vivências cotidianas cujo reforço desses estereótipos é muito presente, conforme descrito por Maritza e Deyni. De acordo com Santos (200I), a materialização do racismo é fundada no pressuposto de que há superioridade de um grupo racial sobre outro, ou parte da crença de que um determinado grupo possui "defeitos de ordem moral e intelectual que the são próprios" (200I:85), como a "periculosidade" nata.

Todavia, as poucas pesquisas sociais sobre o tema indicam que essa é uma percepção mais ampla na sociedade. A visão dos negros como "perigosos" e "não confiáveis" foi uma das justificativas para a existência do racismo entre os entrevistados na pesquisa feita em Cuba de 1993 a 2003, conduzida por um grupo de pesquisadores sociais do Instituto de Antropologia (GONZALEZ et al., 20II: 2004-2005) ${ }^{144}$. Do conjunto entrevistado, praticamente a totalidade afirmou que existe racismo em Cuba. Nas justificativas apresentadas pelos entrevistados do porque haveria racismo, várias das respostas reforçaram a percepção do "medo ao negro", como destacado pelos ativistas acima.

\footnotetext{
Son múltiples las respuestas al porqué de esta percepción afirmativa (de que existe racismo). La mayoría de referidas de la existencia del prejuicio se basan en las relaciones interpersonales, se nutren de anécdotas propias o atribuidas a otras personas, por ejemplo: "cuando una mujer va por la calle y ve que viene un negro..., siempre siente temor que algo pase...", o "siempre que hay un robo se busca al negro" (GONZALES et al., 201 I: 205).
}

A percepção dos ativistas é que o "medo ao negro" é um dos fatores de grande relevância para que não se aborde e visibilize os marcos históricos de luta negra em Cuba. Aponto, abaixo, um trecho do Boletín Ceiba, da Cofradía de la Negritud, de 15 de enero del 2007, dirigido ao diretor do jornal "Granma", veículo impresso do Partido Comunista de Cuba, que questiona a invisibilidade do debate sobre as relações raciais e o racismo nesse veículo. E, traz como um dos elementos causadores dessa invisibilidade, exatamente o "miedo al negro":

Cro. Lázaro Barredo.

Director del periódico "Granma”.

Respetado compañero:

Me estoy dirigiendo a usted en nombre de la Cofradía de la Negritud, un proyecto ciudadano de activismo social que, desde julio de 1998, realiza esfuerzos en la lucha contra el racismo y la discriminación racial en nuestro país; el propósito de esta carta es hacerle los siguientes planteamientos:

\footnotetext{
${ }^{144}$ Os primeiros resultados publicados dessa pesquisa ocorreram em I996, na revista "Temas, No. 7".
} 
El pasado 26 de junio entregué en la sede de la UPEC una misiva dirigida al compañero Túbal Páez, presidente de esa organización, en la que apelaba al deber ć́vico de los periodistas de contribuir a destacar ante el pueblo los hechos relevantes que forman parte de la memoria histórica de la nación, y me refería, específicamente, a la masacre racista de I9I2 cometida contra los independientes de color, hecho de gran importancia ignorado año tras año por la prensa cubana. Entiendo que esta actitud de la prensa está basada en la política oficial respecto al problema racial cubano; una política que, sobre el supuesto de no perjudicar la unidad del pueblo, no asume frontalmente la existencia del problema y, de hecho, parece expresar una variante contemporánea de aquel "miedo al negro" de la época colonial. Por eso no considera la convocatoria al debate social responsable de la cuestión racial, como ha sido solicitado por algunas entidades. La política racial, o mejor dicho, la política seguida para abordar la cuestión racial en nuestro país, no ha sido efectiva y por eso el repunte del racismo y la discriminación racial constituye hoy una de las realidades sociales más lamentables del proyecto socialista cubano. Por otra parte, no se puede resolver un problema que se sabe que existe si no se enfrenta adecuadamente ese problema, que puede hacerse más difícil con el transcurrir del tiempo ${ }^{145}$.

Nesse trecho, Norberto se refere à invisibilidade de um dos acontecimentos históricos mais refletidos pelos ativistas: o massacre do Partido dos Independentes de Color. Esse trecho remete ao debate sobre o "medo ao negro" e demonstra como a percepção de rejeição, de controle e de silenciamento é sentida pelos ativistas e coletivos, e é notada como um elemento conformado no passado, mas atualizado no presente a partir de novas estratégias de poder.

Para além das influências sobre Cuba, vizinha do Haiti, os reflexos da Revolução haitiana foram sentidos em outros contextos mais longínquos na América Latina. De acordo com Marques e Parron (20II), há possibilidades de vinculação das revoltas negras em Cuba e na Brasil, especialmente no período de 1790 a 1825, ou seja, do início da Revolução da Colônia de SaintDomingue (hoje Haiti ${ }^{146}$ ) à outorga da Constituição do Brasil e à decretação para ampliação de vantagens e poder aos capitães generais de Cuba, no contexto imediato do término das guerras de independência no continente.

\footnotetext{
No segundo momento (I824-1837), a concentração dos poderes políticos e militares na figura do capitão general pelo decreto real de maio de 1825 deu às classes senhoriais de Cuba canais mais amplos para lidar com as ameaças embutidas em uma eventual guerra de independência, como o risco de revoltas escravas ou de interferência britânica (MARQUES, 201 I: 7) ) $^{147}$.
}

Essa plataforma conjugava a defesa da ampliação do tráfico negreiro transatlântico com a defesa do enrijecimento das barreiras raciais em Cuba, alterando assim o quadro das relações sociais escravistas que vigorara na ilha até I790. Restringir os direitos de cidadania dos grupos egressos

\footnotetext{
${ }^{145}$ Destaque meu.

${ }^{146}$ O Haiti foi o primeiro país latino-americano a se tornar independente da França, por meio da Revolução Haitiana. Denominada de colônia Saint Domingue, o país era o maior produtor de açúcar do mundo e o principal exportador de café para a Europa. Sua população era constituída de cerca de 500 mil habitantes: 35 mil brancos, 30 mil mulatos livres e mais de 430 mil escravizados negros oriundos da África Ocidental (Fonte: www.mundoeducacao.com.br/historia-america/revolucao-haitiana.htm.)

${ }^{147}$ http://www.fea.usp.br/feaecon//media/fck/File/Rafael\%20Marquese\%20.pdf (acesso em I0/20I3).
} 
do cativeiro, portanto, casava-se com a ideia de silenciar o debate sobre a escravidão e o tráfico (MARQUES e PARRON, 20II).

Impulsionada pelo contexto haitiano, Cuba sediou a Rebelião de Aponte. A rebelião tinha como objetivo o fim da escravidão e do colonialismo espanhol. Reunia negros e negras na condição de escravizados e também livres, organizados em importantes cabildos de nação e milícias.

Para proteger a Ilha de outras potencias europeias e de ataques piratas, a colônia espanhola formou uma milícia composta também por negros livres, pois não havia população branca suficientemente numerosa. É possível remontar as origens da milícia ao século XVI, sendo essa uma importante via de alcançar a libertação e a ascensão social para os africanos e seus descendentes. O século XVIII e XIX, como mencionado anteriormente, agudiza as relações raciais, pelo aumento significativo do tráfico de escravizados e pela ampliação da tensão racial (CHILDS, 20I I).

É nesse período que a milícia conformada para defender o poder colonial, composta de negros livres, passa a ser vista como uma ameaça pelos funcionários coloniais. De acordo com Childs (20II), a milícia possibilitava o acesso a armas para o êxito da rebelião. Além disso, a elevada posição social e econômica dos soldados negros potencializava o seu papel de lideranças nas comunidades para agregar negras(os) livres e escravizadas(os). A rebelião de Aponte, em I8I2, é um capítulo fundamental da história cubana do século XIX, especialmente, no que se refere às lutas abolicionistas e antirracistas.

Os cabildos de nação, organizados a partir da identidade étnica dos povos africanos trazidos a Cuba, se constituíam como espaços privilegiados para encontros, reunião e para o planejamento de ações coletivas de contestação ao regime colonial escravista. Vários líderes da rebelião de Aponte desempenhavam importantes papeis sociais também nos cabildos que integravam e, a partir da estrutura desses grupos, potencializou-se a organização da rebelião. As ligações da rebelião de Aponte com o Haiti são muito mais amplas do que a simples inspiração. Os registros coloniais apontam um fluxo de generais da revolução haitiana que em Cuba apoiavam militar e estrategicamente a rebelião negra (CHILDS, 20I I; FRANCO, 20I0).

A rebelião de Aponte teve início em janeiro de I8I2. Os primeiros atos foram a tomada de cinco fazendas de grandes plantações. Além disso, há informes coloniais da época que apontavam que nas regiões de Bayamo e Holduín, mobilizações negras se formaram. As ações planejadas, segundo os depoimentos de alguns capturados pelas forças coloniais no período, apresentavam 
como planejamento a queima de casas, bloqueio de estradas, assaltos a postos militares para acesso a armas e munições (CHILDS, 201 I). Em fevereiro e março, novas sublevações ocorreram em outras regiões da Ilha.

Na manhã de 09 de abril de I8I2, na fortaleza militar La Punta, em La Habana, foi realizada a execução dos conspiradores cujos ideais apontavam para a abolição da escravidão e para o fim da colonização em Cuba. Entre os executados, estava José Antonio Aponte, considerado líder da rebelião, e Juan Barbier. Esse último, de acordo com os registros judiciais da época, também considerado um dos líderes, teve uma vivência na ex-colônia Saint-Domingue, então recentemente estabelecida como República do Haiti. Nos registros dos depoimentos de escravizados e negros livres sobre a rebelião, vários afirmaram que se tratava de um general do exército haitiano que tinha vindo contribuir com o processo cubano (CHILDS, 201 I).

Juan Barbier simboliza as mudanças radicais que foram produzidas no mundo atlântico durante as primeiras décadas do século XIX. A atenção gerada entre escravos e gente de cor livre, como também entre os oficiais que liquidaram o movimento, ilustra como o Haiti proporcionou imagens contrastantes de fascinação e medo para diferentes setores da sociedade cubana (CHILDS, 20I I: 39).

As mobilizações negras em Cuba, nesse período, também foram fortemente impactadas pela Conspiração de la Escalera, onde importantes atores negros e negras com força econômica, política e intelectual foram condenados e majoritariamente assassinados de forma brutal, acusados de conspiração contra o poder colonial, no princípio do século XIX. Os impactos desse extermínio foram sentidos nas lutas abolicionistas de forma considerável (DESCHAMPS CHAPEAUX, 197I).

José Aponte entra pra história como um dos líderes negros mais importantes na luta pelo fim da escravidão e pelos direitos dos negros. É nesse período, também, que surge a expressão "más malo que Aponte" ${ }^{148}$, usada até a contemporaneidade em Cuba. A rebelião foi duramente reprimida, com o assassinato de seus líderes de forma maciça, em I8I2. Todavia, o sentimento de contrariedade permanecia vivo. Segundo Zuñiga (20II), as denúncias de conspiração negra em Cuba se multiplicaram em meados do século XIX e comprovaram o estado de ânimos dos homens e mulheres "de cor".

A reversão da idéia do "más malo que Aponte" está em diversas iniciativas de ativistas e coletivos de recontar a história dessa rebelião e desse líder afrocubano. Um dos coletivos que acompanhei, inclusive, leva o nome de Aponte em sua homenagem. Heriberto Feraudy Espino, da Comissão

\footnotetext{
${ }^{148}$ Em português, a expressão seria: "mais mau que Aponte".
} 
José Antonio Aponte, em entrevista realizada no dia 17/06/2014, pontua a relevância do líder para a luta antirracista atual:

Foi (Aponte) o primeiro que organizou uma insurreição armada contra o colonialismo espanhol e contra a escravidão em Cuba. Não há um monumento em Havana que foi feito em sua homenagem. Há uma rua onde ele e vários de seus companheiros foram executados. Foram enforcados, arrancaram suas cabeças e as colocaram em uma jaula de ferro e a exibiram publicamente. Estamos lutando para construir um monumento em homenagem a Aponte nesse lugar, e assim creio que vamos alcançar, pois são detalhes que conformam a nossa história ${ }^{149}$.

Aponte, assim como Louverture, no Haiti, marcaram muito as mobilizações negras da época, bem como justificaram o endurecimento das ações repressivas e violentas do poder colonial. As elites negras da época que se organizavam em cabildos e milícias foram sistematicamente assassinadas, em alguns casos maciçamente. Essas são referências históricas que são contadas nas famílias, nos coletivos antirracistas, nas canções e poesias. Apesar de não ter ampla visibilidade e não estar presente no cotidiano das escolas e dos meios de comunicação, esses são enredos que continuam embalando as ações que insistem em questionar as desiguais relações raciais no contexto cubano.

\subsection{Sociedades Negras, Mambises e Minervas}

Assim como a situação de exclusão e violência vivenciadas pela população afrodescendente passou da colônia à república sem grandes mudanças estruturais, as mobilizações negras e seus espaços organizativos também. Como refleti no capítulo anterior, visualizo quatro grandes períodos históricos das mobilizações afrodescendentes nesse contexto da Diáspora Africana nas Américas.

O primeiro refere-se às lutas abolicionistas, entre os séculos XVIII e XIX, que, em muitos casos, traziam mescladas as lutas pela independência. A Rebelião de Aponte, no caso cubano, é uma das fortes referências. O segundo situa-se no início do século XX, com o surgimento e estruturação das primeiras repúblicas da América Latina. As mobilizações afrodescendentes se concentraram em agremiações recreativas, como os clubes negros no Brasil, em sociedades negras em Cuba, ou organizações culturais. Além disso, se conformam os partidos políticos com grande foco na superação do racismo, como os Independientes de Color(Cuba) e a Frente Negra (Brasil).

As sociedades negras cubanas estiveram presentes na transição das lutas pela abolição em Cuba, das Guerras de Independência e do nascimento da República. Mantêm-se como espaços de relevante agregação social até os primeiros anos da Revolução Socialista. Um dos aspectos

149 Tradução minha. 
fundamentais dessas narrativas sobre as lutas negras em Cuba está relacionada à organização desse segmento que são as sociedades de instrução, recreio e ajuda mútua, conhecidas como sociedades de $\operatorname{cor}^{150}$ ou sociedades negras de Cuba.

Após a Guerra dos Dez Anos ${ }^{151}$, é implantada a nova Constituição espanhola de 1876. Ela determina que os cabildos de nação sejam convertidos em sociedades de instrução e recreio para negros, a partir dos modelos já existentes de sociedades brancas. Com o novo marco legal, a partir de 1878, surgem as primeiras sociedades negras de Cuba.

Muitas dessas sociedades negras, apesar da fachada como sociedades, tinham a mesma dinâmica dos cabildos de nação, em que elementos de origem africana compunham a identidade coletiva. Segundo Carmen Arrechea (2004), os cabildos, confrarias e as milícias negras, tais como as sociedades, atuavam em diversas instâncias da vida social. Eram a favor da igualdade, em geral eram a favor da independência e do fim da escravidão. Algumas priorizavam o aspecto cultural e educativo com intuito de passar o legado africano aos filhos e netos.

O caráter elitista e classista entre os negros também era presente nas sociedades negras. Algumas apenas permitiam a adesão dos negros representantes da elite cubana. Tato Quiñones e Gisela Arandia destacam esse aspecto e suas transformações no processo da Revolução:

Recuerdo incluso había una costumbre, tradición de que las orquestas, las buenas orquestas cubanas, le componían números de homenaje a las sociedades donde tocara; así hay una que se llama Buena vista Social Club que era sociedad de negros ahí está todavía el local, otra se llamaba Isora Club que ponían son, danzones en homenaje, y cuando triunfa la Revolución hay una orquesta muy famosa en el año 59 una charanga que era la charanga de Pancho el Bravo, gustaba mucho que daba un ritmo muy chévere, que no duró mucho el ritmo se diluyo pero hubo un momento que pego fuertemente y ellos sacaron un son que se llamaba Circulo Social Obrero todos esos clubes pasaron a círculos sociales obreros donde tú por nada por centavos podías entrar a bailar y tomar cerveza. (Entrevista com Tato Quiñones, realizada em 29/05/2014).

¿Cuál es la reflexión de esas personas, que en la medida en que la Revolución desmontó él tema de las identidades, hasta cierto punto cortó esa identidad o esa conciencia racial que se estaban formando? (Fue) fragmentada porque las sociedades negras eran elitistas, eran clasistas solo iban allí los negros que tuvieran algunas posibilidades, después los negros con menos posibilidades iban a otro por supuesto (Entrevista com Gisela Arandia, realizada em I2/09/20I4).

As mudanças geradas no pós-Revolução socialista nas Sociedades Negras foram brutais. O viés de socialização passou a levar em consideração as vinculações profissionais. A lógica da luta de classes inundou os espaços onde antes estavam presentes outras perspectivas, como as redes de solidariedade pela identidade afrodescendente e a condição socioeconômica existente. As

\footnotetext{
${ }^{150}$ Em espanhol, "sociedades de color"

${ }^{151}$ A Guerra dos Dez Anos faz parte do processo de luta pela independência de Cuba em relação ao domínio espanhol. Durou de I868 a I878.
} 
Sociedades, portanto, deixam de existir em poucos anos após I959, exatamente por chocarem com os princípios revolucionários ${ }^{152}$.

Voltando ao século XIX, a partir da Constituição Espanhola de 1876, que determinava a substituição dos Cabildos pelas Sociedades Negras, surgem outras legislações que impactam nas formas de organização desse segmento. Esses marcos legais surgem e impactam as organizações e formas de manifestações negras, como a Lei de Imprensa, de I879, a Lei de Reuniões, de I880, e a Lei de Associações, de I886. Até então, essas organizações não tinham respaldo legal. Nessa conjuntura, surgem os partidos políticos, coletividades recreativas, de cultura, sociedades de recreação e manifestações na imprensa.

Também nesse processo de transição entre a Colônia e a República, cabe fazer menção à importância dos(as) negros(as) nos processos independentistas de Cuba. A participação negra nas Guerras de Independência foi de grande relevância, tanto entre seus líderes, quanto no que se refere ao contingente. Entre 1895 e 1898, grande quantidade negra uniu-se nas fileiras do exército libertador, que trazia como General Antonio Maceo, também negro, e tinha como um dos idealistas José Marti, cujo projeto previa a construção de uma nação para todos. De La Fuente destaca que a ideologia do exército mambise trazia visões divergentes sobre como se construiria essa nação independente, mas que havia um relativo consenso de que nessa nação para todos os negros estavam incluídos:

Las élites políticas podían soñar con una patria en la que los negros estuvieran simbólica o literalmente ausentes; pero su propia acepción a la idea de una cubanidad incluyente limitaba sus opciones políticas y daba a los afrocubanos herramientas legítimas para pelear por su inclusión en una nación que nadie negaba que era también suya. (DE LA FUENTE, 20I4: 42).

As referências idealizadas desse passado dos Mambises, do Exército Libertador, também compõem as narrativas da luta antirracista. O resgate da figura de Antonio Maceo é um dos pilares desse processo, como destaca Feraudy:

Yo diría que todo el país o la mayoría del país integra el movimiento antirracista. El pueblo cubano por naturaleza es antirracista y la historia lo ha demostrado, Maceo fue un gran antirracista, los mambises constituían un movimiento antirracista, yo creo que el pueblo completo, el pueblo cubano, yo creo a pesar de esas manchas discriminatorias que surgen en la isla entera constituyen un movimiento antirracista. (Entrevista com Heriberto Feraudy Espino, realizada em I5/06/2015).

Esse destaque aos líderes negros cubanos do processo de independência também esteve presente nas narrativas dos movimentos afrocubanos e das mobilizações antirracistas durante toda a República (DE LA FUENTE, 20I4). Os usos desses símbolos nesse período, contudo, eram

${ }^{152}$ Esse processo vivenciado no pós- Revolução socialista pelas sociedades negras será abordado mais detidamente no capítulo "Viva la Revolución! Abajo el Racismo!". 
antagônicos. Políticos se aproveitavam desses símbolos da independência para ressaltar a fraternidade racial cubana, enquanto ativistas da imprensa negra, militantes do partido comunista ou do movimento sindical abordavam esses "heróis negros da independência" para denunciar sua a situação de exclusão desse segmento na sociedade.

Essa memória dos generais negros que participaram do Exército no processo de independência, e que depois foram assassinados e em alguns casos completamente invisibilizados, compõe uma importante parte das narrativas históricas dos ativistas antirracistas entrevistados. No dia 22 de maio de 20I4, participei de um debate, no bairro Jesus Maria, no bairro Centro Havana, sobre a história de Quintín Bandera. No final da atividade, parte do grupo se reuniu e caminhou até a casa onde residiu o general.

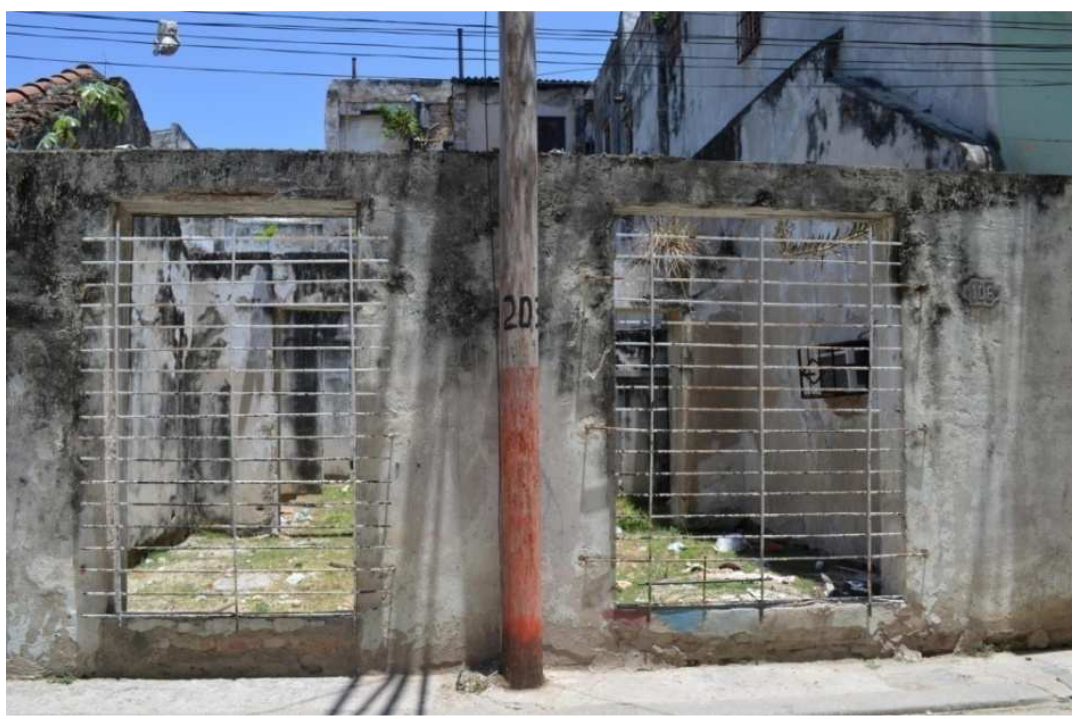

Figura 10: Ruínas da casa de Quintín Bandeira, localizada em Centro Havana, 22/05/2014. Foto: Bárbara Oliveira

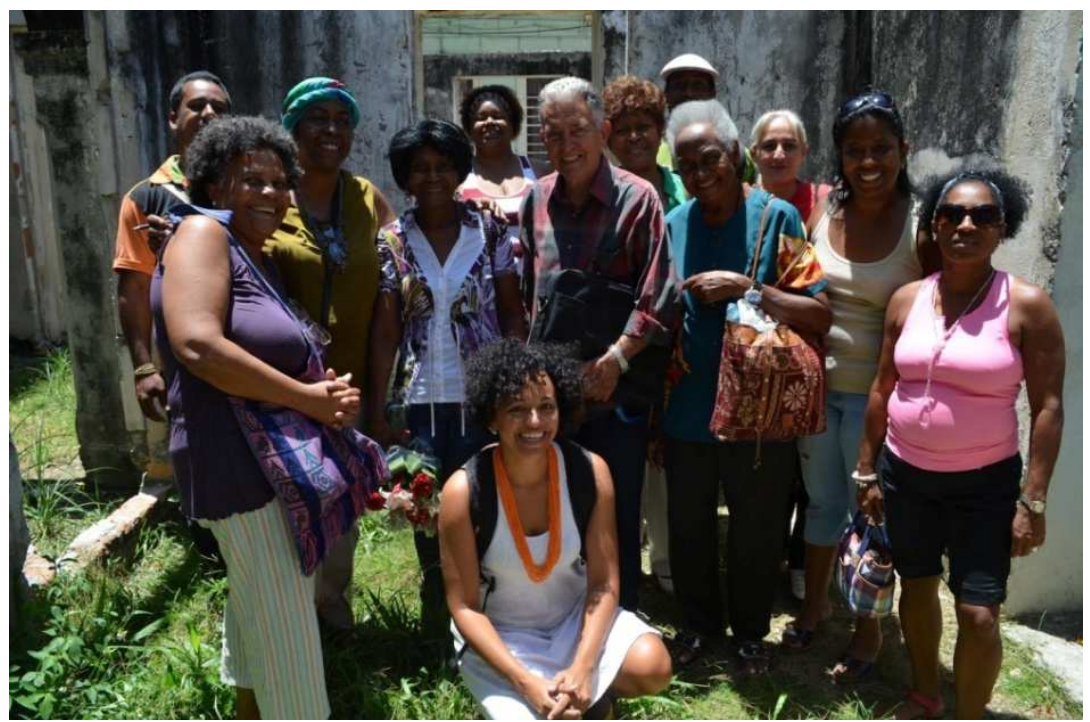

Figura II: Visita a casa de Quintín Bandera, com grupo participante do debate sobre sua história, em 22/05/20I4. Foto: Alfredo Saavedra. 
É sintomático observar que as ruínas da casa do general não trazem nenhuma sinalização sobre quem viveu ali, e que muitos na vizinhança desconhecem a história desse ilustre morador, vívido como um "mártir negro" nas narrativas de ativistas antirracistas do país. Essa invisibilidade, na qual Quintín se materializa como um dos ícones, permeia a história desse segmento da população até os dias atuais. Está presente no imaginário desses ativistas que a trajetória de silenciamento e violência vivenciada por gerações nas famílias negras são elementos importantes das desigualdades raciais hoje existentes.

Os usos desses símbolos históricos por ativistas, todavia, têm diferentes perspectivas. Há um relativo acordo de que a visibilidade desses ícones do passado seja importante. Mas, não são todos os coletivos ou ativistas que utilizam essas narrativas para fazer referência ou alusão à desigualdade racial contemporânea, como um instrumento de denúncia, como visto na abordagem de Bienvenido Rojas. Há alguns enfoques que mantém a visibilização desses ícones, como importantes para a construção da nação cubana, sem, a partir dessas referências, trabalhar as desigualdades atuais. Feraudy, da Comissão Aponte, exalta esses "heróis negros" como símbolos nacionais, conforme destaca a seguir:

\footnotetext{
Cuba no sería Cuba sin el general Antonio Maceo, yo me atrevería decir el hombre que protagonizo la Protesta de Baraguá cuando sus fuerzas están cansadas y diezmadas, Antonio Maceo el hombre que llevo la guerra hasta aquí a las puertas de La Habana, los españoles decían matando a Maceo matamos la Revolución, y así fue, matando a Maceo mataron a la Revolución del 95 entonces hemos rescatado la memoria de Maceo, ahora en estos momentos estamos celebrando la quinta jornada maceista, y como digo Maceo digo Mariana Grajales; el año que viene se conmemora el bicentenario de Mariana Grajales, la Madre de lapatria, nosotros estamos proponiendo que se cree una comisión nacional, es decir que no sea la Comisión Aponte, vamos a proponer, todavía no lo hemos llevado a blanco y negro, les estoy dando la premisa, vamos a proponer que se cree una comisión nacional con todos los organismos para homenajear a la Madre de la patria, quien sino ella, hay que conocer la historia de Mariana Grajales, hay que escribir muchos libros sobre Mariana Grajales y sobre María Cabrales y sobre José Maceo y sobre Marcos Maceo sobre la familia Maceo Grajales, siempre se hemos hablado que época de crisis de valores hay que tener como paradigma a esa familia Maceo Grajales, por ese camino andamos (Entrevista com Heriberto Feraudy Espino, realizada em I6/6/20I4).
}

Situar e reposicionar esses ícones históricos invisíveis no conjunto dos eventos "epitomizantes" da história oficial é uma das estratégias pedagógicas das narrativas antirracistas. Um dos objetivos é influenciar a autoestima desse segmento populacional, uma vez que a partir da história recontada com personagens heróicos negros, pode-se construir outra autoimagem dos afrocubanos, em contraponto à lógica hegemônica embranquecida, como destaca Roberto Diago, artista plástico, entrevistado para o documentário Raza, em 2008:

Yo ahora tengo un niño. Tiene 6 años. Yo paso un trabajo tremendo para buscarle muñequitos donde él se vea consciente de lo que él ya es. De adulto yo no era tan consciente como ahora, padre. Cuando pongo los muñequitos para mi hijo, la sirenita, los muñequitos, la princesa, todos son blancos, todos son rubios. Va llegar un momento que mi hijo se va mirar en el espejo y va decir: ¿Y yo, quién soy? Desde 
ahora yo lo tengo que enseñarte que él es un hombre negro, que tiene un pasado distinto, que pasó eso, que pasó el otro, para que él no se traumatice.

A afirmação da identidade negra, socialmente negada e escamoteada, e a valorização dessa identidade por meio de referências históricas, de heróis e heroínas negros, compõem uma parte importante da formação dessa autoimagem na perspectiva de muitos dos ativistas antirracistas de Cuba. Zurbano, abaixo, argumenta, inclusive, que no presente, a não compreensão da importância de "afro-reparações", ou ações afirmativas, advém do pouco conhecimento dessa parte da história:

Tendencias como las afro-reparaciones, por ejemplo, son muy difíciles de instrumentar en un contexto que niega o desconoce el horrible daño que nuestros antepasados sufrieron desde su salida de África y nos fueron legando en el curso de la Colonia y la República. Ese daño no ha desaparecido aun, hay secuelas muy contemporáneas silenciadas entre la impunidad, el silencio y la irresponsabilidad actuales. (ZURBANO, 2012: 06).

O processo de reverter a invisibilidade do legado dos afrodescendentes também passa por um olhar sobre as mulheres negras. Muitas vezes silenciadas dentro dos próprios movimentos antirracistas, centrados no olhar masculinizado, e dentro dos movimentos feministas embranquecidos, as afrocubanas também buscam dar voz às mulheres negras. O livro articulado por várias dessas ativistas, denominado "Afrocubanas", traz à tona mulheres que têm uma trajetória de luta antirracista em Cuba. Um dos coletivos de mulheres negras, abordado nesse trabalho, é o que se articulava em torno da revista "Minerva”, no final do século XIX:

En fecha tan temprana como I888, dos años después de la abolición de la esclavitud, las negras y mulatas, desde las páginas de la revista Minerva y otras, fueran capaces de articular un discurso completamente diferente al de las mujeres blancas. Abordaron en sus textos temas tales como la reivindicación de su identidad y de su africanía, la experiencia de la esclavitud, el orgullo racial y la exhortación a la superación cultural. (TERRY, 2011: 03).

As citações presentes nesse livro, de alguns trechos da revista "Minerva", denunciam a situação de vulnerabilidade das mulheres negras e apontam para a necessidade das afrocubanas seguirem a mobilização. María del Carmen Barcia (TERRY, 20II: 04) aborda um desses trechos que demonstra o peso de vivenciar a sobreposição de discriminações raciais e de gênero:

La mujer negra, sañudamente tratada por viles exploradores, viene hoy a ser el blanco más saliente a donde dirigen sus saetas envenenadas, aquellos mismos que traficaron con su noble sangre en los luctuosos días de la esclavitud. Por eso [...], nos preparamos a la defensa en el constante batallar, porque estamos pasando; y tal haremos hasta que se nos considere tal como somos y no tal como cada artista pirata le ha parecido o convenido a sus medrosos fines $[. .$.$] nos invitan a luchar, pues luchemos. [...] a$ nosotras, las de raza negra, se nos considera en las últimas capas de ese infamante juicio. (África de CESPEDES, I889: 2-5, In: TERRY, 20I I: 04).

Apesar da importância para a compreensão das mobilizações negras em Cuba, experiências como a revista Minerva e outras protagonizadas pelas mulheres negras são em grande medida silenciadas por pesquisadores, acadêmicos e por muitos ativistas antirracistas, que dão ênfase ao legado dos 
homens negros. Por isso, são tão relevantes as iniciativas protagonizadas por ativistas em estudar a história das mulheres negras.

O final do século XIX é rico de processos de mobilização negra. A existência de uma revista de mulheres negras e as múltiplas sociedades negras pelo país são já resultados concretos das mudanças legais, como a Lei de Associativismo e a Lei de Imprensa.

A participação das mulheres negras nas Sociedades de Color é outro aspecto importante para ser observado. Muitas das sociedades não aceitavam as mulheres como membros. Elas participavam das atividades apenas como esposas ou filhas, quase como uma extensão dos homens que as representavam. Por essa razão, a historiografia indica que algumas sociedades negras eram exclusivamente de mulheres, como a Nuestra Señora del Carmen (ZEQUEIRA, 20I I: 79).

Outro fato histórico que influenciou muito a sociedade cubana no que se refere às relações raciais e mobilizações negras foi o estreitamento da relação dos Estados Unidos com Cuba, especialmente a partir do final do processo de independência. Mesmo após o período de intervenção direta dos EUA sobre o país (em 1902), houve uma relação próxima e dependente com os vários governos que se seguiram no período republicano.

No final da Guerra, a entrada dos Estados Unidos e o seu "apoio" ao projeto de independência de Cuba, custaram o fim do projeto Martiano mais inclusivo. Criou-se uma imensa dependência política, econômica e social de Cuba em relação aos Estados Unidos e uma distância da inclusão social dos negros, tão almejada por aqueles que nesse período de batalhas sonharam com uma Cuba mais equânime. De La Fuente (20I4) aborda a ocupação americana como um período no qual a ideologia racista e as práticas segregacionistas foram reforçadas. Esteban Morales, ativista e intelectual cubano, destaca esse processo:

\footnotetext{
Incluso habiendo sido miembros del Ejercito Libertador, muchos negros que pelearon durante la Guerra de Independencia, y que hasta el final constituyeron casi un 60 o $70 \%$ de las fuerzas armadas del Ejercito Libertador, en realidad cuando en la República se fundaron los cuerpos militares, la policía, la guardia rural, la Marina, el Ejército, los negros prácticamente no tuvieron cabida, no tuvieron espacio. ¿Por qué razón? Porque el ejército norteamericano, tu sabes que intervino en la guerra de independencia cubana afínales de siglo (XIX), y cuando se reorganizo la República, la República se reorganizo bajo el liderazgo del ejercito. Los negros en realidad no tuvieron espacio. Quienes tuvieron espacio fueron los generales blancos, muchos de ellos reformistas. El primer presidente fue Don Tomas Estrada Palma, incluso no era ni ciudadano cubano, era norteamericano y había estado al frente de la actividad del Partido y del movimiento revolucionario en Nueva york, Estados unidos. Finalmente los norteamericanos le pagaron llevándolo como presidente de la primera república que se inauguró en I902. (Entrevista com Esteban Morales, realizada em I4/05/20I4).
}

Os interesses dos Estados Unidos com o território de Cuba eram muito anteriores à Guerra de Independência. Em I807, o então presidente estadunidense Thomas Jefferson propôs a aquisição 
da ilha. Em I823, John Quincy Adams, secretário do Estado, declara que a anexação de Cuba era “indispensável para a continuação e integridade da própria União”.

Em I898, após a explosão de um navio da Marinha estadunidense que matou 268 tripulantes, os Estados Unidos invadem Cuba e passam a atuar junto com o exército dos "Mambises" contra a Espanha. Mas o ideal de um país independente se perdeu logo no princípio da nova república. A Emenda Platt, que passa a compor o texto constitucional cubano a partir de 1903, permitia a intervenção dos Estados Unidos na Ilha, sempre que necessário. Nesse período é construída a base naval americana na Baía de Guantánamo.

Teoricamente democrática, mas com regimes corruptos e ditatoriais, Cuba viveu um processo republicano bastante conturbado, sempre com grande dependência econômica e política dos EUA. Nesse contexto, as tensões raciais compuseram um capítulo importante da história cubana, e as mobilizações negras estiveram presentes em uma variedade de estratégias.

\subsection{População Negra e a República Cubana}

Os estereótipos, a discriminação racial e o racismo contra os não brancos, especialmente os negros, como destaca Esteban Dominguez (2012), passaram da colônia à república sem que se houvesse avançado praticamente nada em sua solução. Na república recém estabelecida, no final do século XIX e início do XX, a Constituição passa a reconhecer mulheres e homens negros como cidadãos. Os homens negros adquirem o direito ao voto. Todavia, o cotidiano no país refletia outra realidade, muito próxima à existente no período colonial, sem uma real efetivação dos direitos ou da condição de cidadania (DOMINGUEZ, 20I2).

Para Scott (200I), tanto a guerra de independência de Cuba, como o processo de abolição da escravidão, geraram como produto a "liberdade" para os negros na Ilha. Todavia, a "liberdade" não possibilitava a completa efetivação dos seus direitos: "Podemos dizer, sem medo de nos equivocar-nos, que os ex-escravos descobriram rapidamente que sua liberdade legal, dentro do contexto colonial, estava incompleta.” (SCOTT, 200I: 25).

Para além do contexto colonial, como coloca o autor, o próprio nascimento da República não incorporou medidas estruturantes para efetivar aos negros e negras acesso ao mercado de trabalho, 
a condições dignas de moradia, a possibilidades concretas de acesso a espaços de representação política, à educação. Enfim, continuaram relegados à exclusão, com uma cidadania fracionada.

O processo de independência cubana trouxe aspectos complexos no que se refere à autonomia do país e ao atendimento às demandas históricas dos grupos mais marginalizados. Os diversos levantes que levaram à independência de Cuba, contaram, em sua etapa final, com o apoio dos Estados Unidos. Bienvenido pondera o quanto esse processo foi difícil para negras e negros que almejavam a possibilidade de maior integração social, após uma atuação destacada no processo de independência nas Forças Revolucionárias Independentistas:

\begin{abstract}
Durante la colonia la esclavitud se disolvió. Entonces llego el momento en que los esclavos junto con sus dueños se alzaron para luchar por la abolición y la independencia de Cuba. Hubo muchos, el Ejército Mambise, que era como se llamaba, en su mayoría estaba constituido por personas negras. ¿Pero que pasa cuando llega la República con Estrada Palma? El primer presidente de la República, después que se termina la colonia, que no se terminó realmente porque surgió la neocolonia, porque Estados Unidos se metió por el medio ahí. Entonces, ¿qué pasó con todos esos negros que estaban, que combatieron contra el colonialismo contra los españoles, que paso con esa gente? Esa gente sencillamente cuando termino la guerra, los mandaron, los desmovilizaron, y ya y se quedaron sin nada. No hubo un cargo para ellos, incluso la gente que fue general, está el caso por ejemplo de Quintín Banderas. Quintín Banderas que estuvo en tres guerras era un generalote, más general y con más cargos y más grados que el mismo Estrada Palma. Después él va a pedirle trabajo a Estrada Palma. ¿Estrada Palma que le dijo? Estrada Palma: Te voy a mandar de cartero, para humillarlo. Entonces él protesta y al final Estrada Palma lo mando a matar, lo mataron a machetazos a un general que se llamó Quintín Banderas. Esto sucede allá por 1906, entonces ¿que pasa con todos esos negros? Una parte de ellos viene a las ciudades y adonde van alojarse en las periferias, sin condiciones, hacen digamos casuchas como las favelas. Ese atraso se va acumulando, se va acumulando, entonces llegamos hasta hoy. Los barracones, los esclavos vivían en barracones primero y después de la guerra de los barracones aquellos pasaron para estos otros barracones que es lo que se llama aquí, por ejemplo, las ciudadelas actuales o los solares. Porque eso tiene una ley, la ley del más fuerte, ahí llegamos. El nivel cultural de esa gente es muy bajo, el nivel adquisitivo es muy bajo, mucha gente se dedica al hurto a robar, la violencia domestica, la puñalada, eso es tremendo. (Entrevista com Bienvenido Rojas, realizada em 04/05/2014).
\end{abstract}

A independência veio, mas não era total. A emenda Platt, adicionada à recém-escrita Constituição Cubana, assegurava aos Estados Unidos o direito de intervir em Cuba sempre que seus interesses estivessem ameaçados. A proximidade e a relação de dependência direta com os Estados Unidos acarretaram situações extremamente complexas, como a instalação de uma base militar estadunidense em Guantánamo, no leste da ilha, e uma sucessão de presidentes que respondiam primeiramente aos interesses estadunidenses, depois da elite cubana. Não havia espaço algum para um processo de reparação histórica ao conjunto da população negra que havia sido por séculos escravizada ou experimentava uma liberdade limitada.

Essa relação de dependência gerou efeitos políticos, militares, econômicos e sociais profundos. Um desses efeitos tinha, obviamente, relação direta com as relações raciais. Com o estreitamento do vínculo de Cuba com os Estados Unidos, o racismo ganhou novas estratégias como ideologia de poder. Na opinião de alguns ativistas antirracistas de Cuba, foi, inclusive, amplificado, como 
ressalta Esteban Morales (2012): "O racismo que já era sentido em Cuba se reforçou com a intervenção norteamericana ${ }^{153}$ " (2012: 16). Niurka Nuñez, investigadora do Instituto Juan Marinelo, na entrevista realizada para essa pesquisa, também destaca essa problemática:

A intervenção norteamericana foi um retrocesso enorme para a problemática racial. Eles vieram com seus esquemas racistas e a reproduziram muito bem durante a etapa de ocupação. E através da influência que exerceram a partir desse momento, por meio da etapa neocolonial, se frustram todos os ideais de igualdade

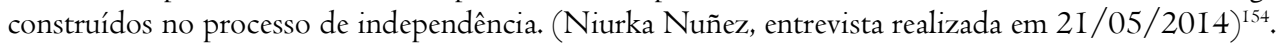

Para Fornias (200I), a presença estadunidense em Cuba adquiriu ares de missão civilizadora, baseada nos conteúdos de uma ideologia imperialista e na superioridade anglo-saxônica, para ditar normas a outras nações, promovendo valores e condutas.

Em 1902, o governador militar dos Estados Unidos abandonava a Ilha depois de ter cumprido o que considerava ser a sua missão: Edificar uma republica anglo-saxônica em um país latino, onde aproximadamente $70 \%$ da população era analfabeta $[. .$.$] , em resumo, estabelecer em pouco mais de três$ anos uma colônia militar latina, uma República calcada exatamente em nossa grande República (estadunidense). (FORNIAS, 200I: 54) ${ }^{155}$.

A intervenção estadunidense se inicia em I898. Com ela, novas abordagens das relações raciais complexificam o quadro, já desfavorável dada toda a carga ideológica do sistema colonial espanhol e toda a situação de exclusão econômica e social a qual estava sujeita a população negra. Morales (20I2) cita Charles Davenport, influente geneticista da época, que referendava esses preceitos racistas: "Os mulatos combinavam ambição com a insuficiência intelectual, o que faz deles híbridos infelizes, propensos a romper a ordem harmônica.” (20I2: I8).

Para o ativista Tato Quiñones, o nascer do período republicano de Cuba traz máculas fundamentais para as relações raciais no país, especialmente fomentadas pelas intervenções estadunidenses:

A intervenção norteamericana em 1898 e na Guerra de 1895 (Guerra de Independência) marcou um momento, uma virada para essa questão, ainda que nas próprias fileiras do exército libertador, depois que o exército libertador em I897 tinha a certeza de que ganharia a guerra contra a Espanha, houve um processo de recuo de forças. Daí vem a intervenção norteamerica e a República livre, democrática, que havia sonhado José Martí, onde haveria a integração de cubanos brancos e negros a trabalhar pelo bem comum, se viu frustrada. Com a intervenção norteamericana, e a implantação de um governo praticamente imposto, uma oligarquia branca se fortalece no poder em Cuba. O racismo herdado da colônia sobrevive, somado aos aportes feitos pelos norteamericanos que já tinham sua própria experiência racista em seu pás. (Tato Quiñones, Entrevista realizada no dia 29/05/2014) ${ }^{156}$.

A academia, mais uma vez, refletia as percepções do período. E os conceitos atingiam, também, a elite cubana hispânica. O exemplo trazido por Dominguez ilustra essa questão. Em visita feita

\footnotetext{
${ }^{153}$ Tradução minha.

${ }^{154}$ Tradução minha.

${ }^{155}$ Idem.

${ }^{156}$ Ibidem.
} 
pelos professores universitários cubanos à Universidade de Harvard, em I90I, estes foram descritos como "niños crescidos que no podían entender la importância de lo que veían" (DOMINGUEZ apud DE LA FUENTE, 2000: 67).

Ainda para esse autor, as principais causas que historicamente impactaram o racismo em Cuba são: (I) O sistema escravista ali implantado e sua a longevidade, cuja abolição ocorreu apenas em I886; (2) O "miedo al negro", que gerou duras ações para evitar que o modelo da revolução haitiana em Cuba se instalasse, com consequências econômicas, sociais, políticas para os negros.

Particularmente, eu concordo com os três pontos levantados. Todavia, creio que seja importante abordar também o caráter ambíguo desse nascer republicano em Cuba, como ressaltado por De La Fuente (20I4). De acordo com esse autor, a desigualdade racial ganhou maiores requintes, como na lógica excludente do mercado de trabalho para negros, balizada pelo racismo científico estadunidense, que os manteve em uma posição subordinada. Mas, destaca que, diferentemente dos outros países latinoamericanos como o Brasil (onde até 1930 só podiam votar aqueles que sabiam ler e escrever, excluindo a grande maioria negra do país), em Cuba o sufrágio universal masculino incluiu toda a população afrodescendente (HELG, 2004; DE LA FUENTE, 20I4). Essa conquista é fruto da relevante participação afrodescendente no exército Mambise e da forte ideologia construída à época de "uma nação para todos", o que permitiu a coexistência de ações ambíguas no período.

Os reflexos dessa participação nos sufrágios foram sentidos por todos os partidos que não podiam ignorar esse segmento da população (HELG, 2006; DE LA FUENTE, 20I4). Todavia, as estratégias foram incrementadas com um crescente cerceamento dos espaços de debate sobre a questão racial, bem como dos espaços de mobilização negras, como partidos, chegando até a criminalização de alguns desses espaços. O resultado disso é o grande massacre que ocorre, em 19I2, com o Partido dos Independientes de Color, conforme descreverei a seguir.

Há, por outro lado, o incentivo para a migração europeia no período. Existe, portanto, um processo de assimilação dessa mão-de-obra europeia e o contínuo processo de exclusão dos negros e negras no país que complexificam uma efetiva inclusão desse segmento da população na nova República cubana.

Em processo semelhante ao vivenciado no Brasil nas primeiras décadas do século XX com o estímulo à migração europeia, Cuba, por meio de iniciativas do governo interventor, deu sequiência a uma política migratória europeia intensa. Depois de I898, estima-se a migração de 70 
mil europeus ${ }^{157}$, majoritariamente espanhóis, num explícito projeto de branqueamento do país. De La Fuente (20I4: 58) aborda o favorecimento da população branca nos programas de colonização:

\begin{abstract}
Las políticas migratorias cubanas sancionaron explícitamente las ventajas raciales y culturales atribuidas al blanco y favorecieron los programas de colonización - es decir, la inmigración de familias blancas [...] Así, del millón de dólares destinados por la ley de inmigración de 1906 para subvencionar la inmigración, el $80 \%$ sería usado para pagar los costos del movimiento de familias de Europa y las Islas Canarias [...]Varios años después, el gobierno cubano designó un delegado especial de Inmigración y Colonización con residencia en Europa, cuyo deber principal era difundir las ventajas de Cuba como destino migratorio. (DE LA FUENTE, 2014: 58-59).
\end{abstract}

Os dados do Censo de 1907 apontavam que cerca de um terço da população cubana era negra, $29 \%$ do total, proporção já consideravelmente inferior a do século XIX. Com a aprovação do direito ao voto, no início do século XX, para a população masculina de forma universal, os homens negros passaram a figurar como estratégicos nos processos eleitorais, representando ao redor de $30 \%$ do eleitorado.

E as demandas por direitos e igualdade para negros cresciam. Depois do período escravista, as mobilizações negras se concentraram nas sociedades conhecidas como Sociedades de la Raza de Color. Elas tinham finalidades, na maior parte das vezes, recreativas, contudo, se configuraram também como importantes espaços de mobilização política. Além das sociedades, as/os negras/os se mobilizavam na estrutura dos antigos cabildos, muitos deles transformados em associações legalizadas, após a Lei de Associações de I886.

Contudo, havia a percepção de que os partidos políticos deveriam pautar as demandas da população negra para efetivar políticas públicas governamentais. Os partidos existentes a época não priorizavam, em absoluto, essa pauta. Desse processo de descaso com as demandas negras, surge a iniciativa de criar um espaço político partidário específico.

\title{
2.5. Independientes de Color
}

Em Cuba é fundado, em 1908, o primeiro partido que representava a luta por direitos e equidade dos negros nas Américas: o Partido Independiente de Color. Helg (2000), em seu trabalho de pesquisa sobre esse partido, destaca a velocidade com que a agrupação conquistou membros em todo o país, com grande poder de mobilização:

${ }^{157}$ FORNIAS, 200I: 65. 
O partido dos negros e mulatos cubanos alcançou com rapidez membros em toda a nação, estabelecendo vínculos do campo com as cidades; Mobilizou trabalhadores, camponeses, artesãos e uns poucos indivíduos de classe média a unir-se em torno de um programa centrado na igualdade racial e nas demandas da classe trabalhadora (HELG, 2000: 5) ${ }^{158}$.

Mais uma vez as histórias de Cuba e Brasil se aproximam. Além de Cuba, no Brasil e no Uruguai foram criados partidos voltados para os direitos da população negra na primeira metade do século $\mathrm{XX}$, que trazia como pauta educação, trabalho digno, dentre outros direitos que pudessem assegurar uma efetiva inclusão dos afrodescendentes. Tinham a concepção que apenas uma representação política diretamente representativa poderia garantir direitos desse segmento. A Frente Negra Brasileira foi fundada em I6 de setembro de I93I, em São Paulo, e atuou até 1937. Oficializou-se como partido político em 1936 e ocupou, na história brasileira, uma singular posição no campo sócio-político na primeira metade do século XX. Em sua sede, desenvolviam-se diversas atividades e prestações de serviços como educação, aulas de teatro, produção de jornal e assistência jurídica.

A criação da Frente Negra teve grande influência do grupo Centro Cívico Palmares, também criado em São Paulo, em 1926, que tinha como prioridade a elevação da escolaridade de negras e negros. Na desagregação dessa entidade, em I929, muitos de seus integrantes se mobilizam para a criação de uma instância mais representativa, que viria a ser, pouco depois, a Frente Negra Brasileira.

Aline Helg (2000) destaca que o Partido Independientes de Color e a Frente Negra Brasileira tinham uma concepção convergente de que a vivência do racismo uniria todos os negros de seus países. Esse processo desafiaria o poder dos partidos existentes, dominados pelos brancos, cuja pauta não incorporava os direitos da população negra.

Todavia, um aspecto que merece destaque, para a autora, refere-se à capilaridade de atuação que teve o Partido Independientes de Color, cuja atuação abarcava todo o território nacional. A Frente Negra padeceu dos limitados direitos políticos existentes, da desigualdade de ferramentas em relação aos partidos hegemônicos e da baixa articulação entre os coletivos negros da época. Por isso, a Frente Negra não significou uma real ameaça aos poderes hegemônicos. Ela atuou até a proibição de todos os partidos políticos, decretada por Vargas em 1937. Autores brasileiros, contudo, destoam da autora e argumentam que a atuação da Frente Negra teve significativa

${ }^{158}$ Tradução minha. 
capilaridade, chegando a possuir núcleos no interior de São Paulo e em diversos estados brasileiros, com milhares de membros filiados (MALATIAN, 20I3) ${ }^{159}$.

Bienvenido Rojas, ativista antirracista, ressalta a criação do Partido dos Independientes de Color e como essa ação foi estratégica para reverter a histórica manipulação do segmento negro:

O Partido Independiente de Color surge por isso, porque quando surge a República, para que os negros serviam? Para massa eleitoral dos diferentes partidos, que manipulavam esse grupo com promessas e não cumpriam nenhuma, nada mudava. Então tem um grupo de pessoas inteligentes, gente que vem da Guerra (Guerra de Independência), muito preparada [...] Eles se dão conta de que para os negros não havia nada. Então dizem: Vamos fazer um partido para lutar por nossas reivindicações! Mas não era um partido só para negros. Havia brancos pobres também que estavam juntos no partido pois a pauta era muito social. Então, começam a organizar isso. Todavia, passa a haver uma oposição dos partidos e no Senado há um negro que obedece à classe dominante, que propõe uma Emenda, que passa a ser conhecida pelo seu nome, Morúa. E é essa Emenda que proíbe a criação do Partido Independientes de Color (Bienvenido Rojas, Entrevista realizada em 04/05/2014) $)^{160}$.

O partido tinha vários líderes, dos quais se destacavam Evario Estenoz e Pedro Ivonnet. A criação e mobilização, majoritária, mas não exclusiva negra, do Partido Independientes de Color, se constitui como um processo fundamental de luta pelo reconhecimento da igualdade e de direitos da população negra.

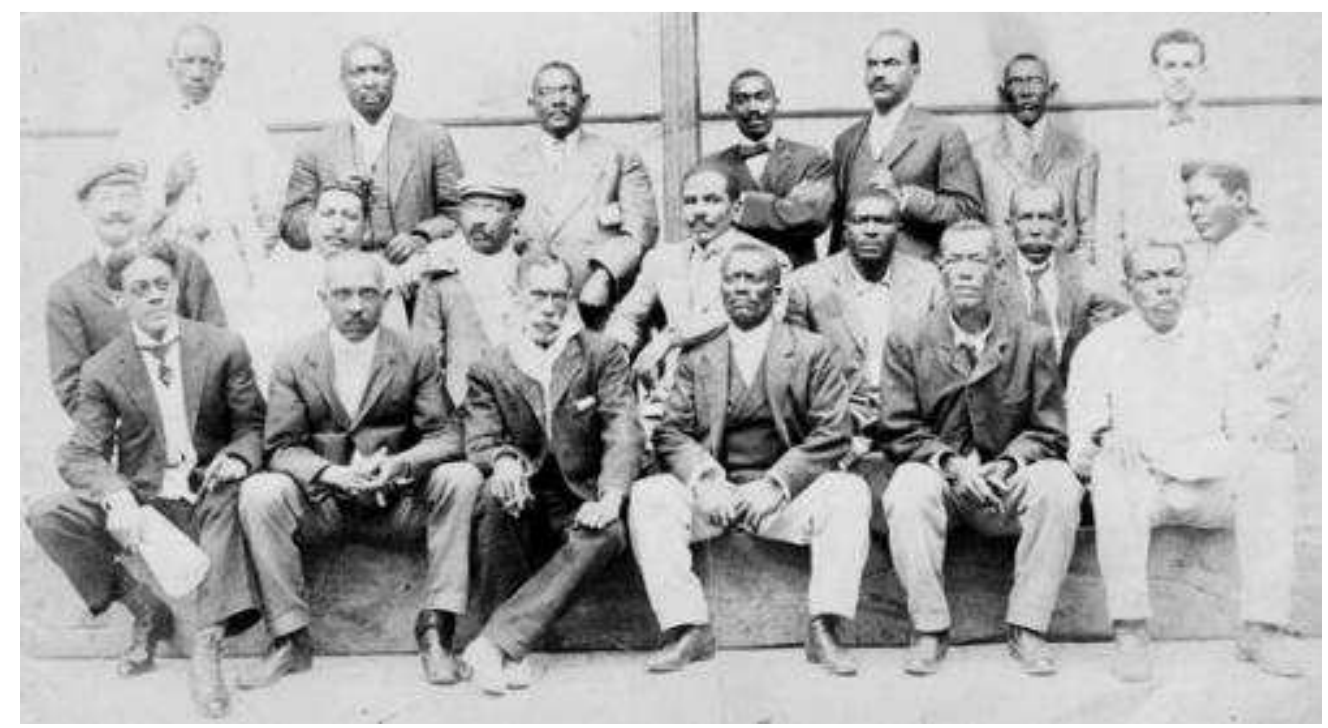

Figura 12: Foto de membros do Partido Independientes de Color. Disponível em: http://www.blackpast.org/gah/partido-de-independiente-de-color-cuba-I908-I9I2. Acesso em: II/09/20I5.

O Partido, criado em 1908, foi posto na ilegalidade pela Emenda Morua sob a alegação de não ser possível a existência de partidos cuja pauta versasse sobre um grupo racial específico. $\mathrm{O}$

${ }^{159}$ Para mais informações, ver PINTO, Regina Pahim. Frente Negra Brasileira. Cultura Vozes, n. 4, jul/ago I996; BARBOSA, Marcio. Frente Negra Brasileira - depoimentos. São Paulo: Quilombo hoje, 1998.

${ }^{160}$ Tradução minha. 
partido tentou diversas formas de legalizar sua atuação. Até a tentativa última de encampar um protesto armado, forma muito usual de protesto na época, que não implicava em tentativa real de batalha, mas em causar impacto político para o alcance de um determinado objetivo ${ }^{161}$.

Antes do "protesto armado", o Partido Independientes de Color fez forte pressão junto ao governo, tentou estabelecer diálogo diretamente com os Estados Unidos, que atuava em uma posição dúbia de reconhecer por um lado o Partido, e por outro marcava sua posição de intervir no país caso houvesse qualquer possibilidade de alteração da ordem. Foi então que a mobilização popular e armada foi colocada em curso.

O êxito extraordinário de mobilização do Partido Independientes de Color teve, como pontua Helg (2000), uma resposta proporcional para dar fim ao processo: o massacre de seus líderes e seguidores, como também de negros não vinculados ao partido, pelo exército de Cuba, em I9I2. O massacre, além de contar com o exército cubano, teve amplo apoio dos Estados Unidos, inclusive com força militar.

Os números exatos dessa matança ainda são indefinidos. Flutuam de uma estimativa de 3.000 a 6.000 pessoas negras assassinadas. A repressão violenta a essa ação imprime o clímax do "miedo al negro", forjado desde os tempos da Conspiração da Escalera em Cuba, e da Revolução Haitiana, no início do século XIX, somada à fortíssima influência estadunidense e a ideologia racista dos cubanos brancos governantes. $\mathrm{O}$ terror não se restringiu aos militantes do Partido Independientes de Color. A população negra em geral foi muito hostilizada pela polícia, exército e grupos populares formados por brancos de diversas classes sociais.

$\mathrm{Na}$ nascente república, que conclamava os direitos igualitários entre brancos e negros, fica explícito qual era o espaço dedicado a cada um. Sob a alegação de que o Partido tinha como plano dividir o país e fomentar uma guerra racial foi colocada em marcha uma ofensiva de grande escala, a partir da soma do exército e dos civis incitados pelos meios de comunicação.

Surge, em 1908, o Partido de los Independientes de Color, como uma forma de retomar a luta pelos direitos dos negros, mas com um programa muito avançado que não tinha como plataforma um corte racial, uma ruptura racial. Era um Programa que, em geral, exigia medidas de justiça social para as classes de menor poder aquisitivo, incluindo aí os negros. Mas não era um programa que estabelecia um corte racial. O Partido de los Independientes de Color, todavia foi perseguido, atacado, agredido por todos os meios existentes, especialmente pela imprensa. Essa história se conclui com o massacre de 19I2, uma das páginas

${ }^{\text {I6I }}$ Foi por meio de estratégia semelhante, ao realizar um "protesto armado", que José Miguel Gomes pressionou politicamente o governo para chegar a presidência de Cuba, apenas alguns anos antes do massacre contra o Partido Independientes de Color, comandado por ele próprio. 
mais vergonhosas da história de Cuba e que acabou com a luta dos negros em organizações independentes (Entrevista com Niurka Nuñez, realizada em 21/05/20I4) ${ }^{162}$.

Bienvenido Rojas, ativista antirracista de Cuba, destaca que o Partido não almejava uma batalha efetiva contra o Governo cubano. Alçamentos armados, como ação simbólica para um propósito político era uma prática comum na época:

Naqueles tempos, era muito usual o que se chamava "protesto militar" ou "alçamento armado" como uma forma de manifestar força social e política. Era usado em situações para estimular o diálogo e os espaços de negociação política. Em 1906, Estrada Palma estava no Governo e queria reeleger-se. Então José Miguel Gómez não estava de acordo com a reeleição de Estrada Palma e faz um "protesto militar", em formato muito similar ao feito pelo Partido dos Independentes de Color, em I9I2. E ainda tem um detalhe importante, Evaristo Estenos, que era um dos líderes do protesto dos negros, foi um dos apoiadores de José Miguel Gómez, no protesto militar de 1906. O que acha disso? (Bienvenido Rojas, Entrevista em $04 / 05 / 2014)^{163}$.

Rojas continua sua análise e aponta os indícios de que, nesse caso do Protesto do Partido dos Independientes de Color, também havia algum acordo com José Miguel Gomez, para a criação de um ambiente político favorável à derrubada da Emenda Morúa:

José Miguel Gomez, presidente na época, traiu o acordo feito, porque a ideia é que eles fizessem o protesto para ganharem força. Mas, se aproveitaram dessa oportunidade para acabar com os negros. E há uma grande matança. Há quem diga que tenham sido em torno de 4 a 5 mil pessoas negras mortas, na parte oriental do país. Aqui, até hoje, há intelectuais que não conhecem nada desse assunto. Nunca ouviram falar. Porque se ocultou isso. Na República, esse assunto foi um silencio completo. Não só na República, mas também na Revolução. Faz, somente, cinco ou seis anos, quando surgiu o Color Cubano, que começou a se falar novamente nesse massacre, a movimentar esse assunto. Antes, de isso não se falava. Estava proibido aqui. Não, não, não, de isso não se podia falar. Engavetaram o assunto. (Entrevista com Bienvenido Rojas, realizada em 04/05/20I4) $)^{164}$

Há uma grande invisibilidade desse massacre e do processo de organização do Partido Independientes de Color até os dias atuais. Não consta como conteúdo nos livros de histórias e currículos escolares. Também não está presente na mídia, para além de menções pontuais. Reflexo dessa invisibilidade é o fato de ativistas antirracistas, estudiosos do tema, terem "descoberto" esse ocorrido há poucos anos:

Yo voy a ser sincero: ninguno de nosostros que fundamos la Cofradía de la Negritud sabíamos nada de los Independientes de Color. Mira que yo era lector de cosas históricas y nunca había oído sobre eso. Y no sabía nada del partido, de Estenos. Entonces, ¿cuando yo conozco eso? Fue por Gloria Rolando y Gisela Arandia. Y esa historia tan tremenda de los Independientes... En la escuela no se hablaba de eso [...] Después de conocer eso me apasiono y pasa algo como pasó a Gloria Rolando. Es como si los muertos me lo dijeran que yo tengo que hacer algo. (Entrevista com Norberto Mesa, realizada em 09/07/2015).

Como evento "epitomizante", na atualidade, durante minha pesquisa de campo, o massacre e a história dos Independientes de Color foram recorrentes em narrativas, debates e abordagens feitos pelos ativistas e coletivos. Interessante perceber, contudo, que essa incorporação é fruto de uma

\footnotetext{
${ }^{162}$ Tradução minha.

${ }^{163}$ Idem.

${ }^{164}$ Ibidem.
} 
construção discursiva coletiva mais recente, que busca romper com o histórico silenciamento sobre o tema.

O documentário de Gloria Rolando, I9I2: Voces para el silencio, retrata de forma impactante a abordagem da imprensa da época e a reação da sociedade cubana. Algumas fotografias e manchetes publicadas nesse período demonstram o escárnio público a que foram submetidos os partidários de cor:

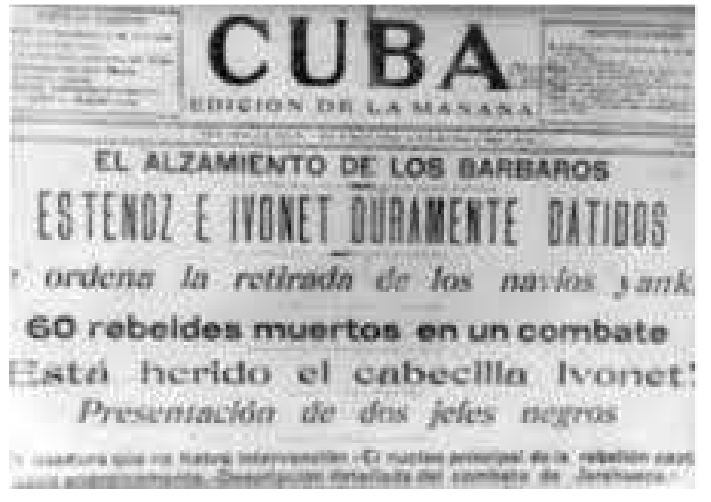

Figura 13: Manchete referente ao Massacre do Partido Impedientes de Color, com menção aos seus líderes, Estenoz e Ivo net. Os partidários são classificados como "bárbaros".

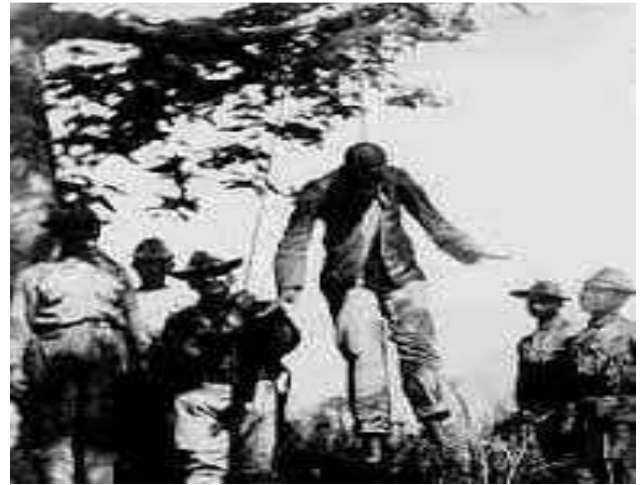

Figura I4: Foto de enforcamento de membros do partido Independientes de Color, em I9I2. Disponível em: https://IO0yearsagotoday.wordpress.com/tag/race. Acesso em: II/09/20I5.

O tamanho dessa barbárie encontra semelhança em poucos casos na história das Américas. Helg (2000) só visualiza semelhança de tal monta na repressão à rebelião de Moram Bay, em I865, onde mais de mil afrojamaicanos foram mortos ou açoitados pelas forças britânicas por protestarem pelas pioras nas condições de trabalho, por mais acesso à terra e pela discriminação judicial. Todavia, mesmo nesse caso, o massacre do Partido Independientes de Color apresenta uma escala ainda mais brutal.

O impacto para as mobilizações negras em Cuba foi profundamente marcante. Helg ressalta que esse fato minou as mobilizações maciças negras posteriores. Destaca, por exemplo, o que ocorreu em 1919 com os "bruxos negros". Numa campanha difamatória de força, alegaram que os "bruxos negros", em uma classificação genérica, estavam matando meninas brancas, além de cometerem uma série de outros delitos. Houve uma forte campanha, inclusive na imprensa, contra os supostos "bruxos", o que gerou uma situação grave de violência, inclusive com o linchamento 
de pessoas negras ${ }^{165}$. Esses "bruxos" eram abaucuás e santeros, estigmatizados historicamente no país.

Houve protestos, especialmente de representantes da classe médica negra. Mas, não se registrou mobilizações de grande monta. A lembrança da matança de I9I2 ainda era muito forte. Ainda que as pautas do Partido Independientes de Color trouxessem abordagens sociais amplas, seu foco nos direitos da população negra foi concebido como uma ameaça concreta ao status quo vigente, e com a argumentação do universalismo se justificou a proibição do Partido e posteriormente o massacre.

Mesmo se configurando como um dos mais violentos massacres a um grupo de ativistas negros da história das Américas no século XX, o líder da chacina, José Miguel Gomez, figura na Avenida dos Presidentes, em Havana, com o maior dos monumentos construídos. No entanto, após a Revolução, os bustos e estátuas de presidentes ou de símbolos anteriores foram, muitos deles, destruídos. Todavia, o de José Miguel Gomez se mantém, como destaca Rojas:

José Miguel Gómez se manteve aí (na Avenida dos Presidentes) e ninguém deu uma explicação do porquê. Aqui derrubaram muitas estátuas. Próximo ao Malecón, por exemplo, derrubaram uma grande águia que havia, que era símbolo dos Estados Unidos. Mas, José Miguel Gómez está aí. Inclusive, reformaram sua estátua, que é a maior da Avenida e a primeira, que está no ponto mais alto. E não apenas o massacre de milhares de negros o marcou. Era um ladrão, um corrupto, foi um dos piores presidentes da República e se mantém ali (Bienvenido Rojas, entrevista realizada em 04/05/20I4) ${ }^{166}$.

Entre ativistas, apesar de não ser um consenso ${ }^{167}$, esse é um tema que surge. Para muitos, a presença do monumento reafirma o racismo contra os negros, exatamente pela participação desse presidente no massacre contra os Independientes de Color. Em 2012, o grupo de rap Obsesión, no disco Negro, compôs uma música que denuncia e propõe a derrubada desse monumento que homenageia José Miguel Gomes. A música se chama Calle $G$, outro nome dado à avenida dos presidentes em Havana, e é composta por Magia López Cabrera e Alexey Rodriguez Mola. Trago, abaixo, um dos trechos da música:

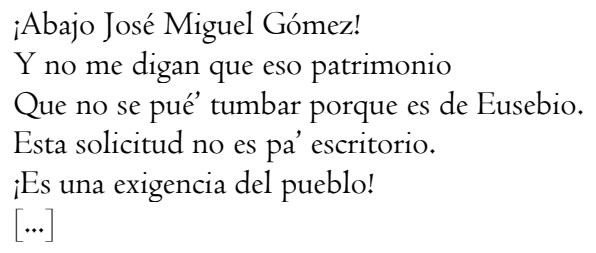

\footnotetext{
${ }^{165}$ Para seguir nesse debate, consta nessa tese, na parte referente à Revolução, outras matérias jornalísticas publicadas décadas depois com teor bastante discriminatório com os "bruxos" e os Abacuá.

166 Tradução minha.

${ }^{167}$ O debate sobre o tema no blog negracubanateniaqueser traz algumas abordagens, inclusive de militantes que apoiam a proposta e outros que questionam o mérito. Disponível em: http://negracubanateniaqueser.com/debates/el-ciberdebate/jose-mig Acesso em: 20/09/2015.
} 
En la mismísima Calle G o Avenida de los Presidentes hay,

Una gran estatua de José Miguel Gómez que si la ve Pedro Ivonet (ay!!)

No entiendo que hace ese tipo ahí, después de una Revolución que se hizo aquí.

$[\ldots]$

¿Que fue lo que pasó con la memoria de este país?

¿No se a ti, a nosotros no nos representa!

(iQue no me den muela!)

Que para mí está claro que está glorificando el racismo al descaro

Túmbenlo!! Urgente!!

Por los Independientes!!

$[\ldots]$

Adema’ en la misma calle están Salvador Allende,

Benito Juárez, Eloy Alfaro... ¿no sé si tú me entiendes?

$[\cdots]$

Porque esta estatua representa la muerte de tantos negros inocentes,

Esta va por los Independientes. Tumbenlo!

(Trecho da música Calle G, grupo Obsesión, 2012)

Outro aspecto marcante é que apesar do massacre ser um marco na história de Cuba, e da América Latina, ainda é uma passagem invisibilizada, como destacado por Rojas na entrevista feita para essa pesquisa. As publicações sobre esse acontecimento são bastante recentes, em sua grande maioria, com um alcance restrito, e os detalhes desse processo ainda não figuram nas escolas, nas universidades e nos meios de comunicação. Apenas disciplinas específicas na universidade abordam, dentre outros aspectos, o Partido Independientes de Color e sua relação com o Estado Cubano ${ }^{168}$.

A lógica de silenciamento em Cuba trouxe máculas importantes, especialmente para o processo de mobilização. De acordo com Covarrubias (2012), a herança da hispanidade estabeleceu o ocultamento do tema, sob o legado de que aquilo que não se fala não existe. $\mathrm{O}$ desconhecimento sobre as histórias e estratégias de mobilizações políticas da população negra cubana, resultado dessa estratégia de silenciamento, causam um enorme dano à sociedade cubana.

De maneira simultânea, esse vazio histórico, apoiado pelo imaginário social com os estereótipos raciais que eram empregados sob a população negra, promove a branquitude como único modelo capaz de alcançar a equidade social, com um impacto social desastroso na autoestima como ser humano (COVARRUBIAS, 2012: 19$)^{169}$.

Em seu boletim periódico, de 15 de janeiro de 2007, Desde la Ceiba, a Cofradía de la Negritud critica veementemente a completa invisibilidade do especial realizado pelo "Granma”, jornal

\footnotetext{
${ }^{168}$ Como exemplo, constam as duas edições do diplomado "Gene, Cultura y Racialidad", realizados na Universidade de Havana, no âmbito da Cátedra de Antropologia, da Faculdade de Biologia, respectivamente em 2013 e 2014, coordenado pelo professor Dr. Antonio J. Martínez Fuentes. Consta que esses foram um dos primeiros cursos do gênero de pós-graduação em Cuba. Mas outros cursos em universidades e centros de pesquisas foram ministrados desde os anos 1990 e 2000, como os realizados por Lázara Menendez, na Universidade de Havana, e por Tomás Fernandez Robaina, na Biblioteca Nacional José Marti.
}

169 Tradução minha. 
oficial do Partido Comunista de Cuba, dos acontecimentos históricos que faziam aniversários completos (décadas ou meia década) naquele ano. Estranhamente, ignorou o massacre do Partido Independientes de Color. Além de não abordá-lo, cita outros fatos históricos de pequena relevância, de acordo com o Boletim, como uma briga entre gangues.

A Confraria segue tecendo considerações sobre o que poderia ocasionar tamanha invisibilidade. Argumenta que tal causa pode ser gerada pela "clara expressão da política oficial com respeito à problemática racial", ou ainda que "os jornalistas que prepararam a lista desconhecem os feitos históricos relacionados com aquele massacre, o que ocorre com a maioria dos cubanos". Para concluir, menciona o dito bastante popular em Cuba: "o povo que se esquece ou ignora seus fatos históricos dolorosos pode estar condenado a repeti-los".

Mesmo sem alcançar a visibilidade devida, espaços como a Frente Negra Brasileira, no Brasil, e o Partido Independientes de Color, em Cuba, têm grande importância para a militância antirracista contemporânea nesses países. Figuram como símbolo da organização e da luta pela construção de equidade e promoção de direitos para afrodescendentes em um período em que o racismo científico orientava políticas estatais, e simultaneamente, era construído o mito dos direitos universais e da democracia racial.

\footnotetext{
Essa frustração (de não se concretizar a efetiva inclusão negra no princípio da República), deu lugar à fundação do Partido Independientes de Color e a famosa insurreição de I9I2. E o que ocorreu depois de I9I2? [...] com a matança deI9I2, com a liquidação de qualquer rebeldia dos negros e negras frente à manutenção da discriminação, da humilhação e do racismo em Cuba, houve uma espécie de conjuração do miedo al negro. Disso surge um dito que se dizia, e ainda hoje se fala: "Não há negro bonito nem tamarindo doce". Os brancos perderam o miedo al negro com aquela matança, percebe, foi uma forma maneira de conjurar esse medo satânico que vinham arrastando consigo desde o princípio do século XIX. Para os negros também foi uma lição (Entrevista com Tato Quiñones, realizada em 29/05/2014) ${ }^{170}$.
}

Bienvenido Rojas também ressalta o vazio e o silêncio gerados pelo massacre do Partido dos Independientes de Color e seus reflexos para as mobilizações negras no país: "Ficou um trauma. As pessoas que vivenciaram isso não a transmitiram, nem sequer falavam sobre isso. Foi tão traumático que tudo recuou. E, além disso, era um assunto que não se podia falar". (Entrevista com Bienvenido Rojas, 04/05/20I4) $)^{171}$.

Nos anos subseqüentes, de fato, a representação negra nos espaços de poder se manteve sob controle, com uma presença apenas simbólica, extremamente baixa, sem nenhuma alteração do status quo. Apesar do processo de organização política negra ter marcos importantes posteriores,

${ }^{170}$ Tradução minha.

${ }^{171}$ Idem. 
como os representantes do "I86 - Sociedades de Color" ${ }^{172}$, em I920, a imprensa negra e a atuação junto a partidos e sindicatos, a sub-representação nos espaços de poder econômico e político, como empresas e cargos no governo, era significativa.

\subsection{No Tempo do Capitalismo}

"Iingel bells jingel bells já chegou Fidel pra tirar o negro macaco que está no poder"II73

A questão racial permaneceu em Cuba, como nos demais países da América Latina, sendo um fator determinante para entraves na ascensão profissional no período pós-abolição. "Poucos negros ingressavam nas universidades, e quando terminavam seus estudos, era muito difícil arrumar emprego" (Morales, 2012: 25) ${ }^{174}$.

Nessa época, as demandas e mobilizações afrocubanas ocorreram por meio da imprensa, dos sindicatos e das organizações de trabalhadores, em partidos (com maior ênfase para o Nacional Socialista), em sociedades negras de recreio e ajuda mútua e nos cabildos. A ênfase maior foi na articulação com organizações cuja pauta não era especificamente voltada às demandas negras, como as organizações de trabalhadores, mas que era possível realizar o ativismo antirracista.

Muitas das denúncias eram provenientes de intelectuais afrocubanos oriundos de uma classe média não branca. A percepção, para muitos intelectuais e ativistas antirracistas na atualidade, é de que havia um distanciamento das reivindicações da maioria dos negros pobres, como destaca Esteban Morales:

De modo que finalmente nunca chegou a produzir-se, avançado o processo da República, um movimento racial unificado, onde as reivindicações sociais dos não brancos mais explorados eram visibilizadas e articuladas. $\mathrm{O}$ que os negros e mestiços dos setores populacionais mais pobres conseguiram, que não foi muito do ponto de vista racial, alcançaram como parte das organizações de trabalhadores e sindicatos ${ }^{175}$. (Morales, 20I2: 29-30).

\footnotetext{
${ }^{172}$ Esse era o nome de uma das sociedades negras da época.

${ }^{173}$ Música cantada na época da queda de Fungêncio Bastista, no processo revolucionário. Relato feito por ativistas com os quais dialoguei na pesquisa de campo. Original em espanhol: "Jingel bells jingel bells ya llego Fidel a tumbar al negro mono que está en el poder". Tradução minha.

174 Tradução minha.

${ }^{175}$ Idem.
} 
O processo de vulnerabilidade do segmento negro pelas condições sociais, políticas e econômicas vivenciadas, incrementadas pelos atos violentos empregados contra suas mobilizações por direitos, como a herança deixada pelos massacres da Conspiração da Escalera (I8I2), da Rebelião de Aponte (I8I2), do Partido de los Independientes de Color (I9I2), e mais um sem fim de atos violentos sob pequenos grupos ou pessoas negras, tiveram impacto profundo nos seus processos mobilizatórios (HELG, 2006).

Todavia, apesar de não ter se constituído grandes organizações massivas voltadas para a pauta negra depois do massacre de I9I2, outras estratégias foram concebidas para as mobilizações afrocubanas. Além das sociedades negras, ou de color, outros espaços que merecem destaque são sindicatos, organizações de trabalhadores e alguns partidos políticos, com maior ênfase para o Partido Socialista Popular. Mesmo que nessas instâncias não houvesse um debate mais focado na pauta antirracista, eram espaços de mobilização política com grande presença negra e onde a pauta racial ganhou fôlego.

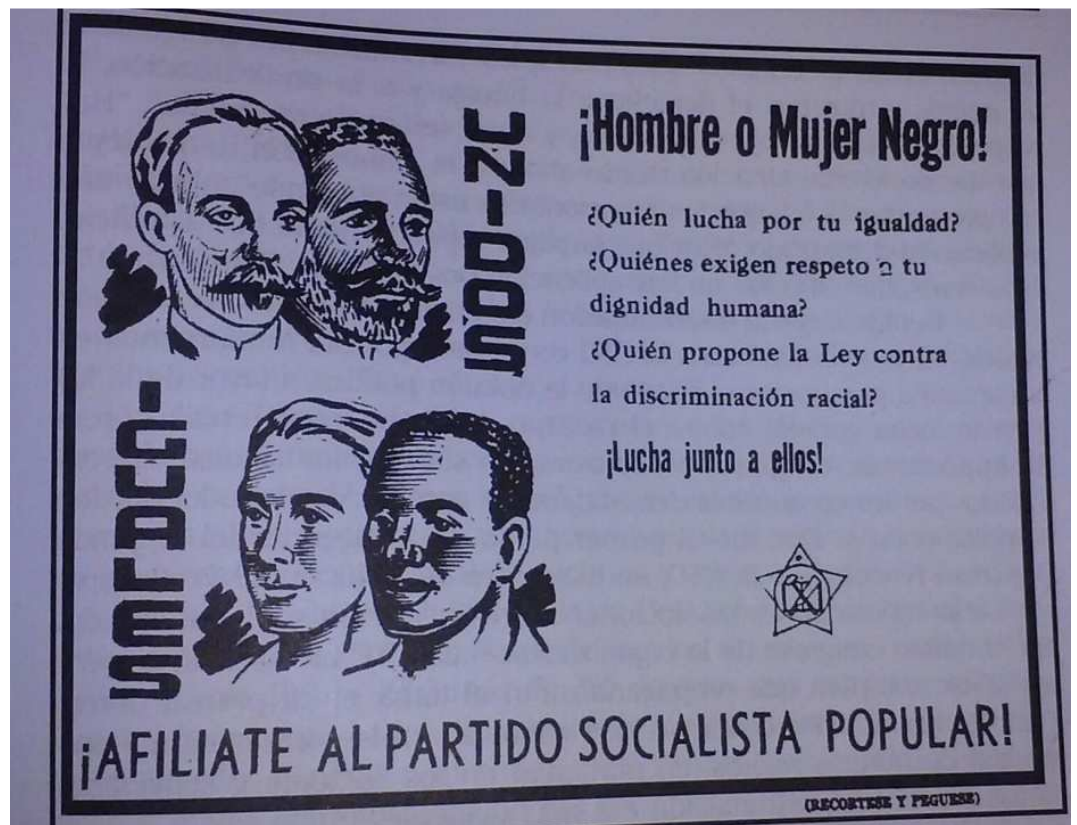

Figura 15: Propaganda eleitoral do Partido Socialista de Cuba, com exaltação à campanha pela igualdade racial. Publicado em Noticias de Hoy, em I2/09/I952. Acervo: Biblioteca José Marti. Fonte: DE LA FUENTE, 20I4: 195.

A mobilização ganha atenção especial no processo constituinte de 1940, em que intelectuais, partidos, especialmente o Partido Socialista Popular, e organizações de trabalhadores se unem para defender a pauta racial e fazer um contraponto duro à influência fascista. Gustavo Urrutia, ativista que se manifestava com freqüência sobre o tema na imprensa, argumentava que: Es bueno y necesario que el negro cubano se haya manifestado, se manifeste y siga manifestándose como tal 
negro [...] en pro de la democracia [...] y contra el nazi-facismo "y el "falangismo" (Gustavo URRUTIA, Unión Fraternal, I94I apud DE LA FUENTE, 20I4: 27I).

Nesse período, também cresce a discussão sobre a situação dos negros no país, especialmente com vias à inclusão de um texto constitucional mais definidor de direitos para esse segmento e mais rigoroso na punição dos casos de racismo. Surge até defensores de sistema de cotas que possibilite a garantia de participação proporcional de negros em todas as fontes de trabalho e candidaturas políticas, como o então senador comunista Juan Marinello (DE LA FUENTE, 20I4: 275).

Todavia, apesar da grande mobilização para a constituinte de 1940, não houve grandes avanços para a pauta racial ${ }^{176}$. Tanto a Constituição Republicana de I90I como de 1940 declarou-se que a discriminação racial era prática ilegal, sem, contudo, assegurar uma mudança concreta na criminalização desses atos. Consequentemente, não há registro de punição de indivíduo ou instituição por prática discriminatória ${ }^{177}$.

Os espaços em que o ativismo negro ganhou fôlego nos anos I930 e I940 foram severamente cerceados nos anos 1950. Isso coincidiu com a expulsão ou derrota de grande parte dos integrantes do partido socialista das instâncias de representação de trabalhadores, como a CTC (Central dos Trabalhadores de Cuba), sindicatos e federações. Com um alinhamento mais conservador, as novas diretorias dessas entidades, apesar de não boicotarem explicitamente, reduziram muito a atuação com a questão racial (DE LA FUENTE, 20I4).

A partir do cerceamento do ativismo em sindicatos e federações de trabalhadores, a mobilização nas sociedades negras se fortaleceu nessa época. Sua representação nacional, por meio da Federação de Sociedades de Color, tinha grande engajamento com a criminalização da discriminação racial e com a inclusão do segmento negro no mercado de trabalho. A Federação e importantes sociedades negras apresentaram, todavia, posições políticas antagônicas. Por exemplo, em alguns períodos foram bastante próximas do Partido Socialista, em outros esse alinhamento foi maior com políticos conservadores, como Batista, especialmente nos anos 1950, onde os apoios e repasses estatais para as sociedades ganharam maior volume (DE LA FUENTE, 20I4: 3I5).

O movimento social negro em Cuba, de acordo com Tomás Fernandez Robaina (2012), se caracterizou pela busca da igualdade, sem o propósito de favorecer os negros com relação aos

${ }^{176}$ A Constituição de 1940, todavia, apresentou em outras searas notáveis conquistas, como no que se refere aos direitos trabalhistas e jornada de trabalho.

177 Morales, 2010. 
demais. Todavia, o caráter elitista marcou parte dessas mobilizações, especialmente nas sociedades negras. Outro fator presente foi a capilaridade em espaços representativos dos trabalhadores. Esteban Morales, na entrevista realizada, relata sua percepção das organizações negras e suas mobilizações políticas no período da República:

Los negros no habíamos podido obtener casi nada, ni en el proceso de la neocolonia, ni en el proceso de la república. Los negros habían fundado organizaciones, habían logrado luchar con el movimiento obrero, que era el movimiento obrero de los que habían podido despuntar. Jesús Menéndez, Lázaro Peña, Aracelio Iglesia eran negros que habían podido despuntar como dirigentes. Eso lo habían logrado a partir de un trabajo muy fuerte que hacia el Partido Socialista Popular. También el Partido Socialista Popular apoyaba a muchos intelectuales y artistas negros. Pero, en general, los negros y mestizos en Cuba antes de I959 no habían logrado nada. En la universidad poco, en la educación no habían suficientes, no habían muchos en posiciones importantes. Solo Batista le dio cabida a muchos negros en su momento como para dar a entender que él era el presidente de los negros. Batista no era blanco, Batista era negro, mulato aunque se decía que era indio. ${ }^{178}$. En general, hay que decir que los negros habían logrado ganar en organizaciones, en algún lugar eran más fuerte o menos fuerte. Por ejemplo, en la provincia de Camagüey, el movimiento organizativo era muy fuerte. En La Habana, tenían algunos clubes, como por ejemplo, el más importante llamado el Club Atenas. Aunque lamentablemente podían ingresar solo profesionales, podían incluso ingresar blancos aunque no fueran negros, gente con posibilidades, gente pudiente. El negro común de la masa negra del país no podía ingresar en esa sociedad. (Esteban Morales, entrevista realizada em I4/05/20I4).

A percepção contemporânea dessas sociedades negras por ativistas é também dúbia. Para muitos, foram espaços fundamentais de mobilização negra, apesar de sua característica elitista relevante, e que na atualidade sua ausência gera dano à própria luta antirracista e à construção de um discurso sobre o tema:

Los discursos son una cosa y son importantes porque no hay un discurso sobre la racialidad. Pero están pasando cosas muy positivas, están pasando cosas negativas también. ¿Por qué cerraron todas las sociedades negras en Cuba? No cerraron ninguna china, ni las hebreas, ni las árabes, ni las españolas, pero las sociedades negras desaparecen. Eso es un misterio, esa es una interrogante que nadie me ha respondido todavía por una parte, por otra parte la cultura popular se desata, mucha música, mucha cultura popular por todas partes, mucha alegría, un cambio etimológico muy fuerte, y es cierto que Fidel dice, esta es la cuarta batalla, esta es una batalla muy difícil (Entrevista com Zurbano, realizada em I5/10/20I4).

Para outros, apesar do reconhecimento de sua importância histórica, essas sociedades eram um dos símbolos da sociedade segregada da República, que a Revolução buscou dissolver para a construção da igualdade. É o que destaca Tato Quiñones, ao analisar o cenário existente antes da Revolução:

As organizações que foram formadas posteriormente (ao massacre do Partido Independientes de Color) têm uma forma de se organizar que retoma um pouco a tradição da colônia, com as Sociedades de Recreio, Cultura e Esporte, completamente segregadas. É esse cenário que a Revolução encontra quando chega ao poder, os brancos ricos, a oligarquia pró-norteamericana, mais pró-americana que nenhuma outra na América Latina, era proprietária de quase tudo, como os grandes clubes, grandes cassinos, os melhores bairros e uma grande vida; uma classe média mais ou menos integrada por brancos majoritariamente e uma classe trabalhadora onde também havia segregação. No fundo do caldeirão do mundo da marginalidade

178 Sobre a presença negra no exército durante o governo de Batista, de La Fuente (20I4: I75) levanntou fontes da inteligência dos EUA que afirmavam que em 1935, 30\% dos soldados eram "negros puros", 35\% "mulatos" e 35\% "brancos". Entre os oficiais, cerca de 20\% era de "negros". 
estavam os negros, e eu diria que uma grande parte desses não eram nem sequer de trabalhadores. É isso que encontra a Revolução, essa segregação, essa divisão. Havia clubes para brancos. Inclusive brancos pobres tinham seus clubes, negros pobres tinham seus clubes e havia até sociedades de mulatos que não eram de brancos nem de negros. Essa divisão, essa fragmentação é o que a Revolução encontra (Entrevista com Tato Quiñones, em 29/05/2014) ${ }^{179}$.

As sociedades negras se constituíram, portanto, como os espaços preferenciais de reunião e mobilização. Todavia, seu caráter elitista e classista, como relatado anteriormente, dificultava a criação de um movimento de massa na escala que foi o Partido Independientes de Color. Desse modo, garantia-se a estabilidade do status quo vigente no que se refere à dimensão racial. Mas, por outro lado, as sociedades negras eram impulsionadoras de um discurso antirracista e participaram das mobilizações na república sobre o tema, como no processo da constituinte de 1940.

Além dos registros historiográficos e da percepção de ativistas e intelectuais antirracistas sobre os fatos e seus reflexos na atualidade, apresento os impactos das vivências pré-revolução na percepção da questão racial de parte dos ativistas.

As histórias de vida de ativistas contemporâneos, que nasceram antes de 1959, exemplificam que o princípio da igualdade de direitos, tão almejado pelos revolucionários mambises, tinha poucos efeitos na prática social desses sujeitos. Tato Quiñones traz um relato de sua infância sobre a existência de espaços físicos segregados, inclusive entre camponeses e classes mais populares:

\begin{abstract}
Após uma decisão favorável pela terra a qual viviam e lutavam por ela, os camponeses decidiram, então, fazer uma festa. Isso foi nos anos 1950, 1950 ou I949, talvez até I95I. Eu tinha nove anos. Fizeram uma festa em um local onde realizavam brigas de galo. Não havia luz elétrica, a cerveja era resfriada colocandose as caixas no rio. Assaram leitão, porcos, e assim começou o baile. Tinha uma menina, criança também, branca, de cabelo vermelho, que desde a organização da festa estávamos nos olhando. Quando, finalmente, o baile começou, havia camponeses brancos e negros, havia um grupo musical de música guajïa, son montuno. Quando começaram a dançar, colocaram uma corda no salão, de um lado ficavam os negros e do outro os brancos. Camponeses que até aquele momento estavam dispostos a morrer e combater juntos por suas terras, na hora de festejar e dançar, estabeleciam uma segregação. Perguntei por que aquilo entre nós. Eu queria dançar com a menina e não podia, pois ela estava do outro lado da corda. Eu pedi ao meu pai o facão dele, que foi do meu avô que lutou na Guerra de Independência, e cortei a corda. Não foi um ato político consciente. Mas, olhando agora, mais de sessenta anos depois, percebo que foi ali que passei a ter consciência de que havia brancos e negros e que havia diferenças. Foi um ato discriminatório, um ato racista, realizado por gente simples, camponeses. (Tato Quiñones, entrevista realizada em 29/05/20I4) ${ }^{180}$.
\end{abstract}

O racismo incide nos corpos e nas mentes com marcas profundas e se torna presente nas relações sociais em todas as esferas, se manifesta nos atos, expressões e concepções dos sujeitos sociais. $\mathrm{O}$ relato de Quiñones acima descrito expressa como a lógica segregacionista da época delimitava inclusive espaços diferenciados em parques e praias para brancos e negros e era internalizada pelos sujeitos em sua cotidianidade. A naturalização do racismo faz parte de um processo 
progressivamente ensinado nas escolas, nos meios de comunicação, nas regras sociais e no cotidiano experienciado, o que acarreta sua reprodução, em grande parte das vezes, sem uma consciência exata do fenômeno. A desnaturalização e a conscientização dessas práticas são fenômenos, todavia, que marcam as histórias de vida de muitos ativistas, processo esse em geral ocorrido após experiências vivenciadas de racismo. Tomás Fernandez Robaina também relata evento semelhante:

En una fiesta en Pinar del Rio, en el campo, en una casa de tabaco, que por lo general las fiestas grandes en el campo se celebraban en las casas de tabaco, estábamos todo el mundo bailando por el santo. De pronto yo observo que casi todas mis amistades negras, los amigos de mis tías que iban todos los días fraternalmente, a tomar café por las mañanas, estaban ahí. Era un desfile de gente que venían de aquí y del otro (lado) y que de pronto yo voy a pasar y choco con una soga que yo no había visto, porque todo el mundo estaba alrededor de la soga. Unos de un lado y otros del otro, y yo no me percataba de que la soga estaba dividendo los negros de los blancos. Eso me sorprendió en aquel momento pero no le di la mayor importancia, teniendo en cuenta, por ejemplo, que todos los que estaban de un lado y del otro se pasaban los vasos de cerveza, y se saludaban, se hablaban de una manera fraternal. Después que ya crecí y me metí en este mundo, en este activismo en contra del racismo, pensé que había racismo, que había discriminación pero que la discriminación y el racismo nuestro es de una singularidad muy estudiada, porque eso jamás hubiera podido ocurrir en una sociedad estadounidense, donde negros y blancos jamás podían concurrir conjuntamente aunque dentro del mismo local separados, no ocurría así. Entonces esto fue otro de los hechos que cuando crecí, me metí a estudiar no solamente a partir de mis experiencias personales sino a través de otras experiencias, a leer, hacer trabajo de terreno, fue conformando el pensamiento que tengo ahora. (Entrevista com Tomás Fernandez Robaina, feita no dia I2/05/20I4).

As narrativas de Quiñones e Tomás Robaina são sintomáticas para situar o contexto da época nas microrelações, nas quais o racismo estrutural se materializava no concreto. Esteban Morales, outro ativista e pesquisador das relações raciais em Cuba, relata situação em sua infância, no período anterior à Revolução, no espaço escolar, e como essa experiência incide sobre sua percepção social das relações raciais na atualidade:

Eu me inscrevi, quando tinha II, I2 anos, em um concurso de composição, cujo tema era José Marti, convocado pelos Cavaleiros Católicos de minha cidade. A planilha do concurso para inscrição não tinha fotos. A preenchi e apresentei meu trabalho no concurso. E esse trabalho ganhou o primeiro lugar. Anunciam que eu havia ganhado o concurso. Dias depois, me chamam em uma reunião com um grupo de pessoas que foram juradas do concurso para, finalmente, entregar o prêmio. O prêmio era uma bolsa de estudos vitalícia na melhor escola católica do meu povoado. Entro na sala, com essas pessoas, e ouço um murmúrio. Me perguntam:

- Qual é o seu nome

- Meu nome é Esteban Morales.

- Você inscreveu essa composição?

- Sim, eu a inscrevi.

A partir daí, começaram a fazer uma série de perguntas sobre a composição para averiguar se era verdade que eu a havia escrito. Fizeram-me umas oito perguntas e as respondi. Quando terminou, me pediram para que eu saísse da sala e fiquei preocupado. Pensei: o que está acontecendo? O que ocorreu, de acordo com que me explicou uma das pessoas que compôs o júri, exclusivamente de pessoas brancas de classe média, e que me conhecia foi que não podiam imaginar que esse negrinho, pobre, tivesse escrito uma coisa como essa e não queriam dar o prêmio. Queriam dar ao segundo lugar. Eu conto esse incidente, pois ele teve um impacto extraordinário em minha vida. (Entrevista com Esteban Morales, feita em I4/05/2014) ${ }^{181}$.

18I Tradução minha. 
Cuba trazia desde sua primeira Constituição, de I90I, e manteve na de 1940, o princípio de igualdade. Todavia, o segregacionismo no regime republicano expresso na diferença de oportunidades e nas desigualdades em instituições como escolas e órgãos públicos marcava o cotidiano de racismo que permeava as relações sociais como um todo e gerava processos de estigmatização e exclusão de um grupo racial e privilégios de outro.

Os impactos que essas vivências trazem na formação de identidades subalternizadas são muito expressivos. No entanto, elas também são geradoras de outras dinâmicas que questionam esses lugares subalternos e possibilitam a construção de uma identidade política, que busca estabelecer um contraponto. São histórias que marcam a vida de grande parte das(os) ativistas entrevistados e são referenciados na dinâmica de tomada de consciência sobre as relañçoes raciais vivenciadas na sociedade.

Georgina Herrera ${ }^{182}$, importante poetiza cubana, ativista negra, com oitenta anos de idade, ao abordar sua infância, descreve o distanciamento fortemente existente entre brancos e negros, tanto no mercado de trabalho, no acesso à educação, como na distribuição espacial da cidade:

\begin{abstract}
Creio que desde sempre eu tive uma consciência de que sendo mulher negra iria ter uma maneira distinta de projetar-me diante da vida e da sociedade, como iria ser essa maneira era o que não estava claro para mim, porque eu era criança, mas sabia que seria diferente pelas coisas que eu ouvia, as coisas que ocorriam, as coisas que contavam. Porém, eu trazia uma certa formação e te repito porque eu tinha consciência de ser negra e de meu lugar social, pelo que ouvia dizer em minha casa, as histórias que contavam das negras escravizadas. Jovellanos, onde nasci, é uma zona de negros e nada mais. Tanto era uma zona de negros que quando se quis construir a autopista central, levaram técnicos brancos. E um dos passeios que eu escutava as tias contarem era ir até as obras para ver tantos brancos juntos. Para elas era uma diversão. Depois eu tirava minhas próprias conclusões do que significava naquele povoado haver apenas negros e que para construir a estrada naquela região, tinham que trazer brancos para executarem um trabalho mais qualificado, como a estrada. Especificamente Jovellanos e os povoados que o cercam continuam sendo bastante negros. Se observar essas comunidades, todos continuam tendo mais ou menos a mesma configuração. Era uma zona onde se trabalhava no engenho açucareiro, e até hoje segue sendo uma zona açucareira (Entrevista com Georgina Herrera, feita em I2/06/20I4) $)^{183}$
\end{abstract}

O relato de Georgina aponta elementos que configuram o que os dados da época demonstravam: majoritariamente os brancos estavam nas universidades. Portanto, o trabalho técnico para a construção de uma autoestrada provavelmente seria realizado por eles. Com relação ao ensino superior, De La Fuente destaca que a proporção de negros (mestiços e negros) nas universidades no final dos anos 1940, era equivalente a dos anos 1920 (de II\% a 16\%), em uma proporção sempre inferior à sua presença na população.

${ }^{182}$ Os contatos que tive com Georgina foram emocionantes. Sua inspiração poética é um importante instrumento em sua luta contra o racismo. Possui experiência na criação de novelas e livros, além de atuação no rádio e na televisão. Participamos, durante a pesquisa, de diversas atividades organizadas por coletivos antirracistas, especialmente aquelas realizadas por Afrocubanas. Em visita à sua casa, tive a oportunidade de realizar entrevista mais aprofundada para a tese.

${ }^{183}$ Tradução minha. 
O acesso à educação foi um gargalo para a ascensão social das famílias negras nesse período republicano. Numa análise da população cubana alfabetizada, pode-se observar, inclusive, uma piora no acesso à educação para a população negra entre os anos 1930 e I940. Entre I93I e 1943 houve um recuo no percentual de população negra alfabetizada de 7I,5\% para 69,2\%. Nesse mesmo período, o percentual da população branca se manteve estável, 74,3\% (DE LA FUENTE, 20I4: I84).

Essa piora no acesso à educação, também estimulada pela crise financeira, atingiu de forma desigual negros e brancos. Esse tema foi pauta de denúncia das sociedades negras, na Convenção Nacional realizada em 1936. Nesse período, houve redução da atividade de instrução dessas sociedades ${ }^{184}$ e um crescimento da privatização da educação. Nos espaços educacionais privados, a segregação era muito presente (DE LA FUENTE, 20I4: I84-I86). Em diálogo com o relato de Esteban Morales, de sua vivência numa instituição de ensino privada nos anos 1950, onde a presença negra era quase nula, percebe-se a manutenção da lógica segregacionista e do racismo institucionalizado.

A concentração dos negros em bairros marginais, com piores condições de moradia e infraestrutura, marcou fortemente esse período. Os "solares", residências precárias com banheiro e cozinha compartilhados, tinham uma sobrerepresentação negra. "La identificación de los solares com espacios "para negros" excluía a los más pobres de la geografía de la ciudad y de la sociedad" (DE LA FUENTE, 20I4: I46). Essa realidade até os dias atuais ainda é muito presente, mesmo com as mudanças implementadas com a Revolução de 1959.

De acordo com o censo de 2012, a concentração de negros (negros e mestiços de acordo com as categorias usadas) é muito superior nos solares, ou "habitación en cuartería":

Tipo de vivenda

\begin{tabular}{lrrrrr} 
& \multicolumn{5}{c}{ Tipo de vivenda } \\
\cline { 2 - 6 } & \multicolumn{5}{c}{ Cabitación } \\
& Apartamento & en cuartería & Bohio & Improvisada \\
\hline Total Cuba & 3.008 .818 & 611.334 & 18.365 & 82.607 & II.727 \\
Brancos & 2.014 .501 & 381.866 & 7.834 & 48.509 & 5.978 \\
\% Brancos X Total & 67,0 & 62,5 & 42,7 & 58,72 & 50,98 \\
Negros & 274.659 & 88.102 & 4.845 & 5.012 & 1.628 \\
\% Negros X Total & $9, \mathrm{I}$ & $\mathrm{I} 4,4$ & 26,4 & 6,07 & 13,88 \\
Mestiços & 719.658 & I4I.366 & 5.686 & 29.086 & $4.12 \mathrm{I}$ \\
\% Mestiços X Total & 23,9 & $23, \mathrm{I}$ & 30,96 & $35,2 \mathrm{I}$ & $35, \mathrm{I} 4$ \\
\hline
\end{tabular}

Figura I6: Gráfico sobre condições de moradias, Censo 2012. Fonte: Oficina Nacional Estatística de Cuba

${ }^{184}$ As sociedades realizavam cursos educativos para seus membros e familiares, em parte financiados pelo Estado. Supriam parcela da demanda de educação não coberta pelas escolas públicas ou privadas. 
Os moradores de habitación en cuarteria, residências também conhecidas como solares ou cortiços, concentram uma proporção de negros cerca de $283 \%$ acima de sua representação na sociedade $^{185}$. Entre os mestiços essa proporção é $12 \%$ superior a sua representação na população entre os moradores de habitación en cuarteria, sendo que a representação do segmento branco é cerca de 33\% menor que sua proporção na sociedade. Mesmo na categoria Improvisada, os negros e mestiços estão em percentual acima de sua participação na população, respectivamente $49 \%$ e $27 \%$. O mesmo ocorre com relação à categoria Bohio ${ }^{I 86}$ para mestiços, também cerca de $27 \%$ acima de sua representação na população global. Para negros, sua participação entre os que vivem em Bohios é mais baixa, pois há uma reduzida população negra no meio rural.

No quesito habitacional, os desafios contemporâneos são relevantes, e, a população negra está marcadamente sobrerrepresentada nessas moradias precárias. Esses são reflexos de ações que não revertem essa herança desigual. Os espaços segregados de moradia entre brancos e negros eram fortemente marcados no período que antecedeu a Revolução.

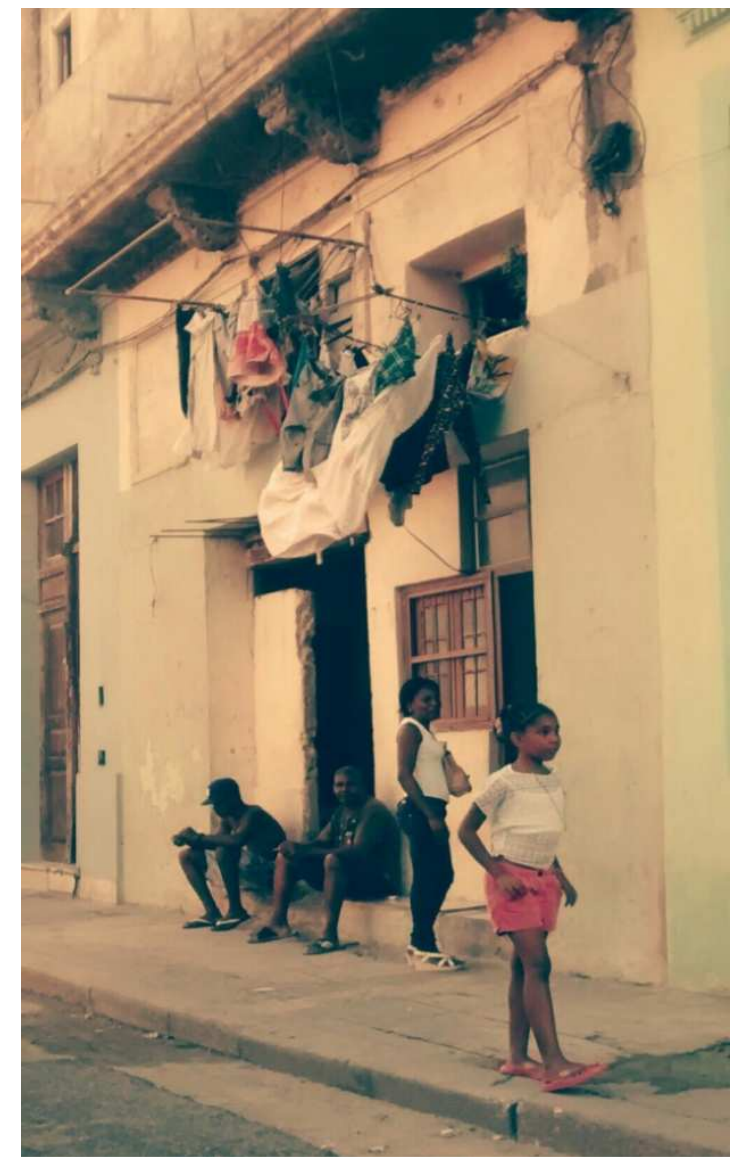

Figura 17: Bairro Centro Habana, com alto índice de moradias precárias e grande presença afrodescendente entre os seus moradores. É um dos bairros mais populosos de Cuba. Foto: Bárbara Oliveira, janeiro de 2015.

\footnotetext{
${ }^{185}$ A população cubana apresenta a proporção de $64,1 \%$ de brancos, 9,3\% de negros e $27,6 \%$ de mestiços, de acordo com o Censo de 2012.

${ }^{186}$ Tipo de habitação muito presente no meio rural, com tecnologias construtivas semelhantes à taipa ou adobe.
} 
As experiências de alguns ativistas que por diversas razões mudaram-se para bairros embranquecidos exprime o cotidiano de violência racial vivenciado no inicio dos anos I950, como demonstra a experiência de Tato Quiñones:

\begin{abstract}
Minha mãe decidiu se mudar para um bairro de novos ricos, de brancos de classe média. Para mim, foi nesse período que tive a clara consciência de que não era branco, e que não ser branco em Cuba era muito difícil. Foi aí que senti o peso da discriminação. Quando eu tinha II, I2 anos, saí para a escola de manhã. Usava, então, umas maletas pequenas, pois não usávamos mochilas como agora. No caminho, dois vizinhos de quadra começaram a me chamar "negro" e riram zombando de mim. Caminhei uma quadra, tirei os livros e os escondi, enchi a maleta de pedras e regressei para passar novamente na frente da casa dos vizinhos. Foi uma chuva de pedras. Um deles, Hugo, que era calvo, ficou com um corte na cabeça e tiveram que levá-lo ao médico. Creio que esse seja o momento da tomada de minha consciência da discriminação, do vexame, da humilhação. Além disso, foi o primeiro ato de rebeldia. (Tato Quiñones, entrevista realizada em 29/05/2014) ${ }^{187}$.
\end{abstract}

O processo de tomada de consciência racial muitas vezes é despertado em momentos dolorosos de contato com práticas discriminatórias. Os relatos dos militantes e ativistas entrevistados para essa pesquisa trazem, também, pinceladas dos seus processos pessoais de descoberta de sua negritude e das desigualdades de cunho racial estabelecidas socialmente. Esses relatos apresentam elementos para compreendermos vivências particularizadas de discriminação, preconceito e racismo, situadas em determinados períodos históricos, mas que dialogam com aspectos macrossociais da hierarquização racialmente estabelecida na sociedade cubana.

Nos anos que antecederam a Revolução, há um incremento do debate racial no bojo das mobilizações revolucionárias e na reação pró-Batista. $\mathrm{O}$ movimento que propulsou o processo revolucionário, o M-26 de julho, no qual militava Fidel Castro, Raul Castro, entre outros posteriores líderes da revolução, tinha, segundo alguns relatos levantados por De La Fuente (20I4: 325), uma tímida presença negra. Todavia, outros registros destacados pelo autor divergem dessa visão, apresentando uma estimativa de que cerca de $50 \%$ dos soldados revolucionários "eram de cor". Alguns dos líderes da Revolução também eram negros, como Calixto García e Juan Almeida.

De qualquer forma, é sintomático que numa sociedade onde a mobilização antirracista foi presente em tantos momentos relevantes, com forte atuação inclusive do partido socialista, a pauta antirracista estivesse completamente ausente nas forças revolucionárias opositoras a Batista. Sobre a questão racial, houve, desde o processo revolucionário, um estranho silenciamento. $\mathrm{O}$ Movimento 26 de julho, que liderou a Revolução, quase não abordou em seus manifestos o tema. Tato Quiñones apresenta suas reflexões sobre a questão:

${ }^{187}$ Tradução minha. 
É curioso, pois todos os manifestos feitos pelo Movimento 26 de Julho, que é o movimento que culmina na Revolução com outras alianças comunistas, não há alusão ao problema racial, não se menciona a questão, não existe. Fidel Castro quando era estudante da Universidade havia composto um comitê universitário de luta contra a discriminação racial, o que demonstra que ele conhecia essa questão, essa problemática, havia lutado contra isso inclusive. Todavia, no programa do Movimento 26 de Julho, talvez cientes, penso eu, que se esse ponto fosse incluído, se fosse levanta essa bandeira na luta contra Batista, provavelmente, não teriam derrotado Batista, ou provavelmente não teria sido tão fácil. Eu penso isso. Havia a necessidade de isolar, de não tocar nesse tema, pois isso de alguma maneira, como dizemos em linguagem da rua, daria ruído no sistema. Todavia, dois meses após a Revolução, Fidel levanta essa bandeira. Pode ser uma tática política de Fidel, uma omissão voluntária, ou de repente se esqueceu. Ou então ele sabia que isso não poderia ser tema do Programa da insurreição contra Batista, porque toda ou uma grande parte da classe média que participou nessa insurreição e até boa parte da classe alta contribuíram com dinheiro para a Revolução. (Entrevista com Tato Quiñones, realizada em 29/05/2014) ${ }^{188}$.

Esteban Morales também comenta o fato de não haver menção à questão racial no Movimento 26 de julho e reflete sobre como esse tema surge nos primeiros discursos de Fidel Castro, no princípio de 1959, já com a vitória da Revolução:

E quando chega a Revolução, se começa a tomar uma série de medidas que dão oportunidade aos negros, por exemplo, as medidas relativas à educação, as medidas relativas à redução dos alugueis, a saúde pública, a política social, a possibilidade de conseguir um trabalho. Inclusive, os primeiros discursos de Fidel, em março de 1959, trazem uma queixa sobre a atitude de algumas pessoas que não queriam dar espaço de trabalho aos negros. Então Fidel dizia: mas que coisa é o que queremos? Para dar emprego a um negro tem que saber inglês, tem que saber francês, se não o educamos para isso, não o preparamos para isso. E essa foi a primeira batalha de Fidel, a discriminação do negro no ambiente de trabalho, nos empregos. Mas isso começou a ser alcançado com o triunfo da Revolução. É importante dizer que a pesar de nunca haver sido tratado em documentos oficiais do processo revolucionário o problema racial, é importante falar que Fidel, desde o princípio, prestou atenção a isso, porque ele havia tido consciência disso. Ele havia sido membro de um grupo anti-discriminatório na própria Universidade de Havana. Ainda que isso não apareça em documentos no livro A História me Absolverá, mas ou menos se pode ver que aparecia em geral, ele sim tinha consciência disso, de que o problema existia, mas eu creio que lamentavelmente as circunstancias não ajudaram (Entrevista com Esteban Morales em I4/05/2014)189.

Apesar do massivo silencio sobre a questão racial, o M-26 de julho, todavia, fez uma publicação sobre o tema, com circulação restrita em I955, conforme apurou De La Fuente (20I4: 327), em que conclamava ações para acabar com os "vestígios de discriminação". Em outros documentos, a menção era vaga e no sentido que qualquer destaque à questão racial poderia prejudicar o projeto coletivo. Em manifesto de 1957, destacaram que os objetivos do movimento eram, dentre outros: "a unidade orgânica da nação" e que "nenhum grupo, classe ou religião deveria sacrificar o bemestar comum para beneficiar seus interesses particulares".

Fato é que alguns dos que conformavam a oposição eram conservadores vinculados ao político Prío e utilizaram a questão racial para diferenciar-se de Batista. E essa diferenciação foi muito marcada pela visão racista de que Batista e seus apoiadores eram negros "primitivos". A charge publicada por esse grupo conservador é um bom exemplo dessa problemática:

188 Tradução minha.

${ }^{189}$ Idem. 


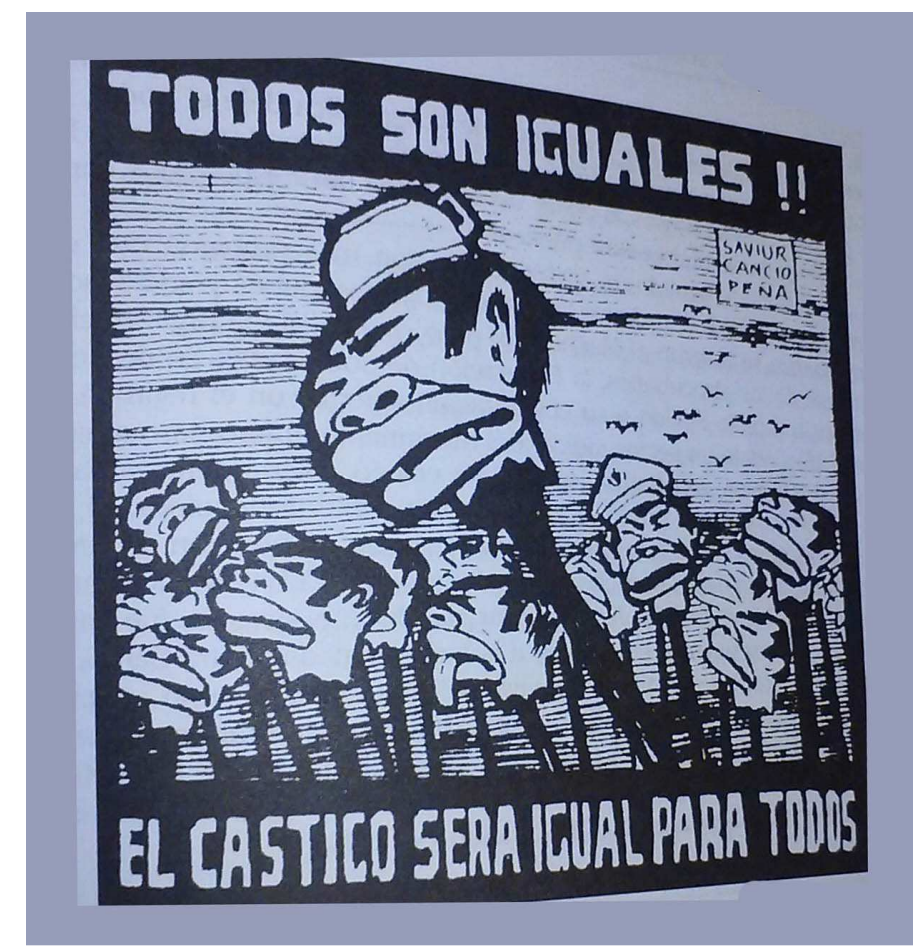

Figura I8: Batista e seus seguidores, representados pela oposição como primatas e com representações estereotipadas do fenótipo negro. Panfleto de I $^{\circ}$ de dezembro de 1954 (Arquivo dos EUA). Fonte: DE LA FUENTE, 20I4: 329.

As narrativas de ativistas antirracistas também descrevem esse período, a partir de suas memórias da transição entre o governo de Batista e o governo Revolucionário. O fato de Batista ser negro pesou muito nas abordagens feitas sobre ele na época, inclusive com cânticos que exaltavam a percepção racista dos negros como selvagens, assemelhando-os aos macacos:

\footnotetext{
Não se esqueça que Batista era um não branco e isso também influenciava muito. Ele dizia que era índio, mas Batista era mulato evidentemente, um mulato talentoso e inteligente, hábil, que soube chegar do nada a ser presidente da República duas vezes! Talento não lhe faltava, mas também era um homem de poucos escrúpulos. Mas foi esse mulato o que provavelmente mais fez pela burguesia cubana, que mais sólidos laços estabeleceu com os Estados Unidos. E, ainda assim, havia contra ele um mal estar, um ressentimento porque não era branco. Muita gente lutou, aportou recursos, ajudou a Revolução sem ter algum objetivo com a Revolução, mas sim com o objetivo de derrubar esse negro que estava no poder. Em I958, no natal desse ano, véspera do triunfo da Revolução, que triunfou em I ${ }^{\circ}$ de janeiro de 1959 , em Havana se cantava uma música, um jingle. Eu nunca o havia escutado antes. Dizia: "Jingel bells jingel bells já chegou Fidel a tirar o negro macaco que está no poder". Essa história não está contada, mas esse jingle se cantava, eu o cantava. Isso quer dizer algo desde um ponto de vista sociológico. (Entrevista com Tato Quiñones, realizada em 29/05/2014 $)^{190}$.
}

Gisela Arandia também remete ao mesmo cântico racista, entoado na época do conflito entre as forças revolucionárias e o regime de Batista. Essa canção está na memória de vários ativistas e demonstra como uma parte significativa da classe média e alta, majoritariamente branca, apoiava Fidel e o movimento 26 de julho talvez também como uma solução para que Batista, negro, deixasse a presidência, como destaca a ativista Gisela Arandia:

${ }^{190}$ Tradução minha. 
En esa investigación que yo hice en Miami, un medico blanco, rico, oftalmólogo en una clínica famosa, me dijo: te voy hacer un cantico jingle bel jingle bel ya llego Fidel, vamos a sacar ese negro de mierda que no podemos con él. Es decir que había en esa burguesía blanca cubana, incluso la que apoya a Fidel, un sentimiento de un racismo furibundo, la evidencia de eso es que al llegar a Miami ese racismo toma nueva forma. Al fin, ellos creen que pueden hacer un proyecto económico sin los negros, por eso triunfaron, consideran ellos, porque era un proyecto sin negros. Entonces estos detalles, entre comillas detalles, de ver al negro de ver a la población negra con un sentimiento. Yo no te diría solo de subalternidad, sino sobre todo de paternalismo, tenía que ver ya con el enfoque hispanista en América Latina. (Entrevista com Gisela Arandia, em I2/09/2014)

Entremeados com as histórias de vida dos ativistas entrevistados nessa pesquisa, ocorriam processos de ruptura e crise social impactantes nos últimos anos da década de 1950. A violência era cotidiana e houve a suspensão de diversos serviços públicos. Universidades e escolas foram fechadas. Mas uma vez, a camada mais frágil pagava com seus corpos o preço da crise vigente. A seguir, trago o relato de experiências vivenciadas por ativistas no governo de Fugencio Batista:

Yo antes de triunfo de la Revolución tuve que venir para La Habana, en octubre 1958. En esa época mataban y cogían preso a la gente. Yo había tenido un problema con un policía de la dictadura. Mi padre me manda para La Habana. Ese policía era negro, en la tenía cogida conmigo. Por supuesto, me amenazaba la vida. En esa época los policías cogían preso a la gente y es por eso que me mandan para La Habana a casa de un amigo en el barrio Jesús María, uno de los barrios más pobres de La Habana, en la calle Vives 258. Allí ese amigo de mi padre tenía un cuarto, mi padre hablo con él. Estuve allí todo ese tiempo hasta el triunfo de la Revolución (Esteban Morales, entrevista realizada em I4/05/20I4).

Daysi Rubiera, uma das ativistas antirracistas entrevistadas nessa pesquisa, escreveu um importante livro para essa temática em Cuba, Reyita Sencillamente: Testimonio de una negra cubana nonagenaria. Nele, ela traz o relato de vida de sua mãe, conhecida como Reyita. A partir de seu olhar, Reyita narra, como mulher negra, a vivência de importantes momentos históricos, como o período que antecedeu a Revolução:

\begin{abstract}
O tempo ia passando, a situação política do país era muito difícil. A Ditadura de Batista era horrível, todos os dias amanheciam jovens mortos em qualquer parte; os guardas faziam o que lhes dava na telha, maltratavam o povo, por qualquer coisa golpeavam as pessoas. A miséria era tremenda; o estado de insalubridade dos bairros era alarmante; muitas crianças pequenas não iam para a escola; faltava trabalho e não havia segurança para as pessoas. Assim estavam as coisas em I958 ${ }^{191}$ (RUBIERA, 20I I: I04)
\end{abstract}

Mavis, liderança feminista, que tem uma trajetória importante junto ao movimento do campo, relata dificuldades vivenciadas no período final da Ditadura de Batista, além do cotidiano de violência:

Quando cheguei a Havana, chego em um momento político forte do país. Isso é em março de I958. A reação dos estudantes foi de protesto e revolta em relação ao golpe de Estado de Batista. A juventude mais progressista, que vinha de famílias de trabalhadores e camponeses, não estavam a favor disso. Foi nesse período que chego a universidade. Não era uma líder estudantil nessa época. Havia poucos estudantes dos extratos mais pobres. Não era para todos a Universidade [...] As mobilizações estudantis incomodavam muito. Incomodavam tanto que fecharam a universidade. Isso foi em 1957. Eu não pude terminar meu curso naquela época. Fecham a universidade e muita gente da minha geração teve que parar de estudar. Muitos se jogaram na clandestinidade, pois já estavam marcados como lideranças estudantis. Outros tantos

191 Tradução minha. 
que não eram líderes, e eu estava entre esses, nos vimos jogados na rua, sem estudo. Fecharam as universidade e nos jogaram nos braços da Revolução. Me perguntavam: Como você se meteu na Revolução? E eu respondia: Não é que eu tenha me metido. É que me meteram [...] Eu era uma alma inconformada, desgostosa do que passava em meu país. O que passava na Ditadura era tão duro, tão injusto. Como iríamos seguir construindo esse país, se não podíamos trabalhar, se não podíamos estudar? Não éramos donos de nada. O país era inundado de empresas estrangeiras. Os americanos eram praticamente donos do país, das finanças, da economia. Assim, o que fizeram então foi nos tornar mais rebeldes e revolucionários (Entrevista feita com Mavis Alvarez, em 28/05/2014) ${ }^{192}$.

Até o triunfo da Revolução e em seus primeiros anos, uma série de incidentes marcou esse momento de grande instabilidade, com significativo impacto sobre os negros, que já ocupavam majoritariamente, as camadas mais vulneráveis da sociedade cubana, como relata Daysi Rubiera:

\begin{abstract}
Não foi fácil para uma pessoa que procede de uma família muito humilde, e onde não há um apoio total por parte da figura principal da casa, que até aquele momento era o meu pai, onde os irmãos podiam contribuir muito pouco, pois seguiam o modelo paterno. Então, após muita dificuldade e trabalho, eu cursei a universidade e me graduei em 1960, 1961. Quando me graduei, eu já estava casada, tinha filhos, mas isso não me impediu de cursar a universidade. Eu estudei em uma etapa de fim do capitalismo e princípio do socialismo, uma etapa onde a discriminação racial era muito forte, muito, muito forte [...] Quando ingressei na Universidade, no meu grupo éramos apenas duas negras e nada mais, e éramos quatro pessoas de origem humilde, pobre. Todos os demais eram da burguesia, que no início estavam ali, mas a medida que foram sendo feitas as reformas da Revolução, que isso foi afetando as propriedades de suas famílias, essas foram saindo do país. Então foi um processo muito difícil esses primeiros anos na Universidade pela simples razão de que os professores se foram do país e Cuba teve que começar o movimento de professores emergentes. [...] Então, foi muito mais difícil adequar o estudo com professores que estavam começando sua vida como docentes. Uma mudança total de bibliografia, muitas vezes não havia livros. Ou seja, foi bastante difícil estudar na Universidade nesse período, pelas condições difíceis que Cuba vivia naquela época e também pelo processo de pobreza e racismo que vivenciávamos. (Entrevista com Daysi Rubiera, feita em I5/05/2014) ${ }^{193}$.
\end{abstract}

A partir do marco da Revolução, em $I^{\circ}$ de janeiro de 1959, foram iniciados processos de mudanças radicais, conforme descreverei a seguir. Nos anos subseqüentes a 1959, uma série de marcos legais e ações políticas foram implantadas no país, dentre os quais cabe mencionar a adesão ao regime socialista no país, a estatização das empresas, a reforma agrária e a aproximação com os países do bloco socialista. Foi decretado o fim da segregação racial de praias, clubes e empresas, e também em pouco tempo foram encerradas atividades de grupos como as chamadas "Sociedades de Color".

É fato que a maioria das pessoas negras se encontrava em uma situação vulnerável e que as ações empreendidas pela Revolução melhoraram a vida da maioria pobre do país. Todavia, é fundamental destacar que havia uma classe média negra, anterior à Revolução, com profissionais em diversas áreas, como arquitetura, exército e comércio, conforme destaca Gisela:

Quiero puntualizar que hay un sentimiento, una emoción, una metáfora de tratar de hacer ver que todos los negros de Cuba antes de la Revolución estábamos en unas condiciones desastrosas. Eso no es verdad, eso para nada es verdad. Antes de la Revolución, desde I844 cuando la conspiración de La Escalera, hubo

${ }^{192}$ Idem.

${ }^{193}$ Ibidem. 
negros clase media y en Aponte en I8I2 hubo negros instruidos. Es decir, uno de los motivos del racismo es querer hacer ver un proyecto de reivindicación cien por ciento. Sin lugar a duda, la Revolución fue un proceso de reivindicación. Vamos aclarar que fue una reivindicación social no racial, fue una reivindicación para todas las personas oprimidas, en que la población negra por supuesto formaba parte de esto. [...] Había familias negras, [...][que formaran] una clase media simbólica, porque no era una clase media que tuviera medios de producción que tuviera un empoderamiento de la perspectiva de dinero, pero si cultural y simbólico. En Cuba, había muchos dentistas, había médicos, los maestros fundamentalmente eran casi todos en su mayoría negros antes de la Revolución, abogados ingenieros, hubo una bióloga. No eran muchos, pero había. [...] En la Revolución, hay una tendencia a ser tabla rasa: antes no existía absolutamente nada, empezamos de cero. Entonces este tema es importante porque de mi investigación en Miami, una de las cosas que critican los negros cubanos que se fueron de Cuba, de los que se fueron al inicio en los 60, se fue un grupo muy minoritario y que sigue siendo en Miami. Es un grupo minoritario clase media que conservó su status de clase media y que se inserto en el racismo de Miami, una sociedad muy racista, pero que se insertaron y tienen un status. No son los del Mariel (salida fuerte de I980), es decir gente con un status. ¿Cuál es la reflexión de esas personas? Que en la medida en que la Revolución desmontó él tema de las identidades, hasta cierto punto cortó esa identidad o esa conciencia racial que se estaban formando, fragmentada porque las sociedades negras eran elitistas, eran clasistas. Sólo iban allí los negros que tuvieran algunas posibilidades, después los negros con menos posibilidades iban a otro. Una sociedad clasista de cualquier sociedad de nuestro continente, pero con esto quiero decirte que de ese grupo de personas, un grupo grande, entiendo yo, asumió la Revolución. Es decir, de esa población cubana negra con un nivel de cultura con un nivel de profesionalidad, no todos se fueron del país. Te quería decir eso para tener en cuenta eso que aparece y tu oyes decir y es una visión absolutamente racista, como que la Revolución nos alfabetizo a todos los negros. (Entrevista com Gisela Arandia, em I2/09/2014) ${ }^{194}$.

O início do processo revolucionário promoveu amplas mudanças. Se por um lado não se tinha mais espaços específicos para a população negra, como as sociedades de color, por outro, as barreiras existentes em clubes, bancos, instituições e até regiões habitacionais a brancos e negros foram fisicamente abolidas. Nesse contexto, em pouco tempo, houve a compreensão de que a grave situação de racismo social em Cuba havia sido superada. Todavia, a trama do racismo permeia caminhos não facilmente apagáveis. A experiência de Cuba hoje, décadas após o início da Revolução socialista, parece mostrar isso. O combate às diversas formas de exploração e desigualdades sem um olhar mais específico ao tema do racismo pode não ser capaz de revertê-lo.

Há, portanto, uma construção narrativa importante desses atores sociais que resgata e reconstitui fatos relevantes da história cubana, com ênfase para as relações raciais e as mobilizações negras, e busca ressemantizar suas identidades a partir desse processo. A percepção, por exemplo, de que a Revolução foi muito importante, mas que antes dela havia uma elite negra, tanto econômica, como intelectual e política, é outro marcador recorrente nas narrativas.

Também é destacado o aspecto de que politicamente, essa parcela da população se movimentava, atuava em diferentes frentes, a partir de variadas linguagens e estratégias. Havia, portanto, mobilizações negras anteriores à Revolução que construíram um legado importante, que perpassaram todos esses processos históricos de Cuba, e que na contemporaneidade influenciam o ativismo antirracista.

${ }^{194}$ Ibidem. 


\section{Capítulo 3 - ¡Viva La Revolución, Abajo El Racismo!}

Escutei a expressão que dá título a esse capítulo diversas vezes, nos inúmeros diálogos feitos durante a pesquisa de campo ${ }^{195}$. É uma frase simbólica que se refere a uma situação hipotética, que traz uma boa síntese da atualidade cubana que mescla a herança do dogmatismo soviético com as demandas subjetivas que ganham força, especialmente dos anos 1990 em diante.

A expressão é explicada por interlocutores a partir da seguinte situação: uma pessoa engajada nos coletivos antirracistas resolve ir no dia $\mathrm{I}^{\circ}$ de maio, dia do trabalho, à praça da Revolução com um cartaz que traz essa frase: Viva a Revolução, Abaixo o Racismo! Apesar de hoje haver uma maior permeabilidade de discussão do tema, ao apresentá-lo asssim em uma situação que reúne milhares de pessoas, esse ato provavelmente não seria bem recebido nem pela polícia, nem por muitos dos militantes do Partido Comunista de Cuba ou de outras organizações de base da Revolução, como os CDR.

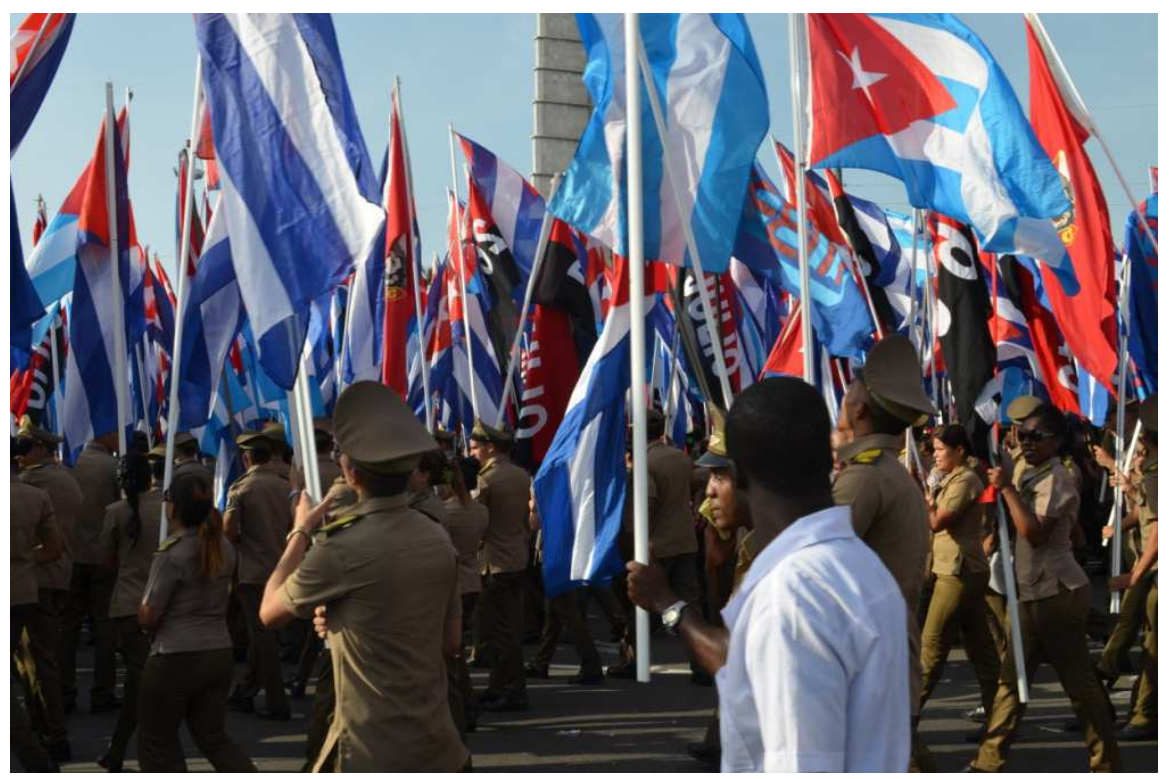

Figura 19: Foto das comemorações do dia do trabalhador, Iº de maio de 20I4, Havana, Cuba, que reúne milhares de pessoas organizadas por categoria profissional. Foto: Bárbara Oliveira.

A situação acima descrita potencialmente se tornaria tensa. $O$ principal motivo, refletivo nas conversas, seria a falta de amadurecimento para tratar o tema racial na sociedade em geral, o que indica a necessidade de que o debate seja ampliado de forma satisfatória. São muitos os avanços na discussão sobre racismo e relações raciais, mas essa ainda é restrita a uma parcela reduzida da

${ }^{195}$ Faço destaque especial às conversas com Rodrigo Espina, pesquisador do Instituto Cubano de Investigação Cultural Juan Marinelo. 
sociedade. A falta de uma campanha ampla com uma abrordagem integrada do tema nos meios de comunicação, impacta nessa vivência fragmentada.

Em espaços nos quais ocorrem atividades de coletivos, as relações raciais são discutidas com profundidade, e logo na rua em frente, é comum pessoas afirmarem ideias como: "Não há racismo em Cuba"; "A Revolução já acabou com isso"; "Não fale disso"; "Pra que se meter em esse debate?"; "Esse tema é problema"; dentre outras expressões ou frases semelhantes, que reproduzem as estratégias de controle do discurso, conforme refleti anteriormente a partir de Foucault (2006).

Essa especificidade, na qual Cuba se insere, tem grande influência nos processos vivenciados na Ilha, alguns ímpares em relação aos demais países do continente americano. O processo revolucionário de 1959, particular de Cuba, caracteriza-se por uma grande ruptura social, econômica e paradigmática, num ápice do drama social, no sentido dado por Victor Turner ao termo: "Se o drama social percorrer seu curso completo, o resultado pode se manifestar através ou da restauraçao da paz e "normalidade" entre os participantes, ou do reconhecimento social de uma ruptura ou cisão irremediável" (TURNER, 2005: 182).

Ainda no diálogo com Turner (2005), a ação reparadora para mediar a crise social pode falhar e não se alcançar a "restauraçao da paz". Se a lei ou os valores religiosos perderem sua eficácia, um faccionalismo contínuo e endêmico poderá tomar a vida pública, ou o ancien régime pode ser rejeitado totalmente, dando início à Revoluçao.

O processo revolucionário cubano é marcado pela ruptura significativa das bases anteriormente postas. Muitos tinham a expectativa de que se tratasse de mais um dos vários golpes que o país havia vivenciado. Uma nova mudança para no final não mudar nada. Todavia, a marcha das transformações foi acelerada e brutal. Nos primeiros anos, já se desenharam novos paradigmas econômicos, fundiários, educacionais e estruturais. Parte da elite e da classe média cubana, que havia apoiado a Revolução, começa, em pouco tempo, a perceber o alcance das mudanças e o impacto que elas geraram em seu status quo e em suas propriedades e negócios. Zurbano aborda o caráter de fato revolucionário desse feito em relação ao contexto do Caribe:

Cuba compartió los mismos patrones coloniales y neocoloniales del Caribe hasta 1959. Antes solo se diferenciaba por su dimensión geográfica y por la vieja fascinación que provoca la Isla en el imaginario imperial de los Estados Unidos. Hay un corte radical en la historia caribeña cuando irrumpe una revolución democrática popular que en dos años proclama su carácter socialista (ZURBANO, 20I2: I3). 
A Revolução cubana remodelou a estrutura de poder vigente na época, que provinha da sociedade colonial, na qual os descendentes dos antigos senhores de escravos se constituíam como a elite cubana. Isso ocorre por meio de uma série de transformações sociais e econômicas, como a reforma agrária, a alfabetização maciça, o fim da propriedade privada sobre os meios de produção e a sua nacionalização.

As elites econômicas, historicamente reprodutoras das relações raciais desiguais desde o período colonial, em grande maioria migram para o exterior, especialmente para os Estados Unidos, e de lá passam a organizar uma forte oposição ao regime Castrista. Os emigrantes eram quase que exclusivamente brancos, o que trouxe impactos na proporção da composição racial no país. De acordo com o censo cubano de I98I (primeiro a divulgar alguns dados desagregados por cor depois da Revolução), a população branca em Cuba era de 66\%. Em 1953, esse percentual era de $73 \%$.

A administração dos bens econômicos passa a ser do Estado cubano. Na educação, são criadas novas escolas e universidades e há uma grande campanha educativa, que abarcava inclusive a alfabetização. Milhares de jovens viajaram por todo o país para atuarem como alfabetizadores. As mudanças iniciadas com a Revolução apresentam resultados expressivos até os dias de hoje, como a taxa de 99,8\% da população alfabetizada e uma expectativa de vida média de 77,64 anos, superior a vários países da América Latina. A maioria da produção agrícola em Cuba é agroecológica, sem o uso de agrotoxicos ou fertilizantes quimicos. Por essas e outras razões, em 2006, Cuba foi definida pela WWF como o único país no mundo com desenvolvimento sustentável ${ }^{196}$. O Índice de Desenvolvimento Humano de Cuba é alto, de mais de 0,8 em 2007, com um baixo consumo de carbono e, portanto, menos impacto ambiental.

Essas transformações tiveram reflexo direto nas vidas de muitas/os ativistas antirracistas com os quais interagi na pesquisa. A campanha de alfabetização, realizada já nos primeiros anos da Revolução, em 1960, I96I, por exemplo, envolveu cerca de duzentos e cinquenta mil voluntários, dos quais cerca de cem mil eram menores de 18 anos. O chamado era: cada cubano que sabe ler e escrever ensinará a um cubano que não saiba. Ativistas entrevistadas nessa pesquisa, como Norma Guillard e Irene Ester Ruz, participaram dessa ampla campanha. Norma ${ }^{197}$ narra sua experiência como alfabetizadora num documentário realizado em 20I4:

\footnotetext{
${ }^{196}$ Fonte: www.wwf.org (acesso em jan/2014).

${ }_{197}$ Ativista antirracista e feminista. Integra os coletivos ARAAC e a Rede de Mulheres Latinoamericanas e Caribenhas, capítulo cubano. Tivemos encontros em atividades e debates feitos sobre a pauta racial, ao longo do
} 
En ese tiempo, yo tenía I5 años. Quedan años y quizás suceda alguna otra cosa. Pero hasta hoy, en mis recientes 58 años cumplidos 22 de mayo, no tengo otra cosa con una fuerza tan grande como esa (campanha de alfabetização) e que me evoque a su vez. Cuando empiezo a hablar de eso me evoca, por la historia de mi vida. Es la cosa más importante que yo he realizado. (Relato de Norma Guillard, no documentário Maestra, de Catherine Murphy, 2014).

Na primeira década após a Revolução, como destaca César (2004), houve um intenso avanço na implementação das políticas sociais. Os pontos principais enfocados, nesse período, foram a reforma agrária (Lei da Reforma Agrária), a nacionalização de empresas, indústrias e bancos (Lei $n^{\circ}$ 890/1960), a redistribuição de renda em favor da maioria da população, ensino gratuito, universalismo e gratuidade dos serviços de saúde, rebaixamento dos preços de alugueis, tarifas elétricas, telefônicas e dos medicamentos, eliminação da segregação racial em espaços públicos, empresas e clubes.

O processo de implementação dessas reformas e mudanças foi complexo, pois impactava relações há muito estabelecidas. Mavis relata em sua entrevista o momento que, com a efetivação da reforma agrária, um grupo de proprietários de terra, que até então apoiava a Revolução passa a se opor:

A experiência da reforma agrária foi muito importante para Cuba. No mundo ideal, nós jovens idealistas, imaginávamos que uma vez triunfada a Revolução, estaria tudo resolvido. Que havia acabado a injustiça, a discriminação. Estava completamente equivocada. As coisas não são assim. Trabalhando com a reforma agrária pude ver a reação nas pessoas durante processo de mudança. A aprovação da lei de reforma agrária, por exemplo, teve um impacto tremendo na sociedade. Os camponeses desejavam desde a colônia ter o direito à terra. Após as duas leis de reforma agrária, de 1959 e I963, percebemos que essa era uma Revolução que vinha pra ficar, que promovia mudanças profundas. Com a ingenuidade da juventude, pensávamos que com a lei de reforma agrária, tudo estava resolvido. Mas, quando começamos a aplicá-la, ao trabalhar com as pessoas, no Instituto de Reforma Agrária, foi que percebi que tudo era muito mais complexo. O maior impacto que tive é que houve muita a resistência, não muitas vezes visível e não muitas vezes frontal, dos grupos que não queriam a reforma agrária. Esses grupos, inclusive, não queriam a ditadura de Batista, tinham inclusive ajudado a derrubar a ditadura. Queriam derrubá-la porque era um regime feroz, criminal, abusivo. Mas, queriam que do ponto de vista econômico, de seus bolsos, não ocorresse nada. (Entrevista com Mavis Alvarez, realizada em 28/05/2014) ${ }^{198}$.

Além da mudança da elite política e econômica do país, diversos atos normativos e políticos visaram combater a discriminação racial na Ilha. Um deles é a medida anunciada em I6 de maio de I96I, que instituiu a nacionalização das empresas, indústrias, dentre outros, e que deliberou, também, sobre a eliminação de todos os interditos raciais existentes anteriormente em clubes, praias, parques e outros espaços públicos. A Primeira Declaração de Havana (I960) estabelece como principio fundamental a incompatibilidade da democracia com a discriminação racial. A

tempo de pesquisa em Havana. A oportunidade de uma interação mais profunda e de uma longa entrevista foi realizada em sua casa, situada em bairro histórico da cidade. Sua formação é em psicologia e integra a direção da Coordenação de Psicólogos de Cuba.

198 Tradução minha. 
Constituição da República de Cuba (I976) reafirma as aspirações revolucionárias, dentre as quais está o combate à discriminação por motivo de raça, cor, sexo ou origem nacional.

Como ressalta Tato Quiñones, a Revolução e suas mudanças significaram uma ruptura estrutural ao modelo anterior:

As mudanças foram óbvias, palpáveis, reais. Muitos lugares de trabalho, em Cuba, estiveram vedados aos descendentes de africanos, sobretudo as companhias norteamericanas que tinham filiais no país, fábrica de pneus, fábrica de tecidos, a Companhia de Eletricidade, a Companhia de Telefone. Todas essas eram dos norteamericanos em Cuba, e nesses locais a presença de negros era ridícula, zero vírgula algo. E era onde se ganhavam os melhores salários. [...] Havia lugares onde os negros sabiam que não poderiam nem pensar em trabalhar (Entrevista realizada com Tato Quiñones, em 29/05/20I4) ${ }^{199}$.

Os bancos eram instituições que refletiam de forma muito marcada a exclusão dos negros e negras no período pré-Revolucionário. Mavis, ao relatar sua experiência profissional no setor financeiro, aborda como viu os primeiros negros entrarem nos bancos como funcionários:

Yo fue administradora de una agencia bancária, cuando se nacionalizó los bancos y algunos de ellos pasaran a dar crédito a los campesinos. Yo fue directora de algunas de esas agencias bancarias. E ahí nunca vi una negra trabajando. Las primeras veces que empezaran los negros trabajar en una agencia bancaria fue después de la Revolución. Cuando a mi me nombraran directora de esa agencia, no había ningún negro y ninguna negra trabajando. Era una discriminación puramente de piel. No había negros. Y resulta que el primero negro que entra a trabajar ahí era lo más graduado de todos, pues era contador. Y la primera mujer negra empezó a trabajar ahí fue sencillamente porque la impusimos nosotros, y no la queremos limpiando, sí trabajando el las cajas. Tuvimos que hacerlo. (Entrevista com Mavis Alvarez, realizada em I8 de maio de 20I4).

Destaco, como já pontuado, que antes da Revolução havia uma elite negra. Desde o período colonial, passando pela República, uma classe média negra ocupava espaços nas Sociedades de Color, nos clubes, nos espaços midiáticos, no comércio, e inclusive, no exército. Batista, ditador que foi deposto pela Revolução, era negro e estimulou, especialmente dentro do exército, uma pequena elite de alto escalão afrodescendente. Os portos também foram espaço de trabalho para a população negra, como coloca Quiñones. Todavia, a maioria negra era socialmente excluída, inclusive em espaços públicos:

\begin{abstract}
A exceção era o Porto de Havana, onde os trabalhadores, e nesse conjunto os negros eram muito numerosos, se ganhava um bom dinheiro graças a um dirigente sindical negroguista dos anos 1940 . O resto que sobrava para os negros era a construção civil, empurrar carretilhas ${ }^{200}$, trabalhos marginais. [...] Trabalhar na grande indústria textil, tabaqueira, cervejeira, elétrica, de telefonia, de pneus, por exemplo, era muito difícil, praticamente impossível para negros. Mais além, havia em Cuba Sociedades culturais e de recreação marcadamente segregadas para negros e para brancos, e em espaços como praias, e Fidel se referiu a isso nesse discurso em 1959, era impossível, improvável que um negro pudesse se banhar com sua família, pois tudo isso havia sido repartido pela burguesia branca. Toda essa mudança foi vista. Não se restringiu a falar
\end{abstract}

\footnotetext{
${ }^{199}$ Idem

${ }^{200}$ Espécie de carro, feito de madeira, com tração humana, onde se realiza o comércio na rua de frutas, verduras e legumes, biscoitos, ferramentas, dentre outros produtos.
} 
sobre mudança simbólica. Era uma mudança palpável. Esse foi o compromisso, mais que as palavras. (Tato Quiñones, entrevista realizada em 29/05/2014) ${ }^{201}$.

Esse processo de romper com a segregação espacial vigente até os primeiros momentos da Revolução não foi uma tarefa simples. Como destacou De La Fuente (20I4), a oposição ao processo de integração não veio apenas da burguesia. Uma pequena burguesia e parte dos trabalhadores e camponeses também apresentaram resistência às mudanças. A integração nos espaços laborais e políticos sofria, muitas vezes, menos resistência do que compartilhar locais de lazer e divertimento, como o relato de um trabalhador da época indica (Fox, Race and Class, apud DE LA FUENTE, 20I4: 338).

Essas mudanças trazidas pela Revolução e as fortes resistências a elas também compõem as histórias de vida de ativistas antirracistas da atualidade. Irene Esther ${ }^{202}$, com grande vinculação ao esporte, relata uma vivência que traz os elementos conflitivos dessa transição, nos primeiros espaços que passam a ser compartilhados entre brancos e negros, logo no início da Revolução:

\begin{abstract}
Yo tenía I4 años, estava en el pré-universitário. Acaba de triunfar la Revolución, yo era esgrimista, a mí siempre me gustó el deporte. Se iba celebrar una competencia de esgrima y iba ser en un club que había sido de la gran burguesía cubana. Mi papá me llevó a la competencia. Era 1959, acababa de triunfar la Revolución y ese todavía era un club privado. Resulta que cuando llego me dice mi papá: Mi hija, jes increíble! aquí yo siempre entré como albañil, como trabajador. En estos lugares nunca se ha entrado por la puerta delante. Y yo te traigo a ti hoy y vas entrar por la puerta delante. Aquí, nada más que los negros entramos por la parte de tras como empleados. A mí aquello me quedó muy fuerte y yo entré con un orgullo. Yo, una joven revolucionaria, pensé: o sea, esas son las cosas nos trajo la Revolución, que tenía que cambiar. Cuando llego al camarín para cambiarme la ropa, para la competencia, estaba lleno de señoras blancas. Ellas me miraran de ácima abajo: ¿que tú que vienes a hacer aquí? Digo: Buenas tardes, yo vengo a la competencia. Ellas me contestan: ¡Ah! ¿Ahora ustedes también tienen que estar aquí? Y yo no me daba cuenta de aquello. Cuando llego al área de la competencia, todos los empleados me miraban. No había nadie. Me dijeran: No señorita, acá no hay competencia. Eso era un domingo. Cuando llega el lunes, que me dicen las muchachas del instituto (donde yo entrenaba): mira, se suspenderán la competencia. Los otros institutos cuando supieran que era una negra no quisieran participar. Aquello para mí fue traumatizante. A partir de ese momento es que yo empiezo a tener una conciencia racial dura, cruda. (Entrevista com Irene Esther, realizada em 0I/07/2015).
\end{abstract}

Essas transformações necessariamente demandavam um debate sobre a questão racial mais profundo. Nos primeiros anos da Revolução, Cuba vivenciou uma grande campanha sobre o tema, onde o racismo era colocado com um aspecto antirevolucionário, que deveria ser combatido por todos. Foram convocados pelo primeiro ministro intelectuais, escritores, jornalistas para debater o tema racial, aprofundar o conhecimento sobre o assunto e demonstrar à população que

\footnotetext{
20I Tradução minha.

${ }^{202}$ A relação com Irene Esther, no percurso da pesquisa de campo, foi intensa. Foi a primeira que tive a opotunidade de conhecer. Juntas, cursamos o diplomado voltado para o debate racial na Universidade de Havana, em 2014. Participamos de muitas atividades focadas no tema, além de termos vivido juntas experiências de projetos em La Marina (Matanzas) e em comunidades em Havana. Temos uma ligação tão estreita, que brincávamos que Irene é "mi mamá cubana". Irene, formada em Ciências Sociais, integra a coordenação da ARAAC e também do coletivo de mulheres negras Afrocubanas, e tem atuação constante com a pauta racial. Foi integrante de uma dos primeiros coletivos de mulheres de Cuba, da sociedaed civil, Magín.
} 
o preconceito racial era um verdadeiro absurdo (DE LA FUENTE, 20I4: 340). Movimentos estudantis, sociedades negras, militantes do partido socialista, organizações de trabalhadores e outros movimentos sociais se juntaram nessa campanha.

As alterações realizadas nos primeiros anos da Revolução para extinguir as discriminações raciais latentes foram fundamentais para construir um sentimento comum de pertencimento ao projeto da Revolução. O significativo silêncio que envolveu o tema desde o processo revolucionário, onde essa questão não foi incorporada de forma explícita em praticamente nenhum dos manifestos do M-26 de julho, é quebrado após o triunfo revolucionário. Um dos momentos de maior visibilidade desse debate foi o que os ativistas antirracistas chamam "Primeiro Chamado de Fidel”, em março de 1959. Abaixo, transcrevo parte do discurso de Fidel Castro:

\begin{abstract}
O problema da discriminação racial é, infelizmente, um dos problemas mais complexos e mais difíceis que a Revolução tem que lidar. O problema da discriminação racial não é o problema do aluguel de moradias, não é o problema dos medicamentos caros, não é o problema da Companhia de Telefonia. Não é nem sequer o problema do latifúndio, que é um dos problemas mais sérios que nós teremos que enfrentar. Talvez o mais difícil de todos os problemas que teremos a diante, talvez a mais difícil de todas as injustiças que existam em nosso meio, seja o problema que implica para nós por fim a essa injustiça que é a discriminação racial, ainda que pareça incrível. [...] Nós não temos apenas que lutar contra uma série de interesses e privilégios que tem gravitado sobre a Nação e sobre o povo; temos que lutar contra nós mesmos, temos que lutar muito fortemente contra nós mesmos. E eu me pergunto que diferença há entre uma injustiça e outra injustiça, que diferença há entre um camponês sem terra e o negro a quem não se dá a oportunidade de trabalhar. É que não se morre igualmente de fome o negro que não trabalha e o camponês que não tem terra? E por que a Revolução há de ter a obrigação de resolver as injustiças, e não vais estar obrigada a resolver essa? Todavia, há gente que vai a igreja e é racista, há gente que se diz revolucionária e é racista, há gente que se diz culta e é racista. [...] Disse bem claramente que não deveria ser necessária uma lei para que se colocasse fim à injustiça que nasce de um preconceito absurdo, e eu sou dos que crêem que os preconceitos não se combatem com leis; se combatem com argumentos, se combatem com razões, se combatem com persuasão, se combatem com a educação (Fidel Castro, discurso realizado em março de $1959)^{203}$.
\end{abstract}

Caracterizado por Fidel Castro como talvez "o mais difícil dos problemas a ser resolvido pela Revolução", o racismo e a discriminação racial estiveram na pauta de outras lideranças revolucionárias, como Che Guevara que abordou o tema em discursos feitos nesse período. Che, inclusive, ao receber o título de Doutor Honoris Causa na Universidade Central de Santa Clara, declarou que as mudanças deveriam estar refletidas no ensino superior: "Que se pinte de negro, que se pinte de mulato, no sólo entre los alumnos, sino también entre los profesores" ${ }^{204}$.

Um ponto demanda uma análise mais profunda. $\mathrm{O}$ tema racial praticamente esteve ausente dos manifestos publicados do Movimento 26 de julho. Apesar disso, era fortemente discutido na sociedade, especialmente no âmbito do Partido socialista, nas sociedades negras, em organizações

\footnotetext{
203 Tradução minha.

${ }^{204}$ Speech of Ernesto Che Guevara at Santiago de Cuba, Habana, 4 de mayo de I959 Apud de La Fuente (2014: 343).
} 
de trabalhadores. O que teria levado os dirigentes desse movimento, e, em especial, Fidel Castro que, anteriormente à Revolução, havia participado da luta antirracista na universidade, a não abordar a questão durante todo o processo revolucionário até os primeiros meses de I959?

Muitos dos ativistas apresentam sua perspectiva para esse fenômeno. Essas idas e vindas estão marcadas na memória e nas narrativas do grupo de ativistas que acompanhei durante a presente pesquisa. Gisela Arandia, da ARAAC, apresenta sua percepção desse processo:

En marzo del 1959 Fidel, como Raúl, habían estado vinculado a través de Walterio Carbonel al movimiento de los derechos civiles y Fidel hizo un discurso donde dijo que uno de los problemas más graves que tenía que enfrentar la Revolución era la discriminación racial. Después dice "por difícil que parezca". ¿Qué paso con ese discurso? No sé si conoces el libro, hay una reflexión que escribió Sixto Gastón Agüero. El libro (fue hecho por este) hombre, que era un periodista negro que se fue de Cuba. Él hace una reflexión sobre este acontecer. Cuando Fidel dijo eso, este país se puso patas arriba. Fue la única vez en la vida de Fidel que él en un discurso enmendó lo que se llama en periodismo, enmendó la plaga, hizo su rectificación. Dijo: "Yo no quise decir esto, yo lo que quise decir fue esto". Fidel se aclaro a sí mismo como a los cinco días. Dijo: no buscamos que nadie baile con nadie, en fin ese es otro segundo discurso. ¿Quiénes son las personas que en ese momento en Cuba rechazan la propuesta de Fidel? Son los propios revolucionarios que estaban con Fidel que no aceptaban porque había un mito, un mito de los años 1930 como el impacto de la guerrita del I9I2 (Partido Independientes de Color), y eso no iba para atrás. Ese mito se fue reafirmando con la presencia de Batista, y es que los negros, la población negra no era confiable, que la población negra no era revolucionaria por decirlo de cierta manera. Ahí puedes encontrar por qué en La Historia me Absolverá (Libro de Fidel Castro), esto no es especulación de Gisela, el tema de la cuestión racial no está planteado. (Entrevista realizada com Gisela Arandia, no dia 12/09/20I4).

Gisela não está isolada, entre os ativistas, nessa percepção de que houve uma pressão interna que estimulou que esse debate não ganhasse vôo pleno, o que de alguma forma freou as ações explícitas contra as discriminações raciais. Por outro lado, há um reconhecimento que as ações sociais da Revolução marcaram a maioria das famílias negras, mesmo não tendo as políticas empregadas um caráter racial explícito.

Pouco a pouco, o avanço na implementação das medidas de integração social e a nacionalização e estatização de diversas empresas privadas foi efetivando uma inclusão crescente da população negra nos vários ramos do mercado de trabalho e também nas instituições educacionais. Ações para a integração de praias, clubes, espaços de lazer também avançaram. Como De La Fuente (20I4) destaca, essas mudanças foram sendo implementadas sem explicitar que se tratava de uma medida para a inclusão racial. A ênfase era a construção da nação e da unidade cubana. Uma ação que teve grande impacto na redução das desigualdades raciais foi a nacionalização das escolas privadas em 196I, que até então formavam a elite do país e tinham uma dinâmica interna bastante elitista e de segregação racial.

As mudanças foram sentidas em todo o país de forma muito intensa. A sociedade como um todo vivenciava experiências de ruptura de códigos e práticas sociais historicamente arraigados e que 
foram em poucos meses modificados radicalmente. Havia um forte sentimento estimulado por esse debate público feito sobre a questão racial de que explicitar práticas racistas e segregacionistas era um ato contra o espírito revolucionário. E os avanços nesse momento foram inegáveis. Todavia, as ações inclusivas fundamentais para a população mais pobre e excluída de forma geral atingiram de modo diferente brancos e negros, exatamente pelo histórico de exclusão desse último segmento.

Essa percepção está presente em narrativas de ativistas sobre o processo revolucionário. Há uma visão crítica que o ponto de partida dos negros e brancos não era o mesmo, o que demandava um olhar diferenciado para essas desigualdades prévias. Nas palavras de Esteban Morales, era necessário ter condições para aproveitar as oportunidades, o que muitas famílias negras não tinham:

\footnotetext{
Entre 1959 e 1962 avanzamos bastante. Como la política social de la Revolución fue extraordinariamente humanitaria, extraordinariamente rica en ventajas para todos, pues sencillamente los negros y mestizos que pudieron, cubrieron sus espacios. Digo que pudieron porque eran oportunidades pero para poder aprovechar esa oportunidad había que tener posibilidad, y los negros y mestizos venían de muy atrás. Habían llegado como esclavos, pero no habían logrado avanzar tanto, a pesar de que en las ciudades habían logrado constituir una cierta clase negra muy fuerte que las represiones anti rebelión esclavistas lo aplastaban lo empujaban hacia atrás. Los negros habían tenido más oportunidades, después del triunfo de la Revolución tuvieron más oportunidades, pero no son suficientes las oportunidades, hay que tener posibilidades, para aprovechar las oportunidades. (Entrevista com Esteban Morales, realizada em I4/05/20I4).
}

Esteban dá voz a uma das críticas dos ativistas em relação às estratégias inclusivas da Revolução: a visão de que há uma desigualdade historicamente presente nas famílias negras e que romper com esse ciclo é um processo complexo, que demanda um olhar específico. Essa é, inclusive, uma das justificativas fornecidas para a continuidade de desigualdades raciais na atualidade. Contudo, essa não é uma percepção global. Há visões antagônicas, como a de que a Revolução possibilitou oportunidade a todos e o ônus da desigualdade hoje existente, na visão de alguns, recai sobre os próprios sujeitos discriminados ${ }^{205}$.

Essa apreensão de que a Revolução apresentou as ferramentas a todos, sem discriminação, e que cabia aos sujeitos aproveitar ou não as oportunidades parte de uma premissa que dialoga com o debate sobre o princípio da meritocracia, que está expresso na Constituição Cubana de I976. No capítulo intitulado "Igualdade", está expressa a proibição da discriminação por motivação racial, de sexo, origem nacional. Também declara que todos os cidadãos teriam acesso aos cargos e empregos do Estado e da economia, e aos serviços e prestações do Estado, de acordo com seus "méritos e capacidades" (HELG, 2004: 36).

\footnotetext{
${ }^{205}$ Maior discussão sobre essa questão na seção "Mito da Igualdade, Mestiçagem e Nação", do capítulo I.
} 
Esse emaranhado de convulsões coletivas, vivenciadas nos primeiros anos da Revolução, com alterações marcadas no cotidiano social, político e econômico, vinha entrelaçado com esses ditos e interditos sobre a questão racial e o racismo. Mesmo com todas as mudanças em curso, tocar nos mecanismos de controle e hierarquização da sociedade cubana com relação à questão racial de forma explícita se mostrou um desafio. O próprio ato de admitir a existência de uma situação racial excludente e perversamente silenciosa e invisibilizada, marcado no $\mathrm{I}^{\circ}$ Chamado de Fidel, só é retomado com ênfase pelo Estado no tumultuado processo de crise do bloco socialista.

Cabe destacar, contudo, que ainda existe um ambiente que rechaça ou dá tons amenos a esse fenômeno, como ocorreu na descrição da situação racial pelo Estado cubano, nos informes periódicos $\left(\right.$ do $14^{\circ}$ ao $18^{\circ}$ ), apresentados ao $\mathrm{CERD}^{206}$. A posição é de que os preconceitos raciais na sociedade cubana "no tienen una significativa entidad y se expresan particularmente en las esferas más íntimas de la vida, con mayor frecuencia en la relación de pareja".

Um dos argumentos constantes para justificar essas décadas de silenciamento oficial é que após a Segunda Declaração de Havana, conhecida como o Segundo Chamado de Fidel para a questão racial, em 1962, houve a interpretação ampla de que a posição oficial indicava que o racismo estava solucionado. Ademais, havia a consciência de que todos deveriam estar juntos para defender o legado da Revolução, de que todos eram cubanos e, desse modo, não cabia questionamentos ou ponderações de cunho racial, como destaca Esteban Morales:

Pero del 1959 al 1962 también se empezó a producir un fenómeno de ataque a Cuba, la contrarrevolución muy fuerte. Y en medio de esas circunstancias, en el año 1962, se dijo que el problema racial estaba resuelto. Eso era un voluntarismo, era una locura. Los negros y mestizos habían avanzado, pero no habían avanzado lo suficiente todavía. En términos de posibilidades, aprovechar las oportunidades. Hay que decir que realmente del 1959 al 1962 eran muy pocos años para decir que un problema creado por 4 siglos, por más de 4 siglos podía resolverse tan brevemente. Pero tampoco se reclamó, porque el ambiente social que se creó en Cuba, fue más bien un ambiente social de solidaridad, de igualitarismo, de que la discriminación no se expresaba abiertamente, y de que todos los cubanos debíamos estar unidos para luchar contra un enemigo más importante que el racismo, que era el imperialismo, en este caso Estados Unidos (Entrevista com Esteban Morales, realizada em I4/05/20I4).

Os entendimentos sobre esse fenômeno podem ser mais amplos e abarcar perspectivas alargadas do processo, que permeiam as possíveis estratégias de dominação e de ocultamento da questão que advinham na entoada da afirmação de Fidel que não havia mais racismo, portanto esse era um problema resolvido. Houve, no sentido foucaltiano, um disciplinamento discursivo. Zuleica Romay complexifica essa questão, ponderando que esse silenciamento refletiu uma série de posições que, de um modo ou de outro, reforçaram essa situação:

${ }^{206}$ Relatório apresentado ao Comitê para a Eliminação da Discriminação Racial da ONU, entre os dias I6 e I7 de fevereiro de $201 \mathrm{I}$. 
La gente te dice: Porque a partir del 1962, porque Fidel (dijo que el racismo se acabó). Yo lo busqué porque a mí me interesaba saber que fue lo que dijo Fidel en el 1962 que la gente dice que después de aquello se prohibió. Fidel lo que dijo fue enumerar los logros de la Revolución y dijo:

Este es un país que ha convertido en dueños de la tierra a mas de cien mil pequeños agricultores, aseguró empleo todo el año en granjas y cooperativas a todos los obreros agrícolas, transformado los cuarteles en escuelas, concedido cien mil becas a estudiantes universitarios, secundarios y tecnológicos, crear aulas para la totalidad de la población infantil, liquidado totalmente el analfabetismo, cuadriplicado los servicios médicos, nacionalizado las empresas monopolistas, suprimir el abusivo sistema que convertía la vivienda en un medio de explotación para el pueblo, eliminado virtualmente el desempleo, suprimido la discriminación por motivo de raza o sexo (Fidel Castro, Techo do Segundo Chamado, 1962).

Es lo único que en la Segunda Declaración de La Habana se dice de eso, y entonces alguno de nosotros que somos tan irresponsables que decimos que después de eso (el racismo se acabó). Fidel enumero un montón de cosas, ¿̇ah qué pasó? Después de eso hubo dos corrientes, los optimistas que dijeron: iporque hemos erradicado la discriminación! Los optimistas apoyados por los silenciosos. Los silenciosos son los que no estaban tan seguros que se hubiera erradicado pero preferían no buscarse problemas. Eso fue una corriente y la otra sí fue la corriente oportunista, la corriente antidemocrática, conservadora que dijo: óiganme no hablen más de eso que ya Fidel dijo que ya eso se acabó. Entonces esa especie, porque eran como dos modos de ver problemas que terminaron por acercarse tanto que convergieron en un mismo punto o sea, los entusiastas con sus alabanzas a lo que se había logrado, los silenciosos con su complicidad y su falta de combatividad, y los que no le convenían que las personas negras y mestizas siguieran luchando por sus derechos fueron confluyendo hasta llegar a una situación que se convirtió casi en una mala conducta hablar de ese asunto. (Entrevista com Zuleica Romay, realizada em I8/08/20I4).

Uma complexa trama envolve esse silenciamento. Ao não explicitar esse enfrentamento, não se debater sobre esse tema, ao não se abordar o assunto, sua reprodução silenciosa se mantém. Portanto, como mazela subjetivamente presente, o racismo passou a ser comunicado de formas indiretas, não explícitas, denominado por Prieto et al. (2006) como racismo de "pero":

Las manifestaciones racistas que pervivieron se vieron en la necesidad de replegarse, adoptando cada vez más la forma de un racismo de "pero". Se trata de la expresión de formas de racismo escondidas en un discurso de igualdad que se apropia de los espacios de poder. Es, por tanto, un racismo replegado que asume este discurso, pero lo condiciona. Generalmente, las personas que adoptan esta actitud, comienzan diciendo, “yo no soy racista, pero...”. De ahí la denominación que hacemos de él. (Prieto et al., 2006: 46).

Analisando a abordagem feita sobre a questão racial em Cuba (DOMINGUEZ, 2012; PRIETO et al. 2006; CASTILHO et al. 20I I), a reflexão que surge refere-se à extrema complexidade de se conceber soluções simplistas para a resolução da questão. Há a concepção, para muitos dos estudiosos do tema, que nesse período de silenciamento o racismo passou a ser comunicado, sobretudo, nas relações interpessoais, familiares, nos ambientes privados da sociedade:

[...] una reducción simplista de un proceso mucho más complejo y multilateral, que cayó profundamente en el mundo espiritual y la cultura de las grandes masas. El efecto más evidente de todo este acontecer es el repliegue experimentado por el racismo hacia las esferas más íntimas de la vida familiar y las relaciones interpersonales, en las que los prejuicios eran reconocidos con cierta culpa, como nota discordante. Pervivía en chistes y fraseologías de uso en la complicidad de la familia y el grupo de amigos cercanos, o quedaba oculto em determinadas formas de paternalismo (PRIETO et al., 2006: 47). 
Todavia, acredito que como fenômeno, o racismo estava, e ainda está, presente de forma estrutural na sociedade cubana, com reflexos nas suas instituições, economia, espaços de poder, instâncias educacionais, familiares, de convivência social. Reduzir sua presença apenas às dimensões privada ou relações interpessoais distorce esse fenômeno, que bebe em fontes mais amplas. A criação de uma espécie de ação afirmativa, nos anos 1980, para cargos no Partido Comunista de Cuba, para garantir vagas e representação de mulheres, negros, jovens (ROBAINA, 2004), demonstra a importância, por um lado, de reconhecer que esse é um problema amplo da sociedade cubana, e que, por outro, medidas diretamente pensadas para sua superação precisam ser criadas e fomentadas.

Nessa conjuntura, de não explicitação do racismo e de sua efetivação em dimensões sociais, o fenômeno passou a ter menos visibilidade e deixou de estar incluído na pauta do Estado cubano por décadas, tanto em sua formulação de políticas públicas, como em suas ações de sensibilização. Até a atualidade, não existe um programa de combate ao racismo, apenas ações pontuais e incipientes.

Isso se reflete, inclusive, na academia. Na produção bibliográfica é possível observar que, após os primeiros anos da Revolução de I959, o tema das relações raciais esteve quase ausente. Outro aspecto que demonstra a invisibilidade sobre a temática é a dificuldade de dados estatísticos que mensurem a população negra no país e sua situação socioeconômica. Sabe-se o quanto, no caso brasileiro, foi importante avançar na qualificação dos dados nesse campo para se lograr alguns avanços com relação a políticas públicas para a população negra no país ${ }^{207}$.

Já nos primeiros anos da Revolução, diversos foram os que questionaram o racismo arraigado na sociedade cubana e a postura silenciosa da Revolução frente ao tema. Muitos destes foram deixando o país e passaram a ser considerados como dissidentes ou contra-revolucionários. Sem entrar no mérito das posições políticas de cada um, um fato chama a atenção: o controle sobre o discurso, que visa invalidar o queixume pela classificação de seus oradores como apoiadores do inimigo. E com o passar dos anos, se avalia que esse silêncio causou dano ao amadurecimento dessa temática.

Nesse sentido, é possível perceber que Cuba convive com realidades antagônicas. Por um lado, a presença negra em postos de trabalho qualificados, universidades e mesmo na hierarquia média do

${ }^{207}$ No início dos anos 2000, os dados estatísticos do Censo Demográfico do IBGE de 2000, com informações mais qualificadas do quesito raça/cor, e suas análises por diversos estudiosos, dentre os quais cabe destacar as análises elaboradas pelo IPEA (Instituto de Pesquisa Econômica Aplicada), reverteram o panorama sobre as relações raciais no Brasil. 
poder legislativo é visivelmente superior ao que vivenciamos no Brasil, por exemplo. Por outro, piadas racistas estão presentes em shows, teatros e espetáculos públicos. O número inspirado no teatro Bufo de blackface que presenciei no Festival Internacional de Circo, em Havana, é um número comum nos teatros cubanos. A abordagem da polícia privilegia os negros, reforçando o estereótipo da periculosidade. Paladares e espaços turísticos, de forma explícita ou não, reproduzem valores racistas na hora de contratar a mão-de-obra.

Prieto et al. (2006) acreditam que grande parte da lógica desse processo de invisibilidade da temática nas últimas décadas estava ancorada na crença generalizada de que com as medidas de igualdade social desenvolvidas a partir da Revolução, com grande ênfase para a educação de qualidade, o racismo seria completamente proscrito. Além disso, o tema desapareceu do debate público como resultado de um conjunto de razões, entre as quais três tiveram uma influência decisiva.

Primeiramente, diante de um panorama social no qual as desigualdades eram reduzidas, e dependiam fundamentalmente do esforço e da qualificação, se chegou a conceber o racismo como um problema resolvido. Essa interpretação, após o denominado Segundo Chamado de Fidel sobre a questão racial, acabou contribuindo para o que Zuleica Romay chama de "particularidade de Cuba" frente ao tabu ainda existente para tratar do tema e suas relações com as políticas implementadas pela Revolução:

\footnotetext{
Porque fijate en el contexto de América Latina: es muy común que todo el mundo diga que resolvieron el problema. Es muy común porque lo que ninguna sociedad admite es declarar un principio en la teoría, ponerlo en la Constitución y después violarlo en la práctica. Nadie admite que eso está ocurriendo, nadie admite que hay un discurso social que dice una cosa y una práctica social que dice otra. Entonces la gente disimula para no darse cuenta que el discurso social y la práctica social no coinciden. ¿La particularidad de Cuba cuál es? En el caso de Cuba, como ha habido una Revolución, como ha habido un avance real de los negros y mestizos, como ha habido una emancipación parcial de la sociedad con relación a los prejuicios de racismo, resulta todavía más difícil desmentir el discurso porque hay una realidad que parcialmente apoya el discurso y entonces la particularidad de Cuba es que desmentir el discurso se hace más difícil. (Entrevista com Zuleica Romay, realizada em 18/08/2014).
}

Cabe destacar que a abordagem do tema racial no período da Revolução não é monolítica. Zurbano discorre sobre a diferenciação de tratamento do tema nos anos 1960, 1970 e 1980, a partir de suas experiências particulares. No princípio da Revolução, Zurbano enfatiza o momento de euforia, de celebração do dito terceiro mundo, no qual referências afro influíram na literatura, teatro, política e outras esferas da vida social:

En los medios de comunicación había una presencia de negros que yo recuerde. Recuerdo por ejemplo algo que no he visto en los últimos 20 años, que en mi niñez y mi adolescencia había muchas aventuras para niños donde aparecían una cantidad de actores negros que están vivos hoy en Cuba, algunos en Cuba y algunos fuera de Cuba, pero ya no los ve en la televisión. Al único que ves es AldenNight, Elvira 
Cervera Gladys Zurbano, que es pariente mía también, Idelfonso Tamayo, Julián Hernández. Había una cantidad de actores negros que tú disfrutabas. Mario Limonta y AldenNight hacían los mambises, que era una aventura que había, Obelia Blanco, había muchos actores negros, incluso muchas actrices negras hacían papeles importantes, que podían ser papeles que podían pasar como papeles que tradicionalmente hubieran hecho actrices blancas, por ejemplo La Casa de Bernarda Alba, esa gran obra de teatro de Federico García Lorca, la Bernarda Alba lo hacia una gran actriz negra que se llamo Hilda Oates. Yo creo que eso tenía que ver con que hubo un cambio. Nace el Conjunto folclórico nacional, Danza contemporánea, o sea los negros tienen un protagonismo en la cultura cubana que no habían tenido antes. (Entrevista realizada com Roberto Zurbano, em I5/I0/2014).

Esse momento de grande diversidade na mídia, do qual Zurbano se refere, não reflete os dias atuais, conforme as narrativas e dados apontam. São poucas as produções que incorporam não apenas o tema, mas inclusive protagonistas negros. Os meios de comunicação, televisão, rádio e jornais impressos, que eu acompanhei no período do campo, de forma muito esporádica abordava o tema. Às vezes, inclusive, a informação passada era contraditória e acabava por reforçar os mesmos estigmas que, em teoria, o programa tinha como objetivo combater ${ }^{208}$. Irene Izquierdo, jornalista e ativista do tema racial na mídia, relata, a partir da experiência como profissional da área, como a questão é muitas vezes tratada:

Acerca de si forma parte o no de las agendas mediáticas, voy a poner de ejemplo la experiencia de un colega cercano a mí desde el punto de vista laboral. Se acercó a uno de los decisores en cuento a la confección de ábaco editorial, para solicitarle un espacio y tratar el tema (racial). El "superior" le respondió que para los de "arriba" ese no era tema de importancia. Y, sin negar que puede interesar y hasta preocupar, no es primordial desde el punto de vista noticioso. Por ese resulta contradictorio, el Partido Comunista de Cuba -responsabilizado con trazar, dirigir y controlar la política informativa de los medios de comunicación- valore: “[...] hace daño a la labor ideológica que desarrollamos la existencia de vacíos, supuestos 'temas tabúes'. Está demostrado que los temas más complejos pueden ser tratados a partir de un alto sentido de responsabilidad política y profesionalidad periodística $[\ldots]$ ”. Y no haya trazado de manera explícita una estrategia encaminada a abordar todas las aristas que el tema puede propiciar. (IZQUIERDO, 20I5).

Irene Esther Ruiz, ao abordar a ausência de personagens negros nas novelas cubanas em papéis protagônicos e sua sobrerrepresentação em papéis estigmatizados, fala do momento atual e dos antecedentes da produção televisiva e cinematográfica de Cuba nos anos I970 e I980:

Yo me acuerdo que en los años 1970, 1980, empezaron a criticar la representación de los negros en la pantalla. Era sólo el negro esclavo, la negra violentada, la gente en el barracón. Entonces, hay la expectativa de que en medio de un proceso revolucionario se va representar al negro con los valores que esos negros aportaron a nuestra cultura y sociedad. Pero, eso no es así. Hay un rechazo a eso de tener en todas las películas siempre el negro en esa posición discriminada. Tú tienes que enorgullecerte de lo que tú eres, tú tienes que sentir que lo que tú eres es un aporte a esta sociedad. Estas cosas han contribuido a que en los medios de comunicación este tema todavía no se ha resuelto. Hoy, lo que esta mas reciente en la pantalla es la telenovela cubana. Me han dicho que hay muchas personas mestizas, pero un mestizaje muy lavadito. La historia es que esa autora, la conozco y conozco su lucha, como guionista, escritora de telenovelas, es una mujer mestiza, siempre defendió la presencia de los negros y en sus telenovelas ponía personajes negros. Pero, eso fue muy rechazado en la televisión y eso le impidió que ella pudiera estar con su obra más presente en los dramatizados. A la hora de hacer el casting, los directores le blanqueaban el personaje negro. Me contaron que esta ultima que está en pantalla (en julio de 20I5), hay algunos

${ }^{208}$ Ver exemplo da mesa redonda sobre o dia da discriminação racial, realizado em 2I de março de 20I5, cujo detalhamento fiz na seção sobre Mestiçagem e Nação, na parte anterior dessa tese. 
personajes ahí que no eran mestizos sino que eran negros. O sea, todavía se mantiene el problema, este problema en la televisión. (Entrevista com Irene Ester Ruiz, realizada em 01/07/2015).

Retomando a reflexão sobre a produção diversa nos primeiros anos da Revolução, o período de celebração terceiro mundista dos primeiros anos da Revolução, que Zurbano se refere, deu, também, visibilidade a líderes africanos em edifícios públicos, fato que casava com um processo de aproximação de Cuba das lutas por independência em muitos países africanos:

Pero, además había un grupo de instituciones cubanas que tenían nombres de líderes africanos: Amilcar Cabral, el Patricio Lumumba se iba a bailar un fin de semana al Patricio Lumumba que hoy es la Casa Central de las FAR, el politécnico Amilcar Cabral. Se hablaba de figuras importantes africanas de las que no se hablan, aunque muchas escuelas tuvieron esos nombres, muchos círculos e instituciones cubanas que tuvieron esos nombres que tú podías decir quiénes eran esas personas y te enterabas de quien era esa persona, eso ha venido desapareciendo con el tiempo. Yo creo que hubo una celebración de esa diversidad y esa celebración del tercer mundo, esa identidad que había ganado esa independencia que se había ganado a partir de 1956 en Ghana, se hablaba de eso [...] En Cuba se publico la colección de la literatura africana más importante que yo he visto en español de los años 1960: del 1963 y 1964. En el 1965 apareció Chinua Achebe, "Las cosas se deshacen", ese de la colección Cocuyo. Ahí aparecían los libros de "Shaka El gran Zulu", con prologo de Juan Francisco del Medio, ahí apareció "El bebedor del vino de palma", de Amos Tutuola. Te estoy hablando del hombre que se hace famoso 30 años después en Estados Unidos, que traduce los mismos libros que se había traducidos en Cuba por primera vez. Traducidos por importantes firmas: Rogelio Martínez Fure, Virgilio Piñera editado por Ambrosio Fornés. O sea, la literatura forma parte de la literatura universal de la celebración de una internacionalización del espacio político que gana la Revolución cubana. Se conoce el mundo de los argelinos, se publica la literatura de Franz Fanon que es el Che quien quiere publicarla en Cuba, "Los condenados de la tierra" y "Piel negra máscaras blancas", se publican a principio de los 1960 en Cuba. Te estoy diciendo lo que después serian premios Nobel. Hay una celebración. Lo que eso no entro suficientemente, lo que eso no fue suficientemente debatido y disfrutado por la propia gente que tenía que enseñar y pensar y entonces yo creo que hay un déficit que yo lo siento. (Entrevista com Zurbano, realizada em I5/I0/20I4).

É fascinante perceber a miríade de vozes que soava em Cuba diferentes perspectivas ${ }^{209}$. Franz Fanon, nesse período ainda desconhecido, já era lido no país. Nessses primeiros anos, os dados indicam que houve um ambiente de construção de novas perspectivas para as sociedades e países historicamente explorados pela lógica capitalista, marcados pelo colonialismo e pelo racismo.

Outra forte influência nos anos 1960 com relação à questão racial e o debate sobre o tema foi o movimento pelos direitos civis nos EUA e os diálogos estabelecidos entre muitos desses ativistas e lideranças revolucionárias, inclusive o próprio Fidel Castro. Especialmente o movimento dos

\footnotetext{
209 Destaco outras produções dos primeiros anos da Revolução, como as de José Luciano Franco, sobre ícones afrocubanos: "Antonio Maceo: apuntes para una historia de su vida y Afroamérica", de I961, "La Conspiración de Aponte", de 1963, e "Plácido", de 1964. Pedro Deschamps Chapeaux, que, dentre outros trabalhos, publicou "E1 negro en el periodismo cubano del siglo XIX", de I963, "La protesta de los negros lucumíes", de I966209. EmI959, Sixto Gastón Agüero publica "Racismo y mestizaje en Cuba" e Ramón Cabrera Torres, lança "Hacia la rehabilitación económica del cubano negro". Do poeta Nicolás Guillén, são feitas as publicações, de I966, Nación y mestizaje" e "Racismo y Revolución". Waltério Carbonel escreveu uma obra fundamental sobre a questão racial na época: "Como surgió la cultura nacional", de 196I. Juan René Betancourt, cujo texto "El negro ciudadano del futuro", foi publicado em 1959. Betancourt também foi autor de outras publicações anteriores à Revolução, como "Doctrina Negra: la única teoría certera contra la discriminación racial en Cuba", de 1955, "Mi opinión y mi raza", de 1948, e "Prejuicio: ensayo polémico", de 1945.
} 
Panteras Negras teve muita relação com o país. Estiveram presentes em atividades públicas e muitos de seus textos foram publicados aqui. Mas, a abordagem do tema era conduzida como um problema dos Estados Unidos, não de Cuba. As possibilidades de trocas e contatos dessas lideranças com negros em Cuba também foram restritas e controladas, como destaca Zurbano:

Imagínate tú que en los 1960 vinieron a Cuba muchos miembros de Las Panteras Negras. Estuvo Sotkely Carmichael, que hizo un discurso grandísimo en la conferencia de OLAS en La Habana en el 1967. Superaplaudido ese discurso. [...] Pasaban por aquí la gente del Black Power. Esta publicado el pensamiento crítico, entrevistas con ellos, textos de ellos. Paso James (Cyril Lionel Robert James) el autor de Los jacobinos negros hablando del poder negro también. Toda esa celebración sucedió en los 1960 y toda esa represión también sucedió en los 1960. ¿Qué pasó con la presencia del Black Power en Cuba, Las Panteras Negras en Cuba? No se le permitía hablar con los negros cubanos y los negros cubanos que fueran hablar con ellos eran castigados, llamados por la Seguridad del Estado: "Ustedes son cubanos ustedes no son como estos negros". Había una visión, la Revolución cubana tenía una visión de ellos como radicales, demasiado radicales, extremistas. [...] No hubo una conversación sobre eso, no hubo debate, no hubo discusión sobre eso. Eso se guardo. (Entrevista com Roberto Zurbano, realizada em I5/I0/20I4).

Essa restrição ao debate se amplifica nos anos 1970, período marcado pela "sovietização" da sociedade cubana, quando as influências políticas e sociais advindas da União Soviética foram internalizadas e houve um rigor extremo com relação à diversidade ${ }^{210}$. $O$ termo que acabou caracterizando esse período, quinquenio griz, foi concebido por Ambrósio Fornet, que o criou "por razões metodológicas, tentando separar e descrever esse período por sua característica dominante ${ }^{211}$ ", e como foi também ressaltado por Zurbano, "separar e contrastar esse período da etapa anterior, caracterizada pelo seu colorido e dinâmica interna, ainda que não isenta de frustrações e sobressaltos"212 (FORNET, 2006: 03).

O auge desse processo, conhecido como quinquenio cinza ou gris em espanhol, nos primeiros anos da década de 1970, marcou enormemente as histórias de vida dos ativistas aqui entrevistados. Um dos pontos relevantes é que foi um período de crescimento do silenciamento sobre a questão racial e sobre o legado africano.

En los años 1970, está entrando la sovietización en Cuba, se va sovietizando el país y de eso (racialidad y africanidad) no se quiere hablar. Fue una cosa muy dura, muy fuerte aquí, esas cosas no se podían decir y eso como venía de África sonaba africanidad. Pues ya africanidad sonaba mal, no tenía mucho que ver sentirse parte de esa africanidad parte de esa africanía era un poco relegada, aquello que fue tan celebrado en el 1959, en el 1960, ya en los 1970 no era así. La sovietización fue una cosa que trato de marcanizar la cultura cubana, trato de pasar por el eje egocéntrico de toda la sociedad cubana, no solamente en el mundo de la economía y el mundo militar sino también en el mundo de la cultura, el mundo de la mentalidad social, también de cómo te vestía, con qué bailabas, que filmes tu preferías, que películas veías en la televisión. El quinquenio gris sí tiene que ver con el triunfo de todos esos dogmas y sobre todo con

${ }^{210}$ Reflexões feitas sobre as identidades étnicas e a construção do nacionalismo na União Soviética contribuiem para o debate sobre essas dinâmicas em Cuba. Para mais referências, ver KHAZANOV (I995).

2II Além de haver uma padronização da produção artística, intelectual e cultural, houve um acirramento do controle sobre essas. Nesse período surgiram, por exemplo, as Unidades Militares de Ajuda à Produção (UMAP), que gerou grandes danos à produção da época (FORNET, 2006: 08).

212 Tradução minha. 
los dogmas en el campo ideológico pero también tiene que ver con el campo de la religiosidad, el campo de la sexualidad, en el campo de la racialidad, en el campo de todas las subjetividades sociales. Porque quería homogeneizar al país, que el país pensara de una sola manera. Ser religioso era muy difícil, te estoy contando lo que le paso a Compadrito que era un hijo de Chango pero puedo contarte lo que le pasaba a una compañerita mía, testigos de Jehová no se ponían pañoletas ni cantaban el himno Nacional. Era una compañerita mía, su hermano estaba en un grado mayor y el otro hermano en un grado menor y la maltrataban tanto en la escuela, la maestra y los estudiantes también, que eso es una cosa impresionante, algo impresionante, solo porque era testigo de Jehová. Pero, hay un contexto, en el contexto de los 1970 es muy pernicioso y muy poco propicio para entender la diversidad para entender las subjetividades del país para entender las identidades también. No se hablaba de identidad, somos cubanos y ya, todos somos cubanos revolucionarios. La identidad que había era una identidad política y nacionalista, ni siquiera nacional sino nacionalista, cubano de una manera así chovinista y revolucionario de una manera que te dejaba sin opciones. No había opciones, no podías ser medio revolucionario, ni revolucionario y medio, sino revolucionario. No había opción entonces era un forcet, era algo que en los 1970 el dogma reventó esa condición revolucionaria esa condición cubana. Porque nos hizo deseosos de otras subjetividades, de saber qué pasaba afuera, saber cómo era otra cosa, saber cómo era lo otro, de saber qué puede suceder si yo tengo dinero si tengo ropa, si tengo posibilidad de viajar, en fin yo creo que se empezaron a crear muchos deseos creados por esa reflexión por esos dogmas. (Entrevista com Roberto Zurbano, realizada em I5/I0/20I4).

Após esse acirramento com relação à abordagem das relações raciais, e do legado cultural de países africanos, o discurso público passou a não mais incorporá-las. Essa dimensão ficou restrita a esfera do discurso privado, tomando como referencial o conceito de Scott (2004). Zurbano destaca como as relações raciais estavam presentes na sua relação familiar:

Dentro del dogma (de los años 1970), estaba la cosa racial. No se podía hablar, pero siempre hubo conversación de la raza en el interior de las familias, las familias blancas y las familias negras. Mi abuela no era partidaria de decirlo, pero muchos viejos amigos de mi abuela decían los negros tenemos que darnos nuestro lugar, su lugar era el lugar subalterno, ser discretos, no destacarnos demasiado, no querer estar donde están los blancos, no querer igualarnos, sino mantener tu perfil bajo. Había conversaciones en las familias blancas también. En espacios públicos se hablaba de eso, se hablaba en intimidades. Tú ibas a la casa del amiguito blanco y las resoluciones que habían allí tenía que ver con lo racial. Había amiguitos negros y amiguitos blancos que lo decían, el negrito, ustedes los negros. (Entrevista com Roberto Zurbano, realizada em I5/I0/20I4).

No diálogo com Scott (2004), é interessante abordar o que o autor denomina esfera do "discurso público" e do "discurso privado". Dentro da relação entre "subordinado" e "dominador", o discurso público do "subordinado" supõe uma forma de comportamento específico diante do "dominador", que envolve diversos elementos apontados pelos conhecidos da avó de Zurbano, tais como "los negros tenemos que darnos nuestro lugat", "ser discretos", "no destacarnos demasiado", "no querer estar donde están los blancos", "no querer igualarnos", "sino mantener tu perfil bajo". São elementos ensinados no âmbito privado para pautar a postura pública.

Scott, inclusive, descreve um ditado jamaicano, muito utilizado entre os escravizados, que dizia: "Faça-se de bobo para ganhar como inteligente" (2004: 27). Nessa "encenação social", de um lado a representação do poder realiza sua atuação de domínio e autoridade, e por outro lado, paralelamente, tenta interpretar a "máscara do subordinado" para saber o que ele realmente pensa. 
É, portanto, uma representação de papeis sociais em circunstâncias nas quais as relações de poder e hierarquização estão colocadas. Nesse caso, apesar de não haver abertamente uma abordagem sobre a questão racial, essa esteve presente nos corpos, habitus, códigos de conduta e relações estabelecidas.

A produção sobre o tema racial nesse período caiu praticamente a zero, com exceção de publicações com abordagem historiográfica de momentos anteriores à Revolução. Livros com esse enfoque foram publicados nas décadas de 1970 e 1980, como um dos clássicos sobre a monumental exploração açucareira e sobre o tráfico negreiro escrito por Manuel Moreno Fraginals "El ingenio", de $1978^{213}$.

Contudo, análises sobre relações raciais contemporâneas à época foram restringidas. Uma das exceções é a publicação de Pedro Serviat "El problema negro en Cuba y su solución definitiva”, de 1986, que trata o problema racial como solucionado pela Revolução. O livro "Procesos del etnos cubano" (1983), de Jesus Guanche, por sua vez, aborda as manifestações de tradições de matriz africana, como a Santeria, como processos em extinção. $O$ contexto no qual se deu a publicação do "El problema negto en Cuba y su solución definitiva" ajuda a compreender seus enredos:

\footnotetext{
En los 1970 no se habla de eso por ninguna parte. Aparece un libro "El problema negro en Cuba y su solución definitiva", de un autor que se llama Pedro Cervantes, negro socialista que yo conocí, amigo de mi papa, y que estaba ciego. Ya yo lo conocí cuando era un hombre viejo y ciego. Entonces es un libro de un hombre de buen corazón, de un hombre que trabajo mucho con el Partido socialista popular mucho tiempo, un hombre de dominio sindical que estudió marxismo con Blas Roca y otras personas, era un hombre marcado por la internacional socialista, marcado por esa situación medio compleja. Era un negro en medio de socialistas, desconociendo en todas sus partes el contexto global (del debate racial). (Entrevista com Roberto Zurbano, realizada em I5/I0/20I4).
}

Outro aspecto diz respeito aos receios que o tema suscitava ante a necessidade de unidade no país. De acordo com Prieto et al. (2006), desde as estruturas de poder, se percebia com desconfiança abordar a questão publicamente, o que converteu o tema em uma espécie de "tabu”. A perspectiva de "tabu" é uma constante nas narrativas dos agentes sociais entrevistados para essa pesquisa. Cito, abaixo, o relato de Deyni Terry que destaca o quanto esse tema foi, e em grande medida, ainda é um tabu no âmbito das polícias e do próprio judiciário:

\footnotetext{
${ }^{213}$ As outras obras publicadas no período, com o recorte histórico sobre a questão negra em Cuba de períodos anteriores, são José Luciano Franco lança "La presencia negra en el Nuevo Mundo", de 1968, "Esclavitud, comercio y tráfico negrero", de 1972, "Los palenques de los negros y cimartones", de 1973, "La diáspora africana en el Nuevo Mundo", de 1975, além de "Comercio clandestino de esclavos", de I980, e "Ensayos sobre el Caribe", esse de 1989. Juan Pérez de La Riva publicou obras relevantes, como "Contribución a la Historia de la gente sin historia", de I974, "El barracón y otros ensayos", de 1975 y "¿Cuántos africanos fueron traídos a Cuba?", de 1976.
} 
Nunca cuando iba a defender un asunto pude decir ante la policía aquí lo que está ocurriendo es un problema racial. Porque en Cuba esto ha sido un tabú. Pero si me daba cuenta que había una diferencia y esto me permitió con los años ir confrontando con algunos abogados que decían stop ese tema no me interesa. (Entrevista com Deyni Terry, realizada em I5/05/20I4).

Deyni Terry destaca as barreiras existentes para abordar a questão racial numa perspectiva de acesso a direitos e à justiça. Atuando como advogada, descreve a situação limítrofe vivenciada, que explicita mecanismos existentes de coerção e de controle para que a abordagem do racismo e das relações raciais não venha à superfície:

La primera vez que yo me atreví hablar de discriminación fue en un juicio, en el Tribunal Municipal de Centro Habana ante una jueza, llamada Mailin. (La jueza) me hace una corrección en sala, porque yo [... al estar defendiendo a una persona en mi área de investigación, al rendir mi informe, hablo de discriminación en el caso del expediente del encartado que yo estaba llevando y la presidenta del tribunal (la jueza) me hace una corrección y me dice que este no era el tema, o sea que yo no podía hablar de aquel tema. Yo, en aquel momento, hago alusión a que no habían áreas deportivas, que a las personas se les estaba abriendo expediente de índice peligrosidad social y la cantidad de negros y negras procesadas por un índice de peligrosidad era alarmante para los estudiosos y debió ser alarmante para el gobierno. (Entrevista com Deyni Terry, realizada em I5/05/20I4).

Nesse caso específico, para compreendermos o contexto dessa abordagem, Deyni expõe o que significa a infração caracterizada como "índice de peligrosidad", e como em seu caráter subjetivo, impacta fortemente sobre corpos estigmatizados socialmente como os jovens negros:

(Índice de Peligrosidad) es una medida pre delictiva para evitar que la persona delinca. Pero es una medida pre delictiva donde se aplica hasta cuatro años de retención en una penitenciaria. Entonces, cuando estoy defendiendo este proceso y hablo de problema racial, y hablo de que la persona que estoy defendiendo jugaba pelota en la calle porque no había área deportiva y enfoco el problema social. La presidenta de mi sala me hace una corrección, y cuando insisto [...] eso me causó una multa de 50 pesos en moneda nacional cubana. Porque, cuando le rebato a la presidenta del tribunal que era mi derecho con la representación de mi cliente, pues me aplicó una multa porque yo estaba hablando de racialidad y estaba hablando de temas sociales.

Eso pasó en el tribunal municipal de Centro Habana y ya estábamos 2006. Teniendo en cuenta que la multa es cuando se supone que el letrado (abogado) está siendo irrespetuoso con la sala y considerando que yo estaba haciendo un informe de defensa adecuado, que lo único que había dicho algo políticamente incorrecto, porque el tema racial en ese contexto era políticamente incorrecto, pues continuo mi informe tratando de poder llegar a término de la persona y que no se sintiera mal mi cliente, lo que logro hacer.

Pero, cuando me voy retirando del estrado, esta jueza Mailin Merencio dice: "por favor, a la agente que estaba en la sala, por favor detenga a la abogada en sala. Me mandan a detener, a coger presa en sala. Esto ocurrió en Cuba en el 2006. Cuando me mandan a detener en sala, yo que era la vicepresidenta de la CTC en mi bufete inmediatamente pido un teléfono y pido hablar con mi presidenta de bufete que en aquel momento era Lisette. Llamo a Lisette y le informo: Estoy siendo detenida en el Tribunal. ¿Pero que paso? Le digo a Lisette: Debe ser un mal entendido. El hilo conductor fue, yo hablé de un problema racial y hablé de un problema político defendiendo a una persona, pero sin violar nada de lo establecido, o sea, yo no he atacado al gobierno, yo estoy defendiendo a una persona. Lisette pide hablar con la presidenta de la sala y que por favor no me fueran a llevar esposada para la estación de policía, porque yo era una abogada de cargos en el sindicato, una abogada de prestigio que tenía cargos directivos municipales, y esto lo pide la presidenta.

La jueza sugiere que me quede allí sentada en el tribunal. Yo mando a buscar a mi presidente del órgano de trabajo. Comienzan a venir abogados alarmados y cuando llegó las dos de la tarde, que eventualmente a ella se le paso la ira y olvido el asunto, me dijo que me podía retirar para el bufete y no pasó nada más. (Entrevista com Deyni Terry, realizada em I5/05/2014). 
Esse depoimento expressa dificuldades encontradas para se tratar a questão e para se buscar ações efetivas que visem o combate ao racismo. A partir de um dos fortes mecanismos de controle, cabe uma reflexão sobre as relações de poder, num diálogo com Foucault (I979). O poder enquanto substância concreta, palatável e fixa não existe. O que existe são as relações de poder, heterogêneas, dispersas em diferentes esferas da vida social.

Trata-se [...] de captar o poder em suas extremidades, lá onde ele se torna capilar; captar o poder nas suas formas e instituições mais regionais e locais, principalmente no ponto em que, ultrapassando as regras de direito que o organizam e delimitam, ele se prolonga, penetra em instituições, corporifica-se em técnicas e se mune de instrumentos de intervenção material, eventualmente violentos (FOUCAULT, 1979: 82).

A situação extremada vivenciada incita algumas reflexões. Os mecanismos de controle e de poder estabelecidos pelo Estado, que são concretizados, efetivados, em instituições locais que, nas palavras de Foucault (1979), ultrapassam as regras das leis e códigos, se penetram em instituições e corporificam-se em técnicas e instrumentos de intervenção, eventualmente violentos. Nesse caso, a punição materializa-se duplamente a partir do viés das relações raciais. $O$ jovem estava detido e em processo de julgamento por se enquadrar no "Índice de Perigo Social". O julgamento pode levar ao cárcere privado por até 04 anos, apenas como "ação preventiva", para que o jovem não venha a cometer algum delito. $O$ julgamento extremamente subjetivo dos agentes de segurança pública e do sistema judiciário de quem são aqueles que apresentam índice de periculosidade ou não, dão margem para a forma aleatória com que as relações de poder se materializam na vida concreta e reforçam os estigmas.

Como destaca Deyni Terry, e diversos outros ativistas, para além do caso do jovem que ela defendia nessa situação específica, há índices alarmantes de prisões de pessoas negras, homens e mulheres, enquadrados nesse mesmo índice de periculosidade social. Isso demonstra o tamanho da abrangência da cisão racial no tocante à segurança pública. No caso de Deyni Terry, advogada do réu em questão, também negra, a abordagem do discurso sobre as relações raciais, da ordem do não dito, da ordem do tabu social, causou uma desestrutura na condução do julgamento. Apesar de não ser um aspecto explícito nos códigos legais essa proibição à menção ao racismo, a interpretação dos códigos legais foi concretizada pela subjetividade da juíza, que passa a ordenar a prisão da advogada e o pagamento da multa pela quebra das "regras" em juízo. É uma ação explicitamente coercitiva que se concretiza como uma das facetas agressivas do controle do discurso.

As vulnerabilidades transpassam uma dimensão também vinculada ao racismo institucional, ao analisarmos a abordagem da polícia e a relação com a justiça. $\mathrm{O}$ racismo institucionalizado se dá, 
por exemplo, quando a polícia trata as pessoas negras como "suspeitos preferenciais", como recorrentemente denunciado por ativistas. E nesse campo, há indícios de que as diferenças de gênero e geracionais exercem um papel decisivo. Jovens negros são mais vulneráveis às abordagens da polícia, às detenções e a condenações por infrações preventivas, como o "índice de periculosidad", que é uma medida aplicada sem que tenha havido nenhum crime propriamente dito. Constitui-se como uma ação para "evitar" o delito, e que pode acarretar até quatro anos de prisão em regime fechado. São aspectos presentes nas vivências de muitos ativistas:

\begin{abstract}
Yo voy a buscar (un amigo) al Hotel Presidente el fin de año para que pase con mi familia el fin de año y alguien no me deja entrar al Hotel Presidente. Cuando aquello los cubanos no podían entrar a los hoteles, no podían entrar a las habitaciones pero llegaban hasta el lobby, a buscar a alguien etcétera. Y yo vi dos personas cubanas, blancas por cierto, subir al elevador, irse con algunos huéspedes y subir a su habitación. Yo estaba sentado ahí y llamo: Chávez estoy aquí. El se estaba bañando: Enseguida bajo. Yo contesté: Yo te espero. Y querían que yo me fuera de allí. Primero, no querían dejarme entrar. Después, que no me sentara allí. Después que saliera y lo esperara afuera. Ese hotel está en mi país y empezamos una gran discusión con la seguridad del hotel. Después me trajeron a la policía. Después bajo mi amigo y se dio cuenta de lo que estaba pasando, sin necesidad del idioma, porque la gente se da cuenta fácilmente. Bueno la gente de fuera. La gente de aquí nunca se quiere dar cuenta. No es que no lo saben, porque hemos aprendido a mirar así y no queremos meternos en eso. Es lo que ocurre en Cuba, la gente si sabe lo que está ocurriendo pero no se quiere meter, no quiere ser partícipe. (Entrevista com Roberto Zurbano, realizada em I5/10/2014).
\end{abstract}

Cabe destacar que as relações estabelecidas entre a polícia e a sociedade são empiricamente diferentes da que vivenciamos no Brasi ${ }^{214}$. Por diversas vezes em meu tempo de estada em Cuba, pude observar policiais conversando com transeuntes de forma descontraída. Outras vezes também fui abordada e a forma de interação se deu a partir de alguns parâmetros de comportamento mínimos. O risco de que haja violência física, por exemplo, por parte da polícia, em uma abordagem corriqueira, é pequeno. As taxas de homicídios efetuados pelo Estado também são muito baixas, assim como na sociedade cubana em geral. Esses são pressupostos importantes para analisarmos a situação de violência e racismo institucional praticados pela polícia cubana. Essa ressalva, contudo, não reduz o peso que o racismo tem dentro da instituição e em como desde as abordagens policiais na rua até a própria limitação do acesso a justiça para casos de discriminação, há uma reafirmação cotidiana dos estereótipos racistas na sociedade, e de seus respectivos interditos.

\footnotetext{
${ }^{214}$ O Brasil é o país que mais mata no mundo, cujas vítimas são majoritariamente jovens negros. Entre os anos 2002 e 2012, a tendência nos homicídios, segundo raça/cor, indicou que os homicídios brancos diminuiram $24,8 \%$ e houve aumento dos homicídios negros de 38,7\%. Tomando em consideração as respectivas populações, as taxas brancas caem $24,4 \%$ enquanto as negras aumentam 7,8\%. Entre os jovens, o número de vítimas brancas cai 32,3\% e o número de vítimas jovens negras aumenta $32,4 \%$. As taxas brancas caem $28,6 \%$ enquanto as negras aumentam 6,5\%. Com isso, o índice de vitimização negra total passa de 79,9\% em 2002 (morrem proporcionalmente 79,9\% mais jovens negros que brancos) para I68,6\% em 20I2, o que representa um aumento de I I I\% na vitimização de jovens negros. Fonte: Mapa da Violência, 2012, e o sítio web da Anistia Internacional: anistia.org.br/campanhas/jovemnegrovivo (acesso em I8/08/20I5).
} 
Essa relação com a polícia e a justiça é também reflexo de um silenciamento para o debate e da falta de medidas legais que criminalizem práticas racistas. Houve, historicamente, dificuldade em se efetivar o debate sobre a questão racial de forma pública e aberta. Esse aspecto é abordado por Prieto et al. (2006) e Dominguez (2012). Com influência da invisibilidade da questão racial, foi gerado certo consenso sobre o que Prieto et al. (2006) denominam "a enorme inconveniência de suscitar essa problemática e trazer a tona essa questão”.

Esses fatores contribuíram para o ocultamento do racismo enquanto fato público, mas também para sua manutenção nas várias instâncias da sociedade, inclusive na própria estrutura estatal. Prieto et al. (2006) relatam que apenas no Terceiro Congresso do Partido Comunista de Cuba, em 1985, a questão saiu de sua mordaça e foi debatida publicamente. Os dados da pesquisa censitária de 1980 revelavam a grande desproporção de negros, mulheres e jovens em postos de direção no país. Houve, o que o autor chama, de políticas de ação afirmativa para diminuir a disparidade nesses espaços.

Apesar de não representar mudanças na alta estrutura de poder, um dos grupos beneficiados por essas "ações afirmativas" foi das mulheres negras, segmento cujos impactos do racismo e do sexismo se apresentam de forma complementária. Sobre essas mulheres, a violência do racismo seria acrescida do que Castillo (2010) denomina "a invisibilidade das mulheres". As mulheres negras seriam um lócus em que as discriminações são sobrepostas. $\mathrm{O}$ debate sobre a discriminação racial e de gênero até a atualidade tem pouca visibilidade, inclusive dentro do âmbito dos coletivos antirracistas e, mais ainda, na forma como o Estado dialoga e implementa ações para esse segmento.

Na próxima seção desse capítulo, avanço no debate sobre os marcos legais e sua aplicabilidade, no que se refere à discriminação racial e o racismo. $\mathrm{Na}$ sequência, analiso questões referentes à representação simbólica e representação equânime, com ênfase para a forma como está disposta a alta hierarquia do poder político em Cuba. Pesquisas censitárias e as formas de representação da sociedade cubana são o tema da terceira seção. Por fim, a última seção traz reflexões sobre diversos aspectos apresentados na tese, e nesse capítulo em especial, em estreito diálogo com teorias sobre racismo estrutural.

\section{I. Antirracismo e a Lei}


O acesso à justiça e a criminalização do racismo são pontos para refletir sobre a ambiguidade das relações raciais em Cuba. Há códigos legais nacionais que criminalizam o racismo. Eles estão presentes na Constituição de I976, nos artigos 4I, 42 e 43. Destaco aqui, o direito à igualdade, a proibição de práticas discriminatórias por motivo de raça, sexo, origem nacional, crenças religiosas, e a proibição de espaços restritos por motivos vinculados à discriminação. Essa criminalização também está presente no Código Penal, no artigo 295. Para sua melhor efetividade, falta, contudo, a regulamentação de sua aplicabilidade.

Cuba é signatária de Convenções internacionais importantes de combate ao racismo. Destaco aqui a Convenção sobre a Eliminação de todas as formas de Discriminação Racial, de I965, das Nações Unidas, assinada em 1969 e ratificada em 1972. Em seu artigo $I^{\circ}$ expressa que a discriminação racial é:

Qualquer distinção, exclusão, restrição ou preferência baseada em raça, cor, descendência ou origem nacional ou étnica, que tenha o propósito ou o efeito de anular ou prejudicar o reconhecimento, gozo ou exercício em pé de igualdade dos direitos humanos e liberdades fundamentais (Convenção sobre a Eliminação de todas as formas de Discriminação Racial, I965, ONU, Artigo Iº).

Cuba também é signatária da Declaração e Plano de Ação da Conferência Mundial contra o racismo, a discriminação racial, a xenofobia e a intolerância associada, que aconteceu em Durban, África do Sul, em 200I. Dentre vários aspectos relevantes, o documento declara que "todos os seres humanos nascem livres e iguais em dignidade e direitos e têm o potencial de contribuir construtivamente para o desenvolvimento e bem-estar de suas sociedades. Qualquer doutrina de superioridade racial é cientificamente falsa, moralmente condenável, socialmente injusta e perigosa, e deve ser rejeitada juntamente com as teorias que tentam determinar a existência de raças humanas distintas (Declaração e Plano de Ação de Durban, 200I, Artigo $7^{\circ}$ ).

Apesar da existência de amplo marco legal que objetiva o combate ao racismo, são poucas as vítimas que chegam a ingressar uma ação judicial contra algum ato discriminatório, dada a força do mito da igualdade racial no país e as dificuldades de acesso à justiça para essa pauta. Além de não haver uma adequada regulamentação da legislação existente, falta preparo e sensibilização do pessoal que atua na polícia, na fiscalía (que equivaleria ao ministério público brasileiro) e nas equipes dos tribunais, além dos próprios juízes.

$\mathrm{Na}$ pesquisa de campo, não consegui informação de nenhum caso de racismo que tenha chegado à justiça e tenha sido julgado como procedente. Portanto, no que se refere ao acolhimento dessas vítimas, minhas conclusões indicam que há um vazio no trato com o Estado. Zuleica Romay 
destaca a necessidade de regulamentação e de incorporar nos cotidianos institucionais e sociais o debate sobre a questão racial:

No hay un ordenamiento legal que deje las cosas claras. Bueno, si tú puedes poner en la Constitución que no se puede discriminar a la gente, correcto. Y cuando a mi me discriminen, qué hago, a donde voy, ¿cuales son los recursos legales? No hay, entonces son preceptos constitucionales que nunca se implementaron en leyes. Entonces hoy, además de no estar entrenados, los ciudadanos están desprotegidos. Cuando yo digo desprotegidos, hablo en un sentido específico. Si en Brasil, [...] a pesar de existir esta maravilla (la ley que criminaliza el racismo), a veces los abogados le aconsejan a la gente: No pero no demandes por un delito de discriminación, demanda por ofensa, demanda por injuria, porque es más fácil ganar un caso de ofensa que un caso de discriminación. Aquí no hay ni siquiera ley. Entonces, cuando a mí me griten negra mona y yo quiera poner una demanda, qué es lo que hacemos, ya uno no sabe y posiblemente si tú haces la demanda a una unidad de policía o a un tribunal la gente se ría de ti: ¡Ay hijo pero no cojas lucha! (Entrevista com Zuleica Romay, realizada em I8/08/20I4).

As ocorrências e denúncias aparecem com frequência, especialmente nos espaços vinculados à economia emergente dolarizada. Nos setores ligados ao turismo, restaurantes, hotéis, paladares e hospedarias em casas particulares, muitas vezes um dos critérios colocados para a contratação é exatamente a cor. Essa é uma regra em geral não explícita. Todavia, mesmo nos casos onde explicitamente isso foi colocado como condição para a contratação, as possibilidades de condenação do responsável pelo ato são pequenas. Descrevo, a seguir, o anúncio do paladar, publicado em um dos principais veículos de divulgação de restaurantes e casas de shows em Havana em maio de 20I4:

"As candidatas ao posto devem cumprir os seguintes requisitos: Mulher, entre 20 e 30 anos de idade, de pele branca, bom corpo e figura, boa aparência e educação. Título de gastronomia de alguma escola e conhecimentos de idioma não são critérios obrigatórios, mas desejáveis. [...] Salário entre 50 e 70 CUC (ou dólares) semanais" (Boletin AlaMesa n² 20/20I4, de 23 de maio de 20I4, Havana, Cuba). ${ }^{215}$.

Apesar de se caracterizar como um nítido caso de racismo e sexismo vinculado ao mercado de trabalho, a percepção sobre esse tipo de fenômeno social é bastante variada, mesmo entre os sujeitos diretamente vinculados às mobilizações antirracistas no país. Ressalto que esses casos vêm crescendo nos últimos tempos com as medidas de abertura econômica. As denúncias com relação a esse anúncio especificamente foram circuladas em meio digital por diversos coletivos, agregadas com manifestações de repúdio. O blog Negra Cubana Tenía que Ser enviou mensagem digital a

\footnotetext{
${ }^{215}$ Destaque meu. Texto original completo: "Las candidatas al puesto deben cumplir los siguientes requisitos: Mujer entre 20 y 30 años de edad, de piel blanca, buen cuerpo y figura, buena apariencia y educación. Título de gastronómica de alguna escuela y conocimientos de idioma, no son requisitos obligatorios, pero sí deseables. Tener al menos entre 3 a 5 años de experiencia en la actividad lo mismo en el sector estatal o particular. Vivir preferiblemente en las cercanías del Cupet de Calle 10 y Vento (Altahabana, Sevillano, Boyeros, Santiago de Las vegas, Aldabó, Mulgoba, Capdevila, Rpto. Martí, Casino Deportivo, Fontanar, Víbora y Santos Suárez). Tener listo Currículo Vitae para la entrevista preliminar. Datos del puesto de trabajo: HORARIO: turnos de 8 am a 4 pm y de 4 pm a I2 am, en semanas alternas y dos días de descanso en cada semana. SALARIO: entre 50 y 70 cuc a la semana. Las interesadas llamar a Yamilé en el teléfono de referencia" (Boletin AlaMesa n 20/20I4, de 23 de maio de 20I4, Havana, Cuba).
} 
diversos coletivos e ativistas com o anúncio supracitado e a seguinte indagação: $O$ que fazemos com esse anúncio racista e sexista216?

Entretanto, alguns vinculam o fato a um direito individual de escolha, não atribuindo ao Estado nenhum papel na regulamentação de leis ou ações para coibir essas práticas. É o que destaca, por exemplo, o presidente da Comissão Aponte, vinculada à União dos Escritores e Artistas de Cuba, UNEAC:

Ahora ese ejemplo que tu acabas de poner (del anuncio del paladar) no se puede resolver por decreto, tú no puedes hacer un decreto prohibiendo que pongan ese cartelito, no, porque está el derecho individual de contratar a quien le dé la gana, lo que hay es que buscar las causas que generan que ese negro o esa negra tenga que ir a ese paladar. (Entrevista com Heriberto Feraudy Espino, realizada em 17/06/20I4).

Essas duas visões sobre esse fato específico demonstram a necessidade de se avançar em aspectos ainda elementares, como haver uma estrutura institucional e jurídica que assegure caminhos para a mediação de situações de conflito e de discriminação como a explicitada nesse anúncio de paladar. O anúncio revela, ainda, outra faceta que é o sexismo e a objetificação das mulheres e de seus corpos, como mais uma referencia mercadológica para esse comércio emergente.

Tato Quiñones, na atividade realizada em Matanzas, no dia I2 de abril de 20I5, fez um relato que coloca esse debate em evidência na parceria com companhias hoteleiras para ampliar a atividade turística em Cuba. Em um dos primeiros acordos firmados, em meados dos anos 1990 , com o hotel Havana Libre, em Vedado, Havana, uma das exigências da empresa Trip, espanhola, era que os funcionários que lidariam diretamente com os turistas fossem brancos. Naquela transição de um modelo exclusivamente estatal para um modelo público em parceria com o privado, houve um significativo recuo no que concerne à garantia de trabalho para pessoas negras.

Os últimos anos vêm imprimindo uma transição econômica e um acirramento das desigualdades raciais, conforme narrativas de agentes sociais entrevistados:

En el turismo, en todas las áreas, la ausencia, más que la ausencia, la presencia de un racismo sublimado no reconocido, la batalla institucional será más larga. (Entrevista com Tomás Fernandez Robaina, realizada em $12 / 05 / 2014)$.

Eso se expresó claramente cuando empezó a entrar en el país la economía de mercado, el turismo etc. Y que se vio que no eran los negros los que más estaban representados en esa economía, se vio que no eran los negros los que tenían las posiciones más protagónicas en esa economía. (Entrevista com Esteban Morales, realizada em I4/05/20I4).

Os salários mensais dos empregados estatais têm uma relativa variação, a depender da carreira. Pode ser de cerca de 200 pesos de moeda nacional, o que significa aproximadamente US\$ 8,33

${ }^{216}$ Tradução minha. 
dólares, a 3.000 pesos - que é o salário dos médicos, que equivale a US\$ I25 dólares. Os salários pagos pela economia emergente, na maioria dos casos, são maiores que o salário mais alto dos funcionários públicos. Podemos pegar como exemplo o anúncio de contratação para o paladar que citei acima. Numa comparação do salário da potencial iniciante com o salário de um professor universitário, de aproximadamente 750 pesos de moeda nacional, este representaria pouco mais de II\% do salário da funcionária do paladar. Um médico ganharia cerca de $44 \%$ do salário inicial dessa funcionária. A desigualdade derivada disso ganha escalas astronômicas, quando se comparam carreiras mais estruturadas da economia emergente.

Ao ver o anúncio do paladar supracitado recordei com veemência do caso em que o Brasil foi condenado na Corte Interamericana de Direitos Humanos, exatamente por não ter estruturas jurídicas e administrativas que protegessem brasileiras e brasileiros de serem discriminados por motivação racial no mercado de trabalho. O caso ocorreu em 1997, quando Aparecida Gisele Silva publicou um anúncio no Jornal "A Folha de São Paulo", na parte de Classificados, em que alegava seu interesse em contratar empregada doméstica, preferencialmente de cor branca. Simone Diniz interessada no emprego telefonou se candidatando. Ao ser questionada na conversa sobre sua cor, disse ser negra e teve como resposta que ela não se adequava ao perfil solicitado.

Simone Diniz, amparada pela Subcomissão do Negro da Ordem dos Advogados do Brasil, denunciou o ocorrido. Desde a abordagem na denúncia até a sentença final da justiça, houve sucessivas frustrações no acesso aos direitos de Simone Diniz. O Ministério Público, por exemplo, alegou que o caso deveria ser arquivado, pois “... não se logrou apurar nos autos que Aparecida Gisele tenha praticado qualquer ato que pudesse constituir crime de racismo, previsto na Lei 7.716/89..." e que não havia "qualquer base para o oferecimento de denúncia".

Sem retorno do Estado brasileiro em suas instâncias competentes, Simone Diniz procurou a Corte Interamericana de Direitos Humanos. Após longa tramitação, em 2004, o Estado brasileiro foi condenado exatamente por não possuir instâncias competentes que assegurem os direitos e combata o racismo e as formas derivadas de discriminação racial. Esse é um dos poucos casos que teve um desfecho positivo no sentido de combater a desigualdade racial e assegurar direitos. $\mathrm{Na}$ atualidade, é difícil se deparar com anúncios como o de Aparecida Gisele no Brasil. Os impactos sociais dessa condenação brasileira foram significativos, apesar de não representarem uma mudança completa no comportamento do mercado de trabalho, que atualiza suas formas de efetivar a discriminação. 
No caso cubano, apesar de haver sanções previstas na Constituição para atos racistas e discriminatórios, para essas se tornarem concretas, é necessário maior detalhamento dos casos que se aplicam e, obviamente, de efetividade no meio social. As poucas denúncias que chegam ao sistema judiciário não têm a situação de discriminação racial reconhecida. Por tanto, não há, até o alcance das fontes levantadas, nenhum caso de condenação por racismo, mesmo quando ocorre explícita menção ao cerceamento de um espaço de trabalho pela cor da pele e pelo fenótipo. São fatores que dificultam a construção de jurisprudência para amparar essa violação de direitos.

Essa é uma das bandeiras levantadas e defendidas por grande parte dos ativistas e coletivos entrevistados. Dentre as prioridades elencadas está a regulamentação do crime de racismo e de discriminação racial e uma sensibilização para o tema por parte do judiciário e da própria polícia.

Há outra prática nos paladares particulares em Cuba que traz reflexos para as discriminações de modo geral, que é o direito que esses espaços têm de selecionar as pessoas que podem ou não ingressar, o que em Cuba se denomina "direito de admissão". Essa "prerrogativa" dos restaurantes privados é baseada em critérios subjetivos e acaba por reproduzir os estereótipos e preconceitos da sociedade. Em Cuba, apesar de haver um crescimento de negócios privados, não há um código do consumidor que regulamente direitos e deveres. Mesmo infringindo os princípios constitucionais $4 \mathrm{I}, 42$ e $43^{217}$, muitas casas noturnas, bares e restaurantes reproduzem práticas discriminatórias em seu cotidiano, limitando o acesso a partir de seus critérios particulares. A jornalista Helen Hernandez Hormilla faz uma referência importante sobre esse "direito de admissão":

Es uno de los riesgos de privatizar los negocios, sobre todo porque existe una alegalidad muy grande con respecto a los actos de discriminación. Los movimientos ciudadanos de muchos países lucharon contra el "derecho de admisión" sobre el que se basó el racismo, el sexismo, la homofobia, la xenofobia. Aquí, sin embargo, se toma como algo normal. Creo que la segregación es terrible, que este tipo de acciones profundizan brechas clasistas (Fala de Helen Hernandez Hormilla apud RAMÍREZ, 20I5).

$\mathrm{Na}$ Constituição de 1976, especificamente no artigo 42, consta que o Estado cubano garante o direito de seus cidadãos, sem distinção de raça, cor, origem nacional, de ter residência em qualquer setor, zona ou bairro das cidades, de se hospedar em qualquer hotel, ser atendido em todos os restaurantes e demais estabelecimentos de serviços públicos, dentre outros pontos importantes como a não separação em transportes públicos, praias, parques e clubes.

\footnotetext{
${ }^{217}$ Art 4I: "Todos os cidadãos gozam de direitos iguais"; Art. 42: "A discriminação por motivo de raça, cor da pele, sexo, origem nacional, crenças religiosas e qualquer outra lesiva à dignidade humana, está proscrita e é proibida pela lei"; Art 43: "O Estado consagra o direito conquistado pela Revolução de que os cidadãos, sem distinção de raça, cor, sexo, crenças religiosas, origem nacional e qualquer outra lesiva à dignidade humana: disfrutan de los mismos balneáreos, praias, parques, círculos sociais, clubes e demais centros de cultura, esporte, recreação e descanso" Tradução minha.
} 
Princípios que regem a igualdade entre os cubanos e o combate às discriminações, dentre as quais a racial está destacada, existem há décadas. A Constituição de I90I, em seu primeiro artigo pregava: "Cuba es un Estado independiente y soberano organizado como república unitaria y democrática, para el disfrute de la libertad política, la justicia social, el bienestar individual y colectivo y la solidaridad humana". O voto era um direito apenas dos homens. Todavia, Cuba é um dos primeiros países da América Latina a assegurar o direito de voto aos homens negros. A Constituição de 1940, por sua vez, garantiu o sufrágio universal secreto para homens e mulheres e afirmava a igualdade entre os cubanos. Já trazia a condenação a qualquer forma de discriminação baseada em sexo, raça, classe, posições políticas ou crenças e práticas religiosas. Helg (2004), afirma que na Constituição de 1940:

Todas las libertades garantizadas por la Constitución de I90I eran mantenidas, pero se añadieron dos áreas nuevas: la primera, familia y educación (se anulaba las distinciones entre hijos legítimos e ilegítimos); la segunda, el trabajo y la propiedad. La Constitución limitaba la propiedad privada y daba amplios derechos a los trabajadores: fijaba el salario mínimo y las horas máximas de trabajo, garantizaba el derecho de huelga y la pensión laboral [Barreras 1940]. Sin embargo, la Constitución cubana de 1940 no se aplicó. Fue seguida por un período de violencia política y por la dictadura de Fugencio Batista, y por la lucha armada que llevó a la revolución de I959. (HELG, 2004: 34).

Nesse momento, dos anos 1930 e 1940, Cuba vivia uma situação de extremos, em que alianças inimagináveis foram feitas para contrapor-se ao movimento fascista que crescia no mundo. E as mobilizações negras, nesse período, reforçaram sua atuação ao compreenderem que a luta contra o racismo era também a luta contra o fascismo: "Es bueno y necesario que el negro cubano se haya manifestado, se manifieste y siga manifestándose como tal negro [...] en pro de la democracia [...] y contra el nazi-fascismo y el falangismo" (Declaração de Urrutia, na Unión Fraternal, 22 de noviembre de I94I apud DE LA FUENTE, 20I4: 27I).

Nas Sociedades de Color e em outros espaços de mobilização do segmento negro da população se defendia não apenas o princípio universal de igualdade legal, já assegurado na Constituição de I90I, mas também a garantia de uma base legal para efetivar a equidade. Além do mais, havia a demanda de tipificar e regulamentar a criminalização do racismo e da discriminação racial. De La Fuente traz outra declaração da época que ilustra esse debate:

Porque no basta - afirmó Nilo Zuásnabar, secretario general de la Federación de Sociedades de la Raza de Color de La Habana - decir 'todos los cubanos son iguales ante la ley', sino que es preciso señalar expresamente el grado de responsabilidad en que se incurre cuando cualquier persona natural o jurídica $[\ldots]$ ose actuar de manera distinta". Algunos afrocubanos, como el periodista camagueyano José Armando Plá, incluso, equipararon la nueva Convención con la revolución "verdadera". (DE LA FUENTE, 20I4, 27I-272). 
Muitos dos planos e ideais construídos no período das guerras de Independência, como uma condição igualitária entre brancos e negros, não se efetivou, como destacou Plá na citação acima. Esse fator mais uma vez lançou as atenções das mobilizações antirracistas para o processo constituinte dos anos 1940, com o objetivo buscar a efetivação dessas demandas históricas. De forma concreta, esse pleito específico, destacado por Nilo Zuásnabar, de haver medidas que criminalizassem aqueles que não respeitassem o princípio de igualdade segue pendente.

Até os dias atuais, essa continua sendo uma das fortes demandas das mobilizações antirracistas de Cuba, ainda sem respostas concretas no âmbito legal e processual. Deyni Terri, do coletivo de advogados Alianza Unidad Racial faz essa ressalva:

\begin{abstract}
Abogamos porque en Cuba haya una ley contra la discriminación en cualquiera de sus formas, sexista, racista, homofóbica. Cualquiera de sus formas porque se están dando muchos crímenes por temas de discriminación. No salen en los medios, porque políticamente el Estado no cuestiona la política. Nosotros tenemos una constitución y el Estado es sabio en decidir por qué esto no sale en los medios. Pero si hay problemas raciales, sí hay ofensas raciales. Todos los humoristas que se paran en un escenario público, hacen chistes contra negros y no hay una ley que me permita a mí ponerme de pie y demandar al teatro. No hay una ley que me diga que hacer con ese humorista, que tiene el carro del año. No estoy hablando de temas, o sea, no estoy haciendo una comparación social que vaya en detrimento de quienes vivan peor, pero no puede un humorista llenarse los bolsillos con temas racistas y todo el mundo reírse como si esto fuera algo que no dejara secuelas. (Entrevista com Deyni Terri, realizada em I5/05/2014).
\end{abstract}

Portanto, se percebe o quanto esse vazio jurídico impactou historicamente os mais vulneráveis, que são os segmentos mais estigmatizados como as mulheres, homossexuais, negros, camponeses, dentre outros. Os impactos objetivos e subjetivos das discriminações que cotidianamente não são tratadas no corpo estatal, jurídico e criminal são incalculáveis quando se coloca as vítimas em perspectiva. Essa situação deixa impunes atos de violência, estigmatização e opressão, e referendam, no dia-a-dia, essas práticas discriminatórias.

Com o triunfo da Revolução, não se construiu de imediato um marco legal máximo, uma Carta Magna. Apenas em 1976 foi aprovada a nova Constituição do país. Até essa data, não houve nenhum tipo de votação em Cuba. As decisões eram tomadas por manifestações públicas das massas. Havia também a ressalva de que todos eram iguais, mas houve forte restrição à liberdade de culto, manifestação e organização. Com relação às organizações sociais e políticas, o Partido Comunista Cubano passou a ser o único, e coexistia com as chamadas organizações sociais de base da Revolução, tais como sindicatos, confederações de trabalhadores, federações, como a Federación de Mujeres Cubanas e os Comitês de Defensa de la Revolución. As sociedades negras, por exemplo, foram fechadas. 
A proposta construída por uma comissão do Partido Comunista de Cuba da nova Constituição do país foi levada a referendo popular em 1976 e aprovada por 99\% dos cidadãos. Helg (2004) destaca que a primeira Constituição de Cuba socialista consagrava as transformações realizadas e desenhava um projeto de Estado focado na classe trabalhadora. Seu preâmbulo iniciava com "Nosotros, ciudadanos cubanos". Não há menção a Deus e faz-se aí um destaque aos "nuestros antecesores" que lutaram contra os opressores: "los aborígenes" y los esclavos, los patriotas de las guerras de independencia, los socialistas, comunistas y revolucionarios de los años treinta a sesenta". Além disso, fazia menção de que os cidadãos cubanos eram "guiados por el ideário de José Martí, Marx, Engels y Lenin". Em seu primeiro artigo, dizia: "La república de Cuba es un Estado socialista de obreros y campesinos y demás trabajadores manuales e intelectuales". No que se refere à discriminação, continua a autora, a Constituição de 1976 proibia "la discriminación por motivo de raza, sexo, origen nacional". Declarava a igualdade e negava, por outro lado, as diferenças (HELG, 2004).

A Constituição dava destaque à necessidade de que as manifestações, comunicações e organizações sociais defendessem os princípios e o legado da Revolução, bem como no caso dos "derechos de reunión, manifestación y asociación" esses só poderiam materializar-se no marco da Revolução, a partir das organizações de base. O direito ao voto livre e secreto era acessível a alguns níveis de representação. As representações definidas depois de certa hierarquia eram eleitas pelo Conselho de Estado ou pela Assembleia Nacional.

Houve nova alteração de poucos artigos da Constituição em I992, especialmente para adaptar a economia cubana às mudanças necessárias para as novas atividades econômicas pós-queda do Bloco Socialista. Nesse momento específico, há também o acréscimo à proibição de discriminação por crenças religiosas. Isso traz impacto aos religiosos de modo geral, mas é também uma medida importante para os santeros, paleros e abacuás. Essa é vista, por Pedro de la Hoz (2012: 174) como uma das principais ações de enfrentamento ao racismo efetivadas pela Revolução.

Atualmente, apenas essas práticas de origem africana necessitam ser informadas à polícia, mas ninguém pode impedi-las, como já ocorreu. Em períodos anteriores, as intimações policiais aos babalawos, abacuás, santeros e paleros era freqüente. Sobre os Abacuá o estigma era amplificado, por se tratar de uma sociedade secreta masculina. Tato Quiñones destaca que uma de suas principais fontes de pesquisa era a polícia, com grande acervo derivado dos inquéritos e interrogatórios:

No te olvides que en mi caso en la investigación que yo hice sobre los Abacuá toda la información que yo encontré, la que utilice en mi trabajo y otras que tengo en mi archivo las encontré en las actas 
policiales, en las crónicas policiacas de los periódicos, y en las actas policiales, y en las actas judiciales de las sanciones, los juicios. Ahí es donde está la información, no está en otra parte, porque eso forma parte de la cotidianidad, la no existencia, la negación en el ámbito social abierto, llamémoslo así para entendernos, pero hay información que queda en la memoria de la gente y en el caso de negros en Cuba por lo menos y sus instituciones [...] las sociedades de negros. (Entrevista com Tato Quiñones, realizada por Daniel Brasil, em setembro de 20I4) ${ }^{218}$.

A invisibilidade, a negação, como destaca o próprio Tato Quiñones, é um lugar comum dessas organizações, manifestações e mobilizações afrocubanas. E o destaque que faz para as inúmeras abordagens policiais é outro elemento que traz a tona o nível de controle e a relação cotidiana desses grupos com o poder repressivo do Estado.

Outro caso que materializa essa dinâmica opressiva em relação às tradições de matriz africana, especialmente a partir dos anos 1970, é o abandono da prática de queimar do boneco San Juan (que no sincretismo representa Ogum) no bairro de La Marina, em Matanzas. Essa era uma prática muito presente no bairro nos anos 1950, 1940.

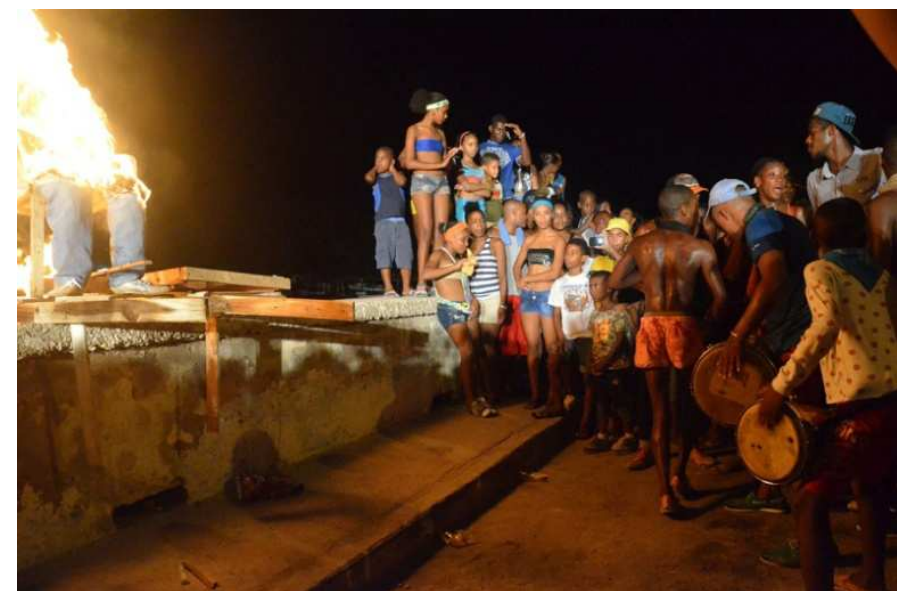

Figura 20: Queima do Boneco de San Juan, no dia 24 de julho de 20I5, no bairro La Marina, Matanzas, Cuba. Foto: Bárbara Oliveira

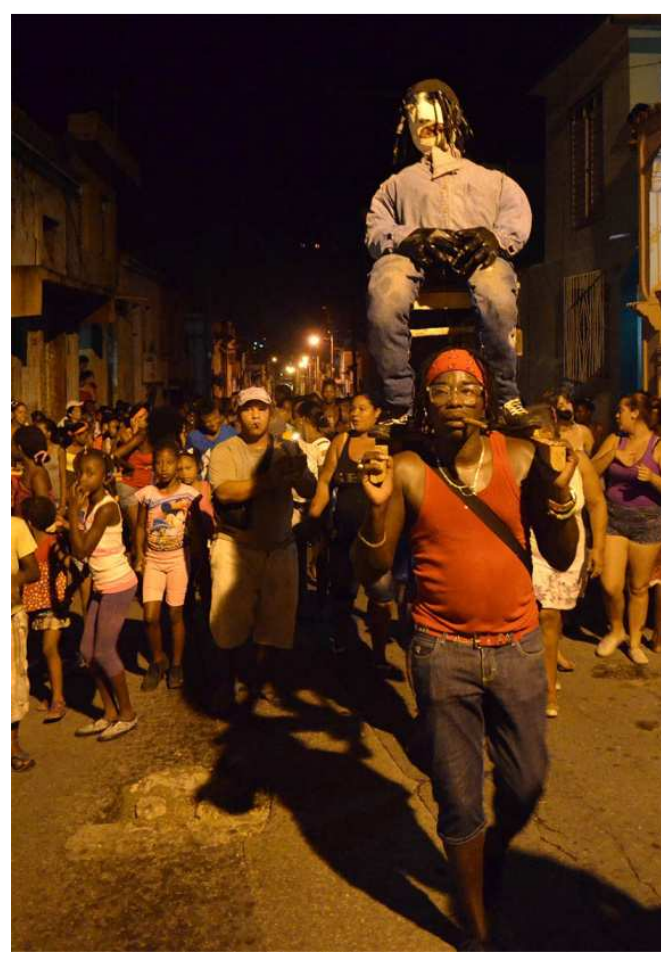

Foto 2I: Cortejo com o boneco pelo bairro La Marina, Matanzas, Cuba, com paradas nos cabildos e casas de santeria, palo monte abacuás. Passagem do dia 23 para 24 de junho de 2014. Foto: Barbara Oliveira

\footnotetext{
${ }^{218}$ Agradeço a Daniel Brasil e Tato Quiñones por cederem essa entrevista para utilização nesse trabalho.
} 
A queima vem sendo retomada nos últimos anos e se apresenta como um evento de grande apelo popular, que reúne entre mil e duas mil pessoas. A caminhada, iniciada nas ultimas horas do dia 23 de junho pelas ruas do bairro de La Marina, é animada com cânticos em espanhol e em yorubá, embalada por batuques e tambores. A festividade é encerrada com a queima do boneco e um espetáculo de Rumba. Durante muitos anos, como destaca Kimbo, essa atividade foi proibida ou havia uma série de constrangimentos que impediam sua realização:

Salí al barrio bestial y bueno: ¿ahora que hago? Y salí a ver a una compañera, se llama Dolores. Le digo: Dolores tu eres la más vieja, madrina, tu eres la más vieja aquí en la Marina y dime algo que podemos hacer. (Ella me contesta) Aquí se hacía el muñeco de San Juan, aquí se hacia (en los años 1950) la comida tradicional, aquí se sacaba la Virgen de Regla de los portuarios. Dolores continua: Si tú quieres empezar, empieza primero por el muñeco de San Juan que se quemaba aquí en la orilla del río Yumurí, que eso es de nosotros los santeros para las enfermedades, que era la entrada de nosotros para poder ir a la playa a bañarnos, porque nosotros los religiosos somos que hasta que no se queme el San Juan, hasta después del 24, nadie va a la playa porque la quema es del 23 para el 24. Yo rescate esa tradición del bairro, que estaba olvidada. Por el camino, pasamos en Simson, donde está el cabildo de San Juan, el cabildo mayor existe aquí en Matanzas. Llegamos allá y llevamos nuestras ofrendas, nuestros derechos. Bajamos hacia la Marina y a las doce un punto se está quemando el muñeco. (Entrevista com Kimbo, realizada em I3/09/2014).

O projeto Identidad y Bairro La Marina, um dos projetos comunitários com as quais eu dialoguei nessa pesquisa, estimula iniciativas como a retomada da queima do boneco de San Juan. Interessante como, apesar das décadas de esquecimento, essas práticas existem na memória coletiva e recobram sentido social com velocidade após tão grande hiato.

Esses espaços estigmatizados e invisibilizados também são comumente vinculados às manifestações de matriz africana, como a Santeria, com grande influência da cultura Yorubá, o Palo Monte, inspirada pelas tradições originárias dos povos do tronco lingüístico Bantu, e os Abacuá, de origem Carabali.

O estigma e discriminação a essas práticas também se expressa nos meios de comunicação. A seguir trarei alguns relatos e publicações da imprensa que demonstram o grau de violência e discriminação a que estavam submetidas(os) cubanas(os) praticantes dessas tradições:

Mais de $90 \%$ dos jovens que entram na seita (Abacuá) possuem antecedentes penais ou são procurados pelas autoridades. Esses são quem resolvem os problemas como homem e buscam uma oportunidade para fazer história (feitos de sangue) e depois jurar-se. Porque, enquanto não pisem numa prisão, não se consideram homens provados $[\ldots]$ Também utilizam afeminados e suas mulheres ambientosas ${ }^{219}$, para formar um escândalo em determinado grupo social e afetar assim o prestígio de homem. Outra estrategema muito empregada pela máfia Abacuá é "fazer a cama" (preparar uma agressão de vários contra um). (Moncada, Ano VI, nº 6, La Habana, Janeiro de 1972, página I3) 220.

\footnotetext{
${ }^{219}$ Sinônimo de promiscuas.

${ }^{220}$ Tradução Minha. Citação feita no livro: QUIÑONES, Serafim. Asere Núncue Itiá: Ecobio Enyene Abacuá. La Habana, Editorial José Marti: 2014.
} 
"Máfia Abacuâ" e o reforço do estigma da "criminalidade", da "periculosidade", reforçam os lugares fáceis do racismo, conforme já discuti. Reflete, também, a presença contemporânea do "medo ao negro", em concordância com denuncias de ativistas antirracistas. Essa lógica de violência está presente, também, nas memórias e narrativas, sobretudo no período em que houve maior estreitamento das relações com a União Soviética, nos anos 1970. Zurbano relata o ocorrido com um vizinho, a partir de suas percepções de criança na época:

Había una represión muy fuerte contra los religiosos. Mi abuela tenía un amigo que se llamó Compadrito que era un gran santero que vivía allá en Vegas que ella iba el 3 de diciembre a cocinar, a matar animales, porque era un gran santero, para celebrar Santa Bárbara. Chango el 4 de diciembre. Y a Compadrito le quitaron todos los santos y se lo montaron en un camión y se lo llevaron a la policía. Eso es hizo en Cuba, y a la semana se lo devolvieron todo. Pero ese tipo de humillaciones se hizo porque un santero era algo de un rezago del pasado y para el mundo los soviéticos eso era un animismo una cosa terrible y aquí esas marcas y esas modas y esos dogmatismos y esos extremismos se vieron. Este hombre sufrió mucho por ese fenómeno y tuvo como dos años que no pudo celebrar fiesta de santo. Siempre mi abuela iba a cocinar, comíamos muy bien los niños, disfrutábamos todos los dulces de una fiesta de santo. Era fabulosa, cocinaba decenas de dulces, dulces caseros era lo que más disfrutábamos los niños, y yo estaba comiendo dulce una semana prácticamente después de aquella fiesta, son inolvidables. Eso fue un acto, digamos, de que hubo una represión contra los religiosos y que se empezó entonces a negar que era religioso, no podías hablar de las religiones negras, no aquel es hijo de Chango. No (había) esa celebración que se ve en Cuba los últimos diez años. Todo el mundo con los collares afuera, la gente vestida de blanco bailando por toda la ciudad con una ropa carísima blanca o de santo etcétera. Yo creo que es el resultado de una consecuencia de tanta corrupción tanto que se reprimió la santería. Hoy aparece gente con crucifijos enormes en la calle todo el mundo vestido de blanco, especulando gente que se hace santo sin saber que cosa es y mucho menos. Ha terminado a ser como una especie de moda, algo que fue tan reprimido. No fue respetado, no fue tomado en cuenta ni la parte de la cultura de la tradición cubana, donde tantos hombres importantes en Cuba pasaron por esa religión con naturalidad lucharon en todos los lugares en Cuba con naturalidad y después eran inferiorizados reprimidos por ser practicante de esa religión. (Entrevista com Roberto Zurbano, realizada em I5/I0/2014).

A partir do relato de Zurbano, gostaria de destacar dois elementos: o primeiro é que os espaços estigmatizados que situam os negros no lugar do "primitivismo", da "periculosidade", do que "necessita de controle", demonstram que apesar das tentativas de desvincular o debate sobre o racismo de seu caráter sistêmico, atribuindo aos negros também o papel de discriminadores, de "racistas ao contrário", os fatos demonstram que essa mazela está estruturalmente presente e que necessita ser tratada de forma mais profunda e continuada não apenas pelos coletivos que tratam o tema, mas pelo próprio Estado e pela sociedade cubana.

Tomás Fernandez Robaina (2004: 368) aborda que por um longo período durante a Revolução, havia a compreensão de que as tradições de matriz africana estavam em um franco processo de extinção. A partir dos ditames de erradicar os preconceitos raciais (explicitamente defendido nos primeiros anos da Revolução), tinha-se a expectativa de que, em virtude da educação e da instrução de negros e brancos, os jovens praticantes de tradições de origem africana se afastariam espontaneamente, na medida em que fossem atingindo "níveis superiores de instrução e cultura". 
Essa visão evolucionista, contudo, gerou resultados contraditórios. A partir dessa constatação da época ${ }^{221}$, foi tratado como urgente o resgate do legado das culturas africanas ainda existentes em Cuba, dado o eminente risco de extinção das mesmas ${ }^{222}$. Por um lado, se tinha a visão de que eram práticas primitivas que seriam extintas. Por outro, esse resgate acabou gerando uma visibilidade das histórias dos orixás, das danças de origem Yoruba, Arará, Congo, Carabalí, o que foi avaliado como positivo por muitos ligados às tradições, de acordo con Tomás Robaina (2004)223.

A Revolução foi um processo social de grande relevância, que marcou profundamente a sociedade cubana. Possibilitou, por um lado, a ampliação de direitos coletivos de forma jamais vista no país, ou talvez, na América Latina. Com uma economia restrita e isolada politicamente de grande parte dos países do mundo, construiu um legado no que se refere à superação do analfabetismo, à universalização do direito à educação, à implantação de um sistema de saúde de qualidade, dentre vários outros aspectos sociais.

Esses avanços marcaram intensamente os cubanos, especialmente os oriundos das classes mais pobres, dos quais muitos eram negros e negras. Contudo, a luta pela igualdade alcançou patamares que passaram a suprimir as demais identidades e sorrateiramente permitir a reprodução de práticas racistas sem nenhum amparo do Estado. Uma vez que esse problema não existia oficialmente, não havia espaço para tratar dele, o que vulnerabilizou suas vítimas.

Essa situação de desigualdade racial fica mais explícita com a crise do bloco soviético e com o advento do período especial nos anos 1990, especialmente pelo crescimento da desigualdade econômica. É nesse período que surgem, também, as primeiras organizações que pautaram esse tema publicamente. As reservas de vagas nos cargos representativos do Partido Comunista de Cuba é um dos exemplos do início da abertura para esse debate. A seguir, refletirei de forma mais profunda acerca da representação simbólica versus representação efetiva da diversidade de segmentos raciais existentes na sociedade nos espaços vinculados à alta hierarquia política cubana, também trazendo o olhar das relações de gênero.

\footnotetext{
${ }^{221} \mathrm{O}$ eminente desaparecimento dessas práticas tradicionais de matriz africana foi relatado em publicações e estudos, como no livro "Procesos Etnoculturales de Cuba", escrito por Jesus Guanche, em I977.

${ }^{222}$ Alguns dos pesquisadores importantes que se aprofundaram sobre esse legado afrocubano são Rogelio Martínez Furé, Argeliers León, Rafael López Valdés.

${ }^{223}$ Essas tradições foram incorporadas em estudos de dança e outras disciplinas artisticas em todo o território da ilha (FERNANDEZ, 2004).
} 


\subsection{Equidade e Representação Simbólica: Ações Afirmativas em Cuba}

Nessa seção, tenho como objetivo avançar na discussão sobre as estruturas de poder e a forma como os diferentes segmentos raciais da sociedade cubana estão representados. Esse é um debate que necessariamente vai abordar os olhares sobre as políticas universais e ações afirmativas, e seus possíveis efeitos em diferentes contextos. Como venho realizando em momentos específicos ao longo da tese, abordarei esse debate sobre Cuba em diálogo com processos vivenciados no Brasil sobre o tema.

É um grande desafio avançar nessas reflexões em Cuba, posto que os dados disponíveis para essa análise são escassos, dispersos e algumas vezes inacessíveis. Em muitos casos, me centrei nas informações obtidas em sítios oficiais da internet sobre conselhos, instituições ou em outras pesquisas já realizadas, como o Censo Nacional de Cuadros del Estado, de 1987, o Censo Nacional de 2002 e 2012. Não tive acesso com facilidade a dados desagregados por cor, como, por exemplo, dos dirigentes do setor turístico. Em alguns casos, parte das informações ora apresentada foi construída pela interpretação de fotos ${ }^{224}$ publicadas em sítios da internet. Por exemplo, no caso da percepção sobre a cor dos ocupantes dos cargos máximos de direção do país, como os que integram o Conselho de Estado e o Bureau do PCC, a obtive a partir de entrevistas com cubanos e cubanas, conforme descreverei a seguir.

A falta de informação sistematizada é parte dos reflexos do tímido avanço da institucionalização das políticas de igualdade racial no âmbito estatal em Cuba, como já mencionado. Um dos avanços foi a iniciativa de diversificar as representações no âmbito do Partido Comunista Cubano, nos anos 1980, reposicionando o lugar de negros, mulheres e jovens nessas instâncias de poder. No III Congresso do Partido Comunista, o então presidente de Cuba, Fidel Castro, aborda a importância de ampliar a representação dos diversos segmentos da sociedade nas estruturas do próprio partido.

Os dados do Censo de I98I influenciaram na decisão de implementar as ações afirmativas nas instâncias representativas de poder ${ }^{225}$. Os resultados concretos das políticas públicas puderam ser sentidos pela população de forma geral e, sobretudo, pela população negra. Como ressalta De La Fuente (20I4), a partir dos dados do Censo de I98I, é perceptível a redução da desigualdade racial em diversas esferas como saúde e educação. Em uma análise comparada entre Brasil, Cuba e

${ }^{224}$ Essas imagens estão disponíveis no anexo desse trabalho.

${ }^{225}$ Essa decisão foi tomada após o III Congresso do Partido Comunista de Cuba, realizado em I986. 
Estados Unidos, no mesmo período, há a situação radicalmente menos desigual de Cuba frente aos demais no que se refere à educação superior:

Percentual da população de 25 anos ou mais, segundo raça/cor, que terminou os estudos pré-universitários (secundários) ou superiores em Brasil, Cuba e EUA - Déc. I980

\begin{tabular}{|c|c|c|c|c|c|}
\hline & Brancos & Negros & $\begin{array}{c}\text { Mulatos/Mestiços/P } \\
\operatorname{ardos}^{226}\end{array}$ & $\begin{array}{c}\text { Diferenças } \\
\text { Branco X Negro }\end{array}$ & $\begin{array}{c}\text { Diferenças } \\
\text { Branco X Mulato }\end{array}$ \\
\hline \multicolumn{6}{|l|}{ Brasil (I987) } \\
\hline Preuniversitário & $\mathrm{I} 3,9$ & 5.3 & 8.0 & 8.6 & 5.9 \\
\hline Universitário & 9.2 & 1.0 & 2.0 & 8.2 & 7.2 \\
\hline \multicolumn{6}{|l|}{$\operatorname{Cuba}($ I98I) } \\
\hline Preuniversitário & 9.9 & II.2 & 9.6 & $-\mathrm{I} .3$ & 0.3 \\
\hline Universitário & 4.4 & 3.5 & 3.2 & 0.9 & 1.2 \\
\hline \multicolumn{6}{|c|}{ Estados Unidos (I987) } \\
\hline Preuniversitário & 56.4 & 52.8 & - & 3.6 & - \\
\hline Universitário & 20,5 & $\mathrm{I} 0,7$ & - & 9.8 & - \\
\hline
\end{tabular}

Figura 22: Quadro com Percentual da população de 25 anos ou mais, segundo raça/cor, que terminou os estudos pré-universitários (secundários) ou superiores em Brasil, Cuba e EUA - Déc. 1980. Fonte: Censo de Cuba de I98I; Andrews: Racial Inequality in Brazil and the United States, 229-263, apud DE LA FUENTE (2014).

Todavia, essas mudanças não se deram nas mesmas proporções no alto escalão do país. Levando em consideração o Bureau político do Partido Comunista Cubano, desde sua primeira eleição em 1965, apenas 9\% era composto de negros e mestiços; 7\% em I975 e em torno de I2\% em I980 (apud DE LA FUENTE, 20I4). É perceptível as dificuldades em se avançar nas representações negras nos espaços mais elevados da hierarquia, conforme veremos a seguir.

Nesse contexto, havia uma preocupação do corpo dirigente de Cuba em relação à desigualdade racial nos postos diretivos. Houve, de forma inédita, o primeiro Censo Nacional de Cuadros del Estado, realizado em 1987. Nesse período, no Terceiro Congresso do Partido Comunista de Cuba, Fidel Castro destacou em seu discurso a necessidade de ampliar a representação de jovens, mulheres e negros nos espaços representativos do Partido, inclusive os mais elevados. Tomás Fernandez Robaina historiciza como ocorreu o processo de reserva de vagas no Comitê Central para negras e negros nesse período:

Triunfa la Revolución en el 1959 y los proyectos, los programas de la Revolución no eran para sectores específicos de nuestra población. Mejor dicho, sí eran proyectos específicos, porque para los campesinos se hizo la Reforma Agraria, se hizo la Campaña de la Alfabetización para alfabetizar a los que no sabían leer ni escribir, es decir, tuvo proyectos específicos para cada sector. Hubo un proyecto para la mujer. Ahora el negro, la problemática negra, no fue considerada como problemática negra, como la sexualidad tampoco fue considerada una problemática social. La prostitución fue considerada una problemática social, entonces todo esto trajo un discurso que era para todos los cubanos. Aquí se refleja una vez más la existencia del racismo solapado, enraizado, que en ningún momento se pensó en la problemática racial como tal y justamente es en el momento en que Juan René Betancourt plantea y le pide al gobierno que explique cuál es la política que va a adoptar en esta etapa. Porque él ve que el Ejército Rebelde está lleno de soldados negros, hay comandantes negros, en el Consejo de Ministros, en aquellos momentos no había ningún

${ }^{226}$ Essa categoria muda a partir do contexto de cada país. Incluí "mestiço" e "pardo" por serem essas as categorias usadas respectivamente nos censos cubano e brasileiro. 
negro. Ahí, es cuando Fidel llama, hace lo que yo califico del primer llamado para prestar atención y ante todas las propuestas de carácter sicológico, de carácter laboral de la proporcionalidad de las acciones llamadas afirmativa, que en los centros de trabajo debe haber una proporción de negros, de blancos etcétera, etcétera. (Tomás Fernandez Robaina, entrevista realizada em I2/05/20I4).

Esse é um marco sintomático de quebra de um relativo silêncio oficial sobre a discriminação racial desde a década de 1960. O líder máximo de Cuba naquele momento ressalta que corrigir essa injustiça histórica não é uma solução derivada da "espontaneidade". Destaca, nesse discurso, a não necessidade de leis para isso, mas que essa diversidade de representações deveria ser impulsionada por ações. Nesse Terceiro Congresso do Partido Comunista de Cuba, de modo inédito, o Comitê Central passa a ser composto por 28\% de negros (DE LA FUENTE, 20I4).

É interessante analisar como foi a evolução desse processo e as mudanças geradas na participação e presença de mulheres e negros nesses espaços historicamente embranquecidos. Será que essas ações possibilitaram a mudança estrutural, para além do aspecto simbólico? Quais são os reflexos dessas ações mais direcionadas à redução da desigualdade, criadas no contexto da década de 1980, nos dias atuais?

Analisarei, a seguir, algumas instâncias de representação política em Cuba: o Conselho de Estado, a presidência da Assembleia Nacional do Poder Popular, o Bureau Central do Partido Comunista de Cuba. Esses são os espaços de mais relevante representação tanto da sociedade política, quanto do Estado cubano.

Como os dados desagregados por cor não são disponibilizados publicamente pelo Estado cubano no que se refere aos integrantes desses espaços políticos, o método que utilizei para aferir a representação dos diferentes segmentos raciais foi apresentar a foto dos integrantes do Conselho de Estado, da presidência da Assembleia Nacional do Poder Popular (de 1976 até o presente momento) e do Bureau Central do Partido Comunista de Cuba a um grupo diverso de cubanos/as. Privilegiei as percepções de pessoas de diferentes origens, idades e identidades raciais, sem vinculação com mobilizações antirracistas, para apresentar suas visões em relação à cor dos ocupantes dessas instituições analisadas, a partir da leitura das fotos disponíveis. São percepções baseadas em categorias e particularidades socialmente conformadas, tendo como referência as categorias existentes no Censo cubano.

É um processo bastante complexo a identificação racial que não seja fruto da autoidentificação, conforme preconizado na Convenção I69 da OIT. Meu objetivo, contudo, nesse trecho, dada a carência de dados oficiais, é apresentar uma perspectiva sobre como são percebidos racialmente os 
representantes desses espaços de poder por um grupo particular de cubanas/os entrevistadas/os. Esse grupo foi composto por homens e mulheres ${ }^{227}$.

A partir das conclusões sobre a cor dos integrantes dessas três instâncias, realizei um cruzamento estatístico para analisar o percentual de presença "negra", "mestiça" e "branca". Esse exercício foi interessante para possibilitar, também, a explicitação de critérios e leituras locais sobre o fenótipo.

No que se refere às instituições analisadas, farei uma breve descrição das mesmas. Com relação ao Conselho de Estado, cabe destacar que é uma instância vinculada à Assembleia Nacional do Poder Popular e que possui uma forte influência sobre demais instâncias do executivo, judiciário e legislativo, além de assuntos de ordem internacional, como ratificação de tratados internacionais. O Conselho tem caráter colegiado e seus representantes ocupam o status de representação de mais alto escalão ${ }^{228}$.

É a Assembleia Nacional do Poder Popular que elege, dentre os seus deputados, o Conselho de Estado, que é composto por: um Presidente, um primeiro Vice Presidente, cinco Vicepresidentes, um Secretário e 23 membros. O Conselho de Estado é formado por 3 I deputados ao todo. É presidido pelo chefe de Estado e Chefe de Governo, que na atualidade é Raul Castro. Na legislatura de 2013 a 2018 da Assembleia Nacional do Poder Popular, o núcleo diretivo é integrado por oito representações. Desse total ${ }^{229}$, seis foram considerados "brancos" (75\%), um "negro" e uma "mestiça" (que somam 25\%); duas são mulheres (25\%) e seis homens ( $75 \%)^{230}$.

Entre os demais 23 membros do Conselho de Estado, há maior equidade na proporção mulheres e homens e maior presença "negra" e "mestiça". Desses, I3 foram considerados "brancos" (56,5\%) e 5 "negras" e 5 "mestiços" (43,5\%). Na proporção de gênero, nesse grupo dos demais membros, há um equilíbrio entre a proporcionalidade de homens (I2 o que representa 52,2\%) e de mulheres (II representantes, 47,8\%).

\footnotetext{
${ }^{227}$ Agradeço ao antropólogo Daniel Brasil pelo apoio na entrevista desse grupo.

${ }^{228}$ Funções do Conselho de Estado, definidas no Artigo 89 da Constituição Cubana, dentre as quais cabe destacar: A realização de sessões extraordinárias na Assembleia Nacional; Elaborar decretos-leis, entre um e outro período de sessões da Assembleia; Dar a leis vigentes, se necessário, uma interpretação geral e obrigatória; Decretar a mobilização geral para assegurar a defesa do país e declarar a guerra em caso de agressão; Substituir, a partir da proposta de seu presidente, os membros do Conselho de Ministros nos intervalos de sessões da Assembleia Nacional do Poder Popular; Deliberar instruções de caráter geral aos tribunais através do Conselho de Governo do Tribunal Supremo Popular; Designar ou retirar, a partir da proposta de seu presidente, os representantes diplomáticos de Cuba; Ratificar e rejeitar tratados internacionais; Suspender as disposições do Conselho de Ministros e disposições das Assembleias Locais do Poder Popular que não estejam amparadas pela Constituição ou leis, ou quando afetem outros interesses do país.

${ }^{229}$ Dados de março de 2014.

${ }^{230}$ A tabela com os integrantes do Conselho de Estado, com as fotos e as categorias de cor empregadas pelo grupo entrevistado estão no Anexo dessa tese.
} 
Um dos aspectos que chamou a atenção durante a entrevista feita com um grupo de cubanos sobre a classificação de cor dos ocupantes dessas instituições foi a quantidade de termos vinculados à identidade racial utilizados pelos entrevistados. Diversas categorias foram empregadas, tais como "trigeño", que "en Cuba a los trigueños se les pone blanco en el carnet de identidad pero son mestizos (...) trigueño es una persona que tiene facciones finas, pelo lacio" ${ }^{231}$; "Jabao": "el jabao viene siendo como de color claro sin llegar a ser blanco, pero con el pelo muy malo"232; "mulata blanconaza"; "mulata colorada"; "mulata oscura"; "indianizado"; "blanco sucio"; "medio chino".

No núcleo diretivo do Conselho de Estado, as representações de mulheres e negros são realmente muito aquém de sua representação na sociedade cubana na atualidade. Todavia, é interessante perceber que entre os demais membros há uma reversão desse quadro em relação às mulheres, $\mathrm{e}$ uma diminuição da desigualdade da participação de pessoas negras.

O Bureau Político do Comitê Central do Partido Comunista de Cuba ${ }^{233}$, outra importante esfera de influência e de poder no país, é composto por I4 membros, dos quais I3 são homens (92,8\%) e uma é mulher (7,2\%). Dos integrantes, dez foram considerados pelo grupo como "brancos" (7I,5\%), dois negros e dois mestiços $(28,5 \%)$ do total ${ }^{234}$. O primeiro secretário do Bureau é Raúl Castro, também presidente do Conselho de Estado e representante máximo de governo e de Estado do país. Como segundo secretário, está José Ramon Machado, que no Conselho de Estado figura como vice-presidente.

Para fechar esse rápido panorama da participação de negros e mulheres na alta hierarquia política cubana, analisarei a composição de oito presidências da Assembleia Nacional do Poder Popular, de 1976 até a atualidade ${ }^{235}$. Cada legislatura tem cinco anos de duração. De I976 até a atualidade, foram oito legislaturas. Em apenas uma delas, houve três diferentes presidentes, de I986 a 1993. Nas demais, houve um ocupante.

\footnotetext{
${ }^{231}$ Danay Ramos, entrevista realizada em 30/10/2015.

${ }^{232}$ Idem.

${ }^{233}$ Aprovada em I5 de fevereiro 1976 mediante referendo, a Constituição da República de Cuba define no Artigo 5 do Capítulo I: "El Partido Comunista de Cuba, martiano y marxista-leninista, vanguardia organizada de la nación cubana, es la fuerza dirigente superior de la Sociedad y el Estado, que organiza y orienta los esfuerzos comunes hacia los altos fines de la construcción del socialismo y el avance hacia la sociedad comunista."

${ }^{234}$ A tabela com os integrantes do Bureau do Partido Comunista de Cuba, com as fotos e as categorias de cor empregadas pelo grupo entrevistado estão no Anexo dessa tese.

${ }^{235}$ A composição por cor e sexo da Assembleia Nacional do Poder Popular em sua totalidade não está disponível até a data da busca feita para essa pesquisa. Fonte: http://www.ecured.cu/index.php/Asamblea_Nacional_del_Poder_Popular
} 
Levando-se em consideração as oito legislaturas, apenas uma teve como presidente uma representação considerada pelo grupo como "mestiça" (de I976 a I98I)236. A atual legislatura é presidida por uma pessoa considerada "negra" (2013 a 2018). Houve também um ocupante "negro" na legislatura que de forma atípica foi composta por três presidentes, sendo que os dois outros foram considerados como "brancos" (1986 a 1993). Das oito legislaturas, seis foram ocupadas por presidentes considerados "brancos" 237 . Ao longo desse período, nenhuma mulher ascendeu a esse cargo.

As ações afirmativas implantadas na década de 1980 em Cuba trouxeram reflexos sobre a participação das mulheres e negros em cargos diretivos de modo amplo no país. Contudo, esse processo ainda não se reflete nas capas mais altas da hierarquia cubana, onde a subrepresentação desse segmento é significativa. Nas faixas mais altas, a presença feminina e negra não superou a dimensão simbólica e estão aquém de sua participação na sociedade. Mesmo após um processo revolucionário de décadas e de iniciativas afirmativas desde a década de I980. Ainda assim, cabe destacar, que a presença negra e de mulheres na totalidade da Assembleia Nacional Popular, nas Assembleias Locais e no próprio Partido Comunista de Cuba tem aumentado consideravelmente. Nesse âmbito as mudanças não são de cunho apenas simbólico.

É sintomático perceber, por outro lado, a grande resistência ao debate de ações afirmativas em Cuba como um dos caminhos possíveis para ampliar a participação de negras e negros em espaços de poder, em postos da economia ou nas universidades, por exemplo. A iniciativa, criada nos anos 1980, de promover mais mulheres, negros e jovens no partido e, por consequência, também nas Assembléias do Poder Popular, foi deturpada e criticada, como relatam alguns ativistas:

En mi opinión el problema más grave que tenemos, en este momento, que tal vez no existieron en el pasado, tal vez no estaba en los años I980: Uno es que la población negra se ha descalificado entre las nuevas tecnologías, la universidad se ha blanqueado. [...] Por ejemplo, en los 1980 se creó el sistema de cuotas, pero fracaso. Yo como periodista estaba cubriendo los congresos y estaba en un salón grande donde había muchos periodistas. Por supuesto la única negra era yo, y cuando se dijo que iba haber un proyecto de promoción para jóvenes mujeres y negros, todos los que estaban en aquel salón se viraron para mí: "Coño negra te salvaste, por negra y mujer". Pero, al mismo tiempo la propia población negra no entendió lo que eso significaba y entonces opusieron resistencia. Un nivel medio de la burocracia saboteo el proyecto asquerosamente, sínicamente. Había cinco mujeres a quien promovieron, a la que sabían que no podía, la que tenía un hijo enfermo, un hijo asmático, proponen a esa porque lo que quieren es demostrar en el consciente y el inconsciente que las mujeres no pueden entonces el proyecto fracaso, el sistema de cuotas fracaso. (Entrevista com Gisela Arandia, realizada em I2/09/2014).

\footnotetext{
${ }^{236} \mathrm{O}$ quadro com a informação sobre as legislaturas, bem como a foto de cada um dos presidentes e a respectiva avaliação pelo grupo da "cor" desses representantes estão nos anexos dessa tese.

${ }^{237}$ Em uma dessas legislaturas, como mencionado, houve 3 presidentes, sendo dois considerados como "brancos" e um "negro".
} 
Outras publicações e manifestações apresentam argumentos e posições contrários ao princípio das cotas. Na publicação intitulada Diálogo al interior del debate racial en Cuba: jacción afirmativa o reempoderamiento ciudadano?, Manuel Cuesta Morúa questiona a efetividade das ações afirmativas e toma como exemplo o Brasil:

Brasil es un ejemplo excelente para contrastar el valor de la acción afirmativa. Consciente de sus limitaciones, el gobierno de Lula creó un ministerio que trata específicamente el tema. Y más consciente aún de que los problemas de su sociedad son estructurales, implementó un programa: hambre cero, para encarar un asunto que no puede resolverse con las políticas positivas de cuota de la acción afirmativa. Allí, por consiguiente, esta política tiene la función de las muletas, no de las piernas, para la visión estratégica del gobierno. No todos los brasileños son negros, pero los negros en Brasil no son una minoría.

En Cuba la acción afirmativa puede ser una muleta, no la visión estratégica para enfrentar el problema de la integración y la desigualdad raciales. $\mathrm{Si}$, como se ha demostrado, aquélla solo favorece a una minoría dentro de la minoría; si su alcance es fundamentalmente individualizador, no necesariamente de grupo; si sus posibilidades dependen de los recursos con los que cuenta el Estado y si su aplicabilidad tiene que manejar los conflictos de capacidad, si es que quiere evitar la infrarrepresentación cualitativa, como sucede ahora mismo en el Comité Central del Partido Comunista de Cuba con la promoción de negros(as) por ser tales, la acción afirmativa tendría un efecto virulentamente negativo. Aquí los destinatarios potenciales son algo parecido a una mayoría. (Cuesta MORÚA, sem data: I4).

Como o artigo não traz data, não é possível precisar exatamente quando foi escrito. De qualquer forma, é em período posterior a 2003, tempos em que no Brasil já se desenvolviam ações afirmativas em várias universidades pelo país, mesmo que de forma incipiente e posteriormente à posse do então presidente Lula. Ao contrário do que propõe o autor, as ações afirmativas foram fundamentais ao Brasil para reduzir a grande iniquidade existente no acesso ao ensino superior. Não se constituem como o único caminho, obviamente, mas tornam o trajeto mais curto para uma inclusão mais imediata da população negra. Por si só, não rompem outras barreiras como a fragilidade de acesso à educação nas etapas anteriores de ensino ou mesmo as condições para a permanência na universidade, por isso a necessidade de ser integrada a outras políticas públicas. Após a execução mais consistente das ações afirmativas no ensino superior no país, é possível aferir um aumento significativo de estudantes negros nessa etapa de ensino:

\footnotetext{
Uma boa notícia é o aumento de estudantes negros nas universidades. O número de negros (soma de pretos e pardos, pela metodologia do IBGE) na educação superior mais do quadruplicou no período de 1997 a 20II. Se considerarmos a população com idade entre 18 e 24 anos, a proporção de jovens negros passa de 4\% em I997 para 19,8\% em 20II. Certamente os debates sobre as políticas de ações afirmativas e sobre a necessidade de políticas públicas voltadas para a inclusão social dos negros bem como a adesão a essas políticas por parte de muitas universidades federais e estaduais contribuíram para o crescimento registrado. Entretanto, cerca de $80 \%$ dos jovens negros ainda não têm acesso ao ensino superior. Os dados demonstram a necessidade da Lei de Cotas e de políticas que promovam um percurso escolar consistente até a chegada à educação (LÁZARO et al., 2012: 6).
}

Em um estudo sobre a inclusão étnica e racial no Brasil (2005), José Jorge de Carvalho apresenta dados que mostram o impacto do racismo no ensino superior. No início dos anos 2000, os negros representavam cerca de $2 \%$ dos universitários e os pardos cerca de I4\%. Apesar de não 
haver naquele período informações relacionadas ao quesito raça/cor, a pesquisa feita pelo professor junto a um conjunto de universidades federais revelou que menos de $\mathrm{I} \%$ do corpo docente dessas universidades era composto por negros. Esse quadro fez com que ocorressem as primeiras iniciativas de ações afirmativas para a promoção da equidade do ensino superior junto aos segmentos raciais mais discriminados. A Universidade de Brasília foi uma das pioneiras, que passou a implementar o sistema de cotas a partir de 2004238. Os dados referentes à inclusão desse segmento nessa universidade são emblemáticos:

Os dados [...] mostram que a UNB já incluiu em 2012 um total de $41 \%$ de estudantes negros (o que é mais do que o dobro do que ela incluía no ano 2000, antes da implementação das cotas). Contudo, a população de pretos e pardos no Brasil como um todo é de 50\%; no Distrito Federal é de 56\%, o que significa dizer que se o sistema de cotas for interrompido, a igualdade racial proposta pelo plano de metas não será alcançada em sua plenitude (Relatório de 10 anos de implementação do Sistema de Cotas da UnB, 2013: 25)".

Em uma análise mais global feita por Lázaro e numa análise mais localizada da implementação das ações afirmativas no ensino superior no Brasil, feita no contexto da Universidade de Brasília, é possível perceber os avanços obtidos e os desafios ainda existentes para romper com as amarras do racismo nessa instância. Portanto, retomando o artigo de Morúa sobre as ações afirmativas no Brasil, cabe mencionar sua descontextualização e não aplicação na realidade. A universidade, de forma universal, é acessada no contexto brasileiro e cubano apenas por uma parcela da sociedade. Ela por si só se situa num lócus mais restrito de acesso à educação. O que é fundamental é que esse espaço seja equânime quanto à representação da sociedade dos segmentos étnicorraciais existentes. A alarmante desigualdade brasileira nesses espaços tem caído também pelos efeitos combinados das ações afirmativas e das políticas universais, apesar de ainda ser considerável a diferença entre os segmentos étnicorraciais.

De acordo com o mapa das ações afirmativas no Brasil, realizado pelo Instituto de Inclusão no Ensino Superior e na Pesquisa da UnB, I28 instituições de ensino superior possuem alguma forma de ação afirmativa, havendo ainda uma maior presença da ação afirmativa para estudantes de escola pública. Os programas de cotas dessas I28 instituições estão assim divididos: IIO para

\footnotetext{
${ }^{238}$ No artigo, "A Legitimação do Intelectual Negro no Meio Acadêmico Brasileiro: Negação de Inferioridade, Confronto ou Assimilação Intelectual?", LIMA (200I), o então estudante de doutorado relata a situação de violência racial sofrida no âmbito universitário embranquecido. Esse foi um dos casos que embasou a proposta de Cotas na UnB, no início dos anos 2000.
} 
escola pública, 66 para indígenas, 53 para negros, 35 para pessoas com deficiência, 25 para residentes da região, I4 para estudantes de baixa renda, 07 para quilombolas ${ }^{239}$.

A partir da lei n I2.7II, de 29 de agosto de 2012, as ações afirmativas nas universidades devem ser implementadas por todas as instituições de ensino superior. Em alguns casos, a lei representa um retrocesso em relação às experiências já existentes, como o caso da Universidade de Brasíliaa ${ }^{240}$. Mas no caso de uma grande parcela das instituições pode significar um avanço, ainda que tímido dado as suas limitações. De qualquer forma, representa uma resposta concreta às históricas demandas do Movimento Negro brasileiro. A educação e acesso ao ensino superior sempre compôs o histórico de lutas, desde a Frente Negra Brasileira nos anos 1930, do processo de organização do movimento em âmbito nacional na década de 1970, na mobilização negra na Constituinte, na Marcha Zumbi em I995, dentre outros marcos.

No caso cubano, há um crescimento da desigualdade no acesso à universidade em relação ao contexto anteriormente citado da década de 1980. As políticas universalistas e amplas da Revolução propiciaram, como visto anteriormente, um quadro praticamente nulo de iniquidade no ingresso na universidade entre os grupos raciais. No quadro anteriormente descrito, em comparação com EUA e Brasil, Cuba apresentava uma realidade de equiparação talvez não alcançada em outra nação proveniente da realidade colonial.

Cuba tem como princípio a universalidade e gratuidade da educação, sem distinção de sexo, raça ou extrato social. Algumas ações da Revolução foram muito emblemáticas nesse campo, como a já citada Campanha de Alfabetização massiva. Com relação ao ingresso no Ensino Superior, até a década de 1970 era realizado sem exame e com livre seleção do curso. A partir da década de 1980, se incorporam os exames de ingresso como requisito para cursos universitários.

Os impactos desse acesso amplo à universidade se refletiram também na ocupação dos postos de trabalho, inclusive em cargos de direção. Os dados de ocupação dos anos 1980 demonstram que persistiam diferenças associadas a cor da pele, mas indicava que negros e mestiços ingressaram massivamente nos setores mais atrativos, como postos técnicos e de direção (DE LA FUENTE, 1998: 27-30).

Todavia, os impactos do período especial e das mudanças posteriores à década de 1990 são significativos para esse crescimento da desigualdade racial nessa esfera do ensino. De acordo com

${ }^{239}$ Fonte: Instituto de Inclusão no Ensino Superior e na Pesquisa da UnB, 20 I I.

${ }^{240}$ Vide relatório de I0 Anos de Ações Afirmativas na UNB, 2013. 
Yulexis Almeida (20I4), na última década, houve retomada de crescimento de matrículas no acesso ao ensino superior, em relação à década anterior:

\begin{tabular}{c|c} 
Ano/Período & Total de Matrículas \\
\hline $2000-2001$ & I28.403 \\
\hline $2005-2006$ & 487.539 \\
\hline $2006-2007$ & 658.134 \\
\hline $2007-2008$ & $743.979^{241}$ \\
\hline
\end{tabular}

Figura 23: Quadro do número de matrículas no ensino superior, Cuba, 2000 a 2008. Fonte: ALMEIDA, 2014.

A composição racial dos estudantes em cursos regulares diurnos teve, contudo, crescimentos antagônicos. Há o crescimento sintomático da desigualdade no acesso ao ensino superior entre brancos e negros (incluindo os "mestiços"), tendo esse último segmento diminuído sua participação consideravelmente nos últimos anos, conforme tabela abaixo:

Participação dos Estudantes por Cor nas Matrículas do Ensino Superior ${ }^{242}$

\begin{tabular}{c|c|c|c} 
Período & Brancos & Negros & Mestiços \\
\hline $2009-2010$ & $57,5 \%$ & $\mathrm{I} 4,2 \%$ & $28,6 \%$ \\
\hline $2013-2014$ & $73,3 \%$ & $9,0 \%$ & $17,7 \%$
\end{tabular}

Figura 24: Quadro sobre participação de estudantes, por cor, nas matrículas de ensino superior de Cuba. Fonte: ALMEIDA, 2014.

A participação das mulheres vem crescendo nos últimos anos. Considerando que não há dados desagregados por cor, mas que ocorreu uma queda de participação de negros e um crescimento das matrículas no ensino superior de mulheres, é sugestivo que esse fator se deva ao crescimento da participação majoritária das mulheres brancas. Seguem, abaixo, os dados apresentados na tese de doutorado de Yulexis Almeida (2015) sobre o assunto:

\section{Percentual Matrícula de Mulheres no Ensino Superior}

\begin{tabular}{l|c} 
Período & $\begin{array}{l}\text { Percentual das Matrículas de Mulheres no Ensino } \\
\text { Superior }\end{array}$ \\
\hline I976-I977 & $40 \%$ \\
\hline $2000-2001$ & $60,5 \%$ \\
\hline $2008-2009$ & $63,2 \%{ }^{244}$
\end{tabular}

Figura 25: Quadro sobre percentual da participação de Mulheres nas Matrículas de Ensino Superior em Cuba. Fonte: ALMEIDA, 2014.

\footnotetext{
${ }^{241}$ Observatorio Nacional Estatístico de Cuba - ONE, 2010: 9.

${ }^{242}$ Dados constantes na tese de Doutorado, pela Universidade de Havana, de Yulexis Almeida (20I4).

${ }^{243}$ Esse percentual não se expressa igualmente nas diferentes carreiras.

${ }^{244}$ Fonte: Observatório Nacional de Estatísticas de Cuba - ONE.
} 
Como destaca Yulexis Almeida (2014), apesar da predominância também de mulheres entre os docentes universitários, essa presença não está equilibrada nos postos de direção com relação a sua proporção na sociedade. Nos cursos de 20I0-20II, as mulheres constituíam 56\% dos docentes, mas eram apenas $38,6 \%$ dos docentes Titulares e representavam $48 \%$ dos cargos diretivos.

Desde o fim dos anos 1990, mesmo com a escassez de dados sobre o assunto, já havia a denúncia de ativistas e coletivos sobre a queda da participação de estudantes negros nas universidades em Cuba. É o que relata Mesa, sobre a denúncia feita pela Cofradía de la Negritud sobre o tema ao ministro da educação da época:

En I999, hicimos una reunión donde hablamos sobre la universidad, pues los negros no estaban accedendo a la universidad. Estaba el lio de los exámenes de ingreso y los maestros, los profesores pagados (que hacían la preparación). Los negros dejaran de ir a la universidad. Entonces, hicimos un análisis de eso y escribimos una carta pública al ministro de educación denunciando eso. Y nunca nos contestaran. (Entrevista com Norberto Mesa, realizada em 09/07/2015).

Apesar do quadro visualizado nos anos 1980, no qual a situação de acesso à educação superior em Cuba havia atingido um nível bastante equânime e num patamar muito diferenciado em relação aos Estados Unidos e Brasil, o mesmo não se reflete nos dias atuais, pouco mais de duas décadas depois. Analisando as informações supracitadas para os casos brasileiro e cubano, percebe-se um caminho reverso no qual as ações afirmativas se constituem como um dos fatores que permitem um crescimento lento e gradual do quantitativo de estudantes negros nas universidades brasileiras e no caso cubano há uma queda acelerada da participação desse segmento nesse nível educacional.

Esse passeio pelo universo das ações afirmativas no Brasil e em Cuba, e sobre o acesso ao ensino superior, possibilita, também, reflexões sobre políticas universais versus políticas focadas, como são as ações afirmativas. Cuba, após décadas de processo revolucionário, com uma possibilidade de concretizar ampla universalização dos serviços educacionais, atingiu um patamar próximo da equidade populacional no que se refere às matrículas nesse nível. Todavia, a escassez de recursos e a séria crise econômica na qual a sociedade cubana está imersa trouxeram impactos globais, desde a renda das famílias até limitações nas políticas públicas. No cenário de escassez, a desigualdade racial rapidamente dá os seus sinais em um dos espaços sociais mais sensíveis: o acesso ao ensino superior.

Por outro lado, o Brasil apresenta um processo bastante diverso no que se refere à universalização do direito à educação, em relação à Cuba. $\mathrm{O}$ acesso à universidade é historicamente mais restrito $\mathrm{e}$ gerou concentração de classe, regional e racial, conforme estudos apontam (LÁZARO, 2012). 
Nos últimos anos, contudo, houve uma considerável expansão das universidades e institutos federais no país, com grande ampliação das vagas. Além disso, foram ampliadas as bolsas para cursos em universidades privadas, parte do programa conhecido como Universidade para Todos Prouni. Essas ações também contribuíram para uma maior representatividade da diversidade da sociedade brasileira no ensino superior. Contudo, as ações afirmativas, como destaca Lazarro (20I2), são um fator determinante para esse crescimento da participação negra nas universidades.

Cuba teve uma experiência significativa com os estímulos afirmativos à participação de mulheres, negros, jovens, nos espaços diretivos do Partido Comunista, iniciada nos anos 1980. Essa ação traz reflexos palpáveis nas Assembleias do Poder Popular e no próprio Conselho de Estado. Contudo, como apresentado anteriormente, essa diversidade de representação na esfera mais elevada desses espaços decisórios ainda reproduz um modelo excludente com mulheres e negros. Os avanços obtidos nas camadas médias desses espaços decisórios, que são relevantes nesse caso específico cubano, são muito vinculados à ação afirmativa levada a cabo a partir do Congresso de I986 do Partido Comunista Cubano.

No encerramento do Terceiro Congresso do Partido Comunista de Cuba, seu Primeiro Secretário (CASTRO RUIZ, 1986: 2) expôs a necessidade de que as mulheres, os jovens e os negros estivessem representados nos diferentes níveis do poder revolucionário: o Estado, o Governo, o Partido, a administração pública em general. Essa proposta foi muito bem recebida pelos que haviam estado sugerindo tal ação. De novo a figura de Walterio Carbonell veio à lembrança dos que sabiam que, em mais de uma oportunidade, ele havia enviado cartas ao nível máximo do Partido expondo a necessidade da representatividade negra. (ROBAINA, 2004: 370-37I).

Como mencionado por Tomás Fernandez, não se pode perder de vista que as vozes que mantiveram um olhar crítico em relação à questão racial durante toda a Revolução, mesmo com as coerções existentes, foram importantes em ações como essa de ampliar a presença de mulheres, pessoas negras e jovens nessa significativa instância de poder cubana. Todavia, o processo de implementação dessa ação afirmativa foi complexo, o que em situações oportunas serviu para deslegitimar a ampliação da estratégia afirmativa em outros espaços, como relata Tomás Robaina:

Sem dúvida operou-se então uma notável mudança (com as ações afirmativas no Partido Comunista de Cuba), mas não se pode afirmar que o balanço final foi totalmente positivo. A orientação não dizia que apenas por ser negro alguém devia ser promovido, mas essa possibilidade foi sugerida fundamentalmente para a promoção de negros e negras que, por seu profissionalismo e experiência de trabalho em suas respectivas esferas, tivessem contribuído para uma imagem que pudesse influir também em outros, para ser tomados como paradigma e promover o interesse pelo estudo e a superação entre os negros. De maneira geral, a orientação não foi interpretada corretamente. Provavelmente foi bem aplicada em muitos casos, mas o que observamos das pesquisas e entrevistas efetuadas, é que nem sempre foram selecionados os mais capazes. Quando foi preciso afastar os que não haviam cumprido as expectativas, o comentário foi uma amostra a mais da existência dos preconceitos racistas, pois não se atribuía a demissão à falta de experiência ou de conhecimento, mas à condição racial. Chama a atenção o fato de que nos casos contrários, o fato de ser negro ou negra não se destacava como exemplo. Mas não podemos ignorar 
critérios ainda prevalecentes que retratam de corpo inteiro os que o emitem quando se encontram diante de um negro altamente qualificado, educado: é um branco em tudo, menos na pele. (ROBAINA, 2004: $37 \mathrm{I})$.

As décadas de ausência de debate sobre o tema racial e o racismo mais uma vez afetaram o processo de implementação das ações afirmativas, como destaca acima Tomás Robaina. As avaliações limitadas sobre a dinâmica de implementação dessa medida, e a própria aversão ao debate aberto sobre a questão racial e às políticas focadas para o tema, podem ter influenciado a não expansão das ações afirmativas para outras áreas.

$\mathrm{Na}$ atualidade, apesar dos dados e das denúncias de coletivos, intelectuais e ativistas, as ações afirmativas não foram expandidas para outros campos importantes da sociedade cubana, tais como as universidades, espaços turísticos (incluindo hotéis e restaurantes estatais ou de economia mista), espaços midiáticos. E com a crescente desigualdade, fomentada especialmente a partir do período especial, cresce a demanda para ampliar essa perspectiva. Todavia, esse é um tema não aceito por muitos no país, inclusive entre os ativistas e intelectuais engajados com o tema:

Nem todos os cubanos que participaram da luta contra a discriminação, desde os tempos mais remotos até o presente, acolheram bem o conceito de ação afirmativa. O referido conceito não era muito conhecido em Cuba, antes de 1959. Depois dessa data, seu emprego em outras latitudes tem sido muito valorizado, mas não sua aplicação entre nós, como uma das alternativas para buscar a solução do problema racial e cultural do negro cubano. (ROBAINA, 2004: 360).

É um debate controverso que congrega diferentes posições. A pesquisadora Niurka Nuñez traz um olhar diferente para nossa reflexão. Ela aborda a dificuldade de não haver um órgão específico na estrutura estatal cubana para atuar com a questão racial, e pontua que antes das ações afirmativas, é fundamental haver mudanças estruturais na sociedade:

Con la universalización (de las políticas) estabas atacando un efecto no una causa. En Cuba se impone prestar atención a situaciones de desventajas estructurales en la base, porque son el sustento de todas las demás problemáticas. Tú puedes trabajar en la lucha contra el racismo, a un nivel ideológico, tu puedes desarrollar acciones afirmativas, tu puedes tomar medidas en una pila de direcciones, que si las condiciones estructurales no cambian, no vas a lograr nada, porque de esas condiciones estructurales se derivan todas las demás. Entonces creo que en Cuba hoy aunque mucha gente lo mira en el contexto comparativo con otras sociedades multirraciales y consideran que Cuba que el problema no es grave, yo pienso que es grave, si es un problema que si no se atiende de manera adecuada puede dar al traste con la unidad nacional. Porque además lastra la dignidad humana. Yo creo que el problema si merece atención particular, que además no ha recibido hasta el día de hoy, porque ha habido intereses sobre el tema. Pero, no ha habido políticas destinadas específicamente al tratamiento de esta problemática. (Entrevista com Niurka Nuñez, realizada em 21/05/2014).

Efetivamente, o racismo estrutural e suas mazelas não serão solucionados apenas pela implementação de ações afirmativas, como Niurka ressalta. Todavia, as ações afirmativas são medidas que permitem em um tempo mais curto a efetivação de parte dos direitos a um segmento populacional historicamente discriminado. Como pontua Gomes (2004), as ações afirmativas são 
medidas para atingir objetivos que seriam inalcançáveis caso a estratégia antirracista fosse restrita a regras meramente punitivas e proibitivas de discriminação. "Não basta proibir, é preciso também promover, tornando rotineira a observância dos princípios da diversidade e do pluralismo" (GOMES, 2004: 55).

As ações afirmativas são demandas importantes, e para além da controvérsia existente, são pautadas por parte dos ativistas. Interessante observar como são construídas as narrativas em torno desse debate da reserva de vagas. Mesmo as narrativas contrárias, como algumas das dispostas acima, abordam a situação de desigualdade existente em Cuba, em relação a negros e brancos. Abaixo, Gisela Arandia ressalta de forma analítica esse debate do universalismo versus focalismo:

\begin{abstract}
Si yo quiero hacer un plan en Cuba contra la pobreza en un país que por 50 años y por siglos ha dicho que no somos racistas. ¿Qué elementos, qué herramientas teóricas practicas, que referencias yo tengo para trabajar esas propuestas? Nos vamos a dirigir a esos grupos a esas comunidades metiendo, como decimos en Cuba, una muela sobre el racismo. ¿Somos racistas o no somos? Eso en realidad no es lo fundamental. Lo fundamental es que tengamos la capacidad, la academia, los escritores, los artistas, el movimiento social, los activistas o ese movimiento social, con interrogación, la capacidad de hacer acciones. Cuando tú me preguntas por qué la acción afirmativa, porque yo deduzco observo y compruebo que hubo un resultado concreto de acción afirmativa. La primera vez en mi vida que visite Atlanta fue así como un choque, porque nunca había visto un lugar, por supuesto en Europa no lo he visto y menos en Paris, una comunidad de negros ricos, de negros pudientes, de negros con conforto. Sobre todo las universidades de Atlanta, hay negros con orgullo, con un gran orgullo de ser negro, con orgullo que se te transmite y la mujer negra, una belleza de mujer negra que ya dejo atrás esas boberías latinoamericanas del pelo no se qué. Sino el esplendor de una esencia de una identidad que a mí me es afín y sí llego a Brasil. [... S Sí, yo quiero hacer un proyecto de políticas públicas. ¿Cual ha sido la política pública relacionada con la racialidad que ha habido aquí, si todavía no tenemos un espacio institucional de Gobierno? Entonces estamos como los bebes, parvulitos. (Entrevista Gisela Arandia, realizada em I2/09/2014).
\end{abstract}

Essa dificuldade de acessar o primeiro escalão, os espaços de decisão, são aspectos presentes na narrativa de muitos ativistas, que conformam suas demandas e suas reflexões sobre as iniquidades existentes no acesso aos espaços de poder. Há, também, o debate sobre assumir a identidade afrodescendente, negra, nessas instituições, num revés da negação do processo de branqueamento e invisibilidade:

Fue siete años presidente de la Asociación de Escritores, siete años y medio director del Fondo cultural de Casa de las América, entre otros. En todos esos espacios, los ejecutivos, la gente profesional de la junta de la directiva, te encuentras muy pocos negros, siempre encuentras muy pocos negros. Y los negros que estamos allí siempre estamos apartados, no creamos una relación cómplice de trabajo ni hablamos sobre nuestra condición de negro. [...] Yo creo que es un déficit de la baja autoestima y creo que tiene que ver con que hay un peso muy fuerte allí en defender una cultura eurocentrica o en defender una manera de pensar, como se dice en Cuba: vamos hacer las cosas como los blancos. Es decir, para hacerlo bien, vamos hacer las cosas como los blancos y siempre pensando en hacer las cosas como los blancos, en mantener una discreción en no decir nada como negro porque quizás sea un complejo que tú tengas, complejo de inferioridad que sientes o como un complejo de superioridad también. Yo creo que se pierde la oportunidad de decir que formamos parte de una diferencia, que formamos parte de una diversidad y que formamos parte de un dialogo que no está resuelto si no hablamos de esas cosas con determinada tranquilidad, honestidad, naturalidad y eso no es lo que suele ocurrir aunque en Cuba se está hablando de que debían haber más negros en espacios de dirección, 
debían haber más negros en espacios donde hay pocos, en espacios de la economía dura, allí donde no hay, generalmente son los espacios de poder. (Entrevista com Roberto Zurbano, realizada em I5/10/2014).

Essa perspectiva impacta na visão socialmente construída da questão, sobre o estereótipo daqueles que são "naturalmente" conformados para ocuparem determinados espaços. É uma seleção, na maioria das vezes, não explícita, mas que conforma a desigualdade na dimensão concreta. E o debate se estende para um panorama mais amplo que a cor da pele, que o fenótipo. Permeiam os históricos familiares, a autoestima, o identificar-se ou não identificar-se com esses espaços de poder, as estratégias sutis de manutenção do status quo. Se por um lado, a dimensão racial pode ser um fator de exclusão, como ocorre com a população negra e indígena em muitos países da América Latina, por outro, pode ser um fator de inclusão, que é o privilégio da branquitude. Abordarei, a seguir, um trecho da entrevista com Roberto Zurbano, onde alguns desses elementos estão presentes:

En Cuba se está hablando de que debían haber más negros en espacios de dirección, debían haber más negros en espacios donde hay pocos, en espacios de la economía dura. Allí, donde no hay, generalmente son los espacios de poder, y son muchos los espacios de poder. [...]Pero, también si los negros alcanzaron un alto nivel de profesionalidad, un alto nivel de educación, pues podrían poder compartir espacios en el poder también y no es lo que ocurre. Lo que ocurre es que siempre encuentras muy pocos negros allí, y para estar allí como negro no estás allí en tanto negro, puede que estés por tu color, pero no por tu pensamiento, no puedes pensar como negro, aunque seas un negro, no puedes pensar desde tu condición racial humana. [...] Es importante si tú estas allí como mujer, o como homosexual o como religioso, que defienda esa condición. Porque otras personas defienden otras condiciones, su condición militar, su condición de hombre blanco. Lo defienden aunque no lo digan que están defendiendo un interés una tradición y un privilegio. El privilegio blanco cubano esta tan visible porque el blanco esta tan visible. Pero, como fueron mis abuelos, yo no tengo la culpa, dice el nieto del esclavista. Pero bueno, el heredó todo lo bueno del abuelo. [...] Entonces como no se habla de eso la gente cree que no sea importante hablar de eso. Yo creo que forma parte de ese silencio, de ese complejo que hay que romper. [...] Yo he hablado con jefes míos, y me decían que de niños ellos daban clases de piano o de ballet, o iba a ver la opera y eran adolescentes Esa historia nunca la oí en mi familia. Entonces, pienso que eso se hace por una cantidad de gente explotada y oprimida para que los niños vayan a un lugar como esos. Yo sé que ella no es culpable pero tiene que saber de algún modo que eso no era casual. Como para mi está claro, estoy consciente que no es casualidad que mis abuelos vinieran acá, como transacción de colonización y de guerra que llegaron aquí, y yo soy resultado de ese proceso. Entonces como soy consciente del resultado de ese proceso soy consciente de una lucha, soy consciente de una atención emancipatoria que no ha desaparecido, de una atención por mejorar por superarnos, por ser iguales que no ha desaparecido y no quieren luchar no para ser superior a nadie, sino para ser igual. (Entrevista com Roberto Zurbano, feita em I5/I0/20I4).

Refletir sobre o "privilégio branco", nas palavras de Zurbano, ou sobre o conceito de branquitude, é fundamental para a compreensão da dinâmica do racismo e das relações raciais. Cardoso (2010) define genericamente a branquitude como a identidade racial branca, construída e reconstruída histórica e socialmente, a partir das influências locais e globais. Há nuances, por exemplo, entre os diferentes países, como África do Sul, Brasil, Venezuela, Bolívia e Estados Unidos $^{245}$. A branquitude seria o lócus de privilégios simbólicos, subjetivos e objetivos que

${ }^{245}$ Conceito dialogado com outros autores apud CARDOSO (20I0): HUIJG, (2007); BENTO, (2002); SOVIK (2004). 
contribuem para a construção social e reprodução do preconceito racial, discriminação racial e racismo (CARDOSO, 2010).

José Jorge de Carvalho (2005) faz uma reflexão da branquitude a partir da conscientização de seu próprio espaço de homem branco na sociedade brasileira:

Todos nós, brancos, nos beneficiamos cotidianamente, e de um modo ilícito, por vivermos em uma sociedade racista. São inúmeros privilégios, pequenos, médios e grandes, que nos ajudam a manter vantagem e concentrar mais recursos. Na medida em que o racismo brasileiro opera no cotidiano, nós brancos somos diariamente favorecidos com algum capital (social, econômico, cultural) que foi distribuído desigualmente segundo critérios raciais: do tempo menor de espera para ser atendido no espaço público a uma carta de recomendação, a um contato importante no mundo do trabalho, a um reforço psicológico da imagem pessoal, ou a uma nova fonte de renda. Ser branco no Brasil é levar vantagem diária sobre os negros. Mesmo não existindo raças no sentido biológico do tempo, a representação social da diferença é racializada fenotipicamente - basta olhar para a televisão, das novelas à publicidade. (CARVALHO, 2005: 97).

Irene Esther, ativista antirracista, relata na entrevista duas experiências vivenciadas dias antes do nosso encontro em julho de 2015 que reforçam como o privilégio da branquitude se expressa em alguns dos meios de comunicação de Cuba:

En las dos últimas semanas, la semana pasada y la anterior (segunda metade de julho de 2015) han ocurrido algunos hechos en la televisión: primero yo conozco que existe un documento por las investigaciones que he hecho sobre la discriminación racial en la televisión en que dice muy claro que no se puede discriminar a nadie por opción sexual, por color de la piel está escrito. Pero eso no se está cumpliendo porque hace unos días sencillamente salió en Hola Habana, que es un programa del Canal Habana, salió una promoción de un casting que estaban haciendo para jóvenes de determinada edad para seleccionar para bailar un dramatizado. Fue dicho que era exclusivo sólo para niñas de piel blanca. Eso no tiene nada que ver con el proyecto Revolucionario. Después de eso se dio en la televisión cubana a un programa que se llama de "Arte y de Corte", en el canal educativo, sobre el peinado y el maquillaje. Ha habido muchas protestas de que nunca ponen nada para negras y para mujeres mestizas y para la gente de pelo rizado. Hace una semana, ponen un programa para arreglarles del pelo y para maquillar las muchachas, y como respuesta ponen una negra. Lo primero que hicieron fue lacearle el pelo para después de laceárselo peinar. Pero no solamente eso, cuando la van a maquillar, el maquillista empezó hacer reducir el grueso de los labios y la nariz abultada. „Eso es una vergüenza! $\mathrm{O}$ sea, para que luzcan bien tienes que dejar de ser negra y semejarte al prototipo que tenemos de mujer blanca. Si nosotros en los medios de comunicación no revisamos estos problemas, ¿que va pasar cuando vengan los americanos que matan a los negros en la calle y que los tienen en los guetos, y que los tienen en el mundo de la droga y los tiene sencillamente en los lugares socialmente más discriminados? (Entrevista com Irene Ester Ruiz, realizada em $01 / 07 / 2015$ ).

De acordo com Frankenberg (1999, apud CARDOSO 2010), a branquitude seria o lugar estrutural através do qual o sujeito branco vê a si próprio e aos outros a partir de um espaço de poder, privilegiado, confortável. A identidade racial branca não é uma identidade marcada, por ser compreendida como padrão normativo único, sinônimo de ser humano ideal.

Outros trabalhos sobre o tema contestam a visão da branquitude como uma categoria não marcada. O processo de colonização delimitou essa diferenciação entre europeus, africanos e 
indígenas. Essa marcação, obviamente, esteve amparada pela construção hierárquica dessas identidades (SANTOS, 2006, apud CARDOSO, 2010).

Matt Wray diz que a definição da branquitude como norma, geralmente seguida pela ideia de que ela é invisível, acaba por privilegiar o ponto de vista dos brancos, que sem se enxergarem, acabam por não questionarem suas vantagens raciais (WRAY, 2004, apud CARDOSO, 2010). A mídia, a escola, os livros didáticos, os círculos sociais, as percepções que são passadas nos núcleos familiares. Colocações muito usuais em Cuba e no Brasil como "estás adelantando la raza"246", "se não suja na entrada, suja na saída", ou "cabelo ruim" e "cabelo bom" são apenas alguns dos muitos exemplos que reforçam os espaços hierarquicamente marcados, dos privilégios da branquitude, como a inteligência, a beleza, a riqueza, e o espaço de estigmatização do negro, feio, rude, pobre.

Como destaca Lawrence (2004), a supremacia branca é uma ideologia historicamente edificada. Do ponto de vista institucional, o sistema colonial perpetuou a exploração e opressão de continentes, nações e povos. Para fundamentar essa exploração, a construção do marcador da desumanização pela raça esteve sempre presente, com o objetivo de manter e defender um sistema de riqueza, poder e privilégio. Esses conceitos continuam sendo ressemantizados no presente, sem contudo, no senso comum, ter alterada sua relação de valorização.

Ainda, de acordo com a autora, o privilégio branco é um direito, vantagem, imunidade, especialmente concedido a um indivíduo ou grupo, e negada a outros. É um sistema que perpetua prejuízo preferencial. Em um sistema de supremacia branca, privilégio branco e opressão racial são dois lados da mesma moeda .

É uma perspectiva que guarda raízes com teorias da superioridade ariana, a partir das construções do contexto colonial, tais como defendido por Gobineau:

\footnotetext{
"A raça suprema entre os homens é a raça ariana, da qual os alemães são os representantes modernos mais puros. Todas as civilizações resultam das conquistas arianas sobre os povos mais fracos; começaram todas a declinar quando o sangue ariano diluiu-se por cruzamentos. Os brancos ultrapassam todos os outros em beleza física. Os povos que não têm o sangue dos brancos aproximam-se da beleza, mas não a atingem. De todas as misturas raciais, as piores, do ponto de vista da beleza, são as formadas pelo casamento de brancos e negros" (GOBINEAU, I853, apud MUNANGA 1999: 43).
}

As mobilizações antirracistas, portanto, permeiam a sociedade em sua complexa gama de relações. Sujeitos que se autodenominam brancos são tão importantes para esse processo como sujeitos que se autodenominam negros e indígenas. A consciência do sistema opressor por parte de sujeitos

\footnotetext{
${ }^{246}$ Tradução minha: está adiantando a raça.
} 
situados no lócus privilegiado branco e sua ação de contestação desse processo, é fundamental para gerar uma quebra nesse ciclo.

Todavia, a naturalização e contínua reprodução das desigualdades e dos privilégios historicamente construídos só geram uma reafirmação da lógica racista. E a quebra desse status quo desigual passa, também, por repensar a conformação dos espaços de poder. Se a dinâmica de privilégios é uma construção social, a sua desconstrução também pode ser. As ações afirmativas é uma das possibilidades para esse caminho, como os dados referentes a Cuba e Brasil demonstram.

Para além dos instrumentos que possam ampliar a participação de segmentos étnicorraciais em diversas instâncias da sociedade, cabe fazer um destaque às demandas de ativistas e coletivos no que se refere à própria estrutura estatal para tratar o tema. Não existe uma instância focada para a questão racial no país, no âmbito governamental, como destaca Gisela Arandia:

\footnotetext{
La segunda fase de Color Cubano ${ }^{247}$ no se pudo concretar, que era la creación de una oficina de Gobierno. Yo no voy a pedir que haya un Ministerio, yo no voy a pedir que haya una Seppir, pero tiene que haber algo parecido a eso porque ni ARAAC, ni la Cofradía (de la Negritud), ni la Comisión Aponte (lo son). Tiene que haber un proyecto de las instituciones en un país donde la institucionalidad ha alcanzado una solidez mundial. Hoy [...] se ha demostrado (resultados) con la Educación, con la Salud Pública, con la Cultura, Deporte. Un país ya que ha creado un sistema institucional sumamente solido, que es demasiado vertical pero que puede modificarse y ser horizontal, ¿porque lo más difícil es crear esa estructura? [...] Entonces la televisión como dice Desiderio Navarro se puede resolver en 24 horas, si llaman por teléfono: yo no quiero más discurso racista en la televisión. Eso es una metáfora, pero hay que tener una voluntad política. (Entrevista com Gisela Arandia, realizada em I2/09/20I4).
}

Portanto, os desafios hoje apontados por ativistas requerem a revisão da participação nas instâncias de poder no país, sobretudo as mais elevadas, para possibilitar uma participação equânime dos vários segmentos representativos da população. Também indicam a necessidade de que as estruturas institucionais do Estado cubano reflitam essa preocupação e possam implementar, entre seus órgãos, uma atuação mais focada com o tema, inclusive com a criação de alguma instância que coordene essas políticas voltadas para a equidade e a superação do racismo.

\subsection{A Cor dos Números}

Essa seção é dedicada a analisar as formas de representação desse agregado abstrato denominado população cubana, suas características de "cor" e como essas abstrações numéricas se materializam para traçar indicações sociais e econômicas sobre a sociedade cubana. A qualificação das pesquisas

\footnotetext{
${ }^{247}$ Projeto voltado para a pauta racial e a superação do racismo. Foi vinculado à UNEAC e extinto em 2009, quando é criado em seu lugar a Comissão Aponte. Mais informações no capítulo 4.
} 
censitárias para o quesito "cor" é uma das principais demandas dos coletivos e ativistas com relação à luta contra o racismo em Cuba.

É relevante avançar na qualificação de informações e estudos sobre as relações raciais para se ter uma melhor dimensão e compreensão dos efeitos do racismo na sociedade. Por sua vez, essa visão mais complexa do fenômeno possibilita propor ações e políticas mais efetivas, para fortalecer o diálogo com o Estado.

As discussões, feitas previamente a essa seção, apontam para o histórico de desigualdade acentuado entre brancos e negros no contexto cubano anterior à Revolução de 1959 (colonial e republicano). Havia desde espaços segregados, como parques, praias e clubes até instituições e empresas com quase nula presença negra entre seus funcionários, como bancos e empresas elétricas. O lócus marginal, da subalternidade, construído no contexto colonial foi, portanto, incrementado no período republicano por fatores que complexificaram as estratégias do racismo, reificando a partir de mecanismos novos sua manutenção.

As mobilizações negras foram significativas no período republicano e incorporaram desde a formação de partidos políticos cuja pauta central era a racial, como o Partido Independientes de Color, à atuação e defesa da luta antirracista em sindicatos e partidos com pautas mais amplas, como o Partido Comunista de Cuba, ou, ainda, nas conhecidas "sociedades de colot", com caráter oficialmente cultural e recreativo, mas redutos de forte mobilização política negra. Muitas das demandas e bandeiras apresentadas por esses ativistas do tema eram embasados em dados estatísticos socioeconômicos, como no trecho destacado a seguir:

En 1942, la tasa de escolaridad descendió a un 31\% la más baja de todo el período republicano [...] Esto era en especial cierto entre los negros, cuyos índices de alfabetización descendieron un 2\% entre I93I y 1943, mientras el de los blancos permaneció igual. [...] Como afirmó en 1936 la Convención Nacional de las Sociedades Cubanas de la Raza de Color, el número relativo de negros que asistía a las escuelas sufrió un descenso considerable. Además, estas sociedades también fueran afectadas por la crisis y algunas tuvieran que cancelar sus actividades, incluyendo la instrucción (DE LA FUENTE, 2014: 185)

Essa análise educacional feita, a partir dos dados oficiais, pelas "Sociedades Cubanas da Raça de Cor" compôs um informe que fundamentava suas denúncias da situação de agravamento no acesso à educação para negras/os naquela década, desde o princípio dos anos 1930 até o início dos anos 1940. Ou seja, faz tempo que os dados oriundos de pesquisas e investigações, como os Censos, são utilizados como uma ferramenta de denúncia e de qualificação das demandas por direitos. 
Do final da colônia até a Revolução socialista, foram realizadas seis pesquisas censitárias em Cuba, nos anos 1899, 1907, I919, I931, 1943 e 1953. Em todos esses, com maior ou menor grau, há dados desagregados por cor da pele, o que factível fazer uma série histórica. Com relação à proporção de negros, mestiços e brancos, por exemplo, é possível verificar como se deslocou essa proporção ao longo dos anos em Cuba, no quadro abaixo:

\section{Los Censos de Población en Cuba: fecha de realización, población y estructura por color de la piel}

\begin{tabular}{|c|c|c|c|c|c|}
\hline Añ̄o & Población & Total & Blancos & Negros & $\begin{array}{c}\text { Mestizos o } \\
\text { mulatos }\end{array}$ \\
\hline 1774 & 171620 & 100,0 & 56.2 & 29.3 & 14.5 \\
\hline 1792 & 273979 & 100,0 & 48.8 & 34.4 & 16.8 \\
\hline 1817 & 553033 & 100,0 & 43.2 & 40.1 & 16.7 \\
\hline 1841 & 1007624 & 100,0 & 41.5 & 48.7 & 9.8 \\
\hline 1861 & 1366232 & 100,0 & 56.8 & \multicolumn{2}{|c|}{$43.2(1)$} \\
\hline 1877 & 1509291 & 100,0 & 650 & \multicolumn{2}{|c|}{$35.0(1)(2)$} \\
\hline 1887 & 1609075 & 100,0 & 67.6 & \multicolumn{2}{|c|}{$32.4(1)$} \\
\hline 1899 & 1572797 & 100,0 & 66.9 & 14.9 & 18.2 \\
\hline 1907 & 2048980 & 100,0 & 69.7 & 13,4 & 16.9 \\
\hline 1919 & 2889004 & 100,0 & 72.2 & 11.2 & 16.6 \\
\hline 1931 & 3962344 & 100,0 & 72.1 & 11.0 & 16.2 \\
\hline 1943 & 4778583 & 100.0 & 74.3 & 9.7 & 16.0 \\
\hline 1953 & 5829029 & 100,0 & 72.8 & 12.4 & 14.8 \\
\hline 1970 & 8569121 & 100,0 & & & (3) \\
\hline 1981 & 9723605 & 100,0 & 66.0 & 12.0 & 22.0 \\
\hline 2002 & 11173743 & 100,0 & 65.0 & 10.1 & 24.9 \\
\hline
\end{tabular}

Figura 26: Quadro dos Censos de População em Cuba, por Cor, de 1774 a 2002. Fonte: Oficina Nacional Estatística de Cuba. (I) e (2) - As pesquisas censitárias fundiram as categorias não brancos em apenas uma classificação. (3) - O quesito "cor" esteve presente no questionário realizado nos anos 1970, apesar de não ter havido nenhuma divulgação a respeito dos dados coletados.

O quadro acima demonstra que a pesquisa censitária de 1970 não divulgou nenhuma informação sobre a população a partir da variável "cor". Sintomático mencionar, contudo, que esse quesito estava presente nos questionários aplicados, porém jamais foi divulgado nenhum dado sobre essa particularidade da população cubana. Esse fato não é baseado numa simples causalidade. Abordarei algumas das motivações para essa ausência, que têm impacto na forma como os dados dessas pesquisas são tratados atualmente.

A Revolução socialista construiu como narrativa fundante a ideia de igualdade, o que representou uma ruptura com o status quo anteriormente forjado. Em poucos anos, espaços segregados foram extintos e se coloriu universidades e instituições como bancos e repartições públicas, conforme já trabalhado.

A construção da perspectiva de igualdade alçou níveis elevados que tocou a dimensão do igualitarismo, conceito utilizado por muitos cubanos, onde as diferenças e as desigualdades que 
conformaram socialmente as relações foram em grande medida desconsideradas e suas nuances embaçadas no ideal da unidade cubana. Mencionar ou fazer alusão à cor, à diferenças ou à desigualdade racial passou a ser interpretado em muitos espaços macro e micropolíticos como uma afronta ao projeto inclusivo "todos somos cubanos".

É significativo ponderar o peso que teve o reforço da Revolução na ideia de igualdade sobre os mais pobres, onde os negros estavam sobrerepresentados, como destaca De La Fuente (20I4: 35I). Nessa análise, os números também possibilitam um vôo sobre as políticas implementadas nesses primeiros anos da Revolução:

\footnotetext{
"Este buscaba beneficiar a los más pobres, donde los negros estaban masivamente representados. Además, la capacidad del gobierno de influir en las prácticas de contratación aumentó de manera significativa cuando, en el otoño de 1960, las industrias y compañías extranjeras y nacionales empezaron a ser nacionalizadas. En 1963, el 70\% de la agricultura, el 95\% de la industria y el transporte, el 75\% del comercio minorista y el I00\% de las actividades bancarias estaban bajo control directo del Estado, que se había convertido en el empleador principal de Cuba".
}

Todavia, a política estatal não possibilitou abarcar diversas fissuras essenciais que estiveram e ainda são presentes, não apenas de forma subjetiva ou como resquícios de uma herança colonial e republicana anterior. Muitos dos mecanismos de reprodução do racismo foram reposicionados e readequados na sociedade cubana, o que se refletiu no silenciamento para esse debate, na pouca e muitas vezes estereotipada presença negra no cinema e televisão, na invisibilidade dos estudos sobre fatos históricos que marcaram profundamente a sociedade cubana e que tinham como um dos eixos centrais o racismo, na baixa presença negra na alta hierarquia política e econômica do país, na estigmatização de tradições de origem africana, como a Santeria, Palo Monte e os Abacuá, como vistos nas seções e capítulos anteriores.

A ruptura significativa de um amplo sistema segregacionista por classe e cor nos primeiros anos da Revolução é relatada com ênfase por ativistas e estudiosos do tema. Os poucos dados disponíveis de pesquisas oficiais também indicam para uma redução abrupta do analfabetismo e da inclusão nas várias etapas educacionais também da população negra.

Todavia, uma análise mais ampla e criteriosa dos impactos sobre a população negra das ações e políticas igualitárias implementadas pela Revolução, do ponto de vista socioeconômico, é ainda bastante limitada. Há grande escassez de informações sobre a situação nesse período. Desde o princípio da Revolução até a atualidade, foram realizadas pesquisas censitárias nos anos 1970, I98I, 2002 e 20I2. Todas elas incluíram o quesito "cor" em seus questionários. Houve uma ampla captação desses dados, mas pouca informação foi divulgada sobre esse quesito. De acordo com o levantamento feito por Loveman (20I4: 24I) sobre as pesquisas censitárias e o quesito 
"cor" na América Latina, Cuba e Brasil são os dois países com mais ampla captação de dados por $\mathrm{raça} / \operatorname{cor}^{248}$ :

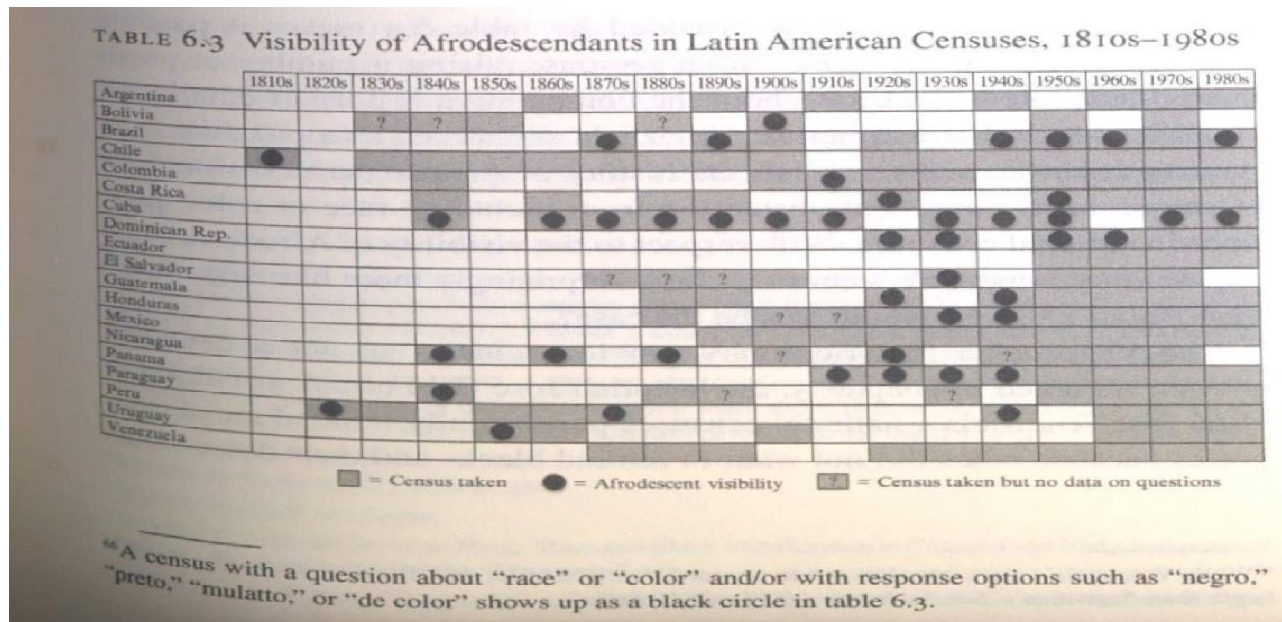

Figura 27: Levantamento feito por Loveman (2014: 24I) sobre as pesquisas censitárias e o quesito "cor" na América Latina. Cuba e Brasil são os dois países com mais ampla captação de dados por raça/cor, conforme quadro.

Porém, essa ampla captação de dados não está presente nas análises e estudos publicados sobre a sociedade cubana pelo Estado cubano. O primeiro deles, de 1970, não divulgou nenhuma informação sobre o tema. O censo de I98I divulgou poucas e limitadas informações desagregadas por cor. Uma das disponibilizadas refere-se à proporção da população por cor, conforme quadro e gráfico comparativo entre os censos de I98I, 2002 e 2012, logo abaixo:

Censos de População de Cuba, por Cor da Pele - Série Histórica

\begin{tabular}{c|c|c|c|c}
\hline Ano do Censo & \% Brancos & \% Negros & \% Mestizos & \% Asiáticos ${ }^{249}$ \\
\hline I98I & 66,0 & I2,0 & 21,6 & 0,3 \\
\hline 2002 & 65,0 & 10,1 & 24,1 & - \\
\hline 2012 & $64, I$ & 9,3 & 26,4 & - \\
\hline
\end{tabular}

Figura 28: Quadro sobre proporção de população cubana por cor, de I98I a 20I2. Fonte: Censo de Cuba I98I, 2002 e 2012.

Para além de mensurar o quantitativo de pessoas por cada segmento racial, são poucos os dados socioeconômicos disponibilizados com essa estratificação. Dentre as poucas estatísticas oficiais que pude acessar em Cuba, está o censo de 2002. De acordo com essa pesquisa, a população cubana era de II.I77.743 de pessoas, sendo 5.597.233 homens e 5.580.5I0 mulheres. A

${ }^{248}$ Essa imagem foi apresentada por Graciela Morais Silva, na palestra "¿Como investigar raza en America Latina?", realizada durante Seminário em Havana, Cuba, em julho de 2015, promovido pela Casa de Altos Estudos Don Fernando Ortiz e a Universidade de Harvard, em referência à pesquisa de Loveman (20I4).

${ }^{249}$ A partir de 2002, a pesquisa censitária excluiu questões específicas sobre asiáticos. Não localizei uma justificativa oficial para essa ausência. No diplomado que cursei em 2014 de Antropologia, parte da turma alegou que essa exclusão foi feita pela baixa densidade demográfica dos considerados "asiáticos". 
composição racial era de 7.27I.926 brancos, I.I26.894 negros e 2.778 .923 mulatos (ou mestiços). ${ }^{250}$

Sem perder de vista os múltiplos interesses que podem estar presentes em contestações de dados do Estado cubano, explicito divergências quanto à proporção racial entre negros e brancos no país. De acordo com o Instituto para Estudos Cubanos e Cubano-Americanos da Universidade de Miami, $62 \%$ da população do país seria negra, enquanto as estatísticas do censo do governo cubano afirmam que $34,9 \%$ da população era negra/mulata em $2002^{251}$. Outros estudiosos sobre a questão racial em Cuba também afirmam que apesar de oficialmente ser reconhecido como um país com maioria branca, a partir dos dados censitários, Cuba é um país de maiora negra (HELG, 2004).

Qualificar as pesquisas censitárias é um dos pontos muito reivindicados pelos ativistas e coletivos antirracistas de Cuba. Eles questionam a qualidade dos dados, a metodologia e a forma como essa informação é sistematizada a partir do quesito "cor". Há ponderações desde a forma como o próprio quesito é preenchido (onde pode ser muitas vezes arbitrariamente marcado pelo entrevistador, com base em seus critérios pessoais, sem respeito à autoidentificação dos entrevistados), até a profundidade dessa avaliação nos dados de emprego, moradia e outras informações socioeconômicas relevantes, além de ponderarem sobre a necessidade de ampla divulgação desses resultados.

\footnotetext{
La ausencia de un censo nacional de población y viviendas (el ultimo databa de 198I) que además considerase la categoría de color de la piel, impidió, hasta hace poco, hacer análisis más fundamentados. El censo de 1981 fue totalmente insuficiente para valorar en serio la situación de la población negra y mestiza en Cuba. Los resultados logrados no son del todo confiables. Se dice que aproximadamente $67 \%$ de la población cubana es blanca y que un $33 \%$ es negro o mestizo. Para el censo del 2002, se asume que la población blanca es de un 66\%, la negra de un I2 y la mestiza de un $22 \%$. Las cifras pareces falsas. Es común aun en Cuba conocer personas que no se asumen como negros o mestizos, sino como blancos, cuando en realidad no lo son. Eso puede ser resultado del fenómeno de la llamada auto discriminación. Ha sido tan absurda la actitud asumida ante el problema, que se ha privado al país de registrar cuanto se ha avanzado en este campo. Fenomeno que queda connotado en general por el llamado "blanqueamiento". (Domínguez, 2012: 176).
}

As demandas apresentadas por coletivos e ativistas incluem outros diagnósticos, como os realizados nos bairros pelo Poder Popular. Em alguns casos, a iniciativa de inserir o quesito "cor" e divulgá-lo parte dos próprios ativistas, como destaca Maritza López:

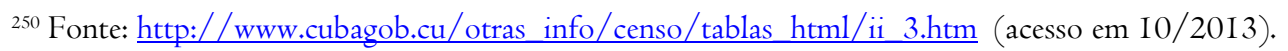

${ }^{25 I}$ Fonte: http://www.miamiherald.com/multimedia/news/afrolatin/part4/index.html (acesso em I0/2013)
} 
[...] Nosotros estamos impulsando para este mandato que se va abrir después de abril, un diagnóstico participativo en la comunidad, y lo primero que hicimos antes de implementarlo fue capacitar a la presidenta del CP y a la vicepresidencia de la asamblea, porque con esto del reordenamiento de la sociedad, cuando no se tienen en cuenta esos datos a la hora de trazar políticas públicas, es fatal lo que pasa. Es la experiencia que nosotros tuvimos, que no creo que Cuba entera la vaya a implementar, porque hemos vivido siempre antes de aprendizaje de que hablar de racismo nos divide. Es al revés, no hablarlo es lo que nos divide, por eso la Comisión Aponte, por eso ARAAC. Porque por ejemplo: mira el cabello de ella y mira el cabello mío, y mira el tuyo, y lo que se dice usualmente es: la pasa, mira él como tiene el suyo. Porque una de las premisas que tenemos nosotros es desaprender lo que se aprendió, romper las visiones racistas". (Diálogo realizado com Martiza López, em I4/09/20I5).

Há um reforço, nesse caso, de contrapor uma das principais barreiras que surgem na justificativa de ocultar o item "cor" de pesquisas e investigações sociais, ou de que dar visibilidade a esse tema "nos divide". O discurso e a narrativa de igualdade estão muito presentes no imaginário coletivo sobre a questão racial. Em uma conversa com a então vice-presidente do Poder Popular de Matanzas, Beatriz Zulueta, esse elemento é explicitado de forma enfática. Ao perguntar a ela se havia dados que referendavam a informação que ela nos dava de que o bairro de La Marina, de Matanzas, era um bairro negro, a seguinte justificativa foi apresentada:

\footnotetext{
(Beatriz Zulueta) - [...] imagínese un lugar (La Marina) donde la gran mayoría, que mira yo creo que eso ni se ha sacado, la gran mayoría somos negros.

(Bárbara) - En los datos hablan de eso...

(Beatriz Zulueta) - No, yo creo que ahí no está tipificado cuantos, no. Porque la idea en esto no es dividirnos, es sumarnos, entonces yo no hago nada con dividir que en La Marina hay, un ejemplo: de los I20 mil habitantes, hay I00.000 que son negros, hay I0.000 mestizos y hay 6.000 que son blancos. No nos hace falta eso, lo que nos hace falta es que los 126000 se sientan partícipes de La Marina, no nos hace falta saber si quien es blanco, moreno o colorado. (Entrevista realizada em I3/09/2014).
}

Essa narrativa talvez representa uma das causas e justificativas da ausência dessa informação desagregada de forma mais ampla nos dados divulgados das pesquisas censitárias em Cuba. Obviamente outros fatores podem justificar essa ausência, como o próprio cuidado de não expor possíveis gargalos e situações desiguais num contexto com fortes resquícios de Guerra Fria. Os resultados práticos são, contudo, concretos. Os gargalos na divulgação dos dados do Censo ainda se apresentam como uma grande dificuldade, apesar dos avanços já alcançados nos censos de 2002 e 2012, em comparação com I98I e 1970.

Entre os dias I4 e I5 de junho de 20I5, após uma longa busca no sítio do ONE - Observatório Nacional Estatístico de Cuba, observei que os dados disponibilizados ao público, desagregados por cor da pele, eram muito reduzidos. Contemplam a contagem populacional, percentual de empregados e desempregados, situação de vínculo matrimonial, local de residência (urbano ou rural).

Um dos motores de desigualdade nos últimos anos são as remessas de recursos provenientes do exterior e o acesso a empregos e atividades no âmbito da economia emergente. São aspectos 
fortemente denunciados por ativistas como um dos lócus de iniqüidade racial na atualidade. No Seminário Internacional "Identidades y Movilizaciones Colectivas", realizado em abril de 2015, em Havana, foi apresentado, por Pablo Rodriguez, informações sobre as remessas:

\begin{tabular}{l|l|l} 
Indicadores & Millones de pesos & $\begin{array}{l}\text { Relación con masa de } \\
\text { dinero de las remesas }\end{array}$ \\
\hline Gastos corrientes del Estado & $4 \mathrm{I} . \mathrm{II} 8$ & $\mathrm{I}, 22$ \\
\hline Consumo de los hogares - 20I3 & $4 \mathrm{I} .658$ & $\mathrm{I}, 20$ \\
\hline Salario y otras remuneraciones - 2008 & $\mathrm{I} 9 . \mathrm{I38}, \mathrm{I}$ & $2,6 \mathrm{I}$ \\
\hline Gastos en adquisición de bienes & $23 . \mathrm{II} 6,4$ & $2, \mathrm{I} 6$ \\
\hline
\end{tabular}

Las remesas unos 2.000 millones por $25=50.000$ millones

Figura 29: Quadro comparativo sobre remessas em Cuba. Fonte: RODRÍGUEZ RUIZ (20I5).

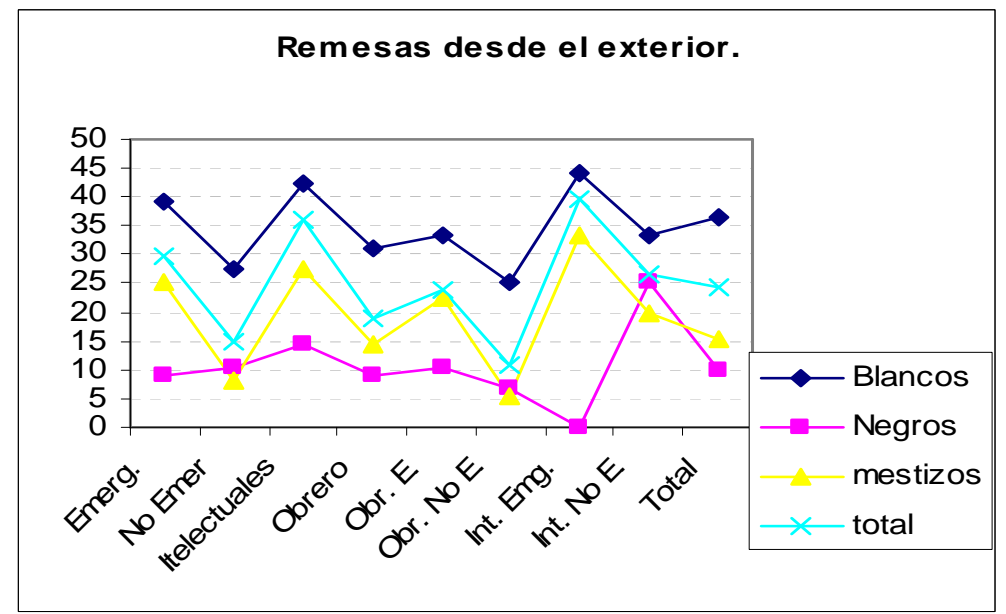

Figura 30: Gráfico sobre participação das remessas, por ocupação e cor da população cubana (20II). Fonte: GONZALEZ et. al. (20I I). Pesquisa realizada entre 1993 e 2003, pelo Instituto Cubano de Antropologia sobre as relações raciais em Cuba. Trecho sobre relações raciais e o mundo do trabalho, realizada em Havana, Santiago de Cuba e Santa Clara, com 518 indivíduos, organizada por setores da economia.

Os dados vinculados às remessas, aos setores de trabalho e à economia emergente, desagregados por cor da pele, apesar de existirem e serem captados nos Censos cubanos, não são disponibilizados. Os dados mostrados anteriormente referem-se a uma pesquisa amostral, realizada pelo Instituto Cubano de Antropologia, concluída em 2003, e um compilado de informações sobre valores das remessas de diferentes períodos posteriores.

Mesmo sem uma melhor qualificação e profundidade dos dados, as poucas informações disponíveis já assinalam grande disparidade de acesso às remessas entre brancos em contraponto aos negros e mestiços. Em todas as categorias analisadas na pesquisa (respectivamente: economia emergente, não emergente, intelectuais, trabalhadores, trabalhadores emergentes, trabalhadores não emergentes, intelectuais emergentes, intelectuais não emergentes), há uma sobrerepresentação dos brancos em todas elas com relação às remessas recebidas do exterior. Os mestiços e negros 
estão abaixo da média nacional, estando os negros situados na rabeira do acesso a esses recursos provenientes do exterior.

A partir da análise do quadro acima, é possível aferir a importância das remessas para Cuba, que chegam a representar mais que o dobro em valores absolutos do que a receita gerada pelos salários no país. Essa relação, de acordo com o gráfico apresentado por Pablo Rodríguez, do Instituto Cubano de Antropologia, é de 2,6I vezes. Ou seja, a receita gerada pelas remessas supera em 2,6I vezes a receita gerada pelos salários no país.

No artigo intitulado "El color de la piel y el racismo en Cuba", publicado no Diário de Cuba ${ }^{252}$, Jorge Calaforra destaca a limitação de acesso aos dados estatísticos no país e apresenta aqueles que teve acesso. Dentre os apresentados, destaco aqui as referências à emigração e às remessas. De acordo com o autor, a emigração externa é branca em $83,5 \%$ dos casos, I2\% é mestiça e $4 \%$ negra. A população não branca, em geral, emigrou em datas mais recentes e ocupa postos com menor remuneração no exterior, o que impacta em sua menor participação nas remessas enviadas a Cuba.

Outro elemento apresentado pelo autor, que também impacta nas desigualdades econômicas crescentes a partir das mudanças econômicas dos anos 1990, é o fato do setor produtivo do campo, que reúne cooperativas e agricultores, quase não reunir pessoas negras (negras e mestiças, de acordo com as classificações cubanas do Censo). Em 2002, apenas 2\% dos agricultores particulares e $5 \%$ dos membros das cooperativas com maior rentabilidade eram negros e mestiços. Por fim Calaforra (2015) destaca dados semelhantes ao de outras pesquisas (como GONZALEZ et al., 2011), que demonstram que nos anos 1990, havia uma sobrerrepresentação dos negros entre os setores mais empobrecidos e vulneráveis da população.

Com vistas a aprofundar o estudo desses aspectos, entrei em contato telefônico, no dia I5 de junho de 2015, com o ONE e perguntei à funcionária que me atendeu onde poderia encontrar as informações mais detalhadas e desagregadas vinculadas ao quesito "cor". Por telefone, a técnica de estatística, que preferiu não se identificar e apresentou apenas o seu cargo, me guiou gentilmente pelo sítio na internet para localizar os dados disponíveis desagregados por "cor". O universo de dados era o mesmo que eu anteriormente já havia encontrado no sítio.

Ao questioná-la sobre quais seriam os caminhos possíveis para acessar os dados não disponíveis coletados no Censo de 2012 e em outras pesquisas do Observatório, a funcionária respondeu:

${ }^{252}$ Disponível em: http://www.diariodecuba.com/cuba/I4267I005I_I3475.html (acesso em I7/09/20I5). 
Os dados disponíveis são os que estão no sítio ou em nossas publicações. Os demais dados, e nesse nível de desagregação que a senhora solicita, ou não estão autorizados para publicação ou não existem [...] A solicitação para acessar esses dados só pode ser feita pela direção do Instituto ao qual está vinculada em Cuba. Após o envio da solicitação, será avaliado se o pleito será atendido ou não ${ }^{253}$.

Essa breve narrativa dá um pouco o panorama de tensão que rodeia e circunda a produção, publicação e o debate relacionado aos dados por raça/cor em Cuba. Acredito que três fatores são fortemente presentes na construção desse contexto atual. $O$ primeiro deles refere-se ao discurso construído após o início dos anos 1960 de que em Cuba o racismo teria terminado ou estaria em processo de extinção, pois era apenas um resquício da sociedade colonial e burguesa, e que esse tipo de categoria "raça ou cor" passaria a não ser mais relevante nas pesquisas sociais em Cuba, exatamente pela não existência do racismo e a não importância desse quesito para as relações sociais. Um dos resultados práticos disso é a não divulgação de nenhuma informação baseada nesse quesito no censo de 1970. Apesar de não haver a defesa monolítica por parte do Estado da exclusão dessa informação, até os dias de hoje há resistência em avançar na qualificação, divulgação e reflexão pública desses dados desagregados por cor, como expressado pela então vice-presidenta do Poder Popular de Matanzas (conforme entrevista acima).

O segundo ponto refere-se ao receio do uso político desses dados por grupos considerados como antirevolucionários e contrários ao regime cubano. Uma parte da oposição interna ao regime e ao governo socialista é composta de organizações negras. Mesmo nos coletivos que compõem a chamada "dissidência", que não tem esse debate racial como ponto específico de sua atuação, uma parte não desprezível é composta de negros e negras. De La Fuente destaca que a presença negra nessa parcela não é irrelevante:

\footnotetext{
La crisis de los (19)90 erosionó algunos de los logros emblemáticos de la Revolución Cubana hasta un grado tal que, los jóvenes negros ya no perciben la restauración del capitalismo como un retroceso importante. La incapacidad del gobierno cubano de mantener sus niveles anteriores de bienestar social, el deterioro de los servicios que aún subsisten y la introducción de limitadas reformas de mercado, con su legado de desigualdad creciente y polarización social, son factores que han contribuido a minar la legitimidad del orden político. Debe destacarse, también, que la participación de los afrocubanos en el movimiento disidente interracial está lejos de ser despreciable; algunos de los líderes más conocidos de la oposición, como Vladimiro Roca y Feliz Bonne Carcassés, son negros o mulatos (DE LA FUENTE, 20I4: 425).
}

O terceiro ponto refere-se à estratégia de controle e manipulação dos dados para os usos e interesses do Estado cubano. Uma vez que as vivências empíricas da grande exclusão da população negra de setores emergentes da economia, como o turismo, não são comprovadas publicamente com dados oficiais e mais globais, os queixumes de ativistas e organizações antirracistas do país com relação a esse tema não ganham força como reivindicação.

\footnotetext{
${ }^{253}$ Tradução minha.
} 
Isso ocasionaria duas situações que poderiam interessar em alguma medida a dimensão do controle estatal: a atividade turística, uma vitrine de Cuba, estaria preservada de um desgaste relacionado ao tema racial; o Estado não seria tão pressionado a realizar profundas alterações no status quo hoje vigente para o setor emergente e para as novas políticas econômicas que vêm sendo colocadas em prática.

Os motivos supracitados, que provavelmente não esgotam as possíveis causas, não se apresentam como justificativas para furtar a sociedade cubana de ter acesso a esses dados. Se os motivos pelos quais esses dados não são divulgados referem-se a outra ordem, também acredito que a não explicitação dos mesmos se configure como o mais tortuoso dos caminhos. Nenhuma das três possíveis causas listadas acima é oriunda de algum posicionamento oficial. Não há uma justificativa do por que esses dados não são públicos. Essas são conclusões minhas a partir do estudo da realidade cubana.

No caso brasileiro, o acesso aos dados desagregados por raça/cor e a melhora da qualidade dos mesmos foram fatores cruciais para qualificar e avaliar o papel do Estado na superação dessas iniqüidades e injustiças no acesso a políticas públicas e a direitos, como a universidade, mercado de trabalho, espaços de chefia, renda, condições de moradia, saúde, dentre outros. Foram décadas de pressão dos movimentos negros e de pesquisadores até que houvesse uma melhora na captação dos dados, sistematização e divulgação no país.

Em Cuba, os censos e pesquisas também estão na pauta de ativistas e coletivos antirracistas. Em um debate organizado pela "Casa de Altos Estudos Fernando Ortiz", sobre pesquisas censitárias na América Latina, no dia 03 de julho de 2015, foram discutidas as situações de Brasil, Colômbia, dentre outros países. Uma das participantes, ativista e pesquisadora do tema, Yulexis Almeida, reforçou a escassez e a limitação de dados estatísticos sobre o acesso à educação superior desagregados por cor da pele em Cuba, o que dificulta a própria compreensão da questão, não apenas para os estrangeiros, mas também para os próprios cubanos que sentem o crescimento da desigualdade, mas poucos elementos têm para compreender o fenômeno de forma mais ampla.

Outros ativistas reforçam que a ausência de dados, por um lado, fragiliza as demandas provenientes da mobilização antirracista, e por outro, reflete a resistência ainda existente no âmbito do Estado cubano de lidar com essa temática como uma questão relevante para suas políticas sociais. Irene Izquierdo, ativista e jornalista cubana, reflete sobre esse tema:

\footnotetext{
Si seguimos una secuencia coherente, veremos que una parte del fenómeno está en la desigualdad: No se
} puede negar que hay pobreza. Igual que sucede con el censo de población y vivienda, en el que los números 
no reflejan colores, ni calidad de vida, durante mucho tiempo estuve trabajando en albergados y residentes en ciudadelas, cuyas viviendas estaban en muy mal estado, pero ellos se negaban a abandonarlas para ir a hacia los albergues de la periferia de la capital. Jamás se me ocurrió analizar que aproximadamente entre el 85 y el 90 por ciento de las más de 25 mil familias en esa situación eran negros o mestizos, con bajos resultados docentes y, desde el punto de vista laboral, con los trabajos peor remunerados. Esta vivencia es un alerta y se puede abordar en la prensa, porque esas son personas que reproducen modelos y estereotipos, desde el alcoholismo, la prostitución y el desempleo, hasta el hacinamiento. (IZQUIERDO, 20I5).

O relato de Irene, além de destacar a falta de abordagem das pesquisas e estudos a partir do quesito "cor", também apresenta dois outros aspectos. O primeiro deles é a naturalização da desigualdade, o que gera uma percepção tardia dela própria acerca da sobrerepresentação negra e mestiça (entre 85 e 90\%) dos que estavam vivendo em moradias precárias com risco de desmoronamento, pessoas com as quais ela tinha contato como profissional. O segundo deles é a ausência dessa temática e dessa análise crítica na mídia cubana. Esses fatores geram ciclos que se retroalimentam: a) A ausência dos dados não permite a reflexão sobre a sociedade cubana a partir das desigualdades raciais existentes; b) A naturalização da ausência do olhar sobre a dimensão racial que está introjetada nos próprios sujeitos sociais; c) A não abordagem sistemática da mídia sobre essa temática. Esses são fatores que geram influência entre si e que contribuem para o silenciamento e a invisibilidade da questão racial na sociedade cubana.

Como no Brasil, o padrão de classificação racial em Cuba é preferencialmente fenotípico e isso está expresso nas categorias censitárias que são utilizadas. Termos como "negro", "mestizo" e "branco" simbolizam categorias cuja significação é um constructo social a partir de atributos físicos como cor da pele, traços fenotípicos (nariz, boca, cor e tipo de cabelo). Esteban Morales destaca esse sobrevalor do fenótipo nas relações raciais em Cuba:

A diferencia de lo que tiene lugar en Estados Unidos, donde en algunos estados la discriminación se ejerce sobre la base del componente negro en la sangre, en Cuba ello no tiene la mayor importancia, pues lo determinante si se va a ejercer la discriminación o no, es el color de la piel. El prejuicio se ejerce sobre la base de la apariencia y no del componente genético; lo que parece hacer más fácil el caso de Cuba, pero no lo es, dado que la carga de componente subjetivo en el sentido ideológico-cultural es demasiado fuerte y resistente a su eliminación. (DOMINGUEZ, 20I2: II5).

Em Cuba, em pesquisas censitárias, foram incluídas as categorias "blanco", "negro" e "mestizo". Havia também "orientais", mas foi excluída a partir de 2002, pois, de acordo com as informações levantadas, foi avaliado que essa representava um segmento muito pequeno da população, cerca de $\mathrm{I} \%$.

No Brasil, em estudos como a PNAD ${ }^{254}$ e o Censo, usa-se a terminologia "raça/cor"255, para aferir a quantidade de pessoas que se distribuem nas categorias genéricas "branca", "preta", "amarela",

${ }^{254}$ Pesquisa Nacional por Amostragem de Domicílios 
"parda" ou "indígena". São categorias problemáticas do ponto de vista da compressão de identidades, mas por outro lado são importantes para a identificação das desigualdades existentes que são fundadas nas relações socialmente construídas entre esses grupos.

Avançar na qualificação das pesquisas censitárias, no que se refere ao quesito raça/cor, bem como disponibilizar as informações coletadas, de forma abrangente para pesquisadoras/es, ativistas e para a sociedade em geral, são desafios ainda presentes em Cuba. Como demonstrei nessa seção, há uma relativa abrangência na captação dos dados sobre cor em Cuba. Mas, as análises disponibilizadas são muito limitadas para possibilitar um estudo apurado e um debate qualificado na sociedade sobre a questão.

Há uma urgência de que o olhar sobre essa produção de dados seja mais amplo e possibilite reflexões críticas e propositivas. Apenas o reconhecimento do racismo é capaz de promover iniciativas para superá-lo. Por mais que os dados quantitativos sejam uma relativa aproximação da realidade, esses representam alguns dos elementos que propiciam uma melhor compreensão da questão racial. Não é em vão que essa seja uma das fortes demandas do ativismo afrocubano.

\subsection{Racismo Estrutural a la cubana?}

Os principais pontos que abordei nesse capítulo buscam situar como as mudanças estruturais promovidas pela Revolução, nessas quase seis décadas, impactaram de forma profunda a sociedade cubana. Foi um processo amplo de rupturas dos pilares sociais e econômicos anteriores. Inclusive para a população negra as transformações foram muito significativas.

A compreensão dos efeitos, contudo, dessas mudanças foi superestimada. Houve o entendimento que elas significariam o fim de uma ideologia presente nas relações de poder, cujas raízes profundas se materializam nas estruturas da sociedade cubana historicamente ao longo de mais de cinco séculos.

Depois do triunfo da revolução acreditou-se que com apenas o apelo à consciência, e com o acesso objetivo a novos postos de trabalho e aos diferentes níveis de instrução, ficavam eliminados o racismo e seus elementos reprodutores: o preconceito e a discriminação racial. Essa crença trouxe como conseqüência a falta de uma atenção mais cuidadosa para evitar o aparecimento dos preconceitos que havia contra os negros e suas manifestações culturais tangíveis e não tangíveis, herdadas dos africanos e das primeiras gerações de negros nascidos em Cuba. Esse descuido contribuiu para que fossem mantidas

255 Mais informações:

http://www.ibge.gov.br/home/estatistica/populacao/condicaodevida/indicadoresminimos/conceitos.shtm (Acesso em 04/04/20I5). 
práticas discriminatórias e preconceitos levantados pelas classes e setores que impunham seus cânones marginalizadores como uma forma de não compartilhar seus espaços sociais, econômicos, políticos e culturais, ante o temor de perder seus privilégios classistas. (ROBAINA, 2004: 368)

A lógica de superar o racismo apenas com ações focadas para a luta de classes, para a superação das desigualdades materiais e para a universalização de políticas sociais e direitos, sem um olhar específico sobre a questão racial, se mostrou falha. De acordo com Tomás Robaina (2004), após o triunfo revolucionário, acreditou-se que como "apelo à consciência, com o acesso objetivo a novos postos de trabalho e aos diferentes níveis de instrução, ficavam eliminados o racismo e seus elementos reprodutores: a discriminação racial e o preconceito" (ROBAINA, 2004:368). Ainda, de acordo com o autor:

Esse descuido contribuiu para que fossem mantidas práticas discriminatórias e preconceitos levantados pelas classes e setores que impunham seus cânones marginalizadores como uma forma de não compartilhar seus espaços sociais, econômicos, políticos e culturais, ante o temor de perder seus privilégios classistas. (ROBAINA, 2004: 368).

O racismo fundamentou ideológica e politicamente a colonização, a escravização, o genocídio de milhares de povos africanos e indígenas. Houve um processo profundo de desumanização de uma gama de povos. Com relação aos africanos e seus descendentes, esses foram reduzidos a "negros", "de cor". Sob esse signo, pairou a materialização do primitivismo, do animalesco, da não-pessoa. Foi um processo de conquista civilizatória de magnitude talvez nunca antes vista. A vitória viria exatamente pelo aniquilamento do outro.

Essa ideologia de desumanização, de inferiorização, de estigmatização, ainda vigora. Nas pequenas relações ela surge. Quando o cabelo crespo é classificado como "ruim", de "pior qualidade", quando os fenótipos negros são tratados como "feios", "grosseiros", quando a índole e a capacidade dos afrodescendentes é marcada com percepções que reforçam sua "periculosidade", "preguiça", "incapacidade", quando esses fenômenos marcam os cotidianos das micro-relações, estamos ainda falando da perversa ideologia racista que desumaniza.

No momento em que analisamos essas relações numa perspectiva macro, passa a ser mais compreensível porque os afrodescendentes se concentram entre os que vivem em condições mais precárias de moradia, entre os alvos preferenciais para revistas e prisões preventivas ${ }^{256}$. Também, se torna mais compreensível que esses sejam minoritários nos espaços midiáticos, na alta hierarquia de poder, nos locais mais cobiçados do mercado de trabalho ${ }^{257}$.

\footnotetext{
256 Conforme pude demonstrar a partir dos poucos dados socioeconômicos disponíveis, das entrevistas e outras pesquisas feitas sobre o tema. A maior parte desses dados está nas seções anteriores do capítulo 3. ${ }^{257}$ Idem.
} 
As décadas de regime revolucionário demonstram que políticas públicas universais de qualidade, ampliação da oferta de ensino superior, reforma agrária, democratização dos espaços no mercado de trabalho e tantas outras ações promovidas se configuram como uma etapa importante na superação das desigualdades raciais. O fato de encontrarmos uma grande quantidade de profissionais qualificados negros e de não haver praticamente analfabetismo em Cuba, são alguns dos resultados palpáveis dessa realidade.

Contudo, o racismo estrutural está presente, apesar de não haver uma intenção explícita do Estado para tal258, e das iniciativas realizadas nessas décadas com relação ao tema. De acordo com Lewrence e Keleher (2004), o racismo estrutural é um sistema hierárquico e desigual, caracterizado pela supremacia branca, a partir do tratamento preferencial, de privilégios e poder, para os brancos, em detrimento dos negros, povos originários e outros grupos discriminados.

Os indicadores chave do racismo estrutural são as desigualdades nas instâncias de poder, no acesso a bens e serviços, nas oportunidades geradas (por exemplo, no mercado de trabalho ou educação), no tratamento e nos impactos produzidos por políticas e resultados (como as de segurança pública), sejam eles intencionais ou não ${ }^{259}$. Racismo estrutural seria mais difícil localizar numa determinada instituição, porque envolve os efeitos reforçadores de várias instituições, normas e padrões culturais, originários no passado e ressignificados no presente, produzindo continuamente o re-produzir de velhas formas de racismo (Lewrence et al., 2004: 0I).

Ainda segundo os autores, o racismo estrutural está permeado nos alicerces da sociedade. Abarca a história que ampara, de forma subreptícia, a base para a supremacia branca, a cultura da vida cotidiana que naturaliza a reprodução do racismo. Ademais, as instituições e políticas interconectadas, assim como os relacionamentos e regras chave no meio social, provêm legitimidade e reforçam a manutenção e perpetuação do racismo. Exemplos incluem a história do racismo, representações culturais dominantes, mitos populares e iniquidades sobrepostas e crônicas (Lewrence e alli, 2004: 0I-02).

As informações levantadas pela presente pesquisa, tanto primárias ou secundárias, indicam que em Cuba o racismo estrutural impacta em diversos aspectos, de forma prejudicial, os negros e negras, e gera vantagens relativas para os brancos. A convivência com práticas racistas, sejam elas realizadas pela polícia, manifestas em espetáculos teatrais e de comédia ou mesmo nas relações

${ }^{258}$ A não intenção explícita para tal, abordada na frase, refere-se ao fato de que não existem legislações em Cuba que explicitamente excluam grupos raciais do acesso a bairros, espaços educacionais e laborais, dentre outros aspectos segregacionistas. Contudo, os dados coletados indicam a existência de iniquidade crescente.

${ }^{259}$ Destaque meu. 
estabelecidas na escola, sem uma adequada punição e coerção das mesmas, acaba gerando sua perpetuação. Os dados, oriundos das narrativas e aquelas provenientes das pesquisas feitas, demonstram uma dificuldade de acesso à justiça para as vítimas de racismo no país.

Os meios de comunicação, na atualidade, contribuem muito pouco com ações concretas de superação do racismo (IZQUIERDO, 2015), e em alguns casos tem veiculado conteúdos que potencializam os fenótipos estereotipados e preconceituosos sobre a representação negra.

A produção de dados sobre o tema ainda é muito incipiente. Há que se reconhecer o avanço significativo na produção nos últimos anos. Todavia, no que se refere à divulgação ampla de dados do Censo cubano, desagregados por cor, que permitam uma melhor avaliação da situação socioeconômica, ainda tem-se um longo caminho a percorrer. Também são escassas as pesquisas nas ciências sociais voltadas ao tema, que envolvam trabalho de campo (como a realizada com GONZALEZ et al., 20II). A invisibilidade e escassez de produção científica é outro fator preocupante, que traz impactos negativos tanto para o governo, que não tem subsídios sobre o tema para a construção de suas prioridades políticas, quanto para os movimentos sociais, que acabam construindo suas narrativas a partir de experiências vivenciadas, sem possibilidades de transpor a análise para patamares mais amplos da sociedade.

Com o acirramento das desigualdades econômicas e sociais, derivadas do período especial (pós I990 $)^{260}$, dados levantados indicam que os afrodescendentes têm sido um dos segmentos mais vulnerabilizados. Esse impacto é agravado pelas restrições, que muitas das denúncias dos ativistas indicam existir, nos espaços da economia dolarizada, em sua grande maioria vinculada ao turismo, para a contratação de afrodescendentes, especialmente para cargos que têm contato direto com o público. Essa realidade foi encontrada também em alguns anúncios para contratação em restaurantes, com explícita vedação para negros, conforme apresentei em seção anterior nesse capítulo, e em minhas vivências empíricas.

Outra questão central é a escassa presença negra e feminina na alta hierarquia de poder do país. Há o reconhecimento de que houve avanços com a implementação das ações afirmativas, a partir

\footnotetext{
${ }^{260}$ Roberto Zurbano (2012) denomina esse processo mais recente presente nas relações raciais cubanas como "neoracismo". De acordo com esse autor, esse neorracismo "es una lacerante realidad social que viene tomando fuerza en medio de otras desigualdades y conflictos de la sociedad cubana del siglo XXI. (... las) formas de dominación instauradas en lo que Immanuel Wallerstein (I3) ha llamado moderno sistema-mundo, se manifiesta a través de distintas épocas, culturas y estructuras políticas. Es decir, que la dominación -el capitalismo, el racismo, el patriarcado y el imperialismo- se manifiesta bajo cualquier sistema político, directa o indirectamente, pues forma parte de estructuras globales del poder que se expresan, sutil o abiertamente, de maneras muy diversas y (a veces) perversas, como suele ocurrir en la Cuba socialista con el tema racial" (Zurbano, 20I2: I4-I5).
} 
do III Congresso do Partido Comunista de Cuba, focadas para mulheres, negros e jovens. Contudo, essa mudança traz impactos para os níveis médios. Ainda têm pouco reflexo nas camadas mais altas de representação política, como os dados mostrados nesse capítulo buscaram descrever.

Há diversos outros fatores que também contribuem para a percepção dos ativistas de que os negros têm sido impactados negativamente pelas contínuas situações de discriminação racial, agravadas nos últimos anos, em outras esferas sociais, inclusive naquelas que simbolizam as grandes "conquistas da Revolução", como a educação. Um dos exemplos é o caso do ingresso nas universidades, na comparação entre negros e brancos, na qual a iniquidade entre esses grupos vem crescendo (ALMEIDA, 20I4).

Por outro lado, as medidas e respostas dadas a essas denúncias e estudos sobre as iniquidades raciais pelo Estado cubano são avaliadas como insuficientes por pesquisadores e ativistas antirracistas. Para além de medidas punitivas e coercitivas de discriminações raciais, faltam iniciativas propulsoras de promoção da equidade racial, como as ações afirmativas.

As medidas concretas e explícitas para a pauta são pontuais e incipientes, como busquei demonstrar. Além disso, há uma considerável resistência com relação à real necessidade de dar ênfase racial para políticas públicas, talvez gerada pelo mito da igualdade e pelo peso dado à meritocracia. Aplicável em contextos onde há equivalência de condições, a defesa da meritocracia é um dos princípios manifestos na Constituição de 1976 e parece influenciar nesse lento avanço da questão racial no país. Tratar como iguais, sem considerar todo o legado perverso que o racismo promoveu para os afrodescendentes, é contribuir para a manutenção dessa iniquidade.

O legado da Revolução é muito importante para a população cubana em relação a diversos pontos. Em referência aos negros, os efeitos também são significativos. Mas a escolha política pela omissão da questão racial nos debates públicos, na grande maioria das políticas públicas promovidas, além das limitações para assegurar esse direito na justiça, traz máculas profundas para as relações raciais na atualidade.

Após cerca de vinte e cinco anos do fim do bloco socialista, as mudanças econômicas e sociais sinalizam para uma crescente desigualdade entre os segmentos negros e brancos na população cubana (ZURBANO, 2012 e 20I5; MORALES, 20I2; ROBAINA, 2004; ROMAY, 20I3; ALMEIDA, 2014 e 20I5; PRIETO et al., 20I I). Contudo, políticas para coibir esse processo 
não foram explicitamente tomadas pelo Estado cubano, que ainda tem limitações para reconhecer a desigualdade baseada em $\operatorname{cor}^{261}$.

Nessas quase três décadas desde a queda do Bloco Socialista, formou-se uma nova geração diretamente impactada pelos efeitos das radicais mudanças sociais e econômicas. Nas ações implementadas pelo Estado (como a permissão de recebimento de remessas de recursos do exterior e a abertura de restaurantes privados) não foram consideradas essas iniquidades geradas. Foram medidas que tiveram, inicialmente, um caráter emergencial, mas após décadas de implementação, essas são alterações que ganham ares estruturais na atualidade. Essa omissão vem consolidando um retrato desigual.

Os desafios colocados para a superação do racismo envolvem a sociedade civil e o Estado cubano de forma abrangente. Os avanços são consideráveis nos últimos anos na Ilha, mas os desafios ainda são muito grandes, como vem explicitando o movimento antirracista cubano nas últimas décadas. O contexto internacional da Década dos Povos Afrodescendentes, estabelecida pela ONU de 2015 a 2024, é um otimizador dessa pauta e pode gerar reflexos positivos interna e externamente para o avanço na superação do racismo em Cuba e na região.

${ }^{261}$ Conforme o próprio relatório elaborado pelo governo cubano para o CERD (20II) demonstra, quando reduz a presença do racismo às dimensões privadas, sem reconhecer sua presença em outras dimensões da sociedade. 


\section{Capítulo 4 - Fluxos e Refluxos do Movimento Afrocubano}

Siempre nosotros, los cuarenta y cuatro ${ }^{262}$

As mobilizações afrodescendentes em Cuba marcaram o país em momentos importantes, como descrevi anteriormente. Nas lutas abolicionistas, independentistas, na conformação dos primeiros partidos políticos, nas sociedades negras, nos cabildos de nação, nos sindicatos e organizações de base. Especialmente até a Revolução socialista de 1959, esses espaços estavam bastante visíveis e palpáveis na sociedade cubana ${ }^{263}$.

A ideologia, construída no processo independentista e depois reforçada, a partir de particularidades, na Revolução socialista, de buscar a construção de uma nação para todos, foi, por um lado, dinamizadora de ações inclusivas realizadas para a população negra ${ }^{264}$. Por outro lado, essa foi a justificativa para silenciar tantas vezes o debate sobre o tema e limitou a promoção de ações voltadas para reverter práticas discriminatórias e a própria estrutura racista. Especialmente a partir de 1962, quando há o entendimento de que o racismo é um problema solucionado no país, há um crescente abafamento dessas vozes e o cerceamento dos espaços de ativismo afrocubano.

Dentre as organizações afrocubanas atuantes antes da Revolução e que, no período pósrevolucionário, não tardaram em ser fechadas, estão as sociedades negras. Essas sociedades não foram eliminadas automaticamente. Por motivos oficialmente técnicos, como não ter uma licença de funcionamento, elas foram encerrando suas atividades nos primeiros anos da década de 1960, nem sempre de forma consensuada ${ }^{265}$. Como destaca De La Fuente, a manutenção dessas sociedades significava um contínuo obstáculo para a apreensão do discurso oficial que apresentava Cuba como um país em que a cor não era relevante e que estava livre da discriminação.

\footnotetext{
262 Tradução minha: "Sempre nós, os quarenta e quatro".

${ }^{263}$ Alguns acontecimentos trágicos, como o massacre do Partido Independientes de Color, impactou severamente essa mobilização. Mas os espaços culturais, de recreação e sagrados permaneceram nesse período da República. Muitos desses eram as sociedades negras. Por diversas vezes, esses espaços de reunião também protagonizaram articulações políticas importantes para a pauta racial.

${ }^{264}$ Nesse conjunto destaco o direito ao voto no princípio do século XX para negros e brancos; o fato do tema racial ter estado presente nos vários partidos e governos do período republicano, mesmo que muitas vezes de forma manipulada; as ações de inclusão em políticas públicas e espaços anteriormente segregados promovidas pela Revolução de 1959.

${ }^{265}$ O exemplo da União Fraternal é patente disso. Durante sua dissolução, seu presidente enviou carta ao Chefe da Ordem Pública protestando contra a medida (DE LA FUENTE, 2014: 363).
} 
Los clubes daban a los negros y mulatos la oportunidad de articular un discurso común en el que la justicia y la igualdad eran sus propios logros, y no beneficios otorgados por el gobierno revolucionario. "Hay una tendencia - declaró en 1968 una actriz afrocubana - a asumir que la Revolución dio a los negros su libertad, nos dio el derecho a entrar en la sociedad blanca, a tener las mismas cosas que ellos tienen. Es una actitud esencialmente paternalista. Y crea resentimiento". Los clubes y la prensa negra eran canales para articular ese resentimiento y romper el silencio oficial sobre el tema racial. Tenían, pues, que ser eliminados". (DE LA FUENTE, 20I4: 363-364).

Há uma queda acentuada das mobilizações negras após esse período. O Partido socialista, que por décadas no período republicano foi defensor das políticas voltadas para equidade racial, se mesclou à própria estrutura da Revolução e acabou por esvaziar o olhar para o tema. Zurbano traz o questionamento do por que a Revolução não levou em consideração o legado antirracista do Partido Socialista, das sociedades negras, dos cimarrones e dos múltiplos espaços de mobilização negra anterior à Revolução:

[...] resulta difícil saber, a ciencia cierta, cpor qué la Revolución no incorporó el legado antirracista del marxismo cubano anterior a 1959, su legado de conciencia racial y de lucha antirracista que transitó desde el cimarronaje, las conspiraciones, los levantamientos de las dotaciones esclavas y su participación en las tres guerras independentistas del siglo XIX y en el siguiente siglo al Partido Independiente de Color, el sindicalismo cubano y la prensa negra cubana que nace a mediados del siglo XIX y desaparece en I960, junto a las Sociedades de Color? ¿No era suficiente? (ZURBANO, 2012: 22).

Os sindicatos também se tornaram organizações de massa da Revolução e passaram a ter suas prioridades e ações baseadas principalmente nas orientações políticas do partido Comunista, cuja posição nesse momento divergia de uma abordagem explícita sobre o tema racial. Esse é um elemento que ficou explícito no estudo que fiz, nas narrativas de ativistas entrevistados, na consulta à bibliografia relacionada com a questão racial em $\mathrm{Cuba}^{266}$. Um dos sintomas mais significativos desse processo foi o severo silenciamento sobre o tema, como aborda Esteban Morales:

Yo diría que nosotros tuvimos un periodo en que se había dicho que el problema de la discriminación y el racismo estaban resuelto. No se podía hablar de eso. Aunque después se empezó a ver, tampoco se podía hablar de eso, porque había un espíritu de represión social. Pero, también había un espíritu de represión administrativa. O sea, el negro que hablara de eso, o cualquiera que sacara el tema a relucir, era reprimido, reprimido incluso administrativamente, que era botarlo del trabajo. Bueno aquí no se deja a nadie sin trabajo, pero por lo menos trasladarlo de trabajo, con el reconocimiento de que había creado un problema determinado. Yo diría que eso ocurrió hasta el principio de los 1980. De la segunda mitad de los 1980 para acá, empezó a abrirse, yo diría, un debate. (Entrevista com Esteban Morales, realizada em I4/05/20I4).

O discurso 'tabu' sobre a temática racial se contrapunha ao projeto de construir uma nação para todos, onde a cor não fosse relevante. Esse 'mito da igualdade' da sociedade socialista cubana se apresentava como um contraponto à desigual e injusta sociedade capitalista. Zurbano reflete, na entrevista feita, sobre a aversão existente no passado, e ainda no presente, de realizar reflexões

266 Como nas referências: DE LA FUENTE, 20I4; HELG 2002; PRIETO, 2006; MORALES, 20I2; ZURBANO, 2015. 
sobre a questão racial e o racismo, fato ainda mais significativo nas primeiras décadas da Revolução:

Era muy difícil plantear conflicto porque cuando se plantea conflicto en una sociedad socialista tú estás diciendo que la sociedad socialista tiene los mismos problemas que la sociedad capitalista. Entonces el dogma no te permite pensar de esa manera, ni siquiera aceptar la idea de que en el socialismo siguen los conflictos del sexismo, siguen los conflictos de la raza, siguen los conflictos de la participación, siguen todos los demás conflictos. Solo que cualitativamente diferente, solo que el contexto lo revierte, y lo debe asumir de manera diferente, y no se deben silenciar esos conflictos (Entrevista com Roberto Zurbano, realizada em $\mathrm{I} 5 / 10 / 2014)$.

Houve vozes dissonantes que pautaram o tema ao longo dos anos da Revolução. Não se pode falar de uma completa ruptura das mobilizações negras. Muitos ativistas abordavam a temática em diferentes épocas, várias vezes de forma isolada. Nos primeiros anos, ativistas como Waltério Carbonel, Juan René Betancourt, Elvira Cervera e Carlos Moore apresentaram críticas e propostas para ampliar o foco do novo governo revolucionário para esse tema. O destino de muitos deles acabou apresentando fissuras com o processo revolucionário. Carlos Moore, por exemplo, vai para o exílio em 1963, após ter ficado um período na prisão e em Unidades Militares de Ajuda à Produção (UMAP) ${ }^{267}$. Moore, em entrevista a jornal brasileiro, descreve a justificativa que foi dada para sua prisão:

\footnotetext{
"Colocaram-me na Vila Marista, de onde as pessoas só saíam para serem executadas em fuzilamento. Fui acusado de subversão racial, o que era considerado um crime muito grave pelo governo, embora não existisse no código penal. Fidel havia decretado que não havia racismo em Cuba e, se você acusasse o Estado do contrário, estaria cometendo um crime contra o Estado" (Entrevista com Carlos Moore, publicada no Jornal Correio, Bahia, em 02/09/2015) ${ }^{268}$.
}

De forma distinta ao vivenciado por Moore, outras vozes que denunciavam o racismo na época, como Waltério Carbonel, também sofreram processos coercitivos. García (20I4), em um estudo sobre a intelectualidade e o antirracismo em Cuba, menciona Waltério Carbonell como, talvez, um dos intelectuais mais controversos da época. A autora faz uma menção à fala de Esteban Morales sobre ele:

\footnotetext{
"Walterio investigaba en el contexto de una situación en que no se publicaba nada que enfocara los problemas relativos a la existencia de la discriminación racial en Cuba (...), le tocó vivir la fatídica época en que se hacía imposible hablar en presente de un problema que se había dado como resuelto" (MORALES, 2013: 238-239, apud GARCÍA, 2014: 52).
}

\footnotetext{
${ }^{267}$ A UMAP foi uma instância criada para reeducação social e moral, mediante o trabalho. Denominada por muitos como "campos de trabalhos forçados", as UMAP reuniam entre seus internos homossexuais, religiosos (especialmente testemunhas de Jeová, de acordo com Fernandez (2004)), e outros atores sociais "antissociais". Existiu durante os anos 1960 e depois foi extinta.

268 Disponível em: http://www.correio24horas.com.br/single-entretenimento/noticia/em-autobiografia-escritorcubano-fala-da-luta-politica-e-militancia-racial/?cHash=c0406cb480dI71707ba79ddda8972c76 (Acesso em: I0/09/2015).
} 
Alguns dos ativistas que acompanhei durante a pesquisa também relataram experiências vividas de "ajuste social". Parte teve alistamentos ao exército já tardios. Outros permaneceram períodos em UMAP para se adequarem ao comportamento social esperado. Houve muita repressão para abordar o tema ou levantar críticas. As vozes dissonantes eram vistas, muitas delas, como contrarrevolucionárias e foram duramente reprimidas.

Vários desses líderes históricos, que de forma isolada quebraram o silêncio sobre o racismo nesse período, são invisibilizados no país. Porém, surgem nas narrativas de ativistas na atualidade, como destaca Robaina:

No se puede dejar de mencionar que es Carlos Moore el primero que sufre directamente las consecuencias de la discriminación racial en Cuba (pós-Revolucionária). Que para irse de Cuba se tiene que asilaren una embajada africana. Independientemente que él asume después una posición, para mí, inaceptable, pero tampoco podemos obviar ese hecho histórico. Los primeros que hablan de la discriminación racial en el periodo revolucionario son Juan René Betancourt, Walterio Carbonell y Carlos Moore. Posteriormente se escucha una que es un ejemplo que es Elvira Cervera. Ella es la primera que publica un libro, escrito por una mujer negra, donde denuncia el racismo. Y ahí están las cartas que ella envía a Abel Prieto, como Ministro, reclamando los derechos. Hay otro: Como surgió la cultura nacional cubana, de Walterio Carbonell. Pero hay Sixto Gastón Agüero, otro de los olvidados que nadie menciona, que también publica unos libros sobre integración. Lo que hay es una crítica social fuerte sobre el problema de la integración de la población cubana. Entonces estos son los embriones, las manifestaciones de la lucha contra el racismo en esos primeros años. [...] Ese discurso se silencia y se adopta en que solamente por la educación y el tiempo eso se va superar. Pero, van surgiendo voces aisladas, individuales, denunciando esta problemática. Pero es interesante como surgen estas voces, estas voces surgen. (Entrevista com Tomás Fernandez Robaina, realizada em I2/05/20I4).

Roberto Zurbano também menciona essas vozes dissonantes, que abordavam a complexidade das estratégias racistas ainda presentes na sociedade revolucionária, apesar das várias mudanças e rupturas econômicas e sociais promovidas pelas reformas de base pós I959:

La Revolución de Enero destruyó, en gran medida, la estructura económica y social que causaba esta opresión racial, pero no sus profundas estructuras ideológicas y culturales, razón por la cual desde sus primeros años surgen las críticas de importantes intelectuales negros como Juan René Betancourt, Sixto Gastón Agüero, Walterio Carbonell y Carlos Moore, quienes advierten sobre la herencia racista que recibe la Revolución, la describen, según sus diversos enfoques y exigen a la Revolución emprender acciones mediatas para desterrar esta ideología reaccionaria sembrada en la cultura cubana mucho antes de que naciera la propia nación (ZURBANO, 2012: I5).

Essas vozes espaçadas, que denunciavam o racismo em Cuba, como menciona Robaina, perpassaram os anos da Revolução, e foram importantes para colocar o debate em pauta. Nesse período, não se chegou a produzir efeitos coletivos amplos, pois havia um forte cerceamento dessas atividades. O que diferencia esse momento do atual, vivenciado após os anos 1990, é exatamente o caráter mais coletivo e público das lutas antirracistas.

Muitas das críticas feitas destacavam a presença quase irrisória de líderes negros na direção da Revolução. Os negros eram aceitos desde que reproduzissem o "modelo comunista", sem vínculo 
com tradições de matriz africana, como a santeria ${ }^{269}$, a rumba ou cabildos de nação. Muitos foram levados a unidades da UMAP para readequação a uma forma de vida sintonizada com a Revolução, como relatam parte das narrativas. O mesmo ocorreu com homossexuais, hippies, cabeludos, religiosos e outros agentes sociais que destoavam e eram considerados como antissociais.

Outro ponto muito criticado é o que a fala da "atriz afrocubana", mencionada na citação do estudo de De La Fuente (20I4) acima, traz. Na visão de parte dos ativistas, no que se refere à relação entre o Estado cubano e a população negra, havia certa exaustão no tratamento dado à ampliação do acesso à população negra a espaços públicos e direitos como uma benesse do Estado cubano, lógica essa que na visão crítica de muitos era um reforço paternalista.

O debate público do tema racial ganha fôlego e voz, especialmente a partir dos anos 1990 e 2000. Pesquisas, estudos acadêmicos, livros, artigos, debates, seminários e projetos passam a compor o cenário da luta antirracista na Ilha ${ }^{270}$. Nesse contexto, coletividades, organizadas por meio de confrarias, projetos, redes, comissões e articulações surgem e ressignificam o lugar dessa temática na sociedade cubana. A mobilização social foi o alicerce para o processo de estruturação de redes, tramas e andanças que envolvem o movimento de luta pelos direitos dos afrocubanos.

A frase que coloco no início do capítulo: "Sempre nós, os quarenta e quatro" escutei muitas vezes durante minha estada em campo, dita por vários dos ativistas antirracistas cubanos. Ela simboliza o sentimento de que sim existem ativistas e coletivos voltados para a luta antirracista, mas que, por outro lado, esses estão isolados, apartados dos grandes espaços políticos e de visibilidade no país. As dificuldades de mobilização social fora das redes vinculadas à sociedade política e ao próprio Estado, como as chamadas organizações de massa, e a falta de uma legalização desses coletivos são fatores que complexificam essa sensação de isolamento. Essa é uma das questões emblemáticas que os movimentos antirracistas vivenciam na atualidade em Cuba. Daysi Rubiera

\footnotetext{
${ }^{269}$ Vistas como práticas primitivas e animistas e severamente perseguidas por décadas no pós-Revoução.

270 Destaco, aqui, algumas das publicações feitas na nesse período com relação ao tema: De Tomás Fernández Robaina, "El negro en Cuba. 1902-1958. Apuntes para la historia de la lucha contra la discriminación racial en Cuba", de 1990; de Manuel Granados "Apuntes para una historia del negro en Cuba, escrita por un negro en Cuba" e "que Eleguá sea conmigo", de 2005; "Bembé para cimarrones", de 2006, de autoria de Ana Cairo; "Reyita", de 1997, de Daysi Rubiera Castillo e "Golpeando la memoria", de 2005, de Daysi e Georgina Herrera; de William Luis: "En busca de la cubanidad: el negro en la literatura y la cultura cubana", de 2003; "El triángulo invisible del siglo XX cubano: raza, literatura y nación" 2006, de Roberto Zurbano; de Barnet, Miguel, de 201 I, "El tema racial en la sociedad cubana actual: letra y espíritu"; Publicações de coletivos de autores como "Raza y racismo", de 2012 e Indagaciones sobre la cuestión racial en Cuba, de 2013; De Esteban Morales, "Desafíos de la problemática racial en Cuba", publicado em 2008; de Zuleica Romay, de 2012, Elogio de la altea o las paradojas de la racialidad; de um coletivo de autoras, com organização de Daysi Rubiera, o livro "Afrocubanas: Historia, pensamiento y prácticas culturales", de 20 II.
} 
ironiza essa expressão e fala da importância de ampliar esse espectro de atuação para a luta antirracista:

En esa lucha estamos nosotros los 44, que ya no son 44 , ahora son 4 . Son los 44 , los 4 o los I4 allí, discutiendo todas las veces las mismas cosas, diciéndonos lo mismo y mirándonos entre todos las mismas caras. Entonces ahí esa batalla no se va a ganar nunca. Esa batalla se irá ganando en la medida que la población en general conozca que es esto y en ese sentido me moví hacia la Red Barrial de Afrodecendiente, que se crea a raíz de todo el proceso de ARAAC. Creo que en la medida que la población logre tener un real conocimiento de lo que es esto entonces podremos avanzar en la batalla contra la discriminación racial. (Daysi Rubiera, coletivo Afrocubanas, entrevista realizada em 0I/08/20I4).

Mesmo com uma articulação dispersa e um isolamento político, há que se analisar a mudança palpável que ganha fôlego a partir dos anos 1990 e 2000, o que permitiu o ressurgimento dessa pauta e de uma mobilização no âmbito da sociedade civil para o ativismo negro, sociedade civil essa desvinculada das organizações de base da Revolução.

Visualizo quatro fatores que contribuíram para esse novo cenário. O primeiro deles refere-se à alteração nas bases econômicas pós-queda do bloco Soviético que geraram uma crise brutal da economia cubana. O produto interno bruto - PIB, no período caiu 35\% em I993, em comparação com 1989 (GONZALES et al., 200I: 3I) 271. De La Fuente, fala em uma queda do PIB de 1989 até 1993 de cerca de 40\%. Houve uma falência de diversos serviços públicos e um drástico desabastecimento. Produtos básicos, como alimentos, remédios e roupas, em pouco tempo se tornaram muito escassos. Esse processo fragilizou a relação do Estado com a sociedade, e, por sua vez, os mecanismos de controle e a lógica centralizada no corpo estatal. A percepção social dessa ruptura surge nas narrativas de ativistas, como expresso a seguir por Roberto Zurbano:

El Estado centralizo todo, daba toda la comida, daba toda la ropa, daba posibilidades, daba la gasolina, todo. Cuando el Estado no pudo dar nada, que se sintió muy mal, pero la gente sintió una libertad diferente. ¡Ah! Ya el Estado aquel paternalista no me da las cosas pero tampoco me dice que es lo que tengo que pensar, ni como me tengo que vestir, ni como tengo que ser yo. Entonces ahí aparecieron todas las subjetividades, la subjetividad negra, la subjetividad feminista, la subjetividad gay, la subjetividad de la Diáspora. Entonces empieza un replanteo y empieza a replantearse la nación, esta nación que es lo que hemos tenido, resulta ser que lo que hemos tenido no ha sido suficiente, no ha sido todo lo pertinente, no ha sido todo lo justo. Aquí han faltado cosas, cuales, empieza a reconsiderarse la nación, estamos en eso, en eso es en lo que estamos todavía, en esa reconfiguración de la nación. La raza es un factor muy importante y emergen las movilizaciones con una fuerza tremenda. (Entrevista com Roberto Zurbano, realizada em I5/10/2014).

Outro elemento que altera o cenário nos anos 1990 e 2000 são as disputas pelos escassos recursos disponíveis, disputas essas que colocam os espaços laborais vinculados à economia

${ }^{271}$ De acordo com García (20I4: 53), a economia cubana era extremamente dependete do bloco socialista: Para el año I985 la ayuda proveniente de la Unión Soviética (URSS) llegó a alcanzar los 2300 millones de pesos. Hay que destacar que el 88\% del comercio exterior cubano era a través del Consejo de Ayuda Mutua Económica y el $80 \%$ de la inversión externa provenía de los países socialistas. 
emergente num patamar de destaque. Um dos exemplos são as atividades turísticas. Nos anos 1980, havia uma presença significativa de negros entre a força de trabalho desse setor: "El 38\% de los empleados en el sector de servicios eran, segun el Censo de I98I negros o mulatos, un porcentage ligeramente superior a su porcentage en la población"(DE LA FUENTE, 20I4: 409). A partir dos anos 1990, essa presença se reverte na percepção social de muitos cubanos, conforme afirma De La Fuente (20I4), e a disputa aí ganha um viés racial mais significativo. Alguns eventos, vinculados a situações de racismo nos ambientes de trabalho, especialmente no meio turístico, começam a surgir e ensejam ações de contestação dessa violação. Uma das experiências vivenciadas foi relatada por Norberto Mesa, fundador da Cofradía de la Negritud:

Cuando llega el período especial, 1989, 1990, me fue para el turismo. Deje de trabajar en la ganadería y empezó a trabajar en el turismo. [...] Una amiga mía era la jefa de recepción del hotel New York. Ella me llamó para hacer un curso de adiestramiento para turismo. [...] Y empiezo a ver que casi toda la gente que trabaja en la carpeta del hotel es blanca, y que casi no hay negros ahí. Yo estava ahí por las casualidades de la vida $[\ldots]$ pero por los mecanismos normales los negros no entraban. Los que trabajaban ahí eran los blancos. Eran muy poquitos negros. Eso me llamó la atención. [...] Era eso lo que estaba pasando en el turismo. [...] Después busco un amigo mío que era gerente en Marina Hemingway. Él me dice que podía buscar algo para yo empezar a trabajar ahí. Él dijo: "pero no es nada de cajero. Yo te voy a poner a trabajar en un almacén". Yo pregunto: "Pero, cpor qué en un almacén?" Él contesta: Porque en el almacén es donde yo tengo posibilidad. Él me lo dijo claro que ahí, en Marina Hemingway, los negros no podían trabajar en contacto con el público. Eso en 1996. Y me fui, pues eso era demasiado" (Entrevista con Norberto Mesa, realizada em 09/07/2015).

Situações como a relatada por Norberto, que se repetiram em outros ambientes de trabalho, foram conformando um clima de descontentamento com as situações de discriminação em empresas hoteleiras das quais o Estado era sócio majoritário ou único responsável. E a situação de indignação se potencializava exatamente pela extrema dificuldade de se acessar na justiça uma ação de reparação ou, ao menos, de reconhecimento da situação de racismo.

O depoimento abaixo é um dos vários que registrei durante a pesquisa. $\mathrm{O}$ escolhi, pois, nesse caso, diferentemente de outros em que a justificativa dada não era explicitamente racial, há uma nitidez no motivo da demissão da trabalhadora por sua cor. Mesmo nesse caso, o tribunal não considerou relevante a denúncia e o processo foi encerrado por haver o entendimento que o fato julgado não se tratava de um delito.

A través de la abogada defensora mía (en el proceso por discriminación en La Marina Hemingway), yo conocí una muchacha que tenía un hijo enfermo. Había una trabajadora social que la atendía y que consiguió un trabajo para esa muchacha en un comedor del ministerio de comunicaciones. [...] Después de un mes de trabajo, terminaran el contrato con ella. Ella recorrió a la justicia laboral y dijo que necesitaba de ese trabajo para mantener su hijo. Ella fue a ese centro de trabajo con la trabajadora social que la atendía hablar sobre su reincorporación. El gerente dijo a la muchacha: "la cuestión es que ese lugar no está apropiado para personas de tu color". Ella apeló. Fue al órgano de justicia laboral. El órgano de justicia laboral habló a favor de la administración. Y entonces van al tribunal de justicia. La trabajadora social ya en esa etapa del proceso era abogada y la acompaña. En juicio, esa trabajadora social y abogada hace un testimonio de lo que habló el gerente, de que aquel lugar no era apropiado para personas de color. El gerente después de contestar acabó por confirmar que lo había dicho. Justificó que 
estaba ofuscado en aquel día. Mismo con todo eso, el Tribunal Municipal dio su parecer a favor de la administración. Apellaron al Tribunal Supremo, que también dio su juicio final a favor de la administración. Y sacaran la muchacha del trabajo. Mismo en ese caso en que hubo una manifestación explicita. Eso fue en 2009. Ese país es así. Y quién habla de ese racismo fuerte que hay aquí? (Entrevista com Norberto Mesa, realizada em 09/07/2015).

Portanto, o agravamento da desigualdade, os recorrentes casos de demissões de pessoas negras, especialmente nesses espaços laborais de grande disputa, os insucessos nos processos impetrados na justiça e a falta de perspectivas de mudanças ou respostas a esse quadro, foram fatores que motivaram o surgimento dos primeiros coletivos afrocubanos, depois de décadas de Revolução. A Cofradía de la Negritud, por exemplo, surge nesse contexto, no fim dos anos I990.

As mudanças na economia cubana, a partir do período especial, também promoveram o crescimento da desigualdade, mesmo sem uma intencionalidade para tal ${ }^{272}$. Das pessoas que migraram para os Estados Unidos, $85 \%$ se declararam brancos (DE LA FUENTE, 20I4). Portanto, há uma maior concentração dos recursos remetidos ao país as famílias brancas.

Um terceiro fator que marca esse crescimento da mobilização antirracista em Cuba são as relações do país com o cenário internacional. Por mais que haja uma limitada relação tanto do Estado com instâncias multilaterais, como as Nações Unidas, como da sociedade civil com redes internacionais, o contexto especialmente da Conferência Mundial de Durban e seus desdobramentos influenciaram no estímulo ao debate sobre a questão racial em Cuba, e, obviamente, na mobilização de atores sociais para o tema.

Os países da América Latina, muitos dos quais Cuba estreitou relações econômicas e políticas, como Equador, Brasil e Venezuela, tiveram avanços na pauta de institucionalização de políticas de igualdade racial, em maior e menor grau. Além dos governos, os movimentos afrodescendentes desses países também aproximaram relações com vários ativistas antirracistas cubanos. Concepções políticas e ideológicas foram intercambiadas nesses diálogos, como destaca Maritza López, sobre a dinâmica de incorporação da denominação "afrodescendente" ao nome do coletivo do qual faz parte:

En el caso de nosotros los de la Red barrial de Afrodescendiente asumimos el nombre [...] [por] una de las opiniones que nos hizo asumir el tema fue la explicación que dieron lideres como Agustín LaoMontes o Dagoberto de Venezuela, o los colombianos. Desde la izquierda, han asumido el término afrodescendiente con una nueva mirada $[. .$.$] Ellos asumen la afrodescendencia, o termino como$ afrodescendiente, desde la perspectiva que una persona puede medir seis pies, tener el pelo por aquí, los ojos azules y tener un antecedente de origen africano y cuando tu le dices afrodescendiente le estas incluyendo para el lado de acá y a nosotros por la coloración de la piel, más negra, también nos incluyen en la misma medida. (Entrevista realizada com Maritza López, em I5/08/20I4).

272 As remessas de recursos provenientes do exterior, majoritariamente de familiares, foram nesse momento, e até hoje são, um dos fatores que potencializaram as desigualdades, conforme descrito no capítulo 3. 
Essas trocas têm se tornado mais intensas a partir da participação crescente de ativistas em atividades sobre o tema racial em outros países da região. Os intercâmbios de estratégias, visões de mundo, perspectivas políticas são inerentes a esses espaços de interação e também trazem influência para a dinâmica vivenciada pelos ativistas e coletivos em Cuba. Pela escassez de recursos, essas articulações e participações internacionais também são almejadas e disputadas, o que algumas vezes gera conflitos nas relações entre ativistas e coletivos.

Por fim, o quarto ponto, que a partir de minha perspectiva contribuiu para o ressurgir desse ativismo com maior visibilidade, se refere à convergência de ideias, debates, reflexões, trocas, expressões artísticas e intelectuais, pesquisas e redes que ganha fôlego a partir dos anos I990, com crescimento nos anos 2000. Criou-se um ambiente em que ativistas, artistas, intelectuais, educadores populares e outros atores sociais envolvidos com a questão racial pautaram o tema e apresentaram novos paradigmas de discurso, até então invisibilizados pela ideia de nação, pátria, e pelo mito da igualdade. Zurbano aborda essa construção processual de um novo discurso sobre as relações raciais e o próprio racismo, imprimindo um olhar crítico a essas dimensões:

Sin embargo, tales percepciones, durante la última década, están siendo cuestionadas y corregidas por la mirada popular, especialmente en la música popular, el hip hop, la religiosidad afrocubana, el cine, el teatro, las artes plásticas y la literatura cubana más reciente, en particular el ensayo. Desde dichas prácticas culturales y religiosas se están descolonizando los modos de percibir el racismo y comienzan a ser reconocidos los escenarios en que tienen lugar debates y propuestas sobre tales asuntos. Vale destacar la fuerza con que las tecnologías de información (revistas digitales, boletines electrónicos, sitios web y blogs) han construido espacios de divulgación, discusión y actualización permanente sobre el tema, constituyéndose en eficaces espacios para dar visibilidad y legitimación al activismo antirracista, sus debates y protagonistas. (ZURBANO, 2012: 30)

Essa convergência de narrativas, movimentos, mobilizações e discursos fortaceleu o olhar sobre o tema, gerando maior visibilidade e debate sobre o racismo e as relações raciais. Esse processo passou a demandar, especialmente do Estado, uma releitura de perspectivas dogmáticas sobre a questão, como a de que Cuba havia superado o racismo, visão essa amparada em ações, discursos e publicações (Serviat, 1986; Castro 1982, 1984, 1985 apud Gonzales et al., 20I I: 30).

Nesses quatro pontos, percebo a convergência dos fatores principais que contribuíram para a dinâmica de emersão dessas mobilizações antirracistas em Cuba nos anos 1990 e 2000, e seu incremento na atualidade. Os desafios que nortearam e inspiraram muitos desses coletivos e ativistas continuam presentes. Em alguns casos, há sinalizações de agravamento das situações de discriminação, como a crescente iniquidade de acesso a postos nos espaços turísticos e da 
economia emergente ${ }^{273}$. Num comparativo com anos anteriores, contudo, um diferencial de avanço se materializa: a possibilidade de falar sobre o assunto, de ampliar as reflexões para além da dimensão privada e familiar.

Nas entrevistas feitas e na vivência do campo, é possível apontar que o grande avanço para a luta antirracista em Cuba é exatamente a possibilidade de abordar o tema. Muitos dos e das ativistas sofreram, em algum momento de sua trajetória, ações coercitivas. Parte perdeu o trabalho ou cargos de direção, outra foi ameaçada de demissão. Outra, ainda, teve que justificar-se para diferentes atores que questionavam suas manifestações e ações ativistas. Enfim, não se pode dizer que o cenário atual seja plenamente aberto ao debate público, a pesquisas sobre a questão racial, aos meios de comunicação. Há certo controle que paira sobre essas mobilizações. Mas, elas existem, apesar das limitações e das ações coercitivas. O cenário atual, diferentemente de décadas atrás, possibilita que essas vozes sejam escutadas de forma mais ampla dentro e fora de Cuba.

No contexto cubano, o mito da unidade como meta é muito concreto. Há certa expectativa compartilhada entre ativistas antirracistas da importância de haver ícones e líderes que unifiquem as mobilizações e ações coletivas para o tema. Porém, a especificidade desse processo na atualidade é exatamente a multifocalidade e a multivocalidade. As disputas por espaços de protagonismo muitas vezes embaralham esse contexto e ganham tons exacerbados. Contudo, a marca central dessas mobilizações afrodescendentes antirracistas em Cuba é que estão organizadas em uma miríade de iniciativas variadas.

As mobilizações afrodescendentes são múltiplas. Estão dispersas em vários coletivos e trazem propostas e perspectivas muito diversas entre si. Todavia, para muitos, há uma percepção dessa multivocalidade como uma fragilidade para o movimento, ou como um fator "atípico", como destaca Robaina:

¿Yo califico de movimiento atípico por que? Porque por lo general todos los movimientos, y no hay un
solo movimiento, sino que hay un movimiento general que está integrado por diferentes grupos que luchan
por sus derechos desde el punto de vista racial, femenino, etcétera, por lo tanto atípico. Porque no hay una
organización que sea la que lidere, no hay un nombre, un líder que lidere esta lucha. Entonces tenemos que
hablar que hay un movimiento atípico porque cada cual desde su nicho, vamos a decirle aś́, o desde su
espacio. (Entrevista com Tomás Fernandez Robaina, realizada em $12 / 05 / 2014$ ).

${ }^{273}$ Com base nas denúncias de ativistas e vivências da própria autora em espaços turísticos e dolarizados. Não obtive, apesar das inúmeras tentativas, os microdados do censo sobre esse tema para que fosse possível avaliar essa questão do ponto de vista quantitativo. 
Muitos dos coletivos e ativistas remetem, em suas narrativas, à necessidade de uma estrutura verticalizada ou de um líder que centralize essa dinâmica. Na perspectiva de vários entrevistados e entrevistadas, uma das justificativas para a fragilidade das mobilizações afrodescendentes em Cuba seria gerada, exatamente, por essa orfandade da questão racial, que não havia sido abraçada por nenhum padrinho ou madrinha politicamente forte, ou que não tivesse a força agregadora de uma liderança. A comparação é feita, principalmente, com duas outras pautas: mulheres e diversidade sexual.

No caso da primeira, mulheres, existe a percepção de que o papel que desempenhou Vilma Espín, importante liderança da Revolução, esposa de Raúl Castro, falecida em 2007, foi central para o fortalecimento da Federação de Mulheres Cubanas - FMC. A Federação, como mencionei anteriormente, é uma das organizações de base da Revolução, com estrutura descentralizada pelo país e forte ligação com o partido comunista e o próprio Estado cubano.

A FMC teve um papel importante ao debater a ocupação por mulheres dos espaços técnicos e científicos, políticos, de poder econômico, questões vinculadas à saúde da mulher, como o direito ao aborto e ao planejamento familiar. Contudo, há uma percepção entre os ativistas que a atuação e priorização da FMC não incorporou o combate ao racismo, nem mesmo o estímulo às mulheres negras para os cargos principais de direção da Federação. Tampouco, a FMC fez grandes esforços no sentido de tipificar os crimes de violência contra mulher de forma diferenciada, tal qual a caracterização do crime de feminicídio.

Outra pauta que se avançou em Cuba é a de diversidade sexual. Tema bastante complexo na Revolução, que suscitou livros, documentários, denúncias e filmes, como o famoso "Fresa y Chocolate"274. No período que estive em campo, esse tema foi debatido em conferências com milhares de ativistas, representantes do governo e pesquisadores, houve campanhas públicas de combate à homofobia e outras ações vinculadas à saúde e mercado de trabalho.

A mobilização a favor da diversidade sexual ganhou fôlego e visibilidade nos últimos anos no país. A percepção social, com base nas entrevistas realizadas, do processo crescente de incorporação da questão se dá, por um lado, pelas reflexões geradas pelas produções críticas sobre a questão e pelo ativismo de coletivos e sujeitos sociais, mas por outro, também, pela entrada em campo de uma madrinha, que é Mariela Castro, filha de Raul Castro. Mariela hoje coordena um dos principais órgãos de atuação com o tema.

${ }^{274}$ Fresa y chocolate, ou Morango e Chocolate, em português, é filme com co-produção entre Cuba, Espanha e México, dirigido por Tomás Gutiérrez Alea e Juan Carlos Tabío. Filme de I994. 
$\mathrm{Na}$ história pós-Revolucionária, muitas das manifestações e mobilizações para temas específicos foram motivadas por dirigentes ou familiares de dirigentes importantes da Revolução, ou por figuras públicas emblemáticas e também próximas de dirigentes, como é o caso da liberação dos cultos religiosos, nos anos 1990, em grande parte atribuída aos intensos diálogos entre Frey Beto e Fidel Castro, parte deles sintetizados no livro "Fidel e a Revolução".

A pauta de combate ao racismo, mesmo sendo uma das mais fortes e presentes nas mobilizações sociais na primeira metade do século XX, foi muito silenciada e hoje ocupa um espaço de relativo "limbo político". O Estado cubano reconhece que há discriminação racial e que é necessário avançar em ações para o tema, mesmo que reduza o reconhecimento de sua incidência especialmente a espaços privados e não aborde o caráter sistêmico do racismo ${ }^{275}$.

Um dos grupos criados, a comissão Aponte, vinculada à União Nacional dos Escritores, Artistas de Cuba - UNEAC, foi elegida como a interlocutora privilegiada e tem estabelecido agendas mensais com o vice-presidente Díaz Canel, conforme noticiou um de seus representantes no debate televisivo "Mesa Redonda" sobre a pauta racial, transmitida em alusão ao dia 2I de março, dia internacional de combate a discriminação racial e o racismo.

Apesar desses avanços, pouco ou quase nenhum diálogo é estabelecido com os demais coletivos e grupos sobre o tema, dando um tom elitizado ao debate e com pouco eco na alta hierarquia política do país. As ações propostas feitas pela Comissão incluem algumas iniciativas ainda pontuais de revisão, no médio e longo prazo, de livros didáticos, etapa, todavia, incipiente. Traz iniciativas também iniciais de formação de professores, de diálogo e sensibilização dos veículos de mídia. Um dos exemplos dados pela Comissão Aponte de vitória é a transmissão da novela "Cara a Cara", cujo modo como a questão racial é abordada é duvidosa, em que há uma versão embranquecida de um conjunto habitacional popular brasileiro, conhecido como favela, e personagens negros em situação de ascensão social que abertamente criticam as ações afirmativas.

Iniciativas voltadas à melhor regulamentação do crime de racismo, que permitam às pessoas violadas o acesso à justiça, não aparecem na pauta como uma prioridade. Inclusive a posição do presidente da Comissão Aponte, Heriberto Feraudy Espino, destoa de uma criminalização de casos de racismo no meio laboral, como o que ocorreu com o anúncio do paladar que exigia entre os critérios de contratação que fossem jovens brancas e com "bom corpo e figura"276. Portanto,

${ }^{275}$ Como manifesto em seu relatório enviado às Nações Unidas, em $201 \mathrm{I}$.

${ }^{276}$ Descrevo esse caso no capítulo 3, "Viva a Revolução! Abaixo o racismo!" 
apesar dos avanços existentes no reconhecimento do racismo pelo Estado cubano, há enorme caminho a trilhar para uma efetiva explicitação do problema.

Com base nas múltiplas narrativas e vivências que pude ter acesso no período da pesquisa junto a coletivos e ativistas, é possível elencar algumas das prioridades levantadas por esses atores sociais. Apesar de não haver uma concordância ampla, a regulamentação do crime de racismo e o acesso à justiça para as vítimas de racismo aparecem como demandas principais, a partir da perspectiva da grande maioria dos ativistas. Deyni Terry, do coletivo Alianza Unidad Racial, é uma das que destaca a relevância de haver uma lei antirracista efetiva no país ${ }^{277}$.

A esse aspecto legal se soma as denúncias das abordagens corriqueiras da polícia de pessoas negras, especialmente em locais turísticos ou centrais. As averiguações feitas muitas vezes terminam com detenções de algumas horas, mesmo sem haver motivo explícito. A experiência relatada por Norberto Mesa, da Cofradía de la Negritud, reflete a incidência do racismo institucional na polícia cubana:

Yo estuve preso, yo lo puedo decir estuve una noche preso por ser negro aquí en zapata. Yo voy estando en el hotel trabajando y una pareja de canadienses me invitan a ir con ellos a Zorra y Cuervo (Casa de Jazz). Dije que sí. Entonces, pasamos por la rampa ahí donde empieza y entonces están los policías allí y pasamos y nadie nos dice nada. Llegamos a la zorra y el cuervo, pero empezaba a las I0: 30 de la noche, era temprano. Yo dije: vamos a una de las zonas más céntricas de Cuba a L y 23. Les explico (sobre) el Habana Libre, el Cine Yara y esa que esta allá enfrente es la heladería Coopelia. Pero, cuando cruzo, un policía (llama): hey compañero, su carnet! Les enseño. Pero, mira, es la misma historia. Dicen: tengo que llamar allá (en la central de policía). Yo pregunte: ¿Tengo algún problema en el carnet de identidad? Me dicen: No, pero usted es un posible asediante. Les contesto: Mire usted sabe lo que significa asediar, como usted va decir que yo puedo ser un asediante si ellos les están diciendo que soy amigo de ellos, que vengo con ellos y que vamos a una actividad, así como usted cree que yo voy a ser un posible asediante. (El policía) Dice: No ellos se pueden ir, pero usted se tiene que quedar con nosotros, nos tiene que acompañar. Entonces llamaron, vino el camioncito con la gente. Pero, cuando voy a montar, hay como I0 o I 2 personas sentados ahí. Las I0 o I2 personas conmigo todo el mundo es negro. Digole: pero venga acá ¿ustedes nada más que recogen negros? Pero esto es el colmo de la discriminación, ustedes nada más que aquí estén recogiendo por el carnet de identidad, entonces los únicos que no usan carnet son los negros? I2 personas aquí adentro y ¿todos somos negros? Nos llevan para la estación de policía de Zulueta, nos bajan. El policía habla: este tipo (apunta para mí), oye, ese es "contestón". Nos meten para dentro, para el calabozo. Entonces, como a las I2 de la noche me llaman: óigame para que firme aquí y diga que usted no va andar más con extranjeros. Me indigne y le dije un bando de cosas ahí, le dije dama acá: (Escribí) Esto es una violación de los derechos, de la dignidad de los cubanos y me voy. Pero eso pasa aquí, eso fue en el 2009. (Entrevista realizada com Norberto Mesa, da Cofradía de la Negritud, em 09/07/2015).

Em outros casos, esse comportamento é reproduzido por seguranças de hotéis, restaurantes e bares. Os ativistas, para além de denunciarem a grande incidência desses eventos com a população negra em geral, são muitas vezes as próprias vítimas. Robaina conta uma das experiências vividas por Walterio Carbonell, que virou um marco das ações de enfrentamento ao racismo em hotéis, bares, restaurantes e casas de shows:

277 Conforme fala de Deyni Terri, presente no capítulo 3, seção "Antirracismo e a Lei". 
Walterio Carbonel1 ${ }^{278}$ foi protagonista de um fato que levou à realização espontânea e violenta de uma ação contra a discriminação. Ao tentar entrar com uns amigos em um cabaré, foi proibida a entrada de um deles por ser negro, mas não a dos brancos. Por isso negros, brancos e mulatos integrantes do grupo decidiram entrar à força. É claro que tudo terminou na delegacia e o processo foi considerado simplesmente como um escândalo em via pública. A conotação racial não apareceu em lugar algum, mesmo que a imprensa tenha mencionado o fato como tal. Provavelmente ocorreram muitos atos como este, mas nem sempre chegaram a ser notícia de jornal (ROBAINA, 2004: 364).

Outra prioridade, abordada por ativistas, é a mudança na representação da sociedade na mídia.

Nos espaços midiáticos, há um reforço a padrões estereotipados, como pessoas negras criminosas, marginais, de caráter duvidoso. E nesses espaços, por outro lado, não se protagoniza uma campanha pública de enfrentamento ao racismo, como destaca Yulexis Almeida:

Es importante, por ejemplo, el debate público sobre el tema. Es importante el trabajo de los medios. Nuestros medios son expresión de esa desigualdad que todavía existe en nuestro país por color de la piel. Tenemos una televisión que no da cuenta de su población. Nuestros productos televisivos están muy blanqueados. Eso no refleja a la población cubana. Muchas veces se trabajan los personajes representados por personas negras desde una mirada muy estereotipada que refuerza la discriminación racial que existe. Son personajes encartonados, son personajes que no reflejan la gran diversidad de la población negra actual. Eso de alguna manera contribuye mucho a reforzar la representación social que hay sobre las personas negras en la sociedad. Tenemos que lograr (un cambio) porque desde nuestra constitución está planteado el tema de la discriminación racial. Sin embargo, los mecanismos no están creados para que las personas puedan canalizar las situaciones de discriminación, que puedan experimentar a través de su vida cotidiana en el centro laboral. No existe y eso hay que crearlo, divulgarlo. No solo divulgarlo, porque, por ejemplo, se ha hecho con la violencia contra la mujer que era un tema sobre el cual no se hablaba mucho. Sin embargo, ya se habla. Hay un debate público desde los medios. Hay que hablar de la discriminación racial, hay que hablar de formas de combatir la discriminación racial, hay que hablar desde el punto de vista penal a qué se enfrenta la gente cuando incurre en esto. (Entrevista com Yulexis Almeida, realizada em I6/06/2014).

Há grande desinformação sobre o racismo, imensa inoperância da justiça para a aplicação dos princípios constitucionais sobre a não discriminação, uma falta de amadurecimento social para a questão. Todos esses são elementos que impactam severamente nas relações raciais no país poderiam ser aperfeiçoados caso houvesse um melhor tratamento da questão nos meios de comunicação.

A produção de conhecimentos, de pesquisas e estudos é outro fator apontado por ativistas como uma debilidade de Cuba para o tema racial. É visto, portanto, como outra das prioridades de ação para o tema, como destaca Gisela Arandia:

Lo pienso actualmente que quizás uno de los problemas más graves que hay en Cuba es que la producción del conocimiento sobre el racismo es muy débil muy frágil, yo lo pienso, tal vez no es verdad, cuando digo esto algunas personas se ponen bravas y hacen otros comentarios, pero yo creo que nuestra producción de conocimientos es muy frágil, fue muy frágil antes de la Revolución y no significa que no haya habido escritores, que no haya habido lideres, pero no hay una producción de conocimiento en el sentido, por ejemplo que hay en Brasil, donde el tema del racismo por supuesto donde desde los años 1930 hay un movimiento negro fuerte un proceso que por supuesto ha tenido un impacto así que

${ }^{278}$ Um dos precursores do ativismo antirracista no período revolucionário. Autor do livro: "Como surgió la cultura nacional", voltado para o processo de formação da identidade nacional em Cuba. 
no se si podre en Cuba se podrá hablar de movimiento, yo siento que tenemos una fragilidad. (Entrevista com Gisela Arandia, realizada em I2/09/20I4).

Também é enfatizada a necessidade de compartilhar informações, debater, refletir sobre a questão racial e o racismo nas comunidades, nos bairros marginais, nas praças e parques. São ações que priorizariam ampliar a mobilização para o tema. Ainda há limitações, até legais, para atividades na rua que agreguem muitas pessoas. O debate acaba ficando restrito a locais e segmentos específicos. No período de minha pesquisa, nos encontros que acompanhei sobre a questão, as atividades se restringiam a espaços fechados, como auditórios e salas. E faz falta essa mobilização, como destaca Norma: unos de los grandes desafio que tenemos es lograr ir la base, a la comunidad hacer algo con la comunidad, conocer, investigar saber realmente de qué manera ayudar y encaminar a muchas personas que se quedaron detrás (Entrevista realizada com Norma Guillard, em 03/02/2015).

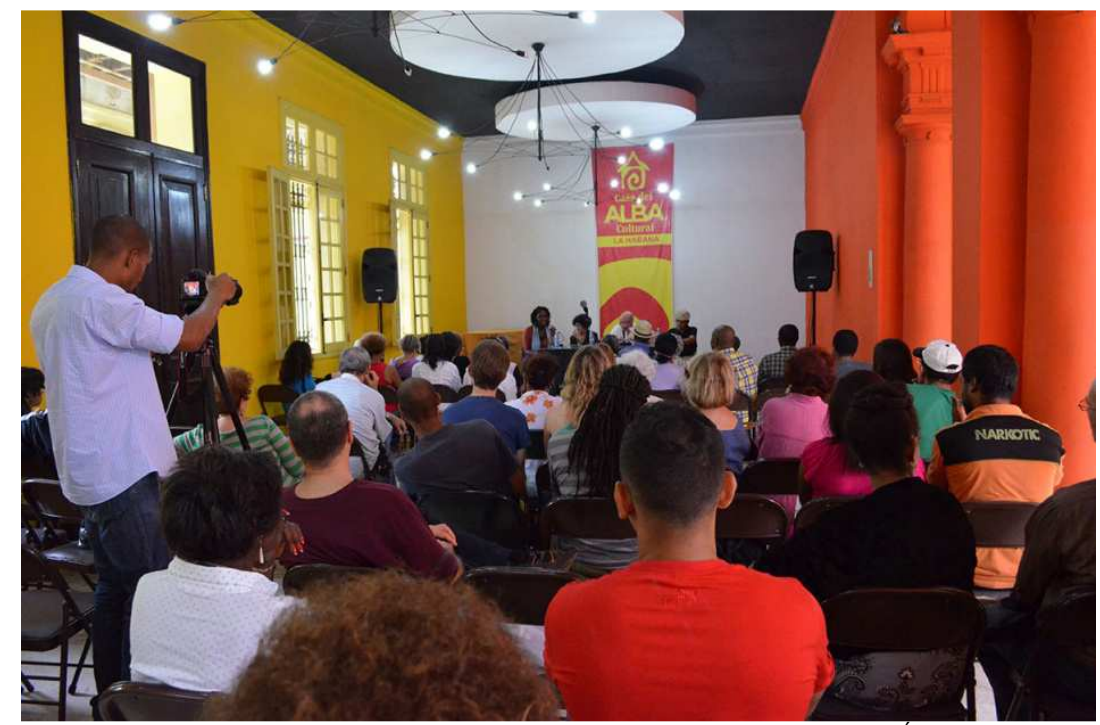

Figura 3I: Debate promovido pela ARAAC, capítulo cubano, em alusão ao dia da África, no dia 29 de maio de 20I4. Local: Casa de Alba, La Habana, Cuba. Foto: Bárbara Oliveira.

Algumas das organizações têm sua atuação focada nos trabalhos comunitários, em bairros periféricos, como é o caso da Red Barrial Afrodescendiente. Esse perfil comunitário é mais escasso entre os coletivos. A Rede articula comunitários e comunidades e bairros marginais em diversos pontos de Havana, com maior atuação em La Lisa e Pogoloti, ambos situados em regiões periféricas e com maior vulnerabilidade socioeconômica. 


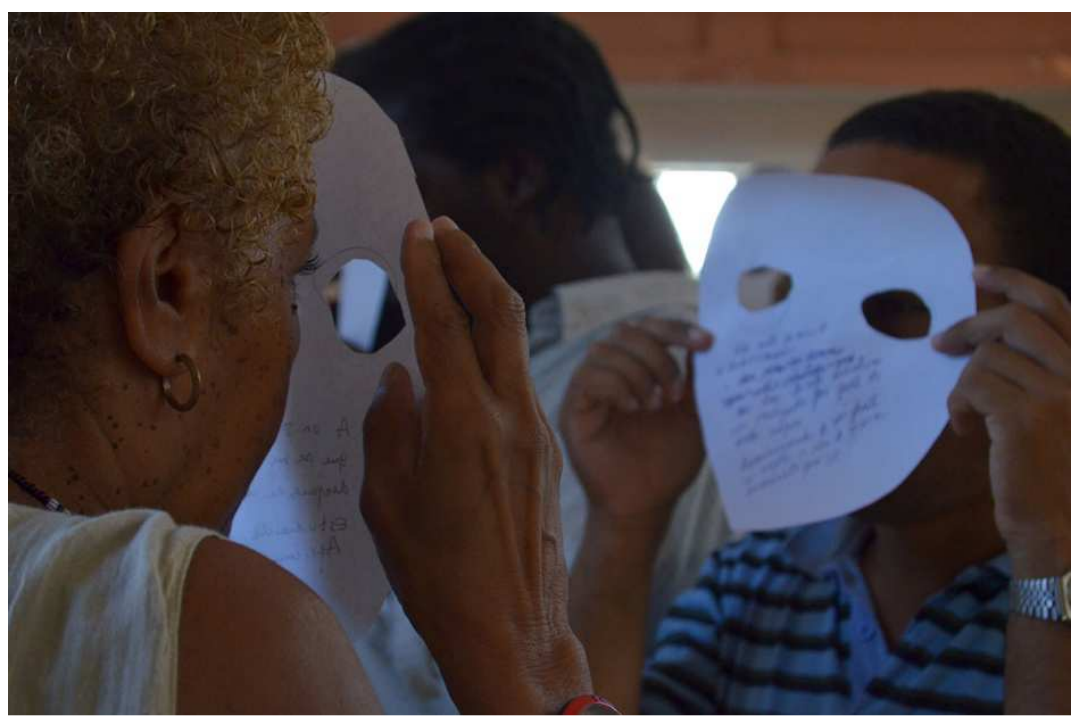

Figura 32: Oficina comunitária realizada pela Red Barrial Afrodescendiente no bairro Pogoloti, em Havana, Cuba, em 16 de outubro de 20I4. A atividade fotografada aborda situações de discriminação vivenciadas pelos participantes, que são narradas nas máscaras. Foto: Bárbara Oliveira

Com relação às mobilizações públicas, em ruas e praças, não pude visualizar, no meu tempo de pesquisa, nenhuma iniciativa nesse sentido de caráter político focado no debate explícito para a questão racial279, apesar do expresso desejo de alguns ativistas, como manifesto muitas vezes, por exemplo, por Tomás Fernandez Robaina. Esse ativista, na entrevista realizada, destaca outra das prioridades muito presentes nas narrativas, que é o necessário rompimento com a perspectiva eurocêntrica, bastante relevante na educação cubana, como destaca Robaina:

En los planes de Educación, había que tratar de abolir esa cosa de los reflejos condicionados en una educación eurocéntrica. Ya tenemos la mente programada: lo que vale son los códigos eurocéntricos. Eso me parece una cosa esencial y eso tampoco son medidas que se pueden aplicar de inmediato en los programas de enseñanza, pues necesitan todo un procesamiento académico en lo establecido. Porque mientras nosotros no cambiemos los planes de enseñanza, desde los centros infantiles hasta los universitarios, no vamos a hacer nada. (Entrevista com Tomás Fernandez Robaina, realizada em I2/05/20I4).

A necessidade de que haja uma diversidade de abordagens, para além da visão eurocêntrica, na escola, na mídia, é um dos pontos de debate onde há maior consenso entre os ativistas. Também é um dos enfoques trazidos por Zurbano, que aborda que o racismo na atualidade também é:

[...] consecuencia de la fuerte matriz eurocéntrica que configuran los sistemas curriculares de la educación en Cuba, donde resulta excepcional encontrar la riqueza de nuestra diversidad, en particular la relativa a los afrodescendientes, su historia y contribuciones sociales. Son los grandes ausentes en la educación y los medios de difusión, y cuando los abordan, generalmente los condenan a la distorsión y a los esquemas más reductores (ZURBANO, 2012: 16).

Cuba tem vivido um processo de ampliação das mobilizações antirracistas em coletivos, redes, projetos, organizações, que têm fomentado narrativas voltadas para direitos humanos, combate ao

${ }^{279}$ Realizada há cerca de I0 anos, alguns coletivos de La Lisa (Havana), em articulação também com a Red Barrial Afrodescendente, fazem, no dia 15 de Noviembre, a atividade denominada "Gala Cultural", com manifestaciones artísticas, folclóricas e religiosas. $\mathrm{O}$ caráter da atividade não está voltado para debates e articulação política sobre a temática racial de forma explícita. $\mathrm{O}$ mesmo se aplica às atividades externas realizadas pelo Proyeco Identidad y Barrio La Marina (Matanzas), cujo caráter cultural é central. 
racismo e a necessidade de uma atuação mais presente do Estado para o tema. É uma ação que, de algum modo, reflete as muitas manifestações feitas em períodos anteriores, especialmente a partir dos anos I990, de artistas plásticos, músicos e intelectuais.

$\mathrm{Na}$ atualidade, há a compreensão de que a luta antirracista conforma-se por atuações que envolvem a sociedade civil e o próprio Estado. Portanto, as mobilizações sociais são parte fundamental desse processo. Muitas das ações necessariamente passam pela esfera estatal, como as relacionadas às políticas educacionais, à legislação e acesso à justiça, às de promoção de equidade no mercado de trabalho, às voltadas aos meios de comunicação e políticas culturais. Mas, além de haver influência da sociedade civil como motor de pressão sobre o Estado para a implementação de políticas antirracistas, os coletivos e ativistas se conformam como importante massa crítica que fortalece o discurso que rivaliza com o "mito da igualdade". Todavia, a relevância da atuação da sociedade civil não é compreendida por todos vinculados aos coletivos antirracistas. De La Fuente ressalta algumas dessas posições, minoritárias, que centra o motor da mudança apenas no Estado:

Esencialmente, el punto de consenso es que la acción ciudadana es necesaria para combatir la discriminación. Una visión centrada solo en la acción estatal, como la articulada por Feraudy en su intervención ante la Asamblea Nacional en diciembre de 20I I, es claramente minoritaria, quizás incluso excepcional. Para la mayoría de los miembros del movimiento, es indispensable algún tipo de acción ciudadana. Algunos sostienen que tal acción debe ser encauzada a través de organizaciones autónomas que, desde la sociedad civil, denuncien las prácticas discriminatorias e influyan sobre los órganos estatales para que las repriman o corrijan. Desde luego, esta es la visión que sostienen la Coneg (Cofradía de la Negritud) y el CIR, dos organizaciones dedicadas, precisamente, a la acción ciudadana. Pero es también la visión de algunos intelectuales, como Zurbano, quien ha sostenido que una de las dificultades que enfrenta la población negra «está en no tener instituciones sociales propias, donde los negros reconstruyan y compartan sus particulares historias, y legitimen tradiciones». Para otros, sin embargo, la acción ciudadana, aunque necesaria, no parece requerir formas organizativas propias. Martínez Heredia señala, por ejemplo, que es necesario «fomentar las acciones y la concientización antirracistas en los ámbitos más diversos de la sociedad, sin esperar todo de la acción y las directivas del Estado, debemos presionar, lograr que actúen juntos los que en el Estado y la sociedad estén dispuestos a hacerlo». Martínez Heredia no hace mención a las «instituciones sociales propias» a que hace referencia Zurbano, ni a las «instituciones de la sociedad civil» a las que refiere el CIR en su programa de trabajo, pero deja abierta una posibilidad participativa desde «ámbitos» no definidos de «la sociedad». (DE LA FUENTE, 2012: 104-I05).

De fato, entre os ativistas entrevistados, majoritariamente se atribuiu importância à sociedade civil e aos coletivos existentes para amplificar as reflexões sobre o racismo na sociedade. Esse perfil atual coletivo das mobilizações antirracistas possibilita que haja debates mais abrangentes sobre questões vinculadas às relações raciais e que se chegue a uma série de prioridades, acordos e desacordos. Há, em várias das narrativas, a busca por estabelecer algumas prioridades comuns. Diversos dos pontos defendidos por diferentes coletivos são convergentes. Todavia, as complexas relações entre parte desses coletivos, a discordância em alguns aspectos e as dificuldades de se criar espaços agregadores são limitantes que eu visualizo como desafios na construção desses consensos abrangentes. 
O caminho para ampliar o debate, e possibilitar que sejam concretizadas em políticas públicas muitas das demandas hoje existentes, vem sendo trilhado com amplo esforço pessoal e coletivo desses e dessas ativistas. Os desafios são grandes. Com a queda de muitas das bases das políticas sociais cubanas, após a derrubada do campo socialista, a escalada de desigualdade tem gerado efeitos mais severos em segmentos vulnerabilizados, como os afrodescendentes. Os dados indicam, portanto, um possível acirramento dos conflitos de ordem racial, especialmente se as respostas oficiais a esse processo não se mostrarem mais efetivas.

Para concluir a análise que faço sobre as mobilizações antirracistas em Cuba, apresentarei, nas próximas seções, um panorama desses coletivos formados a partir dos anos 1990, alguns eventos e agrupações que marcaram esse processo, as dinâmicas das redes entre os bairros e como o debate sobre as relações de gênero estão presentes nas articulações.

\section{I. Andanças pelo Movimento Afrocubano}

Nessa seção, objetivo puntualizar experiências importantes das mobilizações afrocubanas nesse processo que denomino como um ressurgir, especialmente a partir dos anos I990. Iniciarei traçando algumas referências das mobilizações que marcaram esse período até os dias atuais. Não considero que tenha havido uma completa ruptura dessas iniciativas de pautar e denunciar o racismo no pós-Revolução. Todavia, faço essa marcação, pois é a partir dos anos 1990 e 2000 que essas mobilizações ganham um caráter mais coletivo.

São diversas as iniciativas existentes voltadas para a luta antirracista em Cuba. A pluralidade de organizações e formas de atuação é um marcador importante desse processo. Parte das iniciativas é explicitamente vinculada à pauta racial e ao combate ao racismo. Outras envolvem a atuação do tema a partir de outras linguagens, como manifestações culturais vinculadas às tradições de matriz africana, e que em meio a atividades apresentam a pauta antirracista.

Algumas dessas ações não chegaram a se conformar como um coletivo, mas foram importantes para trazer à tona o debate sobre as iniquidades sociais e raciais, que durante o período especial tiveram um crescimento considerável na sociedade cubana ${ }^{280}$. Robaina (2004) levanta algumas dessas iniciativas, como a peña realizada pelo cantor e compositor Gerardo Alfonso, na Quinta dos Molinos, em Havana, em torno a qual se reuniam semanalmente músicos e musicistas,

\footnotetext{
${ }^{280}$ Conforme dados explicitados no capítulo "Viva la Revolución! Abajo el Racismo!".
} 
artistas, comunitárias/os, intelectuais, no princípio dos anos I990. Era um espaço de diálogo sobre experiências vividas, muitas das quais permeavam os preconceitos e discriminações raciais. Tinha-se como objetivo "chamar a atenção oficial para o que estava acontecendo, por esse motivo foram enviadas cartas aos diferentes níveis do Partido e do Estado, para dar a conhecer sobre esse acontecimentos" (ROBAINA, 2004: 382-383).

Posteriormente, o debate se expandiu e surgem, então, as primeiras agrupações, projetos e iniciativas com o foco antirracista mais explícito. A seguir, destacarei alguns dos coletivos, projetos e iniciativas que acompanhei durante minha pesquisa de campo, bem como outros que não existem mais ou que mantém sua atuação, mas que não foram objeto direto do trabalho de campo dessa investigação.

Acredito ser importante listar iniciativas vinculadas ao tema antirracista provenientes da sociedade civil em Cuba, a partir dos anos 1990, pois há grande escassez de informação sobre o assunto. Pude acessar pouco material sobre o tema, o que, portanto, me estimula a compartilhar os dados de meu estudo. Esse levantamento não tem como objetivo abarcar a totalidade das iniciativas existentes, mas busca trazer uma contribuição a essa pauta historicamente silenciada.

\begin{tabular}{|c|c|c|}
\hline Ano & Organização & Descrição Sucinta \\
\hline $\begin{array}{l}1993- \\
1996\end{array}$ & $\begin{array}{l}\text { Magín - Organización } \\
\text { Feminista }\end{array}$ & $\begin{array}{l}\text { Organização feminista voltada para as relações de gênero, foi uma das } \\
\text { pioneiras no pós-Revolução fora do escopo das organizações da "sociedade } \\
\text { civil oficial". Também abordava, em encontros e análises sobre os meios de } \\
\text { comunicação e a publicidade, as relações raciais e o combate ao racismo, } \\
\text { sobretudo no que se refere às mulheres negras. Dentre as principais } \\
\text { lideranças antirracistas na atualidade, ao menos três delas tiveram } \\
\text { importante atuação na Magín (Irene Ruiz, Daysi Rubiera e Norma } \\
\text { Guillard). Foi encerrada por solicitação do Partido Comunista, sob a } \\
\text { alegação de que poderia ser usada como mecanismo pelos "inimigos". }\end{array}$ \\
\hline 1995 & $\begin{array}{l}\text { Proyecto Comunitario } \\
\text { "Concha Mocoyú" (La } \\
\text { California) }\end{array}$ & $\begin{array}{l}\text { Criado em 1995, a experiência focou um conjunto habitacional bastante } \\
\text { precário, conhecido como Califórnia, com significativa presença negra } \\
\text { entre seus moradores e importante reduto de práticas tradicionais como a } \\
\text { Santeria. O projeto envolveu diversas ações, como a reforma de casas, } \\
\text { debates e oficinas de estética afro. }\end{array}$ \\
\hline 1996 & $\begin{array}{l}\text { Obsesión - Coletivo de } \\
\text { hip-hop }\end{array}$ & $\begin{array}{l}\text { Criado em I996, o grupo de rap Obsesión é bastante atuante na pauta } \\
\text { antirracista, seja em letras e músicas, seja em atividades coletivas nas quais } \\
\text { o tema racial é abordado com intensidade. Coordenado por Magia López } \\
\text { Cabrera e Alexey Rodriguez Mola, o grupo estabelece parceria em } \\
\text { atividades com outros coletivos antirracistas, como Afrocubanas e MirArte } \\
\text { Día a Día. Sobre o movimento rap mais amplo, cabe destacar que em } 2005 \\
\text { foi realizado o primeiro simpósio de hip-hop no país. Nas letras de muitos } \\
\text { grupos de rap, ademais de Obsesión, a denúncia ao racismo está presente, } \\
\text { como em Hermanos de la Causa. }\end{array}$ \\
\hline 1998 & $\begin{array}{l}\text { Cofradía de la } \\
\text { Negritud }\end{array}$ & $\begin{array}{l}\text { Criada como resposta a crescentes situações de discriminação, } \\
\text { especialmente no mercado de trabalho. Realiza ações em comunidades e } \\
\text { debates sobre o tema racial. Tem um longo histórico de denúncias feitas } \\
\text { contra práticas racistas em cartas públicas, muitas das quais foram dirigidas } \\
\text { ao Estado cubano. É uma das organizações que acompanhei na pesquisa. }\end{array}$ \\
\hline 1997 & Queloides & Projeto que envolveu artistas plásticos e intelectuais em diversas atividades \\
\hline
\end{tabular}




\begin{tabular}{|c|c|c|}
\hline & & $\begin{array}{l}\text { artísticas. A primeira exposição data de } 1997 . \text { No acervo há pinturas que } \\
\text { retratam a cultura afrocubana e outras que explicitam temas vinculados ao } \\
\text { racismo. Foi organizada pelo artista plástico Alexis Esquivel e teve } \\
\text { curadoria de Omar Pascual Castillo. Outros desdobramentos desse projeto } \\
\text { foram também organizados por Ariel Ribeaux Diago, como a segunda } \\
\text { exposição Ni músico ni deportista. A exposição mais ampla de Queloides } \\
\text { ocorreu em I999. Alejandro De La Fuente também foi co-curador da } \\
\text { exposição. Após esse primeiro momento, esse coletivo de artistas e } \\
\text { intelectuais realizou outras edições do Quelóides, inclusive com exposições } \\
\text { pelo mundo. Em outubro de 20I4, visitei a exposição no museu de } \\
\text { antropologia da Universidade da Colúmbia Britânica, Vacouver, Canadá. }\end{array}$ \\
\hline 2000 & $\begin{array}{l}\text { Movimiento de } \\
\text { Integración Racial } \\
\text { Juan Gualberto } \\
\text { Gómez (MIR) }\end{array}$ & $\begin{array}{l}\text { O coletivo Movimiento de Integración Racial Juan Gualberto Gómez } \\
\text { integra uma das organizações da sociedade civil considerada como } \\
\text { dissidente. É uma das pioneiras no debate em Cuba pós anos I990. } \\
\text { Algumas das propostas que defendem permeiam a adoção de ações } \\
\text { afirmativas e a legalização dos grupos e movimentos independentes. }\end{array}$ \\
\hline $\begin{array}{l}200 I- \\
2009\end{array}$ & $\begin{array}{l}\text { Proyecto Color } \\
\text { Cubano }\end{array}$ & $\begin{array}{l}\text { Grupo de trabalho vinculado à União dos Escritores e Artistas de Cuba, } \\
\text { coordenado por Gisela Arandia. Era composto por acadêmicos e cientistas } \\
\text { sociais, historiadores, artistas, lideranças comunitárias, líderes políticos. } \\
\text { Funcionou até } \text { I }^{\circ} \text { Sem/2009. Sua extinção não teve uma causa } \\
\text { oficialmente pública e foi substituída pela Comissão de Luta Contra a } \\
\text { Discriminação Racial (presidida por Heriberto Feraudy Espino), cujo } \\
\text { nome foi alterado para Comissão Aponte posteriormente. }\end{array}$ \\
\hline 2008 & $\begin{array}{l}\text { Comité de } \\
\text { Integración Racial } \\
\text { Cuba - CIR }\end{array}$ & $\begin{array}{l}\text { É uma das maiores organizações consideradas como dissidentes em Cuba } \\
\text { voltadas para a questão racial e o combate ao racismo. Tem um } \\
\text { importante acervo sobre a questão racial no país, disponível em seu sítio } \\
\text { web. É uma das organizações de relevância para o tema e muitas de suas } \\
\text { reivindicações antirracistas são compartilhadas por outros coletivos que se } \\
\text { posicionam em defesa da Revolução. Dentre algumas das demandas } \\
\text { comuns, está a necessidade de ampliar o debate sobre a questão racial, } \\
\text { sobre "el presente y el futuro de las relaciones interraciales en Cuba" } \\
\text { (CIR, 2008). Defende, também ações e medidas para "garantizar la voz } \\
\text { propia y los espacios para los afrodescendientes cubanos, así como avanzar } \\
\text { hacia esa verdadera integración tan largamente soñada por varias } \\
\text { generaciones" (CIR, 2008). Talvez o grande ponto de divergência com } \\
\text { outros coletivos seja sua posição contrária ao governo revolucionário } \\
\text { explicitamente colocada. Apresenta-se como parte da "fraterna sociedade } \\
\text { civil dissidente". }\end{array}$ \\
\hline 2009 & $\begin{array}{l}\text { Comisión Aponte } \\
\text { (antes chamada "de } \\
\text { Combate à } \\
\text { Discriminação } \\
\text { Racial) }\end{array}$ & $\begin{array}{l}\text { Foi criada como um grupo de trabalho também vinculado à UNEAC } \\
\text { (União Nacional dos Escritores e Artistas de Cuba), em substituição ao } \\
\text { Proyecto Color Cubano. Está atuante e atualmente é o coletivo que maior } \\
\text { interlocução estabelece com representantes do governo cubano. Seu nome } \\
\text { faz homenagem ao líder de uma das fortes rebeliões contra a escravidão em } \\
\text { Cuba, Aponte (séc. XIX). Durante a pesquisa, acompanhei algumas de suas } \\
\text { atividades e realizei entrevistas com parte de seus integrantes. }\end{array}$ \\
\hline 2011 & Afrocubanas & $\begin{array}{l}\text { Coletivo de mulheres que tem como objetivo fortalecer o debate sobre } \\
\text { relações raciais e gênero em espaços comunitários e acadêmicos. Realizou a } \\
\text { primeira edição de artigos e textos sobre afrocubanas, tema muito } \\
\text { invisibilizado, e estão se organizando para a publicação da segunda. É } \\
\text { também uma das organizações que acompanhei durante a pesquisa. Realiza } \\
\text { encontros trimestrais para debater temas vinculados à luta antirracista, as } \\
\text { "Tertúlias Afrocubanas". }\end{array}$ \\
\hline 2010 & MirArte Día a Día & $\begin{array}{l}\text { Coletivo que reune artistas e produtoras culturais. Tem como foco a luta } \\
\text { antirracista, contra a homofobia e o sexismo. Suas coordenadoras, Mirna } \\
\text { Rosa Padrón e Diarenis Calderón, realizam diversas atividades, como a } \\
\text { oficina denominada Con Voz Própria, promovida no bairro Centro } \\
\text { Havana, em Havana, Cuba, em 26/I I/20I4, em parceria com o grupo de } \\
\text { hip-hop Obsesión. }\end{array}$ \\
\hline 2012 & $\begin{array}{l}\text { ARAAC - } \\
\text { Articulación }\end{array}$ & $\begin{array}{l}\text { A articulação da ARAAC tem seus antecedentes em articulações na } \\
\text { Venezuela, Equador e Brasil. No capítulo cubano, busca estabelecer uma } \\
\text { rede mais ampla de luta contra o racismo e agrupa ativistas e coletivos da }\end{array}$ \\
\hline
\end{tabular}




\begin{tabular}{|c|c|c|}
\hline & $\begin{array}{l}\text { Regional de los } \\
\text { Afrodescendientes de } \\
\text { las Americas y el } \\
\text { Caribe - Capitulo } \\
\text { Cubano }\end{array}$ & $\begin{array}{l}\text { sociedad civil cubana. Sua atuação está dividida por eixos de trabalho que } \\
\text { contemplam, entre outros, gênero, comunicação, educação, trabalho } \\
\text { comunitário e infância e juventude. É uma das organizações que } \\
\text { acompanhei na pesquisa de campo. Está situada no que eu denominei } \\
\text { "sociedade civil reconhecida". }\end{array}$ \\
\hline \multirow[t]{3}{*}{2012} & $\begin{array}{l}\text { Rede Barrial } \\
\text { Afrodescendiente }\end{array}$ & $\begin{array}{l}\text { A Rede Barrial Afrodescendiente estabelece articulação com diversos } \\
\text { bairros e localidades de Havana, como Balcón Arimao, Pogoloti, Alamar } \\
\text { Playa, Buena Vista, Jesus María, Párraga, La Ceiba, Los Angeles. Tem } \\
\text { articulação estreita também com outros coletivos e projetos, como o } \\
\text { Afrocubanas, Coletivo Trance, Muñeca Negra e o Identidad y Barrio La } \\
\text { Marina (esse último de Matanzas). Tem como objetivo ampliar a } \\
\text { percepção e o debate sobre práticas discriminatórias raciais, de gênero, bem } \\
\text { como suas estratégias de enfrentamento. Também desenvolve projetos } \\
\text { comunitários para fomentar atividades econômicas para a população negra, } \\
\text { com fortalecimento dos vínculos de solidariedade. Há grande influência da } \\
\text { rede de educadores e educadoras populares em sua atuação. É um dos } \\
\text { grupos que também acompanhei durante a pesquisa. }\end{array}$ \\
\hline & $\begin{array}{l}\text { Proyecto Muñeca } \\
\text { Negra }\end{array}$ & $\begin{array}{l}\text { E um projeto realizado no bairro La Lisa, que tem articulação com a Rede } \\
\text { Barrial Afrodescendiente, que reune artistas e artesãs que trabalham com } \\
\text { papel marché. O foco principal do trabalho é a cultura e as tradições } \\
\text { afrocubanas. São representadas mulheres negras em diversos objetos } \\
\text { decorativos, feitos com papel marché. Além disso, realizam indumentárias } \\
\text { sagradas também de papel para a Santeria e rituais de Palo Monte. É um } \\
\text { trabalho comunitário iniciado por Margarita Montalvo. }\end{array}$ \\
\hline & $\begin{array}{l}\text { Coletivo de Criação } \\
\text { Artística Trance }\end{array}$ & $\begin{array}{l}\text { Projeto de "re-animação" sócio-cultural de La Ceiba, em La Lisa } \\
\text { (Havana). Dentre seus objetivos está o resgate e valorização das tradições } \\
\text { afrocubanas. Tem estreita articulação com a Rede Barrial Afrodescendiente } \\
\text { e desenvolve projetos e ações em parceria. Durante a pesquisa, acompanhei } \\
\text { várias atividades desse coletivo com a comunidade de La Ceiba, em La } \\
\text { Lisa, que envolvem artes marciais, linguagens artísticas e educação popular. }\end{array}$ \\
\hline 2013 & $\begin{array}{l}\text { Alianza Unidad } \\
\text { Racial }\end{array}$ & $\begin{array}{l}\text { Coletivo de Advogados e apoiadores que lutam pelo combate ao racismo, } \\
\text { com ênfase para o meio jurídico, amparo às vítimas de racismo e formação } \\
\text { para a igualdade racial, especialmente no que se refere ao acesso à justiça e } \\
\text { conhecimento das leis. Apesar da ênfase na luta contra o racismo, a AUR } \\
\text { atua na defesa de qualquer tipo de discriminação sexista, religiosa, } \\
\text { xenofobia, de gênero. Estão trabalhando na proposta de texto do Estatuto } \\
\text { da Igualdade Racial. Dentre as atividades que organizam, estão encontros } \\
\text { abertos nos quais vítimas de discriminação, com necessário auxílio jurídico, } \\
\text { compartilham experiências e onde são pensadas estratégias para a busca por } \\
\text { direitos. É um dos grupos que acompanhei durante a pesquisa. }\end{array}$ \\
\hline 2014 & $\begin{array}{l}\text { Proyecto La Marina - } \\
\text { Identidad y Barrio }\end{array}$ & $\begin{array}{l}\text { O projeto busca fortalecer e visibilizar o legado das tradições do bairro La } \\
\text { Marina, em Matanzas, especialmente no que se refere às tradições de } \\
\text { matriz africana, como a Santeria, o Palo Monte, a cultura Abacuá, à } \\
\text { Rumba, aos festejos coletivos, como a queima do boneco de San Juan (que } \\
\text { no sincretismo representa Ogun), e à comparsa de Imaliana, que sai no } \\
\text { carnaval. Estabelece articulações especialmente com a Rede Barrial } \\
\text { Afrodescendente e introduz o debate sobre racismo e discriminação racial } \\
\text { em muitas das atividades realizadas no bairro. }\end{array}$ \\
\hline
\end{tabular}

Figura 33: Quadro sintético das mobilizações antirracistas em Cuba realizadas a partir dos anos I990.

A riqueza de informações de cada coletivo, projeto e iniciativa existente não se esgota nesse pequeno resumo que fiz acima. Todavia, esse panorama colabora para a compreensão de uma parte desse universo das mobilizações antirracistas cubanos na atualidade.

${ }^{281}$ As datas de criação do Coletivo Trance e do Projeto Muñeca Negra são anteriores à data da Rede. Contudo, nesse trabalho, faço a marcação da data de criação da Rede, organização estudada, que estabelece articulação com outros grupos como essas duas iniciativas. 
Há grande controvérsia sobre a existência ou não de um movimento negro ou afrodescendente em Cuba. Fato é que, como explicitado nos debates sobre os conceitos de sociedade civil e de movimentos sociais ${ }^{282}$, esses são modelos teóricos pouco aplicáveis à realidade cubana, por suas especificidades também já debatidas. Todavia, essas mobilizações sociais estão presentes no cotidiano da sociedade e envolvem a articulação de intelectuais, artistas, educadores populares, ativistas e comunitárias/os.

A percepção sobre a existência ou não de um movimento negro, afrodescendente ou antirracista surge nas narrativas dos agentes sociais com atuação nas mobilizações coletivas sobre o tema. Muitas das percepções vinculam movimentos sociais à existência de uma liderança centralizadora, à convergência das mobilizações existentes, e, em alguns casos, ao vínculo com as organizações vinculadas ao que denomino "sociedade civil oficial". Outras visões sobre o tema destacam a fragilidade e as limitações existentes como fatores que debilitam o que poderia ser o movimento afrocubano ou antirracista no país. Para Zurbano:

\begin{abstract}
No se puede hablar de movimiento antirracista todavía. Se puede hablar de nuevas organizaciones donde se han logrado determinadas convocatorias, se ha podido convocar a mucha gente, se ha podido hacer un grupo de acciones explicativas de concientización de pequeños grupos de personas a partir de la iniciativa de pequeños grupos también. De todos estos grupo, llamase la Cofradía, Color cubano, el Comité de Integración Racial, ARAAC, Comisión Aponte, son organizaciones que nacen de una precariedad política y una falta de legitimidad social. No nacen a la sociedad civil cubana como organización que se inscriben y pueden tener su agenda y hacer sus acciones naturalmente. Son organizaciones que están toleradas, pero no están asumidas ni aceptadas, son muy pocas las que son asumidas y aceptadas, digamos la Comisión Aponte, que está en la UNEAC, ARAAC que tiene determinada sombrilla con el Ministerio de Cultura, pero tampoco tiene legitimidad como una asociación de la vida civil. Que somos pocas personas y la manera de organizarnos, la manera de buscar una organicidad todavía no está clara y la claridad de las agendas también es muy rara porque hay organizaciones en Cuba que tienen un sentido de la critica al Gobierno. (Entrevista com Roberto Zurbano, realizada em I5/I0/20I4).
\end{abstract}

As questões levantadas por Zurbano são verificadas na quase totalidade dos coletivos estudados. Nenhum deles é legalizado. Não há estrutura que comporte suas atividades. Muitas das atividades ou manifestações são, de alguma forma, restringidas. Seja pela negação de empréstimo de espaço para a realização de uma atividade, seja pelo cancelamento sem justificativa de um programa de rádio, como ocorrido com o coletivo Afrocubanas. Por outro lado, esses grupos existem, continuam atuando, mas não são integrados como uma sociedade civil legalmente reconhecida. A partir das palavras de Zurbano, são, portanto, "tolerados". Mesmo no caso da Comissão Aponte, vinculada à UNEAC, há uma frágil estrutura para trabalhar, como foi destacado por seu presidente, Heriberto Feraudy, no debate televisivo Mesa Redonda, referente ao 2I de março de 20I5, e não é uma organização da sociedade civil legalizada como tal. É conformada como um grupo de trabalho da União dos Escritores e Artistas de Cuba.

${ }^{282} \mathrm{Na}$ seção "Movimento Afrocubano nos Estertores da Guerra Fria". 
Outras narrativas enfocam essa sociedade civil cubana como embrionária. Para Esteban Morales, as mobilizações existentes estariam em um estágio incipiente:

Existe en Cuba un movimiento antidiscriminatorio, insuficientemente organizado todavía, pero que tiene focos, como ya tú dijiste. Lo tiene en la Cofradía de la Negritud, tiene en la Comisión Aponte, que es una comisión de la UNEAC, que ha sido reconocida como una comisión nacional, una comisión oficial de trabajo de la UNEAC y lo tiene una serie de lugares donde el tema se trabaje. Pero, ahora hace falta generalizar la presencia del tema en los estudios universitarios, que cuando los muchachos se sientan en la escuela se hable de eso, y cuando esos muchachos se encuentren con ese e fenómeno en la familia que tengan capacidad para afrontarlo. Que cuando se encuentren con ese fenómeno en la calle también tengan la oportunidad de afrontarlo. Porque la sociedad no lo ha educado suficientemente en esa dirección que les permita adquirir instrumento, formas de pensamiento que le permitan percibir como luchar contra ese problema y contra esas dificultades que realmente dividen a la sociedad cubana y que afectan a la política social de la Revolución. Eso hay que institucionalizarlo a eso hay que darle forma hay que darle fuerza (Entrevista com Esteban Morales, realizada em I4/05/2014).

Norma Guillard também compartilha de visão semelhante à de Esteban Morales, de que há um movimento afrocubano em processo em crescimento, mas dá ênfase também à necessidade de haver maior articulação entre os coletivos e internamente entre os seus integrantes:

Cada día va creciendo como una sensibilización por el tema. Pudiera ponerle un nombre para ubicarlo como gubernamental que se le llama esta Comisión de Aponte y desde ahí se está yendo a las diferentes universidades a llevar el tema. Existe otro grupo que ya desde hace muchos años que trabajaba que es la Cofradía de la Negritud, que antes se veía cuando ellos comenzaron bien temprano, desde los grupos Abacua, a estar tocando porque vivían y sentían la realidad que estaba expresando la persona de color. A principio se le hizo rechazo, enfrentamiento y ya en estos momentos están reconocidos su espacio, tienen su boletín de su espacio La Ceiba. Lo hacen desde ahí mismo y bueno para ir nombrando espacio. Se han hecho diversos espacios de talleres diversos que pertenece a esta Comisión de Aponte, que pertenece a ARAAC y pertenece a la Cofradía. Entonces, tú sientes ya que vamos un poco integrándonos, que es lo que nos falta. No puedo hablar exactamente aún estamos como en grupos, y aun así en grupo tú sientes en el mismo grupo ARAAC, tú sientes que a la hora encaminarnos, todavía, no hemos podido lograr proyecto de empuje entre nosotros mismo. $\mathrm{O}$ sea, tenemos que hacer un trabajo entre nosotros mismo para agruparnos y no empezar a discrepar desde adentro con las ideas que queremos hacer pero todo eso es un proceso psicológico, no es una cosa que tú quieras hacer por decreto porque ya tu viste que por decreto vivimos todos iguales cuando triunfo la Revolución y la realidad a tu vez es diferente. (Entrevista com Norma Guillard, realizada em 03/02/2015).

Maritza, da Red Barrial Afrodescendente, a partir de sua experiência com a Rede Barrial Afrodescendiente ressalta a falta de uma conscientização sobre o tema e que, apesar de reconhecer a atuação antirracista de muitos grupos e sujeitos, não visualiza uma consciência coletiva sobre a questão racial:

Para que haya un movimiento, tiene que haber conciencia colectiva común. No hay esa conciencia colectiva común, no creo que haya un movimiento antirracista en Cuba. Hay muchas personas que están comprometidas con la lucha antirracista, pero de ahí a hablar de movimiento. Es que yo respeto mucho los movimientos. Cuando se habla de movimiento, se habla de una conciencia colectiva, de una lucha colectiva y eso yo no lo veo aquí, si no ya existiera una legislación. No hay ley que castigue un acto discriminatorio, ni por sexo ni por raza. No hay, y además de no haber percepción sin un instrumento jurídico, ¿de qué movimiento estamos hablando? (Entrevista com Maritza Lopez, realizada em I5/08/20I4). 
Dando ênfase à falta de articulação entre os coletivos existentes vinculados à luta antirracista, Bienvenido apresenta posição sobre o movimento afrocubano, também reforçando a ideia de que esses são elementos que fragilizam a percepção desse processo como um movimento:

\begin{abstract}
No, yo creo que como tal así movimiento afrocubano actualmente no, porque para que sea un movimiento tiene que estar articulado. A mí me parece que para que haya un movimiento realmente tiene que haber una articulación y todavía por ejemplo, la Comisión Aponte está trabajando por su lado, el ARAAC está trabajando por el suyo, la Cofradía de la negritud está trabajando por otro lado, en fin eso todavía no está bien articulado, cuando todo eso este bien articulado es un movimiento, constituye un movimiento, ¿entiende? Pero uno por un lado: no, no, no. O sea, yo lo que creo que actualmente lo que hay es, se está moviendo el tema por diversas vías, en diversas formas en diversos espacios pero para que sea un movimiento como tal un movimiento le hace falta una articulación, que se distribuyan las tareas tú te vas a ocupar de esto, yo me voy a ocupar de esto otro, una estrategia común, esa es la idea, ahí falta eso. (Entrevista com Bienvenido Rojas, realizada em 04/05/2014).
\end{abstract}

Tato Quiñones enfoca a mudança paradigmática ocorrida com relação ao tema racial nos últimos anos. Se há limitações na percepção social do problema, como apontado por Martiza acima, também há o reconhecimento que os debates e o discurso atualmente pronunciado em espaços públicos sobre o racismo em Cuba são uma das conquistas das mobilizações. Esse ativista reconhece o caráter incipiente, frágil e até muitas vezes "virtual" das organizações, mas ressalta o papel dessa mobilização, desse movimento para essas mudanças:

Yo te diría que sí que hay un movimiento incipiente, desorganizado sin una tradición anterior en la cual nutrirse para nada, dando un poco palos de ciego, en la que los activistas no son muy activos, pero hay un movimiento incipiente, eso existe, hay un gen por lo menos porque puede ser genético que existe y que esto pueda crecer. Que por lo menos esto pueda tener un cuerpo un espacio en la sociedad cubana. Hace algunos años era impensable lo que existía eran grupos aislados. Creo que primero fue esto que organizo Gisela Aranda el "Color Cubano", que algo hizo pero también a partir de la nada. Ya eso no existe. A partir de la nada se constituyó entonces la Cofradía de la Negritud, la Comisión Aponte, ARAAC. Ahora, ¿ARAAC existe realmente? Yo me pregunto, ¿ARAAC existe o es más bien una cuestión de papeles? Existe virtual ARAAC, es virtual realmente, como la Cofradía lo es también un poco a su manera. Pero estamos haciendo y estamos luchando y tenemos espacios. Yo mismo, tu sabes, yo tengo un boletín (La Ceiba) que envío y trato de crear una conciencia. Me imagino que no pueda pasar mucho tiempo sin que el tema sea debatido en serio con el gobierno de cubano, no creo que el gobierno cubano sea tan miope, tan torpe como para no ver que este es un problema que compromete muy seriamente el futuro de la nación y se asume con seriedad ahora o estamos comprometiendo el futuro. (Entrevista com Tato Quiñones, realizada em 29/05/20I4).

Os elementos trazidos pelos ativistas entrevistados com reflexões sobre o movimento afrocubano destacam: I) A fragilidade legal e organizacional de seus coletivos; 2) a ainda existente coerção de suas atividades, mesmo que de forma mais branda que anteriormente; 3) A ampliação de um discurso concorrente ao do "mito da igualdade racial" em Cuba, onde as denúncias e críticas em relação ao racismo no país são explicitadas, mas há limitada abrangência especialmente na grande mídia e numa percepção social mais ampla; 4) As reduzidas possibilidades de articulação entre os coletivos e internamente nas relações estabelecidas entre seus integrantes que, entre outras coisas, restringe a construção de uma pauta comum; 5) A dificuldade de organizar uma mobilização social sem um legado continuado das organizações afrodescendentes, dado o processo de ruptura 
desse ativismo nos primeiros anos da Revolução; 6) O reconhecimento de que há coletivos, mesmo que fragilizados, que mobilizam a sociedade civil para a luta antirracista e que quebram o silêncio vivenciado em anos anteriores da Revolução.

A partir dos dados levantados para a pesquisa, com as entrevistas feitas, atividades e encontros realizados, é possível afirmar que existe um movimento afrocubano, que atualmente apresenta uma diversidade maior de iniciativas, projetos, coletivos e organizações que há cinco ou dez anos atrás. Há um crescimento tanto do processo de mobilização como de fortalecimento do discurso que contrapõe a narrativa de que a Revolução solucionou o racismo no país. De fato, a dinâmica dessa mobilização é limitada por diversos fatores, muitos dos quais já foram explicitados nas narrativas anteriormente citadas, como as limitações legais e as ações coercitivas. Mas, não há como negar o processo social coletivo que atualmente está presente na realidade habanera e, em menor grau, na matanzera em relação à luta antirracista.

A forma como esses coletivos se expressam é variada e não há uma centralização dos processos de mobilização. Há uma multivocalidade dessas organizações, sem prejuízo para os possíveis espaços de consenso a serem criados. Em alguma medida, muitos dos temas defendidos já possuem relativa unanimidade entre os agentes sociais e coletivos, conforme descrevi anteriormente nesse capítulo.

O impulso para a criação desses coletivos e do próprio ativismo é, em parte das vezes, derivado de experiências vivenciadas de discriminação racial. Dos novos coletivos e atores sociais que entraram em cena no ativismo antirracista nos últimos anos, muitos trazem essa perspectiva.

Nessa pesquisa, busquei refletir sobre os fatos históricos, os processos sociais contemporâneos, a relação com o Estado, e as dinâmicas internas ao movimento, com base nas visões de mundo, percepções e relações de ativistas antirracistas. Falar dessa dinâmica do mobilizar-se, do contrapor-se a uma visão hegemônica, de construir novas perspectivas, envolveu, na história de vida de muitos desses agentes sociais, processos complexos. São narrativas que refletem o peso de se contrapor ao discurso interdito, que perpassam as coerções, as tentativas de modelar ações sociais. A seguir, trago um pouco dessas vivências adversas que compõem, de forma intensa, o histórico e o cotidiano desse ativismo.

Há exemplos em Cuba de situações na história onde há uma reversão do lócus daqueles sujeitos sociais que se manifestam contra a discriminação racial e o racismo, e passam a ser concebidos como racistas, perigosos, causadores de divisões sociais e uma ameaça à ideia de nação, de união, 
como exemplos dos movimentos abolicionistas, do Partido Independientes de Color, das Sociedades Negras, demonstram.

É sintomático perceber que essa perspectiva ainda é presente nos dias atuais. Como essa visão se materializa nos dias atuais? Muitos desses ativistas e suas demandas de luta contra o racismo são concebidas como promotoras de fissuras e divisões sociais, que abalam a unidade nacional? Os dados da investigação apontam que sim.

Há um processo coercitivo social, mais débil, porém vigente, que se reflete no ativismo antirracista. Ampara-se, grande parte das vezes, nessa reversão de papeis, nos quais quem denuncia o racismo é considerado, por vezes, o próprio racista. Denúncias sobre casos de racismo podem ser convertidas em acusações ou sanções aos que as apresentam. Por outro lado, em grande parte dos casos que acompanhei, não há um enfrentamento do ato racista, da questão que foi denunciada, e dificilmente se buscam soluções que possibilitem ações de resolução, sejam aquelas no nível das microrrelações, sejam num plano mais abrangente.

Apresentarei, a seguir, alguns dos casos vivenciados por ativistas que dialoguei na pesquisa. A advogada e ativista Deyni Terry destacou que situações limítrofes vivenciadas, nas quais o conflito racial foi explicitado, desencadearam maior compreensão das dinâmicas do racismo, o que motivou seu ativismo. Sua narrativa ${ }^{283}$ explicita um dos aspectos violentos de controle com relação aos corpos negros estigmatizados, como os dos jovens afrodescendentes que os sinais apontam serem os mais vulneráveis na prisão pelo "índice de periculosidad". Destaca, ainda, as estratégias coercitivas do discurso ocorridas no exercício de sua atuação profissional na defesa de um desses jovens negros detidos, quando ficou presa por horas, por pronunciar em juízo a situação de racismo vivenciada pelo jovem em julgamento.

Por outro lado, é sintomático como no caso dessa ativista em questão, Deyni Terry, foi a vivência do extremo da situação de controle e coerção para tratar a questão que a estimulou a abordar de forma mais profunda e sistemática a luta contra o racismo em seu cotidiano diário, especialmente no tocante ao direito à justiça. Atualmente, Deyni é uma das integrantes do coletivo Alianza Unidad Racial, que atua na defesa dos direitos e na luta contra a discriminação. Também faz parte da ARAAC.

Outra situação vivenciada por um dos ativistas que acompanhei na pesquisa, que ganhou notoriedade, ficou conhecida como "Caso Zurbano". No dia 23 de março de 20I3, o artigo de

${ }^{283}$ Conforme descrito com mais profundidade e detalhe no capítulo 3. 
autoria de Roberto Zurbano, até então editor chefe da Casa de las Americas, sai publicado no jornal The New York Times, intitulado "para los negros cubanos la Revolución aún no ha comenzado". A publicação do artigo e sua denunciada manipulação pelo jornal estadunidense renderam um longo debate, expresso em revistas e publicações em Cuba e no exterior, de acordo com a compilação feita por García (20I4)284.

Zurbano alegou publicamente, em comunicados, que seu título original era: "Para los negros cubanos la Revolución aún no ha terminado". A alteração sem consentimento do autor foi publicada no mencionado jornal e gerou um dos debates mais polêmicos dos últimos anos com relação ao tema. De acordo com García (20I4: I06):

Una marca de violencia simbólica quedó evidenciada en la intención editorial de La Jiribilla por compilar una variada cantidad de refutaciones al artículo (de Zurbano). A tal punto que la ráfaga de respuestas llegó a ser interpretada por el cantautor Silvio Rodríguez como que le estaban cayendo en pandilla.

A resposta, publicada em 16 abril de 20I4, às várias manifestações feitas contra seu artigo focou na defesa, por Zurbano, da visão crítica que a Revolução deve ter:

Si una izquierda conservadora dentro y fuera de Cuba considera que un negro cubano revolucionario no debe hacer críticas a la Revolución, no ha entendido el papel que han jugado los negros dentro de esta y tampoco qué es un verdadero proceso revolucionario. En la base, en el corazón, en el fondo y en las orillas de este proceso los negros hemos sido buena parte del sostén. Nos asiste tanto el derecho moral a criticarla como el deber de defenderla, porque es aún insuficiente lo que hemos logrado frente a lo que hemos hecho y merecemos. Renunciar a esa crítica es renunciar a mejorar la Revolución y sentirla más nuestra (ZURBANO, 2013 ${ }^{285}$ ).

Um dos coletivos antirracistas, do qual inclusive Zurbano faz parte, a ARAAC, se manifestou poucos dias antes da resposta de Zurbano ter sido publicada. O grupo se posicionou em defesa de da liberdade de expressão e de idéias, da luta contra o racismo e se opondo a qualquer medida repressiva contra a liberdade de expressão:

Urge erradicar en Cuba todo vestigio de racismo, discriminación racial, colonialidad, exclusiones, desigualdades sociales e irrespeto a las diferencias. Reconocemos que tan lamentables prácticas lesivas a la dignidad humana aún persisten en nuestro país, y la lucha contra ellas constituye nuestro más alto propósito, al cual dedicamos nuestros esfuerzos de pensamiento, amor y acción directa - empeño que consideramos parte de las luchas revolucionarias de alcance planetario, que ocurren hoy mismo en aras de los múltiples fines de la emancipación humana.

ARAAC apoya y apoyará resueltamente la libre expresión de ideas por tod@s sus activistas, como parte de la imprescindible libertad de expresión en la sociedad toda.

ARAAC se opone pues a cualesquiera medidas o procedimientos institucionales o personales de carácter obstructivo o represivo contra cualquier participante en tales polémicas que a título personal haya expresado sus opiniones o criterios. (ARAAC, 20I3) ) $^{286}$

${ }^{284}$ Uma das publicações que compilou diversas críticas ao artigo de Zurbano foi a "La Jiribilla", No. 62I, desde el 30 de marzo hasta el 5 de abril de 2013.

${ }^{285} \mathrm{http}: / /$ www.rebelion.org/noticias/2013/4/I668I4.pdf (Acesso em: 20/09/2015).

${ }^{286}$ http://www.afrocubaweb.com/araac.html (Acesso em: 20/09/2015) 
Uma das conseqüências, após a publicação, foi a perda do cargo que Zurbano ocupava como editor chefe da Casa de las Americas após a publicação do artigo. O Jornal New York Times, por outro lado, reafirmou seu direito de fazer a revisão final de forma "autônoma", em violação ao colocado pelo autor, como destacou West-Durán:

Hasta el viernes 5 de abril (de 2013) sabemos que Zurbano fue destituido de su puesto como jefe del Editorial de Casa las Américas, y que se quedará en Casa, tal vez como investigador. El 6 de abril el NYT publicó algo por su reportero desde México sobre el incidente, pero en cuanto al asunto clave del cambio de título, lo esquivaron alegando que Zurbano había dado permiso para la versión final del título, lo cual no es cierto. El NYT dice que su contrato claramente estipula que ni el autor ni los traductores o los editores que trabajan con los autores tienen decisión final sobre el texto o el título, que provee un tono o contexto para el escrito en su totalidad. (WEST-DURÁN, 20I3) 287.

Os custos pessoais de colocar o tema em debate e elevar sua reverberação a outras esferas para além de Cuba foram altos, no caso de Zurbano. No hall de ativistas entrevistados, há outros eventos semelhantes, como relatado nos casos de Eric Corvalán, diretor do documentário Raza, demitido do ICRT ${ }^{288}$, de Norberto Mesa, que perdeu o trabalho no Marina Hemingway, e Deyni Terry, presa durante a tarde, após julgamento no tribunal, por fazer referência à discriminação racial, dentre outras situações apresentadas pelos ativistas, intelectuais e artistas.

Os efeitos dessa coerção não se restringem aos ativistas. Eventualmente, pode haver impactos para membros da família, como ocorreu com a mãe dos filhos de Norberto Mesa, no processo de seleção para um emprego em um Centro de Restauração Neurológica, em Havana:

Ella (esposa de Norberto) iba a trabajar para el Centro de Restauración Neurológica. Tenía todas las condiciones para trabajar ahí. Pero, entonces cuando fueron, porque en esos lugares hacen verificaciones, y cuando fueron al barrio hacer las verificaciones le dijeron un personaje de ahí: No, pero el esposo de ella es de la disidencia y entonces están en la cosa esa de los negros. Entonces, la bloquearon a ella y ella dijo: Se acabó, y entrego el carnet del partido ${ }^{289}$.

Há casos, ainda, nos quais a coerção ou limitação da atuação ocorre com os próprios coletivos e iniciativas existentes. Gisela Arandia, ao relatar que de forma sumária o projeto Color Cubano, no qual ela atuou de 2001 até 2009, foi extinto sem nenhuma explicação oficial, pontua o risco que outras iniciativas correm:

Yo siempre tuve conciencia y la tengo en este momento que para este tema siempre hay un pretexto en estamos en ARAAC hoy pero a lo mejor mañana ARAAC no existe y se disuelve porque siempre hay un pretexto, que se divide la nación, que si el imperialismo, que si le estamos haciendo juego al enemigo, siempre hay un pretexto para no aceptar un proyecto antirracista y eso también es universal nos pasa a nosotros, le pasa a los gitanos, le pasa a los romanos, le pasa a los palestinos el que sea, entonces tú tienes

\footnotetext{
${ }^{287}$ http:/ / www.afrocubaweb.com/alan-west-zurbano-nyt-es.html (Acesso em: 20/09/2015).

${ }^{288}$ Trabalhava no Instituto Cubano de Radio e Televisão. O motivo de sua demissão não foi oficialmente vinculado ao filme, mas houve coincidência temporal de ocorrer logo após do lançamento do mesmo. Uma repórter que divulgou o documentário em programa, no mesmo período, recebeu uma "sanção" de um mês.

${ }^{289}$ Carnê de integrante do Partido Comunista de Cuba. A entrada no partido é restrita. Só se entra por meio de convite.
} 
esa conciencia de que tienes que dar un pretexto entonces. (Entrevista com Gisela Arandia, realizada em I2/09/2014).

A forma como é incorporada e interpretada, contudo, muitas das coerções e práticas discriminatórias com ativistas e lideranças vinculadas ao tema é distinta. Se por um lado, essas vivências ensejam maior engajamento e explicitação do racismo, em outros ocorre um processo de defesa, muitas vezes apaixonada, da Revolução e uma relativa "paciência", tomando de empréstimo as palavras de Zurbano, com as cotidianas situações de racismo vivenciadas:

Es su confianza plena en que las fuerzas revolucionarias erradicarán definitivamente toda forma de racismo. Esa confianza generó entrega apasionada, fe ciega y, sobre todo, un profundo agradecimiento a la Revolución; es un agradecimiento personal, pero también colectivo, por su anterior condición de negro y pobre que fue, para muchos, una sola condición. Esta reflexión no es un pasaje irónico, masoquista o dramático del texto, pues lo que acabo de escribir se constata en la vida de tres generaciones de negros cubanos que han vivido la Revolución como un deber y una esperanza; dicho agradecimiento es históricamente consciente. Y explica, además, la paciencia con que se soportan sucesivas acciones racistas dentro de la Revolución. (Al cabo de varias décadas dicho agradecimiento se ha convertido en un muro de contención ante las crecientes demandas antirracistas y está siendo manipulado por los oportunistas del momento). (ZURBANO, 2012: 25).

Tem havido um maior questionamento dessa visão congelada de gratidão. São reconhecidos os avanços obtidos com a Revolução, mas destaca-se que foram construídos também com a participação de afrodescendentes. Tratar o tema como se esse segmento racial devesse todas as suas conquistas à Revolução, incomoda parte dos ativistas com os quais dialoguei. Há um contraponto dessa perspectiva com o resgate de que antes da Revolução já havia uma elite negra profissional, que produzia conteúdo e era politicamente engajada. Há, também, uma refutação explícita à própria ideia da eterna gratidão. Essa perspectiva surge na atualidade, na narrativa de vários dos ativistas entrevistados:

\footnotetext{
Seguimos aguantando, aguantando (las situaciones de discriminación racial), y somos (vistos como) mal agradecidos. Yo me acuerdo de una actividad que hicimos, se paró un activista y dijo: "Señores, ¿̇pero hasta cuando nosotros vamos estar agradeciendo? Y ¿quien va agradecer a nosotros por todo lo que hemos hecho?". Y es eso, ¿hasta cuando vamos estar agradeciendo? (Entrevista com Norberto Mesa, realizada em 09/07/2015).
}

Sintomático perceber que, derivado dessa dinâmica, pode estar muitas vezes presente a dor e a crise vivenciada por afrodescendentes, que possuem identificação e sentimento de pertencimento com relação à Revolução, nas situações em que esses são vítimas de racismo pelas mesmas instituições que arduamente defendem, ou por sujeitos intrinsecamente vinculados à Revolução. Isso seria o que Zurbano pontua como a "dupla consciência do negro" em Cuba, em diálogo com Du Bois:

Este problema tiene lugar frente a un conflicto también descuidado al cual, readecuando las ideas de W. E. B. Du Bois, llamo doble conciencia revolucionaria del negro en Cuba: consiste en un drama políticamente existencial que afecta a muchos cubanos negros, cuya militancia revolucionaria sufre 
constantes desgarrones éticos, ideológicos, incluso políticos al identificar o sufrir en carne propia los casi habituales gestos, chistes, humillaciones y otras operaciones excluyentes marcadamente racistas que provienen de instituciones y personas probadamente revolucionarias y hasta comunistas, contra las personas negras, sus cuerpos, culturas, religiones, comunidades, oportunidades, organizaciones y discursos. (ZURBANO, 2012:25).

O cotidiano do ativismo antirracista em Cuba reflete também essa dimensão da ambiguidade, inerente à própria condição negra no país. As conquistas sociais promovidas pela Revolução são impactantes e preenchem de significado as históricas lutas sociais cubanas. Esse processo inclusivo das amplas reformas revolucionárias foi vivenciado, também, com ênfase pela população negra. Todavia, a materialização de práticas racistas e do próprio racismo estrutural, que permeia as instituições, as relações sociais e a subjetividade dos sujeitos, complexifica a ambiguidade do ativismo antirracista. E os dilemas, conforme Norberto Mesa e Zurbano explicitam acima, tocam os dias atuais e compõem o debate contemporâneo sobre a questão racial.

No mergulho que fiz sobre as mobilizações afrocubanas, cuja pauta antirracista é o cerne da atuação, estabeleci maior proximidade com alguns desses ativistas e coletivos. De modo a complexificar a argumentação que faço, ao longo da pesquisa, sobre várias estratégias e linguagens existentes nos grupos antirracistas, e nas articulações estabelecidas entre eles, abordarei de forma mais aprofundada, a seguir, nuances de alguns dos coletivos que acompanhei durante a pesquisa, a partir da minha experiência e do meu olhar. São eles a Cofradía de la Negritud, a Red Barrial Afrodescendiente, a ARAAC, a Afrocubanas e o Projeto Identidad y Barrio La Marina, esse último de Matanzas. Todos, fora o Identidad y Barrio La Marina, têm sua atuação focada em Havana.

\subsection{Cofradía de la Negritud}

No processo de preparação para a pesquisa, durante o ano de 20I3, ao buscar informações sobre o movimento afrodescendente em Cuba e sobre a própria questão racial, pude acessar pela internet algumas informações sobre a Confradia de La Negritud. Todavia, foram dados muito limitados. Há pouco material disponível sobre as mobilizações antirracistas, especialmente fora de Cuba.

Após a chegada à Ilha, no início de 20I4, e meu ingresso, meses depois, no Diplomado Raza, Cultura y Gene, da Cátedra de Antropologia, na Universidade de Havana, conheci no final de uma das aulas Tomás Fernandez Robaina, que me foi apresentado como integrante da Cofradía 
de la Negritud. Depois de alguns encontros rápidos, apresentei meu interesse em conhecer mais sua atuação como ativista e marcamos uma entrevista.

Essa foi a primeira entrevista realizada na pesquisa. Fui até sua casa, localizada no bairro Cerro, em Havana, que fica situada em frente a uma fábrica de materiais de construção, inaugurada nos primeiros anos da Revolução pelo então ministro da Indústria, Ernesto Che Guevara. Tomás Robaina foi testemunha ocular do processo revolucionário. Tem memória de Cuba dos tempos de Batista, da Revolução e das primeiras mudanças implementadas pós-1959. Em meio aos vários elefantes que ornamentam sua casa, pude me aprofundar nas histórias de um dos primeiros coletivos que surge após a crise do bloco socialista. Esse diálogo foi realizado bem ao estilo cubano, com muitas interrupções dos vizinhos, que se apresentavam e interagiam conosco, tornando o momento da entrevista mais fluído.

É a partir dos relatos de Tomás e das indicações e referências por ele dadas que consegui acessar dados mais concretos sobre o coletivo. Em I998, surge a Cofradía de la Negritud, uma iniciativa da sociedade civil que significou uma aliança importante com o debate intelectual que vinha num crescente nesse período. A Confraria dá grande ênfase ao trabalho comunitário, com histórico de atuação especialmente no bairro onde está localizada, La Ceiba, em Playa, Havana.

Em seu documento fundacional, Carta de Apresentação de julho de 1998, assinada pelo primeiro confrade Norberto Mesa, são apresentados os objetivos do coletivo. Dentre eles, cabe destaque o de fomentar a plena consciência sobre as crescentes diferenças raciais nas instituições estatais e na sociedade civil, além de disseminar e promover trabalhos sobre a temática racial que tiveram crescente produção a partir dos anos 1990, por artistas, ativistas e intelectuais. O documento destaca, ainda, os significativos impactos, gerados no período especial, sobre as desigualdades raciais em Cuba. O coletivo, na carta, demanda políticas de combate à desigualdade que deveriam levar em consideração as desvantagens históricas acumuladas pelo segmento populacional negro, com ações concretas.

No decurso da pesquisa, conheço outro famoso integrante da Cofradía, Tato Quiñones. Abacuá e Babalawo, Quiñones teve uma atuação muito importante na divulgação de notícias e boletins do coletivo, sendo o mais famoso deles, o boletim "Desde la Ceiba", divulgado em Cuba e no exterior. Quiñones também é um intelectual com vários livros publicados sobre o tema racial.

O último dos integrantes da coordenação que conheci, e que tive a oportunidade de realizar entrevista, foi Norberto Mesa, que é um dos fundadores do coletivo, que escreveu e assinou sua 
carta fundacional. A criação da Cofradía é motivada, inclusive, por casos de discriminação racial vivenciados pelo próprio Norberto, cuja resolução na justiça foi frustrada. A motivação de ampliar esse debate, de denunciar o racismo e articular outros atores sociais a esse processo fez com que um pequeno grupo se reunisse para formar esse coletivo:

Llego el año 1998. Yo tenía un compañero Reberto Monte, que era ingeniero pecuario igual que yo, que hablamos mucho del tema este de la cosa racial, y estaba Josefina, que era profesora de Filosofía en la Universidad de la Habana y Belkis Lamonte, que era la madre de las hijas mías. En la casa de Reberto nos reuníamos nosotros y hablamos de todas esas cuestiones, hasta que un día decidimos: ¡Oye vamos hacer algo más! Me dan la tarea a mí de escribir la carta de presentación. Ahí hicimos la cuestión esta de la Cofradía de la Negritud. En ese período, Reberto era militante del partido, Josefina era militante del partido, Belkis en ese momento era militante del partido. [...] entonces hacemos el documento, la carta de presentación. Eso fue en julio del 98, se cumplían 80 años del nacimiento de Nelson Mandela. Hicimos I0, 20 copias de la carta. Entonces yo salí a repartirla. Me montaba en la guagua y le decía a alguien: Oye, ¿tú crees que en Cuba hay discriminación racial? ¡Sí! Mira, lee esto y si tú crees que es interesante, no te quedes con ella pásaselo a otro. Así la carta de presentación llego hasta México, en un periódico mexicano salió la carta de presentación. (Entrevista com Norberto Mesa, realizada em 09/07/2015).

A partir desse texto, a Cofradía torna públicos seus objetivos, suas posições e críticas em relação à situação de exclusão de negras e negros no país. Por meio dessa divulgação inicial, foi possível articular a participação de dois outros importantes ativistas para essa agrupação: Tato Quiñones e Tomás Fernandez Robaina, conforme descrito a seguir:

Em um debate no ICAIC (Instituto Cubano de Arte e Indústria Cinematográfica), conheci o homem que havia fundado a Cofradía de la Negritud, que é Norberto Mesa. Waltério Carbonell nos apresentou e eu disse a ele que havia lido o texto fundacional e que estava bastante de acordo com os pontos levantados. Mesa me dá uns disquetes, onde estavam os documentos que havia enviado à Assembleia (Assembleia do Poder Popular). Depois de uma reunião [...], Tomás Robaina e eu tomamos a decisão de que era importante apoiarmos a Cofradía de la Negritud, que já tinha alguns anos de fundada e tinha uma estrutura fragilizada, com Norberto e mais algumas pessoas. Tomacito (Tomás Robaina) e eu a apoiamos. Já éramos intelectuais conhecidos, com livros publicados sobre o tema, e resolvemos que deveríamos apoiá-lo. (Tato Quiñones, entrevista realizada em 29/05/2014)290.

Tudo isso (mudanças no debate sobre a questão racial) ocorre nos anos I990. No final dos anos I990, eu tomo conhecimento de que existe o Movimento de Integração Racial. Além desse, surgiram vários outros grupos de negros para lutar por suas demandas nesse período. Houve uma dessas iniciativas que se chamava Cofradía de la Negritud. Quando tenho a oportunidade, pela primeira vez, de ler o seu documento fundacional, isso já em 1998, I999, é Tato (Tato Quiñones) que faz com que esse documento chegue até mim. Tato, inclusive, reforça que, após tê-lo lido, o subscreve por completo. Quando o leio, não o subscrevo totalmente, porque dizia "somos cristãos", e quando está conformando uma organização política, social, não pode qualificá-la nem de santera, nem de religiosa, mas apoiei a iniciativa. (Tomás Fernandez Robaina, em entrevista realizada I5/05/2014) ${ }^{291}$.

Em Cuba, é forte o debate sobre a laicidade, sendo esse também presente nos processos organizativos antirracistas no país. Outro aspecto, porém, foi mais intensamente evidente. Especialmente, nos seus primeiros anos, o embate político acirrado pelas posições pró e contra a revolução foi marcante. A Confraria, como um dos poucos espaços coletivos existentes na época para debater o racismo e suas facetas, passou por diversos processos coercitivos, embebidos na

290 Tradução minha. Original em espanhol.

29I Tradução minha. 
velha conhecida dicotomia ideológica atuante em Cuba até os dias atuais, dos que são considerados "dissidentes" e aqueles considerados como "revolucionários":

Imediatamente após minha incorporação na Cofradía, fui a uma agência de imprensa e divulguei essa iniciativa (da Confraria). Então, imediatamente, as pessoas, digamos, da direita cubana, começaram a alegar que a minha presença e de Tomás Robaina tornava a Confraria oficialista. E justamente eu que sempre estive longe de tudo que era oficialista em toda minha vida. Por outro lado, muita gente começou a dizer que nós éramos dissidentes, que estávamos como Chaplin. Lembra-se do filme de Chaplin, quando ele virava o parafuso para todos os lados? Assim estávamos nós, como Chaplin em Tempos Modernos (Tato Quiñones, entrevista realizada em 29/05/20I4) ${ }^{292}$.

Tomás Robaina também relata experiência que demonstra as dificuldades para a aceitação do debate sobre a questão racial naquele período, influenciadas pela tardia percepção da Guerra Fria ainda exalando seus ares no cotidiano dos cubanos:

Depois daquele momento, começou a se cogitar de que o documento fundacional da Confraria havia sido redigido e divulgado pela própria Segurança do Estado (Inteligência Cubana), para detectar as pessoas envolvidas com essas ações, porque nós os cubanos somos bem paranóicos. [...] Norberto Mesa, no período em que ainda estava no processo de me incorporar à Confraria, vem até minha casa perguntar minha opinião sobre a oferta feita pela Oficina de Interesses dos Estados Unidos, em Havana, para uso de sua sala de navegação, pois ele não sabia como se posicionar. Olha, do meu ponto de vista, todos nós, para que nos respeitem e nos façamos respeitar, devemos estar a mil quilômetros de todas as embaixadas. Da embaixada Yanqui, a um milhão de kilômetros de distância. [...] A partir desse período, eu e Tato nos incorporamos à Confraria. Antes do nosso ingresso, Norberto havia sido um pouco constrangido pela polícia e havia tido muitos problemas também que tinham muita relação com o fato de ser líder da Cofraria. A partir desse momento, todos mais ou menos passaram a aceitar. E hoje a Cofraria já tem uma longa caminhada e é conhecida, sobretudo a partir do Boletím de Tato ${ }^{293}$ (Tomás Fernandez Robaina, entrevista realizada em $\mathrm{I} 4 / 05 / 20 \mathrm{I} 4)^{294}$.

A Confraria traz como eixo central três ativistas em sua organização: Norberto Mesa, Tato Quiñones $^{295}$ e Tomás Fernandez Robaina. Com base nessa organização nuclear, a Confraria estabelece articulação em outras regiões de Cuba e no exterior. Possui boletim periódico, enviado eletronicamente a ativistas, pesquisadores e interessados no tema. Também é publicado em blogs e sítios na web, como no caso do blog "negra cubana tenía que ser". Em períodos anteriores, realizou importantes debates sobre a problemática racial e o aporte histórico e cultural dos negros em Cuba, em grande parte no seu espaço comunitário de debate "A la sombra de La Ceiba ${ }^{296 " . ~}$

Nós começamos a trabalhar e fazer coisas, reunião com a comunidade e intelectuais para discutir, debater.
Intelectuais, pessoas da academia, jornalistas, ativistas, professores, que levávamos ao bairro La Ceiba, meu
bairro, onde vivo há muitos anos e onde existe uma casa comunitária. É nesse espaço que fizemos muitos
encontros e atos de rua públicos. Isso foi dando à Cofraria certo espaço, certa legitimidade, e é a que existe
nesses momentos, pois sem estar reconhecida oficialmente no presente, tem espaço como sociedade civil,
sem compromissos políticos, partidários. Só o compromisso com a Revolução cubana, que é o
compromisso que eu mantenho intacto, e por isso não preciso estar filiado a nenhum partido. Porque, no
caso de Cuba, não foi o partido que levou a Revolução ao poder, foi exatamente o contrário. A Revolução

${ }^{292}$ Idem.

${ }^{293}$ Boletim digital "Desde La Ceiba", redigido por Tato Quiñones.

${ }^{294}$ Tradução mina.

${ }^{295}$ Em abril de 2015, tomo conhecimento que Tato Quiñones se desvinculou do coletivo.

296 Árvore endêmica de Cuba, que pode alcançar até 60 metros de altura, se assemelha ao Baobá africano. Por isso, é considerada sagrada em tradições de matriz africana em Cuba, como a Santeria, Palo Monte e a tradição Abacuá. 
no poder é que cria o partido. Meu compromisso é com a Revolução. O Partido, a Revolução pode criar ou desfazer, si é a Revolução que faz, eu estou de acordo. (Tato Quiñones, entrevista realizada em $29 / 05 / 2014)^{297}$.

Os integrantes da Confraria, marcadamente, se posicionam em defesa da Revolução e defendem que o avanço social depende da garantia de direitos amplos e da luta contínua, inclusive por parte do Estado, contra o racismo. $\mathrm{Na}$ carta fundacional da Confraria, destaco o debate sobre a importância do marco regulatório das organizações da sociedade civil, como as associações. Ainda com poucos avanços legais, essa regulamentação é uma das demandas centrais desses coletivos, exatamente pelo impacto significativo junto a organizações e coletividades da sociedade civil. Em tramitação há anos na Assembleia do Poder Popular, esse normativo ainda não foi atualizado, o que dificulta a oficialização de organizações coletivas.

Finalmente, una cuestión de procedimiento. Los propósitos de la Cofradía de la Negritud, en nuestra opinión, no transgreden ningún precepto legal y, por ello, aspira a tener existencia lícita en nuestro país, lo cual implica un proceso que tiene entre sus pasos la presentación de listas de apoyo con una determinada cantidad de firmas. Si usted, amigo(a) lector(a), cualquiera que sea el color de su piel, considera que este proyecto que le hemos presentado tiene razones válidas para existir; si usted entiende que puede ser útil en nuestra sociedad, incorpórese a la lista que en algún momento pueda serle presentada por alguno de nuestros activistas y muestre así su apoyo a la legitimación de la Cofradía de la Negritud. Ahora bien, si usted admite como propios los propósitos y postulados de este proyecto, si acepta conscientemente las responsabilidades propias de la condición de cofrade, le invitamos a que solicite su incorporación a la Cofradía de la Negritud; de ser aceptado (a) entonces estaremos juntos en alguno de los muchos caminos de nuestra justa lucha. (I ${ }^{a}$ Carta Confradia da Negritude, junho de 1998)

A atuação da Confraria é de grande relevância para o contexto cubano, pois possibilitou que muitas questões, levantadas em debates, seminários e reflexões, se concretizassem em propostas que foram, em diferentes épocas, apresentadas a órgãos governamentais, como a Assembleia do Poder Popular, Ministério da Educação e União dos Artistas e Escritores de Cuba - UNEAC, e instâncias multilaterais, como a Organização das Nações Unidas - ONU. Além disso, a circulação periódica do boletim "Desde La Ceiba" traz informações sobre a atuação da Confraria, de outras organizações, bem como divulga informações relacionadas ao tema racial298.

De acordo com Tato Quiñones, os objetivos da Cofradía de la Negritud passam pela reflexão dos processos históricos no que se refere à pauta racial, à análise do período presente, bem como apresenta ações necessárias para o avanço no tema:

¿Que está pasando en ese momento? ¿Que ha ocurrido en los años 1990 en Cuba? ¿Como esas desigualdades se han multiplicado? Se han hecho cada vez más evidente y la discriminación, la exclusión que está ocurriendo en los centros de trabajo y como el racismo ha rebotado en Cuba con una fuerza realmente inusitada. O sea, lo que demuestra que la hipótesis de los años 1960 estaba equivocada. Mira, lo que está pasando ahora. No solamente el racismo. Los años 1990 fueron devastadores para la realidad cubana. Yo creo que no hay un espacio de la realidad cubana que no haya sido de alguna manera afectada o desbastada por esta situación que ha habido en Cuba, esta situación insólita donde no aparece en ningún país del

${ }^{297}$ Tradução minha.

${ }^{298}$ Os boletins podem ser acessados no endereço www.afrocubaweb.com/coneg/coneg2.htm 
mundo. Es cierto que cuando se fue por el caño la Unión Soviética y todo este mundo de la Europa del Este que se suponía que Cuba se iría también. Cuba no se fue, pero el precio que tuvimos que pagar es elevadísimo, elevadísimo, un precio muy alto en desigualdades, en pérdidas de lo alcanzado y sobre todo en el rebrote de males sociales que creíamos definitivamente muertos y que están hoy más vivos que nunca. El racismo es uno, la prostitución, la corrupción. Puedo seguirte enumerando, crear ataduras de la desesperanza, la frustración. Eso está en la realidad cubana actual, ese el precio que hemos pagado por no habernos ido por el caño de Unión Soviética. Entonces quienes estamos con la posibilidad de un socialismo verdaderamente democrático, popular y participativo realmente, y quienes están de alguna manera intentando reconstruir el capitalismo. El Che Guevara decía que no podemos construir el socialismo con las armas aliadas del capitalismo y aquí hay quienes están intentando reconstruir el capitalismo con las armas aliadas del socialismo. Realmente muy difícil, muy complicado, y seguimos luchando. (Entrevista com Tato Quiñones, realizada em 29/05/20I4).

$\mathrm{Na}$ atualidade, a Cofradía de la Negritud está com sua estrutura fragilizada. A casa comunitária, onde foram realizadas muitas atividades do grupo, hoje está ocupada por várias famílias que perderam seus lares, especialmente pela precariedade dos mesmos, que apresentavam risco de desmoronamento. Seus integrantes mantêm a divulgação de atividades e manifestos, todavia com algumas limitações práticas, como dificuldade de articulação entre seus integrantes e de acesso à internet. O legado e a importância da Cofradía para a história das mobilizações antirracistas é fundamental, especialmente por seu pioneirismo. O que coloca esse coletivo num lugar de destaque no movimento afrocubano atual.

\subsection{Articulação Regional Afrodescendente}

A ARAAC surge como reflexo de um diálogo mais abrangente que permeou a articulação de movimentos afrodescendentes na região da América Latina. É oficializada durante a reunião realizada entre os dias 20 e 2I de setembro de 2012, em Havana, Cuba, com inúmeros ativistas, de seis países americanos. Na reunião, foi ressaltada a importância da construção de acordos e consensos entre os movimentos da região, para fortalecer a luta contra o racismo e a discriminação racial no Caribe e América Latina. 


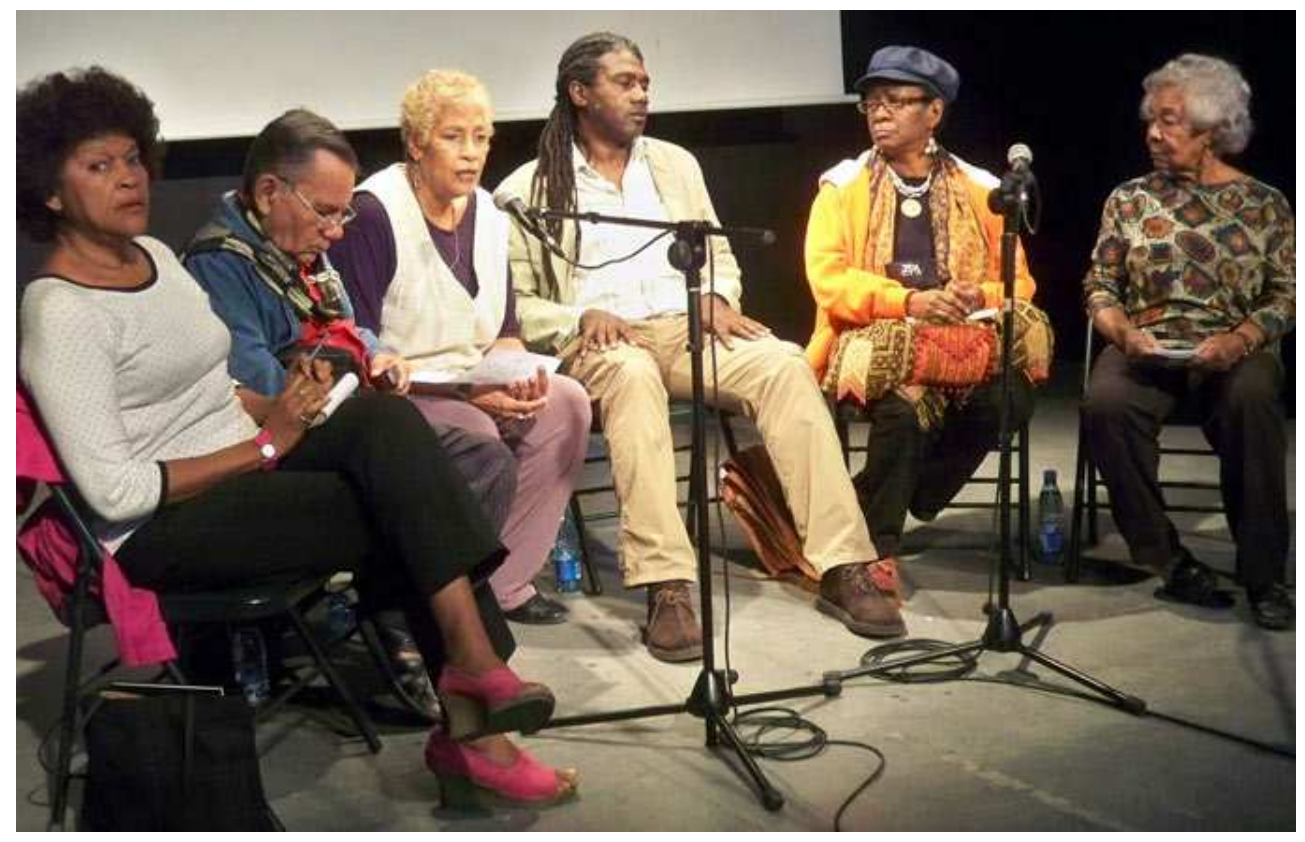

Figura 34: Foto da Coordenação Executiva da ARAAC, 20I4. Da esquerda para direita: Irene Ester Ruiz, Tomás Robaina, Gisela Arandia, Roberto Zurbano, Norma Guillard e Lídia Turner. Disponível em: http://www.afrocubaweb.com/araac.html (acesso em 20/09/2015)

Uma parte considerável dos ativistas entrevistados tem ou teve vinculação com a Articulação. Conforme a foto acima ilustra, fazem parte da executiva da organização Irene Esther Ruiz, Tomás Robaina, Gisela Arandia, Roberto Zurbano, Lídia Turner e Norma Guillard. Quase todos foram entrevistados durante a pesquisa, com exceção de Lídia. Essa é uma organização que, apesar de seus desafios, é importante para o cenário atual da luta antirracista no país.

Em sua reunião de fundação, a ARAAC, capítulo cubano, tornou público um acordo que explicitava o seu vínculo com os processos derivados da Conferência Mundial de Durban (África do Sul, 200I), seu plano de ação e declaração. Posiciona-se como uma articulação da sociedade civil que exige compromissos institucionais do governo com os direitos e demandas afrodescendentes. Ressalta, ainda, a necessidade de contribuir com o protagonismo dos afrodescendentes na região, numa perspectiva emancipatória. Buscam estabelecer metodologia de trabalho que compartilhe as decisões, a partir da "diversidade e do consenso", para alcançar a "unidade estratégica" entre indivíduos, grupos, comunidades e coletivos da sociedad civil.

Objetiva articular atores sociais e comunidades, historicamente marginalizados, na luta pela equidade e por direitos. Busca, também, construir e implementar um sistema de monitoramento das políticas e programas de desenvolvimento na região, com critérios e indicadores antirracistas, além de impulsionar a participação e representação qualificada dos afrodescendentes na vida cultural, social e econômica do país. Por fim, destaco a proposta do coletivo de construir um plano de ação para a Década dos Povos Afrodescendentes, com base em seu espectro de atuação. 
A criação da ARAAC, capítulo cubano, estimulou outros processos mobilizatórios para a pauta antirracista, como o ocorrido com a Rede Barrial Afrodescendiente. Maritza relata que após sua reunião fundacional, sentiu-se estimulada a articular o tema em seu bairro e ampliar o debate em sua comunidade:

La Rede Bartial Afrodescendiente es el resultado de esa coherencia porque en el año 2012, entre agosto y septiembre en Cuba se creó la articulación regional Afrodescendiente en su capítulo cubano. Un grupo de personas fuimos convocadas por el Ministerio de Cultura para una reunión con líderes de varios lugares de Latinoamérica, era más bien un dialogo fraternal sobre el tema discriminatorio en cada contexto, ahí fueron líderes de Venezuela, Costa Rica, República Dominicana, Haití, Colombia y los que estábamos cubanos. En medio de ese dialogo cuando yo mire así a mi alrededor, como hace un rato te hablaba de mi conciencia racial, empecé a visualizar tanta gente que me había ayudado a crecer que estaban ahí presentes, que habían escrito libros o artículos, o habían sido excomulgados porque plantearon el tema en un lugar que a alguien no le gusto, tenía poder y lo desplazo y eso me dio mucho orgullo, pero a la vez mucho compromiso. Porque todavía yo no estoy muy clara de por qué llegue a ese lugar, me imagino que tiene que haber sido por mi trayectoria de vida. Hablando de la coherencia, pero escuchar los testimonios que allí se dieron, qué se pensaba, los diferentes ejes que tenía ARAAC, la forma democrática en las que se propuso que todos los que nos involucramos, participáramos, el hecho de que hubiera un eje específicamente que fuera de trabajo comunitario, a mí me hizo comprometerme mucho más. ARAAC pedía que no se crearan entidades nuevas ni organismos nuevos, sino que en el radio de acción donde nos moviéramos, tratáramos de tener todos los que hemos sido convocados una incidencia. Pues, mi incidencia fue convocar a mi zona, que también al igual que yo estuviesen comprometidas y que nos involucráramos en un proceso de formación, pero a la vez de fortalecimiento de esa conciencia crítica. (Entrevista com Martiza López, realizada em 15/08/2014).

Durante a pesquisa de campo, participei de várias atividades promovidas pela ARAAC. Em muitos delas, havia a motivação vinculada a uma data importante para a questão racial, como o dia internacional de combate à discriminação racial, 2I de março, ou o dia de África, 29 de maio. Em outros casos, a ARAAC promoveu mobilizações mais amplas, como a Jornada contra o Racismo e a Discriminação Racial. Martiza comenta o tema da Jornada e a relevância desse debate para visibilizar as "cores cubanas" e a própria identidade afrocubana:

\footnotetext{
El lema de la campaña este año de la Primera Jornada contra el Racismo y la Discriminación Racial, que no se pasó todo lo justo que nosotros hubiéramos querido en los medios, decía eso: Hablar de racismo duele, pero no hablarlo, nos divide. Desde esa proyección cuando se traza una política pública y usted no tiene estadísticamente los datos registrados, sigue pasando eso que está pasando. Como no se visibiliza la cantidad de negros, mestizos y blancos, eso no es que vayamos a tratar de hacer prevalecer un grupo u otro por el color de la piel, porque lo que si queda claro es que todos somos cubanas y cubanos, pase lo que pase para bien, mal o regular, es Cuba, pero Cuba tiene colores. (Diálogo com Martiza López, realizado em I3/09/20I4).
}

Esse diálogo com Martiza foi realizado com a então vice-presidente do Poder Popular de Matanzas. O fato de ter havido uma Jornada, como a promovida por ARAAC, fez parte de sua argumentação do porque era importante ter dados desagregados por cor da pele. As mobilizações e a realização de atividades, como essa, fortalecem a narrativa desses movimentos e possibilitam problematizar em situações cotidianas outras perspectivas discursivas sobre o tema racial. 
A ARAAC também organiza atividades para aproveitar a presença de lideranças antirracistas estrangeiras ou especialistas, como no caso da palestra com James Early ${ }^{299}$. Nessa palestra, sua abordagem chamou atenção para o dinamismo das mobilizações sociais. Apesar da Articulação Regional Afrodescendente buscar um espaço de diálogo regional, com um plano de ações integrados entre os países e para a região, sobretudo com foco na Década dos Povos Afrodescendentes, há desafios enormes para a consolidação dessas instâncias. Em sua palestra, realizada outubro de 20I4, James Early destacou que das Articulações formadas nos países, a única que continuava em funcionamento era a Cubana.

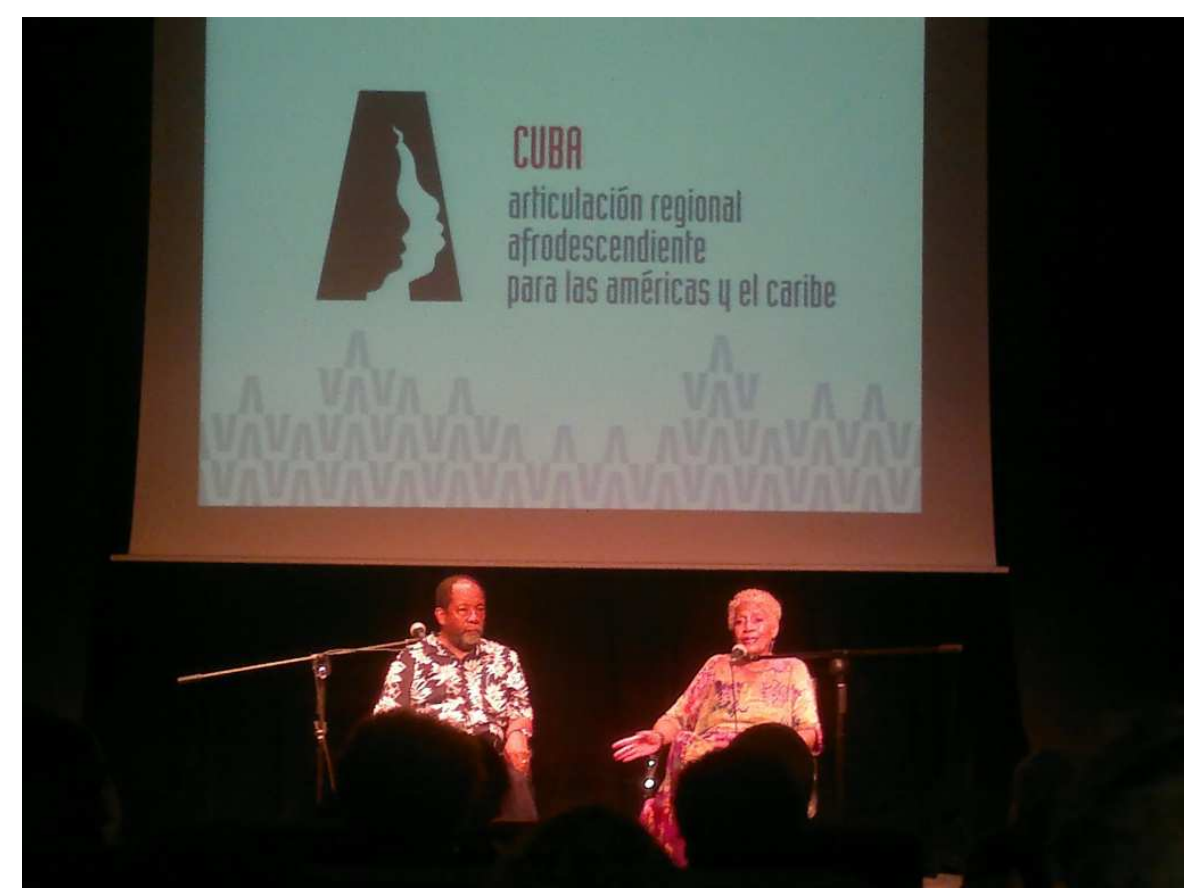

Figura 35: Debate promovido pela ARAAC-Cuba em outubro de 20I4, com James Early e coordenação de Gisela Arandia, na Casa de Alba, Havana, Cuba. Foto: Bárbara Oliveira.

Contudo, as dificuldades de operacionalização são muito concretas, inclusive internas. ARAAC é uma das organizações que busca fortalecer suas articulações também junto às instâncias estatais. Por exemplo, com relação ao plano para a Década dos Povos Afrodescendentes, a ARAAC teve um papel fundamental em mobilizar atores governamentais para apoiarem a iniciativa. $\mathrm{Na}$ atividade promovida por esse coletivo, no dia 20 de agosto de 20I4, de inauguração da Década em Cuba, participaram, dentre outros convidados, o vice-ministro de cultura de Cuba, que no encerramento da atividade declarou:

Eu creio que, uma primeira ideia, é que nessa circunstância atual, é normal quando nos reuninamos para tratar algum assunto e apareçam inquietudes, preocupações. Eu creio que uma primeira lição que, em minha opinião, temos aprendido é que nós estamos de acordo sobre esse assunto e que podemos declarar nosso compromisso com a Década (dos Povos Afrodescendentes), que era o objetivo da reunião. (Mas

\footnotetext{
${ }^{299}$ Diretor de Políticas de Patrimônio Cultural do Smithsonian Institute, Center for Folklife and Cultural Heritage.
} 
não se pode) pensar que não haja coisas para dizer, para ouvir. A primeira coisa que queria destacar é essa, que para mim me parece muito pertinente que surjam essas questões, que os companheiros e companheiras venham expressar-se com toda a liberdade. (Exposição de Fernando Rojas Vice-Ministro de Cultura de Cuba, na inauguração da Década dos Povos Afrodescendentes, em Havana, Cuba, em 20 de agosto de 2014) $)^{300}$.

Em meio a várias críticas apresentadas pelos ativistas e pelo público presente na atividade, grande parte delas vinculada à própria inoperância do Estado para tratar o tema, foi importante tanto a participação, como o compromisso do vice-ministro de cultura com o Plano para a Década. Todavia, pouco se apresentou concretamente sobre o plano. Além dos compromissos que possam ser assumidos por um coletivo da sociedade civil, como ARAAC, sem um comprometimento do Estado, efetivar um plano se torna bastante limitado. Gisela Arandia ressaltou essa questão na mesma atividade, conforme detalhei na seção "Entramos negros, saímos afrodescendentes".

ARAAC possui, desde sua criação, um diálogo mais estreito com o Ministério da Cultura. Muitas vezes, a partir desse diálogo, foi possível obter apoio para algumas iniciativas. Contudo, como vários outros coletivos antirracistas em Cuba, a ARAAC possui uma estrutura muito frágil, sem recursos para promover ações ou mesmo uma atuação mais ampla em outras cidades do país e dificuldades para ampliar seu espectro de ação. Portanto, apesar dessa proximidade com o ministério, a ARAAC não é legalizada como associação, organização não-governamental, e, os apoios recebidos não se materializam em suporte concreto para sua mobilização. Há grande fragilidade estrutural e política. Zurbano, em um artigo de avaliação dos dois anos de existência da ARAAC, declara:

El próximo mes de septiembre (de 2014) se cumplirán dos años en que fundamos en La Habana el capitulo cubano de la Articulación Regional Afrodescendiente para las Américas y el Caribe (ARAAC), cuyo funcionamiento aun deja mucho que desear si pensamos en que uno de sus objetivos es sumar las personas, proyectos e instituciones cubanas que así lo deseen al ideario y el activismo antirracistas. Más allá de algunas declaraciones, panelas de trabajo e intercambio, reuniones ejecutivas e intentos organizativos, no se ya logrado aun horizontalizar la labor hacia una membrecía de personas y organizaciones a través de todo el país ni hacer una propuesta táctica y estratégica que nos permita insertarnos en comunidades reconocidas o no, en algunas instituciones importantes, así como dar una legitimidad pública y sistemática a nuestra labor. (Zurbano, 20I4) (20I. $^{2}$.

Bienvenido Rojas reflete sobre aspectos semelhantes ao exposto por Zurbano, dando ênfase à necessidade de que essa articulação da ARAAC se reflita junto a outros coletivos e a outras cidades do país. Avalia, ainda, que o silêncio sobre o tema foi muito profundo, o que dificulta a própria mobilização:

\footnotetext{
300 Tradução minha.

301 https://afromodernidades.wordpress.com/20I4/I0/06/araac-24-meses-despues-una-propuesta-de-trabajo-unmomento-de-revision-una-reflexion-compartida (Acesso em 20/09/2015).
} 
ARAAC ha llegado en un momento muy oportuno realmente, porque se han ido creando algunos espacios a nivel de las instituciones y del gobierno del Estado cubano, hay una mirada un poquito más suave en relación con este tema, o sea hay una oportunidad de hablar sobre el tema, de debatir. Estamos realmente en un momento crucial para desencadenar todas las fuerzas que puedan conducirnos a una apertura amplia sobre este tema y llegar realmente a cosechar resultados importantes. Ahora es contradictorio a la vez porque parece ser que todos no estamos preparados para este asunto. Ha sido tanto tiempo de ocultamiento que no nos damos cuenta. Entonces el ARAAC hay que dinamizarlo, hay que organizarlo mejor, hay que estructurarlo mejor, hay que trabajar, hay que hacer alianzas con otras organizaciones que están también en la misma lucha, que tienen la misma visión, un ejemplo la misma Comisión Aponte. Hay otras organizaciones que están trabajando en esto. Yo pienso que hay que aliarse a esa gente, hay que ampliar el horizonte del trabajo o de ARAAC, sacarlo de la capital. Hay que llevarlo a las provincias y crear grupos y hay que ir ampliando, me entiendes, ampliando todo el trabajo en la base, hay que interrelacionarse con el trabajo comunitario, o sea que ARAAC tiene que nutrirse y vibrar junto con el trabajo que hacen las comunidades. (Entrevista com Bienvenido Rojas, realizada em 04/05/20I4).

Os desafios da ARAAC permeiam, ainda, as articulações internas, que são muitas vezes complexas. Gisela, uma das integrantes da coordenação executiva do coletivo, pontua os desafios da construção de consensos e diálogos dentro do grupo:

Una de las razones por las cuales no avanzamos en ARAAC porque nos reunimos cinco personas (Ejecutivo) para decir: ¿Vamos a ir al cementerio? Entonces el otro dice: No, no vamos a ir al cementerio, vamos al malecón. Y entonces en esa discusión nos pasamos un mes, dos meses, un año. Si vamos al cementerio, si vamos al malecón si vamos con fulano, si vamos con mengano. (Entrevista com Gisela Arandia, realizada em I2/09/20I4).

Essas relações complexas internas interatuam com outras dinâmicas. Como já refleti em relação às percepções de vários ativistas entrevistados sobre as mobilizações sociais em Cuba, há uma expectativa idealizada de que o movimento antirracista se fortaleça a partir da liderança de uma personalidade importante politicamente, a partir de um alinhamento das várias iniciativas existentes. Essa perspectiva também surge na forma como seus integrantes visualizam a ARAAC. Zuleica Romay, que além de ser ativista nesse grupo também é presidenta do Instituto Cubano do Livro, reflete sobre essa lógica de tradição verticalizada das mobilizações sociais e como isso impacta na dinâmica coletiva:

Yo no voy a decir que no hemos logrado nada, pero una de las cosas que más trabajo nos ha dado en ARAAC es que la gente entienda que la organización funciona si él o ella tienen iniciativa y que la iniciativa no viene de arriba y que lo que hace que la organización funcione es que todo el mundo este en algo. Porque los movimientos sociales de hoy funcionan así, sobre la base de la iniciativa de pequeños grupos que se van articulando y tejiendo redes hasta que son una fuerza poderosa. Bueno, aquí la gente está esperando que venga alguien a decir, porque una sociedad que ha funcionado así verticalmente. Esa es otra particularidad cubana que contribuye a inhibir los movimientos sociales que buscan mejoras en el ordenamiento institucional en el ordenamiento institucional en el respeto a los derechos. ¿Por qué? Porque la gente no se ven unos a otros, todo el mundo está así, esperando a que le baje una idea, una orientación, una orden, esa es otra particularidad cubana. (Entrevista com Zuleica Romay, realizada em I8/08/20I4).

Mas, mesmo com essas debilidades colocadas, a ARAAC é atualmente uma das importantes organizações da sociedade civil em Cuba. Como coloca uma das integrantes do executivo do grupo, é um coletivo que busca se firmar, se consolidar: 
Yo creo que sería como grupo más oficial Aponte y ARAAC que estamos tratando de tomar vuelo, tratando de constituirnos, como bien se dijo en el evento que tu estuviste. Ni siquiera tenemos una legitimación fuerte, porque a veces puede llegar a un barrio o puede llegar a una institución cy ARAAC? No sabemos que es eso, no sabemos de que se trata, tanto de un proceso en gestación pudiéramos decir y Aponte por otro lado de la cual formé parte también, es una organización que su objetivo es negociar con instituciones pero no es una organización donde va la gente, donde hay un discurso público, eso no existe. (Entrevista com Gisela Arandia, realizada em I2/09/20I4).

As articulações feitas pela ARAAC são mais amplas que a escala nacional. Seus representantes participam de encontros, fóruns e seminários no exterior, o que fortalece a reverberação do debate racial cubano em instâncias internacionais, como também gera influências dessas trocas de saberes e práticas entre os movimentos de diferentes países.

Uma parte dessas articulações é feita para a pauta de mulheres negras especificamente, na Rede de Mulheres Afrolatinoamericanas y Afrocaribenhas, capítulo cubano, que também se compõe como parte do escopo de atuação da ARAAC. Norma Guillard, que compõe o executivo da ARAAC, também atua na Red de Mulheres e ressalta o contexto da criação da sua criação:

En esos años, empezamos a visibilizar una realidad diferente, porque con la caída (de la URSS) y las dificultades económicas que había con ese bloqueo de Estados Unidos, constante a limitarnos como proyecto al querer desaparecernos, en ese enfrentamiento salíamos perdiendo las personas negras que no teníamos apoyo. Porque las personas blancas en su mayoría tienen alguna familia que ha estado y con la remesa que recibían fueron encontrando como salida. Se empezó a ver que había esa diferencia. Porque cuando empieza el turismo se empezó a ver que tampoco a los negros son a los que le dan las plazas y empiezas a ver diferencias ya en muchas aéreas. Nos damos cuenta que alguna cosa había que hacer para empezar a reconocer más abiertamente que había algo. Justamente en los proyecto que estoy trabajando con esos talleres de empoderamiento con mujeres negras, con ese espacio de la Red de Mujeres Afrolatinoamericanas y Afrocaribeñas, capítulo cubano. Es con esa intención de visibilizar esas realidades que uno a veces se conforma creyendo que es lo que le toca. (Entrevista com Norma Guillard, realizada em 03/0272015).

As dinâmicas da ARAAC refletem muitas das particularidades da mobilização social antirracista em Cuba. Traz várias das limitações que a sociedade civil de modo geral enfrenta, como dificuldades legais, de comunicação, infraestrutura, aliadas às complexas relações internas e externas, tanto com integrantes do próprio coletivo, de outros grupos, como nas relações estabelecidas com o Estado.

\subsection{Afrocubanas}

A reflexão sobre as relações raciais em Cuba passa, necessariamente, por um olhar sobre a mulher negra e as relações de gênero. Essa dimensão é debatida por coletivos negros no país, como a "Afrocubanas". Portanto, outra abordagem de relevância diz respeito às relações de gênero. No caso das mulheres negras, cabe destacar que sobre elas incide um marcador social que as colocam em situação duplamente diferenciada. Tanto gênero como raça são marcadores sociais que 
desfavorecem e dificultam a transformação e reconhecimento da mulher negra na promoção e no acesso aos direitos.

Ao descrever o conceito de gênero, Haraway (2004) considera importante entendê-lo como uma categoria capaz de organizar as relações sociais e também como uma estrutura de identidade individual e coletiva. O conceito de gênero desmistifica as diferenças sociais baseadas na visão biologicamente restrita do sexo. Tais diferenças, socialmente estabelecidas, apresentam reflexos das relações de poder entre homens e mulheres.

Pierre Bourdieu trata especificamente da dominação do masculino sobre o feminino em sua obra “A dominação Masculina” (2005). Para o autor, a dominação do homem sobre a mulher é exercida por meio de uma violência simbólica, compartilhada inconscientemente entre dominador e dominado, determinado pelos esquemas práticos do habitus.

\footnotetext{
[...] O efeito da dominação simbólica (seja ela de etnia, de gênero, de cultura, de língua etc) se exerce não na lógica pura das consciências cognoscentes, mas através dos esquemas de percepção, de avaliação e de ação que são constitutivos dos 'habitus' e que fundamentam, aquém das decisões da consciência e dos controles da vontade, uma relação de conhecimento profundamente obscura a ela mesma. Assim a lógica paradoxal da dominação masculina e da submissão feminina, que se pode dizer ser, ao mesmo tempo e sem contradição, espontânea e extorquida, só pode ser compreendida se nos mantivermos atentos aos efeitos duradouros que a ordem social exerce sobre as mulheres (e os homens), ou seja, às disposições espontaneamente harmonizadas com esta ordem que as impõem (BOURDIEU, 2005: 49/50).
}

Esse autor descreve a violência simbólica como um ato sutil, que oculta relações de poder que alcançam não apenas as relações entre os gêneros, mas, toda a estrutura social. Para o estudo de organizações afrocubanas, são considerados, também, estudos temáticos desenvolvidos sobre as lutas por reconhecimento das mulheres negras no mundo contemporâneo.

Tais estudos são fundamentais para a compreensão das organizações afrocubanas, por reconhecimento de direitos, na recuperação da auto-estima e da autonomia abalada pela reificação do lugar de subordinação racial e de gênero a que historicamente são submetidas as mulheres negras. No Brasil, por exemplo, essa perspectiva esteve fortemente presente no Movimento Negro Brasileiro, como relata Silva (2003: 17)

No Brasil, como resposta a um quadro de opressão específica vivenciado pelas mulheres negras, constituiu-se, a partir de meados da década de 1980, o Movimento de Mulheres Negras. Organizadas até aquele momento em instituições de homens e mulheres, nas quais, o mais das vezes, desempenhavam apenas tarefas de suporte, distantes dos processos de decisão política, as mulheres negras resolveram organizar-se em comissões para discutir e produzir alternativas para suas questões.

Em Cuba, esse debate vem num crescente. Muitas ativistas denunciam a invisibilidade das mulheres negras na sociedade de modo geral, como também dentro dos coletivos existentes, na 
produção acadêmica sobre a questão racial e na história e cultura afrocubana. Daysi Rubiera declara:

Reflexionando sobre a invisibilidad de las mujeres negras dentro de la invisibilidad general de las mujeres, pensé en lo imperativo de avivar la memoria histórica, para comenzar a llenar el vacío existente en la historia y en la sociedad cubana sobre su imagen, acción, subjetividad, pensamiento y valores. [...] Por otra parte, es cuestionar la sistemática ausencia que el discurso oficial nos ofrece, y el deliberado o no, olvido académico - salvo algunas excepciones. [...] Además, poner al descubierto la constante agresión a la cual ha sido sometida la mujer negra, acompañada de su lucha por el reconocimiento y aceptación de sus valores, que se mantienen en nuestra sociedad actual. (RUBIERA, 20I I: I I-I2).

Rubiera ressalta, ainda, a invisibilidade das mulheres negras, dentro do discurso antirracista e da pequena produção acadêmica sobre o tema racial:

Se hablaba mucho de discriminación racial pero cuando se hablaba de discriminación racial nada más se contemplaba al varón, lo englobaban siempre dentro de todo el proceso de los varones, comenzó el debate muy incipiente en aquel momento pero comenzó el debate por la cuestión racial en Cuba pero igual que en América Latina el debate era masculino, las mujeres siempre estábamos ocultas no aparecíamos aunque estuviéramos presentes y se me ocurrió hacer el libro de Afrocubanas. Dije que pensé que había que hacer un libro donde se hablara de mujeres negras, cual fue la contribución de la mujer negra a la historia en lo económico político y social de este país que no apareció y que con mencionar a Mariana Grajales, a Dominga Moncada, a María Cabrales madre y esposa de los grandes hombres negros que hubo en Cuba, aunque muchos de ellos bastante poco mencionados, con excepción de Antonio Maceo, había que hablar de las mujeres, con eso no bastaba y entonces se me ocurrió pedirle a un grupo de mujeres que ya había conocido profesionales casi todas, algunas que habían escrito, otras que no habían escrito nunca pero que tenían ideas podían hacer cosas que podían aportar y era una posibilidad de que las personas comenzaran a manifestarse, comenzaran a expresar por alguna vía lo que estaban sintiendo, lo que estaban viviendo, lo que la motivaba porque estaba a su alrededor y invite a muchas mujeres a participar conmigo en este proyecto que lógicamente no se llamaba Afrocubana era un proyecto donde vamos a hacer un libro donde vamos hablar de mujeres negras y mestizas de lo mismo que en la historia que en la filosofía que en la cultura y entonces a partir de ahí salió Afrocubanas historia, pensamiento y practica cultural, que aunque en Cuba y no tengo ningún ningún temor de decirlo, que aunque en Cuba no ha tenido el impacto que realmente debió de haber tenido ese libro porque ese es un libro fundacional, ese es un libro que marca una etapa en la historia de Cuba, marca un ciclo en las relaciones interraciales cubanas es un libro que por primera vez pone de manifiesto la historia de las mujeres negras, es un libro que se inserta en el debate por la problemática racial en Cuba. (Entrevista Daysi Rubiera, em 0I/08/2014).

Yulexis Almeida, outra integrante do coletivo Afrocubanas, reflete sobre o processo de articulação para o livro que dá nome ao coletivo e de como essa dinâmica possibilitou outras formas de mobilização além da publicação:

A mí me da gracia porque hay muchos investigadores prestigiosos que abordan el tema (racial) en el país, que cuando han escrito sus artículos han dicho: sería interesante explorar esto como se expresa en el caso de las mujeres negras. Pero, el caso queda para otra investigación, eso queda para otro momento, y al final es un tema de la gran postergación. Entonces, con este objetivo de visibilizarlo a la convocatoria de Daisy y de Lalita respondimos un grupo de mujeres, nos unimos para que cada una desde sus ámbitos de acción seguieramos juntas trabajando la temática racial. (Entrevista com Yulexis Almeida, realizada em I6/06/20I4).

Essa dinâmica de recontar as histórias das mulheres negras se reflete no processo de busca para melhor compreender como o racismo e o sexismo se expressam na atualidade. Parte dessa dinâmica de resgate gerou o aprofundamento do olhar sobre as próprias ativistas e sobre suas 
relações familiares. Um dos exemplos disso é a elaboração do livro "Sencillamente Reyta", de Daysi Rubiera, que narra a história de sua própria mãe. A proposta surge da reflexão sobre o lugar das mulheres negras na sociedade cubana, como relata Daysi na entrevista feita para essa pesquisa:

Yo empiezo a tomar conciencia en ese momento porque cuando ya yo estoy sentada delante todos esos documentos en el archivo y empiezo a mirar todas esas diferencias y empiezo a leer bibliografías relacionadas con el tema la bibliografía de Fernando Ortiz Los negros esclavos, Los negros brujos, el libro El barracón, el libro de Moreno Fraginal, de Chang etcétera, empiezo a entrar en la bibliografía relacionada con el tema entonces empiezo a darme cuenta de que hay un problema racial grave en nuestro país y hay que trabajar sobre eso [...] yo llegue a mi casa y empecé a hablar con mi mama de esto del problema de cómo las mujeres negras hemos sufrido, que diferente ha sido la vida de nosotras y en esa conversación surgió todo el testimonio de mi mama, de Reyita. (Entrevista com Daysi Rubiera, em 0I/08/2014).

Ademais dos coletivos que pautam a questão das mulheres negras contemporaneamente, houve uma das organizações sociais pioneiras no debate racial e de gênero, na década de I990, que após alguns anos de fundação foi desativada por recomendação do Partido Comunista de Cuba. Denominada Magín, essa organização foi muito importante para a ampliação do debate sobre o feminismo negro, apesar de não ser exclusivamente voltada para o tema racial. Irene aborda a importância da articulação Afrocubanas na atualidade e da ampliação do debate e da atuação sobre relações de gênero e raciais na organização criada anteriormente, que foi Magín:

Surge afrocubanas como un proyecto que Inés María Martiatu y Daysi Rubiera empreenden y me llaman a formar parte. El antecedente de esta decisión de ya involucrarme en un grupo de personas para trabajar sobre este tema estaba en haber sido gestora de un grupo de mujeres comunicadoras que empezaron aprender a tener una mirada de género hacia los problemas sociales (Magín). Para mí fue fundamental para poder llegar ahora a estos problemas de racialidad. (...) Al ser parte yo de las mujeres comunicadoras (Magín) y trabajar en la televisión me dió la base para el activismo, para mi participación, para el compromiso con lo que se está haciendo en Cuba ahora en contra de la discriminación. Esto no fue fácil porque este grupo lo formaban mujeres de todo tipo, desde el punto profesional desde el color de la piel y desde las clases sociales, estaba integrado por todas aquellas mujeres. (Entrevista com Irene Esther, realizada em 0I/07/20I5)

A experiência de Daysi, de como passa a conceber sua atuação de mulher negra, a partir de sua vivência nesse coletivo feminista, é interessante para demonstrar a importância desses processos coletivos como espaços formadores e de troca de experiências:

Mi libro (Reyita Sencillamente) tenía como un denominador, el hilo conductor el libro era la discriminación racial pero cuando llego a La Habana con mi manuscrito debajo del brazo ya terminado esa primera versión, tengo una antigua amiga que me invita a participar en una asociación a la que ella pertenece que es el grupo de Magín, del cual tú debes haber oído hablar, y me incorporo al grupo de Magín. En Magín me doy cuenta, después que paso un tiempo de estar en Magín me doy cuenta de que mi libro adolecía de una parte, yo estoy con un hilo conductor de una mujer pobre y negra pero no me doy cuenta que hay una discriminación de género, yo no sabía nada de género, aprendo todo esto en Magín y me doy cuenta que mi libro adolece de esto y es cuando apoyada por el colectivo me voy de nuevo para Santiago a hacerle nuevas preguntas a mi mama, nuevas entrevistas para darle al libro lo que le faltaba que era el enfoque de género y ya con el enfoque de género se abrió un nuevo horizonte, nueva perspectiva, me di cuenta que con la transversalizacion de esta categoría por las diferentes variables veía más clara toda la problemática racial y ahí estuvimos, yo fui una de las últimas personas que entro en Magín estuve aproximadamente dos años y pico en eso llego la desactivación pero ya estaba consciente de que había que seguir trabajando en esta dirección. (Entrevista com Daysi Rubiera, realizada em 0I/08/20I4). 
Outros livros que abordavam a história de mulheres negras, tal qual Reyita, foram publicados, como o que narra a trajetória de Georgina Herrera ${ }^{302}$, além da própria coletânea de artigos "Afrocubanas". As produções feitas e a mobilização para essa pauta fomentou iniciativas comunitárias, encontros e debates, além da articulação com outros coletivos antirracistas. Daysi Rubiera, uma das idealizadoras do Afrocubanas, comenta os primeiros passos para a mobilização em torno desse coletivo:

Lalita y yo analizamos bastante, discutimos bastante y creamos el grupo de Afrocubanas en el 20II. E1 grupo de Afrocubanas tenía como objetivo fundamental empoderar de saberes relacionados con la discriminación racial a la población que no tiene acceso a eventos, viajes de académicos, viajes profesionales, población que no lee mucho, tampoco porque el ritmo de la vida no se lo permite y si se lo permitía ahora ya no se lo permite porque el ritmo de la vida en Cuba es muy difícil, y la gente no tiene mucho tiempo de sentarse a leer. Entonces se creó ese grupo con esa intención. En principio, éramos unas pocas, empezamos a trabajar en esta dirección, no libre de contradicciones, de criterios y esas cosas y a raíz de que el grupo estaba más o menos consolidado, batallando por un espacio, que ese es otro de los grandes problemas, batallando por un espacio que nunca tuvimos que lo mismo nos reuníamos un día en mi casa que nos reuníamos en el patio interior de una casa comunitaria, donde vivía Inés María en la Habana Vieja. Afrocubana está ahí, trabajando algunas veces con más personas, otras veces con menos personas interesadas, pero estamos ahí tratando de aportar a esta lucha por la problemática racial en Cuba desde nuestra condición de profesional y como podamos. Por otro lado yo soy de la que considero que en Cuba no se va a resolver el problema de la discriminación racial por ahora pero que hay que poner a la gente a conocer, la gente tiene que saber qué es esto, la gente tiene que saber que es el racismo, que es lo que es la discriminación racial, cuales son las formas más sofisticadas que tiene el nuevo racismo en nuestro país, que no es en nuestro país sino en el mundo entero, pero estamos hablando de nuestro país, entonces por tanto esto nada más que se gana en la base, esto no se gana en los eventos donde siempre somos los mismos, (Entrevista Daysi Rubiera, em 0I/08/20I4)

A atividade mais rotineira desse coletivo são as tertúlias, realizadas com diferentes temas, sempre a partir do olhar crítico sobre as desigualdades e o racismo a partir da visão das mulheres negras, com periodicidade trimestral. $\mathrm{Na}$ pesquisa de campo, acompanhei algumas das tertúlias realizadas. Abaixo, um dos convites para a atividade da Afrocubanas:

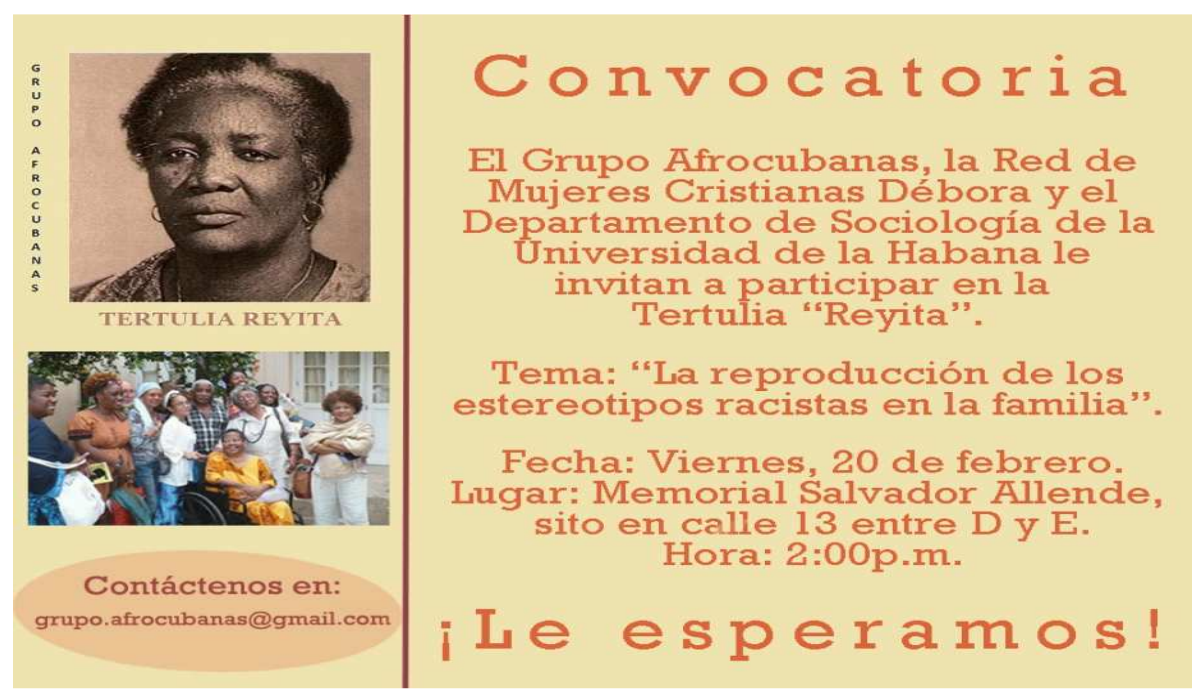

${ }^{302}$ Autoria de Daysi Rubiera e Georgina Herrera. 
Figura 36: Convite para a atividade promovida pelo coletivo Afrocubanas, referente ao debate sobre a reprodução dos estereótipos racistas na família, realizado no dia 20/02/2015, em Havana, Cuba.

Além das tertúlias, o coletivo organiza atividades em parceria com outros grupos antirracistas de Havana, como a Rede Barrial Afrodescendiente. Nessa articulação, realizaram diversos conversatórios, especialmente com as comunidades dos bairros de La Lisa e Pogoloti, sobre relações de gênero e relações raciais e sobre o legado da mulher negra na história e na cultura cubana.

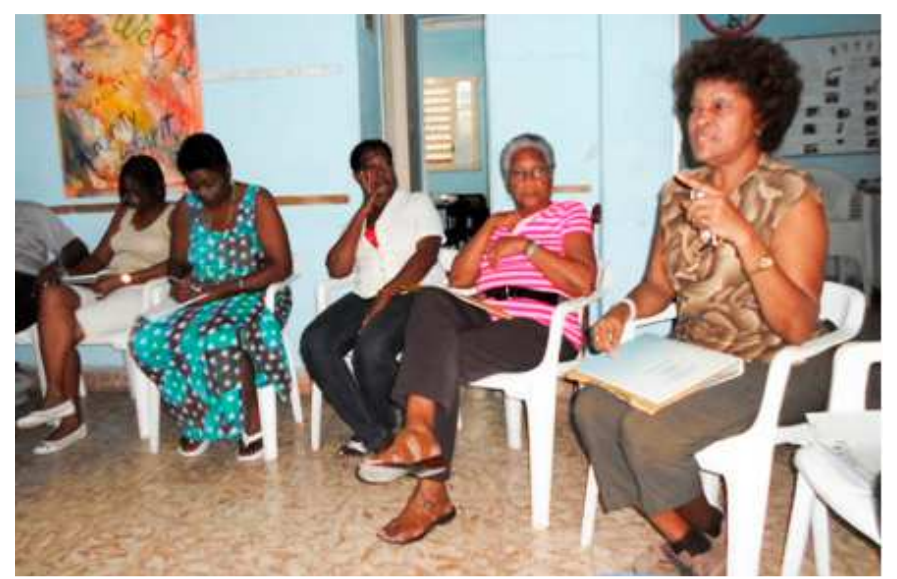

Figura 37: Atividade realizada em 20I4, parceria da Afrocubanas e da Red Barrial Afrodescendiente. Com Irene Esther, Daysi Rubiera, Maritza López. Foto: Acervo Afrocubanas.

\subsection{Red Barrial Afrodescendiente}

Todo eso (claramente) define la perfección de su prisa Su pánico perfecto a los barcos negreros

La aspereza del monte y la inconformidad de sus Orishas Ahora mismo, La Habana pregunta donde esconder su rostro Matutinos presagios amenazan la suerte del tacimetro Parques y mariposas hacen un sobresfuerzo de memoria Para saber qué fueron Pero nosotros (los amigos de Bárbara) Aguardaremos juntos entre el té y el hollin Seguiremos sus hilos hasta los quilombos Cuerno adentro, nubes, horizonte...

(Alfredo Sánchez Saavedra - Coletivo de Criação Trance Red Barrial Afrodescendiente, Havana, 20I4)

O primeiro contato com a Red Barrial Afrodescendiente foi estabelecido durante a aula do Diplomado que fiz na Universidade de Havana, no princípio do primeiro semestre de 2014. Em um dos dias da aula, as coordenadoras da Rede, Martiza López, Damayante Matos, Hidelilza Leal, apresentaram experiências de trabalho da rede nos bairros La Lisa e Pogoloti, em Havana. 
Após esse contato inicial, fiz uma primeira longa entrevista com Maritza López em sua casa, em La Lisa, que acabou se transformando em um amplo diálogo com sua família e outros participantes da Rede. Rolando Zulueta, historiador, entrou na conversa e abordou detalhes sobre a história e o debate racial no Brasil até hoje pouco conhecidos, como o discurso de Jango sobre o tema, nos anos I960. Moraima relatou um pouco de sua atuação no partido comunista e como o tema racial teve reflexos em sua atuação. Conheci, também, Margarita Montalvo, uma das integrantes do Projeto Muñeca Negra, que passava por ali e se incorporou à conversa.

Essa entrevista, e as várias outras que ocorreram na pesquisa, em um dos bairros onde a Rede atua, possibilitou me integrar um pouco na dinâmica da articulação que cotidianamente é feita. As caminhadas, o cafezinho junto, as visitas, são práticas que estão incorporadas à teia de projetos, coletivos e iniciativas da Rede Afrodescendente. Ademais do projeto Muñeca Negra, outros coletivos também se articulam com a rede, como o grupo de artistas Trance.

Parte das ações realizadas pela Rede, em parceria com outros coletivos, é vinculada à comunidade do bairro de La Lisa. Muitas dessas atividades enfocam tradições santeiras e paleras ${ }^{303}$. Uma das comunidades do bairro, La Ceiba, é importante na mobilização para diversas atividades da Rede, além de se constituir como referência para as tradições de matriz africana. Uma das atividades coletivas de maior vulto, organizada pela Rede Barrial Afrodescendiente em parceria com outros coletivos, é feita ao redor da Ceiba, que para as tradições africanas é sagrada. Muitos atribuem isso à sua semelhança com o Baobá africano.

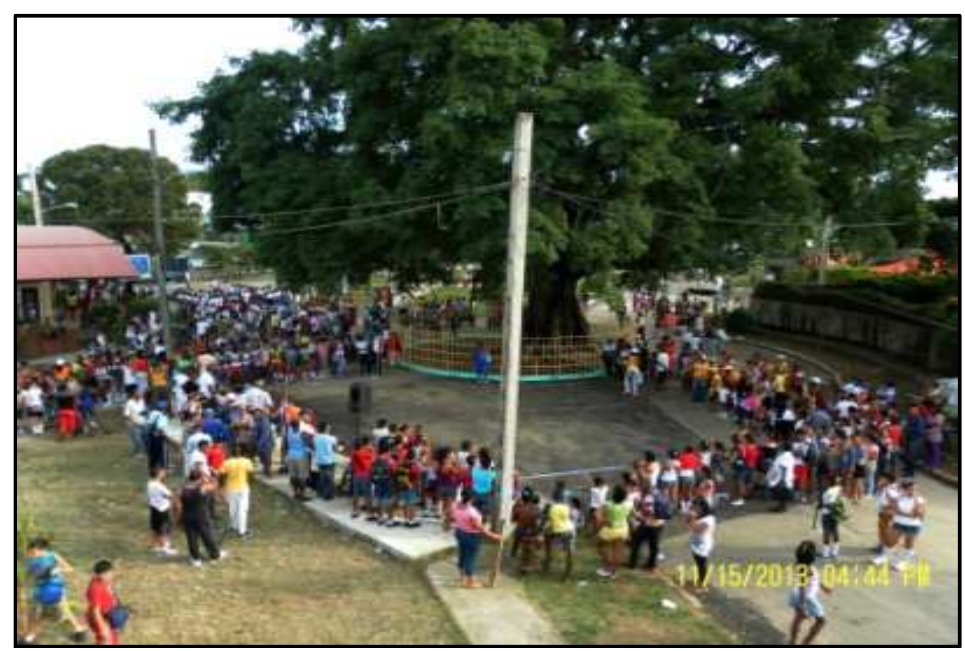

Figura 38: La Ceiba de Balcón Arimao, "La Gala Cultural", I5/I I/20I3. Foto: Acervo Red Barrial Afrodescendiente

${ }^{303}$ Há muitas casas e uma forte tradição de Santeria e Palo Monte na comunidade La Ceiba, em La Lisa, Havana. 
Dentre as várias interações que tive ao longo da pesquisa entre 2014 e 2015 com a comunidade de La Ceiba e com a Red Barrial Afrodescendiente, estão debates, oficinas realizadas, atividades comunitárias e visitas periódicas feitas. Dentre as atividades, destaco a oficina de Cartografia Social, realizada junto à comunidade de La Ceiba, uma das localidades que têm grande atuação da Rede.

$\mathrm{Na}$ oficina de Cartografia Social realizada na comunidade de La Ceiba, nos dias 29 e 30 de novembro de 2015, o vínculo com a árvore para a comunidade se mostrou central. É sintomático como o debate sobre as relações raciais e de gênero são incorporados nas atividades cotidianas da Rede, e dialogam com as tradições afrocubanas fortemente presentes. Nessa atividade da cartografia, participei da coordenação, juntamente com outros pesquisadores da própria comunidade, da Casa Comunitária Paulo Freire, da Rede Barrial Afrodescendiente, do Instituto Juan Marinello e do Projeto Nova Cartografia Social ${ }^{304}$.
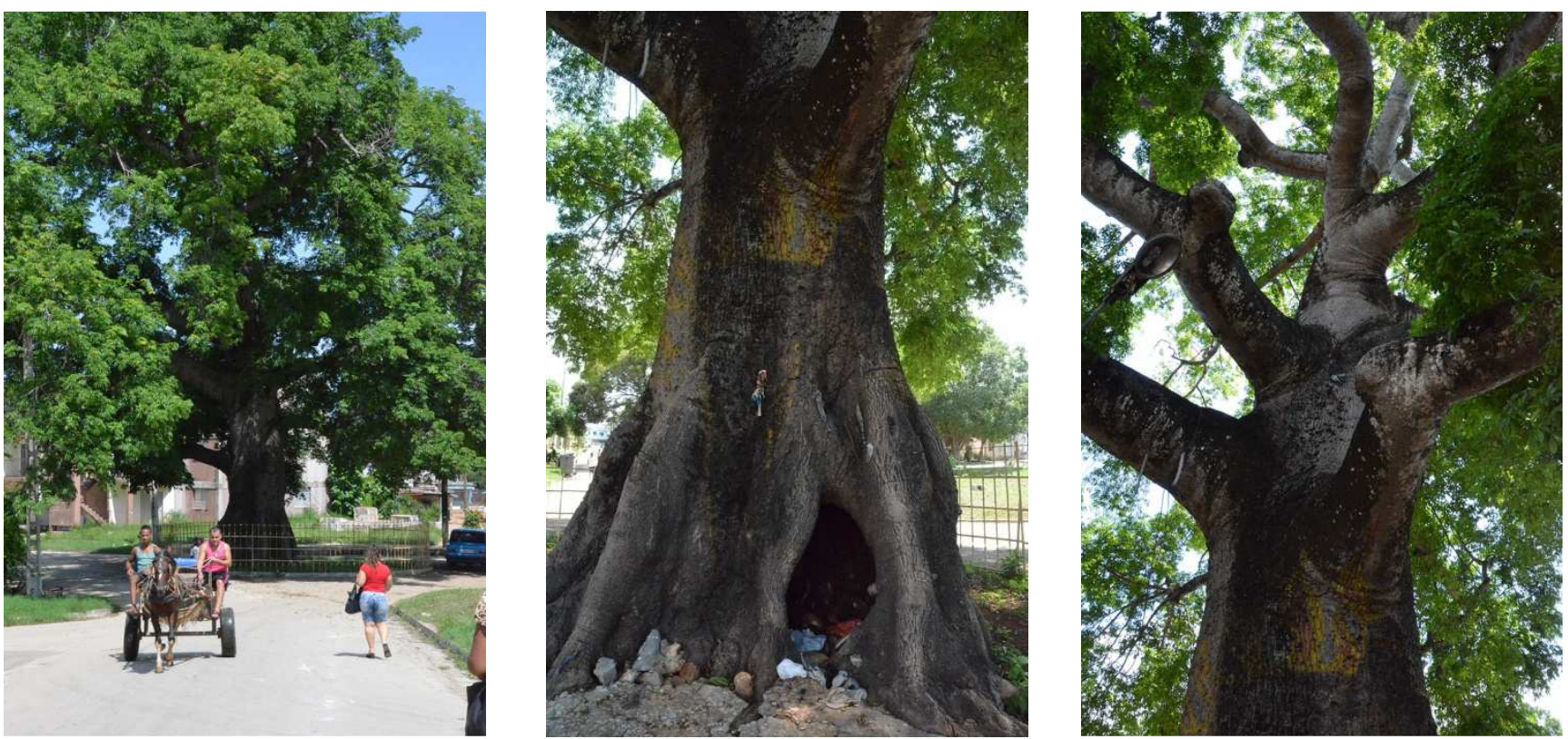

Figura 39: Iroko, ou Ceiba, da comunidade de La Ceiba, situada em Balcón Arimao, La Lisa, Havana, 20I5. Em seu oco, são depositadas as oferendas aos orixás. Foto: Bárbara Oliveira.

A Red Barrial Afrodescendiente estabelece articulação com várias localidades de Havana, como Balcón Arimao, La Ceiba, Pogoloti, Alamar (Playa), Buena Vista, Jesus Maria, Párraga, Los Ángeles. Durante o percurso da pesquisa, além das atividades em La Ceiba, acompanhei outras organizadas pela Rede em bairros como Jesus Maria e Pogoloti. Essas atividades envolveram, majoritariamente, atores sociais das próprias comunidades. Abaixo, disponibilizo foto de uma das atividades realizadas: uma oficina de cinco dias sobre discriminações, que abarcava a dimensão

304 Mais informações: http://novacartografiasocial.com/significados-de-iroko-para-la-comunidad-la-ceiba-debalcon-arimao-la-habana-cuba/ 
racial, de gênero, orientação sexual, de pessoas com deficiência, e suas respectivas bases legais, tanto nacionais como internacionais.

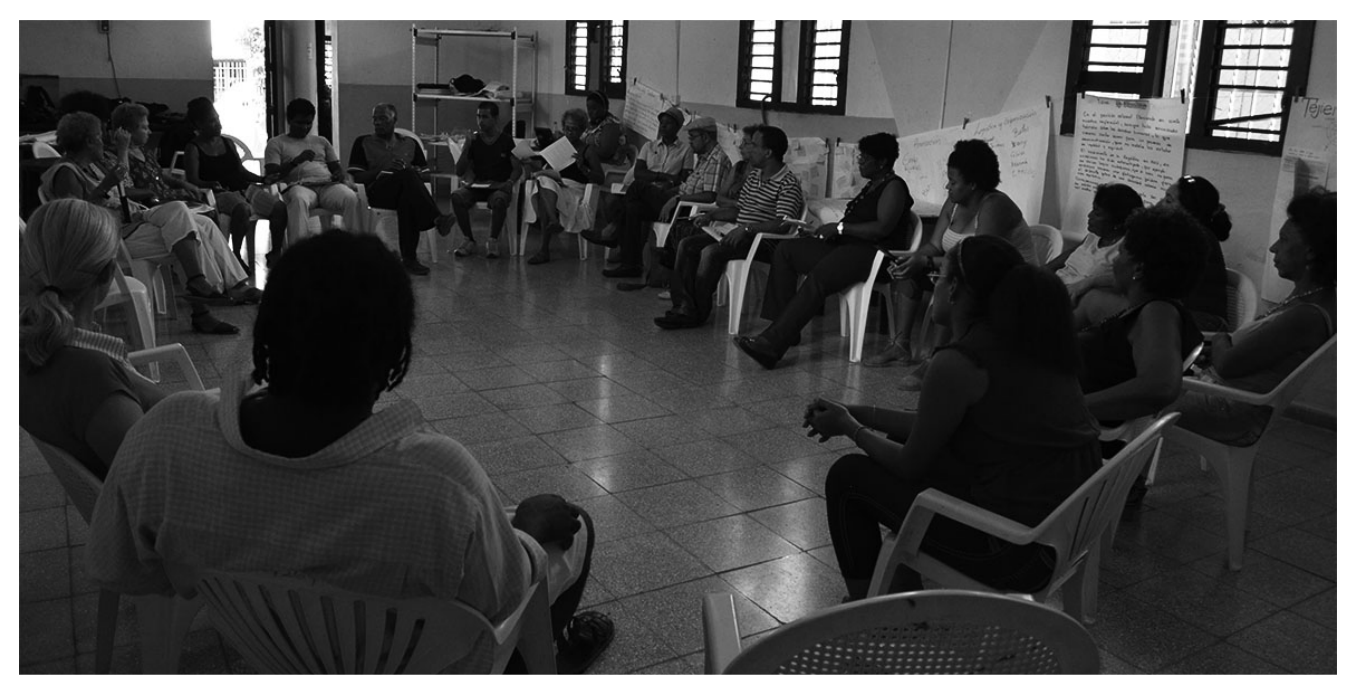

Figura 40: Oficina realizada pela Red Barrial Afrodescendiente, no bairro Pogoloti, em Havana, de I5 a 19/09/2014, sobre Discriminações e Direitos. Foto: Bárbara Oliveira

A Red Barrial, na atualidade, desempenha um papel importante não apenas na articulação de suas comunidades locais. Também promoveu espaços de diálogo e avaliação, que reuniu diversos coletivos antirracistas e ativistas com atuação em Havana. Com o objetivo de fazer uma avaliação dos avanços e desafios na luta antirracista e pensar possibilidades, a Rede promoveu um encontro no dia I5/08/20I4 um debate aberto sobre o tema.

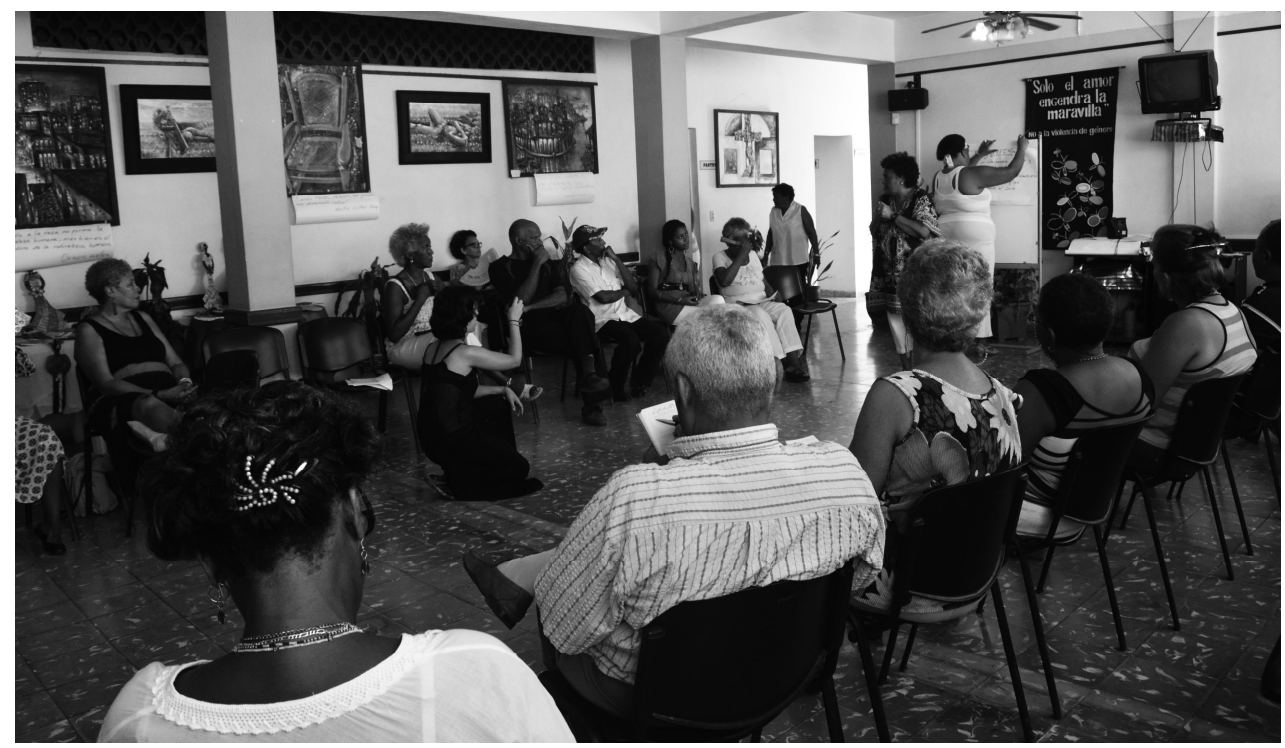

Figura 4I: Oficina de Avaliação, realizada junto a representantes de diversos coletivos antirracistas, em I5/08/20I4, Havana, Cuba. Foto: Bárbara Oliveira. 
A coordenação da Red Barrial Afrodescendiente, bem como muitos colaboradores e integrantes, são educadoras e educadores populares. Assim, várias das articulações envolvem também a rede de educadores populares. Maritza López, além atuar na Rede, é coordenadora da Casa Comunitária Paulo Freire, situada em La Lisa, cujo nome foi dado em homenagem ao pedagogo brasileiro que é uma grande referência da educação popular.

Foi por meio dessas articulações estabelecidas entre a Red Barrial Afrodescendiente e alguns educadores populares de outras cidades de Cuba que conheci, no final do primeiro semestre de 20I4, o bairro La Marina, em Matanzas. E nesse bairro, pude me aproximar do universo de atuação de outro ativista que dialoguei bastante nesse trabalho, Kimbo.

Outros encontros foram possíveis por meio de minha participação em atividades da Rede Barrial Afrodescendiente. Essa Rede, cotidianamente, atua em conjunto com outras iniciativas locais que enfocam a luta antirracista por meio de linguagens vinculadas à arte e às tradições de matriz africana. Um desses projetos chama-se Muñeca Negra, que alia o trabalho com papel marché ao legado das mulheres negras e das tradições da santeria.

Com Margarida, coordenadora do Projeto, dialoguei sobre o encontro de dois mundos. Levei de presente para o projeto uma boneca da comunidade quilombola de Conceição das Crioulas (Pernambuco - Brasil). A boneca se chama Francisca e representa a matriarca fundadora do quilombo. Francisca, também, é um dos nomes dados às bonecas que simbolizam, na santeria cubana, a proteção dada pelos orixás. É guardada nas residências dos que são vinculados às tradições afrocubanas. 


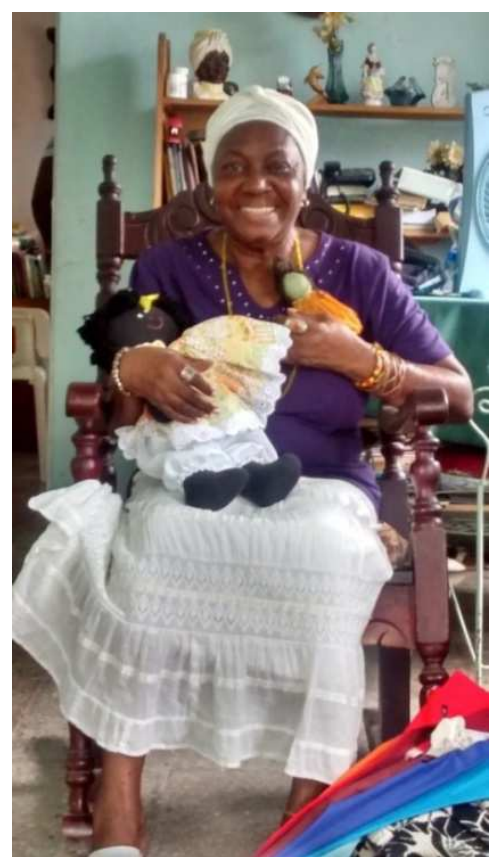

Figura 42: Margarita, do projeto Muñeca Negra, com a boneca "Francisca" do quilombo de Conceição das Crioulas (Brasil), 2015. Foto: Bárbara Oliveira

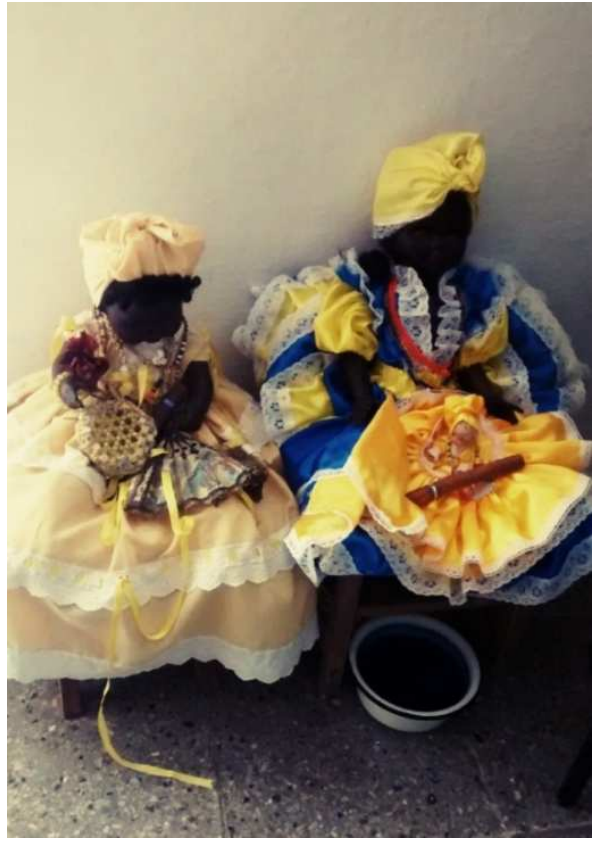

Figura 43: Boneca Francisca, da casa de Margarita, do Projeto Muñeca Negra, La Lisa, Havana, 2015. Foto: Bárbara Oliveira

Apenas após esse diálogo, compreendi o papel que desempenha as várias bonecas que eu já havia visto na casa de muitos dos ativistas e amigos com os quais tive relação em Cuba. A boneca Francisca, que representa um orixá, traz proteção. Os bonecos podem simbolizar, também, os Jimaguas, os Ybeyes. As possíveis conexões das "Franciscas" do quilombo brasileiro com as "Franciscas" da santeria cubana nos ensejou muitas reflexões.

Nesse contexto, outro projeto coletivo, articulado com a Rede, é o Coletivo de Criação Artística Trance, que realiza diversas interações artísticas, educacionais e participativas na comunidade La Ceiba, em La Lisa, relacionadas com as tradições de matriz africana e com a luta contra a discriminação. O poema que abre o capítulo foi escrito por Alfredo Saavedra, integrante do coletivo Trance, e presenteado a mim durante a pesquisa. A conexão entre os navios negreiros, os quilombos e a resistência negra dá um tom amplificado aos possíveis olhares sobre a Diáspora Africana. O coletivo Trance reúne um grupo de artistas e comunitários na pauta identitária da comunidade, a partir de diversas linguagens, como a poesia, artes plásticas, música e artes marciais, como a Aiki Ram Jutsu. A coordenação desse projeto é de Beatriz García Machado, Esther García Calderín e Alfredo Sánchez Saavedra.

Como os demais coletivos, a Red Barrial Afrodescendente, contra o racismo e a discriminação racial, é uma organização da "sociedade civil reconhecida" também não legalizada, que possui limitações estruturais em sua organização, como a falta de equipamentos, de sede, e de materiais 
básicos como papeis. A centralidade de sua ação, contudo, reside no processo de mobilização de comunidades situadas em bairros considerados "marginais". A Rede toca a Havana profunda, como destaca Zurbano (20I5), e promove a reverberação do debate antirracista em esferas locais, ampliando essa atuação para além dos espaços acadêmicos e de promoção cultural do centro da cidade.

\subsection{Identidad y Barrio La Marina}

La Marina entra no universo dessa pesquisa por meio das redes que são estabelecidas entre os ativistas, que superam os limites de Havana. Apesar da pesquisa ter maior foco na capital, foi interessante ampliar os horizontes a partir das redes existentes entre os próprios coletivos. Maritza López, da Rede Barrial Afrodescendiente sugeriu minha ida até Matanzas, situada a cerca de $90 \mathrm{Km}$ de Havana, para conhecer um bairro com forte tradição afrocubana e mobilizações coletivas por direitos. Lá, ela indicou que procurássemos Kimbo, uma das principais lideranças do lugar.

Essa primeira viagem eu fiz juntamente com Irene Ruiz, que além de ter uma relação de proximidade comigo, também é ativista na ARAAC e Afrocubanas. Ao chegarmos na cidade, caminhando pelos casarões antigos do centro, cuja parte foi construída no século XVIII e XIX, deparamos com um bairro também com casas seculares, sendo uma grande parte delas em péssimas condições de conservação e outras com alterações de suas fachadas, que mesclavam tijolos de concreto moderno com desenhos coloniais seculares.

A casa de Kimbo foi fácil de localizar, pois, ao perguntar aos comunitários, todos conheciam e foram nos guiando pelo bairro. Eu e Irene entramos, então, em um corredor muito estreito, passamos pelas casas de várias famílias. Quase no final dessa passagem, surge a casa de Kimbo. Ele nos esperava sem camisa, com ar desconfiado, em frente a um grande boneco de couro, feito por ele, dependurado na parede, que representava Xangô.

A primeira conversa, logo virou a primeira das entrevistas que fiz no bairro La Marina. Mas, antes do início, Kimbo já avisou que só estava me recebendo, porque eu vinha indicada por uma pessoa muito importante para ele, Maritza López, pois ele estava cansado de "pesquisadores que aparecem e somem sem deixar vestígio". Desse primeiro encontro, até esse momento da escrita, foram inúmeros os contatos e atividades que participei com eles. Mas, esse primeiro encontro 
marcou muito a interação e avivou o peso das articulações entre os ativistas, como Kimbo e Maritza.

Kimbo, como Martiza, é educador popular. Conheceram-se quando estavam desenvolvendo um projeto no bairro La Marina denominado "Projeto Sócio-Cultural", que tinha como objetivo promover um "movimento de transformação de vizinhança" (Daniel, 2007: 130 apud BRASIL, 2015), através do envolvimento de várias instituições locais, principalmente governamentais, com líderes comunitários, a fim de resolver os problemas do bairro em relação à valorização das atividades de cultura, esporte e lazer, alternativas econômicas, e melhoria das condições de moradia e de outros locais comunitários do bairro. Kimbo inicia sua atuação nesse projeto em 2001 .

Esse projeto, como ressalta Brasil (2015), explicitou a situação de vulnerabilidade vivida pelo próprio Kimbo, que era até então "jinetero" ${ }^{305}$, com histórico de conflito com a lei, sem moradia adequada. Ao passar a interagir com questões vinculadas a sua comunidade, suscitou sua percepção sobre a forma como a cidade percebia o próprio bairro majoritariamente negro, sua cultura e tradições, e como esses aspectos incidiam em suas vivencias pessoais.

Nessa dinâmica, os intercâmbios entre Kimbo e a Red Barrial Afrodescendente foram intensos no sentido de explicitar relações raciais violentas vividas, que eram naturalizadas, em alguma medida, nas relações estabelecidas por ele e por sua comunidade. Em minha primeira entrevista, realizada em abril de 2014, Kimbo e diversos outros comunitários estavam já afastados de iniciativas vinculadas ao bairro, promovidas pelo projeto Sociocultural ${ }^{306}$, uma vez que ocorreram, de acordo com as narrativas, desdobramentos, a partir das decisões do diretório do Partido e do Poder Popular, para definir, de forma arbitrária e sem diálogo local, a forma de gestão comunitária.

Poucos meses depois, em agosto de 20I4, surge a proposta dos comunitários de dar sequência à mobilização do bairro em uma iniciativa que envolveu parte dessas lideranças locais. Surge, então, o projeto Identidad y Barrio La Marina, coordenado por integrantes do bairro. Eu, Daniel Brasil, Rolando Zulueta e Maritza López ${ }^{307}$ fomos incorporados ao projeto como colaboradores. O primeiro nome da proposta seria Agbara Dudu, que em Yorubá significa "Força Negra", dada a forte presença da cultura de matriz africana nessa comunidade. Contudo, o grupo gestor do

305 Esse adjetivo quando usado para mulheres refere-se à prostituição. Para homens, relaciona-se a atividades vinculadas ao comércio ilegal de charutos, rum e outros itens para turistas.

${ }^{306}$ Projeto promovido no bairro pela Diretoria de Cultura, Poder Popular e Centro Memorial Martin Luther, de I 997 a 2009, que enfocou mobilização comunitária e melhoria das casas e praças.

${ }^{307}$ Daniel Brasil realizou seu trabalho de campo sobre o bairro La Marina e Maritza López e Rolando Zulueta são da Rede Barrial Afrodescendiente. 
projeto achou prudente não explicitar esse nome num primeiro momento, para não causar um rebuliço junto aos poderes locais. A coordenação do projeto é composta por Raúl Dominguez Valdez (Kimbo), Milagros Valdés Portillo, Lisandra Rodrigues Valdés Rodriguez, Diana Rosa de Almas Valdés, Maria Regla Márquez Drake, Yudania García Alberja, Berta Rosa Vento de Armas e Jesús B. Toledo Terón.

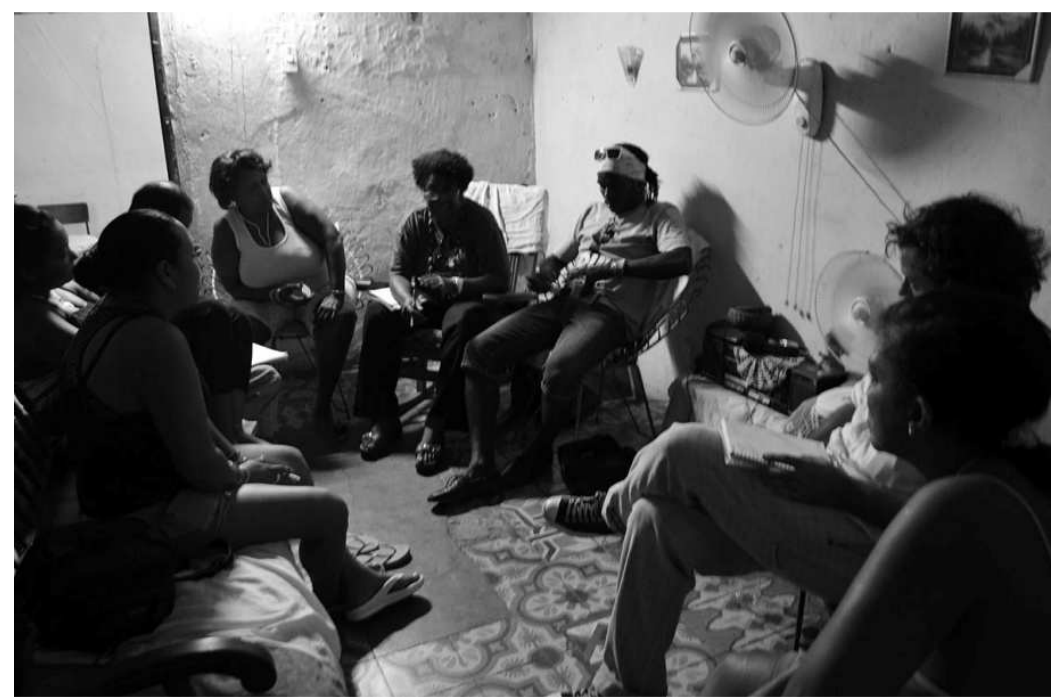

Figura 44: Reunião do grupo gestor do Projeto Identidad y Barrio La Marina, realizada em I7/10/2014, na casa de Milagro, bairro La Marina, Matanzas, Cuba. Foto: Bárbara Oliveira

O projeto tem como objetivo levantar a história do bairro, seu legado, especialmente vinculado às tradições de matriz africana, como a Santeria, o Palo Monte, a cultura Abacuá, a Rumba, os festejos coletivos, como a queima do boneco de San Juan (que representa Ogun), a comparsa de Imaliana, que sai no carnaval.

O foco de mobilização do bairro está vinculado às suas tradições culturais. $\mathrm{O}$ debate antirracista é estimulado especialmente por Kimbo e pelas articulações que ele estabelece com a Red Barrial Afrodescendente. As reflexões sobre as relações raciais, sobre o racismo, não são explicitamente dadas, mas permeiam muitas das discussões, conversas e atividades realizadas pelo projeto. Esse coletivo tem um perfil diferenciado em relação aos demais, exatamente por essa característica de abordar o debate antirracista como um elemento dentre as atividades culturais e tradicionais realizadas. Nos demais coletivos que acompanhei durante a pesquisa, o foco para a luta antirracista e para o debate racial era o central da ação. 


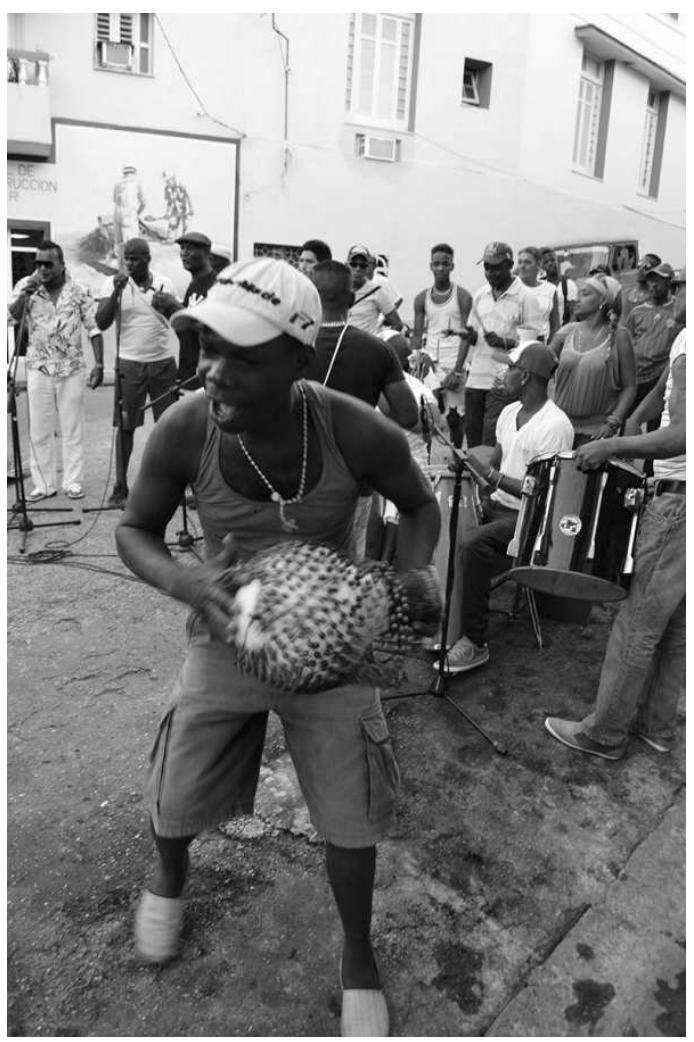

Figura 45: Espetáculo de rumba, tocado por Rumba Timba, no bairro La Marina, em agosto de 2014. Foto: Bárbara Oliveira

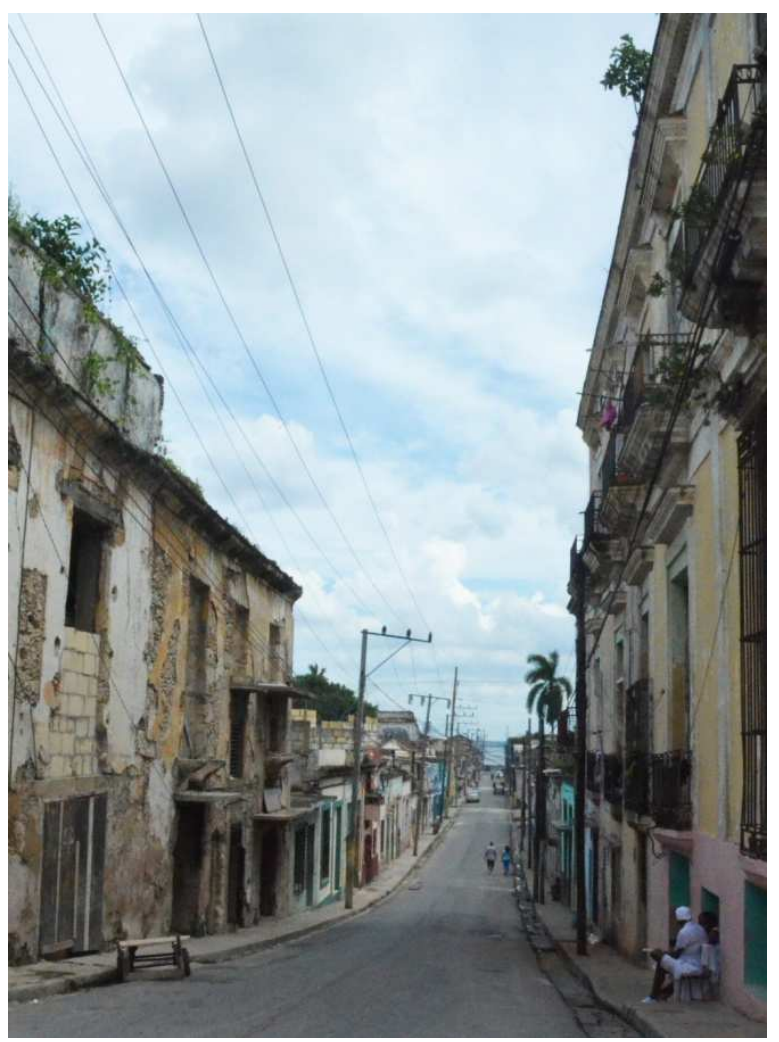

Figura 46: Entrada do bairro La Marina e a presença de duas Iyabos.

Foto: Bárbara Oliveira

Em La Marina, como na comunidade de La Ceiba, realizamos, durante o período da pesquisa de campo, oficinas de Cartografia Social, que envolveram grande grupo de comunitários, e permearam a entrevistas de referências do bairro, como santeiros importantes, músicos de rumba, idosos importantes, crianças e jovens. Nessa atividade da cartografia, participei da coordenação, juntamente com outros pesquisadores da própria comunidade do Projeto Identidad e Barrio La Marina, do Instituto Juan Marinello e do Projeto Nova Cartografia Social ${ }^{308}$.

Nesse capítulo, busquei fazer um debate sobre as formas de organização, estratégias e articulações das mobilizações afrocubanas, tomando como referência as vivências de ativistas e coletivos negros ao longo da história de Cuba. Mesmo após a Revolução de 1959, período em que houve uma abrupta queda das mobilizações afrodescendentes e do debate sobre a questão racial e o racismo, como discutido nos capítulos 3 e 4, vozes dissonantes, como Waltério Carbonel, Elvira

\footnotetext{
${ }^{308}$ Mais informações: http://novacartografiasocial.com
} 
Cevera e Carlos Moore, entraram em cena e ocuparam um importante espaço ao trazer à tona reflexões sobre o tema, em meio ao silêncio na sociedade.

A crise advinda da queda do Bloco Socialista gerou intensas mudanças sociais e econômicas na sociedade cubana. Como abordei na análise dos dados sociais, nas vivências de ativistas e pesquisadores/as, e em fatos ocorridos, a forma como essas alterações foram sentidas revelou-se diferente entre os vários segmentos da população, sendo os afrocubanos um dos mais vulneráveis nesse processo. Esse quadro mais frágil parte de uma construção histórica, com reificações no presente.

Foi nesse cenário que Cuba vivenciou um ressurgir de mobilizações afrocubanas, que se expressam em uma variedade de linguagens. As experiências sintetizadas na seção "Andanças do movimento afrocubano" e as descrições dos demais coletivos feitas posteriormente, objetivou dar maior concretude de como essa miríade de organizações, projetos e coletivos se organizam e se articulam, afastando a concepção de movimento organizado a partir de uma centralidade orientadora. Essa é uma característica relevante entre as organizações que denominei como "sociedade civil reconhecida", como também o são os coletivos vinculados à "sociedade civil dissidente", em oposição às organizações de base da Revolução, cuja atuação é mais verticalizada.

As mobilizações antirracistas apresentam similitudes e diálogos de suas pautas, ao mesmo tempo em que delineam formas diversas de organização, foco e narrativa, conforme analisado no capítulo 4. Com base nas reflexões feitas ao longo da pesquisa, destaco a relevância nas lutas afrocubanas de desconstruir os ícones que invisibilizam o legado negro e as desigualdades étnicorraciais. O ideal da nação cubana, da igualdade, o mito da mestiçagem fundamentam barreiras sociais para manter a limitação no reconhecimento do racismo e na necessidade de políticas voltadas para a promoção da igualdade racial. A estratégia de denunciar, desconstruir e reposicionar esses aspectos ideológicos fundantes, ainda difusos nas narrativas de muitos agentes sociais com os quais dialoguei, são desafios colocados. A batalha por resultados mais palpáveis da superação do racismo envolve a necessária denúncia à iniquidade de poder, material e do status quo, e a proposição por rumos mais inclusivos e diversos ${ }^{309}$.

A possibilidade de imersão nesse universo foi rica para compreender formas de organização da luta antirracista em um contexto tão particular quanto o de Cuba. Essa imersão e as interações existentes me levaram a casas, atividades coletivas, conversas e sentimentos vinculados às relações

\footnotetext{
${ }^{309}$ Análises influenciadas por diálogo feito com Ari Lima, durante a banca de doutorado, em dezembro de 2015.
} 
raciais. Durante a pesquisa de campo, por vezes, minha sensação estava na dança entre a ideologia que permeia o sentir da "Revolução" e a construção da igualdade, com dinâmicas identitárias e comunitárias diversas, entremeadas por seus conflitos cotidianos. As experiências, muitas delas compartilhadas nessa tese, hoje compõem os olhares que tenho sobre as dinâmicas que em Cuba, e no conjunto mais amplo como do Brasil, nos fazem sentir parte do contexto diaspórico africano. 


\section{Considerações Finais}

As duas maneiras de perder-se são: por segregação, sendo enquadrado na particularidade, ou por diluição no universal

Aimé Cesaire

As perguntas fundamentais que nortearam essa tese foram: Qual é o contexto atual da luta contra o racismo no país? Como são constituídas as percepções sociais com relação às identidades raciais? Há um movimento antirracista em Cuba? Como se organizam as mobilizações sociais para esse tema? Quais são seus enredos, relações, representações, construções e desconstruções?

As mobilizações coletivas voltadas para as relações raciais e a luta antirracista no agitado contexto cubano contemporâneo são conformadas por um conjunto de organizações e agentes sociais que reconhecem a necessidade de atuar e produzir conteúdos como ferramenta contra a opressão racial, bem como para o exercício de identidades coletivas. A partir da pesquisa, concluo que há um movimento afrocubano que atualmente se apresenta em uma diversidade de iniciativas, projetos e coletivos.

Observa-se um crescimento da mobilização e do discurso que contrapõe a narrativa de que a Revolução solucionou o racismo no país, em comparação com décadas anteriores. Contudo, há uma limitada abrangência dessa narrativa contra-hegemônica, especialmente na grande mídia, e certa fragilidade de articulação e organização desses coletivos afrocubanos. Outro aspecto relevante, como as narrativas de ativistas destacam, é o mito da unidade como meta, criado em torno da expectativa de que haja uma união nas mobilizações e ações coletivas antirracistas. Mas, na atualidade é exatamente a multifocalidade e a multivocalidade que melhor situam essas mobilizações, em uma variedade de iniciativas.

Faço, na pesquisa, uma leitura crítica dos conceitos de sociedade civil e movimento social e ressalto a complexidade de se aplicar na pesquisa social modelos fechados, especialmente para o caso cubano. Os limites que separam o Estado, mercado e sociedade civil são confusos, e, no caso cubano, dificultam a leitura a partir de concepções como a defendida por Cohen (200I), que fragmenta essas três esferas.

Sem perder de vista essa complexidade, há formas particulares de organização social que são compreendidas em Cuba como iniciativas da sociedade civil. Nesse conjunto, teço três grandes diferenciações: (I) "Sociedade civil oficial", conformada pelas organizações de base da Revolução 
cuja relação é marcada pela atuação estreita tanto com a sociedade política, especificamente o Partido Comunista, como com o Estado; (2) "Sociedade civil reconhecida", composta por ativistas que se denominam defensores da Revolução, mas são críticos à situação de exclusão e desigualdade racial que vivenciam os negros e negras em Cuba; e (3) "Sociedade civil dissidente", integrada por coletivos que apresentam uma oposição sistêmica ao regime socialista, além da crítica sobre o racismo.

A ênfase de meu estudo permeou os coletivos do conjunto que denomino "Sociedade civil reconhecida", pelo fato desses terem como a base de sua organização a luta antirracista. Em segundo lugar, privilegiei o conjunto da "Sociedade civil dissidente". De acordo com os dados levantados pela pesquisa, nenhuma das organizações da "Sociedade civil oficial" possui uma atuação sistemática com a questão racial e o combate ao racismo.

A análise sobre as mobilizações antirracistas contemporâneas e sobre as relações raciais é feita, também, com base na reflexão sobre quatro grandes períodos das lutas afrodescendentes em Cuba e seus vínculos com cenários mais amplos da América Latina. São eles: (I) as lutas abolicionistas e independentistas, especialmente na passagem do século XIX para o XX; (2) as organizações sociais e políticas negras nas nascentes repúblicas latinoamericanas, que nas primeiras décadas do século XX imprimiram uma forma própria de organização; (3) o processo de institucionalização dos movimentos negros na América Latina, a influência do movimento pelos Direitos Civis nos EUA, e o reflexo dessa dinâmica nas novas Constituições; e, por fim, (4) o processo mais recente desencadeado pela Conferência Mundial de Durban (200I) e pelas articulações crescentes sobre o tema racial entre os países (Estados nacionais e sociedade civil).

A abordagem que fiz privilegiou as narrativas de ativistas sobre fatos históricos e como esses são incorporados nas suas estratégias discursivas e passam a constituir eventos "epitomizantes" (Raymond FOGELSON apud FURNISS I998: I8) da luta antirracista. Esses eventos são epitomizantes $^{310}$, pois, a partir da complexidade dos processos históricos, dá-se ênfase a determinados eventos que marcam a construção dessa narrativa sobre as mobilizações afrocubanas. A formação do Partido Independientes de Color, e seu respectivo massacre em 19I2, a Rebelião de Aponte, em I8I2, as Minervas (na passagem do século XIX para o XX), as sociedades negras, são alguns dos exemplos da construção desses eventos epitomizantes nas narrativas antirracistas, que buscam apresentar elementos distintos em contraponto à historiografia oficial para a construção de outras referências. 
Cuba vivenciou dinâmicas muito particulares em relação ao tema, em comparação com demais países da região. Sua história tem significativa reverberação nas quase seis décadas de Revolução. Décadas de busca pela superação das desigualdades materiais que possibilitaram diversos avanços inclusivos para a população negra em Cuba, como o grande número de profissionais afrodescendentes qualificados. Todavia, as engrenagens do racismo são muito profundas e se mostram de forma estrutural nos espaços de poder, na mídia, na educação, nas instâncias judiciais e de segurança pública, no mercado de trabalho, nas relações sociais cotidianas.

O país vive, presentemente, uma mudança estrutural, mas por uma via não violenta. Diferentemente do vivenciado na Revolução de 1959, nas batalhas pela independência, nos vários golpes militares das primeiras décadas do século XX, o processo atual se expressa sem conflitos explicitamente dados. Um dos pontos mais relevantes são os diálogos e negociações crescentes com os Estados Unidos. Ainda que seja um alvo de tensão, não se trata de um conflito armado. Contudo, é perceptível a apreensão daqueles que vivenciaram por décadas o processo revolucionário, mas ainda desconhecem o que está em pauta nas reuniões bilaterais, exatamente pela não discussão ampla desse tema nos bairros, nas comunidades, nos meios de comunicação ${ }^{311}$.

Nessas transformações aceleradas, o fosso de desigualdade no país vem se amplificando, com maior prejuízo para a população negra. Estudos destacam que a parcela que sofreu os maiores impactos nesse processo foi a população negra (MORALES 20I2; ZURBANO, 20I5; ROBAINA, 20I2; ROMAY, 2012; PRIETO, 2006, 2015; ALMEIDA, 2015; RODRIGUEZ RUIZ, 20I5), minoritária nos espaços turísticos e na economia emergente. Os poucos dados quantitativos disponíveis apontam para uma maior concentração dos negros entre os que vivem em condições de moradia precárias e empregos mal remunerados e não especializados (PRIETO, 20I5), como vendedores de frutas em carinhos e bicicletas pela cidade.

As medidas emergenciais tomadas pelo Estado cubano no princípio da crise gerada pela queda do bloco socialista foram sentidas de forma desigual pelos diferentes segmentos da população. Como afirma Morales (2012), o impacto sobre os negros foi severo, exatamente por se configurarem como uma parcela mais vulnerabilizada da população. Contudo, medidas reparatórias ou políticas direcionadas não vêm sendo tomadas pelo Estado cubano de forma satisfatória, ao longo de mais de duas décadas, potencializando esse lócus de exclusão afrodescendente.

\footnotetext{
${ }^{311}$ Desde 17 de dezembro de 20I4, quando os presidentes Raul Castro e Barack Obama anunciaram medidas de aproximação, as modificações são latentes. Um dos exemplos são os turistas estadunidenses que superlotam cada vez mais os pontos turísticos cubanos. Contudo, não há um debate amplo sobre as negociações em curso.
} 
A busca focada na superação das desigualdades materiais foi insuficiente para a luta contra o racismo. Além dos estudos e dados que apontam a iniquidade crescente, destaco as inúmeras denúncias de ativistas sobre a não resposta da justiça aos casos de discriminação, sobre o racismo institucional existente na polícia e nos meios de comunicação, e a ainda desigual composição dos espaços de poder no país. Por isso, um dos intelocutores que dialoguei na pesquisa, Roberto Zurbano, intitulou seu polêmico artigo publicado no New York Times ${ }^{322}$ como: "Para los negros cubanos, la Revolución aún no ha terminado".

O tratamento do racismo como um "não tema", um "não assunto", marcou a sociedade cubana nas últimas décadas e limitou o debate social sobre a questão racial e sobre as denúncias contra a discriminação. O fator inovador surge a partir dos anos I990, com ênfase nos anos 2000, com a criação das primeiras organizações voltadas para a luta antirracista no contexto revolucionário, cujo discurso rompe com a perspectiva do "mito cubano da igualdade racial".

O que denomino o "mito cubano da igualdade racial" está amparado na ideia da existência da igualdade entre os diversos segmentos raciais, exatamente pela ausência, ou quase, de desigualdades raciais e do próprio racismo estrutural. Trata-se o racismo existente como resquícios isolados provenientes de tempos idos republicanos e coloniais, que são manifestos, sobretudo, em ambientes íntimos. Outro aspecto relevante na construção desse mito é a percepção de que o racismo é inerente às relações sociais, nas quais tanto brancos podem ser racistas com negros, como negros podem ser racistas com brancos. Essa perspectiva nega o caráter sistêmico do racismo, que no caso cubano não prescindiu de estar amparado numa dinâmica hierarquizada a partir do referencial hegemônico branco.

A frase de Aimé Cesaire, que abre as considerações finais dessa tese, reflete um dos grandes esforços que vem sendo empreendido por esses agentes sociais que objetivam romper com a "diluição no universal", com o mito da igualdade, com as perspectivas totalizantes da idéia de mestiçagem e com a carga sufocante dada pela luta de classes, que, por décadas, silenciou o debate sobre outras identidades e dinâmicas sociais, como as reflexões sobre as relações raciais.

A ruptura brutal realizada pela Revolução com a histórica elite cubana, fartamente composta de latifundiários, industriais, banqueiros, dentre outros, trouxe reflexos na sociedade que são sentidos até o presente momento. Apesar das relações de poder, econômicas e sociais terem passado por um processo de mudança entre os períodos colonial e republicano, a lógica racista

\footnotetext{
${ }^{312}$ Artigo publicado em 23 de março de 2013.
} 
perpassava essa configuração de forma profunda até o triunfo revolucionário, conforme refleti especialmente no capítulo 2 da presente tese. A segregação racial era sentida no cotidiano da sociedade, em ônibus, parques, praias e espaços de trabalhos, mesmo não sendo explícita em leis.

A Revolução, em uma grande medida, rompe com isso. Todavia, na atualidade se percebe, a partir do trabalho de pesquisa feito, que outros mecanismos de controle, dominação e subalternização foram reestruturados nessas décadas de poder revolucionário. Parte desses mecanismos está diretamente relacionada à dimensão da dominação racial, baseada no privilégio da branquitude. $\mathrm{A}$ falta de um debate público sobre o tema racial inviabilizou um maior amadurecimento social para a questão e manteve, muitas vezes de forma não explícita, práticas e discursos que reafirmavam o racismo.

Argumento que a situação racial é, dada as especificidades de Cuba, ambígua. Por um lado, os avanços sociais promovidos pela Revolução e as reformas de base, ampliaram muito a presença negra em universidades, bancos, empresas, no setor de serviços. Esses avanços sociais promoveram dilatado acesso à educação e saúde, por exemplo. Como busquei demonstrar no capítulo 3, isso gerou, nos anos I980, situações de equidade em algumas instâncias como nas universidades, onde era praticamente nula a diferença de acesso entre brancos e negros, conjuntura oposta ao vivido no Brasil e EUA da época, por exemplo, em que havia uma colossal desigualdade. Até os dias de hoje, apesar da crise vivenciada há décadas no país, os indicadores sociais demonstram relativa qualidade das políticas sociais em comparação com outros países latinoamericanos ${ }^{313}$.

Todavia, poucos esforços foram feitos no sentido de promover uma educação com bases menos eurocêntricas, que visibilizasse o legado afrocubano. Nos meios de comunicação e na alta hierarquia de poder as iniquidades continuaram sendo reproduzidas, conforme as narrativas e dados apresentados no capítulo 3 buscaram demonstrar.

O chamado "período especial", a partir dos anos 1990, agudizou esse quadro, imprimindo uma crescente desigualdade econômica e de acesso a bens e serviços. Com a possibilidade de famílias receberem recursos provenientes do exterior, aliada à liberação para o estabelecimento de negócios privados de pequeno porte (conhecidos como "cuentapropismo"), as desigualdades se amplificaram, como demonstrei especialmente no capítulo 3.

\footnotetext{
${ }^{313}$ Por exemplo, com relação às metas estabelecidas pela Unesco para educação, no período de 2000 a 20I5, Cuba foi o único país da região que atingiu a totalidade do previsto. Nessa mesma avaliação, o Brasil cumpriu apenas com duas das seis metas estabelecidas. Fonte: Unesco, 2015.
} 
Nesse mesmo período, dos anos 1990 e 2000, identifico um ressurgir das lutas antirracistas. A dificuldade de acesso à justiça para resolução dos casos de racismo e a não observância do Estado em promover ações que visassem estancar o crescimento das iniquidades foram alguns dos fatores que estimularam e estimulam as mobilizações afrocubanas, e têm como pano de fundo o acirramento dessas desigualdades e os severos impactos sobre os afrodescendentes.

Uma das estratégias do ativismo antirracista é reposicionar, discursivamente, o lócus de líderes afrocubanos da história de Cuba, homens e mulheres, que, a partir de variadas estratégias de luta, atuaram pela promoção de direitos para a população negra nos processos abolicionistas, no nascimento da República e na Revolução. Sintomático como esses eventos epitomizantes, invisibilizados pela historiografia oficial, são importantes para o discurso e a narrativa antirracista atual.

Outro aspecto presente nas estratégias dos ativistas é buscar romper com o ideal de que o racismo em Cuba foi extinto. Imprimir uma nova perspectiva para as relações raciais na Revolução não foi, nem tampouco é, tarefa fácil. As décadas de silêncio oficial sobre o assunto trazem reflexos até a contemporaneidade. As vozes dissonantes, desses ativistas e coletivos, destacam que as lutas de classes não abarcam a totalidade das complexidades das lides negras, e que as raízes do racismo tocam dimensões mais profundas, que necessitam ser observadas de forma diferenciada.

A luta de classe pressupõe que haja uma disputa por direitos e por recursos. A classe trabalhadora, os operários eram e são percebidos como sujeito de direito, como humanos. Estão imersos em uma situação de dominação e exploração, mas não são vítimas de uma lógica na qual sua humanidade e sua identidade sejam negadas ${ }^{314}$.

O racismo, contudo, nesse contexto da Diáspora Africana, é estruturado sobre bases coloniais mais profundas de dominação que negam a própria humanidade, e são refletidas até o presente. Dos milhares de povos africanos escravizados, suprimiu-se, primeiramente, o seu pertencimento. Os povos arrancados de suas terras, tais como os Yorubanos, Carabalis, Ararás, dentre outros, foram reduzidos às classificações reducionistas: "negros" ou "de cor". Passaram a ser denominados com o sobrenome do "senhor", como uma propriedade. A desumanização foi o alicerce da dominação colonial, validada pela igreja católica e pelos poderes estatais. É sobre essa base que se fundam os Estados nacionais no continente americano, do qual Cuba é uma das grandes protagonistas.

\footnotetext{
${ }^{314}$ Trecho inspirado também em reflexões da liderança quilombola Antônio Bispo dos Santos (Piauí/Brasil).
} 
É contra esse legado mais amplo e profundo que as lutas negras se lançam. As construções desse estigma que arranca a humanidade dos povos africanos e seus descendentes nas Américas foram forjadas em contextos anteriores, coloniais, separados da atualidade por pouco mais de um século. Todavia, essa herança está presente nos dias de hoje, a partir da ressignificação das práticas e da própria lógica racista.

A dinâmica atual de desconstruir essa herança colonial, de imprimir um discurso que visa reposicionar categorias estigmatizadas como "negro", "afrodescendente", como identidades afirmativas, e de denunciar e buscar reverter o racismo estrutural presente na sociedade cubana é uma das estratégias do ativismo. São vozes, muitas vezes, dispersas, minoritárias, mas que estão avançando no debate nos últimos anos. Apesar das limitações existentes, há expectativa de que esse debate e a mobilização ganhem espaço, inclusive no contexto internacional, e passem a se refletir de forma mais concreta em políticas públicas que promovam a equidade racial e étnica.

Refletir sobre as mobilizações e lutas antirracistas em um contexto latinoamericano, cujo regime socialista foi implementado com antiguidade de décadas de forma única na região, possibilita reflexões mais amplas sobre as dinâmicas do racismo na Diáspora Africana nas Américas. Oportuniza conexões abrangentes dos efeitos que são gerados pela análise, tantas vezes, fria do marxismo com relação às lutas negras, dos reflexos contemporâneos do legado colonial, e de como se organizam os processos de ativismo afrodescendente em um contexto hostil à sua reverberação.

Possibilita, também, leituras sobre contextos capitalistas, como o Brasil por exemplo. Um dos argumentos muito presentes nesse país por aqueles que se contrapõem às políticas de igualdade racial, ou mais especificamente, às políticas de ação afirmativa, se baliza em que a desigualdade é de classe, não de raça. Esses defendem que medidas para combater a pobreza e políticas universais, somadas, em alguns casos, a ações afirmativas para pessoas de menor poder aquisitivo, resolveriam também as iniquidades raciais que são gritantes de acordo com os dados socioeconômicos no país ${ }^{315}$.

Todavia, a análise do contexto cubano demonstra que é uma questão mais complexa. Nas quase seis décadas de Revolução houve uma luta intensa pela igualdade no país, o que ocasionou, especialmente até o período especial, uma redução cavalar da desigualdade material. Contudo, a inexistência de uma estratégia específica para lidar com o tema racial, e o não tratamento

\footnotetext{
${ }^{315}$ Censo 2010 do IBGE é um dos exemplos de pesquisas sobre o tema.
} 
adequado à questão, possibilitou a reprodução do mesmo em escala ampla na sociedade. É um forte exemplo de que apenas o tratamento do aspecto econômico não soluciona demais desigualdades, como a racial, cujas raízes são seculares e profundas.

A busca por não perder-se, ou pelo encontro, retomando o diálogo com Aimé Cesaire, passa pela afirmação da identidade negra (pela sua não diluição no universal), conjuntamente com a luta contra o racismo e a segregação. É esse o caminho sobre o qual vem trilhando as lutas contra o racismo em Cuba. A valorização da autoestima negra, a ênfase nas lideranças afrocubanas nas narrativas sobre a história do país, a busca pelo fortalecimento da diversidade étnicorracial nos meios de comunicação e nas escolas, a superação do racismo nos espaços vinculados à economia emergente e a amplificação do debate sobre o racismo e a promoção da igualdade racial (especialmente nas comunidades mais periféricas) são algumas das prioridades desenhadas pelo ativismo antirracista cubano para trilhar esse caminho. 


\section{Informações sobre ativistas e entrevistadas/os para a pesquisa:}

- Beatriz Zulueta - Foi vice-presidente do Poder Popular de Matanzas até maio de 2015. Atualmente é funcionária do Poder Popular.

- Bienvenido Rojas - Jornalista e ativista antirracista. Com grande experiência em rádio e jornal, atualmente é coordenador do programa Songo Roco Songo, sobre cultura afro. Atua, especialmente, na ARAAC.

- Caridad Massón - É pesquisadora do Instituto Cubano de Investigação Cultural Juan Marinello. Historiadora tem ampla pesquisa relacionada à história dos partidos comunistas em diversos países.

- Clara Urrutia Noriega ou Ochun Taguarde (nome tradicional) - Cuidadora do Cabildo Santa Tereza, La Marina, Matanzas, Cuba.

- Daysi Rubiera - Historiadora e ativista antirracista. Sua atuação está focada nas iniciativas vinculadas ao coletivo Afrocubanas, voltado para as mulheres negras. É autora e organizadora de importantes publicações sobre o tema racial e de gênero, como o Afrocubanas (20II) e Reyita (2012).

- Deyni Terry - Advogada. Atua no coletivo sociojurídico Alianza Unidad Racial, dedicado ao assessoramento de vítimas de discriminação em suas diversas dimensões, como racial, de gênero e religiosa. Tem ampla experiência com o meio jurídico em Cuba. Realiza oficinas, junto a outros integrantes do projeto, abertas à comunidade para debater casos de discriminação, com ênfase para o debate racial.

- Diarenis Calderón - Ativista, educadora popular e produtora cultural. Tem experiência com curadoria de arte. Sua atuação é focada na luta antirracista e pela diversidade sexual. Integra a coordenação do projeto MirArte diaDia.

- Eric Corvalán - Cineasta e documentarista. Dirigiu o documentário "Raza" (2008), que abordou as relações raciais e o racismo na contemporaneidade. Teve longa experiência de trabalho na televisão cubana.

- Esteban Morales Domínguez - Ativista, professor e investigador titular da Universidade de Havana e membro da Academia de Ciências de Cuba. Foi diretor do Departamento de Economia Política da Faculdade de Economia e da Escola de Ciências Políticas da Universidade de Havana. Integra a Comissão Aponte e a ARAAC. Autor de livros sobre a questão racial, tais como Desafios de la problematica racial en Cuba (20I2). 
- Georgina Herrera - Poetisa, novelista e escritora, trabalhou com rádio e televisão e atualmente se dedica à poesia. Ativista, atua em articulação especialmente com Afrocubanas. Autora de diversos livros, dentre os quais destaco Gritos, de 2004, e Áfricas, de 2006.

- Gisela Arandia - Ativista, integra a coordenação executiva da ARAAC e a Rede de Mulheres Latinoamericanas e Caribenhas, capítulo cubano. É pesquisadora sobre a questão racial e possui livros vinculados ao tema. Foi coordenadora do projeto Color Cubano, criado em 2001 e extinto em 2009, que foi um dos pioneiros no país.

- Irene Esther Ruiz - Cientista política, com ampla experiência de atuação nos meios de comunicação e com políticas esportivas. Atualmente integra o grupo de especialistas no INDER já aposentados. É ativista feminista e antirracista, tendo histórico de atuação desde o início dos anos 1990, no coletivo Magín. Atualmente integra a coordenação executiva da ARAAC e o coletivo Afrocubanas.

- Heriberto Feraudy - Preside atualmente a Comissão Aponte, coletivo vinculado à União dos Escritores e Artistas de Cuba. Foi embaixador em diversas missões representando o governo cubano, inclusive em países africanos. É autor de livros voltados para a cultura afrocubana.

- Kimbo (Raúl Dominguez) - Educador popular e ativista. É um dos principais líderes comunitários de seu bairro. Integra a coordenação do Projeto Identidad y Barrio La Marina, cujo objetivo é visibilizar e promover iniciativas da comunidade, com grande foco nas tradições afrocubanas.

- Maritza López McBean - Educadora popular e ativista na Rede Barrial Afrodescendiente e na ARAAC. Sua atuação antirracista possui grande ênfase nos trabalhos comunitários em diversos bairros de Havana, com ênfase para La Lisa e Pogoloti.

- Mavis Alvarez - Ativista feminista e pelos direitos camponeses. Atuou com a reforma agrária na Revolução. Escritora, é autora do livro Yagruma e otras historias.

- Mirna Rosa Padrón Wilson - Ativista, educadora popular e produtora cultural. Sua atuação é focada na luta antirracista e pela diversidade sexual. Integra a coordenação do projeto MirArte diaDia.

- Niurka Nuñes - Pesquisadora sobre diversos temas, inclusive o racial, do Instituto Juan Marinello. Formada em Antropologia.

- Noemi de Cárdenas - Ativista feminista. É professora da Universidade de Artes de Cuba, especialista em semiótica e corporalidade. 
- Norberto Mesa - Foi fundador e primeiro confrade da Cofradía da Negritude, criada em I998, um dos primeiros coletivos voltados à questão racial em Cuba no pós-Revolução. É engenheiro pecuarista e teve experiências de trabalho no meio turístico, onde vivenciou situações de racismo, cujo desfecho na justiça não levou em consideração os atos praticados.

- Norma Guillard - Ativista feminista e antirracista, integra a ARAAC e a Rede de Mulheres Latinoamericanas e Caribenhas, capítulo Cubano. É psicóloga de formação e é parte da coordenação da associação de psicólogos de Cuba.

- Regla Gonzales Miró - Educadora popular e liderança do bairro La Marina, Matanzas Cuba. Atualmente é diretora da casa de cultura do bairro.

- Roberto Zurbano Torres - Ativista, escritor e pesquisador. É vinculado ao coletivo ARAAC, como um dos coordenadores executivos. Foi diretor do Fundo Editorial da Casa de las Américas, vice-presidente da União dos Escritores e Artistas de Cuba, chefe da redação da revista Catauro, da Fundação Fernando Ortiz. Autor de diversos artigos e ensaios sobre a questão racial.

- Rolando Zulueta - Historiador e ativista vinculado à Red Barrial Afrodescendiente. É professor de história da faculdade de engenharias, Cujae, em Havana e integrou as missões de solidariedade de Cuba com Angola.

- Tomás Fernández Robaina - Ativista, pesquisador e professor titular da Biblioteca Nacional José Martí. Integra a coordenação executiva da ARAAC. Realiza há mais de três décadas, seminários sobre a historia e cultura afrocubana. Autor do livro El Negro em Cuba, uma das primeiras publicações que abordam a questão racial no pósRevolução.

- Tato Quiñones - Escritor, Babalawo e Jornalista. Foi membro da Cofradía de la Negritud e autor do boletim digital Desde La Ceiba. Realizou e coordenou muitas atividades do coletivo Cofradía de la Negritud na casa comunitária La Ceiba, dentre os quais muitos foram debates sobre a questão racial. Escreveu livros sobre a identidade afrocubana, muitos dos quais vinculados às tradições Abacuá e Santera.

- Yulexis Almeida - Integrante do Afrocubanas. É professora de sociologia na Universidade de Havana. Produz pesquisas e textos sobre a questão racial e de gênero. Sua tese de doutorado enfoca a crise de acesso ao ensino superior para os afrodescendentes em Cuba, após o período especial, com ênfase para os anos 2000. 
- Zuleica Romay - Cientista social e escritora. Ganhadora do Prêmio Casa das Américas, de 20I2. É integrante da ARAAC. Presidenta do Instituto Cubano do Livro, vinculado ao Ministério da Cultura.

- Grupo entrevistado para debate sobre a cor de integrantes do Conselho de Estado, Bureau Partido Comunista de Cuba e Presidência da Assembléia do Poder Popular (Capítulo 3, Seção "Equidade e representação simbólica: Ações Afirmativas em Cuba):

- Olga Lidia Tió Valencia - 45 anos, nasceu em Havana, se declara "mulata";

- Maria Martinez Romero - 65 anos, nasceu em Chaparra, oriente de Cuba, se declara "negra".

- Yoana Golzavez Valdez- nasceu em Havana, se declara "mestiça", tem 27 anos;

- Gilberto Quintana Arredondo - nasceu em Havana, se declara "mestiço" de 47 anos.

- Danay Ramos - De Santiago de Cuba, se declara "branca", tem 3 I anos.

- Mercedes Cañete - 63 anos, se declara "mulata", nasceu em Havana.

- Carlos Ernesto Cañedo Tapanes, 33 anos, nasceu em Havana, se declara como "branco".

- Grupo entrevistado sobre categorias de ativismo e organização social (capítulo I, Seção "Movimento afrocubano nos estertores da Guerra Fria"):

- Maria Martinez Romero - 65 anos, nasceu em Chaparra, oriente de Cuba, se declara "negra".

- Lizmare Machado Lao - 23 anos, nasceu em Holguín, se declara "branca"

- Liban Moya Hernández - 45 anos, nasceu em Cinfuegos, se declara como "branco" 


\section{REFERÊNCIAS}

\section{REFERÊNCIAS BIBLIOGRÁFICAS}

ADESKY, Jacques. Pluralismo étnico e multiculturalismo: racismo e anti-racismo no Brasil. Rio de Janeiro, Pallas: 2009.

ALMEIDA, Alfredo W. B. de. Os Quilombos e as Novas Etnias. In: O’Dwyer, Eliane Cantarino. Quilombos: Identidade Étnica e Territorialidade. Rio de Janeiro, Editora FGV, 2002.

ALMEIDA, Yulexis. La Educación Superior en Cuba. Un análisis desde el género y la raza. Tertúlia da Afocubanas realizada, na Casa de Alba, La Habana, Cuba, noviembre, 2014.

Color de la Piel: Un Desafio para las Políticas de Aceso a la Educación Superior en Cuba. La Habana, Anais del Seminario "Identidades y Movilizaciones Colectivas", Instituto de Investigación Cultural Juan Marinello, 2015.

ALONSO, Angela. As teorias dos movimentos sociais: um balanço do debate. São Paulo, Lua Nova, 2009: 49-86.

ARAAC. Posición de la Articulación Regional de Afrodescendientes de Latinoamérica y el Caribe, en su Capítulo Cubano (ARAAC), 2013. Disponível em: http://www.afrocubaweb.com/araac.html

ARENDT, Hannah. Origens do totalitarismo, Atisemitismo, Imperialismo, Totalitarismo. São Paulo, Companhia das Letras, 2006.

ASPEN Institute. Structural Racism And Community Building. Washington, The Aspen Institute, 2004.

AUSTIN, David. Miedo a una nación negra. Raza, sexo y seguridad en el Montreal de los años sesenta. La Habana, Fondo Editorial Casa de las Americas, 2014.

BAINES, Stephen G. Imagens de liderança indígena e o Programa Waimiti-Atroari: índios e usinas hidrelétricas na Amazônia. São Paulo: Revista de Antropologia - USP, 2000, V. 43 nº 2.

BARBOSA, J. B. Barbosa. A repecpção do instituto da ação afirmativa pelo direito constitucional brasileiro. In: SANTOS, Sales Augusto (Org.). Ações Afirmativas e Combate ao Racismo nas Americas. Brasília, Ministério da Educação, SECAD, 2005.

BARBOSA, Marcio. Frente Negra Brasileira - depoimentos. São Paulo: Quilombhoje, I998.

BARNET, Miguel. Biografía de un cimarrón. La Habana, Editorial Letras Cubanas, 2012.

El tema racial en la sociedad cubana actual: letra y espíritu. Casa de las Américas, No. 264, julio-septiembre, La Habana, 201 I.

BENTES, R. Nilma de Melo. Negritando. Belém, Graphite, I993. 
BENTO, M. A. da S. Branqueamento e branquitude no Brasil. In: Carone, I.\& Bento, M. A. da S. (org.), 2002.

BERBEL, Márcia, (et al.). Escravidão e política. Brasil e Cuba, c.I790-1850. São Paulo, Hucitec, 2010 .

BETHENCOURT, F. Racisms - From the Crusades to the Twentieth Century. Priceton, Ed. Priceton University Press, 2013.

BARÓ, Dionísio L. Poey. Cuba: Estratégia de Sobrevivência de Mulheres Negras (Século XX). Brasília, Departamento de História da Universidade de Brasília, 2009. (Mimeo)

BHABHA, Homi. Dissemination: time, narrative and the margins of the modern nation. In: BHABHA, Homi (org.). Nation and narration. London/New York, Routledge, I990: 29I322.

O Local da Cultura. Tradução de Miriam Ávila Lourenço e Gláucia Gonçalves. Belo Horizonte, Editora UFMG, I998.

BLANCH, Hedelberto López. Cuba: Pequeño gigante contra el Apartheid. La Habana, Ed. Abril, 2008.

BOSI, Ecléa. Memória e Sociedade: lembrança de velhos. São Paulo, T. A Queiroz, Editora da Universidade de São Paulo, 1987.

BOURDIEU, Pierre. A dominação masculina. Rio de Janeiro: Bertrand Brasil, 2005.

O Poder Simbólico. $7^{\mathrm{a}}$ Edição - Rio de Janeiro; Bertrand Brasil, 2004.

BRAH, Avtar. Diferença, diversidade, diferenciação. Cadernos Pagu (26), janeiro-junho de 2006: pp.329-376.

BRASIL. Análise do Sistema de Cotas para negros na Universidade de Brasília - 2004 a 2013. Brasília, Universidade de Brasília, 2013. Disponível em http://www.unb.br/administracao/decanatos/deg/downloads/index/realtorio_sistema_cotas.p df

BRASIL, Daniel R. The Underdog World. Tese de Doutorado. Brasília: Universidade de Brasília; Vancouver: University of British Columbia, 2015.

BRIONES, Claudia. Mestizaje y blanqueamiento como coordenadas de aboriginalidad y nación em Argentina. Runa XXIII, pp. 6I-88, 2002.

BUTLER, Judith. Cuerpos que importan. Sobre los límites materiales y discursivos del "sexo". Buenos Aires, Ed. Paidós, 1993. 1990. El género en disputa. El feminismo y la subversión de la diversidad. Barcelona, Paidós,

Imitación e insubordinación de género. Buenos Aires, Grafías de Eros. Historia, género e identidades sexuales, Edelp, 1989. 
CALAFORA, Jorge. El color de la piel y el racismo en Cuba. Varsóvia, Diário de Cuba, 2015. Disponível em: http://www.diariodecuba.com/cuba/I4267I005I_I3475.html

CARDOSO, Lourenço. Branquitude acrítica e crítica: A supremacia racial e o branco anti-racista. $\begin{array}{llll}\text { Rev.latinoam.cienc.soc.niñez juv } & \text { 8(I): 607-630, }\end{array}$ http://www.umanizales.edu.co/revistacinde/index.html;

CARVALHO, José Jorge de (Org). O Quilombo Rio das Rãs: histórias, tradições e lutas. Salvador, EDUFBA, I996.

A Morte Nike: Consumir, o Sujeito, Universa, Vol. 8, No 2, 38I-396. Universidade Católica de Brasília, junho, 2000

Transformações da Sensibilidade Musical Contemporânea, Horizontes Antropológicos, Ano 5, No. II, 59-I18, 1999.

O olhar etnográfico e a voz subalterna. Horizontes Antropológicos. Porto Alegre, ano 7, n. I5, julho de 200I. pp. I07-I47, 200I.

Poder e silenciamento na representação etnográfica. Brasília, Série DAN Departamento de Antropologia, Universidade de Brasília, 2002.

Racismo fenotípico e estéticas da segunda pele. Estéticas da Biopolítica, 2007. http://www.revistacinetica.com.br/cep/jose_jorge.htm

CASHMORE, Ellis. Dicionário de Relações Étnicas e Raciais. São Paulo, Selo Negro, 2000.

CASTELLS, Manuel. The information age: economy, society and culture. London: Blackwell Publishers, 1996.

CASTILHO, Daisy Rubiera e TERRY, Inés María Martiantu. Afrocubanas: História, pensamento y practicas culturales. La Havana, Editorial de Ciencias Sociais, 201 I.

CÉSAR, Maria Auxiliadora. Mulher e Política Social em Cuba: O contraponto socialista ao bemestar capitalista. Brasília: Edições Alva, 2004.

CHILDS, Matt D. La Rebelión de Aponte de I8I2 en Cuba y la Lucha Contra la Esclavitud Atlántica. Santiago de Cuba, Editorial Oriente, 2011.

CLASTRES, Pierre. Sobre el etnocidio. En: Investigaciones en Antropología Política. Gedisa, Barcelona, 1996 (p.: 55-64).

CLIFFORD, James. Antropologia e literatura no século XX. Rio de Janeiro, Editora UFRJ, 1998.

COHEN, Jean L.; ARATO, Andrew. Sociedad Civil y Teoria Política. México: Fondo de cultura económica, $200 \mathrm{I}$.

Colectivo de autores. Raza y racismo. Caminos, Antología, La Habana, 2012.

Colectivo de autores. Indagaciones sobre la cuestión racial en Cuba. Publicaciones Espacio Laical, La Habana, 2013. 
CONTINS, M. e SANT’ANNA, L.C. O movimento negro e a questão da ação afirmativa. Estudos Feministas. IFCS/UFRJ-PPCIS/Uerj, v.4, n.I.

COSTA, Sérgio. A mestiçagem e seus contrários - etnicidade e nacionalidade no Brasil contemporâneo. Tempo Social; Rev. Sociol. USP, S. Paulo, I3(I): I43-I58, maio de 2001.

COVARRUBIAS, Gisela Arandia. Población afrodescendente cubana atual. La Havana, Instituto Cubano de Investigacion Cultural Juan Marinello e Fundo de las Naciones Unidas para la Población - UNFPA, 2012.

DAGNINO, Evelina; OlVERA, Alberto e PANFICHI, Aldo. A Disputa pela Construção Democrática na América Latina. São Paulo, Paz e Terra, 2006.

DAVIS, Samuel Furé. La cultura Rastafari en Cuba. Santiago de Cuba, Editorial Oriente, 201 I.

DE FRIEDEMANN, NINA. Estudios de negros en la antropología colombiana. En Un siglo de investigación social: antropología en Colombia. J. Arocha y N. de Friedemann. Etno. Bogotá, 1984.

DE LA FUENTE, Alejandro de la. Una Nación para Todos. La Habana, Ed. Imagen Contemporanea, Casa de Altos Estudios Don Fernando Ortiz, 2014.

"Tengo una raza oscura y discriminada» El movimiento afrocubano: hacia un programa consensuado. Revista Nueva Sociedad No 242, noviembre-diciembre de 20I2, ISSN: 025I3552, <www.nuso.org $>$.

DESCHAMPS CHAPEAUX, Pedro. Los cimarrones urbanos. La Habana, Editorial Ciencias Sociales, 1983.

Etnias africanas en las sublevaciones de los esclavos en Cuba. Revista Cubana de Ciencias Sociales. No I0, IV.pp I4-30. (Enero-Abril).La Habana, I986.

Habana, I97I.

El negro en la sociedad habanera del siglo XIX. Premio ensayo UNEAC, I970. La

DOMINGUES, Perônio. O mito da democracia racial e a mestiçagem no Brasil (I889-I930. Aarhus: Diálogos Latinoamericanos, número 0I0, 2005.

DOMINGUEZ, Esteban Morales. A Durban entramos negros y salimos afrodescendientes. La Habana, Blog Negra Cubana Tenía que Ser, 20I5. Disponível em: http://negracubanateniaqueser.com/2015/07/08/a-durban-entramos-negros-y-salimosafrodescendientes-reflexion-de-esteban-morales/

Cuba: raza después de 1959. La Habana, UNEAC, 2012.

El tema racial y la subversión anticuba. La Habana, La Jiribilla, 2007. Disponivel em: http://www.lajiribilla.co.cu/2007/n33I_09/33I_I8.html

Marti, 2012.

La problemática racial em Cuba: Alguno de sus desafios. La Habana, Editorial José 
DORIA, Siglia Zambrotti. Confrontos discursivos sobre territórios no Brasil: o caso das terras dos "remanescentes de quilombos". Tese de doutorado. Brasília, departamento de antropologia Unb, 200I.

DRAKE, F. C. (et al.). Secret History of the Slave Trade to Cuba Written by an American Naval Officer, Robert Wilson Shufeldt, I86I. The Journal of Negro History, v. 55, n. 3: 218-235, 1970.

DUMONT, Louis. Homo Hierarchicus: O sistema de castas de suas implicações. São Paulo: Ed. Universidade de São Paulo, 1992.

FANON, F. Em defesa da revolução africana. Terceiro Mundo, Tradução de Isabel Pascoal. Portugal: Livraria Sá da Costa Editora, 1980. Los condenados de la tierra. Ciudad de Mexico, Fondo de Cultura Económica, I963.

FELTRAN, G. S. Desvelar a política na periferia. Histórias de movimentos sociais em São Paulo. São Paulo: Associação Editorial Humanitas: Fapesp, 2005.

FERNANDEZ, M. A La Sombra Del Arból Tutelar. La Habana, Editorial de Ciencias Sociales, 2004.

FOLEY, Robert. Os Humanos Antes da Humanidade: uma perspectiva evolucionista. São Paulo: Editora UNESP, 2003.

FORNET, Ambrosio. El Quinquenio Gris: Revisitando el término. La Habana, revista Criterios, 2006.

FORNIAS, Carlos Venegas. La Arquitectura de la intervención (I898-1902). In: HEREDIA, F. et al.. Espacios, silêncios y los sentidos de la libertad: Cuba em I878 y I9I2. La Havana: Ediciones Union, $200 I$.

FOUCAUlT, M. A ordem do Discurso. São Paulo, Edições Loyola, 2006.

Microfísica do Poder. Rio de Janeiro: Edições Graal, 1979.

FRANCO, José Luciano. Historia de la Revolución de Haití: Una batalla por el dominio del Caribe y el Golfo de Mexico. La Habana: Editorial de Ciencias Sociales, 2010.

FREIRE, Paulo. 1987. Pedagogia do Oprimido. I7ª. Ed. Rio de Janeiro: Paz e Terra.

FREYRE, Gilberto. Casa-grande e senzala. Ia edição I933. São Paulo/Rio de Janeiro, Record, I999.

FUERTES, Digna C. Demandas Judiciales de La Esclava Belén Alvaréz. In: CASTILHO, Daisy Rubiera e TERRY, Inés María Martiantu. Afrocubanas: História, pensamento y practicas culturales. La Havana, Editorial de Ciencias Sociais, 20 I I.

FUNARI, Pedro P. de Abreu. A arqueologia de Palmares: sua contribuição para o conhecimento da história da cultura afro-americana. In: GOMES, Flávio dos S. e REIS, João J. (Orgs). Liberdade por um fio: História dos Quilombos no Brasil. São Paulo: Companhia das Letras, 2000 . 
FURNISS, E. The Burden of History. Colonialism in the frontier of Canada. Vancouver, UBC Press, 1998.

FUSS, Diana. Essentially Speaking. London, Routledge, 1989.

GARCÍA, María Alejandra Casanova García. Debate racial: entre dichos y hechos. El debate público intelectual en torno a la problemática racial durante 2008-20I3. Trabajo de Diploma. La Habana, Facultad de Comunicación, Universidad de La Habana, 2014.

GEERTZ, Clifford. A Interpretação das Culturas. Rio de Janeiro: LTC Editora, I989.

GENOVESE, Eugene. Esclavitud y capitalismo. Ariel. Barcelona. cimarronaje en Vuelta Abajo.Notas sobre el diario de un rancheador. Barcelona, Boletín Americanista - No 37, I97I, pp 203-2I4.

GOBINEAU, I853, apud MUNANGA, Kabengele. Rediscutindo a mestiçagem no Brasil: identidade nacionais. Editora Vozes. Petrópolis, RJ: Vozes, I999. Pg 43.

GOFFMAN, E. Estigma: notas sobre a manipulação da identidade deteriorada. Márcia Bandeira de Mello Leite Nunes (Trad.). Rio de Janeiro: LTC, 2005.

GOHN, Maria da Glória. Movimentos sociais na contemporaneidade. In: Revista Brasileira de Educação v. 16 n. 47 maio-ago, 201 I.

Teoria dos movimentos sociais: paradgmas clássicos e contemporâneos. $6^{a}$ Edição. São Paulo, Edições Loyola, 2007.

GOLDMAN, Marcio. Poder E Resistência: Um Ensaio Sobre a Dimensão Conceitual do "Império". Artigo bibliográfico. MANA 9(2):183-200, 2003.

$200 I$.

Segmentaridades e Movimentos Negros nas Eleições de Ilhéus. MANA 7(2):57-93,

GOMES, Nilma Lino. Alguns termos e conceitos presentes no debate sobre relações raciais no Brasil: uma breve discussão. In: Educação anti-racista: Caminhos abertos pela Lei FederalI0.639/2003. Brasília, Ministério da Educação, 2005.

GONZALEZ et al. Las relaciones raciales en Cuba. Estudios contemporáneos. Colectivo de Autores. La Habana, Fundación Fernando Ortiz, 201 I.

GRAU, Maria Isabel. La Revolución Negra. La Rebelión de los Esclavos en Haití I79I-I804. Mexico DF, Ocean Sur, 2009.

GUIMARÃES, Antonio Sérgio Alfredo. Raça, cor, cor da pele e etnia. Cadernos de Campo, Revista dos alunos de pós-graduação em antropologia social da Universidade de São Paulo. São Paulo, n. 20: I-360, 201 I.

Racismo e anti-racismo no Brasil. São Paulo: Fundação de Apoio à Universidade de São Paulo, 34ª ed,I999.

HABERMAS, Jurgen. Life-World and System: A critique os Functionalist Reason. Vol. 2 de Theory of Communicative Action, 1987, p. 393. Apud HANCHARD, Michael George. Orfeu e 
o poder: movimento negro no Rio de Janeiro e São Paulo (I945-1988). Rio de Janeiro, Ed. UERJ, 200I

A nova intransparência. Novos Estudos Cebrap, no I9, setembro, I987.

HALL, Stuart. The Centrality of Culture. Notes on the cultural revolutions of our time. In Thompson, Kenneth (ed.). Media and Cultural Regulation. Lonfon, Thousand Oaks, New Delhi The Open University SAGE Publications, 1997.

2006.

Da Diáspora: Identidades e Mediações Culturais. Belo Horizonte, Editora UFMG,

New Ethnicities. In: Black Film, British Cinema. ICA Documents 7. London, Institute of Contemporary Arts, I989.

HANCHARD, Michael George. Orfeu e o poder: movimento negro no Rio de Janeiro e São Paulo (I945-I988). Rio de Janeiro, Ed. UERJ, 200I.

HARAWAY, Donna. "Gênero" para um dicionário marxista: a política sexual de uma palavra. Cadernos Pagú, 2004.

HASENBALG, Carlos. Discriminação e Desigualdades Raciais no Brasil. Belo Horizonte, Editora UFMG; Rio de Janeiro, IUPERJ, 2005.

HELG, Aline. Lo que nos corresponde: La lucha de los negros y mulatos por la igualdad. La Habana, Imagen Contemporanea, 2000.

Constituiciones y práctivas sociopolíticas de las minorías de origen africano: una comparación entre Colombia y Cuba. In: AROCHA, Jaime (Comp.). Utopía para los excluídos: el multiculturalismo en África y América Latina. Bogotá, Universidad Nacional de Colombia. Facultad de Ciencias Humanas, 2004.

HERRERA, Georgina y RUBIERA, Daysi. Golpeando la memoria. La Habana, Ediciones Unión, 2005.

HOZ, Pedro de la. Durban: Diez años después. Una batalla cubana por la plena equidad racial. La Habana, Instituto Cubano del Libro - Editorial Letras Cubanas, 2012.

IZQUIERDO, Irene. Fuera de la agenda. Artigo inédito, presentado presentado en el Diplomado Raza, Cultura y Gene. La Habana, Cátedra de Antropología, Universidad de La Havana, 2015.

INIKORI, Joseph E. Africa in World History. The Export Slave Trade From Africa and the Emergency of the Atlantic Economic Order. In: B. A. Ogot (ed.). Africa from the sixteenth century to the eighteenth century. Vol. 5 of General History of Africa. Berkeley, Califórnia, 1992.

JACCOUD, Luciana; BEGHIN, Nathalie. Desigualdades Raciais no Brasil: um balanço da intervenção governamental. Brasília : Ipea, 2002.

KHAZANOV, Anatoly. After the URSS: Ethnicity, nationalism and politics. Un. Wisemsin Press, 1995. 
LA ROSA CORZO, Gabino. Tatuados: Deformaciones étnicas de los cimarrones en Cuba. La Habana, Fundación Fernando Ortiz, 201 I.

LAO-MONTES, Agustín. Cartografias del campo político afrodescendiente en América Latina. Bogotá, universitas humanística no.68 julio-diciembre de 2009 pp: 207-245.

LAVIÑA, Javier. Doctrina para negros. Barcelona, Sendai Editores, I989.

Santiago de Cuba en I860: Esclavitud color y población. Madrid, Boletín de la Asociación de Geógrafos Españoles, No I5-I6. pp. I7-34. I992.

LAWRENCE, Keith et al. Strong and Pervasive Evidence of Racial Inequalities, Poverty Outcomes, Structural Racism. In: Race and Public Public Policy, 2004.

LÁZARO, Andre et al. Inclusão no Ensino Superior. In: Ações afirmativas e Inclusão no Brasil: um balanço. Cadernos do GEA n.2, jul.-dez. 2012.

LE VEN, Michel M., FARIA, Erika \& MOTTA, Miriam H. S. Historia Oral de Vida: o instante da entrevista. In: Os desafios contemporâneos da historia oral. SIMSOM, Olga (org.). Campinas, Unicamp, Centro de Memória - ABHO. I997. (pp. 213-222).

LEVI-STRAUSS, Claude. O pensamento selvagem. Campinas, Papiros, 2005.

LIMA, Arivaldo. A Legitimação do Intelectual Negro no Meio Acadêmico Brasileito: Negação de Inferioridade, Confronto ou Assimilação Intelectual?. Afro-Ásia, 25-26, $200 \mathrm{I}$.

LÓPEZ VALDÉS, R. Procedencia de los africanos introducidos en Puerto Rico. Ponencia presentada en el encuentro de africanistas celebrado en San Juan de Puerto Rico, de 20 a 2I de noviembre de 2003.

LOVEMAN, Mara. National Colors: Racial Classification and the State in Latin America. Oxford: Oxford University Press, 2014.

MACHADO, Jorge. Ativismo em Rede e conexões identitárias: novas perspectivas para os movimentos sociais. Sociologias, no.I8, Porto Alegre, July/Dec. 2007.

MAGGIE, Y. e FRY, P. A reserva de vagas para negros nas universidade brasileiras. Rio de Janeiro, Enfoques (Revista Eletrônica), vol. I, n I, 2002, pp. 93-II7.

MALATIAN, Teresa. O cavaleito negro: Arlindo Veiga dos Santos e a Frente Negra Brasileira (1931-1934). Anais do IV Encontro Nacional do GT História das Religiões e das Religiosidades. In: Revista Brasileira de História das Religiões v. V, n. I5. Maringá, 2013.

MARCUS, George. Contemporary Problems of Ethnography in the Modern World System. In: Writing Culture: The Poetics and Politics of Ethnography. J. Clifford and G. Marcus. Berkeley, University of California Press, I986.

MARQUES, Leonardo. A Participação Norte-Americana no Tráfico Transatlântico de Escravos para os Estados Unidos, Cuba e Brasil. In: História: Questões \& Debates - n. 52. Curitiba, Editora UFPR, 2010. 
MARQUES, Rafael e PARRON, Tâmis. Revolta Escrava e Política da Escravidão: Brasil e Cuba, I79I - I825. In: Revista de Indias, 201 I, vol. LXXI, n. ${ }^{\circ}$ 25I, 19-52. São Paulo, Universidade De São Paulo, 201 I.

MARTÍNEZ HEREDIA, Fernando. En la defensa del socialismo Cuba está obligada a ser antirracista. Casa de las Américas, No. 264, julio-septiembre, La Habana, 2010.

MCADAM, D., J.; ZALD, M. N. Comparative perspectives on social movements: political opportunities, mobilizing structures and cultural framings. Cambridge: Cambridge University Press, 1996.

MCCARTHY, J. D.; ZALD, M. N. Resource mobilization and social movements: a partial theory. American Journal of Sociology, vol. 82, no 6, I977.

MELUCCI, A. Getting involved: identity and mobilization in social movements. International Social Movements Research, vol. I, I988.

MONTEJO ARRECHA, Carmen Victoria. Sociedades de instrucción y recreo de pardos y morenos que existieron en Cuba Colonial. I878-1898. Veracruz, Instituto Veracruzano de Cultura, 1993.

MOORE, Carlos. Racismo e Sociedade. Novas Bases Epistemológicas para Entender o Racismo. Belo Horizonte, Mazza Edições, 2007.

MORAIS, Fernando. Os últimos soldados da Guerra Fria. São Paulo, Cia das Letras, 2011.

MORÚA, Manuel Cuesta. Diálogo al interior del debate racial en Cuba: ‘acción afirmativa o reempoderamiento ciudadano? In: Reflexiones en torno al problema racial en Cuba. La Habana: ISLAS, sem data.

MOURA, Clovis. Brasil: as raízes do protesto negro. São Paulo: Global, I983.

MUNANGA, Kabengele. Rediscutindo a mestiçagem no Brasil: identidade nacionais. Editora Vozes. Petrópolis, RJ: Vozes, I999.

NASCIMENTO, Abdias. O Quilombismo. Rio de Janeiro: Ed. Vozes, I980.

NOGUEIRA, Oracy. Preconceito racial de marca e preconceito racial de origem. São Paulo: Tempo Social, revista de sociologia da USP, v. I9, n. I, 2006.

NUÑEZ JIMÉNEZ, Antonio. Los esclavos negros. La Habana, Editorial Letras Cubanas, I998.

ORTIZ, Fernando. Contrapunteo cubano del tabaco y el azúcar. Introdución de Malinowsky. La Habana, Consejo Nacional de Cultura, 1963.

Sociales, 1992.

Los cabildos y la fiesta afrocubanos del Día de Reyes. La Habana, Ed. Ciencias El Negro en Cuba. La Habana, Editorial Ciencias Sociales, 1975.

ORTNER, Sherry. Resistance and the problem of ethnographic refusal, Comparative Studies in Society and History. Vol 37, No. OI, 1995. 
PECHINCHA, Mônica Thereza Soares. O Brasil no discurso da antropologia nacional. Goiânia: Cânone Editorial, 2006.

PENA, Sérgio D. J. e BIRCHAL, Telma S. A inexistência biológica versus a existência social de raças humanas: pode a ciência instruir o etos social?. REVISTA USP, São Paulo, n.68, p. I0-2I, dezembro/fevereiro 2005-2006.

PETRAS, J., \& VELTMEYER, U. Social movements and state power. Argentina, Brazil, Bolivia, Ecuador. London: Pluto Press, 2005.

PORTUONDO, Gladys. La transculturación en Fernando Ortiz: imagen, concepto, contexto. Mérida, Oralteca.unimagdalena.edu.co, julio de I999.

PRICE, Richard. Maroon Societies: Rebel Slaves Comunities in the America. Maryland, Jonhs Hopkins University Press, 1996.

PRIETO, Rodrigo Espina y RUIZ, Pablo R. Raza y desigualdade en la Cuba actual. Havana, Temas - Cientro de Antropología, no. 45: 44-54, 2006. (http://afrocubaweb.com/News/Cuba/RazaDesigualdad_Rodrigo.pdf)

PRIETO, Rodrigo Espina. Itinerario personal en las relaciones raciales en Cuba. Algunas consideraciones. La Habana, Anais del Seminario "Identidades y Movilizaciones Colectivas", Instituto de Investigación Cultural Juan Marinello, 2015.

PINTO, Regina Pahim. Frente Negra Brasileira. Cultura Vozes, n. 4, jul/ago 1996

PLANO DE AÇÃO DE DURBAN. Durban, Nações Unidas, $200 \mathrm{I}$.

QUIJANO, Aníbal. ¡Qué tal Raza! In: ALAI - América Latina en Movimiento, No. 320, 2000. Disponível em: http://alainet.org/publica/320.phtml

QUIÑONES, Serafim. Asere Núncue Itiá: Ecobio Enyene Abacuá. La Habana, Editorial José Marti: 2014.

QUIRÓS, Ronald et al. Mestizaje, indígenas e identidad nacional en Centroamérica: De la Colonia a las Repúblicas Liberales. San José, Cuaderno de Ciencias Sociales I43 - Facultad Latinoamericana de Ciencias Sociales (FLACS), 2007.

RAMÍREZ, Sandra A. Es constitucional en Cuba el "derecho de admisión"? La Habana, el Toque, 2015.

REY, Estrella. Conquista y colonización de la isla de Cuba (I492-1553). Disponível em: http://www.cubaliteraria.cu/autor/estrella rey/conquista.html - acesso em I0/2013

RIBEIRO, Matilde. Políticas de promoção da igualdade racial - I986 a 20IO. Rio de Janeiro, Ed. Garamond, 2014.

RIOS, Flavia Mateus. Elite Política Negra no Brasil: Relação entre movimento social, partidos políticos e Estado. São Paulo, Faculdade de Filosofia, Letras e Ciências Humanas, 2014. (mimeo)

RIVERO, Sandra Estévez, MONTERREY: C., ZÍNIIGA, O. P. (coord). Por la identidade del negro cubano. Santiago de Cuba, Comitê Provincial de la UNEAC, Ediciones Cesarón, 2011. 
RODRIGUEZ, Rolando. La conspiración de los iguales: La protesta de los independientes de color em I9I2. La Habana, Imagen Contemporanea, 2010.

RODRÍGUEZ RUIZ, Pablo. Migración, Remesa y Desigualdad Racial. Apresentação feita no Seminário Identidades y Movilizaciones Colectivas. La Habana, Instituto Cubano de Investigación Juan Marinelo, 2015.

ROBAINA, Tomás Fernandez. El negro en Cuba. Colonia, República, Revolución. La Habana, Ediciones Cubanas, Artex, 2012.

A luta contra a discriminação racial em Cuba e as ações afirmativas: convite à reflexão e ao debate. In: SANTOS, Sales Augusto (Org.). Ações Afirmativas e Combate ao Racismo nas Americas. Brasília, Ministério da Educação, SECAD, 2004.

2009. Identidad afrocubana. Cultura y nacionalidad. Editorial Oriente, Santiago de Cuba,

ROMAY, Zuleica Guerra. Elogio de la altea o las paradojas de la racialidad. Habana, Fondo Editorial Casa de las Américas, 2012.

RUBIERA, Daysi Castilho. Reyita Sencillamente: Testimonio de una negra cubana nonagenaria. La Habana, Ediciones Alba: 20II.

RUBIERA, D. y MORREIRO, L. C. (Org). Afrobartiando: Experiencias Comunitarias. La Habana, Grupo de Reflexión y Solidaridad Oscar Arnulfo Romero, 2014.

RUBIERA, D. y MORO, S. Magin: Tiempo de Contar esa Historia. Asociación de Mujeses Comunicadoras. La Habana, Ed. Magín, 2015.

SANTOS, B. de S. Entre Próspero e Caliban: colonialismo, pós-colonialismo e inter-identidade. São Paulo: Cortez Editora, 2006.

SANTOS, Helio. Discriminação Racial no Brasil. In: SABÓIA, G. V.; GUIMARÃES, S. P. (Orgs). Anais de seminários regionais preparatórios para a Conferência Mundial contra o Racismo, Discriminação Racial, Xenofobia e Intolerâncias Correlatas. Brasília, Ministério da Justiça, $200 I$.

SCHERER-WARREN, Ilse. Das Mobilizações às Redes de Movimentos Sociais, Sociedade e Estado. Brasília, v. 2I, nI: I09-I30, jan./abr. 2006/2007.

SCHUCMAN, L. V. Sim, nós somos racistas: estudo psicossocial da branquitude paulistana. São Paulo, Psicologia \& Sociedade, 26(I), 83-94, 2014.

SCOTT, James. Los dominados y el arte de la resistencia: Discursos ocultos. Cidade do Mexico, Ediciones Era, 2004.

SCOTT, Rebecca J. Reclamando la mula de Gregoria Quesada: el significado de la libertad en los vales del Arimao y del Caunao, Cienfuegos, Cuba (I880-1899). In: HEREDIA, F. et al.. Espacios, silêncios y los sentidos de la libertad: Cuba em I878 y I9I2. La Havana: Ediciones Union, 200I.

SEGATO, Rita Laura. La nación y sus otros: raza, etnicidad y diversidad religiosa em tiempos de políticas de la identidad. Buenos Aires:Prometeo Libros, 2007. 
SIDER, Gerald M. Lumbee: Indian Histories. Race, Etnicity dan Indian Identity in the Southern United States. New York, Cambridge University Press, 1993.

SILVA, Maria Aparecida (Cidinha). Apresentação à Edição Brasileira. In: SUDBUR Y, Julia. Outros Tipos de Sonhos: Organizações de Mulheres Negras e Políticas de Transformação. São Paulo: Summus, 2003.

SOUZA, Bárbara O., SOUZA, Edileuza Penha. Preconceito, estereótipo e discriminação no espaço escolar. In: SOUZA, Edileuza P. et al. (Orgs). História e Cultura Afrobrasileira e Africana na Escola. Brasília, Ágere, 2008.

SOUZA, Bárbara Oliveira. Aquilombar-se: Panorama histórico, identitário e político do Movimento Quilombola Brasileiro. Brasília, Departamento de Antropologia da Universidade de Brasília, 2008. (Mimeo)

Perspectivas Históricas, identitárias e políticas do Movimento Quilombola Brasileiro. In: MOURA, Carlos A. et al.. Diversidade Cultural Afrobrasileira: Ensaios e Reflexões. Brasília, Fundação Cultural Palmares, 2012.

Una Mirada sobre la Lucha Anti-Racista en Cuba y Brasil: Raza, Color y Afrodescendiencia. Anais del Seminario Identidades y Movilizaciones Colectivas. La Habana, Instituto de Investigación Cultural Juan Marinelo, 2015.

SOVIK, L. Aqui ninguém é branco: hegemonia branca no Brasil. In: WARE, Vron. Branquidade. Identidade branca e multiculturalismo. Rio de Janeiro: Garamond, 2004.

SPIVAK, G. C. In Other Worlds: Essays in Cultural Politics. London, Methuen, 1987.

1999. A critique of Postcolonial Reasons: Toward a History of the Vanishing. Howard,

STOLCKE, Verena. Los mestizos no nacen sino que se hacen. In: Verena Stolcke \& Alexandre Coello (Org.), Identidades Ambivalentes en América Latina (Siglos XVI-XXI), Barcelona: Bellaterra, 2007.

STUTZMAN, RONALD. El mestizaje: an all-inclusive ideology of exclusion. En Cultural transformations and ethnicity in modern Ecuador. N. E. Whitten (ed.). University of Illinois Press. Urbana, I98I.

TERRY, Inés María Mariatu. El rito como representación. Teatro ritual caribeño. La Habana, Ediciones Unión: 2000.

Prólogo. In: Afrocubanas: Historia, pensamiento y practicas culturales. Colectivo de autoras. La Habana, Editorial de Ciencias Sociales, 201 I.

TILLY, C. From mobilization to revolution. Newberry Award Records, I978.

TOURAINE, Alain. Os movimentos sociais. In: A. Touraine. Iguales y diferentes: podemos vivir juntos? Lisboa: Instituto Piaget, I998: I27-I72.

La production de la société. Paris: Editions du Seuil,I973. 
TRECCANI, Girolamo Domenico. Terras de Quilombo: Caminhos e Entraves do Processo de Titulação. Belém, 2006.

TURNER, Victor. Dewey, Dilthey e Drama: um ensaio em Antropologia da Experiência (primeira parte). De Victor Turner (Dewey, Dilthey, and Drama: An Essay in the Anthropology of Experience". Cadernos de Campo No. I3: I77-I85, 2005.

WADE, Peter. Gente negra, nación mestiza: las dinámicas de las identidades raciales en Colombia. Ediciones Uniandes. Bogotá, Ediciones de la Universidad de Antioquia-Siglo del Hombre Editores-Instituto Colombiano de Antropología, 1997.

Racismo, democracia racial, mestizaje y relaciones de sexo/género. Bogotá: Tabula Rasa, No.I8: 45-74, enero-junio 2013.

Repensando el Mestizaje. Instituto Colombiano de Antropología e Historia Colombia. Revista Colombiana de Antropología, vol. 39, enero-diciembre, 2003, pp. 273-296.

WIEVIORKA, Michael. O Racismo, uma introdução. São Paulo: Perspectiva, 2007.

ZEQUEIRA, María del Carmen Barcia. Mujeres en torno a Minerva. In: Afrocubanas: Historia, pensamiento y practicas culturales. Colectivo de autoras. La Habana, Editorial de Ciencias Sociales, 20II.

ZUÑIGA, Olga P. Cimarronaje y conciencia politica. In: RIVIERO, Sandra E. et al.. Por La Identidad Del Negro Cubano. Santiago de Cuba, Ediciones Caserón, 20I I.

ZURBANO, Roberto. Racismo Vs. Socialismo en Cuba: Un conflicto fuera de lugar (apuntes sobre/contra el colonialismo interno). Meridional, Revista Chilena de Estudios Latinoamericanos. Número 4, abril, 2015, p. II-40.

Cuba: Doce Dificultades para Enfrentar al (Neo)Racismo o Doce Razones para Abrir el (otro) Debate. In: Negros con clases; Racismo y publicidad comercial; Racialización, Racialismo y Racimos. La Habana, Revista Universidad de la Habana Nº 273, 2012.

Escucho, aprendo y sigo en la pelea. La Habana, La Jiribilla, 2013. Disponível em: http: www.lajiribilla.cu/articulo/4408/escucho-aprendo-y-sigo-en-la-pelea?page=I

\section{FILMES E DOCUMENTÁRIOS}

Raza - Direção: Eric Corvanlán, 2008.

Maestra - Direção: Catherine Murphy, 2014.

1912 - Voces para el Silencio - Direção: Glória Rolando, 2010.

\section{MÚSICAS}

Calle G-Autoria: Grupo Obsesión. Album Negro, 2012. 
Lágrimas Negras - Autoria: Hermanos de la Causa, 2002.

\section{SÍTIOS ELETRÔNICOS}

http://afrocubana.wordpress.com/

http://www.scielo.br/pdf/ha/v7nI5/v7nI5a05.pdf

http://www.slavevoyages.org

http://estebanmoralesdominguez.blogspot.com.br/20I I/09/notas-sobre-el-tema-racial-en$\underline{\text { la.html }}$

http://www.fea.usp.br/feaecon//media/fck/File/LeonardoMarques_TraficoEUA.pdf

http://www.revistacinetica.com.br/cep/jose_jorge.pdf

http://www.unb.br/administracao/decanatos/deg/downloads/index/realtorio sistema cotas.p $\underline{\mathrm{df}}$

http://negracubanateniaqueser.com/

http://afrocubaweb.com/ 


\section{ANEXOS}

a) Membros do Bureau Político do Comitê Central do Partido Comunista de Cuba ${ }^{316}$

\begin{tabular}{|c|c|}
\hline PRIMERO SECRETARIO & SEGUNDO SECRETARIO \\
\hline $\begin{array}{c}\text { General de Ejército Raúl Castro Ruz } \\
\text { Presidente de los Consejos de Estado y de Ministros } \\
\text { ("branco") }\end{array}$ & $\begin{array}{l}\text { José Ramón Machado Ventura } \\
\text { Vicepresidente del Consejo de Estado y de Ministros } \\
\text { ("branco") }\end{array}$ \\
\hline $\begin{array}{l}\text { General de Cuerpo de Ejército Leopoldo Cintra Frías } \\
\text { Ministro de las FAR y Miembro del Consejo de Estado } \\
\text { ("mestiço" }\end{array}$ & $\begin{array}{l}\text { General de Cuerpo de Ejército Abelardo Colomé Ibarra } \\
\text { Ministro del Interior y Miembro del Consejo de Estado. } \\
\text { ("branco") }\end{array}$ \\
\hline $\begin{array}{c}\text { Miguel Mario Díaz-Canel Bermúdez } \\
\text { Primer Vicepresidente de los Consejos de Estado } \\
\text { ("branco") }\end{array}$ & $\begin{array}{c}\text { General de Ejército Ramón Espinosa Martín } \\
\text { Viceministro del Ministerio de las FAR } \\
\text { ("branco") }\end{array}$ \\
\hline $\begin{array}{c}\text { Esteban Lazo Hernández } \\
\text { Presidente de la Asamblea Nacional del Podel Popular } \\
\text { ("negro") }\end{array}$ & $\begin{array}{c}\text { General de Cuerpo de Ejército Álvaro V. López Miera } \\
\text { Viceministro Primero de las FAR } \\
\text { ("branco") }\end{array}$ \\
\hline $\begin{array}{c}\text { Lázara Mercedes López Acea } \\
\text { Primera Secretaria del Comité Provincial del Partido en La Habana } \\
-\left(\text { "mestiça" }^{318}\right)\end{array}$ & $\begin{array}{l}\text { Marino Alberto Murillo Jorge } \\
\text { Vicepresidente del Consejo de Ministros, Ministro del MEP - } \\
\text { ("branco" }{ }^{119} \text { ) }\end{array}$ \\
\hline
\end{tabular}

316 Não obtive os dados de raça/cor oficiais. Não estavam disponíveis. As classificações por "cor" aqui feitas e demais categorias apresentadas foram produto da entrevista realizada com diversos cubanos, homens e mulheres, com relação à percepção sobre a "cor" dos integrantes do Conselho de Estado, Bureau Partido Comunista de Cuba e Presidência Assembléia Poder Popular (Capítulo 3, Seção "Equidade e representação simbólica: Ações Afirmativas em Cuba).

${ }^{317}$ Alguns teceram comentários sobre ele como "cuase blanco", "medio indio"

${ }^{318}$ Lázara Mercedes também foi classificada pelo grupo como "jabao": "El jabao viene siendo como de color claro sin llegar a ser blanco, pero con el pelo muy malo" (fala de Danay Ramos, na entrevista realizada com grupo no dia 30/10/2015).

${ }^{319}$ Houve certo debate nesse caso. Parte do grupo defendeu que Marino Alberto é "Trigeño": "Marino es trigueño y en Cuba a los trigueños se les pone blanco en el carnet de identidad pero él es mestizo. (...)trigueño es una persona que tiene facciones finas, pelo lacio" (entrevista realizada em grupo no dia 20/20/2015. Fala de Danay Ramos). 


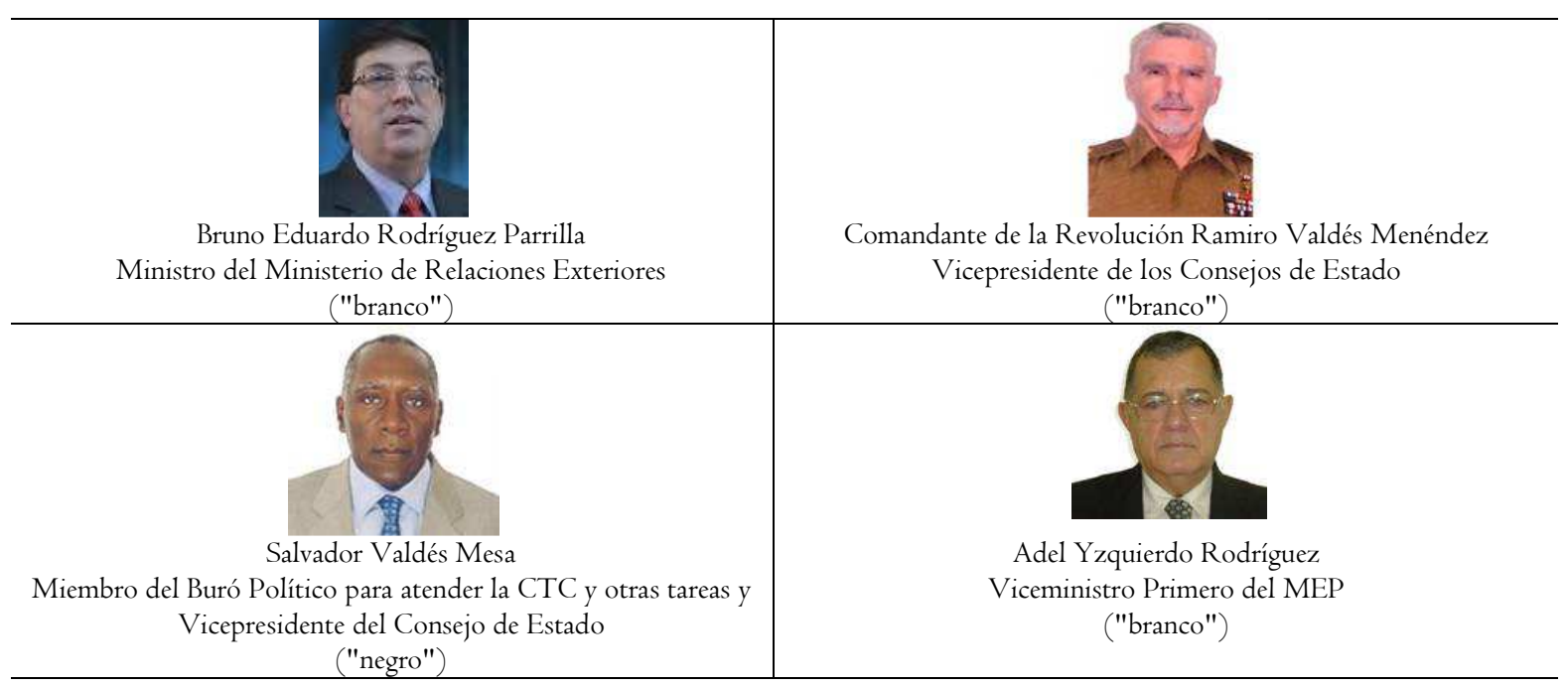

Fonte: http://www.pcc.cu/eo_buro_politico.php (Actualizado em: 06/I I/20I4) 
b) Quadro da Presidência da Assembléia Nacional do Poder Popular - Legislaturas de I976 a $2013^{320}$

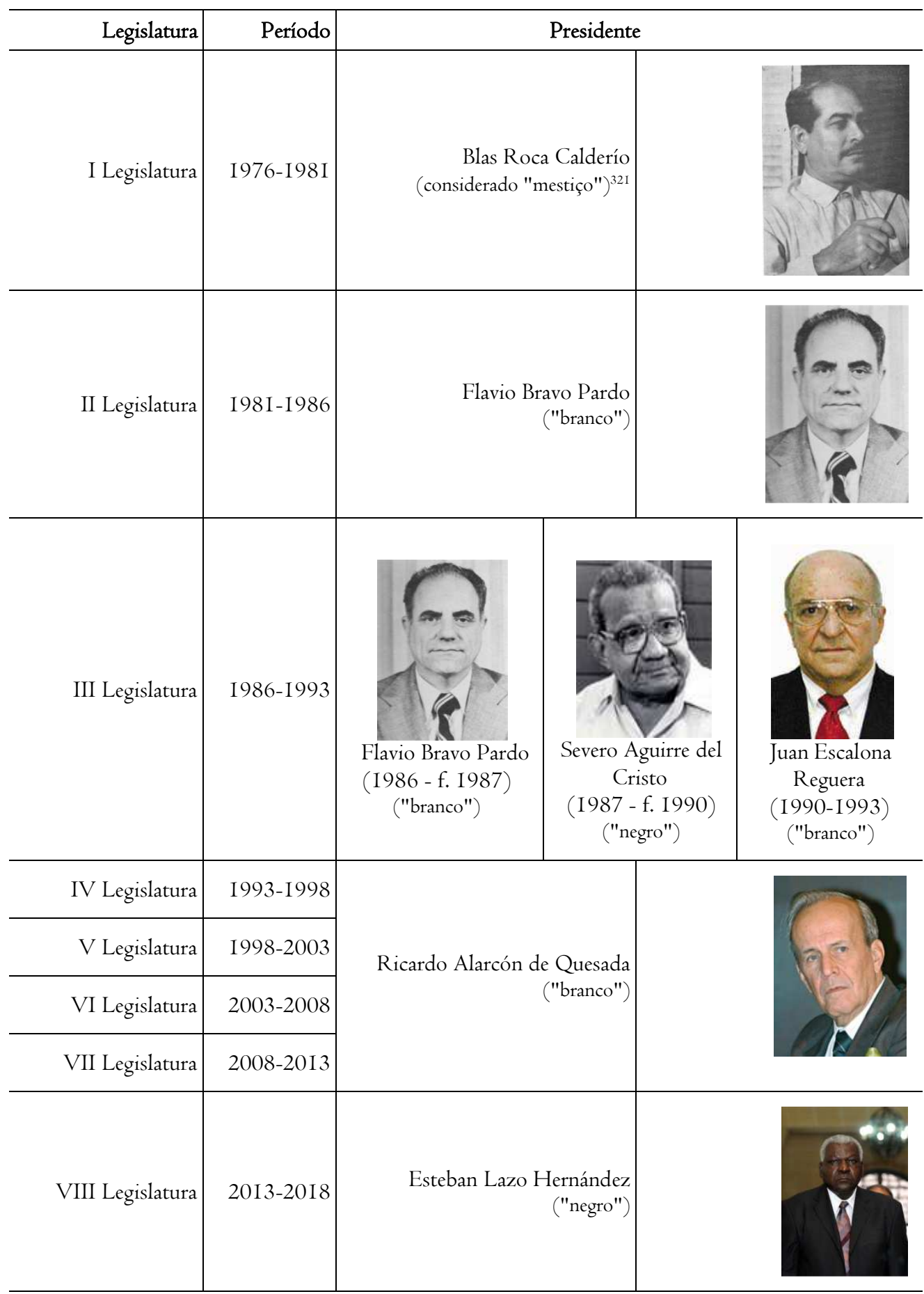

320 Não obtive os dados de raça/cor oficiais. Não estavam disponíveis. As classificações por "cor" aqui feitas e demais categorias apresentadas foram produto da entrevista realizada com diversos cubanos, homens e mulheres, com relação à percepção sobre a "cor" dos integrantes do Conselho de Estado, Bureau Partido Comunista de Cuba e Presidência Assembléia Poder Popular (Capítulo 3, Seção "Equidade e representação simbólica: Ações Afirmativas em Cuba).

${ }^{321}$ Também foi classificado como "mulato" pelo grupo. 
c) Membros do Conselho de Estado (Núcleo Dirigente e Direção Ampliada)

Oitava Legislatura da Assembléia do Poder Popular de Cuba (2013-20I8)

\begin{tabular}{|c|c|c|}
\hline Cargo & Nome & $\operatorname{Cor}^{322}$ \\
\hline Presidente & Raúl Castro Ruz & "branco" \\
\hline Primer Vicepresidente & $\begin{array}{l}\text { Miguel Mario Díaz-Canel } \\
\text { Bermúdez }\end{array}$ & "branco" \\
\hline Vicepresidente & José Ramón Machado Ventura & "branco" \\
\hline Vicepresidente & Ramiro Valdés Menéndez & "branco" \\
\hline Vicepresidente & Salvador Antonio Valdés Mesa & "negro" \\
\hline Vicepresidenta & Gladys María Bejerano Portela & "branca" \\
\hline Vicepresidenta & Lázara Mercedes López Acea & "mestiça" \\
\hline Secretario & Homero Acosta Álvarez & "branco" \\
\hline
\end{tabular}

322 Não obtive os dados de raça/cor oficiais. Não estavam disponíveis. Esse critério foi definido em entrevista com grupo de cubanos, mulheres e homens, de diferentes idades, origens e pertencimentos étnicorracial, conforme descrito no Capítulo 3. 


\section{DEMAIS MEMBROS DO CONSELHO DE ESTADO}

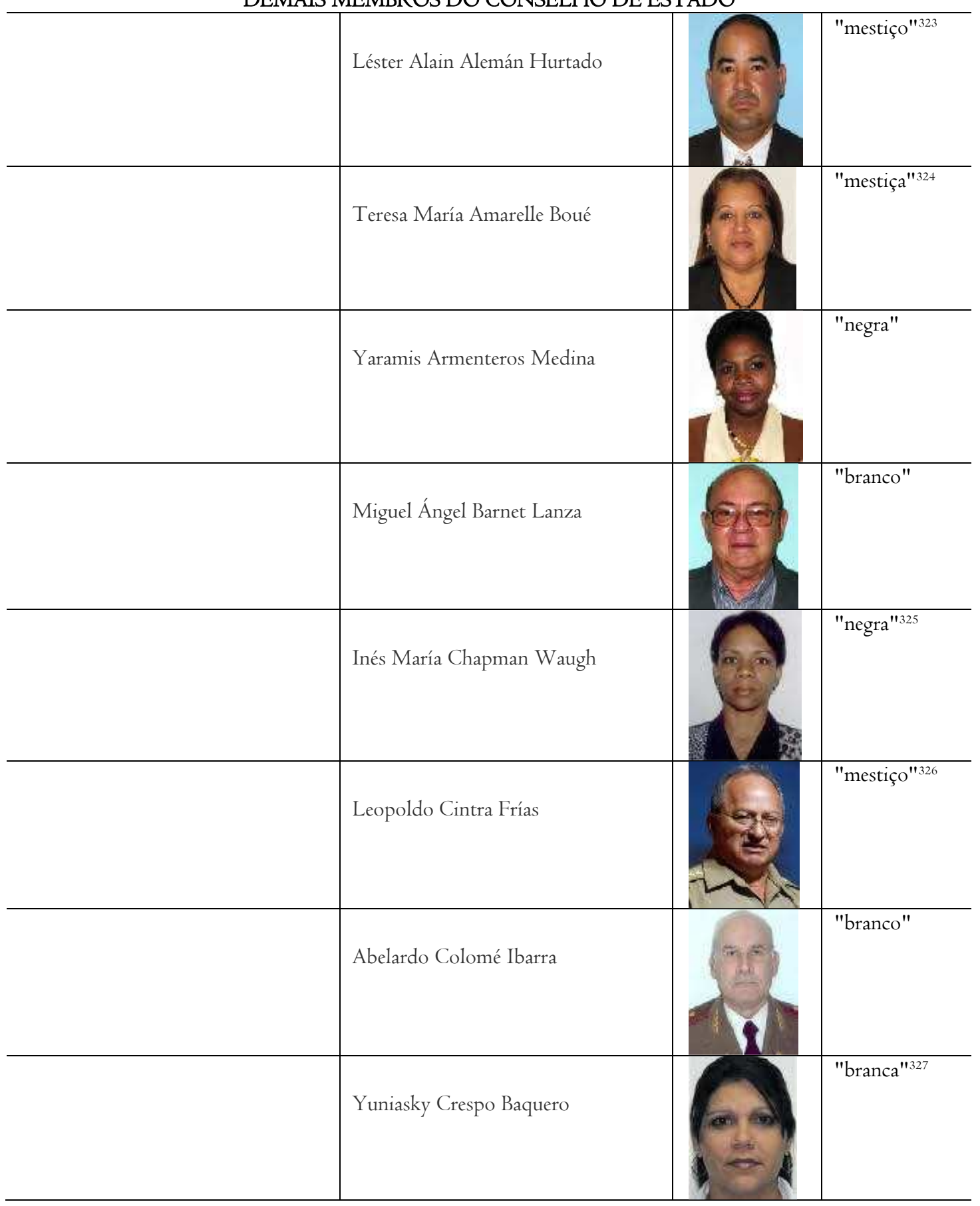

${ }^{323}$ Foram dadas a ele outras descrições tais como "mulato claro", "trigeño". Em alusão à identificação de cor de Léster, Olga Lídia faz uma comparação que mescla o meio social e a vestimenta com a identificação da cor: "si le quitas la guayabera, con un desmangado y lo tiras en la Habana Vieja... lo perdemos" (Olga Lídia, na entrevista de grupo, em 30/I0/2015), em alusão ao fato de que ele passaria a ser "mestiço" sem dúvida.

324 Outras categorias atribuidas a ela são: "mulata blanconasa" e "media china"

325 Também a classificaram como "negra colorada".

${ }^{326}$ Alguns teceram comentários como "cuase blanco", "medio indio"

327 Apesar de apresentarem Yuaniasky como "branca", houve algumas ponderações no grupo, tais como: "Ella no es la blanca legítima. Trigueñita asi..." (Mercedes Cañete, na entrevista em grupo, em 30/10/2015) 


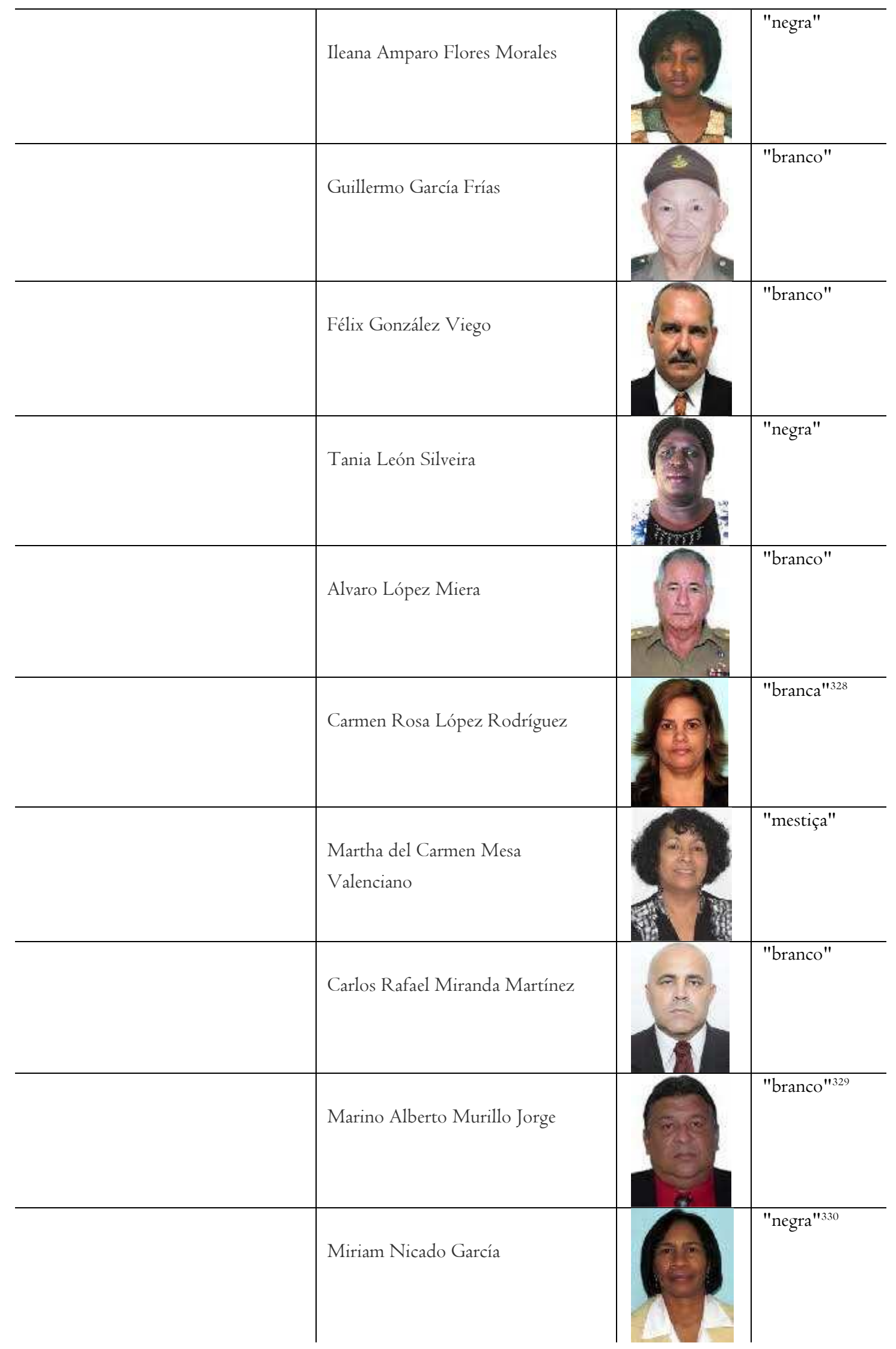

328 Também foi denominada como "mulata blanconaza" por uma integrante do grupo.

${ }^{329}$ Foi considerado por uma minoria do grupo como "Trigeño".

330 Também foi considerada "mulata" por parte do grupo, "mulata oscura". 


\begin{tabular}{l|l|l|l|} 
& Miladys Orraca Castillo & "branca" \\
\hline Sergio Juan Rodríguez Morales & Bruno Eduardo Rodríguez Parilla & "branco" \\
\hline & Liz Belkys Rosabal Ponce & "branco" \\
\hline & Adel Onofre Yzquierdo Rodríguez & \\
\hline
\end{tabular}

331 Considerada também como "mulata". 
d) Carta de Autorização de Pesquisa para o Doutorado em Cuba

\section{INSTTUUTO CUBANO DE INVESTIGACTÓN CULTURAL Juan Marinello}

La Habana, 16 de abril de 2014.

"Año 56 de la Revolución"

A quien pueda interesar:

El Instituto Cubano de Investigación Culural "Juan Marinello" se sirve de este documento para certificar que la ciudadana de nacionalidad brasileña Barbara Oliveira Souza, con visa diplomática y doctorante de la Universidad de Brasilia, Brasil, se encuentra realizando una estancia de investigación respaldada por el Instituto Cubano de Investigación Cultural "Juan Marinello", con la anuencia del Ministerio de Cultura y el Ministerio de Relaciones Exteriores, para complementar la realización de su Tesis de Doctorado sobre la cultura de los afrodescendientes en Cuba.

Solicitamos le sean brindadas todas las facilidades pertinentes a fin de que pueda tener acceso a la bibliografia y los medios necesarios para su investigación. Sirvase usted de contactarnos en caso de alguna duda o necesidad de aclaración. Agradecemos de antemano su gestión.

Saludos cordiales

Msc. Elena sofarrás de la retio

Directora

Instituto Cublno de investignación Cultiral

"Juan Marinello"

MINCULT

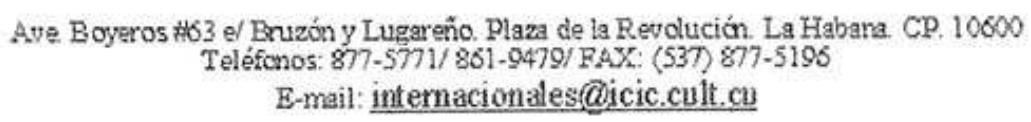

